UNIVERSIDADE DE SÃO PAULO

FACULDADE DE FILOSOFIA, LETRAS E CIÊNCIAS HUMANAS DEPARTAMENTO DE LETRAS CLÁSSICAS E VERNÁCULAS PROGRAMA DE PÓS-GRADUAÇÃO DE FILOLOGIA E LÍNGUA PORTUGUESA

CELCIANE ALVES VASCONCELOS

Estudo semântico-lexical do vocabulário setecentista em Paranaguá

V. 1 


\section{Estudo semântico-lexical do vocabulário setecentista em Paranaguá}

Tese apresentada ao Programa de Pós-Graduação em Filologia e Língua Portuguesa da Universidade de São Paulo, como requisito para a obtenção do título de Doutor.

Orientador: Prof. Dr. Manoel Mourivaldo Santiago Almeida

v. 1

São Paulo

2013 
VASCONCELOS, Celciane Alves. Estudo semântico-lexical do vocabulário setecentista em Paranaguá. Tese apresentada ao Programa de Pós-Graduação em Filologia e Língua Portuguesa da Universidade de São Paulo, como requisito parcial para a obtenção do título de Doutor.

Aprovado em: 11/03/2013

Banca Examinadora

Prof. Dr. Manoel Mourivaldo Santiago Almeida (Presidente) Instituição: FFLCH - USP Assinatura:

Prof. Dr. Osvaldo Humberto Leonardi Ceschin (Titular) Instituição: FFLCH - USP

Assinatura:

Profa. Dra. Maria Valíria Aderson de Mello Vargas (Titular) Instituição: FFLCH - USP Assinatura:

Profa. Dra. Vanderci de Andrade Aguilera (Titular) Instituição: UEL - Externo Assinatura:

Profa. Dra. Joyce Elaine de Almeida Baronas (Titular) Instituição UEL - Externo Assinatura: 
Dedico aos meus filhos Bruno e à minha bebê nascitura, são inspiração e razão de todo meu esforço e dedicação, mamãe vos ama. 


\section{AGRADECIMENTOS}

A Deus que derramou sua benção sobre mim, me concedendo paz de espírito e muita força de vontade, para que eu pudesse continuar sempre firme e forte nos meus propósitos.

À Fundação de Amparo e Pesquisa do Estado de São Paulo (FAPESP) pela bolsa concedida durante o doutoramento, ajuda mais que imprescindível para o desenvolvimento da presente pesquisa.

Ao paciente e sábio professor Mourivaldo por toda orientação, aprendizado, amizade e confiança que depositou em meu trabalho. A você, só tenho a agradecer, obrigada.

À professora Vanderci pela dedicada participação em minha pesquisa, pelos sábios e férteis ensinamentos e pelo incentivo e apoio em momentos incertos e duvidosos.

À professora Joyce pela prontidão em aceitar fazer parte da banca de qualificação e defesa, e também pelas contribuições e instruções que só favoreceram ao enriquecimento deste trabalho.

À Fabiane, uma pessoa muito querida, que demonstrou ser uma companheira fiel nos momentos em que mais precisei. Deixou todos seus afazeres só para me acomapanhar durante minha primeira viagem de pesquisa de campo. Sabia que com esta atitude me faria sentir mais segura.

Ao Ênnio, que tanto contribuiu com suas prontas e confiáveis respostas e sugestões quanto à leitura e interpretação dos manuscritos.

Ao Cláudio, outro querido amigo, com sua tranquilidade e competência colocou-se à minha disposição para ajudar no tratamento do corpus oral, ferramenta indispensável para a visualização e análise dos dados.

Aos meus colegas do projeto PHPP e da sala de pesquisa 169 da UEL, principalmente à Lidiane e à Rebeca, que se dispuseram a me acompanhar e a me ajudar para a realização das entrevistas no município de Paranaguá.

Aos informantes e colaboradores diretos e inderetos de Paranaguá, agradeço pelos dados fornecidos que serviram de base para a feitura desta tese.

À Kika por sua imensurável competência profissional durante a revisão e formatação da tese. Dedicação e responsabilide são uma das qualidades que resumem o produto final de seu trabalho. 
À minha querida amiga Débora, que gentilmente, por inúmeras vezes, me ofereceu pouso para que eu pudesse pernoitar e descansar das longas viagens a São Paulo.

Ao meu amado e companheiro Wagner, que por tantas vezes abdicou de seu lazer para me levar ou buscar na rodoviária e no aeroporto; ficar ao meu lado, trazendo-me água, café e lanchinho, e também me proporcionando massagens aliviadoras nos momentos em que as dores nas costas imperavam.

À minha família, que sempre esteve ao meu lado, em especial à minha mãe, pelo cuidado e zelo com que se dedicou ao netinho Bruno, nos momentos em que precisei me ausentar.

E, especialmente, ao meu filhinho Bruno, por entender, mesmo tão pequeno, que a mamãe precisava ficar horas a fio em silêncio, dedicando-se à tese. 
"As coisas mudam no devagar depressa dos tempos" João Guimarães Rosa 


\section{RESUMO}

VASCONCELOS, Celciane Alves. Estudo semântico-lexical do vocabulário setecentista em Paranaguá. 2013. 604 f. Tese (Doutorado em Filologia e Língua Portuguesa) - Faculdade de Filosofia, Letras e Ciências Humanas, Universidade de São Paulo, São Paulo. 2013. 2 v.

O objetivo geral desta tese é fazer um estudo do léxico no município de Paranaguá-PR, propondo uma discussão sobre manutenção, tendência à manutenção, desuso e tendência ao desuso de lexias extraídas de fontes manuscritas setecentistas, datadas da mesma localidade. Para a realização deste estudo são utilizados, além dos documentos manuscritos digitalizados, dicionários da Língua Portuguesa e material oral. A base teórico-metodológica que norteia esta pesquisa é a da Dialetologia, mas aproxima-se também das utilizadas em pesquisas filológicas (edição de documentos), sociolinguísticas (pesquisa de campo e análise das lexias considerando células sociais) e lexicográficas (elaboração do glossário). Os objetivos específicos são: (i) traçar o panorama histórico da área estudada para auxiliar na compreensão dos aspectos socioculturais, (ii) fazer a edição semidiplomática, acompanhada da reprodução fac-similar dos documentos manuscritos, servindo de base para a caracterização do estado da língua setecentista; (iii) elaborar o glossário visando apresentar a definição dos itens lexicais selecionados com acepções e abonações extraídas do corpus escrito; (iv) investigar as lexias selecionadas por meio dos dados orais coletados com auxílio do questionário semânticolexical, adotando para a seleção dos informantes as variáveis sociais: faixa etária, sexo, naturalidade e grau de escolaridade; e, por fim, (v) verificar, a partir das lexias testadas, o grau de manutenção, tendência à manutenção, desuso e tendência ao desuso, em relação às acepções registradas nos documentos em questão. Tomando por base a análise do contexto de fala dos informantes de Paranaguá, constatou-se que há, no geral, a tendência ao desuso das lexias extraídas do corpus escrito, principalmente por parte dos informantes da primeira faixa etária. Em suma, espera-se que os resultados dessa pesquisa possam contribuir e, ao mesmo tempo, fornecer dados confiáveis aos estudos linguísticos sobre o estado de língua escrita no período setecentista e seus ecos na variedade portuguesa falada em Paranaguá e, por extensão, no Brasil.

Palavras-chave: Estudo semântico-lexical. Edição de manuscritos. Dialetologia. Manutenção e desuso. Português escrito e falado no Paraná. 


\begin{abstract}
VASCONCELOS, Celciane Alves. Lexical-semantic study of Eighteenth Century vocabulary in Paranaguá. 2013. 604 f. Thesis (Ph.D. in Philology and Portuguese). Faculty of Philosophy, Languages and Arts, and Human Sciences, University of São Paulo, São Paulo. 2013. 2 v.
\end{abstract}

The overall objective of this thesis is to study the lexicon in the city of Paranaguá-PR, proposing a discussion on maintenance, tendency to maintenance, disuse and tendency to disuse of lexicon extracted from eighteenth-century manuscript sources, dating from the same locality. For this study, in addition to scanned handwritten documents, dictionaries of Portuguese and oral material are used. The theoretical and methodological basis that guides this research is the Dialectology, but also the basis used in philological research (document editing), sociolinguistic research (field research and analysis of lexicon considering social cells) and lexicographic research (preparing the glossary) .The specific objectives are: (i) to trace the historical background of the study area to assist in understanding the socio-cultural aspects, (ii) to do the semi-diplomatic editing, followed by facsimile reproduction of the handwritten documents, providing the basis for characterizing the state of eighteenth-century language, (iii) to select the lexicon to be tested in the city of Paranaguá, and, from them, to prepare the glossary seeking to present the definition of lexical items with meanings and accreditations extracted from the written corpus, (iv) to collect oral data with the aid of a lexical-semantic questionnaire, adopting for the selection of informants the following social variables: age, sex, place of birth and education level, and finally (v) to verify, from the lexicon tested, the level of maintenance, tendency to maintenance, disuse and tendency to disuse, regarding the meanings recorded in the documents in question. Based on the analysis of the context of the speech of informants from Paranaguá, it was found that, in general, there is a tendency to disuse of lexicon extracted from the written corpus, especially by the informants from the first age group. In short, it is expected that the results of this research can contribute and, at the same time, provide reliable data for linguistic studies on the state of written language during the eighteenth century and its echoes on the Portuguese variety spoken in Paranaguá and, by extension, in Brazil.

Keywords: Lexical-semantic study; Manuscripts editing; Dialectology; Maintenance and disuse; Written and spoken Portuguese in Paraná. 


\section{LISTA DE FIGURAS}

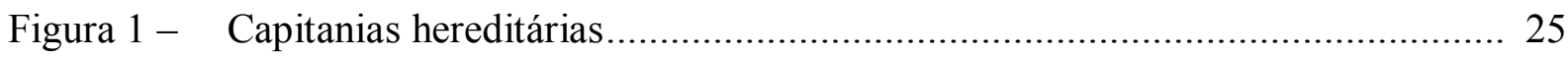

Figura 2 - Vista aérea do município de Paranaguá................................................... 38

Figura 3 - Exemplo de tratamento do corpus escrito: listagem dos vocábulos em ordem alfabética, número de frequência e texto transcrito conforme normas exigidas do programa Léxico 3 ............................................................................. 105

Figura 4 - Exemplo de tratamento do corpus escrito: frequência do vocábulo ballandra e suas ocorrências no documento manuscrito para busca das contextualizações no glossário 106

Figura 5 - Esquema de enquadramento das variáveis........................................... 340 


\section{LISTA DE GRÁFICOS}

Gráfico 1 - Índice de porcentagem de ocorrência por manutenção, tendência à manutenção, desuso e tendência ao desuso ................................................................... 338

Gráfico 2 - FAIXA ETÁRIA I: Porcentagem de ocorrência por manutenção .................... 342

Gráfico 3 - FAIXA ETÁRIA I: Porcentagem de ocorrência por desuso ......................... 343

Gráfico 4 - FAIXA ETÁRIA I: Porcentagem de ocorrência por NSR. .......................... 344

Gráfico 5 - FAIXA ETÁRIA II: Porcentagem de ocorrência por manutenção ................. 345

Gráfico 6 - FAIXA ETÁRIA II: Porcentagem de ocorrência por desuso ........................ 346

Gráfico 7 - FAIXA ETÁRIA II: Porcentagem de ocorrência por NSR .......................... 347 


\section{LISTA DE QUADROS}

Quadro 1 - Relação completa dos documentos manuscritos, com especificação dos fólios,

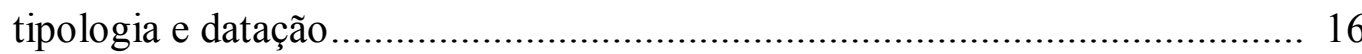

Quadro 2 - Itens lexicais selecionados para análise semântico-lexical........................... 107

Quadro 3 - Quadro das variáveis: escolaridade, sexo e faixa etária ............................. 115

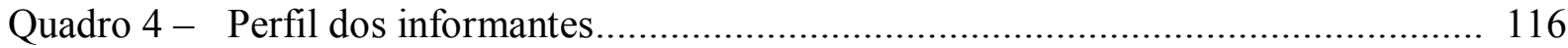

Quadro 5 - Distribuição dos itens lexicais por manutenção, tendência à manutenção, desuso e tendência ao desuso ........................................................................ 336

Quadro 6 - Quadro descritivo da porcentagem local das variáveis ............................... 341 


\section{SUMÁRIO}

1 INTRODUÇÃO

2 CAPÍTULO I - PERCURSO HISTÓRICO: BRASIL COLÔNIA ATÉ MUNICÍPIO DE PARANAGUÁ..

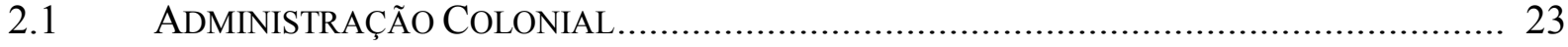

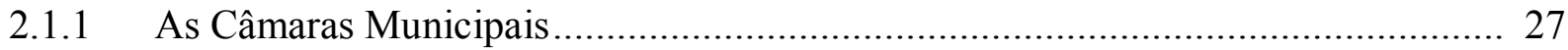

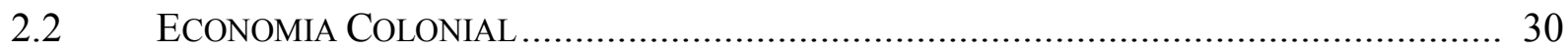

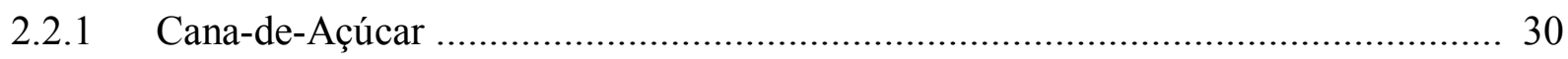

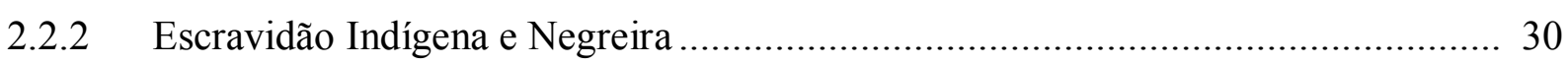

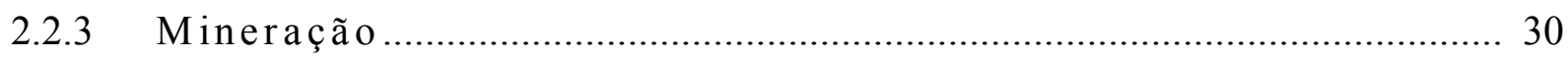

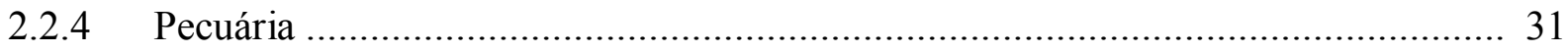

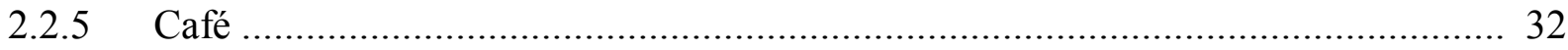

2.3 EXPANSÃo TERritorial RUMO AO EXTREMO SUL ............................................ 32

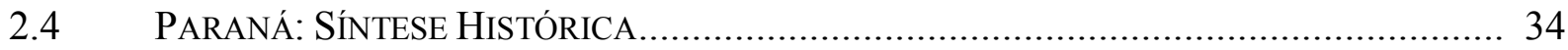

2.5 PARANAGUÁ: CONTEXTO SÓCIO-HISTÓRICO ...................................................... 35

2.5.1 Povoação e Fundação de Paranaguá...................................................................... 36

2.5.2 Capitania de Paranaguá ...................................................................................... 40

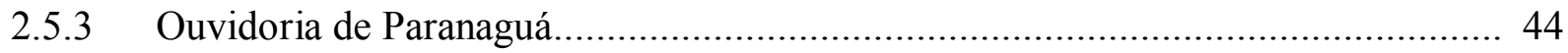

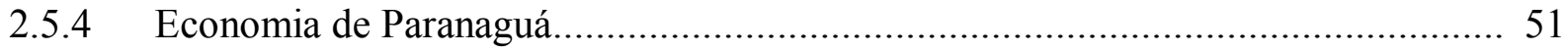

2.5.5 Origem e Desfecho do Colégio dos Jesuítas em Paranaguá .................................. 55

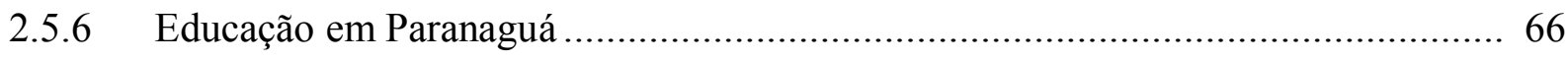

3 CAPÍTULO II - CRITÉRIOS DE EDIÇÃO DE TEXTOS............................. 72

3.1 COMENTÁRIOS PALEOGRÁfICOS DOS MANUSCRITOS ............................................. 81

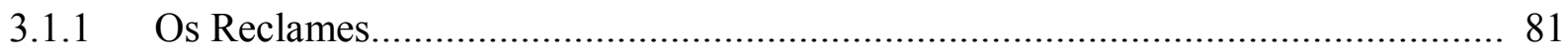

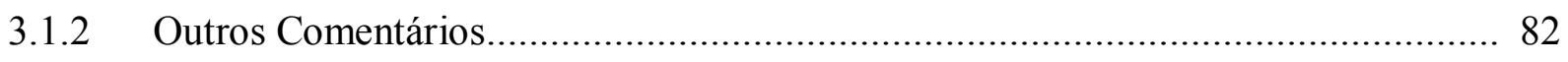

3.2 CARACTERÍSTICAS DA ESCRITA DO SÉCULO XVIII ............................................. 83

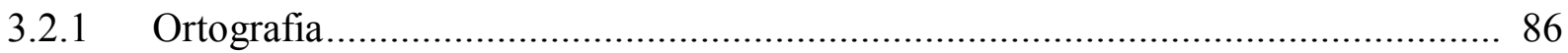

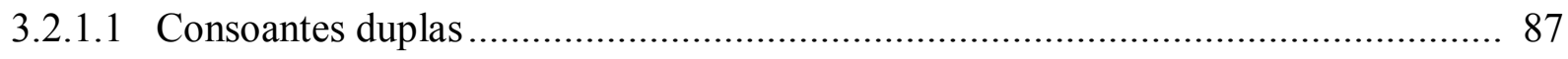

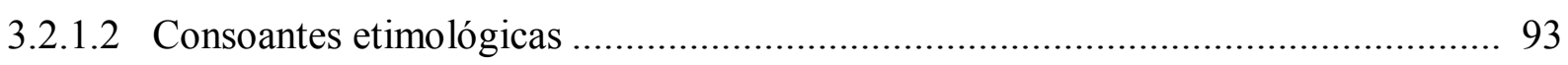

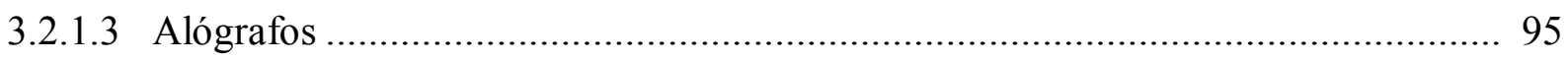

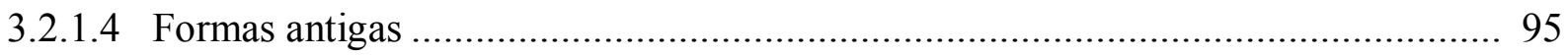

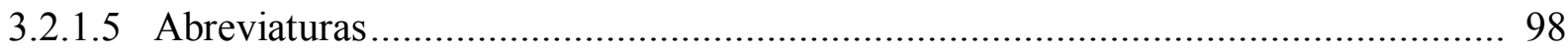




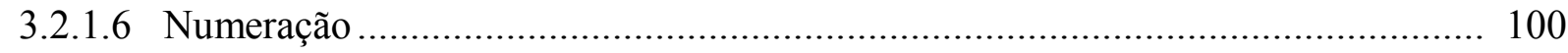

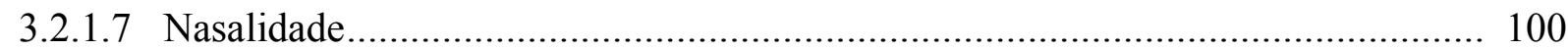

4 CAPÍTULO III - TRATAMENTO DO CORPUS ESCRITO: CRITÉRIO E SELEÇÃO DOS ITENS LEXICAIS .................................................... 105

5 CAPÍTULO IV - PESQUISA DE CAMPO: PROCEDIMENTOS DA COLETA

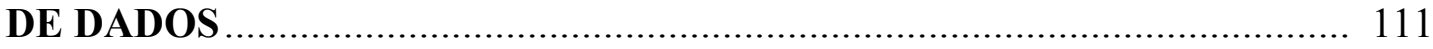

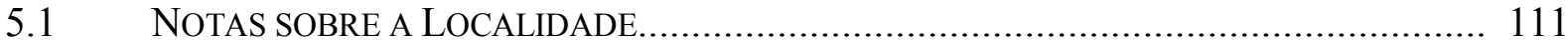

5.2 APLICAÇÃO DO QUESTIONÁRIO SEMÂNTICO-LEXICAL .......................................... 113

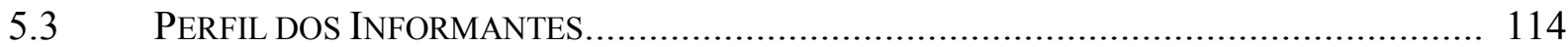

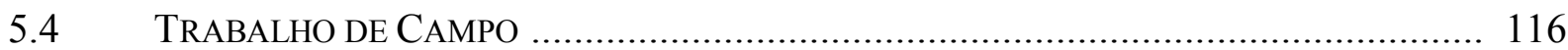

6 CAPÍTULO V - ESTUDO SEMÂNTICO-LEXICAL ................................... 115

6.1 ANÁLISE SEMÂNTICo-LEXICAL DAS LEXIAS INVESTIGADAS ................................ 119

6.2 Distribuição dos Itens LeXiCAis POR MANUTENÇÃO, TENDÊNCIA À MANUTENÇÃO, DESUSO E TENDÊNCIA AO DESUSO..................................................................... 336

6.3 ANÁLISE DAS VARIÁVEIS: FAIXA ETÁRIA, GÊNERO E ESCOLARIDADE...................... 339

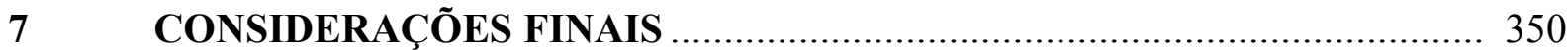

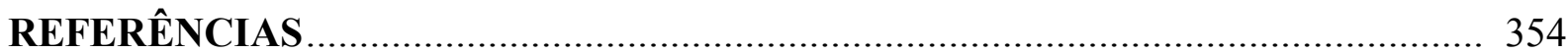

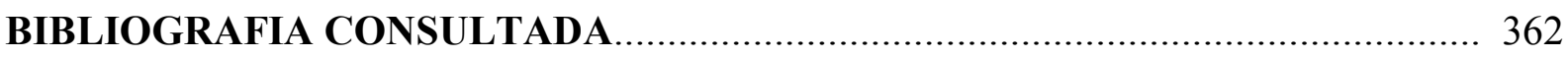

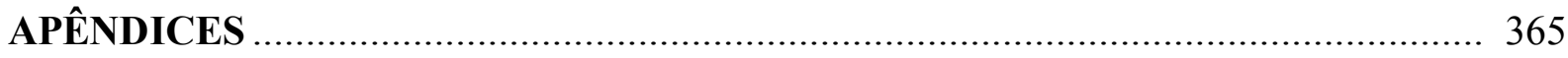

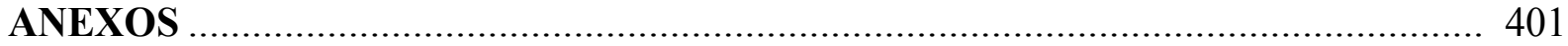


Grntroducão 


\section{INTRODUÇÃO}

A ideia inicial deste trabalho surgiu do projeto interinstitucional Para a História do Português Brasileiro - PHPB (coordenado pelo Dr. Ataliba Teixeira de Castilho) e da necessidade de fazer um estudo histórico da língua portuguesa usada no Paraná colonial, tendo como fonte de investigação documentos manuscritos. Atualmente, é desenvolvido, na Universidade Estadual de Londrina (UEL), o projeto Para a história do português paranaense: estudos diacrônicos de manuscritos dos séculos XVII a XIX - PHPP (coordenado pela prof. ${ }^{a}$ Dr. ${ }^{a}$ Fabiane Cristina Altino), o qual propõe uma pesquisa sobre a história do português brasileiro, baseada em documentos escritos durante os séculos XVII, XVIII e metade do século XIX, nas antigas vilas que hoje se constituem municípios do Estado do Paraná. O material utilizado pelo PHPP compõe-se de manuscritos conservados no Arquivo do Estado de São Paulo ${ }^{1}$ e digitalizados em CD-ROM por iniciativa da prof. ${ }^{a}$ Dr. ${ }^{\text {a }}$ Vanderci de Andrade Aguilera. Constitui um banco de dados referente a documentos oficiais, a maioria dos quais enviada pela Câmara dos Vereadores dessas primeiras vilas fundadas no litoral da então Capitania de São Vicente - como Paranaguá, Antonina, Guaraqueçaba, Guaratuba, Vila Nova do Príncipe e Castro - às autoridades maiores, como governadores, bispos e rei. Esta proposta de estudos pautados em registros escritos se justifica pela necessidade de recuperar, o quanto antes, um número significativo de manuscritos, oficiais ou não, à espera de uma edição confiável e de estudos linguístico-filológicos, que possam complementar as pesquisas que hoje buscam lançar luzes à história do português vernáculo brasileiro.

Com o intuito de continuar trilhando os caminhos da história do português brasileiro no Paraná, com ênfase no léxico diacrônico, para esta pesquisa procedeu-se a uma leitura prévia da coleção de manuscritos referentes à vila de Paranaguá, para depois serem selecionados 49 documentos, com um total de 80 fólios, datados entre 1721 a 1800 .

$\mathrm{Na}$ versão digitalizada, estes manuscritos recebem a sequência numérica de 591 a 676 (quadro 1). Os fólios 618, 619, 626 e 630 foram excluídos por não pertencerem a Paranaguá, e os fólios 643 e 660 são cópias reduplicadas dos documentos 639 e 656, respectivamente. A relação completa dos documentos, com a especificação dos fólios, tipologia e datação é a seguinte:

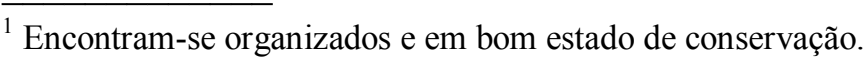


Quadro 1 - Relação completa dos documentos manuscritos, com especificação dos fólios, tipologia e datação

\begin{tabular}{|c|c|c|c|c|}
\hline $\begin{array}{c}\text { No. Doc. Banco de } \\
\text { Dados UEL }\end{array}$ & No. Doc. & Fólio & Tipologia & Datação \\
\hline 593 & 01 & $1 \mathrm{r}$ & Carta Oficial & 11/Novembro/1721 \\
\hline 594 & 01 & $1 \mathrm{v}$ & Carta Oficial & 11/Novembro/1721 \\
\hline 595 & 02 & $1 \mathrm{r}$ & Carta Oficial & 14/Novembro/1721 \\
\hline 597 & 03 & $1 \mathrm{r}$ & Carta Oficial & 04/Dezembro/1721 \\
\hline 598 & 03 & $1 \mathrm{v}$ & Carta Oficial & 04/Dezembro/1721 \\
\hline 600 & 03 & $2 \mathrm{r}$ & Carta Oficial & 04/Dezembro/1721 \\
\hline 596 & 04 & $1 \mathrm{r}$ & Carta Oficial & 20/Dezembro/1721 \\
\hline 599 & 05 & $1 \mathrm{r}$ & Carta Oficial & 20/Dezembro/1721 \\
\hline 601 & 06 & $1 \mathrm{r}$ & Carta Oficial & 01/Janeiro/1722 \\
\hline 602 & 07 & 1r & Carta Oficial & 06/Janeiro/1722 \\
\hline 603 & 08 & $1 \mathrm{r}$ & Carta Oficial & 12/Janeiro/1722 \\
\hline 604 & 09 & $1 \mathrm{r}$ & Lista & 12/Janeiro/1722 \\
\hline 605 & 10 & $1 \mathrm{r}$ & Carta Oficial & 17/Março/1722 \\
\hline 606 & 10 & $1 \mathrm{v}$ & Carta Oficial & 17/Março/1722 \\
\hline 591 & 11 & 1r & Carta Oficial & 29/Maio/1722 \\
\hline 592 & 11 & $1 \mathrm{v}$ & Carta Oficial & 29/Março/1722 \\
\hline 607 & 12 & $1 \mathrm{r}$ & Carta Oficial & 25/Agosto/1722 \\
\hline 608 & 12 & $1 \mathrm{v}$ & Carta Oficial & 25/Agosto/1722 \\
\hline 609 & 13 & $1 \mathrm{r}$ & Carta Oficial & 09/Dezembro/1723 \\
\hline 612 & 14 & $1 \mathrm{r}$ & Carta Oficial & $04 /$ Fevereiro/1725 \\
\hline 613 & 14 & $1 \mathrm{v}$ & Carta Oficial & $04 /$ Fevereiro/1715 \\
\hline 614 & 15 & $1 \mathrm{r}$ & Carta Oficial & 04/Fevereiro/1725 \\
\hline 615 & 16 & $1 \mathrm{r}$ & Carta Oficial & 05/Novembro/1731 \\
\hline 616 & 17 & $1 \mathrm{r}$ & Carta Oficial & 23/Agosto/1732 \\
\hline 617 & 18 & $1 \mathrm{r}$ & Carta Oficial & 10/Novembro/1732 \\
\hline 622 & 19 & $1 \mathrm{r}$ & Lista & 11/Dezembro/1732 \\
\hline 620 & 20 & $1 \mathrm{r}$ & Carta Oficial & 29/Dezembro/1732 \\
\hline 621 & 20 & $1 \mathrm{v}$ & Carta Oficial & 29/Dezembro/1732 \\
\hline 623 & 21 & $1 \mathrm{r}$ & Carta Oficial & 30/Dezembro/1732 \\
\hline 610 & 22 & 1r & Carta Oficial & 04/Março/1734 \\
\hline 611 & 22 & $1 \mathrm{v}$ & Carta Oficial & 04/Março/1734 \\
\hline 624 & 23 & $1 \mathrm{r}$ & Carta Oficial & 12/Abril/1735 \\
\hline 625 & 24 & $1 \mathrm{r}$ & Carta Oficial & 12/Abril/1735 \\
\hline 627 & 25 & $1 \mathrm{r}$ & Carta Oficial & 27/Dezembro/1743 \\
\hline 628 & 25 & $1 \mathrm{v}$ & Carta Oficial & 27/Dezembro/1743 \\
\hline 629 & 26 & $1 \mathrm{r}$ & Carta Oficial & 03/Julho/1762 \\
\hline 631 & 27 & $1 \mathrm{r}$ & Carta Oficial & 08/Maio/1767 \\
\hline 632 & 28 & $1 \mathrm{r}$ & Carta Oficial & 15/Junho/1767 \\
\hline
\end{tabular}


continuação

\begin{tabular}{|c|c|c|c|c|}
\hline $\begin{array}{l}\text { No. Doc. Banco de } \\
\text { Dados UEL }\end{array}$ & N’. Doc. & Fólio & Tipologia & Datação \\
\hline 633 & 29 & $1 \mathrm{r}$ & Carta Oficial & 04/Julho/1767 \\
\hline 634 & 30 & $1 \mathrm{r}$ & Carta Oficial & 26/Agosto/1769 \\
\hline 635 & 31 & $1 \mathrm{r}$ & Carta Oficial & 12/Fevereiro/1785 \\
\hline 636 & 31 & $1 \mathrm{v}$ & Carta Oficial & 12/Fevereiro/1785 \\
\hline 637 & 32 & $1 \mathrm{r}$ & Carta Oficial & 25/Fevereiro/1785 \\
\hline 638 & 32 & $1 \mathrm{v}$ & Carta Oficial & 25/Fevereiro/1785 \\
\hline 639 & 32 & $2 \mathrm{r}$ & Carta Oficial & 25/Fevereiro/1785 \\
\hline 640 & 33 & $1 \mathrm{r}$ & Carta Oficial & 1785 \\
\hline 641 & 33 & $1 \mathrm{v}$ & Carta Oficial & 1785 \\
\hline 642 & 33 & $2 \mathrm{r}$ & Carta Oficial & 1785 \\
\hline 644 & 34 & $1 \mathrm{r}$ & Carta Oficial & 28/Fevereiro/1789 \\
\hline 645 & 34 & $1 \mathrm{v}$ & Carta Oficial & 28/Fevereiro/1789 \\
\hline 646 & 35 & $1 \mathrm{r}$ & Carta Oficial & 31/Dezembro/1789 \\
\hline 647 & 36 & $1 \mathrm{r}$ & Carta Oficial & 15/Julho/1792 \\
\hline 648 & 36 & $1 \mathrm{v}$ & Carta Oficial & 15/Julho/1792 \\
\hline 649 & 37 & $1 \mathrm{r}$ & Carta Oficial & 26/Março/1798 \\
\hline 650 & 37 & $1 \mathrm{v}$ & Carta Oficial & 26/Março/1798 \\
\hline 651 & 37 & $2 \mathrm{r}$ & Carta Oficial & 26/Março/1798 \\
\hline 652 & 38 & $1 \mathrm{r}$ & Carta Oficial & 26/Março/1798 \\
\hline 653 & 39 & $1 \mathrm{r}$ & Carta Oficial & 29/Maio/1798 \\
\hline 654 & 40 & $1 \mathrm{r}$ & Carta Oficial & 03/Novembro/1798 \\
\hline 655 & 40 & $1 \mathrm{v}$ & Carta Oficial & 03/Novembro/1798 \\
\hline 656 & 41 & $1 \mathrm{r}$ & Carta Oficial & 18/Novembro/1798 \\
\hline 657 & 42 & $1 \mathrm{r}$ & Carta Oficial & 18/Novembro/1798 \\
\hline 658 & 42 & $1 \mathrm{v}$ & Carta Oficial & 18/Novembro/1798 \\
\hline 659 & 43 & $1 \mathrm{r}$ & Carta Oficial & 18/Novembro/1798 \\
\hline 661 & 44 & $1 \mathrm{r}$ & Carta Oficial & 23/Fevereiro/1799 \\
\hline 662 & 45 & $1 \mathrm{r}$ & Carta Oficial & 14/Maio/1799 \\
\hline 663 & 45 & $1 \mathrm{v}$ & Carta Oficial & 14/Maio/1799 \\
\hline 664 & 46 & $1 \mathrm{r}$ & Carta Oficial & 14/Maio/1799 \\
\hline 665 & 46 & $1 \mathrm{v}$ & Carta Oficial & 14/Maio/1799 \\
\hline 666 & 46 & $2 \mathrm{r}$ & Carta Oficial & 14/Maio/1799 \\
\hline
\end{tabular}


continuação

\begin{tabular}{|c|c|c|c|c|}
\hline $\begin{array}{c}\text { No. Doc. Banco de } \\
\text { Dados UEL }\end{array}$ & No. Doc. & Fólio & Tipologia & Datação \\
\hline 667 & 47 & $1 \mathrm{r}$ & Carta Oficial & $07 / \mathrm{Julho} / 1800$ \\
\hline 668 & 47 & $1 \mathrm{v}$ & Carta Oficial & $07 / \mathrm{Julho} / 1800$ \\
\hline 669 & 47 & $2 \mathrm{r}$ & Carta Oficial & $07 / \mathrm{Julho} / 1800$ \\
\hline 670 & 47 & $2 \mathrm{v}$ & Carta Oficial & $07 / \mathrm{Julho} / 1800$ \\
\hline 671 & 47 & $3 \mathrm{r}$ & Carta Oficial & $07 / \mathrm{Julho} / 1800$ \\
\hline 672 & 47 & $3 \mathrm{v}$ & Carta Oficial & $07 / \mathrm{Julho} / 1800$ \\
\hline 673 & 48 & $1 \mathrm{r}$ & Carta Oficial & $07 / \mathrm{Julho} / 1800$ \\
\hline 674 & 48 & $1 \mathrm{v}$ & Carta Oficial & $07 / \mathrm{Julho} / 1800$ \\
\hline 675 & 48 & $2 \mathrm{r}$ & Carta Oficial & $07 / \mathrm{Julho} / 1800$ \\
\hline 676 & 49 & $1 \mathrm{r}$ & Carta Oficial & $08 /$ Dezembro/1800 \\
\hline
\end{tabular}

Para fins de esclarecimento, o termo 'documento' é entendido neste trabalho como "todo registro material de informação" e, segundo Gonçalves (1998, p. 18), "costumam apresentar elementos característicos comuns: suporte, forma, formato, gênero, espécie, tipo e contexto de produção". Em um primeiro momento, pode-se asseverar que os documentos em estudo apresentam como suporte: papel; forma: cópia; formato: folha; e gênero: documentação textual. Quanto a espécie e tipo, esses documentos foram classificados como cartas oficiais e lista de itens, adotando os conceitos de Spina (1987) e Belloto (2002). Os dois autores atribuem ao gênero carta as mesmas características, ou seja,

... a carta possui certa padronização: Protocolo Inicial: datas tópica e cronológica. Endereçamento. Direção. Texto e Protocolo Final: fecho de cortesia, assinatura, nome e cargo do signatário. Questões de caráter oficial ou particular que se desejasse expor ao Rei, quaisquer que fossem os assuntos, desde que não de caráter peditório, eram-lhe dirigidas por meio de carta. (BELOTTO, 2002, p. 52).

Já os documentos 09 e 19 foram classificados como lista baseando-se nos conceitos de Belloto (2002, p. 72): “LISTA/LISTAGEM - documento não-diplomático testemunhal de assentamento ou informativo. Rol de nomes ou itens diversos reunidos com uma finalidade específica". 
Em resumo, a tipologia documental dos manuscritos em questão é de cunho administrativo, caracterizada como Cartas Oficiais e Lista de itens, emitidas pela Câmara de Vereança de Paranaguá a autoridades supremas como governadores gerais de São Paulo ou do Rio de Janeiro.

Dando continuidade ao trabalho, este tem por objetivo geral fazer o estudo do léxico no município de Paranaguá-PR, propondo uma discussão sobre manutenção, tendência à manutenção, desuso e tendência ao desuso de lexias extraídas de fontes manuscritas setecentistas, datadas da mesma localidade. Os objetivos específicos são: (i) traçar o panorama histórico da área estudada para auxiliar na compreensão dos aspectos socioculturais; (ii) fazer a edição semidiplomática, acompanhada da reprodução fac-similar dos documentos manuscritos, servindo de base para a caracterização do estado da língua setecentista; (iii) elaborar o glossário visando apresentar a definiç̧ão dos itens lexicais selecionados com acepções e abonações extraídas do corpus escrito; (iv) investigar as lexias selecionadas por meio dos dados orais coletados com auxílio do questionário semânticolexical, adotando para a seleção dos informantes as variáveis sociais: faixa etária, sexo, naturalidade e grau de escolaridade; e, por fim, (v) verificar, a partir das lexias testadas, o grau de manutenção, tendência à manutenção, desuso e tendência ao desuso em relação às acepções registradas nos documentos em questão. A base teórico-metodológica que norteia esta pesquisa é a da Dialetologia, mas aproxima-se também das utilizadas em pesquisas filológicas (edição de documentos), lexicográficas (elaboração do glossário) e sociolinguísticas (pesquisa de campo e análise das lexias considerando células sociais).

O presente trabalho está organizado em dois volumes. O primeiro elenca o contexto histórico do corpus escrito, descrição e análise do estado da língua setecentista, tratamento dos dados linguísticos, processo da coleta de dados orais, análise semântico-lexical das lexias seletivas e considerações finais. Este volume está assim constituído:

Capítulo I - apresenta a reconstituição de dados históricos sobre formação do Estado do Paraná e do município de Paranaguá, com intuito de contextualizar o período pelo qual passava a região de origem dos documentos manuscritos. Historiadores como Negrão (1934), Viana (1976) e Santos (2001) afirmam que os textos produzidos em determinado período relatam os fatos que aconteceram nesse período e reforçam a questão de que viver da memória desses documentos é retratar os atos e fatos que foram testemunhados.

Capítulo II - discute a importância dos documentos manuscritos como fonte primária para os estudos diacrônicos, apresenta os tipos e critérios de edições e faz uma breve análise 
do estado da língua setecentista. A realização de edição de textos é primordial e a viabilização dos estudos diacrônicos da língua depende, principalmente, da realização de edições rigorosas e fidedignas, nas quais as características originais do texto sejam mantidas e, caso necessite de intervenções, que sejam necessárias para garantir a sua inteligibilidade.

Capítulo III - descreve o tratamento do corpus escrito, desde o levantamento de frequência, contagem e agrupamento dos vocábulos, com auxílio da ferramenta computacional Léxico 3, até a seleção de 259 vocábulos a serem testados na comunidade de Paranaguá, com o propósito de investigar os traços de manutenção, variação e mudança em relação às acepções registradas nos documentos em questão.

Capítulo IV - após a seleção dos vocábulos, deu-se início à elaboração do questionário semântico-lexical para, em seguida, aplicá-lo em pesquisa de campo com informantes pré-selecionados. O perfil do informante desta pesquisa contemplou indivíduos dos dois sexos, de duas faixas etárias - 18 a 30 anos e 50 a 65 anos - e de diferentes níveis de escolaridade (completos ou incompletos) - oito com nível fundamental (quatro de $1^{\mathrm{a}}$ a $4^{\mathrm{a}}$ séries iniciais e quatro de $5^{\mathrm{a}}$ a $8^{\mathrm{a}}$ séries finais), quatro com nível médio e quatro com grau superior. Buscou-se o total de 16 informantes naturais de Paranaguá e com pais de preferência pertencentes à mesma comunidade linguística.

Capítulo V - consiste na confecção de tabelas das ocorrências lexicais, classificação, acepções dos dicionaristas, análise semântico-lexical dos itens selecionados (descritos no capítulo III), a partir da acepção trazida nos documentos manuscritos e análise do contexto de fala dos informantes parnanguaras. Em seguida, apresenta a distribuição dos itens lexicais por manutenção, tendência à manutenção, desuso e tendência ao desuso, e as análises das variáveis: faixa etária, gênero e escolaridade.

A conclusão encerra o trabalho, seguida das referências, dos apêndices e dos anexos.

O segundo é composto pela edição semidiplomática acompanhada da reprodução fac- similar de cada fólio, em ordem cronológica, com a respectiva transcrição justalinear e pelo glossário de termos setecentistas.

Espera-se que os resultados da análise possam contribuir e, ao mesmo tempo, fornecer dados confiáveis aos estudos linguísticos sobre o estado de língua no período setecentista produzidos no Paraná. 


\section{Capútulo I}




\section{PERCURSO HISTÓRICO: BRASIL COLÔNIA ATÉ MUNICÍPIO DE PARANAGUÁ}

A história do Brasil já foi escrita várias vezes, por estudiosos renomados e à luz de farta documentação. Aqui se apresenta um mero resumo, destinado a dar o fundo histórico da época em que se redigiram os manuscritos do corpus. De fato, para quem estuda períodos um tanto recuados da história do idioma, será útil conhecer aspectos da sociedade na qual o idioma era utilizado, pois os acontecimentos históricos auxiliam a compreensão e interpretação de escritos antigos.

Em vista do que foi exposto, apresenta-se a seguir uma síntese da história do Brasil Colonial, a formação do Estado paranaense, focando principalmente a região litorânea Paranaguá durante o século XVIII, tendo como base os historiadores Abreu, Azevedo, Botelho e Reis, Calmon, Martins, Nascimento Junior, Negrão, Santos, Viana, Wachowicz e Westphalen.

O Brasil quinhentista, antes do sistema de colonização, se caracterizava por uma vastidão territorial com pouquíssimos núcleos de povoamento. Nos anos anteriores à fundação de São Vicente, o máximo de organização que ocorreu foram as feitorias, porém não de ordem política/administrativa, e sim de caráter comercial e militar. Alguns historiadores atribuem às feitorias os primeiros embriões de nossas cidades surgidas no litoral brasileiro, nos 30 primeiros anos do século XVI. Mas, segundo Azevedo (1956, p. 9), há certo exagero em afirmar que das feitorias resultaram núcleos de organização político-administrativa e que pouco a pouco foi se convertendo em aldeamento ou povoado, tornando- se vila ou cidade. Documentos remotos comprovam que as feitorias foram criadas em alguns pontos do litoral a fim de: (i) servir como ponto de embarque e desembarque das caravelas que buscavam o nosso pau-brasil; (ii) garantir a defesa dos exploradores contra os aborígines; e (iii) afugentar os navios piratas. Além disso, apresentava função econômica insignificante e extrema precariedade.

Portanto, Portugal inicia seu sistema de colonização, 30 anos depois de sua primeira expedição, chefiada por Pedro Álvares Cabral, quando descobriu a Terra de Santa Cruz, em 24 de abril de 1500. Foi o medo de perder a posse sobre a extensa terra da América, ameaçada pelos estrangeiros que excursionavam pelo Brasil, que fez Portugal 
enviar, em 1530, uma expedição chefiada por Martim Afonso de Souza² ao Brasil. Segundo Abreu (1963, p. 63), dentre essas pessoas estava também seu irmão: "anuncia-lhe el-rei a resolução de demarcar a costa, de Pernambuco ao rio da Prata, e doá-la em capitanias de cinquenta léguas: a de Martim teria cem; seu irmão Pero Lopes seria um dos donatários". A missão de Martim Afonso era combater os piratas franceses, fazer um reconhecimento da costa brasileira e indicar os melhores locais para iniciar o povoamento. Seus poderes são definidos em cartas régias ${ }^{3}$, podendo doar terras, nomear capitães- mores ${ }^{4}$ e oficiais de justiça e, onde for possível, organizar núcleos de povoados.

Em 30 de abril de 1531, depois de deixar soldados no litoral de Pernambuco, Martim Afonso chega à região da Guanabara. Depois, navega até o rio da Prata, que, pelo Tratado de Tordesilhas, está em território espanhol. Mesmo assim, manda uma de suas naus navegar rio acima, para explorar o interior, e toma posse da região em nome de Dom João III.

Ao retornar do Prata, Martim Afonso aporta na região de São Vicente, que já é um centro de comércio de índios escravizados. Com a ajuda de João Ramalho ${ }^{5}$, funda a vila de São Vicente, a primeira oficialmente criada na colônia, em 22 de janeiro de 1532.

\subsection{AdMinistraÇão COLONIAL}

Sem dinheiro para bancar os custos de um processo de colonização centralizado, Dom João III cria um novo plano com o objetivo de abranger todo o território e às custas de

\footnotetext{
2 Martim Afonso de Souza (1500-1571), filho de nobres portugueses, vive na corte desde muito jovem. Estuda matemática, cosmografia e navegação. É nomeado pajem do duque de Bragança e, mais tarde, do infante dom João, o príncipe herdeiro. Ao subir ao trono, dom João III garante a Martim Afonso posições de prestígio. Recebe o comando da primeira expedição colonizadora ao Brasil e, quando a colônia é dividida em capitanias, é nomeado donatário de São Vicente e do Rio de Janeiro. Em 1533, é nomeado capitão-mor do mar das Índias. Provido de muitos prestígios, é nomeado vice-rei das Î́ndias por dom João III, em 1542. O fim de sua carreira é controverso. Alguns historiadores dizem que Martim Afonso volta a Portugal em 1545 e assume um lugar no Conselho de Estado, onde fica até morrer. Outros afirmam que ele é chamado de volta a Portugal sob acusação de desvio de dinheiro da Coroa e enriquecimento ilícito, mantendo-se afastado da vida pública até morrer.

3 Documento expedido diretamente pelo rei e por ele assinado que continha determinação específica para uma autoridade (BOTELHO; REIS, 2008, p. 41).

${ }^{4}$ Patente dos primeiros governadores das capitanias. [...]. No período colonial, sua função era manter a paz na localidade, vigiando estranhos e prendendo criminosos. Havia diversas autoridades coloniais nas vilas, como o juiz ordinário; mas, em algumas localidades, a autoridade máxima era o capitão-mor (BOTELHO; REIS, 2008, p. 37).

${ }^{5}$ Naufrágio acontecido entre os anos de 1512 e 1515, na costa de S. Vicente, de um navio português que vinha demandar a costa do Brasil, do qual escaparam os portugueses Antônio Rodrigues e o bacharel João Ramalho (SANTOS, 2001, p. 14).
} 
seus ocupantes - adota o modelo das capitanias $^{6}$ (já experimentara com sucesso nas possessões da África). Este fato pode ser confirmado nas palavras de Martins (1995, p. 201):

É ponto geralmente sabido da história do Brasil que o sistema de colonização adotado por Portugal nos seus domínios americanos foi o da divisão da costa do país em capitanias hereditárias, doadas a fidalgos que as pudessem fazer prosperar e defender, como com bom resultado já havia sido feito nas ilhas da Madeira e dos Açores.

Dessa forma, em 1534, são criadas as capitanias hereditárias (figura 1, na página seguinte). Consistia, cada uma delas, na porção de terra doada aos donatários, num total de doze, dentre eles Martim Afonso de Souza, que recebeu a maior fração em recompensa aos serviços prestados.

As capitanias só seriam transmitidas hereditariamente. Cada senhor de terra era senhor absoluto em seu território, tinha poderes para fundar vilas, aplicar a justiça, estipular e arrecadar tributos dos colonos, conceder sesmarias ${ }^{7}$, garantir a defesa da terra e de seus moradores, expulsar os invasores e enviar à Coroa uma parte do que arrecadava.

Dentro deste contexto, as capitanias que interessam ao presente estudo são: a de São Vicente, doada a Martin Affonso de Souza “desde a barra de São Vicente ou de Santos até 12 léguas ao sul da ilha de Cananéia" (MARTINS, 1995, p. 201); e a de Santo Amaro, doada a Pero Lopes de Souza, que "se estendia da Barra de Paranaguá até ao sul da Laguna" (MARTINS, 1995, p. 201). Os donatários das capitanias citadas anteriormente foram:

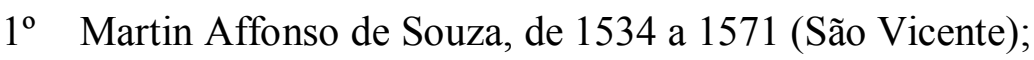

$2^{\circ}$ Pero Lopes de Souza, filho de Martin Affonso de Souza, de 1572 a 1586 (Santo Amaro);

$3^{\text {o }}$ Lopes de Souza, de 1587 a 1610 ;

$4^{\circ}$ Condessa de Vimieiro (Mariana de Souza Guerra) por cessão feita por Lopo de Souza, filho bastardo de Lopo de Souza e confirmação régia de 22 de outubro de 1621;

\footnotetext{
${ }^{6}$ Divisão territorial e administrativa estabelecida no Brasil desde o início da colonização. [...]. Na medida em que uma região era colonizada, criava-se a capitania, nomeando-se o administrador ou o delegado do rei. As capitanias foram designadas de províncias, no Império, e de Estados, na República (BOTELHO; REIS, 2008, p. 35).

7 Terra inculta doada ao sesmeiro. O direito de doação era atributo dos capitães donatários e, posteriormente, dos governadores das capitanias da Coroa. [...]. A doação de sesmaria findou apenas em julho de 1822. A palavra sesmaria origina-se de sesmar, repartir (BOTELHO; REIS, 2008, p. 189).
} 


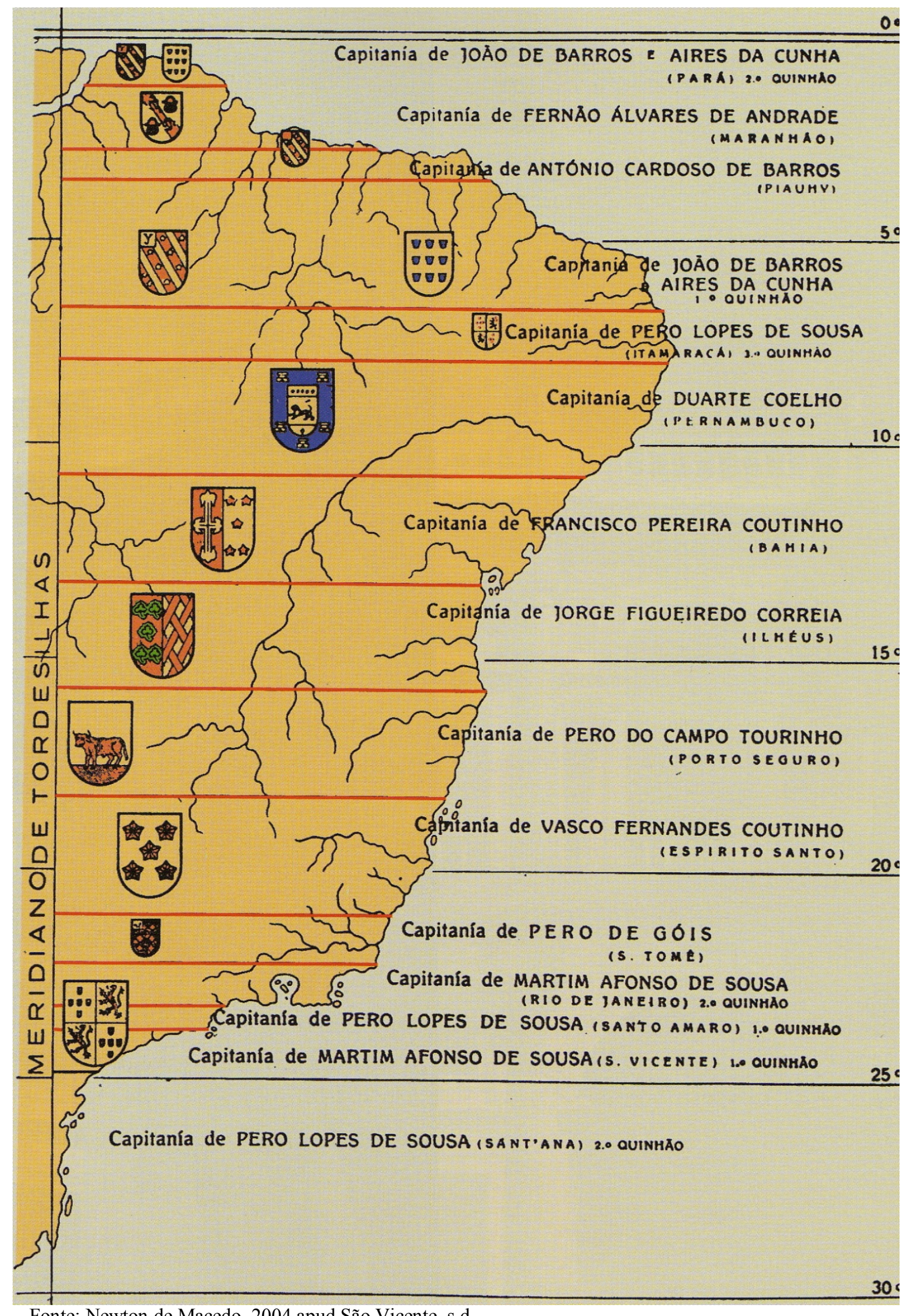

Fonte: Newton de Macedo, 2004 apud São Vicente, s.d.

Figura 1 - Capitanias hereditárias 
$5^{\circ}$ Conde de Monsato, D. Alvaro Pires de Castro e Souza, bisneto de Pero Lopes de Souza, que em 1623 expulsou de São Vicente a condessa de Vimieiro;

$6^{\circ}$ Martin Affonso de Souza, filho de Pero Lopes de Souza, da Capitania de Santo Amaro. A este sucedeu sua irmã;

$7^{\circ} \quad \mathrm{D}^{\mathrm{a}}$ Jeronima de Albuquerque Souza. A esta sucedeu sua filha;

$8^{\mathrm{o}} \quad \mathrm{D}^{\mathrm{a}}$ Isabel de Lima de Souza Miranda;

$9^{\circ}$ Lopo de Souza, donatário da Capitania de SãoVicente e também da de Santo Amaro por doação por sua prima D. Isabel Miranda;

$10^{\circ}$ D. Sancho de Faro de Souza, 1646;

$11^{\circ}$ Diogo de Faro de Souza, filho de D. Sancho, em 1648;

$12^{\circ} 1^{\circ}$ Conde da ilha do Príncipe, D. Luiz Carneiro, em 1678;

$13^{\circ} 2^{\circ}$ Conde da ilha do Príncipe, D. Francisco Luiz Carneiro, filho do precedente, em 1691;

14 Marquês de Cascais, D. Luiz Alvaro de Castro e Souza, até 1711. (MARTINS, 1995).

Estes capitães donatários ${ }^{8}$, segundo Abreu (1963, p. 64), "saíram em geral da pequena nobreza, dentre pessoas práticas da Índia, afeitas a viver ao largo da conquista [...]. Muitos nunca vieram ao Brasil, ou desanimaram com o primeiro revés. El-rei cedeu às pessoas a quem doou capitanias alguns dos direitos reais".

Nessas capitanias, os donatários foram senhores absolutos e deviam obediência apenas ao rei. Tinham autonomia civil e criminal sobre as terras cedidas, recebiam a propriedade sobre dez léguas de terra ao longo da costa e direitos de posse e usufruto sobre a produção do restante da capitania. Podiam fundar vilas, nomear ouvidores ${ }^{9}$ e tabeliães e doar lotes de terra - as sesmarias - aos cristãos que tinham condições de torná-las produtivas.

Com o fracasso das capitanias hereditárias, a Coroa Portuguesa implantou o Governo-Geral $^{10}$, cujo representante tinha o poder político para administrar as colônias em nome do rei. Das doze capitanias, só três prosperaram. Mesmo assim, Portugal não estava

${ }^{8}$ Responsáveis pela administração da capitania hereditária. [...]. O capitão era fiscalizado por funcionários reais, subordinados à Coroa (BOTELHO; REIS, 2008, p. 36).

9 Mais alta autoridade judiciária nas capitanias, exercia jurisdição sobre o crime e o civil. De acordo com os regimentos, dirigiam também o policiamento (BOTELHO; REIS, 2008, p. 145).

${ }^{10}$ A criação legal do governo-geral, na verdade, se deu em 1548, pelo Regimento de 17 de dezembro, entretanto, somente em 7 de janeiro de 1549, D. João III nomeou Tomé de Souza como governador-geral, que desembarcou na Bahia em 29 de março (BRAGA, 2008, p. 187). 
contente com o resultado obtido pelos donatários, não estava lucrando com a colônia e ainda se sentia ameaçado pelos insistentes estrangeiros contrabandistas. Então, na tentativa de reverter a quadro político-econômico, cria o novo sistema administrativo.

Com o governo-geral, as capitanias fracassadas que não possuíam herdeiros, ou após indenização aos seus donatários, passaram para domínio real, como previsto nos forais. O governador-geral e capitão-mor do Brasil, com poderes outorgados antes dos donatários, tinha por missão aplicar a justiça, garantir a defesa da terra e arrecadar tributos. (BRAGA, 2008, p. 187).

Com o fim da era filipina, Portugal encontra-se falido, sem recursos para se reestruturar. Neste momento, seu principal trunfo é iniciar um sistema de centralização administrativa e política na colônia, concedendo-lhe maior autonomia sobre os concelhos.

Ciente de que os recursos da agricultura não eram suficientes, incentiva algumas bandeiras em busca de ouro. Com este novo plano político e econômico, iniciam-se transformações sociais na estrutura territorial do país.

\subsubsection{As Câmaras Municipais}

As Câmaras Municipais são instituições antigas herdadas dos colonizadores portugueses. Durante o período colonial, as Câmaras só eram implantadas com a elevação de vilas, concedidas através do Ato Régio. "Criada a vila, a seis léguas uma da outra (no interior do país) e levantando o pelourinho no centro duma praça, estava instalado o município" (TONIOLO, 2007). A primeira vila do Brasil foi fundada por Martim Afonso de Souza, em 1532, quando foi organizado, em São Vicente, o primeiro concelho com a nomeação dos vereadores. Segundo Miranda (2002, p. 56-57), nesta época, as Câmaras Municipais exerciam um número bem maior de funções do que atualmente:

A Câmara Municipal de São Paulo fiscalizava o comércio, cuidava de pesos e medidas, arrematação de contratos para o abastecimento de gêneros essenciais, como o sal e a farinha, cuidava da feitura das leis e da justiça, ocupava-se da defesa da cidade, legislando acerca do fardamento, do pagamento de soldos das companhias de ordenança e das tropas, expedia ordens, além de se ocupar das questões da administração pública. Cabia 
ainda à Câmara Municipal tratar dos caminhos e pontes da cidade convocando os moradores para as necessárias construções e reparos.

Além das várias funções exercidas pelas Câmaras Municipais, elas "foram igualmente órgãos fundamentais de representação dos interesses e das demandas dos colonos" (BICALHO, 1998, p. 252).

No período colonial, toda organização jurídica, política e administrativa das casas legislativas municipais fundamentava-se nas Ordenações Manuelinas (1521-1580) e, mais tarde, nas Ordenações Filipinas (1580-1640).

As Ordenações garantiram funções judiciais, administrativas e legislativas às Câmaras. Nas Ordenações é que aparece a figura do vereador, em substituição aos alcaides. Segundo Negrão (1934, p. 79), a administração do município, no começo do século XVII, era composta de três vereadores (eram eleitos entre os proprietários de terra e de escravos), dois juízes ordinários ${ }^{11}$ - de eleição popular - ou um de fora - nomeado pela coroa -, um procurador, um tesoureiro (onde houvesse), senão o procurador acumulava as funções, todos eleitos pelos "homens bons"12, e os demais oficiais escolhidos pela Câmara, como os almotacés (ou fiscais) e os escrivões.

Competia aos juízes a aplicação da justiça, julgando as infrações civis e criminais que tivessem conhecimento, aplicando a devida pena, se assim fosse o caso. Eram executadas pelos alcaides ou meirinhos (oficiais do concelho) as prisões determinadas pelos juízes.

Aos vereadores competia manter a ordem das vilas, aplicando correição e, quando não acatada, criavam-se novas posturas. Também era obrigação deles verificar as contas do procurador e do tesoureiro do ano anterior.

Pode-se afirmar que o procurador era o representante legal do povo junto à Câmara. Cabia a ele as reivindicações populares. Entre as suas funções, competia a ele levar ao

\footnotetext{
${ }^{11}$ Maior autoridade judiciária de vila que não fosse sede de comarca. [...]. Eram eleitos anualmente e não recebiam vencimento fixo. Normalmente, esses juízes eram pessoas sem grande instrução formal no campo do direito, sendo comum pagarem advogados para auxiliá-los nas setenças (BOTELHO; REIS, 2008, p. 115).

${ }^{12} \mathrm{Na}$ seguinte passagem, Macedo (1999) explica com detalhes o que significa 'homens bons': "[...] A lei portuguesa exigia no mínimo 30 famílias, ou como diziam na época 'fogões', para que uma localidade tivesse autoridades e Câmara Municipal. Esses 30 homens casados tinham que ser proprietários de terras, por isso eram também chamados de 'homens bons'. Os outros, que não tinham bens, não eram considerados 'maus', mas por serem pobres não eram contados como aptos a votar para eleição das autoridades" (MACEDO, 1999, p. 10).
} 
conhecimento do Conselho as demandas e questões da população, fazendo com que esta pudesse ser ouvida pelas autoridades municipais.

O escrivão exercia a função de escriturar todos os documentos, inclusive contábeis, e também tomar nota de todas as decisões da Câmara.

Os almotacés eram funcionários oficiais da administração colonial encarregados de realizar várias funções, tais como: providenciar para que não faltassem alimentos, verificar e conferir medidas e pesos dos gêneros alimentícios, promover a limpeza das ruas, fiscalizar a execução das posturas municipais, etc.. Segundo Botelho e Reis (2008, p. 17), esses funcionários exerciam esses deveres sem receber vencimentos.

Esses oficiais da Câmara Municipal representavam o poder supremo da colônia, tinham força para exercer, em seu território, a voz mais poderosa, "demonstrando assim uma certa tendência ao auto-governo" (BICALHO, 1998).

Pela ineficiência das capitanias, o exercício destas funções tornou-se imprescindível, uma vez que os colonos necessitavam de representantes para suprir suas demandas.

Para Calmon (1961, p. 1281), a Câmara Municipal era a "única instituição de fato existente na Colônia", por isso a defesa da vida e dos bens eram representadas por estas assembleias.

Pode-se concluir que, no período colonial, a função das Câmaras ia além de cobranças de impostos e de boas condutas, era sinônimo de ordem e defesa a favor do povo.

Naquilo que o povo reivindica, a Câmara agia com o objetivo de defender seus interesses. O povo era a vila, a vila era o município, o município era a câmara, e por fim, esta era a estrela solitária da organização política existente onde o povo se identificava e agasalhava-se. (BRAGA, 2008, p. 192). 


\subsection{ECONOMIA COLONIAL}

\subsubsection{Cana-de-Açúcar}

O cultivo da cana-de-açúcar é introduzido no Brasil por Martim Afonso de Souza, na Capitania de São Vicente. Seu apogeu ocorre entre 1570 e 1650. Estimativa do final do século XVII indica a existência de 528 engenhos na colônia. O monopólio português sobre o açúcar assegura lucros consideráveis aos senhores de engenho e à Coroa. Esse monopólio acaba quando os holandeses começam a produzir açúcar nas Antilhas, na segunda metade do século XVII.

\subsubsection{Escravidão Indígena e Negreira}

Até meados do século XVIII, a caça ao índio é um negócio local e os ganhos obtidos com sua venda permanecem nas mãos dos colonos, sem lucros para Portugal. Por isso, a escravização do nativo brasileiro é gradativamente desestimulada pela metrópole e substituída pela escravidão negra. O tráfico negreiro é um dos mais vantajosos negócios do comércio colonial e seus lucros são canalizados para o reino. A primeira leva de escravos negros que chega ao Brasil vem da Guiné, na expedição de Martim Afonso de Souza, em 1530.

\subsubsection{Mineração}

O chamado "ciclo do ouro" traz uma grande diversificação social para a colônia. Segundo Furtado (1963, p. 94), “O estado de prostração e pobreza em que se encontravam a Metrópole e a colônia explica a extraordinária rapidez com que se desenvolveu a economia do ouro nos primeiros decênios do século XVIII". Na passagem do século XVII para o XVIII, são descobertas ricas jazidas de ouro no centro-sul do Brasil. A Coroa Portuguesa, sob o 
reinado de D. José I, volta toda sua atenção para as terras brasileiras. A região das minas torna-se polo de atração de migrantes: portugueses em busca de fortuna, aventureiros de todas as regiões do Brasil e escravos trazidos do Nordeste.

\subsubsection{Pecuária}

Os primeiros colonizadores espanhóis assim que chegaram em terras sul-americanas se surpreenderam por não haver aqui nenhum animal doméstico. Após esta constatação, Cristóvão Colombo, em 1494, retorna à América com os primeiros exemplares de cavalos (AGUILERA; VASCONCELOS, 2012, p. 347). Na história do Brasil, segundo Goulart (1964, p.43), somente a partir de 1520, por ordem do Governador do Maranhão, "vieram os primeiros cavalos".

Durante o período da indústria açucareira, que se estendeu até o século XVII, os bois e cavalos foram empregados com o intuito de produzir força motriz aos engenhos, como também auxiliar no transporte do produto do açúcar.

Como o ciclo da mineração (começo do século XVIII), inicia uma nova fase econômica no Brasil Colônia, principalmente no interior do país. Com o auxílio das tropas cavalares e de muares foi possível desbravar regiões antes inóspitas, surgindo assim, inúmeras vilas que hoje constituem importantes cidades brasileiras. De acordo com Simonsen (1977, p. 187), este novo modelo econômico destacou-se devido à importância da pecuária para o desenvolvimento econômico do país.

Dessa forma, a pecuária é considerada um fator essencial na ocupação e povoamento do interior, se desenvolvendo no vale do rio São Francisco e na região sul da colônia. Muitos proprietários arrendam as regiões mais distantes a pequenos criadores, contribuindo para a formação de novos arraiais. Furtado (1963, p. 98) elucida ainda que, “Ao contrário do que ocorrera no Nordeste, onde se partiu de um vazio econômico para a formação de uma economia pecuária dependente da açucareira, no Sul do país a pecuária preexistiu à mineração". 


\subsubsection{Café}

O café entrou no Brasil pelo Pará, trazido da Guiana Francesa pelo sargento-mor Francisco de Melo Palheta, em 1723. Durante o século XVIII, seu cultivo limita-se ao nordeste, onde os solos não são adequados. O café chega ao Paraná através de agricultores paulistas que, ao conhecerem a fertilidade da terra roxa, investem nesta plantação. Portanto, a cafeicultura só se desenvolve a partir do século XIX, quando o produto começa a ser cultivado na região Sudeste.

\subsection{EXPANSÃo TERritorial RUMO AO EXTREMo SUL}

A expansão e ocupação territorial foram consequências de ordem econômica e política, visando aos interesses dos colonos e da Metrópole. Os principais fatores responsáveis pela expansão territorial foram: a busca de mão de obra indígena, a pecuária e a mineração, que resultaram na ocupação de terras para áreas além dos limites do Tratado de Tordesilhas. Essa política de expansão foi estimulada pela Coroa Portuguesa.

Tive como núcleo de irradiação a Capitania de São Vicente, especialmente a cidade de São Paulo. Com o declínio da produção açucareira, a capitania passa a viver de uma economia de subsistência, aprisionando índios para usá-los como mão de obra doméstica, sendo os aldeamentos jesuíticos os alvos principais. Com uma população pobre, o único meio foi procurar recursos fora do território paulista, daí a formação das bandeiras.

Os bandeirantes ingressam, então, numa fase de apresamento maciço, penetrando no sertão, atacando as missões jesuíticas, localizadas na região do Paraná, Paraguai e Rio Grande do Sul, onde milhares de índios trabalhavam na terra ou no pastoreio.

Com o início do tráfico de negros, trazidos por Portugal ao Brasil, há uma mudança do quadro econômico na colônia portuguesa. Os colonos preferem o trabalho do escravo negro, por considerá-lo mais produtivo que o indígena brasileiro. Além disso, os lucros do comércio escravista passam para os portugueses, deixando de ser dos paulistas bandeirantes. 
Dessa forma, o apresamento indígena entra em declínio, deixando como resultado a escravidão de milhares de índios, a destruição das missões e a ruptura da linha de Tordesilhas, penetrando em terras espanholas que, mais tarde, seriam incorporadas ao Brasil.

Nesse contexto, a Coroa Portuguesa, ansiosa em aumentar sua arrecadação, incentiva a busca de metais preciosos, prometendo honrarias e privilégios aos que descobrissem minas. Assim, os bandeirantes paulistas, que atravessavam a decadência da preação de índios, devido ao restabelecimento do tráfico negreiro, partem para o interior em busca de metais preciosos.

A expansão em direção ao sul, num primeiro momento, dirige-se por mar para o rio da Prata, porta de entrada para o interior do continente. Uma segunda rota de ocupação parte de Laguna e desce ao sul por terra. Em geral, é feita por paulistas que chegam ao pampa à procura de gado xucro, introduzido na região pelos jesuítas e que se reproduzia em grandes manadas sem donos, quando os religiosos são expulsos do Brasil.

Baseando-se em dados de Aguilera e Vasconcelos (2003), durante os séculos XVII e XVIII, a atividade mineradora, as bandeiras de preação de índios e a criação de gado foram responsáveis pela ocupação do planalto curitibano, tornando indispensável a mão de obra indígena para a realização das três atividades.

No caso da mineração, economicamente falando, esta atividade serviu apenas de origem aos primeiros arraiais, tanto no litoral como no planalto curitibano, embriões das cidades de Paranaguá (1640), Curitiba (1668), Antonina (1714), Bocaiúva do Sul (1710), Morretes (1769) e São José dos Pinhais (1741).

Passado o ciclo do minério, a partir de 1730, outra fase econômica - a da criação e do comércio de gado - vem contribuir para o povoamento do território paranaense, incentivando a conquista de áreas até então desertas ao longo desse caminho, dando origem ao tropeirismo, que propiciou a formação dos núcleos populacionais conhecidos hoje como Lapa (1731), Ponta Grossa (1751), Castro (1751), Palmeira (1819), Jaguariaíva (1823), Rio Negro (1827) e Piraí do Sul (1872).

Em suma, o período colonial começa com a expedição de Martim Afonso de Souza, em 1530, e vai até a Proclamação da Independência por Dom Pedro I, em 7 de setembro de 1822. 


\subsection{PARANÁ: SíNTESE HistóRICA}

As primeiras movimentações de colonizadores no atual território paranaense tiveram início no século XVI, quando diversas expedições estrangeiras percorreram a região à procura de madeira de lei, embora não existisse ali pau-brasil. No século XVII, portugueses e paulistas começaram a ocupar a região, a partir da descoberta de ouro e da procura de índios para o trabalho escravo. A mineração, no entanto, foi relegada a segundo plano pelos colonizadores, que se dirigiram em maior número às terras de Minas Gerais. Azevedo (1956, p. 47), ao traçar a geografia das vilas no período setecentista, observa que "no século XVIII, a 'Região Sul' assistiu à criação de apenas 20 novas vilas, isto é, bem menos da metade do total registrado no Leste, que foi de 48". Segundo este autor, a Região Sul não possuía nenhuma riqueza econômica que justificasse a manutenção do ritmo anterior de seu crescimento demográfico e urbano. Por este motivo, "deslocara-se para o Leste brasileiro o eixo econômico, social e demográfico da então Colônia, graças ao ciclo do ouro e das pedras preciosas [...]”. (AZEVEDO, 1956, p. 47).

Macedo (1999, p. 16) comenta que a extinção da Capitania de Paranaguá, “tem sua origem no desinteresse do Marquês de Cascais pelas nossas terras, a partir do desaparecimento dos veios de ouro". Deste momento em diante, ocorre a transferência da história jurídica do 'nosso território' para os anais de São Paulo. A soma desses fatores retardou a ocupação definitiva da área paranaense, que pertenceu à província de São Paulo até meados do século XIX, com sua economia baseada na pecuária.

Portanto, até o século XVIII, existiam apenas cinco vilas na Região Sul: Nossa Senhora do Rosário de Paranaguá (1653), Nossa Senhora da Luz dos Pinhais de Curitiba (1693), Vila Nova de São Luís de Guaratuba (1771), Antonina (1797) e Castro (1798). (AZEVEDO, 1956).

Atualmente, o território paranaense concentra sua economia no setor agroindustrial. É um dos Estados brasileiros de maior expressão na produção agrícola. Suas “características geográficas, aliadas à fertilidade de suas terras, fazem com que o seu desenvolvimento econômico se processe através de seu interior" (MAACK, 1981, p. 82).

Já o litoral paranaense, de pequena dimensão - o $2^{\circ}$ menor do país -, pode ser considerado, de acordo com uma visão desenvolvimentista, como "uma zona de passagem ou uma porta para o oceano" (MAACK, 1981, p. 82). Essa escassa proporção da costa 
paranaense é mais detalhada por Nascimento Junior (1980a, p. 35): “Tão pequeno é o litoral paranaense que, de uma elevação de poucos metros, pode-se avistar montanhas de um e de outro Estado"13.

O esteiro paranaense constitui cinco baías: Paranaguá, Antonina, Laranjeira, Pinheiros e Ibupeva, "formando todas em conjunto e sem solução de continuidade, a mais vasta extensão interior de águas, um verdadeiro Mediterrâneo, em cujas margens poderiam assentar numerosos portos" (NASCIMENTO JUNIOR, 1980a, p. 35).

Portanto, a conquista do Estado do Paraná se deu através de Paranaguá, quando os primeiros colonizadores ali se fixaram, surgindo assim, o primeiro núcleo de povoamento: Vila Nossa Senhora do Rosário de Paranaguá.

\subsection{Paranaguá: ConteXto Sócio-Histórico}

Quando se leem os manuscritos, verifica-se a ausência de certas informações específicas que dificultam a compreensão do conteúdo de cada um deles. Por isso, fez-se necessário encontrar maiores detalhes que esclarecessem o assunto dos documentos manuscritos de Paranaguá durante o século XVIII. Por meio das várias literaturas consultadas, foi possível reconstituir o contexto histórico- social dessa cidade, que, como já se fez referência, surgiu devido às minas de ouro. Portugal sempre almejou encontrar ouro em terras brasileiras, por isso, ao ter notícia de minérios na região litorânea do Paraná, incentiva a política de povoamento, que daí em diante só cresceu. Entretanto, formado o arraial, as famílias de bem que seguem a doutrina cristã, reivindicam a presença de padres, bem como de educação e cultura para seus filhos. Em meio a este contexto, os parnanguaras solicitam a presença dos padres jesuítas, prometendo-lhes a construção de um colégio, residência, dinheiro e propriedade para o estabelecimento da agricultura.

Os documentos aqui editados, em sua maior parte, requerem à autoridade suprema da época - com maior frequência ao governador-geral das Capitanias e, em outros casos, ao Rei de Portugal -, maior segurança na vila, melhores condições de vida, construção do colégio e fixação dos padres da Companhia de Jesus.

\footnotetext{
${ }^{13}$ Refere-se aos Estados vizinhos São Paulo e Santa Catarina.
} 
Assim, este subitem apresenta uma síntese das informações coletadas nos livros de história, tendo como diretriz básica o conteúdo dos manuscritos, procurando esclarecê-los e, simultaneamente, lançar luz aos textos das obras históricas consultadas, inserindo excertos dos manuscritos para ilustrar os pontos históricos.

\subsubsection{Povoação e Fundação de Paranaguá}

Domingos Peneda, fundando a Aldeia de Paranaguá, lançou a "semente" da civilização, do labor e do progresso. Ela foi boa; vingou e deu frutos. Mas o solo indigena também foi dadivoso. Ambos se completaram - terra e semente - numa união fraterna e indissolúvel!... (VIANA, 1976, p. 13)

O estudo das origens confusas da sociedade brasileira, nos primeiros e esparsos núcleos de povoamento do litoral nos dois primeiros séculos da descoberta, oferece apenas uma pálida ideia do que seriam esses agrupamentos humanos, isolados e distanciados uns dos outros por dezenas ou centenas de léguas entre si, mantendo rara comunicação (AZEVEDO, 1956). Este fato pode ser corroborado numa passagem do manuscrito que segue:

[Doc.01, fol. 1r, 11/novembro/1721]

Excelentissimo Senhor

Aos 11 de outubro reçebemos a carta

de Vossa Excelencia, com a qual nos fazia a honrra

e muita de notesiarnos a decisaõ, que Sua Magestade

que Deos guarde foi seruido fazer das Capi=

tanias de Sam Paullo, e agregar esta Villa

ao Gouerno de Vossa Excelencia. Bem se deixa ver

a Real benignidade de Sua Magestade em=

querer fauoreçer, e amparar a estes

seus vassallos, que pella distan

çia dos Senhores Generais naõ podiaõ ser

tambem ouuidos, nos seus requerimentos

como o seram, agora de Vossa Excelencia, como sua

Ilustre fidalgia nos está asegurando. 
Longe da metrópole, só a espaços distanciados de meses, recebiam notícias por uma ou outra caravela desgarrada das frotas e que em arribada ${ }^{14}$ ou em serviço do Rei visitava as povoações da costa. Tais núcleos deviam constituir, por efeito desse isolamento, redutos dentro dos quais a necessidade de defesa contra tantos inimigos era a única determinante da união de indivíduos corajosos. Pedidos constantes eram enviados a autoridades da época, suplicando auxílio e ajuda para a defesa das vilas:

[Doc.12, fol.1r, 25/Agosto/1722]

[...] E nella tambem

demos a Vossa Excelentissima em como esta

Terra tem tres barras abertas por

onde emtram embarcassonins, e

por huã navios de alto bordo como

o tem experimentado estava

sem mais fortificaçaõ, ou de

fenssam que os moradores della com

a âvulssam de suas propias pesso

as, com que acodem aos rebates a de

fender o impeto dos varios estran-

geiros. Pella qual experauamos

segunda resoluçam de Vossa Excelentissima;

e como thê o presente a nam temos

tido, Resoluemonos a mandar -

este proprio com esta a Vossa Excelentissima

pondonos com ella aos seus pés,

para que queira compadecersse deste

povo, e moradores desta Villa, a que

nam seja jente della por [ser]

com portos abertos e sem for-

tificaçam alguã. $\mathrm{O}$ que espe

[Doc.12, fol.1v, 25/Agosto/1722]

Experamos da benignidade

de Vossa Excelentissima, e em sermos bem

sucedidos no que lhe Representa

mos nestas suplicas.

Assim sendo, a história de Paranaguá, à luz de documentos, começa com a ação de Gabriel de Lara, que promoveu o povoamento, a agremiação dos selvagens restantes das preações às atividades dos povoadores, o descobrimento e exploração do ouro, a organização

\footnotetext{
${ }^{14}$ Arribada significa: Náut. Entrada em porto a que não se destinava o navio, por causa de um temporal ou qualquer outro imprevisto (CALDAS AULETE, 1948).
} 
social e a sua fundação política e administrativa. Entre as cidades do Paraná, Paranaguá merece um destaque todo especial, dadas as circunstâncias como foi fundada e, principalmente, quanto aos fatores sociais, econômicos, culturais e religiosos.

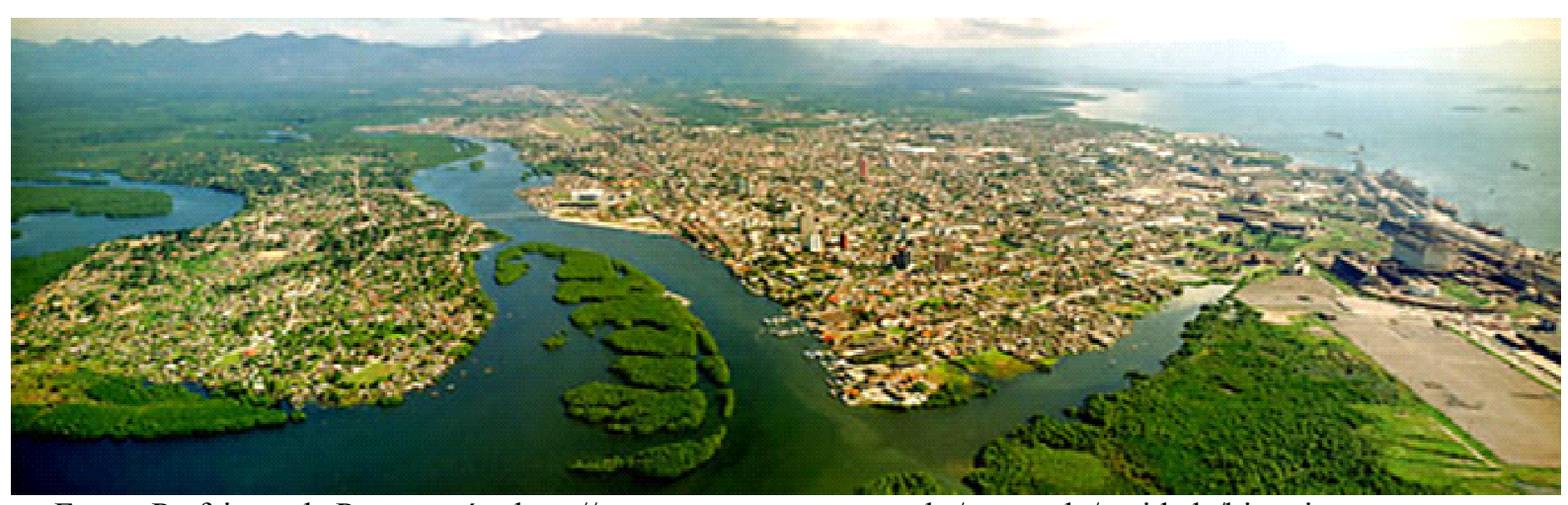

Fonte: Prefeitura de Paranaguá. <http://www.paranagua.pr.gov.br/conteudo/a-cidade/historia >

Figura 2 - Vista aérea do município de Paranaguá

Segundo alguns historiadores, a descoberta da costa paranaense data de 1531, quando chegou a Cananéia a expedição de Martim Afonso de Sousa, cuja missão era percorrer e explorar a costa brasileira até o rio da Prata.

Receosos de ataques dos índios Carijó ${ }^{15}$, que habitavam o continente, esses moradores se estabeleceram na ilha do Cotinga, formando um arraial. O historiador Antônio Vieira dos Santos

... calcula que a região do litoral contava então com seis a oito mil índios. Não foram, entretanto, estes comerciantes ou preadores de índios que iniciaram o povoamento permanente no litoral, [...] foi somente com a notícia do descobrimento de ouro, nos ribeirões da baía de Paranaguá, que para aí se dirigiu grande número de habitantes vindos de Santos, São Vicente, Cananéia, São Paulo e até do Rio de Janeiro, atraídos pelo alvorôço levantado com o descobrimento. (WACHOWICZ, 1967, p. 26).

\footnotetext{
${ }^{15}$ A nação dos índios Carijó ocupava habitantes desde os montes da Juréia, ou desde Cananéia, e povoavam toda a costa até a Ilha de Santa Catarina. Dos aborígenes foram os Carijó os mais afáveis e por isso os primeiros apreendidos pelos Vicentistas (SANTOS, 2001, p. 12).
} 
Depois de alguns anos, esses colonos tiveram maior afinidade com os aborígines, a ponto de passarem suas habitações para terra firme, às margens do rio Taquaré, conhecido atualmente como Itiberê. Hoje, neste local, situa-se a cidade de Paranaguá.

Acredita-se que, de 1560 em diante, os primeiros povoadores, alojados na Ilha da Cotinga, foram se arriscando a pisar a terra firme e a subir os rios de nossa baía, à medida que iam negociando com os índios Carijó. Dentre estes pioneiros, Domingos Peneda ${ }^{16}$ foi a pessoa de maior destaque:

No ano de 1550 (metade do século XVI), Domingos Peneda, Diogo de Unhate, velho bandeirante e outros aventureiros, chegam às praias de Ararapira e Superagüi, e em plena baía, ficam extasiados ante tamanha beleza. Principiam logo a construir as primeiras habitações e fundam assim um núcleo ao sopé do morro. [...] Fundado o primeiro 'arraial', trataram de conquistar a amizade da tribo 'carijó', que habitava toda a margem esquerda do rio 'Taquaré'. Foi nessa histórica e secular 'Cotinga' de nossos ancestrais que surgiu o primeiro povoado de brancos, nele chantando-se o marco civilizador da terra paranaense [...]. Acontece, porém, que a terra habitada por essa valente tribo, já possuía o gracioso nome de 'Pernagoá' (grande mar redondo), dado pela raça audaz. Nome que, com os anos, sofreu a corruptela de Paranaguá (Pernagoá - Parnagoá - Parnaguá - Paranaguá). (VIANA, 1976, p. 11).

Essa aldeia, já então de brancos e de índios, foi fundada durante a época da exploração das minas. O afluxo de habitantes oriundos das vilas e povoações do norte do país, atraídos pelo progresso da mineração, atingiu seu maior êxito por volta do ano de 1640. A existência de ouro naquele local despertou interesses da coroa portuguesa e acirrou a disputa pela posse da capitania entre os herdeiros de Martim Afonso de Souza. Com relação a esta contenda, o historiador Wachowicz (1967) comenta que, quando Dom João III dividiu o Brasil em capitanias hereditárias, o litoral paranaense pertenceu aos dois irmãos donatários: Martim Afonso de Souza e Pero Lopes de Souza. Ao primeiro coube a Capitania de São Vicente e ao segundo a de Sant'Anna. Nenhum dos dois irmãos interessou- se seriamente pelo progresso de suas capitanias. Após a morte desses donatários, surgiu o problema de herança do lado de Pero Lopes de Souza. De um lado D. Mariana de Souza, Condessa de Vimieiro, e seu marido, Diogo Vaz de Escobar, o Conde da ilha do Príncipe; de outro Luís Alvares de

\footnotetext{
${ }^{16}$ PENEDA não foi um Juiz formado; pouco estudo teve; apenas um homem rude. Todavia, procurou manter a Justiça, a seu modo, é verdade numa povoação ainda sem Leis e sem controle administrativo. Foi mau; implacável mesmo. Contudo, era a única solução para lidar com o gentio e mesmo com a massa ignara... Em tais circustâncias, qualquer outro faria assim (VIANA, 1976, p. 12).
} 
Castro e Souza, o Conde de Monsato, conhecido como Marquês de Cascais. O Conde da ilha do Príncipe, inconformado por ter perdido a causa na justiça, transferiu a sede de sua Capitania para Itanhaém, no litoral paulista. Ambas as facções continuaram disputando a posse das terras, que constituem hoje o litoral do Paraná.

Em meio a essa disputa, o Marquês de Cascais, a fim de organizar e defender seus interesses na Capitania de Paranaguá, nomeou Gabriel de Lara como capitão-mor ${ }^{17}$. Segundo Correa (1972, p. 221),

Gabriel de Lara, homem de largas vistas, tratou de conquistar a simpatia dos Penedas - família de maior preponderância -, casando-se com Brígida Gonçalves Peneda, [...] e, desde logo, passou a adquirir prestígio político, desempenhando em nossa terra um notável papel histórico, ocupando as mais eminentes posições.

Como foi citado anteriormente, Gabriel de Lara, nomeado, mais tarde, capitão, logrou impor-se aos paranaenses e aos governadores da capitania como legítimo representante da terra, conseguindo imprimir um cunho civilizador ao povoado, tanto é que, em 1646, consegue a ereção do pelourinho e sua nomeação para o cargo de capitão povoador ${ }^{18} \mathrm{e}$ sesmeiro $^{19}$ da Vila de Paranaguá. Por essas ações grandiosas, Lara tem um papel de destaque dentro da história de Paranaguá, pois conseguiu fazer o que Penedas, de certa forma, não fez: proporcionar o progresso desta vila.

\subsubsection{Capitania de Paranaguá}

A Capitania de Nossa Senhora de Paranaguá foi criada pelo Marquês de Cascais, sucessor hereditário de Pero Lopes de Souza. Este, na qualidade de herdeiro, conferiu plenos poderes a Gabriel de Lara, tornando-o administrador de todos os seus interesses, lugar-tenente e procurador, capitão- mor, ouvidor e alcaide-mor.

\footnotetext{
${ }^{17}$ Mor é forma sincopada da palavra maior. Capitão-mor era a maior autoridade local, porque representava o Governo Imperial e/ou o maior interessado. Este era um cargo indicado, enquanto que o Capitão povoador era eleito pelos moradores do povoado (STECA; FLORES, 2002, p. 4).

${ }_{18}$ Pessoa encarregada, nos tempos coloniais, de povoar uma região (WACHOWICZ, 1967, p. 38).

${ }^{19}$ Sesmeiro era o nome dado ao recebedor de terras do Capitão Donatário (STECA; FLORES, 2002, p. 4).
} 
A Carta Régia de D. João III, de 21 de janeiro de 1535, que fez doação a Pero Lopes de Souza, das 80 léguas de terra, autorizava-o e a todos os seus sucessores a criar vilas em toda e qualquer povoação. O Pelourinho, símbolo da criação da Vila, foi erigido em Paranaguá por Gabriel de Lara em 1646, portanto, dois anos antes da Ordem Régia que mandava criar a Justiça e proceder à eleição das autoridades locais. Em 1654, a Câmara deu posse da Vila a Diogo Vaz de Escobar, governador da Capitania de Itanhaém, assim reconhecendo ser a localidade pertencente ao conde da ilha do Príncipe, mas, em 1656, empossou a Simão Dias de Moura, igualmente governador da dita capitania, porém representante do Marquês de Cascais, que mantinha com o Conde acirrada demanda pela sucessão nos direitos do primitivo donatário da parte meridional da Capitania de Santo Amaro. Naturalmente, as disputas entre os herdeiros dos donatários foram a causa de tal demora, pois, do contrário, para essa instalação não seria necessária Ordem Régia, por ser atribuição privativa dos donatários e seus sucessores. Talvez esta seja uma explicação ao comentário de Martins (1995, p. 205): “A Capitania de Paranaguá [...] não passou de uma unidade de segunda ordem entre as demais capitanias e esteve sempre subordinada ao governo geral do Rio de Janeiro e depois ao de São Paulo".

A respeito dos capitães povoadores, estes tinham grandes poderes no começo do século XVII. Não se limitavam ao comando e governo militares, suas atribuições eram tanto de ordem militar como civil. Administravam os povos da sua jurisdição de forma quase absoluta. Comenta o historiador Francisco Negrão (1926, p. 108, grifos do autor):

Foi ao Capitão povoador Gabriel de Lara que o povo paranagüense recorreu, em 1646, solicitando a criação da justiça e da administração da Vila. Foi ao Capitão Gabriel de Lara que o Ouvidor Geral do Brasil, dr. Manoel Pereira Franco, escreveu, enviando a Carta Régia de 29 de Julho de 1648, autorizando-o a proceder à eleição das primeiras autoridades da villa de Paranaguá. Em virtude dessa autorização, Gabriel de Lara convocou o povo 'alimpar e apurar' - e com o seu resultado se conformou e deu posse aos eleitos a 7 de Janeiro de 1649.

Com o intuito de conhecer os capitães-mores da Capitania de Paranaguá, segue abaixo uma lista contendo os nomes e mais algumas informações que se julgam importantes. Apresentam-se em ordem cronológica desde sua criação, em 1660, até sua incorporação à Coroa, em 1711:

$1^{0}$ capitão Gabriel de Lara - nomeado alcaide-mor, capitão-mor e ouvidor e provedor da Capitania de Nossa Senhora do Rosário de Paranaguá, pelo Marquês de Cascais, de 
quem foi procurador, lugar-tenente e sesmeiro. Natural de São Paulo e filho de Diogo de Lara e de Antonia de Oliveira, faleceu em dezembro de 1682, em Paranaguá, ainda em exercício do seu cargo de capitão-mor;

$2^{\circ}$ capitão Tomaz Fernandes de Oliveira - de simples soldado foi promovido a alferes, tenente e capitão da Companhia de Infantaria de Ioloro-Angola. Com a morte de Gabriel de Lara, foi elevado ao cargo de capitão-mor, assumindo-o em $1^{\circ}$ de janeiro de 1683 até maio de 1689 ;

$3^{0}$ capitão Martins Leme - capitão-mor e lugar-tenente do Marquês de Cascais. Mesmo com idade já avançada, conservou-se no Governo, em Curitiba, até sua morte em 1697;

$4^{\circ}$ capitão Gaspar Teixeira de Azevedo - por patente de 7 de maio de 1689, confirmada a 20 de novembro de 1690, foi nomeado, por D. Pedro, II capitão-mor das minas da Capitania de Paranaguá. Exerceu o cargo de 1689 até sua morte, em 1712;

$5^{\circ}$ capitão Francisco da Silva Magalhães - por patente de 31 de dezembro de 1692, foi nomeado capitão-mor. Exerceu o cargo até sua morte, em 1707. Foi nomeado também ouvidor por Lei, em junho de 1682;

$6^{0}$ capitão João Rodrigues de França - foi nomeado capitão-mor por patente de 6 de dezembro de 1707, passada por D. Fernando de Mascarenhas e confirmada por D. João em 19 de janeiro de 1711. Exerceu o cargo até sua morte, em 1715. Foi o último capitão-mor, lugar-tenente e sesmeiro do donatário Marquês de Cascais, por ter este, em 1711, vendido a sua capitania à $\operatorname{Coroa}^{20}$;

$7^{\circ}$ sargento-mor Antonio Garcia - por patente de 20 de março de 1716 até setembro de 1717, exerceu cargo de capitão-mor. Foi nomeado por D. Francisco de Távora, governador e capitão-general da Capitania do Rio de Janeiro;

$8^{\circ}$ mestre de campo André Gonçalves Pinheiro - por patente de 17 de setembro de 1717, passada por Antonio de Brito Freire de Menezes, governador do Rio de Janeiro, foi nomeado capitão-mor. O posto militar de mestre de campo era equivalente ao de coronel. Foi, também, provedor dos quintos reais da Casa de Fundição de Paranaguá;

$9^{\circ}$ coronel Anastacio de Freitas Trancoso - era coronel-comandante do Regimento de Ordenanças da Capitania de Paranaguá e seus distritos. Exerceu por algum tempo o cargo de capitão- mor e o de governador. Em 1732, recebeu, do Conde de Sarzedas, a ordem de efetuar a prisão de toda e qualquer pessoa que passasse em Paranaguá

\footnotetext{
${ }^{20}$ A extinção da Capitania de Paranaguá foi devido ao desinteresse do Marquês de Cascais, quando por escritura de venda e quitação, de 11 de setembro de 1711, vende a Capitania de Paranaguá à Coroa Portuguesa, pelo preço de 40 mil cruzados, mais 4 mil cruzados de luvas (MACEDO, 1999, p. 16).
} 
vinda das minas de Cuiabá, devendo confiscar-lhe todo o ouro que houvesse em seu poder. Faleceu no ano de 1742;

$1^{\circ}$ capitão D. João Francisco Laynes - nomeado capitão-mor pela Câmara, tomou posse em 22 de junho de 1743;

$11^{\circ}$ capitão Antonio de Souza Pereira - faleceu no dia 24 de agosto de 1779;

$12^{\circ}$ capitão Antonio Ferreira Mathoso - foi nomeado por patente de 5 de setembro de 1763. Exerceu o cargo até março de 1766. Foi procurador dos bens do confisco dos padres da Companhia de Jesus;

$13^{\circ}$ capitão Manoel Nunes de Lima - foi nomeado pela Câmara em vereança e pelo seu sogro, sargento-mor Domingues Cardozo de Lima, a cargo de capitão-mor, por patente de 15 de dezembro de 1765. Faleceu neste mesmo ano;

$1^{\circ}$ capitão José Carneiro dos Santos - tomou posse do cargo em 8 de outubro de 1766. Em 29 de janeiro de 1789, obteve segunda patente de capitão-mor;

$1^{\circ}$ capitão Manoel Antonio Pereira - foi nomeado em março de 1815 e tomou posse em 22 de abril do mesmo ano. Foi o último capitão-mor de Paranaguá, por ter sido extinto esse cargo em 1833 e criado o de Prefeito.

De acordo com Negrão (1934), com a extinção da Capitania de Paranaguá, os capitães- mores passaram a ser nomeados trienalmente. A curta duração de sua gestão tornou o cargo mais acessível a muitos cidadãos, diminuindo, assim, o prestígio dos capitães-mores, pois, finalizado o seu mandato, estes voltavam às suas antigas profissões. O povo paranaense ficou, portanto, sujeito à jurisdição do governo de São Paulo, a partir de 1711.

Porém, em 9 de maio de 1748, por provisão Régia, as comarcas de São Paulo e a de Paranaguá foram anexadas à Capitania do Rio de Janeiro. A partir desta data, constantes conflitos de jurisdição se estabeleceram. Segundo Negrão (1934, p. 135), este fato desencadeou o declínio da então extinta Capitania de Paranaguá: “A anarchia invadiu a administração e a justiça entrou a perecer, retardada pela distancia em que ficava da sede do Governo. Entorpecido o progresso da antiga Capitania de Paranaguá, as energias de seus habitantes começaram a desfalecer".

Em 1765, por Carta Régia, foi restaurado o governo de São Paulo, ficando a Capitania de São Paulo no seu antigo Estado, sendo nomeado para governador e capitão general D. Luiz Antonio de Souza Botelho Mourão, o Morgado de Matheus.

Para o historiador Francisco Negrão (1934), a extinção do governo de São Paulo durante quase duas décadas foi um "grave erro político do Governo portuguez" (NEGRÃO, 
1934, p. 135), pois a grande extensão territorial dessa região, que fazia "fronteira meridional com os castelhanos do Prata, dos hespanhóes do Paraguay e parte das antigas reducções jesuíticas" (NEGRÃO, 1934, p. 135), ficou completamente abandonada, e "desse erro, hábil e geitosamente se aproveitaram os nossos visinhos, que acabaram ocupando grande parte do novo territorio" (NEGRÃO, 1934, p. 135). Deste episódio, Negrão (1934) conclui que o interesse da Coroa Portuguesa era somente a exploração do ouro, pouco importando o progresso e expansão do Brasil Colônia:

Só ao ouro dava a Metropole importancia; extinctas as minas de S. Paulo e de Paranaguá, e descobertas as Minas Geraes e Cuyabá, extinguiu-se o Governo daquelas Capitanias e creou-se o destas ultimas.

Era este o criterio politico do Governo lusitano, critério prejudicial ao Brasil, e de que se soube aproveitar a Corôa castelhana com visivel habilidade.

\subsubsection{Ouvidoria de Paranaguá}

De acordo com documentos históricos, desde a instalação da divisão territorial em capitanias hereditárias, no Brasil, ouvidores eram indicados pelo Rei de Portugal para exercerem as suas atribuições juntamente com os governadores gerais.

Os ouvidores possuíam o poder de lavrar e promulgar leis, estabelecer Câmaras de Vereadores, atuar como comissários de justiça e, principalmente, ouvir reclamações e reivindicações da população sobre improbidades e desmandos administrativos por parte dos servidores do governo.

Nessa hierarquia, o ouvidor era a segunda autoridade da capitania. Seus poderes incluíam as ações novas, tanto do lugar onde estava a outro extremo de todo o território da capitania, exercendo, dessa forma, a Justiça de $1^{\mathrm{a}}$ e $2^{\mathrm{a}}$ instâncias, juntamente com os juízes. Além disso, exerciam também função administrativa, mas, de modo similar, junto ao capitão, como um Secretário de Estado.

Paranaguá, primeiro município fundado no Paraná, foi transformado pelo Marquês de Cascais em capitania na data de 8 de março de 1655, ocasião em que a Câmara Municipal deu posse a Gabriel de Lara para as funções de ouvidor, alcaide-mor e capitão-mor, cargo que ocupou até sua morte. 
Até 1700, havia só um ouvidor para as Capitanias do Rio de Janeiro, São Vicente e Espírito Santo, e por provisão régia de D. Pedro II de Portugal. Em 22 de junho de 1700, foi criada uma ouvidoria geral para as Capitanias do Sul, ficando o ouvidor estabelecido em São Paulo (SANTOS, 2001). Em 1719, Rafael Pires Pardinho foi nomeado ouvidor geral para as Capitanias do Sul. Em suas andanças, ele percebeu que era impossível ao ouvidor de São Paulo fazer uma boa distribuição da Justiça em todo o território sob sua jurisdição.

Após percorrer algumas vilas, Pardinho demonstrou ao Conselho Ultramarino a necessidade de desmembrar parte da Ouvidoria de São Paulo e criar uma nova, com sede em Paranaguá.

Em Paranaguá, o ouvidor baixou 77 provimentos entre fevereiro e junho de 1721, os quais tratavam da constituição e organização da Vila, concessões de terras, economia, índios e escravos, ordem jurídica, defesa da Vila e culto divino. Os provimentos de Paranaguá foram confirmados pelo Rei, em 10 de janeiro de 1724, passando a ter força de lei.

A Ouvidoria de Paranaguá foi instalada em 24 de agosto de 1724 e,

... em 12 de novembro de 1725, foi feita a divisão das duas Capitanias, ficando a de Paranaguá com juridição sobre as vilas da costa do mar: de Iguape, Cananéia, São Francisco, ilha de Santa Catarina, Laguna, e até o Rio da Prata, e as vilas da serra acima de Nossa Senhora dos Pinhais de Curitiba até o lugar das Furnas. (SANTOS, 2001).

Antonio Alves Lanha Peixoto foi nomeado o primeiro ouvidor pós-capitania, empossado em 24 de agosto de 1724, mas, até novembro daquele ano, ainda não havia tomado posse, face às diversas atribuições que lhe foram ordenadas pelo capitão general da Capitania de São Paulo.

Antes dessa época, os ouvidores eram nomeados por um ano, por provisões dos tenentes generais governadores gerais e as nomeações interinas feitas pelos capitães-mores.

Em 20 de novembro de 1749, foi criada a Ouvidoria de Santa Catarina e, dessa forma, foi dividido o imenso território sob o domínio de Paranaguá.

Foram criadas várias comarcas em 1812 e, pelo alvará de 12 de março daquele ano, deu- se a transferência da sede da comarca de Paranaguá para a Vila de Curitiba, alegando-se a sua maior proximidade ao Registro das Tropas, às margens do rio Iguaçu (MACEDO, 1999, p. 19). 
O ouvidor da Comarca do Sul residia, inicialmente, em Paranaguá, mas, por um decreto em fevereiro de 1812, recebeu ordem de se fixar em Curitiba. A cidade tornou-se, então, a verdadeira sede da Comarca do Sul, com a denominação de Comarca de Paranaguá e Curitiba, "sem dúvida para não despertar a rivalidade dos habitantes do litoral" (MACEDO, 1999, p. 20). Este ato foi executado pelo ouvidor João de Medeiros. Dessa forma, o desenvolvimento econômico que começara a se fazer sentir em Curitiba pode ser citado entre as razões para a transferência da sede da comarca.

A Ouvidoria de Paranaguá foi extinta em 29 de novembro de 1832. De acordo com Negrão (1926), foram ouvidores, com sede em Paranaguá até 1812, e em Curitiba até 1832, os seguintes magistrados:

1. Dr. Antonio Alves Lanhas Peixoto: nomeado e empossado no dia 24 de agosto de 1724 , erigiu Vila a povoação de Desterro (atual Florianópolis) a 26 de março de 1725. Em maio de 1730, foi morto pelos índios paiaguás na embocadura do Rio Jaguari, em Mato Grosso;

2. Dr. Antonio dos Santos Soares: tomou posse em 7 de julho de 1730. Era natural de Portugal, tendo sido Juiz de fora de Olivença e servido até 1734. Casou-se em Paranaguá com Joana Rodrigues de França, filha do capitão-mor João Rodrigues de França;

3. Dr. Manoel dos Santos Lobato: nomeado em 4 de maio de 1734, era natural de Portugal e foi Juiz de fora. Foi casado em Paranaguá com Antonia da Cruz França, neta do capitão-mor João Rodrigues de França e enteada do ouvidor Antonio dos Santos Soares;

4. Dr. Gaspar da Rocha Pereira: serviu de 1741 a 1743;

5. Dr. Manoel Tavares de Siqueira: serviu de 1744 a 1748. Ex-Juiz de fora da Vila de Redondo, na Província do Alentejo, em Portugal. Era um nome literário em evidência, tendo sido secretário da Academia dos Seletos, fundada no Rio de Janeiro em 1752;

6. Dr. Antonio da Silva Pires Mello Porto Carreiro: serviu durante o ano de 1755. Da comarca, no seu tempo, foi desmembrada Santa Catarina, a $1^{\circ}$ de junho de 1750 , quando o Dr. Manoel José de Faria tomou posse da nova comarca ali criada pela Carta Régia de 20 de novembro de 1749. Até 1755, há vestígios seus na Ouvidoria de Paranaguá, mas já não era ouvidor em 1757; 
7. Dr. Jerônimo Ribeiro de Magalhães: serviu de 1756 a 1760. Tornou-se despótico e vingativo, pelo que sofreu forte acusação do povo e Câmaras Municipais. Quando preso, foi mandado para Lisboa, morrendo nas prisões de Limoeiro;

8. Dr. Antonio Barbosa de Matos Coutinho: serviu de 1777 a 1783. Em 1777, era ouvidor de Paranaguá. Em 1779, fez correição na Vila de Iguape;

9. Dr. Francisco Leandro de Toledo Rendom: nomeado em 2 de abril de 1783. Era irmão do tenente general José Arouche de Toledo Rendom, primeiro diretor do Curso Jurídico de São Paulo, e de Diogo de Toledo Lara Ordonhes, desembargador do Paço Conselheiro de Fazenda, sócio correspondente da Academia Real das Ciências de Lisboa e alcaide- mor da Vila de Paranaguá por despacho de 22 de janeiro de 1820;

10. Dr. Manoel Lopes Branco e Silva: foi nomeado por provisão régia em 12 de outubro de 1789. Era natural de Portugal, onde foi casado em primeiras núpcias com Maria Lúcia de Menezes. Do seu primeiro matrimônio teve, além de outros filhos, Maria Joana, casada com o capitão José Francisco Cardoso de Menezes; Isabel Branco, casada com o coronel Luciano Carneiro Lobo; do seu segundo matrimônio teve o filho capitão Joaquim Matheus Branco, que foi desembargador;

11. Dr. João Batista dos Guimarães Peixoto: nomeado em 1799. Era pernambucano. Por fazer uma péssima administração da justiça, foi denunciado e suspenso do cargo em 1802, tendo fugido para não ser preso;

12. Dr. Antônio de Carvalho Fontes Henrique Pereira: tomou posse do cargo de ouvidor a 9 de fevereiro de 1804. Tomou parte na vereança de Iguape em que se tratou do refazimento da igreja matriz. Serviu de 1804 a 1807;

13. Dr. Antonio Ribeiro de Carvalho: de 1807 serviu até 1810;

14. Dr. João de Medeiros Gomes: em 1810 foi nomeado. Mais tarde foi desembargador e Cavaleiro da Ordem de Cristo. Este, por carta régia de 19 de fevereiro de 1812, transferiu a sede da ouvidoria para Curitiba. Em 1822 era ouvidor em Itu;

15. Dr. José Carlos Pereira de Almeida Torres: seguiu no ano de 1822, passando depois a Visconde de Macaé. Era natural da Bahia. Em virtude de representação do povo contra ele, foi suspenso do cargo em 1822. Foi presidente de São Paulo e Ministro de Estado;

16. Dr. José Wernech Ribeiro de Aguilar: último ouvidor da comarca, tomou posse em 26 de julho de 1824, servindo até 1826. Em Curitiba, casou com Ana Eufrásia de Sá Sotto Maior, a 21 de julho de 1825, filha do coronel Ignacio de Sá Sotto Maior, o velho. 
Foi nomeado desembargador da Relação da Bahia, por decreto de 26 de julho de 1826.

Com a extinção das ouvidorias, foi a antiga capitania elevada à $5^{\mathrm{a}}$ Comarca de São Paulo, sendo nomeado seu primeiro Juiz de Direito, em 20 de abril de 1833, o Dr. José Antonio Pimenta Bueno, que, mais tarde, foi Marquês de São Vicente.

Conforme Negrão (1926, p. 147), o último Juiz de Direito da $5^{\text {a }}$ Comarca de São Paulo foi o Dr. Antonio Francisco de Azevedo, nomeado por decreto de 6 de agosto de 1847, servindo até 1853 , quando se deu a emancipação política da $5^{\text {a }}$ Comarca, que passou a constituir a Província do Paraná.

Os historiadores Cardoso e Westphalen (1986) alegam que um dos motivos da emancipação político-administrativa do Paraná foi a tensão causada pelos movimentos revolucionários Farroupilha (1835) e Liberal de Sorocaba (1842), pelos quais os paranaenses possuíam grandes interesses.

\footnotetext{
Houve temor que os paranaenses, apoiando os dois movimentos revolucionários, permitissem a sua junção. Por isso, o Presidente de São Paulo, Barão de Monte Alegre, confiou a João da Silva Machado, tropeiro muito bem relacionado com os paranaenses, a tarefa de evitar essa aliança. De fato, havia simpatias, principalmente nos Campos Gerais, pela causa liberal. (CARDOSO; WESTPHALEN, 1986, p. 56).
}

Assim, a emancipação foi prometida aos paranaenses, em troca de sua neutralidade com relação aos ideais revolucionários. Um primeiro projeto foi apresentado em 1843, mas, como contrariava os interesses paulistas, não teve andamento. Após muitas reivindicações, finalmente foi criada a Província do Paraná, em 19 de dezembro de 1853, sendo instalada pelo seu primeiro presidente, Zacarias de Góes e Vasconcellos.

Ainda com relação à ouvidoria em Paranaguá, houve um fato curioso e que merece ser comentado, sobre o ouvidor Dr. Antônio Barbosa de Matos Coutinho, $8^{\circ}$ na sucessão de ouvidores em Paranaguá: Nascimento Junior (1980b), em seu artigo O despotismo dum ouvidor, dá detalhes de sua personalidade desde o início de sua nomeação até a substituição do seu cargo pelo Dr. Francisco Leandro de Toledo Rendon.

Eis os fatos: o Dr. Antônio Barbosa de Matos Coutinho foi nomeado por provisão régia de 8 de abril de 1772 ao cargo de ouvidor geral e corregedor da Comarca de Paranaguá, trazendo em sua companhia um sobrinho, o Dr. Antônio Vidal Lage de Barbosa, que estava à procura de emprego. Segundo consta, este ouvidor possuía um espírito colérico, iniciando de 
imediato divergência com outras autoridades locais e até mesmo com a sociedade que o acolhera. Para piorar a situação, utilizou de sua influência, na qualidade de ouvidor geral, para nomear seu sobrinho ao cargo de Juiz de Órfãos, que na época estava vago. O provimento desta vaga só poderia ser feito pela Câmara Municipal, o que causou protesto por parte de alguns vereadores. Entretanto, os desentendimentos não param por aí: na tentativa de se reaproximar dos vereadores, começa uma perseguição contra os comerciantes do então povoado de Morretes (negando licença para abertura de novas casas de negócio), com intuito de impedir seu desenvolvimento, que contrariava os interesses de Paranaguá. Interferiu também no conserto da estrada da Serra, prejudicando a comunicação com Curitiba pelo morro do Cadeado. Estes feitos acabaram por denegrir ainda mais a sua imagem. Até o povo parnanguara, aderindo à hostilidade aos Barbosas (tio e sobrinho), aproveitou o Sábado de Aleluia de 1785, para expô-los ao ridículo, apresentando dois judas trajados com vestes e fisionomias muito parecidas com as do ouvidor e de seu sobrinho. Os Barbosas ficaram possessos, interpretando o ato como um desacato à autoridade, iniciando, assim, uma severa perseguição contra o vereador mais velho da Câmara, José Joaquim Pinto de Castro, acusando-o de ter fornecido as vestes que foram colocadas nos bonecos. Na verdade, tal acusação foi um pretexto: o que realmente o motivou foi uma discussão política que gerou profunda inimizade entre o vereador e o ouvidor geral.

Na sede de vingança, tio e sobrinho formularam uma denúncia contra o vereador ao capital-general de São Paulo, da qual resultou, dias depois, a ordem de prisão do vereador, sendo encarcerado primeiro na fortaleza da Barra e, depois, numa das enxovias da Cadeia Velha. A indignação popular foi grande, motivando a Câmara, em 30 de junho de $1785^{21}$, a prestar queixas contra o ouvidor geral e seu sobrinho, pedindo suas exonerações. Portanto, no dia 21 de julho de 1785, o novo ouvidor tomou posse, anulando o processo intentado contra Pinto de Castro, colocando-o em liberdade.

Na citação a seguir, constata-se que Santos (2001, p. 175) também faz alusão à figura do ouvidor geral Antônio Barbosa de Matos Coutinho como um sujeito tirano e cheio de ardis:

\footnotetext{
${ }^{21}$ Segundo Nascimento Junior (1980, p. 268), desde 17 de julho de 1783, o Dr. Francisco Leandro de Toledo Rendon se achava nomeado para substituir o Dr. Antonio Barbosa de Matos Coutinho. Sobre o mesmo fato, acrescenta: "ao que parece sem grande desejo ou pressa de assumir o cargo, aqui aparecendo dois anos depois, precisamente no mais aceso da guerra ao seu antecessor". Tal passagem explica a datação de posse do ouvidor Antonio Barbosa de Matos Coutinho, registrada por Francisco Negrão (1926).
} 
... a terra pondo e dispondo com despótico domínio queixando-se do Vereador mais velho José Joaquim Pinto de Castro que à ordem do mesmo General foi preso na fortaleza e dali conduzido à enxovia da cadeia, formando-lhe o mesmo Ouvidor culpa com falsas testemunhas, somente por capricho de sua paixão.

No corpus deste trabalho, há um documento oficial, datado de 25 de fevereiro de 1785, redigido pelo ouvidor Antônio Barbosa de Matos Coutinho, o qual acusa o vereador José Joaquim Pinto de Castro de ser um 'rábula' e 'perturbador' da paz, na vila de Paranaguá, por isso ordena sua prisão na Fortaleza da Barra.

[Doc.32, fol.1v, 25/Fevereiro/1785]

[...] Eu conhe

ci muitos annos esta camera pacifica; porem depois que aquelle

Rabula se fes dominante aconselhando os he a mais inqui

eta de toda a capitania. Deixaraõ de arrematar o

contrato da Corte por intereces particulares, fizeraõ a

arremataçaõ da serca a custa dos bens do concelho,

contra a despozição dos Provimentos aprovados por Sua Magestade

e otras obras que naõ pertenciaõ a sua destribuicaõ;

e porque temem que em correição serão punidos deraõ de tudo

conta a Sua Magestade per concelho de Jose Joaquim, segurando

lhes que estando afecto a Sua Magestade naõ pode o Corregedor

tomar conhecimento. Estes factos me obrigarão a prende lo na

Fortaleza da Barra, porque estou certo que sessa tudo,

e tudo fica Logo em pas; porque quando Vossa Excelencia o castigou conteves

se muito tempo, e só agora depois de vereador principiou no

va perturbaçaõ: porque elle so tem ardil para fomentar novi

dades, e inquietaçoens. A que dava occazião o persua

dirse que com a minha retirada me portaria froixamente,

emquanto naõ xega meo sucessor, porem eu nã̃

[d] evo deixar de fazer a minha obrigaçaõ ate o ul

timo instante, asim Como naõ deixo da pedir

sempre a Deus Continue a Vossa Excelencia sempre,

[Doc.32, fol.2r, 25/Fevereiro/1785]

Saude perfeita, e que o guarde e felicite por muitos anos.

Parnagua 25 de Fevereiro de 1785.

Beija as maons de Vossa. Excelencia

Seu mais humilde subdito, e mais atento Criado

Antonio Barboza de Mattos Coitinho

Num primeiro momento, lendo este documento isoladamente de seu contexto histórico, tem-se a impressão de ter sido o ouvidor geral vítima das artimanhas do vereador 
José Joaquim Pinto de Castro. Mas, buscando entender o contexto dos personagens envolvidos em tal documento, verifica- se que a situação é oposta: o ardiloso e 'rábula' desta história é o próprio Dr. Antonio Barbosa de Matos Coutinho, pois, levando em consideração as passagens descritas pelos historiadores anteriormente citados, constata-se que a figura deste ouvidor está assoaciada à de um déspota rancoroso que, utilizando- se de seu poder e influência política, procurava beneficiar a si próprio, julgando-se no direito de punir àqueles que iam contra os seus interesses.

Neste excerto histórico, tanto o ouvidor geral como seu sobrinho, exemplo de políticos corruptos, foram exonerados de seus cargos, depois de constatado abuso de poder. Portanto, assim que o ouvidor e seu sobrinho foram deportados à Portugal, esse episódio dramático tem seu fim.

\subsubsection{Economia de Paranaguá}

O ouro foi, seguramente, o melhor fator do povoamento, aliás, bem rápido, da nossa costa marítima. (B.I.H.G.E.P, 1972, p. 49)

Desde o descobrimento do Brasil, encontrar metais preciosos sempre foi o objetivo maior da Metrópole portuguesa. Inicialmente, os indícios desses metais preciosos eram escassos. Por isso, o governo português abriu mão do monopólio e estimulou o descobrimento das minas, concedendo-as aos seus descobridores.

Saboya Côrtes (1972), em seu artigo Paranaguá, berço da civilização paranaense, registra uma passagem escrita por Pedro Joaquim Castro Correa e Silva, na qual declara:

Demonstrei, que Pernagoá foi aonde na America Portugueza se descobrirão as primeiras minas de oiro que tiverão o credito de grandiosas, emquanto se não atrahirão a maior parte dos seus mineiros das abundancias dos oiros que se descobrirão nas minas gerais, ficando sempre Pernaguá athé o dia de hoje, com huma mineração actual, arbitrio dos seus povos. [...] pódem tão bem mostrar a antiguidade de seu estabelicimento, pois das suas minas as primeiras que aparecerão no Brazil e tirarão tantas porções de oiro e copiózas riquezas que ela ofereceo ao seu soberano, o Sr. Rey Dom Pedro 
Segundo ainda no tempo em que governava o Reyno como Príncipe Regente. (CÔRTES, 1972, p. 236-237).

Como ilustra o documento e elucida Martins (1995, p. 220), “dentre as regiões onde primeiro apareceram notícias de minas de ouro e que mais esperanças despertaram de grandes êxitos, figurou Paranaguá".

Embora, em meados do século XVI, portugueses e espanhóis praticassem, em solo brasileiro, o tráfico de escravos indígenas, a grande economia inicia-se no século XVII, com a exploração aurífera do litoral e do planalto. Antes dessa época, a mineração não tinha sido iniciada em nenhuma parte do Brasil.

Segundo Steca e Flores (2002), com a descoberta do ouro nos ribeirões que deságuam na baía de Paranaguá, considerável fluxo populacional, provindo das regiões de Santos, São Vicente, Cananéia, São Paulo e Rio de Janeiro, dirigiu-se para aquela área. A finalidade era explorar o metal precioso e, para isso, fazia-se necessária muita mão de obra. $\mathrm{O}$ ouro de aluvião, encontrado no leito dos rios, requeria muito trabalho, e só a mão de obra escrava poderia viabilizar a exploração. Portanto, esse tipo de exploração era muito dispendioso e o retorno nem sempre compensador. Porém, em decorrência desse fator, ocorreu a integração dessa economia regional à economia colonial que, por sua vez, também era sustentada pelo trabalho escravo.

Diante das informações existentes, construiu-se em Paranaguá a primeira Casa de Fundição do Ouro no Brasil. O governador-geral do Sul do Brasil, Duarte Corrêa Vasqueannes, expediu Eleodoro Ébano Pereira como administrador das minas do Sul, Pedro de Souza Pereira como provedor da Fazenda Real, e Mateus de Leão para delegado em Paranaguá. Gabriel de Lara veio de Iguape com um grupo de companheiros e, diante das riquezas que viu, empenhou-se junto ao Governo Geral do Rio de Janeiro para "Ordem de Povoação e Pelourinho" que, desde 1640, chefiava os seus mineradores. Segundo Martins (1995, p. 222, grifos do autor),

... o próprio fato da presença de autoridades oficiais nas regiões das minas então descobertas, contribuiu para despertar o interesse por esse novo gênero de atividade econômica sertanista e em breve Iguape e Paranaguá se tornaram 'as povoações mais florescentes da costa, enquanto não foram descobertos os ricos aluviões de Minas Gerais'. 
Côrtes (1972) relata que, ao receber um trabalho histórico do professor Dr. Nélson de

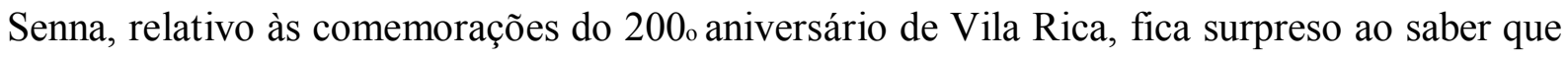
os paranaguenses foram os primeiros mineradores dos sertões e montanhas de Cataguazes, iniciando, assim, a famosa "Era do Ouro" nas Minas Gerais e, consequentemente, inaugura ali uma nova civilização. Este autor faz um paralelismo entre paranaenses e mineiros, dizendo que estes "possuem os mesmos traços familiares, semelhança de costumes e de aspectos físicos, pela mesma afeição à vida aventurosa dos 'garimpos' e à rude, mas livre, existência dos que se entregam pelos nossos sertões, à vida agropecuária" (CÔRTES, 1972, p. 241).

Apesar de as minas de ouro terem beneficiado não só a Coroa Portuguesa, mas também a determinada casta da época, a vida dos mineradores não era nada fácil: muitas vezes agrupavam-se em acampamento, formando um arraial, onde moravam em toscas cabanas de pau, cobertas com folhas de palmeira ou capim. Possuíam uma alimentação deficiente, porque poucos se dedicavam à agricultura e à pecurária. Nascimento Junior (1972), em seu artigo Paranaguá no Continente, comenta:

Dando em 1721, o Ouvidor Pardinho, os seus Provimentos [...] faz clara referência à situação de anarquia administrativa e judicial em que encontrou a povoação, tanto que providenciou sobre devassas para apuração de crimes atrozes e outras malversações praticadas, por onde se aufere a convicção de que se a um século de distância da fundação era aquele o estado de coisas, pior devia ser nas origens, quando nenhuma outra autoridade, além da do donatário, aliás mui frouxa e platônica, pelas muitas léguas que separavam a sede da Capitania das suas povoações, se fazia sentir. (NASCIMENTO JUNIOR, 1972, p. 170).

Com o passar dos tempos, a produção das minas foi ficando economicamente inviável na região. Segundo consta do manuscrito de número 03, esta decadência já acontecia no início do século XVIII:

[Doc.03, fol.1r, 04/dezembro/1721]

No particular das minas foi publicado nesta Villa hi bando do Gouernador Dom Bras

Balthazar da ssilueira em que ordenaua se naõ lauraçe nas minas Velhas e Sendo emformado o Gouernador do Rio de Janeiro Francisco de Tauora do dito bando auisou a esta Camera por carta sua de $\underline{26} \mathrm{de} \mathrm{Ju}$ lho de 1714 annos que esta villa estaua sugeita ao seu Gouerno e que Se no em tanto ouueçe 
noua Ordem de sua Magestade que Deos guarde o fa ria presente a esta Camera por cuyas

[Doc.03, fol.1v, 04/dezembro/1721]

cuyas rezois nosos antesesores naõ

prohiuiram o faiscar nas ditas minas

velhas do destrito desta villa, e al

guns ${ }^{\sim}$ moradores e homes de fora andauã

laurando nas ditas minas e naõ sa

uemos o rendimento dellas so nos dizem

estam ja tam relauadas que case todos

tem despejado e se apareçe algum ouro

nesta villa he uindo de Coritiba e por esta

causa tendo notisia o ouuidor Geral [Doutor]

Raphael Pires pardinho [...]

Contudo, o governo português não queria acreditar neste fato, e recorreu, então, a um novo tipo de imposto, a captação e, como salienta Wachowicz (1967, p. 37),

Tal sistema, no Brasil, foi um desastre, principalmente no sul. A situação tornou- se gravíssima quando surgiu mais um impôsto, o chamado 'donativo dos chapins da Rainha', que tinha por finalidade angariar fundos para o casamento dos príncipes portuguêses.

De qualquer forma, em 1734, as oficinas de fundição de ouro em Paranaguá foram fechadas, porque sua manutenção era mais onerosa do que o lucro que proporcionava.

O esgotamento do ouro no Paraná, associado à descoberta do ouro em Minas Gerais, no século XVIII, provocou a saída dos garimpeiros, atraídos por maiores ganhos. Houve um esvaziamento populacional nas áreas mineradoras paranaenses. Dos que ficaram, uns permaneceram tentando a sorte nas minas, outros procuraram no planalto regiões que permitissem a prática da agricultura, extração da erva-mate e/ou a criação de gado.

Segundo Ladeira (1990), a sociedade parnanguara, atualmente, constitui-se de elementos étnicos e de miscigenação. Centra-se naquela região, uma 'aristocracia' pequena, detentora do poder político, índios Guarani e uma grande população mestiça que compõe a maioria das vilas de pescadores. Desse modo, a população formada possui distintas categorias que permanecem nitidamente distanciadas no convívio social, principalmente quando se comparam moradores das ilhas com os do continente. Fatores econômicos também são divergentes. As comunidades isoladas nas ilhotas de Paranaguá desenvolvem uma economia de subsistência: a pesca, aliada às roças, garante o sustento da população. A inexpressividade dessa atividade no âmbito econômico é atribuída a dois fatores: a localização dos portos e a 
pequena dimensão do litoral. O desenvolvimento da técnica da pesca artesanal tem contribuído para a fonte de renda, mesmo que escassa, dessa população regional. Por outro lado, pode-se afirmar que a atividade mais significativa de Paranaguá é o Porto D. Pedro II. Situado no interior da baía de Paranaguá ${ }^{22}$, com condições de atracagem favoráveis, destacase entre os maiores portos exportadores de grãos do Brasil. Desde sua existência até os dias de hoje, está ligado aos cinco ciclos econômicos do Paraná: do ouro, da erva-mate, da madeira, do café e diversificações (milho, soja, farelo, algodão, óleos vegetais etc.).

\subsubsection{Origem e Desfecho do Colégio dos Jesuítas em Paranaguá}

Falar em Escola ou Colégio, é falar da cultura de um povo. A mais modesta cidade, por pequena que seja; interessando-se pelo 'ensino' de seu povo, está dando a conhecer de que é culta, ou pelo menos, assim o deseja ser.

(VIANA, 1976, p. 39).

A fundação do colégio dos jesuítas em Paranaguá é relatada por muitos historiadores como um fato que ganhou páginas da história dessa cidade, por isso merece ser analisada à luz do contexto sócio-histório pertinente ao período em que foram produzidos os documentos manuscritos, corpus deste trabalho.

Recuando no tempo, Freitas (1999) assegura que, por volta do século XVI, já se tinha notícia da entrada dos primeiros jesuítas em terras parnanguaras, cuja missão era aproximarem-se dos índios carijó com o propósito de resgatar uns náufragos espanhóis capturados pelos selvagens:

Leonardo Nunes foi o primeiro religioso que percorreu as praias da região de Paranaguá, em 1550, quando da viagem realizada entre São Vicente e Lagoa dos Patos, a fim de conseguir a liberdade de algumas famílias de fidalgos espanhóis que se dirigiam ao rio da Prata e haviam sido aprisionadas pelos índios. (FREITAS, 1999, p. 159).

\footnotetext{
${ }^{22} \mathrm{Na}$ realidade, o que se conhece popularmente como baía de Paranaguá é um conjunto de três baías, a de Paranaguá, Antonina e Laranjeiras (município de Guaraqueçaba), todas elas interligadas numa mesma formação geográfica (KRAEMER, 1983, p. 18).
} 
Antes mesmo da instalação da Casa Jesuítica em Paranaguá, Freitas (1999) menciona que já havia uma preocupação em enviar missões volantes à baía de Paranaguá. A primeira Casa de Missão estável para a região foi em São Vicente e, depois, em Cananéia:

Periodicamente, ao tempo de Leonardo Nunes, desta casa de missão de Cananéia, faziam os jesuítas missões entre os Carijó e primitivos povoadores da margem esquerda do rio Taguaré (Itiberê), como a de Pedro Correia e João de Sousa que deveria durar sete anos, porém, ao chegarem até os planaltos, foram flechados e mortos nas fraldas da Serra do Mar, sertões dos Carijó, em $1556^{[23]}$ (FREITAS, 1999, p. 160)

Após esse acontecimento, o padre Leonardo Nunes também desapareceu. Em viagem a Roma, sua nau naufragou e o missionário morreu afogado. E, como consequência, a ação jesuítica, não somente nos sertões de Paranaguá, mas também em todo o litoral sul, fica enfraquecida, sendo retomada 10 anos depois pelos padres José de Anchieta e Manoel da Nóbrega, a partir do ano de 1566 em diante.

Em 1605, uma nova missão, composta pelos religiosos João Lobato e Jerônimo Rodrigues, é enviada a Paranaguá pelo padre Fernão Cardim. Ermelino de Leão (1926, p. 942) informa que, “entre os anos de 1606 e 1640, os missionários jesuítas, que deviam operar em Paranaguá, resolveram instalar no Superagui, junto ao Varadouro Velho, a primeira casa de Missões no território do atual Paraná".

Com a ação missionária, os Carijós foram, aos poucos, assimilando a vida civilizada, diminuindo os conflitos entre os índios e a população daquela região. Devido aos benefícios prestados à colonização, os habitantes de Paranaguá sentiram a necessidade da fixação desses padres no povoado, ou seja, de um colégio jesuítico onde eles pudessem não só catequizar os gentios, como também instruir os filhos dos colonos. Entretanto, segundo Nascimento Junior (1929), neste período, o povoamento teve de se contentar com as visitas dos padres da Casa das Missões do Colégio de Jesuítas de São Vicente, regularmente feitas em constantes viagens à costa Sul do país. Essas visitas, conhecidas como 'missões volantes',

\footnotetext{
${ }^{23}$ Sobre este episódio, Leão (1926) e Nascimento Junior (1929) informam que o maior responsável pelo assassinato dos dois jesuítas foi o castelhano Ruy Moschera, que provavelmente se achava em Cananéa ou em Superaguy. Por meio de falácia supôs aos índios serem os religiosos espiões da tribo inimiga dos tupiniquis, urdindo assim uma intriga contra os jesuítas. Amotinados, os Carijó, investiram contra os padres, flechando-os mortalmente.
} 
... agiram em Paranaguá em todo o decurso do século XVII, sem estabelecimento fixo, pois só em começo da seguinte centúria é que a Camara, em sessão de vereança de 3 de Agosto de 1704 e provalvemente em cumprimento de algum voto de 20 annos antes quando assolada a villa pela peste conhecida pelo nome de 'bicha', teriam os moradores recorrido á Providencia com a promessa, a Camara, repetimos, tomou a sim o encargo, em nome do povo, de erigir para a Companhia de Jesus uma casa sob o padroado de N. S. das Mercês. (NASCIMENTO JUNIOR, 1929, s/p.).

Baseando-se nos dados do Dicionário Histórico-Biográfico do Estado do Estado do Paraná (1991), o Colégio dos Jesuítas, desde o ano de 1682, representava antigo anseio da população parnanguara, pois, conforme petição da Câmara Municipal de Paranaguá, os seus moradores solicitavam ao Superior Geral da Companhia de Jesus, a residência de padres jesuítas em sua Vila, visando à educação de seus filhos.

Em 1690, a Câmara volta a insistir nessa petição. Unida à representação do povo, solicitou ao Provincial da Companhia de Jesus a vinda de seis padres, com a promessa de construir para eles um colégio e residência à custa do povo, bem como a dar o dinheiro necessário para a aquisição de terras e escravos africanos para seus estabelecimentos agrícolas. Tudo isso prometiam em troca de aulas de ensino primário e de latinidade e, ainda, de religião.

No ano de 1699, a Câmara entregava aos jesuítas seis escrituras de doação e, em agosto de 1704, com a chegada do padre Antônio da Cruz, foi possível concretizar o possível estabelecimento dos religiosos em Paranaguá. Consoante a isso, a Câmara fez a promessa em nome do povo, à Companhia de Jesus, de doar bens e as alfaias $^{24}$ da Capela de Nossa Senhora das Mercês para a fundação do colégio na vila. O cronista Antônio Vieira dos Santos (2001, p. 64) descreve em detalhes todos os bens que foram doados por Antônio Morato ${ }^{25}$ :

À f. 18 do livro 15 de Registros 1689 a 1719, se acha promessa que fez este povo da Vila de Paranaguá à Religião da Companhia de Jesus, para efeito de fundarem convento nesta Vila. A padroeira Nossa Senhora das Mercês, com uma coroa de prata e seus mantos: 2 ornamentos, a saber, um de chamalote carmesim novo e outro de séda pouco usado; 4 castiçais, 2 de latão e 2 de estanho; 1 missal, 1 cálice e 1 patena de prata, 1 alva, toalhas e o mais necessário; 1 Ilha chamada da Cotinga a metade dela, 1 igreja da dita Senhora na forma em que está acabada, a minha pessoa [Antônio Morato]

\footnotetext{
24 Alfaia: móvel ou adereço de residência como banco, cadeira, bofete, tapete, tapeçaria, entre outros. Designação também de peça ou ornamento utilizado em cerimônia litúrgica (BOTELHO; REIS, 2008, p. 14).

${ }^{25}$ Antonio Morato - filho e sucessor do provedor Manuel de Lemos Conde, doador de metade da ilha da Cotinga à Companhia de Jesus.
} 
para servir aos reverendos Padres, no que puder, [...]. Em dinheiro de contado $842 \$ 8240$ réis, 100 cabeças de gado vacum, nos Campos de Curitiba, 1 casa c om quatro cubículos assobradadas, de pedra e cal à roda, ficando incluída com o muro, todas as terras pertencentes ao Varador, casa para morarem os outros dois Padres, enquanto durar a obra (do Colégio) nos obrigamos a dar cumprimento na forma escrita por nós e nossos sucessores. Paranaguá, em Câmara de agosto de 1704.

As contribuições para a fixação dos jesuítas em Paranaguá não param por aí. De acordo com Westphalen (1902, p. 1), no dia 2 de maio de 1707, "a Câmara Municipal doa aos padres da Companhia, sete mil cruzados para a edificação da igreja, e mais dois currais e quatrocentas cabeças de gado, para a côngrua, bem como terras suficientes para o pastoreiro e plantações".

Portanto, no dia 14 de maio de 1708, chegam à vila de Paranaguá, enviados pelo provincial da Companhia de Jesus João Antônio Andrioni, os padres Antônio da Cruz e Tomás de Aquino, recebidos pela população com grande alegria e debaixo de palio e conduzidos até a igreja matriz, onde cantaram Te Deum laudamus. Conforme atestam os historiadores, a fundação do colégio consta a partir desta data, contudo sua construção sofreria embaraços em virtude da lei, que exigia a apresentação do alvará régio para a construção de institutos religiosos em qualquer parte dos domínios portugueses. A obra foi embargada em 3 de fevereiro de 1709, pelo Dr. João Saraiva de Carvalho, ouvidor geral do Sul do Brasil (NASCIMENTO JUNIOR, 1929).

Porém, em 1720, a construção sofreria novo embargo. O ouvidor geral de São Paulo Raphael Pires Pardinho, em visita de correição à Vila de Paranaguá e demarcação dos terrenos do Rocio (incluindo a Ilha da Cotinga), não reconheceu as doações feitas por Antonio Morato à Companhia (através do provimento de $\mathrm{n} .{ }^{\circ} 60$ ), da metade da ilha da Cotinga e das terras do Varadouro. Neste mesmo provimento, o ouvidor Pardinho alega que "tendo sido na Cotinga a sede da primeira povoação, justa não era a cedência dessa ilha aos Jesuítas em prejuízo do patrimônio municipal" (NASCIMENTO JUNIOR, 1929, s/p). Segundo este autor, consta ainda, em tal provimento, a anulação de "outros bens dados de mão beijada à poderosa Ordem para prestar benefícios públicos que, entretanto, ainda não haviam prestado apesar de aqui residirem desde 1708, isto é, há longos doze anos" (NASCIMENTO JUNIOR, 1929, s/p).

No entanto, os parnanguaras não desistem de seus anseios. Conforme se verifica no Doc. 10 (fol.1r/fol/1v), datado em 17 de março de 1722, a Câmara de Paranaguá envia ao rei uma representação pedindo permissão para fundarem o colégio e prosseguimento das obras, e a permanência dos padres na vila: 
[Doc.10, fol.1r, 17/Março/1722]

Dous saõ os motivos que emcu

ulcam alentar ce nossa ouzadia

a prezenciar lhe a grande afliçam

em que de presente se acha o $\mathrm{po}=$

vo desta villa. O Primeiro hê a serteza

de andar ô Illustre de seu sange

vinculado as commizeraçonins

para emparo dos que athe se arri=

maõ. O outro a grande propençaõ

que reconhecemos do begnino de

seu natural que naõ estranha

râ valernomos de tam poderosa-

emtercençaõ para o nosso socego-

e bem de tantas mil Almas que

compreende esta e as mais villas

sircumvezinhas em cazo, que os

Reverendos Padres da Companhia nos dezampa=

rem como o intentaõ; e o Reverendo -

Padre Superior se tem despedido nes

te senado, por ordem que tem de seu

provinssial; por que alem de serem

faltas de sacerdotes, sam os des

trictos de seus abitadores com-

intençaõ, de des, ou doze legoas -

mediando grandes Bahyas de muitos ris

cos de vida, emposiuel o Remedio

de suas nessecidades, âs maýores de

ligencias de seu vigario, e só os ditos

Reverendos Padres os socorriaõ por esta-

rem pronptos a este grande [servisso]

de Deos, e faltando elles ficaremos

viuendo, e morrendo como irracio

[Doc.10, fol.1v, 17/Março/1722]

Irracionais, e nossos Filhos sem

o emsino comveniente, por que as

nossas posibilid $a$ des nam abrangem

ao dezempenho que nos presisa a $\tilde{o}=$

brigaçam pondo os onde alcanssem

decorozo estado. Vossa Excelentissima pello

sangue de Iesu Christo se dig=

ne por nestes seus suditos, e ne

ssas petiçonins os olhos: pois-

da autoridade de taõ exselco asi $=$

lo, e do piadozo, e catolico de seu

zello, esperamos felix despacho

para a suspençaõ da ida dos ditos Padres

thê ultima Resoluçaõ de aver, o cinaõ 


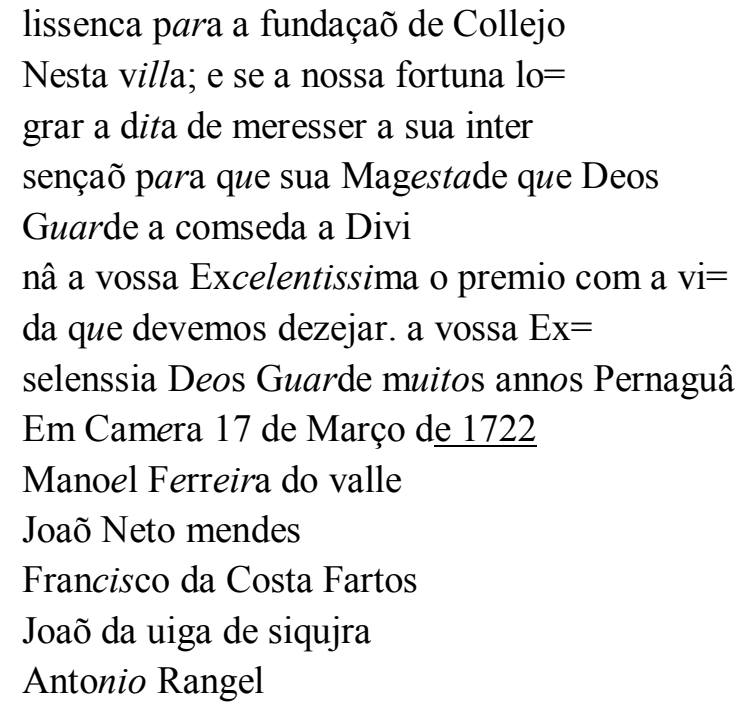

Analisando o contexto desse documento oficial, constata-se a necessidade dos colonos, de haver em sua vila um colégio para instruir o povo, uma vez que a distância percorrida pelos reverendos de uma barra a outra, dificultava a implementação de um ensino regular. A Ordem dos Jesuítas representava a cultura letrada para os habitantes daquela região, quase todos moradores de pequenas vilas como Paranaguá, que em sua grande parte eram analfabetos. Isso explica a necessidade dessa cultura letrada justificada pelo argumento da carência religiosa e dos sacramentos. Desse modo, os padres, e especialmente os jesuítas, eram sempre vistos como ilustres figuras políticas e religiosas.

Voltando ao contexto histórico, verifica-se que a relação entre o ouvidor Pardinho e os padres jesuítas estava estremecida devido ao embargo da obra que constava no provimento de $n^{\circ}$. 60. Aparentemente, o ouvidor não era contra a fundação do colégio, no entanto, estava bastante receoso em relação aos bens doados à Companhia de Jesus. Segundo Boutin (2005, p. 188), os jesuítas

... possuíam estabelecimentos agrícolas e criação de gado na barra do Superagüi e Araripe. Metade da ilha da Cotinga e vasto sítio em Morretes e terras no Varadouro. Serra acima, a fazenda da Borda do Campo com criação de gado e lavras de ouro, fazendas em Pitangui (Ponta Grossa) e no Capivari.

Passadas duas décadas, esse cuidado com a expansão da propriedade dos jesuítas também pode ser entendido a partir de uma representação da Câmara de Paranaguá contra os jesuítas, conforme consta do doc. 25 (fol.1r/fol.1v), datada em 27 de janeiro de 1743, 
acusando os padres de avançarem com os pilares do colégio 100 braças de terras num lugar chamado Ribanceira:

[Doc. 25, fol.1r]

Naõ pouco temos est $\div$ mado a boa vinda de vossa Ilustrissima Deus graça sempre conceruarlhe saude para reparaçaõ e aumento desta capi tania e anos Mandarnos como seus humilde subditos Nesta oCaziaõ se nos offereçe reprezsentar a vossa Ilustrissima exselinssia que os Reverendos Padres da companhia de Iesus que exsiste nesta villa aprezentaraõ Ao Juiz ordinario hua portaria de vossa Ilustrissima por onde ordena se faça refazer dentro em tres dias huns pillares que Os mesmos Reverendos Padres tinhaõ fundado em huas braças de chaons q que dizem puçuir Nesta villa na pa raje ribançeyra Os quais prinçipios Os avia Mandado demu Lir Os nossos Antipaçados, e dandoçe Logo A mesma portaria seo enteyro complimento se achaõ já os mesmos pillares rete ficados como de antes; Mais como este prossedimento em contra em parte $\mathrm{O}$ disposto que hâ sobre este particular Nos pare .. sseo dar a vossa Illustrissima de tudo Conta emviandolhe as copias emclusas pellas coais Vera vossa Illustrissima que vindo a esta villa o Doutor Dezembargador Raphael Pires Pardinho em corre $\div$ caõ ante Vendo que os Reverendos Padres se asenhoreavaõ de sem [brasas de chaons'] em coadra Na Milhor paraje que tem esta villa para ô seo aumento Proueo sinaõ goardaçe a tal data de chaons . como da Mesma Copia Consta e os Mesmos Reverendos Padres sem que ordinariamente vintillasem A posseçaõ dos tais chaons pertenderaõ Leuantar nelles edefficios afim de se entridozirem $\mathrm{Na}$ poçe e com efeito o ffizeraõ dando por prinçipio os referidos pillares $\mathrm{O}$ que vendo os ditos Nossos anteseçores e o provimento em contrario e ordens ${ }^{\sim}$ Reais por onde Sua Magestade que Deos guarde auia por comfirmados Os tais capitullos como das copias juntas se manifestaõ Atendendo outro sim Os $\mathrm{m}[\mathrm{esm}]$ os officiaes que os Reverendos Padres estauaõ bastante Mente acomodados com outros chaons que de novo si thes deo na doãçaõ que se lhes avia feito da Capella de Nossa Senhora do terço Onde Oie fundaõ seo Collegio e tirem muito

[Doc. 25, fol.1v]

Muitos chaons ocupados No lugar e ponta da villa onde em the o prezente a sistem e atalharem por este fim aver lugar para outras relligioins $\sim$ su fficientes atendendo outro sim que no alvarâ por que Sua Magestade fo - seruido conçeder Licenca para a fundaçaõ do Collegio mandou nella declarar que os Reverendos Padres naõ compraçem nem pe ssuiçem mais terras das que peçuhiaõ determinaraõ mandar demulir os tais pillares pella referida rezaõ, e nos parece de viaõ os Reverendos Padres deduzir ordinariamente a peçuido e naõ pellos me $\div$ os extraordinarios como portendem em atençaõ do que pedimos e rogamos a vossa Illustrissima eexselençia a prouidençia 
sobre esta materia por naõ emcontrarmos o disposto e or dens reais e menos conheçaõ os Reverendos Padres e se lhes naõ faz viollençia mandando nos a oservar os ditos Cappitulos e ordens atendendo outro sim o prejuizo que receberâ o aumento da pouoaçaõ com a priuança das sem brasas de chaons em coadra de que seguirem apoçar os ditos Reverendos Padres de que ficamos es perando a desizaõ para sauermos o que devemos obrar

Todos ficamos rogando a Deos Guarde a vossa Illustrissima exselen çia por muitos annosPernagoa em camera $\underline{27}$ de janeiro de $\underline{17}$

43 De vossa Illustrissima Exse Lensia

Senhor General Dom Luiz Mascarenhas

Os menores de seus subditos

Domingos Correa da Silva Antonio João de Mendonca Caetano (M Fernandes) Antonio deSousa Pereira

José (Pires) dinis

Esse documento de 1743 foi endereçado ao general Dom Luis Mascarenhas, e é um exemplo da preocupação das autoridades em relação às terras doadas aos jesuítas em Paranaguá. Em trecho da representação, a Câmara local exige que em, no máximo, dez dias a partir da data da carta, os padres restituíssem as terras invadidas e fizessem novas demarcações. O receio que se tinha em Paranaguá em relação aos bens dos padres jesuítas refletia a realidade colonial. Os colonos se preocupavam cada vez mais, e logo também se preocupou a Coroa Portuguesa, com o fortalecimento dos padres, bem como os inúmeros bens materiais que possuíam, além do controle sobre os índios nas reduções.

Na primeira metade do século XVIII, o conflito entre colonos e jesuítas se acirrou e, mais que isso, a administração pública portuguesa também temia o avanço do chamado império jesuítico. A riqueza dos padres começava a incomodar a Coroa Portuguesa, bem como a autonomia das reduções, dos colégios e sua autossuficiência (NASCIMENTO JUNIOR, 1929).

Pode-se explicar, a partir disso, a resistência da Coroa Portuguesa em permitir a fundação de um colégio jesuítico em uma posição militar e economicamente estratégica. $\mathrm{O}$ fato indica que, já no início do século XVIII, havia grandes disputas políticas no reino português. Mas, o mais frequente dizia respeito aos bens dos padres inacianos e às riquezas advindas de doações que eles tão bem administravam. A essa fama de bons administradores, Leão (1926, p. 944) comenta que os jesuítas sabiam unir, às funções catequistas, "uma perfeita intuição economica: eram bons gestores dos bens da Companhia e empregavam todos 
os esforços para enriquecel-a, cada vez mais, não só no magistério, como nas artes e industrias".

Leão (1926), com intuito de reforçar sua opinião sobre a ambição e boa administração dos jesuítas, cita uma observação feita por Saint Hilaire referente ao contraste entre a gestão da Fazenda da Borda do Campo antes e depois do confisco: "Todas as obras dos jesuítas prosperavam; denotavam trabalho e perfeita direção administrativa: as do governo decahiam, arruinavam-se; davam o triste exemplo de desorganização e de defraudação do fisco" (LEÃO, 1926, p. 945).

Quanto à reputação dos jesuítas e ao longo tempo para o estabelecimento efetivo do colégio dos jesuítas, na Vila de Paranaguá, Nascimento Junior (1929, s/p.) nos informa:

Eram os abusos jesuíticos, já há muito em pratica na Europa, que começavam a se implantar no Brasil; e por tel-os constatado é que Pardinho achou conveniente golpear o predominio aqui manifestado pelos Padres da Companhia, sob aspectos tão pouco recomendáveis.

Somente em 1726, quando ocorre a substituição do ouvidor Pardinho pelo ouvidor geral e corregedor da Ouvidoria de Paranaguá, o Dr. Antonio Álvares Lanhas Peixoto, há o reconhecimento das doações feitas à Companhia de Jesus, pelo Provimento $n^{\circ}$. 5. Todavia, o Conselho Ultramarino, ainda receoso, em novembro de 1735, pedia informações sobre a origem do dinheiro para a despesa da fundação do Colégio e sustento dos padres.

Em carta de 28 de março de 1737, a Câmara Municipal prestou as informações solicitadas pelo Conselho Ultramarino, acerca dos recursos com que os padres poderiam contar para a construção e manutenção do Colégio.

Finalmente, depois de tantas petições e de anos passados, a 19 de setembro de 1738, foi mandado passar provisão de licença aos padres da Companhia de Jesus para fundarem o Colégio na Vila de Paranaguá.

Na vereança de 2 de dezembro de 1739, compareceu o Padre Antonio da Cruz, a fim de comunicar que, conseguida a autorização real, os padres desejavam logo iniciar as obras. Assim, em 1740, teve princípio de fato a construção do colégio, cujas obras se prolongaram até 1759.

A data canônica de sua fundação é a de 10 de dezembro de 1752. A transferência dos padres para a sua nova casa, bem como dos serviços religiosos para a nova igreja junto ao 
colégio, foi em 1754. Até esta data, os padres viviam em casa alheia e praticavam o culto também em igreja alheia.

A inauguração oficial do colégio e da igreja, contudo, foi realizada somente a 19 de março de 1755, sendo o colégio colocado sob a proteção de Nossa Senhora do Terço e a igreja sob a invocação de Santa Bárbara (WESTPHALEN, 1902).

Mas, apesar da boa vontade do povo em cooperar com esta obra, os jesuítas tiveram pouco tempo para o seu trabalho em Paranaguá. Em 1759, o Marquês de Pombal obteve a "bula do Papa Clemente XIV, na qual declarava extinta a Companhia de Jesus, e tratou de expedir, rapidamente, ordens terminantes para a expulsão e prisão dos padres e confisco de todos os seus bens" (NASCIMENTO JUNIOR, 1929, s/p).

Na opinião de Freitas (1999, p. 164), Pombal fora impulsionado por questões políticas, o qual alega:

... os jesuítas tinham dificultado as tentativas de demarcação, quando os indígenas do Sete Povos das Missões revoltaram-se contra as forças lusocastelhanas, na denominada 'Guerra Guaranítica' e que também teriam participado da conspiração, ao lado dos nobres, contra o rei, o poderoso ministro atacou a Companhia de Jesus, providenciando a expulsão dos padres do reino e domínios portugueses, inclusive o Brasil.

Portanto, em 15 de fevereiro de 1761, por ordem do governador-geral do Brasil, vieram a Paranaguá o general Gomes Freire de Andrade, para realizar o confisco dos bens dos jesuítas, e o desembargador Seraphim dos Anjos Pacheco de Abreu, para arrolar tudo o que a Companhia possuía e incorporar à Real Fazenda. Toda essa ação foi desempenhada com muita cautela e sigilo, de modo a evitar manifestações, protestos ou mesmo levantes (WESTPHALEN, 1902).

As fazendas foram a principal preocupação no sequestro dos bens dos jesuítas, sendo vendidas e o dinheiro revertido para a Coroa. Já os bens do colégio e da igreja anexa a ele foram entregues a um capelão, que manteve a conservação dos bens e alfaias e as missas na igreja. O prédio do colégio foi ocupado somente em 1821, por determinação do governo da província de São Paulo para servir de quartel às tropas do coronel governador Miguel Reinardo Bilstein. Ficou nessa situação até o ano de 1832, quando iniciaram os primeiros pedidos para reformas no prédio (WESTPHALEN, 1902).

Em 1838, parte do prédio foi ocupada pela irmandade da Santa Casa de Misericórdia, com o intuito de transformá-lo em um hospital, o que não se concretizou devido aos enormes 
gastos para se fazer os reparos necessários. Dois anos depois chegava a autorização para a reforma. No ano de 1841 passou a funcionar, em uma das salas, uma classe primária. A igreja, que havia se tornado ruínas, foi demolida em 1896.

Levando em consideração relatos dos historiadores sobre a política de Pombal, percebe- se, claramente, pontos de vista divergentes. Para alguns, como Viana (1976, p. 41), a Lei Pombalina trouxe

[...] imenso prejuízo da infância e da juventude tão carentes de sadios ensinamentos; depois de 50 anos de labuta e sacrifícios em prol da instrução em nossa terra... [...] Paranaguá sentiu imensamente a saída desses educadores, que tantos benefícios vinham trazendo à nossa gente.

Na visão de Freitas (1999, p. 164), os jesuítas prestaram "indispensáveis e relevantes serviços à coroa portuguesa, não somente em Paranaguá, mas diversas regiões das terras brasileiras, principalmente quanto à catequese e civilização dos índios e a abnegada ação escolar".

Estes cronistas não deixam de ter razão quando afirmam que os jesuítas foram os principais responsáveis pela assistência espiritual e pela educação dos brancos e gentios, no período colonial. Mas, com a mudança do quadro econômico e político de Portugal e Brasil Colônia, os jesuítas deixam de ser vistos como meros catequistas e passam a incomodar os interesses da Coroa quando esta dá início à política de expansão territorial, com auxílio dos bandeirantes paulistas. Deste posicionamento a favor da ação de Pombal, Negrão (1934, p. 136) é da seguinte opinião:

Felizmente a ascenção ao poder do grande ministro de D. João I - o marquez de Pombal - veiu modificar completamente a norma politica até então seguida pela metrópole.

Ao restabelecer o Governo de S. Paulo, foi recomendado ao novo Governador nomeado - o Morgado de Matheus, que insuflasse a vaidade dos paulistas e se appellasse para o seu nunca desmentido patriotismo, afim de que viessem prestar a sua Patria os serviços que sempre lhe haviam prestado os seus antepassados, os intrépidos - bandeirantes.

[...] Convem que seja estimulada a vaidade dos Paulistas. Para isso deve o Governador convidar as principaes pessoas da Capitania de S. Paulo, mostrando- lhes os serviços prestados por seus antepassados, nos sertões, nas lutas contra os jesuítas castelhanos, senhores dos indígenas. 
Leão (1926, p. 945), mesmo reconhecendo alguns aspectos positivos das obras jesuítas - conforme se constata na passagem: "Não se pode negar a acção educadora, moral e politica foi incontestavel e mais benefica do que perniciosa" -, é um tanto crítico quando se refere à função econômica da Companhia de Jesus: "os jesuítas visavam dois fins: um ostensivo - a conquista das almas para o céo e outro oculto, a conquista das riquezas para a Companhia. Elles sabiam o valor do dinheiro: quando não era possível persuadir, facil lhes era corromper" (LEÃO, 1926, p. 945).

Em suma, não se pode negar que os missionários jesuítas desempenharam um importante papel educacional no Brasil Colônia, tanto com a catequese dos gentios quanto com a instrução dos filhos dos cristãos. Como os interesses da Companhia de Jesus se estenderam além do âmbito religioso, passando a atuar também em assuntos relacionados à política e à economia, a Coroa Portuguesa sente-se ameaçada pelo processo de fortalecimento das instituições jesuíticas, e os expulsa do território brasileiro, sob o pretexto de representarem um atraso na sociedade colonial, passando, assim, o sistema educacional para a responsabilidade da administração colonial.

\subsubsection{Educação em Paranaguá}

Com a expulsão dos jesuítas de solo brasileiro, a situação precária do atendimento educacional no Paraná é sentida durante todo o período setecentista, pois "o pouco que se tinha devia- se à ação dos jesuítas e desde as medidas pombalinas de laicização do ensino o povo da $5^{\text {a }}$ Comarca ficou basicamente desprovido de educação pública" (TRINDADE; ANDREAZZA, 2003, p. 408).

De acordo com Ribeiro Filho (1967, p. 137-138), foram enviados à Vila de Paranaguá, ainda ano final do século XVIII, apenas dois mestres-régios ${ }^{26}$. Em vereança de 26 de julho de 1783, a Câmara representou à rainha D. Maria I, sobre a necessidade de haver um professor régio para o ensino das primeiras letras. A soberana, em consentimento à representação da Câmara, por meio da Provisão Régia de 28 de abril de 1788, nomeou

\footnotetext{
${ }^{26}$ Martins (1995, p. 132) faz uma observação interessante quanto à diferença entre mestres de ler e escrever e os mestres-régios. Estes "eram mais capacitados e provisionados pela capitania com a confirmação do rei", enquanto aqueles eram "destinados a ministrar rudimentos educacionais e provisionados por prazos de um ano, pagos pelo subsídio literário".
} 
Francisco Inácio do Amaral Gurgel, para mestre- régio, na Vila de Paranaguá. Esses dados se confirmam nas palavras de Santos (2001, p. 177):

... fazendo a mercê a Francisco Inácio do Amaral Gurgel do lugar de substituto da escola de ler e escrever e do catecismo na Vila de Paranaguá da Capitania de S. Paulo, no Estado do Brasil, vencendo o ordenado anual de Rs. $120 \$ 000$ pagos a quartéis adiantados, que se lhe pagarão pelo cofre do subsídio literário. Este professor um dos melhores e mais instruídos que tem havido em Paranaguá; de sua aula sairão ótimos discípulos e muitos tomarão as ordens sacras, outros seguirão várias ciências, e a maior parte se aplicarão ao comércio pelos seus bons talhos de letras e peritos contadores. Ele foi mestre régio na corte de Lisboa, aulista da Real Junta do Comércio da mesma Corte. Acadêmico da Real Academia das Ciências de Sua Majestade, seu lente, examinador desta Comarca e catedrático da literatura, escrita, aritmética, ortografia, gramática portuguesa, catecismo e urbanidade civil.

O conceito do professor Amaral Gurgel era tão elevado que o governador da Capitania de São Paulo, em convite através da carta de 19 de outubro de 1790, ofereceu-lhe a abertura de uma escola na Vila de São Paulo, mas este não aceitou (RIBEIRO FILHO, 1967, p. 139).

Outro professor, José Carlos de Almeida Jordão, foi nomeado em 15 de junho de 1789, por Provisão Régia, para ministrar aulas de Gramática Latina. "Era mestre conceituado, recebendo 300 mil réis anuais de ordenado, pagos pêlos Cofres do Subsídio Literário". (RIBEIRO FILHO, 1967, p. 147).

No começo do século XIX, o cenário educacional em Paranaguá continua decadente. Em vereança de 4 de dezembro de 1820 , a Câmara dirigiu uma petição ao rei D. João VI solicitando a nomeação de um professor para o ensino primário, por se encontrar vago o cargo. Ribeiro Filho (1967, p. 148), citando o trecho redigido pela Câmara, expõe o motivo da escassez de professores na vila: “o cargo de Professor vagou não havendo quem o queira ocupar, pois a função que era gratificada com a importância de 120 mil réis anuais, havia sido reduzida para 80 mil réis anuais, pelo governador da Província de São Paulo, João Carlos Augusto Oyenhausen".

Outros fatores que contribuíram para o quadro deficitário da educação na Província do Paraná foram: (i) a prioridade dos alunos do sexo masculino em detrimento do sexo feminino; e (ii) a distinção das matérias de acordo com o sexo. Segundo Kubo (1986, p. 153), “desde 1821 há menção de ensino para os alunos de sexo masculino em Curitiba e em Paranaguá, desde 1826”. Já as meninas de Curitiba “apenas em 1835, as de Paranaguá em 
1836 e nas demais localidades o ensino público feminino terá início nas décadas seguintes”. Havia também diferença de matérias a serem ensinadas nos programas escolares, "aos meninos eram destinadas matérias como geometria e às meninas, apenas a parte da aritmética que habilitava efetuar as quatro operações. Para compensar, elas aprendiam prendas domésticas" (KUBO, 1986, p. 64).

Nesta época, os representantes do Paraná fixados na Província de São Paulo tentavam encaminhar mestres para as vilas paranaenses, mas poucas vezes lograram sucesso. Esta situação educacional era preocupante, uma vez que a carência de estabelecimento de ensino interferia na possibilidade de sua elevação à condição de vila. Consoante a esta situação, Trindade e Andreazza (2003, p. 409-410) exemplificam a "antiqüíssima freguesia de São José dos Pinhais, que à época possuía 600 fogos, e não pudera chegar à categoria de villa, pela falta de rudimentos literários dos moradores". Confrontando esta passagem com os dados do documento que se segue, verifica-se que Pernagoa, mesmo com 425 fogos, já havia adquirido sua condição de vila, e a freguesia de São José dos Pinhais, com uma quantidade maior de fogos, ainda lutava por sua elevação. Portanto, pode-se inferir que a arrecadação dos subsídios literários desta freguesia não eram suficientes para custear os honorários dos mestres de ensino.

[Doc.19, fol.1r, 11/Dezembro/1732]

Rendimento que tem as Camaras desta

Comarqua de Pernagoa cada hi

anno

Com o de 1732, com pouca differença aos de

mais annos atrazados

Villa de Pernagoa ... 250\$000 esses aplicados para

a obra da cadeya, que se acha fazendo, e athe aqui tem

pago seis mil cruzados, custando a obra treze

Villa de Coritiba...............................60 $\$ 000$

Villa de Iguape ............................. $35 \$ 000$

Villa de Cananeya ...................... 25\$000

Villa do Rio de Saõ Francisco....... 27\$000

Villa da Ilha de Santa Catharina ......nada

Villa da Laguna ............................ $15 \$ 000$

Fogos

Pernagoa …..............................425

Coritiba ......................................

Jguape .......................................181

Cananeya .....................................122

Rio de Saõ Francisco ..................144 
Em 1827, o império regulamenta oficialmente a educação, com a lei aplicada em 15 de novembro, atribuindo às províncias o poder de legislar sobre o ensino primário, reservando para si o poder sobre o ensino secundário e superior.

As autoridades provinciais, na pretensão de melhorar o precário atendimento escolar, neste período, adota o método Lancaster ${ }^{27}$, cuja proposta de ensino mútuo foi considerado

... vantajoso não só pelo grande número de alunos que podiam ser instruídos com apenas um mestre, mas também por ser de baixo custo, por apresentar rápido resultados, por estar mais de acordo com a índole dos alunos e por seu método de castigos e estímulos para o aprendizado. (KUBO, 1986, p. 69-70).

No tocante à instituição de ensino no Paraná, no Relatório Oficial emitido em 15 de julho de 1854, pelo presidente da Província do Paraná, Zacarias de Góes e Vasconcellos, observa-se que a precariedade da educação no estado ainda é preocupante, pois, além da falta de professores capacitados para a função do magistério, há a idade avançada de alguns alunos matriculados no ensino primário. Segundo o documento, na cidade de Paranaguá frequentavam as primeiras séries alunos entre 12 e 14 anos.

Consta ainda deste relatório que os professores não recebiam boas gratificações para as funções que exerciam:

Em um paiz como este, onde qualquer carpinteiro ou pedreiro ganha por dia $2 \$ 000$ ou mais, onde a ultima pessoa do povo tem, quando não queira dar-se á outro trabalho, o facil recurso dos hervaes silvestres para tirar quanto baste para suas precisões, querer que hum professor ganhe em alguns lugares menos de 800 rs. diarios, he hum absurdo. (PARANÁ, 1854).

Levando em consideração os dados apresentados anteriormente, pode-se afirmar que grande parte dos problemas atuais advém do sistema precário de ensino, implantado após a expulsão dos jesuítas. Muitos historiadores consideram a política pombalina um retrocesso para a educação brasileira, uma vez que se rompeu toda a estrutura escolar que havia até então. A partir do momento, em que o governo local assume a responsabilidade da educação

\footnotetext{
${ }^{27}$ A aplicação do método de Lancaster no Brasil começou em 1823, inicialmente no Rio de Janeiro, quando o decreto de $1^{\circ}$ de março instituiu uma escola de primeiras letras por este método. (KUBO, 1986, p. 70).
} 
no Brasil, a estrutura escolar caminha a passos vagarosos, sentindo uma parca modificação, quando a coroa portuguesa aqui se instala oficialmente.

Uma vez apresentado, neste capítulo, o contexto histórico de Paranaguá, o capítulo seguinte tratará da edição dos manuscritos e dos comentários paleográficos e codicológicos. 
Capítulo II 


\section{CRITÉRIOS DE EDIÇÃO DE TEXTOS}

Ao eleger os textos antigos ${ }^{28}$ como fonte de pesquisa, os estudiosos se deparam com muitas dificuldades, principalmente, as que se referem à forma como está grafado o texto. Por se tratar de uma linguagem escrita diferente da utilizada atualmente, os elementos formais do texto causam estranheza tanto à primeira vista como em um nível mais profundo de análise. Na concepção de Araújo (1985, p. 19), "um dos principais elementos encontrados nos antigos textos, que parecem estranhos e de interpretação complicada ao leitor moderno, é sem dúvida a sua ortografia peculiar". Por isso, é preciso que o editor tenha um conhecimento prévio das leis fonéticas regentes durante os séculos anteriores.

Além dos aspectos ortográficos, o mesmo autor menciona, ainda, outros problemas que dificultam a compreensão de registros manuscritos: (i) a transposição ao uso contemporâneo de um texto distante há século - inúmeras formas lexicais e construções sintáticas divergem das empregadas atualmente; (ii) as abreviaturas - nem sempre são compreendidas à primeira vista, há muitos casos de variações abreviantes; (iii) os numerais aparecem representados na forma romana e em minúsculas e a forma arcaica $b$ equivale a $v=$ 5; (iv) os nomes próprios - encontram-se abreviados e/ou rubricados, de difícil interpretação, e merecendo, dessa forma, uma atenção especial por parte do editor. Corrobora também, neste sentido, o estado de conservação em que o respectivo documento se encontra.

Assim, o texto exige uma adequação para que um número maior de pessoas possa fazer uso deles - linguistas e historiadores, por exemplo. Há que buscar em dicionários etimológicos, gramáticas históricas e bibliografia pertinente todo o aparato necessário para a compreensão do material grafado dos textos.

Merecendo atenção neste sentido, Acioli (1994, p. 1) ressalta a importância dos manuscritos para a reconstituição da história: “O documento manuscrito é considerado a mola-mestra da História. É indiscutível que ele proporciona recursos inestimáveis ao historiador, representando o melhor testemunho do passado, fonte direta de informação básica para o estudo da História."

\footnotetext{
${ }^{28}$ Entende-se texto antigo no sentido da dificuldade de leitura pelo fato de a escrita antiga apresentar caracteres diferentes dos da escrita atual (ACIOLI, 1994, p. 5).
} 
Seguindo este caminho, há alguns anos a Historiografia tem utilizado fontes pouco exploradas e que passaram a fornecer um leque maior de opções ao pesquisador, tais como processos judiciais, devassas civis e eclesiásticas, processos-crime, documentos paroquiais, recensiamentos de população, entre vários outros. Conforme Samara (1986, p. 39), “esse tipo de documentação revelou uma nova ótica para o período colonial, possibilitando a análise de temas inexplorados ou a retomada de outros sob novas perspectivas".

Preocupado em reconstituir uma "história" ocultada por longos anos, o historiador "deparou-se com uma questão crucial, que lhe exigiu enorme esforço, ou seja, a busca por documentos" (SAMARA, 1986, p. 39). Esta tarefa não foi nada fácil, seja pela: (i) desorganização dos acervos e difícil acesso aos documentos manuscristos, (ii) dificuldade proveniente da própria ausência de fontes para alguns temas ou mesmo das limitações oferecidas pela documentação, como naturalmente ocorre em pesquisas desse tipo (SAMARA, 1986).

Esta preocupação em buscar documentos inéditos não coube somente à Historiografia. Muitos linguistas estão "buscando em fontes até então relegadas a segundo plano, quando não ignoradas, textos rigorosamente fiéis ao estado de língua em que foram escritos" (CUNHA; CAMBRAIA; MEGALE, 2001), uma vez que nossas gramáticas e dicionários utiliza[ra]m-se predominantemente de textos literários, privilegiando, assim, uma parcela muito restrita de documentação da língua. As fontes citadas por Cunha, Cambraia e Megale (2001), como os documentos "notariais e jurídicos" e "cartas", foram bastante produzidas no período colonial, e pouco se sabe de sua existência, a não ser em trabalhos acadêmicos.

Portanto, a preocupação de um linguista vai além da escolha da tipologia. É preciso ter cuidado em verificar se o texto editado adotou critérios de edição, "a fim de assegurar, por um lado, a fidelidade às características lingüísticas do original e, por outro, a adequada compreensão do conteúdo do texto" (CUNHA; CAMBRAIA; MEGALE, 2001).

Um aspecto relevante que merece ser abordado são os diversos tipos de edição de textos. Cambraia (2005) os divide em quatro tipos ${ }^{29}$ diferenciados com base no grau de mediação: fac-similar, diplomática, paleográfica e interpretativa.

\footnotetext{
29 Essas edições são subdivididas em duas grandes classes: monotestemunhais (baseadas em apenas um testemunho de um texto) e politestemunhais (baseadas no confronto de dois ou mais testemunhos de um mesmo texto) (CAMBRAIA, 2005, p. 91). Para esta pesquisa o interesse tem como foco as edições baseadas em apenas um testemunho.
} 
A edição fac-similar baseia-se, em princípio, no grau zero de mediação, por ser cópia exata de documento manuscrito obtida por meio fotomecânico, eletrônico, xerografia etc.. Segundo este autor, a vantagem dessa edição é "permitir o acesso ao texto de forma praticamente direta, o que confere ao consulente grande autonomia e liberdade na interpretação do testemunho" (CAMBRAIA, 2005, p. 91). Uma década antes, esta opinião já havia sido assinalada por Acioli (1994, p. 1):

Problemas sérios têm sido enfrentados por historiadores que se fiam cegamente nas publicações de textos raros, comuns nos livros e revistas de História. O confronto dos originais com as suas transcrições tem demonstrado quão viciadas são muitas dessas edições, por vários erros de leitura paleográfica. Por isso, julga-se como o melhor processo de divulgação de textos manuscritos as edições em fac-símile por oferecerem, ao pesquisador escrupuloso, oportunidade de análise; este, quando acostumado à prática de leitura do manuscrito, poderá discernir, mesmo numa cópia impressa de um texto, os erros introduzidos na transcrição em conseqüência da má interpretação na leitura de um documento.

Em contrapartida, a edição diplomática vem perdendo espaço, se comparada com as demais edições. Sua transcrição consiste em reproduzir tipograficamente o manuscrito original, como se fosse completa e perfeita cópia da grafia, das abreviações, das ligaduras, de todos os seus sinais e lacunas, inclusive dos erros e das passagens estropiadas, caracterizandose assim um grau baixo de mediação (CAMBRAIA, 2005, p. 93). Esse tipo de edição era bastante produtivo no passado, suprindo a falta do contato direto com o documento manuscrito. Hoje em dia, este tipo de edição é considerado por alguns transcritores um método obsoleto, pois “com o desenvolvimento das técnicas de reprodução mecânica, essa função praticamente deixou de existir" (CAMBRAIA, 2005, p. 94). Portanto, muitos editores passaram a questionar a função dessa edição dentro do contexto tecnológico no qual estamos inseridos. A esse respeito, Silva Neto (1956, p. 21, grifos do autor) compartilha da seguinte opinião:

Hoje, em virtude dos progressos técnicos da fotografia e da reprodução facsimilida, a transcrição puramente diplomática é um atraso, pois com ela ficamos sempre na estreita dependência do critério e da perícia do editor, que, no entanto, pode ler mal e não compreender algumas palavras. [...] Por outro lado, em muitos passos, as edições meramente diplomáticas são deficientes e imperfeitas, já que as tipografias modernas são incapazes de reproduzir certos sinais medievais. Com o atual progresso da técnica só se justifica a edição diplomática quando ela vem ao lado da fac-símile. Dessa 
maneira o leitor pode acompanhar e policiar a leitura - o que, todavia, mais parece um exercício paleográfico do que uma tarefa de caráter filológico.

A edição paleográfica, também denominada semidiplomática, paradiplomática ou diplomático-interpretativa, apresenta um texto mais compreensível ao leitor não familiarizado com certas características originais de um documento manuscrito. Na tentativa de melhorá-lo, o editor realiza modificações, tais como: divisão das palavras, desdobramento das abreviaturas, inserção ou supressão de elementos por conjectura, etc.. A este processo de reprodução, Cambraia (2005, p. 95) caracteriza como grau médio de mediação, pois o editor atua de forma mais interventiva. Este mesmo autor acrescenta que este tipo "tem sido adotado na edição de documentos para o estudo da história da língua portuguesa", por proporcionar melhor compreensão e identificação dos caracteres escritos e por reproduzir de forma mais fiel possível a escrita original (CAMBRAIA, 2005, p. 95).

Por fim, Cambraia (2005) esclarece que a edição interpretativa assemelha-se em alguns pontos à edição paleográfica (desenvolvimento de abreviaturas e conjecturas), diferenciando-se sob outros aspectos. O texto passa por um forte processo de uniformização gráfica, compreendendo um grau máximo de mediação por parte do editor. Tal procedimento permite apresentar o texto em uma forma acessível a um público amplo (desaparecendo as dificuldades gráficas com a uniformização), além de oferecer ao leitor um texto mais apurado, na medida em que os elementos desconhecidos tornam-se mais inteligíveis (CAMBRAIA, 2005, p. 97).

Cambraia (2005) faz uma ressalva quanto ao termo crítica ser atribuído para este tipo de edição. Tal confusão precisa ser revista, pois a edição interpretativa baseia-se somente em um testemunho manuscrito, ao contrário da edição crítica, que se caracteriza pelo confronto entre vários testemunhos ${ }^{30}$.

Dentre os tipos de edições apresentados, elegeram-se para este trabalho as edições fac- similar e semidiplomática, de forma justalinear, de maneira a facilitar o seu cotejo. Assim, a edição fac-similar constitui-se da reprodução mecânica ou fotográfica do documento e proporciona ao leitor a análise da escrita do século em que foi redigido o manuscrito (ACIOLI, 1994), ao passo que a edição semidiplomática, na tentativa de melhoramento do texto, oferece o preenchimento de lacunas e uniformização de grafias, contribuindo, assim,

\footnotetext{
${ }^{30}$ No livro "Publicação de documentos históricos", de Emanuel Araújo (1985), tanto os termos crítica quanto interpretativa servem de exemplo para o mesmo tipo de edição.
} 
para a eliminação de certo grau de dificuldades de leitura por parte dos pesquisadores. Compartilhando desta mesma opinião, Cunha, Cambraia e Megale (2001, p. 8) adotam a transcrição semidiplomática justalinear à reprodução do manuscrito ( $f a c$-símile), assegurando que esta edição "há de ser de primeira utilidade para o levantamento de dados lingüísticos, e para o conhecimento da letra cursiva da época do descobrimento do Brasil" (CUNHA; CAMBRAIA; MEGALE, 2001, p. 8).

Sendo assim, a edição semidiplomática apresenta muitas vantagens: dispensa o leitor da árdua tarefa de decifrar as formas gráficas da escrita original dos manuscritos e possibilita a reconstituição histórica da língua, resultando num dos objetivos propostos nesta tese.

Antes de relacionar o elenco das normas de edição, faz-se necessário discorrer, de forma sucinta, sobre algumas noções gerais das áreas de conhecimento da paleografia, diplomática e codicologia.

A Paleografia, em linhas gerais, pode ser definida como "o estudo das escritas antigas" (CAMBRAIA, 2005, p. 23). Etimologicamente, é formada pelos radicais gregos palaios: antigo e graphien: escrita. Várias são as conceituações dadas à Paleografia. Para Blanco (1987, p. 13), "é a ciência que ensina a ler corretamente toda a classe de documentos manuscritos ou impressos, abordando também a origem e evolução da escrita". Na concepção de Acioli (1994, p. 6), esta área de conhecimento vai além de um simples instrumento de leitura das antigas formas da escrita,

... é a ciência que lê e interpreta as formas gráficas antigas, determina o tempo e lugar em que foi redigido o manuscrito, anota os erros que possa conter o mesmo, com o fim de fornecer subsídios à História, à Filologia, ao Direito e a outras ciências que tenham a escrita como fonte de conhecimento.

No Brasil, a necessidade desta ciência surge, com maior ênfase, apenas em fins do século XX e início do século XXI. Os estudos paleográficos eram feitos graças à iniciativa particular de alguns historiadores. Como tal ciência tardou nas universidades de Portugal, é bem possível que esta tenha sido a causa dos estudos manuscritos brasileiros não terem sido incluídos no currículo universitário até a primeira metade do século XX, quando a Universidade de São Paulo, em 1952, introduziu a Paleografia como disciplina complementar no curso de História (ACIOLI, 1994).

Segundo Cambraia (2005, p. 24), a Paleografia possibilita, ao pesquisador, condições necessárias para a leitura perfeita de um documento antigo: 
a) classificação da escrita, localização e datação;

b) descrição sucinta de características da escrita [...];

c) descrição sucinta do sistema de sinais abreviativos empregado na referida escrita;

d) descrição dos outros elementos não-alfabéticos existentes e de seu valor geral: números, diacríticos, sinais de pontuação, separação vocabular intralinear e translinear, paragrafação, etc.;

e) descrição de pontos de dificuldade na leitura e as soluções adotadas.

Mesmo havendo uma vasta bibliografia paleográfica disponível no mercado, obras em língua portuguesa ou voltadas para a escrita latina são raras e geralmente encontradas somente em bibliotecas acadêmicas, pois quase todas se encontram com número de edição esgotadas.

A ciência Diplomática ${ }^{31}$ remonta ao século XVII, com a edição De Re Diplomatica Libri Sex (1681), de autoria do padre beneditino Jean de Mabillon. Na tentativa de normatizar a maneira pela qual os documentos eram lidos e a forma de se estabelecer autenticidade, nasce a Diplomática com a urgente missão de distinguir os atos escritos falsos dos verdadeiros, valendo-se de técnicas da Paleografia e do Direito Eclesiástico (DIAS; BIVAR, 1986, p. 15).

O campo da Diplomática, por vezes confundido com o da Paleografia, tem com esta a mesma origem em comum: a escrita e o documento. Cambraia (2005, p. 25) esclarece que “as origens da diplomática estão fortemente entrelaçadas com as da paleografia, já que os tratados mais antigos visavam a orientar a avaliação da autencidade de documentos legais, tanto através de sua escrita quando de sua forma e de seu conteúdo". Concomitante a este assunto, Acioli (1994, p. 6) salienta ser a Diplomática

... muitas vezes [...] identificada com a Paleografia mas suas tarefas são diferentes. Enquanto esta lê e analisa o documento levando em consideração o seu aspecto exterior (grafia, material, selo), aquela procura avaliar a veracidade dele através de seus caracteres internos (língua, texto), de sua parte formal e alterações que possa ter experimentado através dos séculos.

Portanto, a Diplomática caracteriza-se como a ciência que se preocupa em investigar os caracteres intrínsecos dos documentos, certificando-se da sua autenticidade e veracidade.

\footnotetext{
${ }^{31}$ Os procedimentos diplomáticos, com a finalidade de verificar a falsidade dos documentos, são, porém, muito antigos, mas a Diplomática só se constitui como ciência nos fins do séc. XVII e princípios do séc. XVIII. (SPINA, 1977, p. 20).
} 
A Codicologia preocupa-se em analisar o material empregado na produção do manuscrito e também em verificar em que condições os documentos se encontram. Em resumo, é uma disciplina que tem por finalidade o "estudo da técnica do livro manuscrito, isto é, do códice" ${ }^{32}$ (CAMBRAIA, 2005, p. 26).

Segundo Cambraia (2005), modernamente, a Codicologia tem servido de grande utilidade à Crítica Textual, "fornecendo informações ao editor, permitindo-o compreender algumas das razões pelas quais os textos se modificam no processo de sua transmissão". Além disso, conhecer os processos que envolvem os estudos codicológicos, auxilia na árdua tarefa da descrição dos textos preservados em manuscritos, seja no seu aspecto material, formação, datação, conteúdo e as mãos que o transcreveram, dentre outras aspectualidades.

Portanto, todas essas ciências elucidadas têm como objeto comum a escrita, e são consideradas como complementares e se auxiliam mutuamente.

Retornando ao contexto dos critérios de edição, Santiago-Almeida (2002) comenta que a transcrição de textos antigos exige atenção especial, principalmente quando tais textos se destinam a estudos de caráter linguístico filológico. Para isso, é necessário um refinado tratamento de certos aspectos que, para estudos de outra natureza, poderiam estar em segundo plano. Somente uma transcrição extremamente fidedigna e cuidadosa pode deixar transparente todos os traços linguísticos possíveis de serem analisados nos originais manuscritos. Dessa forma, tanto o êxito do trabalho quanto a solidez dos resultados certamente estão condicionados à qualidade da edição dos textos que estão na base desse estudo linguístico. Em verdade, é a natureza dos textos e, sobretudo, a finalidade da edição que, de certa forma, determina os métodos e normas de transcrição.

Para a edição dos manuscritos do corpus foi preciso elaborar algumas normas próprias de transcrições, como também utilizar as normas eleitas para o projeto Para a História do Português Brasileiro, apresentadas e discutidas durante o segundo seminário, realizado em Campos do Jordão, no período de 10 a 16 de maio de 1998, pela comissão de pesquisadores composta por Heitor Megale (USP), César Nardelli Cambraia (USP), Gilvan Müller de Oliveira (UFSC), Marcelo Módolo (mestrando USP), Permínio Ferreira (UFBA), Sílvio de Almeida Toledo Neto (USP), Tânia Lobo (UFBA) e Valdemir Klamt (UFSC).

\footnotetext{
${ }^{32}$ Forma característica do manuscrito em pergaminho, semelhante à do livro moderno, e assim denominada por oposição à forma do rolo. (FERREIRA, 1987).
} 
Dessa forma, decidiu-se aplicar a edição semidipomática, com reprodução justalinear e acompanhada do fac-símile, que implica os seguintes critérios:

1. As abreviaturas, alfabéticas ou numéricas, serão desenvolvidas, marcando-se, em itálico, as letras omitidas nas abreviaturas: Fev.ro $>$ Fevereiro, 9 bro $>$ Novembro, obedecendo aos seguintes subcritérios:

a. respeitar a grafia do manuscrito, ainda que manifeste idiossincrasias ortográficas de quem escreveu, como no caso da ocorrência munto, que leva a abreviatura m.to a ser transcrita munto;

b. no caso de variação no próprio manuscrito ou em coetâneos, a opção é pela forma mais próxima da atual, como no caso de ocorrências Deos e Deus, que levam a abreviatura: D.s a ser transcrita Deus;

2. As fronteiras de palavras devem ser estabelecidas ou modernizadas. No entanto, é mantida a grafia dos manuscritos quando, ao contrário, uma palavra é, de maneira sistemática, grafada separadamente. Isto pode ocorrer com os elementos constitutivos de determinadas palavras. Exemplos: sô mente, intro duçaõ, taõ bem ou tam bem. Da mesma forma, não se introduz hífen simples () ou duplo $(=)$, apóstrofo ou qualquer outro sinal gráfico onde não há;

3. A pontuação original é rigorosamente mantida;

4. A acentuação original (presença ou ausência do diacrítico) também é rigorosamente mantida. Exemplos: comercio, camerâ, naõ hâ, há, he, hé, hê;

5. As letras $s$ e $z$ quando traçadas, por alguns escrivães, de forma idêntica, foram transcritas obedecendo o uso da ortografia atual;

6. O emprego de maiúsculas e minúsculas também é rigorosamente respeitado como se apresenta no original. As variações gráficas resultadas de fatores cursivos não são consideradas relevantes. Assim, a comparação do traçado da mesma letra deve propiciar a melhor solução;

7. Os atestados e eventuais equívocos do escriba ou copista, como inversões e duplicações silábicas e repetições de palavras ou frases, são mantidos: fallecidade, fugigiram, o gentio Payaguâ Payaguâ, porém, remetidos para as notas subsequentes, onde se deixa registrado o erro, com indicação da respectiva linha. 
Exemplos: 1: facellidade, ms: fallecidade, 4: fugiram, ms: fugigiram, 13: o gentio Payaguâ, ms: o gentio Payaguâ Payaguâ;

8. As supressões feitas pelo escrevente no original também são suprimidas pelo editor, mas, da mesma maneira, são remetidas para as notas subsequentes, onde serão tachadas, com indicação da respectiva linha. Exemplo: 8: todos os presentes, ms: todos ninguem dos presentes;

9. As variações nos traçados de grafemas não são mantidas pelo editor, mas devem ser remetidas para os comentários paleográficos, com a indicação dos contextos e da linha;

10. Os diferentes registros da mesma palavra ou passagem observados em outra(s) via(s) do manuscrito, quando há, são remetidos em nota de rodapé;

11. As inserções feitas pelo escriba ou copista nas entrelinhas ou nas margens laterais, superior ou inferior entram na edição entre diples $<>$, no local indicado. Exemplo: Capitania <e letrados $>$ por nesta haver falar delles;

12. As intervenções escritas de terceiros no documento original são evidenciadas entre colchetes duplos [[1752]]; os sinais públicos, como carimbos, aparecem nos comentários que compõem a descrição do manuscrito;

13. As leituras por conjectura, sem probabilidade de erros, das lacunas existentes por deterioração do documento, devem vir entre colchetes. Exemplo: $e$ tambem de que ne[lla se con]cervem para sempre os ditos petrechos;

14. As lacunas existentes por deterioração do documento, sem possibilidade de lição segura por conjectura ou inferência, são indicadas com ilegível sublinhado e entre colchetes. Exemplo: Como expomos [ilegível] derã̃ no Real Decreto de 22 de Mayo de 1753;

15. As linhas em branco, que parece haver no corpo do texto, não se representa tal fato na transcrição por não ter sido possível determinar com clareza todas as suas ocorrências;

16. Os nomes próprios que constam das assinaturas, quando é incerta sua decifração devem vir entre parênteses. Exemplo: Antonio (M) Fernandes;

17. As linhas, na edição, são numeradas continuamente de cinco em cinco à margem direita da mancha, ou à esquerda do editor; 
18. A divisão das linhas do documento original será preservada ao longo do texto (formato justaposição). A mudança de fólio receberá a marcação com o respectivo número na sequência: fól.1r, fól.1v, fól.2r.

A edição semidiplomática e os fac-símiles encontram-se no segundo volume desta tese. Constitui esta parte do trabalho: (i) a transcrição dos fólios, conforme os critérios adotados e elucidados anteriormente; (ii) os fac-símiles, distribuídos no corpo do trabalho do lado esquerdo das edições, e as transcrições do lado direito do leitor. No início de cada documento encontra-se uma ficha sucinta contendo: número do documento, composição, tipologia, assunto/resumo, datação e assignatários. Em seguida, quando considerado oportuno, pontos julgados de maior relevância foram esclarecidos em notas de rodapé.

\subsection{COMENTÁRIOS PALEOGRÁFICOS dOS MANUSCRITOS}

Ciente da importância que a análise codicológica apresenta para a verificação da autencidade de um documento manuscrito, seguem alguns aspectos codicológicos que puderam ser verificados no corpus editado deste trabalho.

\subsubsection{Os Reclames}

O reclamo consistia na parte de uma palavra, em palavra inteira ou, ainda, em um grupo de palavras que se colocava, fora da mancha, à direita da margem de pé da página, repetindo o que deveria estar no início da coluna, página ou caderno que se seguiria. Para indicar a ordem dos cadernos, empregava-se a assinatura, que consistia de elemento de natureza alfabética ou numérica (CAMBRAIA. 2005, p. 73).

Uso dos reclames em alguns fólios:

Doc.01, fól.1r, 1.30 (de emfermidades) // fól.1v, 1.02 (De emfermidades);

Doc.03, fól.1r, 1.30 (Cuyas) // fól.1v, 1.02 (cuyas);

Doc.10, fól.1r, 1.35 (irracio) // fól.1v, 1.01 (Irracionais);

Doc.11, fól.1r, 1.33 (pedindo lhe) // fól.1v, 1.02 (Pedindolhe); 
Doc.12, fól.1r, 1.37 (espe) // fól.1v, 1.01 (Experamos);

Doc.14, fól.1r, 1.31 (a presente) // fól.1v, 1.02 (A presente);

Doc.20, fól.1r, 1.34 (pa) // fól.1v, 1.01 (pagace);

Doc.25, fól.1r, 1.35 (muito) // fól.1v, 1.01 (Muitos);

Doc.33, fól.1r, 1.28 (para) // fól.1v, 1.01 (para);

Doc.33, fól.1v, 1.24 (a vista) // fól.2r, 1.01 (A vista);

Doc.36, fól.1r, 1.36 (tem=) // fól.1v, 1.01 (tempo);

Doc.37, fól.1r, 1.36 (que) // fól.1v, 1.01 (Que);

Doc.37, fól.1v, 1.39 (settecen) // fó1.2r, 1.01 (Centtos);

Doc.42, fól.1r, 1.38 (plan) // fól.1v, 1.01 (Plantas);

Doc.45, fól.1r, 1.34 (Parnagua) // fól.1v, 1.01 (Parnagua);

Doc.46, fól.1r, 1.38 (se prinssi) // fól.1v, 1.01 (Se principiou);

Doc.46, fól.1v, 1.33 (Excelencia) // fól.2r, 1.01 (Excelencia);

Doc.47, fól.1r, 1.37 (em alguñs annoz) // fól.1v, 1.01 (Em alguns annos);

Doc.47, fól.1v, 1.37 (do Arros) // fól.2r, 1.01 (Do Arros);

Doc.47, fól.2r, 1.38 (subci) // fól.2v, 1.01 (Subcidio);

Doc.47, fól.2v, 1.37 (de cen) // fól.3r, 1.01 (De cento);

Doc.47, fól.3r, 1.31 (Antonio Manuel) // fól.3v, 1.01 (Antonio Manuel);

Doc.48, fól.1r, 1.40 (e combina) // fól.1v, 1.01 (e Combinados);

Doc.48, fól.1v, 1.39 (en cada al) // fó1.2r, 1.01 (En cada alqueire).

\subsubsection{Outros Comentários}

a) Papéis de cores amarela, azul ou marrom, às vezes manchados pela tinta por ser escrito no recto e verso;

b) Existência de segmentação da margem esquerda e direita;

c) Nos documentos de número: 01, 03, 07, 08, 11, 13, 15, 33, 34, 39, 40, 43, 44, $45,47,49$ e principalmente 10 e 12 , verifica-se que o corpo do texto está mais 
alinhado para a direita do leitor. Sobre este recurso, Acioli (1994, p. 55) comenta: "É habitual, principalmente às consultas do Conselho Ultramarino, redigi-las quase em coluna, na segunda metade da folha, deixando-se a primeira, à esquerda, para pareceres dos procuradores da coroa ou despachos régios";

d) A cor da tinta parece ser ferrogálica (marrom em tons claros e escuros);

e) Nos fólios selecionados há um carimbo circular de cor azul escrito em que se lê: Departamento do Arquivo do Estado. Existem ainda, em alguns manuscritos, anotações a lápis do arquivista, indicando a data, a cidade e o código do documento.

Com relação aos aspectos paleográficos, observa-se uma caligrafia homogênea, escrita moderna com letra cursiva, tamanho pequeno e tombada para a direita. Alguns fólios contêm várias abreviaturas, enquanto tais recursos foram usados parcimoniosamente em outros deles. Na pontuação, verifica-se o uso de vírgula, dois pontos, ponto final, hífen ou sinal de igual para separar sílabas e/ou indicar final de linha. Na acentuação, para marcar a nasalidade coocorrem duas formas: o til $(\sim)$ e um acento com formato de vírgula ('), colocados (na maior parte) na sílaba final do ditongo nasal; o acento circunflexo $\left(^{\wedge}\right)$ às vezes é usado com valor de agudo ('). O acento diacrítico usado atualmente como indicador de crase ( ) é representado na maioria das vezes pelo circunflexo.

\subsection{CARACTERísticas da Escrita do SÉCUlO XVIII}

Pinto (1988, p. 15), ao tratar da diacronia do português no Brasil, afirma haver somente duas fontes para a reconstituição do estado da língua portuguesa no século XVIII: “os trabalhos lingüísticos então publicados e os textos literários, em prosa e em verso, dos autores setecentistas, portugueses e brasileiros”. Esta asserção é um tanto questionável, uma vez que se discutiu nesta tese a possibilidade de estudar o estado da língua portuguesa no Brasil por meio de outras fontes que não sejam, especificamente, os textos literários. Vários estudiosos da língua utiliza[ra]m-se de documentos notariais, eclesiásticos, cartas, entre outros, como fontes confiáveis para o estudo paleográfico de séculos anteriores. 
Quanto à produção escrita no território brasileiro, Dias e Bivar (1986, p. 18) traçam as seguintes características:

No século XVI, produziu-se no Brasil Colonial documentação caracterizada pela forma eclética de escrita. Assim, persistem documentos com formas gráficas uniformes e elegantes [...], como documentos de escrita rápida e malcuidada, típica de escrivães apressados que não tinham formação caligráfica.

Segundo as autoras, essa tendência irá continuar no século XVII, e a preocupação com o rigor ortográfico será menor ainda. Já no século XVIII, “assiste-se a uma progressiva retomada dos rigores ortográficos e caligráficos, que segue até meados do século XIX, quando a escrita cursiva torna-se similar à atual” (DIAS; BIVAR,1986, p.18).

Ao contrário das citadas autoras, Pinto (1988, p. 15-16) descreve a situação ortográfica no século XVIII ainda como caótica, e sua causa seria múltipla: "primeira, de natureza teórica, foi a indecisão do ortografista, dividido entre a tradição ou o costume ortográfico, a etimologia (revalorizada pelo culto das letras e das tradições clássicas) e as realidades fonéticas da língua, que presenciava e procurava não ignorar”.

Em relação à periodização que se faz da ortografia portuguesa, é comum os linguistas históricos (COUTINHO, 1967; MELO, 1971; WILLIAMS, 1973) dividi-la em três períodos ou tendências: o fonético, o pseudoetimológico e o simplificado. O período fonético se inicia com os primeiros documentos redigidos em português e vai até o século XVI. Segundo Coutinho (1967, p. 67), “apesar de existir certa flutuação na escrita das palavras, a preocupação fonética aflora a todo instante. Costuma-se dizer que a língua era escrita para o ouvido e não para os olhos, já que, à época, era uma minoria que dominava a leitura". No período quinhentista se inicia o etimológico ou pseudoetimológico - caracterizado pelo emprego de consoantes geminadas e insonoras, de grupos consonantais impropriamente chamados gregos -, que dura até o início do século XX, em 1904, data da publicação da Ortografia Nacional de Gonçalves Viana, que marca o início do período simplificado até nossos dias.

Apesar de Williams (1973, p. 41) afirmar ter sido o século XVIII "período de amargas polêmicas ortográficas; e terminou por predomínio arrasador da ortografia etimológica", tal corroboração não se constata nos dados analisados nesta tese, apesar de a escrita do corpus ser referente ao período setecentista. 
No que tange à polêmica sobre o período fonético, atualmente, começam a surgir novas propostas esclarecedoras, as quais refutam o termo 'escrita fonética' para definir o período ortográfico entre os séculos XII a XIV. Segundo Cagliari (1994) e Massini-Cagliari (1998), em estudos do português arcaico, há um crença de que a escrita do português, nessa época, era fonética, ou seja, procurava transcrever fielmente os sons da fala de quem produziu o texto. Os autores argumentam que a falta de uma tradição ortográfica comum até início do século XX, em Portugal, fez com que esse período fosse marcado por um "grande caos ortográfico". Para eles, então, não se deve ressaltar um período de ortografia fonética para o português antigo, mas salientar que o que ocorria era uma escrita baseada no modelo latino, ou seja, ortográfica, por isso, grande parte dos escribas usava sua intuição no ato de escrever, o que ocasionava muitas confusões ortográficas devido à variação dialetal e ao uso individual que as pessoas faziam das grafias das palavras. Portanto, Massini-Cagliari (1998, p. 177) propõe uma revisão do emprego do termo 'fonético',33 atribuído à periodização da ortografia da língua portuguesa, e esclarece que 'período fonético' só seria aceitável se considerado em oposição ao 'período etimológico':

... quanto [...] ao caráter fonético da escrita nessa época do desenvolvimento da língua, podem ser tomadas como verdadeiras apenas se se fizer a ressalva de que, embora inadequadamente, o termo 'fonético' é, nesses casos, usado em oposição a 'etimológico' - e não no seu sentido primeiro de 'transcrição fiel da fala'. Assim procedendo, estaremos nos livrando das armadilhas a que o rótulo pode conduzir, através da utilização de uma terminologia mais adequada.

Depois de precedida por este breve comentário, a proposta desta seção é mostrar o estado de língua em que se encontram os manuscritos, descrevendo os principais elementos linguísticos constantes do corpus.

\footnotetext{
33 Apesar da autora Massini-Cagliari não ser favorável ao emprego do termo 'fonético' atribuído à periodização da ortografia da língua portuguesa, também não sugere qual termo utilizar em seu lugar.
} 


\subsubsection{Ortografia}

Observa-se que a grafia utilizada nestes textos frequentemente se assemelha à utilizada na atualidade, porém, em alguns pontos (consoantes e vogais duplas, escrita etimológica, arcaísmos etc.), possui características próprias, que se passa a estudar nesta seção. Sabe-se que os fonemas constituem o material sonoro da língua (COUTINHO, 1967) e que, desta maneira, ao grafar os vocábulos, movido por diversos fatores (por exemplo: falta de fixação das normas gramaticais, pressa, equívoco, nível de escolaridade, entre outros), o escriba poderia fazê-lo de forma diferente da que era exigida pelas gramáticas da época.

Dicionaristas como Viana (1904), Morais Silva (1945) e Caldas Aulete (1948) observam que discrepâncias na grafia dos vocábulos podem ocorrer tanto pela flutuação das formas, como pela chamada pseudoetimologia. A ortografia brasileira não segue uma uniformidade em sua história. O pseudoetimologismo teve, segundo Coutinho (1967), grande aceitação no meio letrado e observou-se uma tendência fonética na ortografia. Isto gerou muitas complicações gráficas, sobretudo depois do Renascimento, que proclamava um maior conhecimento dos clássicos gregos. A partir daí, as palavras sofrem uma influência etimológica, apresentando maior número de letras que o necessário para a pronúncia.

Os manuscritos que aqui se encontram transcritos podem ser situados no período pseudoetimológico devido ao período em que foram produzidos. Observa-se, também, a flutuação na ortografia das palavras: no mesmo texto ou pelo mesmo punho, encontra-se a mesma palavra grafada de formas diferentes. No corpus do trabalho, o mesmo copista escreve:

\section{a) mesmo documento}

Doc.03, fól.1v, 1.15: Cappitam / 1.26: Capitam;

Doc.10, fól.1r, 1.04: Sâo / 1.25: Sam;

Doc.10, fól.1r, 1.07: de / 1.17: di;

Doc.17, fól.1r, 1.18: leaes / 1.22: Leais;

Doc.22, fól.1r, 1.19-20: perços / 1.25: preço;

Doc.33, fól.1v, 1.17: axaõ / fól.2r, 1.05: acha;

Doc.37, fól.1r, 1.21: ffeitos / fól.1v, 1.27: feitto / fól.1r, 1.34: Ministtro / fó1.1v, 1.03: ministro; 
Doc.46, fól.1r, 1.12: sussistençia / 1.17: suscestençia / 1.24: Excelencia / 1.25: Excilencia.

\section{b) mesmo punho em documentos diferentes}

Doc.01, fól.1r, 1.12: tambem / Doc.03, fól.3r, 1.11: tanbem;

Doc.01, fól.1v, 1.15: Homildes / Doc.03, fól.2r, 1.05: Omildes;

Doc.10, fól.1v, 1.15: Collejo / Doc.11, fól.1v, 1.02: Colegio;

Doc.45, fól.1r, 1.21: segundo / Doc.46, fól.1r, 1.37: cegundo.

Segundo Williams (1973), a letra $h$ foi usada para marcar o hiato entre duas vogais de qualidades diferentes ou para marcar a sílaba tônica da palavra:

Doc. 03 , fól.1v = 1.19: athe / 1.24: dahi;

Doc.07, fól.1r, 1.11: ahde;

Doc.10, fól.1v, 1.14: Thê;

Doc.11, fól.1r, 1.13: prohiuimos;

Doc.15, fól.1r, 1.15: ancehar;

Doc.25, fól.1v, 1.08: peçuhiaõ;

Doc.31, fól.1r, 1.27: sahio / Doc.36, fól.1r, 1.26: sahem;

Doc.32, fól.1r, 1.11: Cohibir / Doc.46, 1v, 1.08: Cohibido.

\subsubsection{Consoantes duplas}

Consoantes duplas existiam no latim clássico e podiam ser encontradas no português arcaico e, em geral, só se dobravam consoantes quando tinham valores diferentes das simples. Além do r e s, as outras que aparecem geminadas são c, $\mathbf{f}, \mathbf{l}, \mathbf{m}, \mathbf{n}, \mathbf{p}$ e t:

\section{a) duplicação do c}

Doc.22, fól.1r, 1.04: occasiaõ.

Doc.36, fól.1r, 1.10: occurrentez 


\section{b) duplicação do f}

Doc.01, fól.1r, 1.18: offeçiais;

Doc.15, fól.1r, 1.12: officios;

Doc.19, fól.1r, 1.08: differença;

Doc. 21 , fól.1r = 1.11: effeito / 1.20: offerece;

Doc.25, fól.1v, 1.04-05: Sufficientes;

Doc.34, fól.1v, 1.07: refferido ;

Doc.36, fól.1r, 1.28: difficuldade / fól.1v, 1.07: efficacia;

Doc.37, fól.1v, 1.02: ffazendo / 1.06: ffizer.

\section{c) duplicação do 1}

Doc.01, fól.1r = 1.06: Sam Paullo / 1.10: vassallos, pella;

Doc.02, fól.1r, 1.03: villa;

Doc.11, fól.1v, 1.18: tiralla;

Doc.14, fól.1r, 1.23: nullo

Doc.17, fól.1r, 1.03-04: collocamos;

Doc.21, fól.1r = 1.14: pocibillidades / 1.21: Representallos;

Doc. 22 = fól.1r, 1.06-07: Collonia / fól.1v, 1.02: fallar;

Doc.25, fól.1r, 1.12: pillares;

Doc.31, fól.1r, 1.20: Illustre / 1. 1.23: daquelle / 1.26: ellegendo.

\section{d) duplicação do m}

Doc.10, fól.1r, 1.10: commizeraçonins;

Doc.17, fól.1r, 1.08: commum;

Doc.33, fól.1r, 1.16: imminentes / 1.18: Commarca.

\section{e) duplicação do n}

Doc.01, fól.1r, 1.30: annos;

Doc.15, fól.1r, 1.03: sennado; 
Doc.31, fól.1r, 1.14: innovar;

Doc.37, fól.1r, 1.11,21,25: penna;

Doc.47, fól.2v, 1.10: melecianna.

\section{f) duplicação do p}

Doc.03, fól.1v, 1.15: Cappitam;

Doc.21, fól.1r, 1.25: cappitania;

Doc.22, fól.1v, 1.06: cappitulos;

Doc.26, fól.1r, 1.13: appareceo / 1.13: ocuppasaõ;

Doc.31, fól.1v, 1.03: supposto;

Doc.33, fól.1v, 1.12: applicada / fó1.2r, 1.02: supplicantes;

Doc.36, fól.1r, 1.09: Supplicaz.

\section{g) duplicação do $t$}

Doc.12, fól.1r, 1.14: Remetter;

Doc.21, fól.1r = 1.09: Attendido / 1.20: attender;

Doc.22, fól.1r, 1.13: attenção;

Doc.37, fól.1r, 1.01: Pettisaõ / 1.01-02: aprezenttado / 1.02: dettreminaçaô / 1.05:

Douttor, Tenentte / 1.06: destta / 1.08: ttem / 1.09-10: feittos / 1.11-12: impôstta /

1.12-13: Suplicantte / 1.13: Custtuma, efeittos / 1.14: outtros / 1.15-16: néstta / 1.17: contta / 1.20: ttodos / 1.25: impedimentto / 1.29-30: mottivos / 1.33: reprezentta / 1.36: juntta / fól.1v, 1.12-13: manttimenttos.

A troca de $\mathbf{s}$ por ss, $\mathbf{z}$ ou mesmo ç é frequente e acontece pela confusão de sons do fonema $/ \mathrm{s} /$ e pelo fato de o sistema ortográfico não se ter firmado ainda naquela época. Segundo Paiva (1988, p. 36) “por volta de 1550, começa a haver confusão entre os fonemas, grafando-se $c ̧$ e $s s$ ou ss por $c ̧$; $s$ por $z$ e vice-versa. Daí as dificuldades que ainda se encontram hoje na grafia de sons semelhantes como $c$ e ss e $s$ intervocálico e $z$." (grifos do autor).

Em textos mais antigos, esta diferença existia pelo fato de que, em certas regiões de Portugal, se fazia a distinção de /s/ intervocálico e /z/, /s/ surdo inicial, final de palavra ou sílaba, sonoro quando intervocálico ou antes de consoantes sonoras. A escrita distingue o que 
o ouvido, na época, já percebia, entretanto não se havia fixado o uso desta ou daquela letra de forma eficiente para sanar confusões deste tipo. Seguem exemplos:

\section{a) $\mathbf{c}$ por $\mathrm{s}$}

Doc.22, fól.1r, 1.19: venderce / fól.1v, 1.11: concelho;

Doc.25, fól.1r, 1.06: conceruarlhe;

Doc.22, fól.1r, 1.22: concideraçaõ;

Doc.30, fól.1r, 1.09: cegundo;

Doc.33, fól.1r, 1.16: cegue;

Doc.46, fól.1r, 1.30: concervaram / 1.37: cegundo / fól.1v, 1.14: conceguinte;

Doc.47, fól.1v, 1.07: sencivel;

Doc.48, fó1.1r, 1.39: instruir-ce.

\section{b) c por sc}

Doc.36, fól.1r, 1.33: crecimento.

\section{c) ç por c, s, sç e ss}

Doc.01, fól.1r, 1.02: Reçebemos / 1.09: fauoreçer / 1.16-17: çertidam / 1.20: benefiçio;

Doc.11, fól.1r, 1.30: Prouençial; Doc.44, fó1.1r, 1.14: suçesivos;

Doc.45, fól.1r, 1.12: ojtoçentos / 1.18: conferençia / 1.29: pareçe;

Doc.46, fól.1r, 1.25: inçinua / fól.1v, 1.26: pençam, emporçe; Doc. 36, fól.1r, 1.33: creção.

Doc.01, fól.1r, 1.21: poçiuel; Doc.25, fól.1v, 1.07: compraçem;

Doc.35, fó1.1r, 1.14: Peçoa;

Doc.46, fól.1r, 1.08: foçe / 1.19: Profeçor / 1.38: dezaçeis.

\section{d) $\mathbf{s}$ por $\mathrm{c}$}

Doc. 03 , fól.1v = 1.11: notisia / 1.26: exersendo;

Doc.04, fól.1r, 1.07: Sertificamos;

Doc.07, fól.1r, 1.12: Sinco; 
Doc. 10 = fó1.1r, 1.08: serteza / fó1.1v, 1.21-22: Exselenssia;

Doc.11, fól.1r, 1.24: nesesidade;

Doc.14, fól.1r, 1.09: Sesar;

Doc.22, fól.1r, 1.10: seifa;

Doc.25, fól.1v, 1.19: desizaõ;

Doc.32, fól.1v, 1.12: serca;

Doc.33, fól.1v, 1.06: sitado;

Doc.37, fól.1v, 1.11: merse;

Doc.41, fól.1r, 1.21: sego;

Doc.43, fól.1r, 1.12: segueira;

Doc.46, fól.1r, 1.06: serto / 1.09: serurgiam;

Doc.47, fól.3r, 1.20: siencias.

e) $\mathbf{s}$ por ç

Doc.03, fól.1v, 1.18: momeasam;

Doc.08, fól.1r, 1.10: expediSam;

Doc.11, fól.1r, 1.14: ComeSam;

Doc.21, fól.1r, 1.18: fasa;

Doc.25, fól.1v, 1.17: brasas;

Doc.26, fól.1r, 1.19: ocuppasaõ / 1.21: obrigasoens;

Doc.31, fól.1r, 1.20: presensa.

\section{f) $\mathrm{s}$ por sc}

Doc.46, fól.1r, 1.20: desipolos.

\section{g) s por ss}

Doc.02, fól.1r, 1.10: paSa;

Doc.03, fól.1r, 1.13: aSim / fól.1v, 1.02: nosos;

Doc.04, fól.1r, 1.14: aSigna;

Doc.10, fól.1r = 1.29: emposiuel; 
Doc.11, fól.1r, 1.24: nesesidade;

Doc.12, fól.1r, 1.11: deseseis;

Doc.13, fól.1r, 1.23: Pesoa;

Doc.28, fól.1r, 1.12: outrosim;

Doc.37, fól.1v, 1.17: Ilostrisimo / 1.26: dese;

Doc.41, fól.1r, 1.20: emposebelitado;

Doc.44, fól.1r, 1.11: poses.

h) sc por c

Doc.39, fól.1r, 1.06: falescido;

Doc.42, fól.1v, 1.07: felescite;

Doc.47, fól.3r, 1.26: felescidade.

\section{i) ss por $\mathrm{c}$}

Doc.10, fól.1r, 1.24: provinssial / fól.1v = 1.05: alcanssem / 1.17: meresser / 1.21-22:

Exsselensia;

Doc.37, fól.1v, 1.01: mersses.

\section{j) ss por ç}

Doc.12, fól.1r, 1.15: embarcassonins / fól.1v, 1.07: seruisso;

Doc.21, fól.1r, 1.18: fassa;

Doc.31, fól.1r, 1.18: fassão;

Doc.32, fól.1v, 1.01-02: Prassa;

Doc.35, fól.1r, 1.07: nomeassoens;

Doc.40, fól.1v, 1.05: rematassaõ.

\section{l) ss por $\mathrm{s}$}

Doc.12, fól.1r, 1.33: compadecersse;

Doc.16, fól.1r, 1.10: ssua;

Doc.48, fól.1v, 1.21: subssidio. 


\section{m) $\mathbf{S} \operatorname{por} \mathbf{z}$}

fes: Doc.16, fól.1r, 1.05 / Doc.23, fól.1r, 1.06 / Doc.24, fól.1r, 1.07;

ves: Doc.32, fól.1r, 1.21 / Doc.46, fól.1r, 1.13. Arros: Doc.47, fól.1v, 1.37.

\section{n) $z$ por $s$}

Doc.11, fól.1r, 1.12: e az outras;

Mezes: Doc.14, fól.1r, 1.21 / Doc.45, fól.1r, 1.17 / Doc.47, fól.2r, 1.22 / Doc.48, fól.1v, 1.24 .

\subsubsection{Consoantes etimológicas}

A grafia de letras, que não eram pronunciadas no meio de palavra e que, mais tarde, foram abolidas sem nenhum prejuízo para seu perfeito entendimento, era muito comum na epóca em que os manuscritos foram escritos (século XVII - XVIII). Conforme Coutinho (1967, p. 75),

... o critério adotado pelos que seguem a grafia etimológica é respeitar, tanto quanto possível, as letras originárias da palavra, embora nenhum valor fonético representem. Apesar da influência do latim se fazer sentir em nossa língua, em todo o decurso de sua história, é a partir do século XVI que ela se torna predominante.

Assim, consoantes aparentemente "sem função" fonética são justificadas pela etimologia da palavra, ou por analogia com outras palavras semelhantes.

Said Ali (1964) afirma que a oclusiva $p$, consoante de transição no grupo latino $m p t$, deixou de subsistir desde o momento em que $m$ perdia seu valor de consoante labial nasalizando a vogal precedente. Em pronptos, pronpta, promptidão pode-se confirmar a origem do latim promptu, portanto este $p$ é etimológico. A palavra aSigna vem do latim assignare, o grupo consonantal gn simplifica-se em $n$. Em acto também reside o fundamento da etimologia latina do vocábulo, vem do latim actum -i. No processo de evolução fonética do grupo consonantal - ct, ocorre a "assimilação da consoante - $c$ - ao -t- e depois redução dos -tt- a 
-t-" (COUTINHO, 1967, p. 124). Desse tipo de assimilação, tem-se as seguintes ocorrências no corpus: acteuidade, actual, afecto, destrictos, Exactamente, factos, objecto e projectos.

Há também registros de ocorrências de vocábulos pseudoetimológicos nesta fase ortográfica, a saber:

Doc.01, fól.1r, 1.10: vassallos;

Doc.02, fól.1r. 1.05: pella;

Doc.27, fól.27, 1.20: votto;

Doc.31, fól.1r, 1.26: ellegendo;

Doc.32, fól.1v, 1.03: fallavão;

Doc.33, fól.1r, 1.14: attentas;

Doc.37, fól.1r, 1.05: Tenentte / 1.13: Custtuma / 1.28-29: mottivos / fól.1v, 1.30: pustturas;

Doc.42, fól.1r, 1.13: volumptaria;

Doc.47, fól.2r, 1.03: iresoluptos.

Encontra-se também o verbo ser na terceira pessoa do presente do indicativo, frequentemente com $|\mathrm{h}|$ : he (algumas passagens: Doc.01, fól.1v, 1.07; Doc.03, fól.1v, 1.10; Doc.09, fól.1r, 1.17; Doc.13, fól.1r, 1.14; Doc.14, fól.1r, 1.23; Doc.15, fól.1r, 1.15). Williams (1973) aponta que he por é ocorria provavelmente, para distinguir o verbo da conjunção $e$.

\subsubsection{Alógrafos}

Outro aspecto interessante são os alógrafos (variantes gráficas) existentes nos manuscritos, indicando marcas do português arcaico. Nas cartas encontra-se o $|\mathrm{S}|$ longo em posição medial: Doc.01, fól.1r, 1.10: vassalos, fól.1v = 1.09: notisia, 1.10: possa, e raros os casos em posição inicial: Doc.01, fól.1r, 1.10: seus, 1.13: sua. Este tipo de $|\mathrm{S}|$ difere do maiúsculo inicial: Doc.04, fól.1r, 1.16: Sete; Doc.08, fól.1r, 1.06: Sua, 1.12: SeruiÇo.

$\mathrm{O}|\mathrm{R}|$ em posição medial por vezes aparece grafado com formato de curva: Doc.01, fól.1r, 1.19: pRimeiro; Doc.02, fól.1r, 1.12: pResente; Doc.03, fól.1v, 1.02: pRohiuiram. $\mathrm{O}|\mathrm{R}|$ final é sempre reto: Doc.03, fól.1r, 1.17: pRouedor, 1.20: partiCular, 1.21: Gouernador. Em 
uma leitura desatenta, pode-se confundir o $|\mathrm{R}|$ curvo com o $|\mathrm{L}|$, elimina-se a dúvida apenas pelo sentido da palavra.

Outros exemplos de alógrafos nos documentos:

Doc.01, fól.1r, 1.20 / doc.13, fól.1r, 1.15: vnico;

Doc.13, fól.1r, 1.15: vsado:

Doc.47, fól.3v, 1.06: vmildes;

Doc.10, fól.1v, 1.07: Iesu / Doc.25, fól.1r, 1.09: Iesus;

Doc.25, fól.1r, 1.35: Oie;

Doc.11, fól.1r, 1.10 / Doc.21, fól.1r, 1.15: vaj;

Doc.11, fól.1r, 1.17: Rej / fól.1v, 1.23: Majo;

Doc.13, fól.1r, 1.15: mejo / 1.17: aJnda;

Doc.14, fól.1v, 1.05: escrevj;

Doc.45, fól.1r, 1.12: ojtoçentos.

\subsubsection{Formas antigas}

Said Ali (1964) considera que a maior diferença entre o português brasileiro e o de Portugal refere-se à pronúncia e que alguns acreditam ser tais diferenciações todas inovações brasileiras quando, em boa parte, são apenas arcaísmos fonéticos e prosódicos conservados por nós, brasileiros. Isto pode ser explicado pelo fato de a língua portuguesa ter entrado no Brasil em 1500 e conservou-se mais ou menos próxima do que era, principalmente nas áreas que se encontram distantes do centro urbano.

Segundo Coutinho (1967, p. 136), “em algumas palavras, a influência literária restabeleceu o $-u$ depois de consoante velar. Por vezes, conserva-se o $-u$ como mero expediente gráfico". Os próprios gramáticos indicam a confusão que era gerada ao grafar o fonema, pois, na fala, ele não era pronunciado. Inclusive o próprio Williams (1973) cita este tipo de ocorrência numa lista intitulada Confusão de grafias, onde dispõe vários outros termos, entre eles o uso de qu por $c$ : cinquo por cinco, e o uso de $c$ por qu é encontrável, mas raro: pecena por pequena. Exemplos interessantes ocorrem dentro do texto: 
Doc.02, fól.1r,1.05: publicei (por publiquei);

Doc.46, fól.1r, 1.22: comvocemos (por convoquemos);

Doc.03, fól.1v, 1.08: case (por quase) / 1.19: porcoanto (por quanto);

Doc.11, fól.1r, 1.08: coando (por quando);

Doc.14, fól.1v, 1.03: Coatro (por quatro);

Doc.15, fól.1r, 1.19: coase (por quase);

Doc.16, fól.1r, 1.05: as coais (por as quais);

Doc.25, fól.1r, 1.23: coadra (por quadra);

Doc.23, fól.1r, 1.07: Comarqua (por comarca).

Estas palavras referem-se mais à problemática de ordem fonética que gráfica. Constata-se, também, a troca do $\boldsymbol{u}$ átono de final de palavra por $\boldsymbol{o}$. Exemplos:

Doc.03, fól.1r = 1.05: Deos / 1.10: partio;

Doc.11, fól.1r, 1.33: esCreveo;

Doc.16, fól.1r, 1.03: Recebeo;

Doc. 22 , fól.1v = 1.05-06: correo / 1.13: seos;

Doc.25, fól.1r, 1.24: Proueo.

Ocorrem casos de metátase, que, segundo Coutinho (1967), é o fato em que dois ou mais fonemas trocam de lugar. Exemplos:

Doc.01, fól.1v, 1.02: treSeiro;

Doc.21, fól1r, 1.17: detriminará;

Doc.37, fól.1r, 1.02: dettreminaçaõ / fól.1v, 1.37: dettreminado;

Doc.11, fól.1r, 1.29: emtreseder;

Doc.22, fól.1r, 1.19-20: perços;

Doc.25, fól.1r, 1.27: pertenderaõ / fól.1v, 1.11: portendem;

Doc.31, fól.1r, 1.06: pertende / 1.11: perjuizo / 1.27: pertendem / fól.1v, 1.06: pertendo;

Doc.32, fól.1r, 1.06: pertendia / 1.12-13: percizas;

Doc.33, fól.1v, 1.04: perciza / 1.16: percizo;

Doc.37, fól.1v, 1.25: porhebirse;

Doc.44, fól.1r, 1.05: perterito; 
Doc.46, fól.1r, 1.05-06: percizarem / 1.15: percizam / fól.1v, 1.03: percionada / 1.13: percizava.

Há casos também de alternância entre $e / i$ e $o / u$. Há um rebaixamento do $i$ e $u$ e alçamento do $e$ e $o$. Este processo ocorre nos seguintes exemplos:

a) abaixamento: $<$ i $>$ por $<$ e $>,<$ u $>$ por $<$ o $>$

Doc.01, fól.1r, 1.04: notesiarnos / 1.18: offeciais;

Doc.03, fól.1r, 1.09: emformar / fól.1v, 1.04: destrito;

Doc.03, fól.1v, 1.10: Coritiba;

Doc.05, fól.1r, 1.07: trebutos;

Doc.08, fól.1r, 1.16: meLitares;

Doc.08, fól.1r, 1.19: Omildes;

Doc.10, fól.1r, 1.29: emposiuel / 1.30-31: deLigências;

Doc.29, fól.1r, 1.06: regestado;

Doc.31, fól.1r, 1.08: Logar (por lugar);

Doc.33, fól.1r, 1.17: Creador.

b) alçamento: $<$ e $>$ por $<$ i $>,<$ o $>$ por $<$ u $>$

Doc.01, fól.1r, 1.29: inpuSibilidade;

Doc.02, fól.1r, 1.08: Rigistado;

Doc.11, fól.1v, 1.10: CompRimento (por cumprimento);

Doc.17, fól.1r, 1.15-16: disculpará;

Doc.20, fól.1r,1.32-33: dispeza;

Doc.27, fól.1r, 21: institutu;

Doc.37, fól.1r, 1.08: empidido / fól.1v, 1.30: pustturas / fól.2r, 1.08: comfiri. 


\subsubsection{Abreviaturas}

Quanto às abreviaturas, observa-se largo uso em praticamente todos os textos. De acordo com Houaiss (1967), o uso de abreviaturas só se mostra interessante quando se abreviam palavras frequentes no corpo da obra, pois, de outra maneira, pode tornar-se obscuro ou incompreensível, além de ser quase nula a economia que decorre de uma abreviação esporádica. As abreviaturas eram, tal como hoje, grupos de letras que são substituídos por traços, pontos ou linhas (reta, curva ou envolvente) e que contraem grupos maiores de letras por vezes sílabas inteiras - com a finalidade de diminuir o tempo gasto com a escrita ou economizar o espaço reservado para tal, variando de obra para obra, de autor para autor, em função da frequência de certos vocábulos empregados. Sua profusão se explica em razão da raridade e, consequentemente, do custo elevado do material da escrita (SPINA, 1987). Outro fator frisado por Acioli (1994, p. 46) é "a lei do menor esforço, que levava o escriba a abreviar as palavras para dispender [sic] menos tempo e energia no seu trabalho". Encontramse, nestes manuscritos, diversos tipos de abreviatura que, segundo Cambraia (2005), podem ser classificados nas seguintes categorias:

a) suspensão ou apócope - acontece a supressão de elementos finais do vocábulo: Doc.01, fól.1v, 1.10: p. para, 1.12: q. quem, 1.14: a. annos;

Doc.11, fól.1r, 1.09: q que;

Doc.16, fól.1r, 1.07: vm vossa mercê.

b) siglas - consistiam, como ainda hoje se usa, na representação das palavras pela sua inicial maiúscula, acompanhada de ponto:

Doc.01, fól.1v, 1.15: V. Vossa;

Doc.03, fól.1r, 1.21: D. Dom;

Doc.06, fól.1r, 1.04: D. Doutor, 1.05: G. General;

Doc.09, fól.1r, 1.05: S. Sam;

Doc.17, fól.1r, 1.09: S. Sua.

No Doc.11, fól.1r, 1.26, constam duas abreviaturas geminadas que indicam plural: R.R.= Reverendos P.P. $=$ Padres. 
c) contração ou síncope - consiste na supressão de letras intermediárias de uma palavra, permanecendo sempre a terminação. Este tipo de abreviatura foi o mais usado pelos escribas nos manuscristos em questão:

Doc.01, fól.1r, 1.10: m.to muito, 1.12: Requerim.tos Requerimentos, 1.16: 1.o livro, fól.1v, 1.08: Seqr.a Sequeira, 1.14: nobr.o novembro;

Doc.03, fól.1r, 1.29: g.de guarde;

Doc.18, fól.1r, 1.05: Ex.mo Excelentíssimo;

Doc.19, fól.19, 1.01: Rendim.to.

e) mista - supressão de letras intermediárias com presença de letra final:

Doc.01, fól.1r, 1.11: senhres senhores;

Doc.03, fól.1v, 1.15: Glz Gonçalvez;

Doc.06, fól.1r, 1.5: Roiz Rodriguez.

f) por sinal - ocorre a supressão das letras e a indicação de um sinal, geralmente sobreposto:

Doc.06, fól.1r, 1.04: Vigr' Vigario.

Neste texto estas abreviaturas foram desenvolvidas de acordo com as "Normas para a transcrição de documentos manuscritos para a história do português no Brasil" 34 , marcando em itálico a parte que foi omitida no original. Para as que suscitaram alguma dúvida, recorreuse ao trabalho de Borges Nunes (1981) e Flexor (1990) onde se eliminaram, praticamente, todas as incertezas.

\footnotetext{
${ }^{34}$ Normas apresentadas e discutidas durante o $2^{\circ}$ Seminário do Projeto PHPB realizado em Campos de Jordão, no período de 10 a 16 de maio de 1998, pela comissão de pesquisadores composta por Heitor Megale (USP), César Nardelli Cambraia (USP), Gilvan Müller de Oliveira (UFSC), Marcelo Módolo (USP), Permínio Ferreira (UFBA), Sílvio de Almeida Toledo Neto (USP), Tânia Lobo (UFBa) e Valdemir Klamt (UFSC).
} 


\subsubsection{Numeração}

Segundo Acioli (1994, p. 51), a numeração por extenso "foi usada, principalmente entre os séculos XIII e XVIII para documentos de chancelaria. Os escrivães da corte, por decreto de Afonso X, foram proibidos de usar letras para substituir nomes de cidades, pessoas, números, etc., escreviam por extenso as quantidades e as datas".

Os algarismos que constam dos documentos estão, em sua maioria, relacionados à data. Aparecem ora no início: Doc.07, fó1.07, 1.04-05: "Reçebemos a Carta de Vossa Excelência de deZaSete de deZenbro de 1721"; ora no final: Doc.02, fól.1r, 1.12-13: "Pernagua 14 de novembro de 1721 annos". Said Ali (1964, p. 86, grifos do autor) esclarece que

escrevendo por extenso os números 16,17 e 19 o português antigo ora separava os termos componentes, ora os ligava, de acordo com a pronúncia, em uma só palavra, mas sempre interpondo a copulativa e entre a dezena e a unidade. Seria uma questão de princípio o uso desta letra e não de outra; provável é que então, como mais tarde, proferidos os números rapidamente, a pronúncia da conjunção vacilasse entre $e$ e $a$. Por lhes soar antes como $a$, alguns quinhentistas e, como mais firmeza, os seiscentistas passaram a escrever dezaseis, dezasete, dezanove em lugar de dezesseis, dezessete, dezenove.

\subsubsection{Nasalidade}

O sistema consonantal nasal do português é representado pelas consoantes $\mathrm{m}, \mathrm{n}$ e nh, em contextos pós-vocálicos, representados foneticamente por [m],[n],[N].

Segundo Said Ali (1964), o til ( ) indica nasalidade quando sobreposto à vogal, que recai sobre o $-o$ ou $-e$ final, em casos de ditongos $-a o$ e $-o e$. A nasalação também pode aparecer com $-m$ ou $-n$ final. "Com relação à dificuldade da articulação da vogal nasal posta no fim do vocábulo, remediou-se nasalando a vogal que a precedia. Assim originaram-se palavras em n, til ou m" (SAID ALI, 1964, p. 37).

Quanto à grafia das nasais em documentos do século XVIII, observaram-se os seguintes fatos linguísticos: 
a) quando se trata de substantivos, atualmente grafados com ão, a maioria vem grafada com am:

Doc.01, fól.1v, 1.07: Joam;

Doc.03, fól.1v: 1.15: Cappitam / 1.18: momeasam;

Doc.07, fól.1r, 1.07: esCriuam;

Doc.10, fól.1r, 1.06: afliçam;

Doc.13, fól.1r, 1.15: disimulaçam;

Doc.46, fól.1v, 1.23: contribuicam;

Doc.48, fól.1v, 1.17: arecadassam.

b) quando se trata de desinência número-pessoal e modo-temporal ( $3^{\mathrm{a}}$ pessoa do plural do presente e dos pretéritos do indicativo), normalmente é grafada com $-a \tilde{\boldsymbol{o}} / \boldsymbol{a} \hat{\boldsymbol{o}}:$

Doc.03, fól.1v, 1.05: andauaõ;

Doc. 10 = fól.1r, 1.21: intentaô / 1.32: soccorriaô;

Doc.13, fól.1r, 1.12: puZeraõ;

Doc.16, fól.1r, 1.04: Acompanhauaõ;

Doc.22, fól.1r, 1.11-12: padeciaõ.

c) com til temos o artigo/numeral e pronome:

Doc.03, fól.1r = 1.14: huã / 1.21: hi;

Doc.12, fól.1r, 1.37: alguã;

Doc.22, fól.1r, 1.12: algũ.

Como também podem ser grafados sem o til, conforme observação de Paiva (1988, p. 38):

Doc.01, fól.1r, 1.23: hum;

Doc.03, fól.1v, 1.09: Algum;

Doc.14, fól.1r, 1.24: Alguns;

Doc. 25 = fól.1r, 1.12: huns / 1.13: huas. 
d) formando a sílaba inicial, o $m$ e $\mathrm{o} n$ alternam-se qualquer que seja o fonema da sílaba seguinte:

Doc.01, fól.1r = 1.29: inpuSibilidade / 1.30: emfermidade;

Doc.03, fól.1r, 1.16: emtregar;

Doc.08, fól.1r, 1.09: enbargo;

Doc.10, fól.1v, 1.02: emsino;

Doc.15, fól.1r, 1.11-12: emquanto.

e) os ditongos nasais, ou ditongos fonetizados, raramente recebem o til, mas sempre aparecem com o grafema $\boldsymbol{n}$ para indicar a nasalidade:

[ans]

Doc.14, fól.1r, 1.30: orffans.

[aons]

Doc.25, fól.v, 1.17: chaons / Doc.31, fól.1v, 1.18: maons.

[oens]

Doc.26, fól.1r, 1.21: obrigasoens / Doc.32, fól.1v, 1.03: petiçoens, 1.23: inquietaçoens Doc.35, fól.1r, 1.07: nomeassoens / Doc.36, fól.1r, 1.22: determinaçoens, fól.1v, 1.06: reflexoens.

[oins]

Doc.14, fól.1r, 1.16: prouizoins / Doc.27, fól.1r, 1.20: proficoins / Doc.30, fól.1r, 1.10: associacoins / Doc.46, fól.1r, 1.06: embarcacoins, 1.21-22: Extrucoins.

[ons]

Doc.18, fól.03, 1.1r: orfons / Doc.47, fól.2r, 1.19: habitasons.

Ocorrem nos documentos outros casos de nasalidades: ou sem a marca de nasalidade, ou com acento diacrítico com formato de vírgula:

Doc.12, fól.1r, 1.11: homenins;

Doc.10 = fól.1r, 1.10: commizeraconins / fól.1v, 1.09: petiçonins / Doc.12, fól.1r, 1.15: embarcassonins.

Doc.03, fól.1v, 1.18: Capitais';

Doc.25, fól.1r., 1.30: ordens'. 
O vocábulo também normalmente aparece desmembrado, formando dois vocábulos, isto é, grafado separadamente como tão bem.

Doc.32, fól.1r, 1.15: taõ bem;

Doc.40, fól.1r, 1.11: tão bem;

Doc.47, fól.1v, 1.26: tao’ bem. 


\section{Capitulo III}




\section{TRATAMENTO DO CORPUS ESCRITO: CRITÉRIO E SELEÇÃO DOS ITENS LEXICAIS}

Finalizada a transcrição e revisão dos 49 documentos manuscritos (total de 80 fólios), a próxima etapa consiste em analisar a frequência dos vocábulos. Para a análise da frequência, contagem, agrupamento vocábulos e localização das abonações usadas nos verbetes, este trabalho serviu-se de ferramenta computacional: o programa Léxico3, desenvolvido pela equipe YLED-CLA2T, da Universidade de Sorbonne Nouvelle-Paris 3.

Segue abaixo uma pequena amostragem da ferramenta Léxico 3, que serviu de base para o tratamento do corpus escrito.

Figura 3 - Exemplo de tratamento do corpus escrito: listagem dos vocábulos em ordem alfabética, número de frequência e texto transcrito conforme normas exigidas do programa Lexico 3

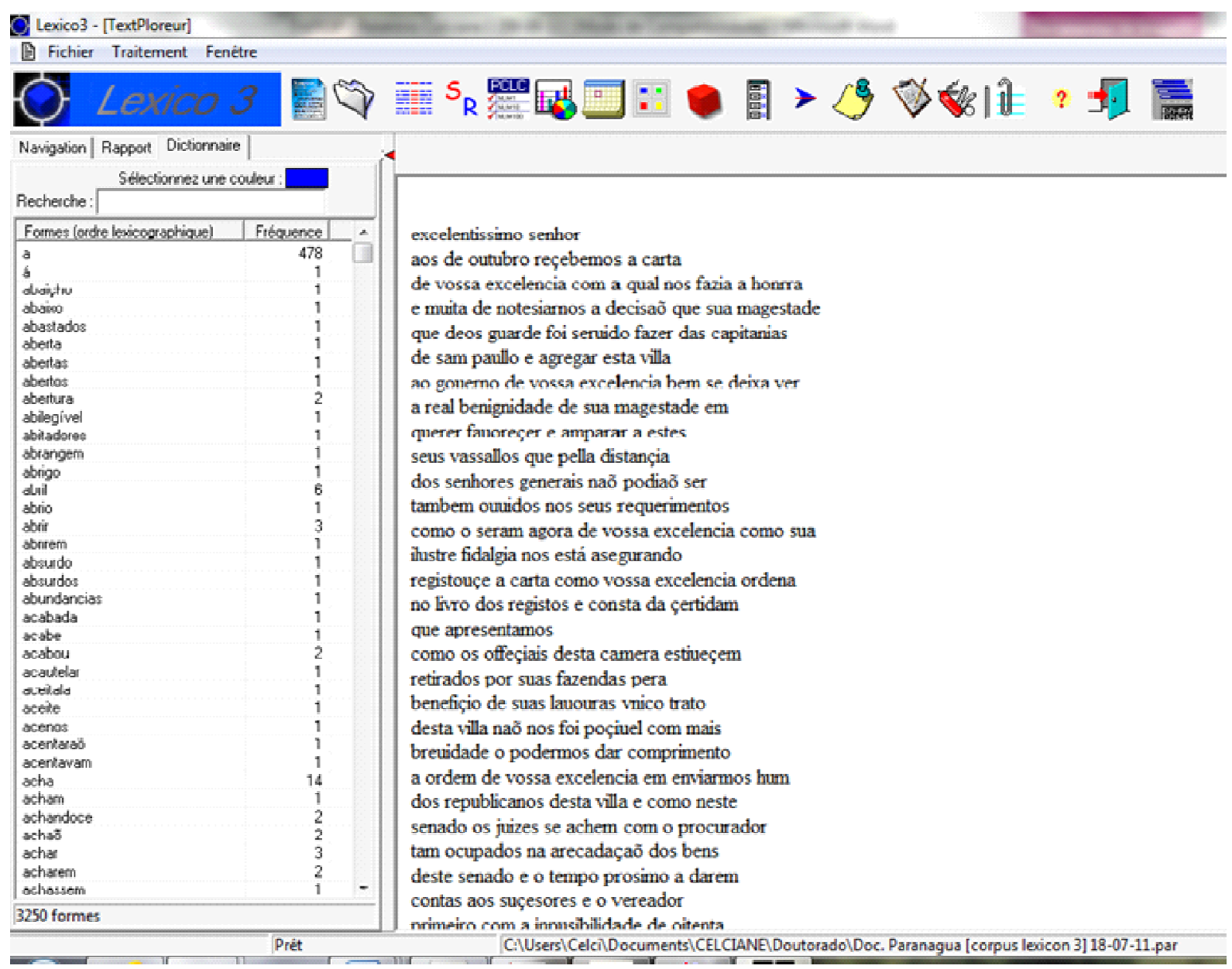


Figura 4 - Exemplo de tratamento do corpus escrito: frequência do vocábulo ballandra e suas ocorrências no documento manuscrito para busca das contextualizações no glossário

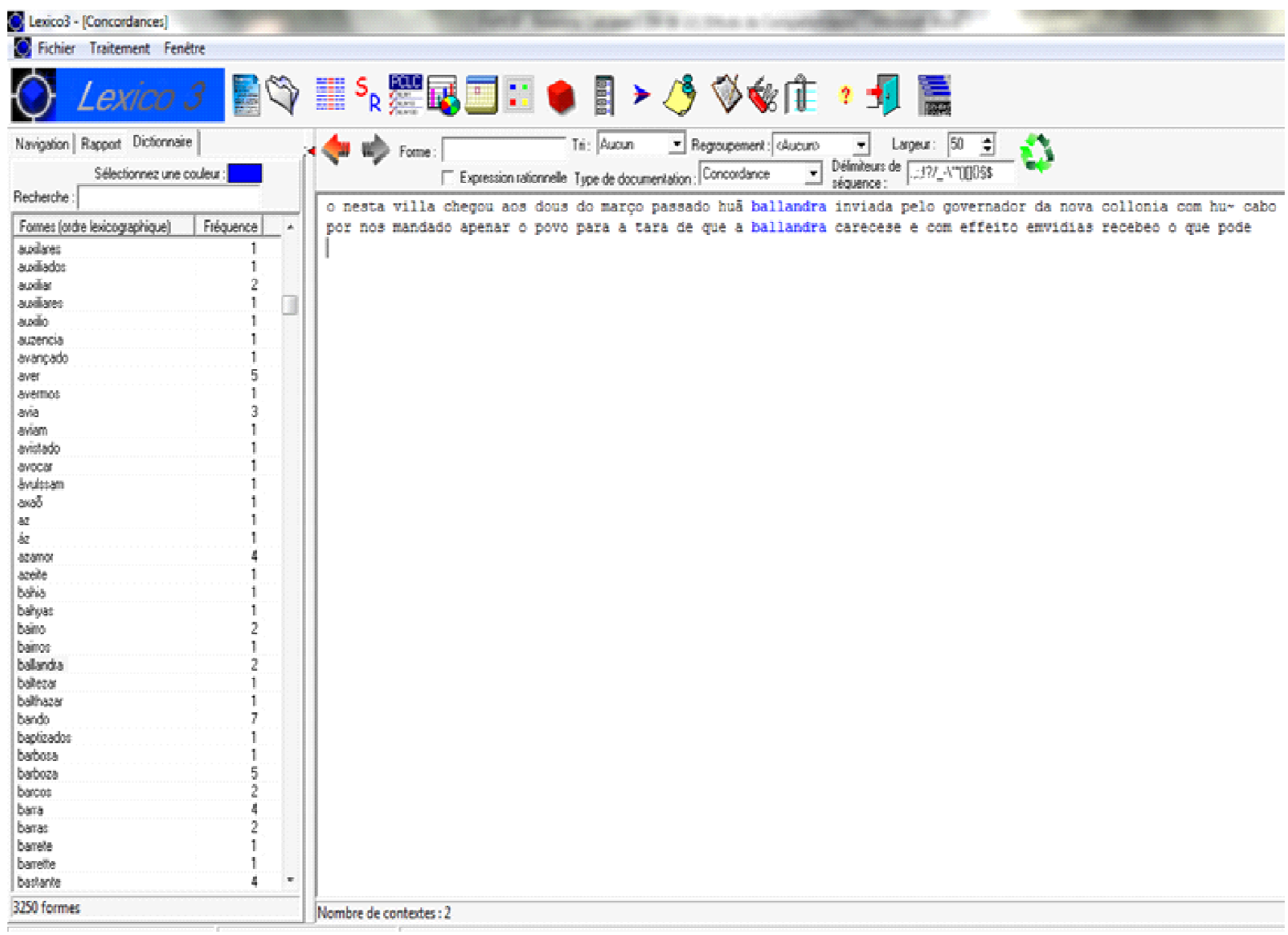

O conjunto dos documentos transcritos foi convertido em blocos de textos e aplicados à ferramenta Léxico 3, gerando uma lista de 3.276 (três mil e duzentos e setenta e seis) vocábulos (Apêndice A).

É importante ressaltar que os vocábulos constantes desta lista sofreram alteração apenas de maiúscula para minúscula, uma vez que o programa Léxico 3 reconhece apenas a escrita grafada ou em caixa alta ou em caixa baixa. Para o estudo que envolva a necessidade em pesquisar alternâncias entre maiúscula/minúscula, reportar-se ao segundo volume da tese, onde se encontra a edição semidiplomática, acompanhada dos fac-símiles, e que tem também por escopo 'fornecer dados confiáveis aos estudos linguísticos sobre o estado de língua no período do século XVIII', caracterizando- se como corpus genuíno da tese.

A lista, além de facilitar a leitura e a compreensão dos termos registrados nos documentos manuscritos e apresentar, de modo geral de 'A a Z' todos os vocábulos e 
suas respectivas variantes lexicais, fornece também dados linguísticos que se constituem num significativo corpus diacrônico, acessível a pesquisadores interessados em estudar variantes lexicais de documentos setecentistas produzidos no Paraná.

Quanto ao extenso número de ocorrências de vocábulos constantes da listagem, fezse necessário um recorte. Como o objetivo desta tese é estudar o léxico setecentista produzido em Paranaguá, optou-se, então, por selecionar para o estudo diacrônico os verbos, substantivos, adjetivos e advérbios, por constituírem a maior parte do inventário vocabular de uma língua. Segundo Martinet (1973), as palavras pertencentes a essas classes gramaticais são consideradas palavras lexicais, por conterem o significado lexical de determinada língua.

Portanto, a seleção dos vocábulos em verbos, substantivos, adjetivos e advérbio resultou numa lista de 1.212 (um mil e duzentos e doze) vocábulos (Apêndice B). É preciso ressaltar que, em manuscritos setecentistas, a ortografia ainda se encontra bastante oscilante, o que representa a ocorrência de variantes ortográficas. Como o objetivo deste trabalho não visa ao estudo dessas variações, elas foram convertidas para a grafia atual, conforme consta dos dicionários contemporâneos (substantivos e adjetivos passaram para a forma masculina e singular e os verbos para o infinitivo).

Partindo para a análise lexical de cada vocábulo listado, verificou-se que a maioria é de uso corrente do nosso dia a dia. Mas, foi possível observar, também, que alguns destes vocábulos, ou trazem uma acepção diferente da empregada atualmente - mesmo sendo termos conhecidos entre os usuários da língua portuguesa -, ou são vocábulos de pouco conhecimento do nosso vernáculo. Utilizando-se, então, desse critério de seleção, chegou-se a um total de 176 lexias julgadas mais pertinentes ao presente estudo.

Quadro 2 - Itens lexicais selecionados para análise semântico-lexical

\begin{tabular}{|l|l|l|l|}
\hline \multicolumn{4}{|c|}{ VERBOS } \\
\hline ACAUTELAR & ACOMPANHAR & ACORDAR & ACUDIR \\
\hline ADMOESTAR & ALENTAR & ANSIAR & APANHAR \\
\hline APENAR & APOSSAR & ARRIMAR & ARROMBAR \\
\hline ASSENHOREAR-SE & ASSISTIR & ATALHAR & $\begin{array}{l}\text { AVANÇAR A } \\
\text { DINHEIRO }\end{array}$ \\
\hline AVOCAR & BOTAR & BOTAR PINGOS & BROTAR \\
\hline CESSAR & COIBIR & COMISERAR-SE & DELIBERAR \\
\hline DEMITIR & DEPOR & DESPEJAR & EMBARAÇAR \\
\hline EMPREGAR-SE & ENJEITAR & ERIGIR-SE & ESCUSAR \\
\hline
\end{tabular}




\begin{tabular}{|l|l|l|l|}
\hline EXPENDER & FACULTAR & FAISCAR & FELICITAR \\
\hline FOMENTAR & INCORRER & INTEIRAR & INTENTAR \\
\hline LANCEAR & LAVRAR & LOGRAR & MEDIANDO \\
\hline OBRAR & OBVIAR & PATENTEAR & PENDER \\
\hline PERVERTER & PÔR OS OLHOS & SUBITAR & SUBSCREVER \\
\hline SUSTAR & VENTILAR & $-\boldsymbol{-}-\boldsymbol{-}$ & $-\boldsymbol{-}-\boldsymbol{-}$ \\
\hline TOTAL $:$ 54 &
\end{tabular}

\begin{tabular}{|c|c|c|c|}
\hline \multicolumn{4}{|c|}{ SUBSTANTIVOS } \\
\hline ACENO & AGUARDENTE & ALQUEIRE & ALUGADOR \\
\hline ARBITRAMENTO & ARDIL & ARREMATAÇÃO & ARROBA \\
\hline ASILO & ATRAVESSADOR & AULISTA & AVULS $\widetilde{A} O / E V U L S \widetilde{A}$ \\
\hline BALANDRA & BANDO & BARRA & BOTICA \\
\hline BRAÇA & BRAÇAME & CAMARISTA & CEIEA \\
\hline CIRCUITO & CIRCUNVIZINHANÇ & CÔMPUTO & CONJUNTURA \\
\hline CONSTERNAÇÃO & CULTURA & DATA & DEMAS IA \\
\hline DESARRANJO & DESCONSOLAÇÃO & DESMEMBRAÇÃO & DETRIMENTO \\
\hline DILIGÊNCIA & DISCÍPULO & DITO & EMBARGO \\
\hline EMOLUMENTO & ENFERMO & ENGENHO & ESTERILIDADE \\
\hline EXCRETO & EXPEDIÇÃO & FAISQUEIRA & FIEL \\
\hline FINTA & FOGO & FORTUNA & HABITADOR \\
\hline IMINENTE & INCONVENIENTE & INCUMBÊNCIA & LAVRA \\
\hline LÉGUA & LETRA & LIBRA & LONGES \\
\hline MANT IMENTO & MEIRINHO & 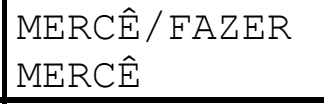 & MESTRE \\
\hline MILICIANO & MOLÉSTIA & MOLHADO & NAU \\
\hline OBSERVÂNCIA & OPULÊNCIA & ORDENAÇÃO & ORDENADO \\
\hline PARAGEM & PARIDADE & PENÚRIA & PRIVANÇA \\
\hline PROPINA & RÁBULA & REBATE & RÉDITO \\
\hline $\begin{array}{l}\text { REMÉDIO DA SUA } \\
\text { FOME }\end{array}$ & RIPA & ROSSIO & SEARA \\
\hline SOLDO & SUMACA & SUSTENTAÇÃO & TABUADO \\
\hline TABULARIA & VERAS & VIGÁRIO & $-\quad-\quad-\quad-$ \\
\hline
\end{tabular}

\begin{tabular}{|l|l|l|l|}
\hline \multicolumn{4}{|c|}{ ADJETIVO } \\
\hline ABASTADO & ACOMETIDO & ACOMODADO & AFETO \\
\hline APONTADO & ASSENTADO & ASSOMBRADO & BRIOSO \\
\hline CABAL & DE BOA NOTA & DECOROSO & DEPOSTO \\
\hline DERROGADO & DESCONCERTADO & DILATADO & DIMINUTO \\
\hline EMBRENHADO & ENFADONHO & FALTO & FINDO \\
\hline FRÍVOLO & INDECOROSO & IRRESOLUTO & LADINO \\
\hline LIMITADO & LUZIDO & MÓDICO & OB-REPTÍCIO \\
\hline
\end{tabular}




\begin{tabular}{|l|l|l|l|}
\hline OBSEQUIOSO & PERNICIOSO & PERVENCIDO & PRINCIPIADO \\
\hline PROFITENTE & RELAVADO & ------- & ------ \\
\hline TOTAL $: 34$
\end{tabular}

\begin{tabular}{|l|}
\hline \multicolumn{1}{|c|}{ ADVÉRBIO } \\
\hline DEBALDE \\
\hline TOTAL: 01 \\
\hline
\end{tabular}

Selecionados esses vocábulos, a próxima etapa consiste em testá-los com falantes de Paranaguá, com o objetivo de verificar o grau de manutenção, tendência à manutenção, desuso e tendência ao desuso em relação às acepções registradas nos documentos em questão. Adotou-se como critério para considerar "traço de manutenção" o fato de a acepção de determinado item lexical estar registrado nas entrevistas com o mesmo valor da acepção documentada nos documentos manuscritos. Estas considerações serão retomadas no quinto capítulo desta tese: Estudo Semântico-Lexical.

A busca de acepções nos dicionários de língua portuguesa foi feita para constatar se tal vocábulo já estava registrado, e também para averiguar se o significado condiz com o do corpus escrito ou com o do corpus oral. A escolha dos dicionários justifica-se pela importância que ocupam no meio acadêmico, e, além disso, pela possibilidade de trabalhar com as obras lexicográficas pertencentes às várias fases da língua portuguesa (desde o séc. XVIII até o séc. XXI): Bluteau (1712-1728), Morais Silva (1813), Cunha (1997), Ferreira (2004) e Houaiss (2007). 


\section{Capizulo IV}




\section{PESQUISA DE CAMPO: PROCEDIMENTOS DA COLETA DE DADOS}

Para a realização da pesquisa de campo, o presente trabalho valeu-se dos procedimentos metodológicos da Dialetologia, que se estabeleceu como um ramo da Linguística edificada a partir da complexa metodologia de trabalho em campo, visando a busca do registro dos dados linguísticos orais.

No que tange ao procedimento da coleta lexical, a pesquisa dialetológica concentrase em três fases distintas: o antes, o durante e o depois. A fase antes é o momento de definir: (i) quem vai ser entrevistado (os informantes); (ii) o que perguntar (o questionário); e (iii) onde se vai perguntar (as localidades). A fase durante é o período dedicado ao trabalho de campo, ou seja, momento da recolha dos dados. E a fase depois resume-se na análise e descrição dos dados levantados.

Portanto, como salienta Ferreira e Cardoso (1994, p. 9):

Dialetologia não é ciência de gabinete, por isso o durante, às vezes, pode ser até penoso, mas sem dúvida, é o trabalho de campo o melhor livro de dialetologia que se conhece; só quem esteve lá, e pode ser difícil chegar lá, é capaz de lhe dar a sua real dimensão.

Discorre-se, a seguir, sobre os procedimentos metodológicos adotados para a realização do trabalho em campo.

\subsection{NOTAS SOBRE A LOCALIDADE ${ }^{35}$}

Paranaguá é a cidade mais antiga do Estado do Paraná. Sua colonização teve início aproximadamente em 1550, primeiramente na Ilha da Cotinga, movida pelo interesse na extração de ouro. Está localizada no litoral paranaense, a uma distância de $91 \mathrm{~km}$ da capital do Estado - Curitiba -, fazendo limite ao norte com Antonina e Guaraqueçaba através da Baía de Paranaguá, ao sul com Guaratuba e Matinhos, a leste com Pontal do Paraná e a oeste com

\footnotetext{
35 Informações sobre o município de Paranaguá foram pesquisadas nos sítios: <www.paranaguá.pr.gov.br> e $<$ www.ibge.gov.br>. Acesso em: 2 jul. 2012.
} 
Morretes. Segundo dados do censo realizado em 2010, pelo Instituto Brasileiro de Geografia e Estatística (IBGE), o município ocupa uma área de 826,652 quilômetros quadrados, com 140.469 habitantes, sendo 69.306 homens e 71.163 mulheres e um PIB de R\$ 7.107.175.000.00. A densidade demográfica é de 169,92 habitantes por quilômetro quadrado: 135.386 localizados na zona urbana e 5.083 na zona rural. Os habitantes naturais desse município são denominados parnanguaras.

Paranaguá situa-se na maior baía do estado paranaense, compondo cerca de 30 ilhas, das quais se destacam: Ilha dos Valadares, Ilha da Cotinga, Ilha do Mel, Ilha das Palmas, Ilha das Cobras, Ilha das Pescas, Ilha do Amparo, Ilha do Teixeira, Ilha de Piaçaguera, Ilha de São Miguel, Ilha Rasa da Cotinga, Ilha Eufrasia, Ilha Ponta do Ubá (anexo A).

O Porto D. Pedro II, de Paranaguá, exerce a principal atividade econômica do município, sendo considerado o maior porto exportador de grãos do país. Destaca-se pela sua importância quanto à escoação de grãos e carga em geral do sul do Brasil e do Mercosul. Foi inaugurado em 1935 e sua existência, até os dias de hoje, está ligada aos cinco ciclos econômicos do Paraná: ciclo do ouro, da erva-mate, da madeira, do café e da diversificação. Outros setores econômicos também contribuem para a renda local, tais como: agricultura, indústria, produção do pescado, pecuária e a silvicultura.

No cenário cultural, Paranaguá destaca-se pelo fandango, que é uma prática caiçara, feita de lirismo e humor, que se expressa na batida dos tamancos, nos ritmos, danças e coreografias criadas e recriadas pelos moradores do litoral. O termo caiçara é usado, atualmente, para se referir aos moradores que habitam a região, que vai do litoral sul do Rio de Janeiro até o Litoral Norte do Paraná. Historicamente, o fandango caiçara começou quando os primeiros europeus ocuparam o litoral. Da miscigenação entre portugueses, índios e negros, aos poucos, foram se formando famílias, adquirindo novas culturas e dançando fandango. Antigamente, os bailes de fandango aconteciam tanto nas cidades como nas áreas rurais, mas, depois de um tempo, essa manifestação passou a acontecer só no litoral, pois as pessoas da cidade achavam que o fandango não era elegante. Em resumo: o fandango é uma manifestação cultural típica do caiçara parnanguara, caracterizada como uma mistura de conhecimento dos povos que habitavam o litoral, e que até hoje acontece pela força da memória e da tradição dos fandangueiros. 


\subsection{APLICAÇÃo DO QUESTIONÁRIO SEMÂNTICO-LEXICAL}

A aplicação de questionário em pesquisa de campo tem se tornado um instrumento de coleta de dados cada vez mais frequente, dada a eficácia desse procedimento metodológico em áreas de investigação linguística (AGUILERA; FIGUEIREDO, 2002, p. 9-10). O emprego desse instrumento, segundo Aguilera e Figueiredo (2002, p. 10), tem "assegurado o caráter científico necessário à pesquisa e ainda torna menos complexa a obtenção do registro dos fenômenos lingüísticos que se pretende estudar".

Para Silva Neto (1957, p. 19), o questionário além de ser uma ferramenta que auxilia o trabalho do inquiridor, oferece também "duas vantagens: a de se poder metodicamente, investigar determinados grupos de designações e auxiliar, portanto, a memória do inquiridor ou dos inquiridores, - e a de ser aplicável a todo o território, conferindo, assim, a possibilidade de se comparar os materiais".

Com o intuito de coletar dados lexicais no município de Paranaguá, o presente trabalho optou pela pesquisa de campo in loco (c.f. SILVA NETO, 1957, p. 18), recolhendo dados de natureza oral, utilizando-se do método direto, na modalidade inquérito. Conforme corroboram Aguilera e Figueiredo (2002, p. 12), é comum, em estudos dessa natureza, a adoção de tal método científico, pois,

Os estudos de cunho léxico são os que mais exigem a utilização de questionários estruturados pela necessidade de homogeneizar os resultados, que só se obtém mediante a elaboração e aplicação de questionário com formulações claras, bem definidas, que não deixem margem à dupla interpretação quanto ao(s) nome(s) dos referentes investigados.

Dessa forma, é necessário destacar que a elaboração do questionário visa somente à investigação lexical, tendo por objetivo o registro da acepção de determinadas lexias, buscando identificar quais dos vocábulos extraídos da documentação setecentista ainda são formas correntes na fala dos parnanguaras.

É importante ressaltar que as questões elaboradas estão diretamente relacionadas à escolha dos itens lexicais selecionados com intuito de verificar o grau de manutenção, tendência à manutenção, e desuso e tendência ao desuso referente às acepções registradas no corpus escrito. Assim, a elaboração do questionário semântico-lexical contou com 176 questões divididas em quatro classes gramaticais: verbo, substantivo, adjetivo e advérbio 
(Apêndice C). Como um dos objetivos do trabalho era documentar a presença de possíveis traços de manutenção ou desuso, no nível semântico-lexical, na fala em Paranaguá, caso o informante conhecesse o vocábulo, pedia-se ao final de cada questão: "pode dar um exemplo desta palavra dentro de uma frase?".

\subsection{PERFIL DOS INFORMANTES}

Quando se pretende investigar a linguagem de determinada comunidade, é preciso que haja, a partir de pré-requisitos, a seleção do grupo de informantes, considerando fatores de natureza social, como escolaridade, faixa etária e sexo. Esse modelo advém dos métodos empregados pela Dialetologia moderna, que tem se beneficiado das contribuições teóricas da Sociolinguística, no tocante aos aspectos extralinguísticos, não separando língua de história e de cultura.

Para a seleção dos informantes, foi adotada a proposta contida no Atlas Linguístico do Brasil (COMITE NACIONAL DO PROJETO ALIB, 2001), que consiste nos seguintes critérios: duas faixas etárias (faixa 1: 18-30 e faixa 2: 50-65 anos), contemplando ambos os sexos (masculino e feminino) e naturalidade (nascidos no local e, de preferência, pais pertencentes à mesma comunidade linguística). Quanto à escolaridade, buscou-se investigar uma rede de informantes com diferentes níveis de escolarização (completos ou incompletos), variando desde as primeiras e últimas séries do ensino fundamental (primeiras séries: $1^{\mathrm{a}}$ a $4^{\mathrm{a}}$ / últimas séries: $5^{\mathrm{a}}$ a $8^{\mathrm{a}}$ ), ensino médio e ensino superior. A preocupação por investigar duas faixas etárias e quatro níveis de escolaridade atende ao objetivo do trabalho, que pretende averiguar em qual variável há vestígio de manutenção e de tendência à manutenção de lexias antigas ou se o contato com os meios de comunicação e com a tecnologia tem provocado tendência ao desuso ou o desuso.

A rede de informantes constitui o total de 16 entrevistados (oito homens e oito mulheres), distribuídos igualmente por duas faixas etárias e contemplando os dois sexos. 
Quadro 3 - Quadro das variáveis: escolaridade, sexo e faixa etária

\begin{tabular}{|c|c|c|c|c|c|c|c|c|c|}
\hline \multicolumn{2}{|c|}{ Escolaridade } & \multicolumn{2}{|c|}{$\begin{array}{c}\text { Ensino } \\
\text { Fundamental } \\
\text { primeiras séries } \\
\left(1^{\mathrm{a}} \mathrm{a} 4^{\mathrm{a}}\right)\end{array}$} & \multicolumn{2}{|c|}{$\begin{array}{c}\text { Ensino } \\
\text { Fundamental } \\
\text { últimas séries } \\
\left(5^{\mathrm{a}} \mathbf{a} \mathbf{8}^{\mathrm{a}}\right)\end{array}$} & \multicolumn{2}{|c|}{$\begin{array}{l}\text { Ensino } \\
\text { Médio }\end{array}$} & \multicolumn{2}{|c|}{$\begin{array}{c}\text { Ensino } \\
\text { Superior }\end{array}$} \\
\hline \multicolumn{2}{|c|}{ Sexo } & M & $\mathrm{F}$ & $\mathrm{M}$ & $\mathrm{F}$ & $\mathrm{M}$ & $\mathrm{F}$ & $\mathrm{M}$ & $\mathrm{F}$ \\
\hline \multirow{2}{*}{$\begin{array}{l}\text { Faixa etária } \\
\quad \text { dos } \\
\text { informantes }\end{array}$} & $\mathrm{F} 1$ & \multicolumn{2}{|c|}{$18-30$} & \multicolumn{2}{|c|}{$18-30$} & \multicolumn{2}{|c|}{$18-30$} & \multicolumn{2}{|c|}{$18-30$} \\
\hline & $\bar{F} 2$ & \multicolumn{2}{|c|}{$50-65$} & \multicolumn{2}{|c|}{$50-65$} & \multicolumn{2}{|c|}{$50-65$} & \multicolumn{2}{|c|}{$50-65$} \\
\hline
\end{tabular}

Para o preenchimento dos dados pessoais do informante, adotou-se o modo fichário (Anexo B), modelo aplicado no Projeto ALiB (COMITÊ NACIONAL DO PROJETO ALIB, 2001), tendo por finalidade organizar as informações pessoais do informante. Esses dados registrados nas fichas poderão servir a futuras pesquisas de cunho sociolinguístico, cujo interesse seja estudar as variáveis sociais desse grupo linguístico.

Com o intuito de facilitar a identificação dos informantes no corpo do texto, foram criadas algumas convenções:

$\mathrm{F} 1$ e F2 = faixas etárias 1 e 2;

$\mathrm{H}=$ informante masculino $/ \mathrm{M}=$ feminino;

$\mathrm{P}=$ ensino primário $^{36} / \mathrm{F}=$ fundamental $/ \mathrm{M}=$ médio $/ \mathrm{S}=$ superior; $\mathrm{C}=$ ensino completo / I = incompleto.

\footnotetext{
${ }^{36}$ Os informantes de ensino fundamental de primeiras séries $\left(1^{\mathrm{a}}\right.$ e $\left.4{ }^{\text {a }}\right)$ serão identificados como "ensino primário', e os de ensino fundamental de últimas séries $\left(5^{\text {a a }} 8^{\text {a }}\right)$ como 'ensino fundamental'.
} 
Quadro 4 - Perfil dos informantes

\begin{tabular}{|c|c|c|c|c|c|}
\hline $\begin{array}{l}\text { Faixa } \\
\text { Etária }\end{array}$ & Nome & Sexo & Escolaridade & Idade & Informante \\
\hline F1 & M.N.P. & masculino & E. Primário/C & 29 & F1-H-EP \\
\hline F1 & C.R.V. & feminino & E. Primário/C & 26 & F1-M-EP \\
\hline F1 & M.D.L.S.L. & masculino & E. Fundamental/I & 22 & F1-H-EF \\
\hline $\mathrm{F} 1$ & K.C.M.D.L. & feminino & E. Fundamental/C & 29 & F1-M-EF \\
\hline F1 & P.M.C.D.S. & masculino & E. Médio/C & 24 & F1-H-EM \\
\hline $\mathrm{F} 1$ & E.C.P.D.O. & feminino & E. Médio/C & 24 & F1-M-EM \\
\hline F1 & P.E.E.G. & masculino & E. Superior/C & 27 & F1-H-ES \\
\hline F1 & E.S.D.O. & feminino & E. Superior/I & 23 & F1-M-ES \\
\hline F2 & G.D.R. & masculino & E. Primário/C & 61 & F2-H-EP \\
\hline $\mathrm{F} 2$ & L.D.N.P. & feminino & E. Primário/C & 59 & F2-M-EP \\
\hline $\mathrm{F} 2$ & A.S. & masculino & E. Fundamental/I & 61 & F2-H-EF \\
\hline $\mathrm{F} 2$ & C.D.S.R. & feminino & E. Fundamental/I & 54 & F2-M-EF \\
\hline $\mathrm{F} 2$ & G.A.S. & masculino & E. Médio/I & 50 & F2-H-EM \\
\hline $\mathrm{F} 2$ & J.A. & feminino & E. Médio/C & 54 & F2-M-EM \\
\hline F2 & F.W.J. & masculino & E. Superior/C & 52 & F2-M-ES \\
\hline $\mathrm{F} 2$ & I.L. & feminino & E. Superior/C & 57 & F2-M-ES \\
\hline
\end{tabular}

\subsection{Trabalho de CAMPo}

As entrevistas com os informantes em Paranaguá foram realizadas em dois momentos: o primeiro em janeiro de 2012, e o segundo em março do mesmo ano. Durante a primeira visita ao município de Paranaguá, a pesquisadora teve certa dificuldade para encontrar informantes que se enquadrassem no perfil da pesquisa. Por não ter tido contato, anteriormente, com moradores, ou funcionários da prefeitura ou de escolas (conhecidos como facilitadores) que pudessem auxiliar na busca do informante ideal, a pesquisadora, em visitas 
à Câmara de Vereadores, à Prefeitura e à Secretaria Municipal da Educação e conversando com alguns funcionários, chegou ao contato com algumas pessoas que, aparentemente, se encaixavam no perfil buscado. Ressalta-se 'aparentemente', porque, durante a entrevista, descobria-se que o informante: ou morou em outras cidades por mais de 10 anos, ou não tinha a idade entre 18-30 e 50-65 anos, sendo, portanto, necessária a busca por mais informantes, num segundo momento.

Encontrar informantes que tivessem apenas o ensino fundamental das séries inicias $\left(1^{\mathrm{a}} \mathrm{a} 4^{\mathrm{a}}\right)$, foi uma tarefa não muito fácil. Em conversa com a Secretária da Educação Municipal, tomou-se conhecimento de que informantes, neste perfil, só seriam encontrados nas comunidades das ilhas locais. Logo, com o auxílio de uma professora que trabalha nestas comunidades, foi possível fazer o deslocamento até a ilha do Amparo e realizar as quatro entrevistas que faltavam.

Finalizadas as 16 entrevistas, procedeu-se às transcrições dos dados orais. Considerando que o estudo prioriza o nível lexical, optou-se pela transcrição grafemática, adotando o modelo proposto pelo Comitê Nacional do Projeto $\mathrm{ALiB}^{37}$, que visa os seguintes objetivos:

Descrever a realidade lingüística do Brasil, no que tange à língua portuguesa, com enfoque na identificação das diferenças diatópicas (fônicas, morfossintáticas, léxico-semânticas e prosódicas)

Examinar os dados coletados na perspectiva de sua interface com outras áreas do conhecimento afins - história, sociologia, antropologia e outras -, de modo a poder contribuir para fundamentar e definir posições teóricas.

Oferecer aos estudiosos da língua portuguesa (lingüistas, lexicólogos, etimólogos, filólogos), aos pesquisadores de áreas afins (história, sociologia, antropologia e outras) e aos pedagogos (gramáticos, autores de livro-texto para o ensino fundamental e o ensino médio, professores) subsídios para o aprimoramento do ensino/aprendizagem e para uma melhor interpretação do caráter multidialetal do Brasil.

Oferecer aos interessados nos estudos lingüísticos um considerável volume de dados que permita aos lexicógrafos aprimorarem os dicionários, ampliando o campo de informações; aos gramáticos atualizarem as informações com base na realidade documentada pela pesquisa empírica; aos autores de livros didáticos adequarem a sua produção à realidade cultural de cada região; aos professores aprofundarem o conhecimento da realidade lingüística, refletindo sobre as variantes de que se reveste a língua portuguesa no Brasil. (COMITÊ NACIONAL DO PROJETO ALIB, 2001).

\footnotetext{
${ }^{37}$ C.f. Ata da XIII Reunião do Comitê Nacional. Recife, UFPE, 16 e 17 de julho de 2003.
} 


\section{Capitulo V}




\section{ESTUDO SEMÂNTICO-LEXICAL}

Ao estudar a língua de uma comunidade, é possível averiguar processos das transformações e mudanças pelos quais essa língua passou no decorrer de sua história. Essas transformações estão diretamente relacionadas à formação histórica de um povo e sua cultura, entendida como atuação do homem sobre o mundo. Das diversas possibilidades de estudo, optou-se pelo nível lexical, uma vez que cada palavra tem o seu significado próprio de acordo com a época, com o grupo social e com o momento em que está sendo utilizada. Conforme assinalam Oliveira e Isquerdo (1998, p. 7):

... o universo lexical de um grupo sintetiza a sua maneira de ver a realidade e a forma como seus membros estruturam o mundo que os rodeia e designam as diferentes esferas do conhecimento. Assim, na medida em que o léxico recorta realidades de mundo, define, também, fatos de cultura.

Apesar de a língua ser um sistema dinâmico suscetível a influências de diversas naturezas, principalmente no que diz respeito ao acervo vocabular, há, em determinados grupos sociolinguísticos, a presença de unidades lexicais que representam momentos diferentes da história da língua, conservadas ao longo do tempo, como é o caso das linguagens regionais (ISQUERDO, 1996, p. 568). Sobre essa questão, elucida:

No caso da Língua Portuguesa falada no Brasil, percebemos que, motivado por determinantes de natureza geo-histórico-cultural, seu léxico reúne termos que revelam tanto a influência da língua do colonizador, em diferentes fases da história, quanto da língua natural de povos nativos habitantes da região. (ISQUERDO, 1996, p. 569).

Cunha (1986), discorrendo sobre o caráter conservador da nossa variante linguística, argumenta:

É, porém, de uma evidência que dispensa maior comprovação o fato de ter a língua portuguesa se desenvolvido no Brasil, durante séculos, em condições socioculturais mais propícias à conservação do que à renovação de suas formas. Tendo vivido mais de trezentos anos sem contato com outros povos, sem imprensa, sem núcleos culturais de importância, com um número exíguo de escolas, a América Lusitana foi alcançando nesse largo período algumas das etapas que levam os povos aos estados lingüísticos paralisantes. Esse imobilismo cultural e, conseqüentemente, idiomático é ainda muito sensível 
nas regiões interioranas, onde continuam a existir populações marginalizadas dos próprios acontecimentos históricos. (CUNHA, 1986, p. 202-203).

Porém, estudando o município de Paranaguá, verifica-se a presença de elementos sócio-históricos pertinentes ao que Cunha (1986) considera ser uma condição propícia à conservação de formas linguísticas características da variante portuguesa da época da colonização: (i) localidade litorânea afastada do grande centro; (ii) cidade com características interiorana; (iii) município com mais de 400 anos.

Partindo desse princípio, de que áreas linguísticas afastadas de grandes centros e de colonização remota são passíveis de isolamento, ou até mesmo de estagnação da língua, o presente trabalho espera encontrar, na modalidade oral dos moradores de Paranaguá, vestígios de manutenção de uma variedade do português do tempo de sua colonização.

Assim, investigar o grau de conservação e desuso na variedade oral de uma comunidade linguística, no nível lexical, pressupõe um estudo apurado das unidades lexicais, visto que o léxico de uma língua passa por constantes mutações, como já notara Biderman (2001, p. 179): “o Léxico se expande, se altera e, às vezes, se contrai. As mudanças sociais e culturais acarretam alterações nos usos vocabulares; daí resulta que unidades ou setores completos do Léxico podem ser marginalizados, entrar em desuso e vir a desaparecer".

Deve-se considerar também que, em meio a essas mudanças, um rol de palavras do léxico geral poderia passar a incorporar uma terminologia específica, como também poderia ocorrer o inverso, um termo pertencente a um domínio especializado ter o seu conceito expandido para a língua cotidiana, adquirindo, com o tempo, outros significados, o que é muito comum hodiernamente, devido à disseminação da ciência em meios de comunicação populares, como jornais impressos e/ou televisivos, e revistas.

Portanto, quando se pretende estudar o léxico de determinado grupo linguístico, busca-se compreender como se dá o processo de aquisição desta ou daquela lexia no conjunto de palavras que forma o seu repertório vocabular e qual seu significado para a constituição histórica da comunidade linguística.

Na pretensão de verificar se o uso de determinado termo é específico ou não de uma comunidade em estudo, pesquisas desta natureza caminha para a análise do léxico em seu contexto de utilização, pois, segundo Leite (2003, p. 28), "não é possível examinar o léxico fora de sua enunciação, a língua tem de ser analisada em relação à sua realidade social”.

Seguindo este raciocínio, Benveniste (1989, p. 100) faz a seguinte asserção: 
Os testemunhos que a língua dá deste ponto de vista [do vocabulário] só adquirem seu valor se eles forem ligados entre eles e coordenados à sua referência. Existe aí um mecanismo complexo cujos ensinamentos é preciso interpretar prudentemente. $O$ estado da sociedade numa época dada não aparece sempre refletido nas designações de que ela faz uso, pois as designações podem muitas vezes subsistir quando os referentes, as realidades designadas já mudaram [...]. O que se chama polissemia resulta desta capacidade que a língua possui de subsumir em um termo constante uma grande variedade de tipos e em seguida admitir a variação da referência na estabilidade da significação.

Nesse processo de transformação do léxico, o binômio discurso e enunciadores são agentes participativos e, portanto, devem ser considerados dentro do contexto de elocução. A propósito, Biderman (2001, p. 179) ressalta:

Embora o Léxico seja patrimônio da comunidade lingüística, na prática, são os usuários da língua - os falantes - aqueles que criam e conservam o vocabulário dessa língua. Ao atribuírem conotações particulares aos lexemas, nos usos do discurso, os indivíduos podem agir sobre a estrutura do Léxico, alterando as áreas de significação das palavras. É por isso que podemos afirmar que o indivíduo gera a Semântica da sua língua [...]. Ao fim e ao cabo, o universo semântico se estrutura em torno de dois pólos opostos: o indivíduo e a sociedade. Dessa tensão em movimento se origina o Léxico.

Ainda sobre essa questão, Biderman (1984, p. 17) elucida que o léxico de uma língua reúne um conjunto de signos linguísticos por meio dos quais o homem se expressa, se comunica, e é capaz de criar e assimilar novos conhecimentos dentro de sua própria civilização, como também absorver de outras culturas. Por isso, as categorias e denominações linguísticas de alguns itens lexicais podem variar, daí a importância de serem analisadas dentro de seus contextos de produção.

Partindo para a análise do corpus oral desta pesquisa, foram levados em consideração alguns critérios, a saber: (i) os 176 itens lexicais foram observados a partir do contexto de uso do enunciado durante as entrevistas; (ii) para cada lexia em estudo comparou-se a acepção buscada (a mesma designação registrada nos documentos manuscritos) com as acepções conhecidas e utilizadas pelos informantes; (iii) a consulta aos dicionários de Bluteau (17121728), Morais Silva (1813), Cunha (1997), Ferreira (2004) e Houaiss (2007) foi feita para verificar se determinada lexia consta registrada, e também para averiguar se o significado deste item lexical está registrado com o mesmo valor da acepção do corpus escrito ou com o valor do corpus oral. 
Procedendo às análises, é importante frisar que o objetivo maior deste trabalho é verificar o grau de manutenção, tendência à manutenção, desuso e tendência ao desuso em relação às acepções registradas no corpus escrito. Por conseguinte, considera-se "grau de manutenção" de determinado item lexical, quando ocorrer uma sinonímia entre as acepções buscadas com as acepções empregadas/conhecidas pelos informantes de Paranaguá. Portanto, durante a análise do contexto de fala dos informantes de Paranaguá, considerou-se caso de manutenção quando houve o reconhecimento da lexia e da acepção buscada, por parte de todos os informantes ou quando o reconhecimento se concentrou, em sua maior parte, na primeira faixa etária. Ao contrário, foi considerado caso de desuso quando o informante não reconheceu a lexia, ou a reconhecia, mas com outros significados distintos da acepção buscada. Em alguns casos, o sentido desta lexia era substituído por outro item lexical, o que corresponde, em alguns casos, ao emprego de um homônimo ${ }^{38}$. Já nos casos de tendência à

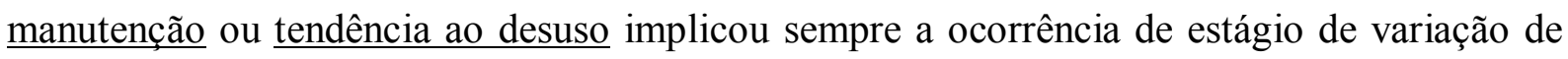
significados para um único item lexical, ou seja, além do informante empregar a acepção em estudo, ele também faz uso de outras designações para um único referente. A diferença entre tendência à manutenção e tendência ao desuso está no número de ocorrências quanto ao reconhecimento da lexia e da acepção buscada. Quando houve maior ocorrência de reconhecimento na primeira faixa etária, classificou-se como tendência à manutenção, e quando ocorreu o inverso, o reconhecimento se concentrar na segunda faixa etária, classificou-se como tendência ao desuso.

Na seção a seguir, apresentam-se as tabelas onde se destacam: (i) a lexia em estudo; (ii) o número do documento onde se encontram a lexia e a acepção investigada; (iii) o registro das acepções buscadas; (iv) o contexto de utilização dos itens lexicais conhecidos pelos informantes; (v) a sigla NSR, a qual significa que o informante 'não soube responder' a questão referente à lexia investigada; (vi) as acepções dicionarizadas; e por fim (vii) a análise semântico-lexical retomando o contexto de uso da lexia pelo informante, a partir da acepção trazida nos documentos manuscritos. Os itens lexicais foram classificados em: verbos, substantivos, adjetivos e advérbios; e dentro dessa divisão estão alocados em ordem alfabética.

\footnotetext{
${ }^{38}$ Homônimo: "Diz-se de palavra que se escreve e se pronuncia ou só se pronuncia da mesma maneira que outra, mas cujo significado é diferente". (CALDAS AULETE, 1948).
} 


\subsection{ANÁLISE SEMÂNTICO-LEXICAL DAS LEXIAS INVESTIGADAS}

\section{VERBOS}

\begin{tabular}{|c|c|}
\hline \multicolumn{2}{|c|}{ 1. ACAUTELAR / DOC.37, fól.1v, l.11-15 } \\
\hline $\begin{array}{l}\text { Acepção } \\
\text { buscada }\end{array}$ & Prevenir, precaver. \\
\hline $\begin{array}{l}\text { Acepção(ões) } \\
\text { conhecida(s) } \\
\text { pelos } \\
\text { informantes }\end{array}$ & $\begin{array}{l}\text { F1-H-EP: NSR. } \\
\text { F1-M-EP: NSR. } \\
\text { F1-H-EF: NSR. } \\
\text { F1-M-EF: NSR. } \\
\text { F1-H-EM: NSR. } \\
\text { F1-M-EM: Conheço como ter cautela do que a gente faz. } \\
\text { F1-H-ES: NSR. } \\
\text { F1-M-ES: Acautelar vem de cautela. } \\
\text { F2-H-EP: NSR. } \\
\text { F2-M-EP: NSR. } \\
\text { F2-H-EF: Acautelar seria como você acolher alguém. } \\
\text { F2-M-EF: NSR. } \\
\text { F2-H-EM: Está acontecendo uma briga, o outro vai lá e acautela, } \\
\text { apazigua. } \\
\text { F2-M-EM: NSR. } \\
\text { F2-H-ES: Acautelar é ter cautela. } \\
\text { F2-M-ES: Acautelar é a pessoa ser calma. }\end{array}$ \\
\hline $\begin{array}{l}\text { Acepções } \\
\text { registradas } \\
\text { nos } \\
\text { dicionários }\end{array}$ & $\begin{array}{l}\text { Bluteau (1712-1728): ACAUTELARSE, Usar de cautela. Acautelarse } \\
\text { das ciladas. } \\
\text { Morais Silva (1813): ACAUTELAR, v. at. Prevenir, precaver, que não } \\
\quad \text { suceda algum danno, ou inconvemiente. } \\
\text { Cunha (1997): cautela sf. Acautelar 'prevenir, precaver' } 1562 . \\
\text { Ferreira (2004): acautelar 3. Evitar, prevenir. } \\
\text { Houaiss (2007): acautelar datação } 15311 \text { prevenir(-se) contra a } \\
\quad \text { ocorrência de um mal, um embaraço, um inconveniente, um dano. }\end{array}$ \\
\hline \multicolumn{2}{|c|}{$\begin{array}{l}\text { Os dicionaristas pesquisados registram a entrada acautelar com o sentido de 'ter } \\
\text { cautela, prevenir, precaver, evitar algum perigo'. Analisando o seu contexto de utilização } \\
\text { pelos informantes de Paranaguá, constata-se que sua ocorrência é escassa. Dez } \\
\text { entrevistados disseram desconhecer o item lexical, e outros três informantes (F2-H-EF, } \\
\text { F2-H-EM e F2-M-ES) o conhecem com variação de significado: 'acolher', 'apaziguar' e } \\
\text { 'ser calmo'. Apenas dois informantes de faixas etárias distintas (F1-M-EM / F2-H-ES) }\end{array}$} \\
\hline
\end{tabular}


conhecem o significado da unidade lexical acautelar com a acepção buscada 'prevenir, precaver', mas consta-seque sua forma lexical está sendo substituída pela locução verbal 'ter cautela': F1-M-EM: Conheço como ter cautela do que a gente faz. F2-H-ES: Acautelar é ter cautela. A informante feminina, da faixa I, do ensino superior, respondeu de forma genérica: 'acautelar vem de cautela', sem especificar o que seria cautela.

Verificando o contexto de uso desta lexia na fala dos entrevistados, dados apontam indicativo de substituição do item lexical acautelar pela locução verbal ter cautela, com o mesmo sentido de 'prevenir, precaver'. No estágio atual de variação, a unidade lexical acautelar apresenta tendência ao desuso, uma vez que somente dois informantes (um da faixa I e outro da faixa II) ainda empregam acautelar como 'ter cautela', no sentido da acepção em estudo.

\begin{tabular}{|c|c|}
\hline \multicolumn{2}{|c|}{ 2. ACOMPANHAR / DOC.40, fól.1v, l.03-06 } \\
\hline $\begin{array}{l}\text { Acepção } \\
\text { buscada }\end{array}$ & Seguir, observar. \\
\hline $\begin{array}{l}\text { Acepção(ões) } \\
\text { conhecida(s) } \\
\text { pelos } \\
\text { informantes }\end{array}$ & $\begin{array}{l}\text { F1-H-EP: Acompanhar é chamar alguém pra ir junto com você. } \\
\text { F1-M-EP: NSR. } \\
\text { F1-H-EF: Acompanhar uma pessoa pra determinado local. } \\
\text { F1-M-EF: Quando acompanho alguém pra algum lugar. } \\
\text { F1-H-EM: Acompanhar de ir junto. } \\
\text { F1-M-EM: Quando você acompanha alguém pra um lugar. } \\
\text { F1-H-ES: Acompanhar as pessoas: eu vou te acompanhar até a saída. } \\
\text { F1-M-ES: Acompanhar no sentido de ir junto. } \\
\text { F2-H-EP: Acompanhar aqui é acompanhar uma pessoa quando não } \\
\text { conhece um lugar aqui, então acompanha. } \\
\text { F2-M-EP: Acompanhar, por exemplo, se eu sair pra algum lugar, e falo: } \\
\text { você quer me acompanhar? } \\
\text { F2-H-EF: Acompanhar tem vários sentidos: acompanhar de acompanhar } \\
\text { mesmo e acompanhar se eu vou supervisionar, acompanhar um } \\
\text { trabalho, assim tal. } \\
\text { F2-M-EF: Vou acompanhar alguém num médico. } \\
\text { F2-H-EM: Quando você não quer ir sozinho, pede pra outra pessoa te } \\
\text { acompanhar. } \\
\text { F2-M-EM: Quando alguém te acompanha até a escola, vai junto com } \\
\text { você. } \\
\text { F2-H-ES: Em todos os sentidos acompanhar de estar presente, junto, e } \\
\text { acompanhar processo. } \\
\text { F2-M-ES: Acompanhar alguém, ir junto. }\end{array}$ \\
\hline
\end{tabular}




\begin{tabular}{|c|c|}
\hline $\begin{array}{l}\text { ões } \\
\text { adas } \\
\text { ários }\end{array}$ & $\begin{array}{l}\text { Bluteau (1712-1728): ACÒMPANHAR, ou Accompanhar. Fazer } \\
\text { companhia. } \\
\text { Morais Silva (1813): ACOMPANHAR, v. at. Ir em companha de } \\
\text { alguem, por obrigação, obsequio, ou pompa. } \\
\text { Cunha (1997): companhia sf. 'aquilo ou aquele que acompanha' } \\
\text { 'comitiva, séquito etc.' Acompanhar | XIV. } \\
\text { Ferreira (2004): acompanhar 1. Ir em companhia de; fazer companhia } \\
\text { a; seguir. } \\
\text { Houaiss (2007): acompanhar datação sXIII } 16 \text { presenciar, assistir a } \\
\text { (esp. algo que é exposto ou apresentado, ou uma sucessão de eventos, } \\
\text { episódios, o desenrolar de um fato, história, drama etc.). }\end{array}$ \\
\hline \multicolumn{2}{|c|}{$\begin{array}{l}\text { O item lexical acompanhar com o sentido de 'seguir, observar' esteve presente } \\
\text { somente na fala de dois informantes (F2-H-EF e F2-H-ES). Tanto um, como o outro, } \\
\text { disseram usar a lexia em vários contextos, inclusive no sentido de 'observar': F2-H-EF: } \\
\text { 'acompanhar se eu vou supervisionar, acompanhar um trabalho'; F2-H-ES: } \\
\text { 'Acompanhar processo'. Os demais informantes (sete da faixa I e seis da faixa II) } \\
\text { empregam essa lexia somente no sentido de 'ir junto', 'fazer companhia'. A acepção aqui } \\
\text { buscada não consta de nenhum dicionarista. Houaiss (2007) registra diversas acepções, e } \\
\text { na décima sexta sugere o significado investigado: 'presenciar, assistir a (esp. algo que é } \\
\text { exposto ou apresentado, ou uma sucessão de eventos, episódios, o desenrolar de um fato, } \\
\text { história, drama etc.)'. Dessa forma, presume-se que 'presenciar' e 'assistir' pode ser } \\
\text { entendido como 'acompanhar uma sucessão de eventos e episódios, portanto, por extensão } \\
\text { de sentido, infere-se 'seguir/ observar' uma sucessão de eventos. } \\
\text { Analisando o contexto de utilização do item lexical pelos informantes parnanguaras e a } \\
\text { acepção buscada, presume-se que, e m dado momento, nesta comunidade linguística, } \\
\text { estas acepções começaram a concorrer entre si e, no estágio atual de variação, há indícios } \\
\text { do favorecimento da acepção 'ir junto', 'fazer companhia' em detrimento da acepção } \\
\text { documentada no corpus escrito, lembrada apenas por dois informantes da faixa II. } \\
\text { Portanto, a unidade lexical acompanhar no sentido de 'seguir, observar' aponta tendência } \\
\text { ao desuso. }\end{array}$} \\
\hline
\end{tabular}

\begin{tabular}{|l|l|}
\hline \multicolumn{2}{|l|}{ 3. ACORDAR / DOC.48, fól.2r, l.11-15 } \\
\hline $\begin{array}{l}\text { Acepção } \\
\text { buscada }\end{array}$ & Decidir conjuntamente. \\
\hline $\begin{array}{l}\text { Acepção(ões) } \\
\text { conhecida(s) } \\
\text { pelos } \\
\text { informantes }\end{array}$ & $\begin{array}{l}\text { F1-M-EP: NSR. } \\
\text { F1-H-EP: Acordar alguém que tá dormindo. } \\
\text { F1-M-EF: Quantar, despertar. } \\
\end{array}$ \\
$\begin{array}{l}\text { F1-H-EM: No sentido de despertar, levantar e de fazer um acordo. } \\
\text { F1-M-EM: Acordar do sono. }\end{array}$ \\
\hline
\end{tabular}




\begin{tabular}{|c|c|}
\hline & $\begin{array}{l}\text { F1-H-ES: Acordar de manhã, do sono, acordar pra vida. } \\
\text { F1-M-ES: No sentido de acordar, amanhecer, abrir os olhos. } \\
\text { F2-H-EP: Acordar aqui chega de manhã cedinho tem que acordar. } \\
\text { F2-M-EP: Quando alguém não quer ver as coisas, então a gente diz pra } \\
\text { acordar, observar aquilo ali, acordar pra vida. } \\
\text { F2-H-EF: Acordar é despertar do sono. } \\
\text { F2-M-EF: Acordar em vários sentidos: vou acordar cedo, vou acordar } \\
\text { pro mundo, pras coisas. } \\
\text { F2-H-EM: De manhã a gente acorda do sono. } \\
\text { F2-M-EM: Acordar bem cedo. } \\
\text { F2-H-ES: Acordar também, eu acordo de manhã cedo e também eu } \\
\text { acordo, do aceitar, do acordo. } \\
\text { F2-M-ES: Acordar pra vida, ficar esperta com as coisas: eu tô acordado, } \\
\text { não durmo no ponto. }\end{array}$ \\
\hline $\begin{array}{l}\text { Acepções } \\
\text { registradas } \\
\text { nos } \\
\text { dicionários }\end{array}$ & $\begin{array}{l}\text { Bluteau (1712-1728): ACORDAR do sono. Acabar de dormir. Acordar } \\
\text { a quem dorme. } \\
\text { Morais Silva (1813): ACORDAR, v. at.; } 7.10 . \S \text {. Resolver } \\
\text { unanimemente. } \\
\text { Cunha (1997): acordar } v b . \text { 'resolver, convir, concordar' XIII. } \\
\text { Ferreira (2004): acordar } 15 . \text { Chegar a um acordo; concordar. } \\
\text { Houaiss (2007): ' acordar datação sXIII } 3 \text { decidir ou resolver } \\
\text { conjuntamente; levar a efeito a decisão assim tomada. }\end{array}$ \\
\hline \multicolumn{2}{|c|}{$\begin{array}{l}\text { As definições apresentadas pelos lexicógrafos (com exceção de Bluteau) evidenciam o } \\
\text { mesmo sentido da acepção buscada: 'decidir em conjunto', 'chegar a um acordo', 'a uma } \\
\text { decisão'. Dentre as várias designações empregadas pelos informantes: 'acordar do sono', } \\
\text { 'levantar', 'despertar', 'acordar pra vida', 'acordar pro mundo', 'ficar esperto'; somente } \\
\text { dois informantes (F1-H-EM / F2-H-ES) empregam a lexia acordar (além de outros } \\
\text { significados), com o sentido de 'fazer um acordo'. Portanto, a unidade lexical acordar (do } \\
\text { lat. cordátus, a, um) no sentido de 'fazer acordo' é desconhecida pela maior parte dos } \\
\text { entrevistados. Estes falantes, em seu contexto de uso, empregam o seu homônimo acordar } \\
\text { (do lat. accordare) com as acepções 'despertar do sono', 'levantar cedo', 'ficar esperto'. } \\
\text { Considerando os dados em análise, a unidade lexical acordar, possivelmente, está } \\
\text { sendo substituída pela locução verbal 'fazer acordo', quando se deseja expressar o sentido } \\
\text { de 'decidir conjuntamente'. } \\
\text { Dessa forma, o item lexical acordar com o sentido de 'fazer acordo', indica tendência } \\
\text { ao desuso, pois foi lembrado apenas por dois informantes de faixas etárias distintas, e em } \\
\text { contexto de variação de significado. }\end{array}$} \\
\hline
\end{tabular}




\begin{tabular}{|c|c|}
\hline \multicolumn{2}{|c|}{ 4. ACUDIR / DOC.12, fól.1r, 1.23-27 } \\
\hline $\begin{array}{l}\text { Acepção } \\
\text { buscada }\end{array}$ & Socorrer, ajudar. \\
\hline $\begin{array}{l}\text { Acepção(ões) } \\
\text { conhecida(s) } \\
\text { pelos } \\
\text { informantes }\end{array}$ & $\begin{array}{l}\text { F1-H-EP: Acudir é ajudar alguém que tá precisando. } \\
\text { F1-M-EP: NSR. } \\
\text { F1-H-EF: Acudir é um socorro, uma ajuda. } \\
\text { F1-M-EF: Acudir alguém, socorrer. } \\
\text { F1-H-EM: Acudir é ajudar uma pessoa. } \\
\text { F1-M-EM: Acudir é socorrer. } \\
\text { F1-H-ES: Socorrer. } \\
\text { F1-M-ES: Acudir no sentido de prestar socorro a alguém. } \\
\text { F2-H-EP: Acudir, se uma pessoa ali necessita de uma ajuda tem que ir lá } \\
\text { socorrer. } \\
\text { F2-M-EP: Acudir é quando uma criança cai, aí vai acudir. } \\
\text { F2-H-EF: Acudir é socorrer, salvar. } \\
\text { F2-M-EF: Acudir as pessoas. } \\
\text { F2-H-EM: Uma criança cai de uma árvore, você vai acudir. } \\
\text { F2-M-EM: Quando alguém tá precisando de ajuda, vamos acudir. } \\
\text { F2-H-ES: Acudir de ajudar, de auxiliar. } \\
\text { F2-M-ES: Acudir é socorrer e ajudar quem precisa. }\end{array}$ \\
\hline $\begin{array}{l}\text { Acepções } \\
\text { registradas } \\
\text { nos } \\
\text { dicionários }\end{array}$ & $\begin{array}{l}\text { Bluteau (1712-1728): ACUDIR. Ajudar a alguem. } \\
\text { Morais Silva (1813): ACUDIR, v. at. Vir trazer soccorro, auxilio, ao } \\
\text { que implora. 3.2. §. Acudir-se, ou acudir a alg. coisa ou pessoa; } \\
\text { socorrer-se, recorrer a ella. } \\
\text { Cunha (1997): acudir } v b \text {. 'vir em socorro de, acorrer' XIII. } \\
\text { Ferreira (2004): acudir 1. Acorrer, ir em socorro, defesa ou proteção } \\
\text { de; socorrer; auxiliar. } \\
\text { Houaiss (2007): acudir datação } 12622 \text { servir a ou ter utilidade para; } \\
\text { favorecer (alguém em dificuldade); auxiliar, ajudar, socorrer. }\end{array}$ \\
\hline \multicolumn{2}{|c|}{$\begin{array}{l}\text { Os dicionaristas registraram a entrada acudir evidenciando o mesmo valor atribuído } \\
\text { pelos informantes: 'ajudar alguém', 'socorrer', 'proteger', 'acorrer'. Todos os informantes } \\
\text { (com exceção da informante F1-M-EP, que disse desconhecer acudir em todos os seus } \\
\text { sentidos) utilizam a lexia acudir com o significado empregado nos documentos } \\
\text { manuscritos: 'socorrer, ajudar'. } \\
\text { Analisando o contexto de uso desta unidade lexical com as respostas dos informantes, } \\
\text { verifica-se que a acepção buscada é bastante produtiva na fala dos entrevistados, supondo } \\
\text { então, tratar-se de um caso de manutenção. }\end{array}$} \\
\hline
\end{tabular}




\begin{tabular}{|c|c|}
\hline \multicolumn{2}{|c|}{ 5. ADMOESTAR / DOC.44, fól.1r, 1.06-09 } \\
\hline $\begin{array}{l}\text { Acepção } \\
\text { buscada }\end{array}$ & Avisar, advertir, aconselhar \\
\hline $\begin{array}{l}\text { Acepção(ões) } \\
\text { conhecida(s) } \\
\text { pelos } \\
\text { informantes }\end{array}$ & $\begin{array}{l}\text { F1-H-EP: NSR. } \\
\text { F1-M-EP: NSR. } \\
\text { F1-H-EF: NSR. } \\
\text { F1-M-EF: NSR. } \\
\text { F1-H-EM: NSR. } \\
\text { F1-M-EM: NSR. } \\
\text { F1-H-ES: NSR. } \\
\text { F1-M-ES: NSR. } \\
\text { F2-H-EP: NSR. } \\
\text { F2-M-EP: NSR. } \\
\text { F2-H-EF: Admoestar seria atrapalhar, incomodar, julgar. } \\
\text { F2-M-EF: NSR. } \\
\text { F2-H-EM: Quando uma pessoa erra, a outra vai lá exortar, admoestar. } \\
\text { F2-M-EM: NSR. } \\
\text { F2-H-ES: Admoestar só se for pra molestar alguém. } \\
\text { F2-M-ES: NSR. }\end{array}$ \\
\hline $\begin{array}{l}\text { Acepções } \\
\text { registradas } \\
\text { nos } \\
\text { dicionários }\end{array}$ & $\begin{array}{l}\text { Bluteau (1712-1728): ADMOESTAR, ou Amoestar. Reprehender com } \\
\text { brandura. } \\
\text { Morais Silva (1813): ADMOESTAR, v. at. Avisar da obrigação, } \\
\text { lembrá-la. Dizemos admoestar alguém de alguma coisa. 1.3. } . \\
\text { Avisar, lembrar. } \\
\text { Cunha (1997): admoestar vb. 'aconselhar, advertir' XVI. } \\
\text { Ferreira (2004): admoestar } 4 \text {. Advertir; lembrar, avisar. } \\
\text { Houaiss (2007): admoestar datação sXIV } 2 \text { advertir (alguém) de } \\
\quad \text { maneira branda (sobre alguma coisa); aconselhar. }\end{array}$ \\
\hline \multicolumn{2}{|c|}{$\begin{array}{l}\text { A unidade léxica admoestar está registrada por todos os dicionaristas com a mesma } \\
\text { acepção buscada 'avisar, aconselhar, advertir, lembrar'. Dos dezesseis entrevistados, } \\
\text { apenas o informante masculino, da faixa II, do ensino médio, utilizou 'admoestar' com a } \\
\text { acepção mais próxima do sentido empregado nos documentos manuscritos: 'exortar } \\
\text { alguém sobre algum erro'. Quanto à resposta dos outros dois informantes, o contexto uso } \\
\text { é totalmente diferente: o informante F2-H-EF conhece admoestar no sentido de } \\
\text { 'atrapalhar, incomodar, julgar'. Já o informante F2-H-ES associou 'admoestar' com outro } \\
\text { item lexical: 'molestar'. Analisando os dados em questão, constatou-se que o item lexical } \\
\text { admoestar com o sentido da acepção buscada não se encontra mais registrado em contexto } \\
\text { de fala dos entrevistados de Paranaguá. Das três ocorrências proferidas pelos informantes } \\
\text { da faixa II, o conceito atribuído por eles refere-se a diferentes significados. }\end{array}$} \\
\hline
\end{tabular}


Considerando o contexto de fala dos informantes, presume-se que a acepção buscada, 'avisar, advertir, aconselhar', em concorrência com as demais acepções, perdeu forças e deixou de ser utilizada, tendo sido provavelmente substituída por outra lexia para designar o significado em estudo. Quanto aos informantes da faixa I, estes disseram nunca ter ouvido tal lexia, inferindo dessa forma, tratar-se de um caso de $\underline{\text { desuso. }}$.

\begin{tabular}{|c|c|}
\hline \multicolumn{2}{|c|}{ 6. ALENTAR / DOC.10, fól.1r, 1.04-08 } \\
\hline $\begin{array}{l}\text { Acepção } \\
\text { buscada }\end{array}$ & Dar ânimo, encorajar. \\
\hline $\begin{array}{l}\text { Acepção(ões) } \\
\text { conhecida(s) } \\
\text { pelos } \\
\text { informantes }\end{array}$ & $\begin{array}{l}\text { F1-H-EP: NSR. } \\
\text { F1-M-EP: NSR. } \\
\text { F1-H-EF: NSR. } \\
\text { F1-M-EF: O mesmo que consolar alguém. } \\
\text { F1-H-EM: NSR. } \\
\text { F1-M-EM: NSR. } \\
\text { F1-H-ES: NSR. } \\
\text { F1-M-ES: NSR. } \\
\text { F2-H-EP: Alentar aqui é alentar uma pessoa, ela não sabe a gente alerta. } \\
\text { F2-M-EP: Conheço só alertar, por exemplo: criança não faça isso, tô } \\
\text { alertando. } \\
\text { F2-H-EF: Alentar seria acalmar. } \\
\text { F2-M-EF: NSR. } \\
\text { F2-H-EM: NSR. } \\
\text { F2-M-EM: Vamos alentar aquela pessoa, vamos fazer isso pra ela pra } \\
\text { animar. } \\
\text { F2-H-ES: Dar um alento, dar uma proteção ou proteger. No jurídico se } \\
\text { coloca como proteger alguém, dar um alento, proteger. } \\
\text { F2-M-ES: Alentar é acalmar alguém quando tá aflita. }\end{array}$ \\
\hline $\begin{array}{l}\text { Acepções } \\
\text { registradas } \\
\text { nos } \\
\text { dicionários }\end{array}$ & $\begin{array}{l}\text { Bluteau (1712-1728): ALENTAR. Dar animo. Dar forças ao corpo. } \\
\text { Morais Silva (1813): ALENTÁR, v. at. Nutrir, dar vigor ao corpo, brios } \\
\quad \text { ao animo. Esforçar: animar. } \\
\text { Cunha (1997): alento sm. 'coragem, ânimo, força' XVI. Alentar XVI. } \\
\text { Ferreira (2004): alentar } 1 \text {. Dar alento, ânimo, coragem, a; encorajar. } \\
\text { Houaiss (2007): alentar datação sXV } 1 \text { dar alento a; animar, encorajar. }\end{array}$ \\
\hline $\begin{array}{l}\text { Mais da } r \\
\text { sete informa } \\
\text { 'acalmar', 'c } \\
\text { item lexical }\end{array}$ & $\begin{array}{l}\text { dos entrevistados disse não conhecer a lexia alentar. Das respostas dos } \\
\text { averigua-se um considerável índice de variação do significado: 'alertar', } \\
\text { ar', 'proteger' e 'animar'. Somente a informante F2-M-EM emprega o } \\
\text { a mesma acepção buscada: 'Vamos alentar aquela pessoa, vamos fazer }\end{array}$ \\
\hline
\end{tabular}


isso pra ela, pra animar'. Quanto ao registro desta unidade lexical nos dicionários, todos trazem o sentido empregado nos documentos manuscritos: 'dar ânimo, forças, encorajar, animar'.

Analisando o contexto de uso de alentar e comparando com a acepção buscada, presume-se tratar de uma lexia com tendência ao desuso, visto que apenas uma informante da faixa II reconhece o item lexical com o sentido documentado no corpus escrito. A baixa ocorrência registrada na fala dos informantes refere-se a seus homônimos, e não ao mesmo item lexical em estudo.

\begin{tabular}{|c|c|}
\hline \multicolumn{2}{|c|}{ 7. ANSIAR / DOC.15, fól.1r, l.13-17 } \\
\hline $\begin{array}{l}\text { Acepção } \\
\text { buscada }\end{array}$ & Oprimir, afligir. \\
\hline $\begin{array}{l}\text { Acepção(ões) } \\
\text { conhecida(s) } \\
\text { pelos } \\
\text { informantes }\end{array}$ & $\begin{array}{l}\text { F1-H-EP: NSR. } \\
\text { F1-M-EP: NSR. } \\
\text { F1-H-EF: Anseia, ansioso pra alguma coisa. } \\
\text { F1-M-EF: Quando a pessoa fica ansiosa. } \\
\text { F1-H-EM: NSR. } \\
\text { F1-M-EM: Conheço só ansioso. } \\
\text { F1-H-ES: NSR. } \\
\text { F1-M-ES: Ansiar no sentido de ansioso. } \\
\text { F2-H-EP: NSR. } \\
\text { F2-M-EP: Quando está ansiosa por alguma coisa, daí às vezes não dá } \\
\quad \text { certo, então fica ansiosa. } \\
\text { F2-H-EF: Ansiar é uma pessoa que tá ansiosa, querer fazer as coisas } \\
\quad \text { rápido, sei lá. } \\
\text { F2-M-EF: Vou trocar meu carro esse ano, anseio pra mudar de casa. } \\
\text { F2-H-EM: NSR. } \\
\text { F2-M-EM: NSR. } \\
\text { F2-H-ES: Desejo, vontade. } \\
\text { F2-M-ES: Quando a pessoa é muito ansiosa. }\end{array}$ \\
\hline $\begin{array}{l}\text { Acepções } \\
\text { registradas } \\
\text { nos } \\
\text { dicionários }\end{array}$ & $\begin{array}{l}\text { Bluteau (1712-1728): N.D. } \\
\text { Morais Silva (1813): ANSIÁR, v, at. Causar ansias. } \\
\text { Cunha (1997): ânsia } s f . \text { 'aflição, angústia'. Ansiar XIV. } \\
\text { Ferreira (2004): ansiar 1. Causar ânsia ou ansiedade a; oprimir, } \\
\quad \text { angustiar. } \\
\text { Houaiss (2007): ansiar datação sXIV } 1 \text { provocar ou sentir ânsia, } \\
\quad \text { preocupação ou sofrimento; afligir(-se), angustiar(-se), consumir(-se). }\end{array}$ \\
\hline
\end{tabular}


Os lexicógrafos, com exceção de Bluteau, registraram a entrada ansiar com a mesma acepção buscada neste estudo: 'causar ansiedade', 'oprimir', 'angustiar', 'afligir' e 'consumir'. Verifica-se que dos nove informantes que conhecem a lexia, sete deles (F1-HEF, F1-M-EF, F1-M-EM e F1-M-ES / F2-M-EP, F2-H-EF e F2-M-ES) empregam com valor adjetival: ansioso/ansiosa. $\mathrm{O}$ emprego da forma lexical ansiar foi utilizado somente pela informante F2-M-EF: 'anseio pra mudar de casa', mas analisando o contexto desta lexia empregada no enunciado da informante, o sentido não é o mesmo da acepção buscada, refere-se a outro significado, do qual Houaiss informa, na quarta acepção, tratarse de derivação: sentido figurado: 'desejar com veemência ou anseio, almejar'. Já o informante F2-H-ES disse empregar o item lexical ansiar apenas com o sentido de 'desejo, vontade'. O mesmo dicionarista informa, na segunda acepção, tratar-se de derivação: sentido figurado.

A unidade lexical ansiar registrada por Cunha e Houaiss como do séc. XIV comprova tratar-se de uma lexia de uso antigo, enquanto que a forma adjetivada 'ansioso', foi fixada quase três séculos depois, em 1589 (HOUAISS, 2007). Desde então, presume-se, pelos dados analisados, que estas duas formas estão concorrendo entre si, havendo indícios do favorecimento da variante 'estar/ficar ansioso' em detrimento de ansiar. Portanto, a unidade lexical em estudo apresenta tendência ao desuso.

\begin{tabular}{|c|c|}
\hline \multicolumn{2}{|c|}{ 8. APANHAR / DOC.13, fól.1r, l.09-13 } \\
\hline $\begin{array}{l}\text { Acepção } \\
\text { buscada }\end{array}$ & Capturar, pegar. \\
\hline $\begin{array}{l}\text { Acepção(ões) } \\
\text { conhecida(s) } \\
\text { pelos } \\
\text { informantes }\end{array}$ & $\begin{array}{l}\text { F1-H-EP: Quando a gente apanha da mãe e pai e quando a gente pega } \\
\text { uma fruta no pé. } \\
\text { F1-M-EP: Quando a gente bate nas crianças, elas apanham. } \\
\text { F1-H-EF: No sentido de bater, de ser violento, tipo querer agredira uma } \\
\text { pessoa. Também apanho uma fruta. } \\
\text { F1-M-EF: Conheço no sentido de apanhar de alguém, quando bate e de } \\
\text { pegar alguma coisa. } \\
\text { F1-H-EM: Apanhar da mãe ou pegar alguma coisa. } \\
\text { F1-M-EM: Apanhar quando alguém bate em você. } \\
\text { F1-H-ES: No sentido de levar uma surra e pegar as coisas. } \\
\text { F1-M-ES: Apanhar de pegar algo ou apanhar de levar surra, nos dois } \\
\text { sentidos. } \\
\text { F2-H-EP: Apanhar, tem um troço ali a pessoa tem que ir lá apanhar o } \\
\text { objeto. } \\
\text { F2-M-EP: É quando a gente apanha da mãe e pai. Pra pegar alguma } \\
\text { coisa também uso. } \\
\text { F2-H-EF: Apanhar seria tipo, ser agredido. Também tem os sentido: } \\
\text { apanha ali pra mim tal, de pegar. }\end{array}$ \\
\hline
\end{tabular}




\begin{tabular}{|c|c|}
\hline & $\begin{array}{l}\text { F2-M-EF: Apanhar um objeto que eu deixei em casa. } \\
\text { F2-H-EM: Conheço apanhar uma fruta no pé e também, uma criança } \\
\text { quando é desobediente, ela apanha dos pais. } \\
\text { F2-M-EM: Apanhar de alguém, quando alguém te bate. } \\
\text { F2-H-ES: É de pegar. } \\
\text { F2-M-ES: Apanhar de alguém e também pegar alguma coisa }\end{array}$ \\
\hline $\begin{array}{l}\text { Acepções } \\
\text { registradas } \\
\text { nos } \\
\text { dicionários }\end{array}$ & $\begin{array}{l}\text { Bluteau (1712-1728): APANHAR. Alcançar, \& prender pessoas, que } \\
\text { fogem. Vid. Tomar: tomar na mão. } \\
\text { Morais Silva (1813): APANHÁR, v. at. Colher: } v . g \text {. apanhar frutos, } \\
\text { folha. §. Tomar na mão. } \\
\text { Cunha (1997): apanhar } v b \text {. 'colher, recolher, segurar, levantar' XIV. } \\
\text { Ferreira (2004): apanhar 6. Prender, capturar, agarrar. } \\
\text { Houaiss (2007): apanhar datação sXIII } 1 \text { capturar, recolher, segurar ou } \\
\text { tomar posse de (algo), com auxílio das mãos ou de objeto; pegar. }\end{array}$ \\
\hline \multicolumn{2}{|c|}{$\begin{array}{l}\text { Os dicionaristas registram a entrada apanhar com o mesmo sentido da acepção } \\
\text { buscada: 'prender, segurar, capturar, pegar'. Analisando o contexto de uso dessa unidade } \\
\text { lexical, constata-se que todos os informantes a utilizam no seu dia a dia, porém com } \\
\text { significados diferenciados: apanhar de 'pegar algo' e apanhar de 'alguém ser agredido'. } \\
\text { Três informantes (F1-M-EP e F1-M-EM / F2-M-EM) utilizam o item lexical somente na } \\
\text { acepção de 'ser agredido por alguém'. E três informantes (F2-H-EP, F2-M-EF e F2-H-ES) } \\
\text { empregam apanhar apenas na acepção de 'pegar um objeto'. } \\
\text { Analisando o contexto de utilização da lexia apanhar, observa-se no estágio atual de } \\
\text { variação, considerável frequência da ocorrência dos dois significados distintos para um } \\
\text { único referente apanhar. Neste cenário linguístico, conclui-se então, que a unidade lexical } \\
\text { apanhar no sentido de 'captura, pegar', presente em quase todas as respostas dos } \\
\text { informantes em Paranaguá, apresenta tendência à manutencão. }\end{array}$} \\
\hline
\end{tabular}

\begin{tabular}{|l|l|}
\hline 9. APENAR / DOC.22, fól.1r, l-13-14 \\
\hline $\begin{array}{l}\text { Acepção } \\
\text { buscada }\end{array}$ & Obrigar, impor pena. \\
\hline $\begin{array}{l}\text { Acepção(ões) } \\
\text { conhecida(s) }\end{array}$ & F1-H-EP: NSR. \\
pelos & F1-M-EP: NSR. \\
informantes: & F1-H-EF: Dar pena. \\
& $\begin{array}{l}\text { F1-H-EM: NSR. NSR. } \\
\text { F1-M-EM: NSR. } \\
\end{array}$ \\
& F1-H-ES: NSR. \\
& F1-M-ES: NSR. \\
\hline
\end{tabular}




\begin{tabular}{|c|c|}
\hline & $\begin{array}{l}\text { F2-H-EP: Punir alguém. } \\
\text { F2-M-EP: NSR. } \\
\text { F2-H-EF: Apenar seria de corrigir, de prender. } \\
\text { F2-M-EF: NSR. } \\
\text { F2-H-EM: NSR. } \\
\text { F2-M-EM: NSR. } \\
\text { F2-H-ES: Apenar é a questão jurídica da pena, quando é apenado ele já } \\
\text { tem um processo contra ele com uma decisão, então ele já é apenado. } \\
\text { A gente usa muito quando no pró-ingresso, por exemplo, o cidadão é } \\
\text { apenado, ele tem uma pena. } \\
\text { F2-M-ES: É a mesma coisa que ter pena. }\end{array}$ \\
\hline $\begin{array}{l}\text { Acepções } \\
\text { registradas } \\
\text { nos } \\
\text { dicionários }\end{array}$ & $\begin{array}{l}\text { Bluteau (1712-1728): APENAR. Pôr pena. } \\
\text { Morais Silva (1813): APENÁR, v. at. Dar pena, condemnar, castigar. } \S \text {. } \\
\text { Obrigar com pena, ou multa, se o obrigado cair em comisso. } \\
\text { Cunha (1997): pena' }{ }^{1} f \text {. 'castigo, punição, sofrimento' | XIII. No port. } \\
\quad \text { med. documenta-se, também, apenar (séc. XV). } \\
\text { Ferreira (2004): apenar } 1 \text {. Condenar a pena; castigar, punir. } \\
\text { Houaiss (2007): apenar datação } 14591 \text { impor pena a; punir, castigar, } \\
\quad \text { condenar. }\end{array}$ \\
\hline \multicolumn{2}{|c|}{$\begin{array}{l}\text { Os dicionaristas registram a entrada apenar com a mesma acepção utilizada pelos } \\
\text { informantes parnanguaras: 'impor pena, punir, castigar, obrigar, condenar'. Dos dezesseis } \\
\text { entrevistados, somente quatro informantes (F1-H-EF / F2-H-EP, F2-H-EF e F2-H-ES) } \\
\text { reconheceram a lexia apenar empregando-a com o mesmo sentido registrado nos } \\
\text { documentos manuscritos. Já a informante F2-M-ES reconheceu com o sentido de 'ter } \\
\text { pena'. Esta acepção não consta dicionarizada por nenhum dos lexicógrafos para a entrada } \\
\text { apenar. } \\
\text { Embora este item lexical ainda esteja presente na fala de alguns moradores de } \\
\text { Paranaguá, observa-se que seu uso é pouco produtivo. Dos onze informantes que } \\
\text { desconhecem a lexia apenar, sete são da faixa I. E dos poucos que a utilizam com o } \\
\text { sentido de 'impor pena', três são da faixa II. Pressupõe-se, dessa forma, que a lexia } \\
\text { apenar revela tendência ao desuso. }\end{array}$} \\
\hline
\end{tabular}

\begin{tabular}{|l|l|}
\hline 10. APOSSAR / DOC.25, fól.1v, l.17-19 \\
\hline $\begin{array}{l}\text { Acepção } \\
\text { buscada }\end{array}$ & Tomar posse, apoderar-se. \\
\hline $\begin{array}{l}\text { Acepção(ões) } \\
\text { conhecida(s) } \\
\text { pelos } \\
\text { informantes }\end{array}$ & $\begin{array}{l}\text { F1-H-EP: NSR. } \\
\text { F1-EP: Quando alguém pega alguma coisa da gente e não devolve, } \\
\text { F1-H-EF: Se apossar de alguma coisa que é dos outros. }\end{array}$ \\
\hline
\end{tabular}




\begin{tabular}{|c|c|}
\hline & $\begin{array}{l}\text { F1-M-EF: Quando alguém se apossa de alguma coisa, de algum objeto } \\
\text { que não é seu. } \\
\text { F1-H-EM: Apossar de alguma coisa. } \\
\text { F1-M-EM: NSR. } \\
\text { F1-H-ES: Sentido de tomar posse. } \\
\text { F1-M-ES: Tomar posse. } \\
\text { F2-H-EP: NSR. } \\
\text { F2-M-EP: Apossar de alguma coisa que não é nosso, daí a gente quer se } \\
\text { apossar. } \\
\text { F2-H-EF: Apossar é de tomar e pegar, se apossar. } \\
\text { F2-M-EF: É pegar algo de alguém, que não é da gente. } \\
\text { F2-H-EM: Apossar é você pegar alguma coisa que não é tua. } \\
\text { F2-M-EM: Vou me apossar daquele terreno que não tem dono. } \\
\text { F2-H-ES: Pegar, tomar, tirar de alguém, se apossar, ainda se usa muito. } \\
\text { F2-M-ES: Apossar é você querer tomar conta daquilo ali pra você, } \\
\text { apoderar, se apossar. }\end{array}$ \\
\hline $\begin{array}{l}\text { Acepções } \\
\text { registradas } \\
\text { nos } \\
\text { dicionários }\end{array}$ & $\begin{array}{l}\text { Bluteau (1712-1728): APOSSARSE. Tomar posse. } \\
\text { Morais Silva (1813): APOSSÁR, v. at. Metter de posse. } \S . \text { Apossar-se: } \\
\quad \text { metter-se de posse, senhorear-se, apoderar-se. } \\
\text { Cunha (1997): posse } s f \text {. Substantivação do lat. posse 'ser capaz, poder' } \\
\quad \text { apossar XVI. } \\
\text { Ferreira (2004): apossar } 3 \text {. Tomar posse; apoderar-se, conquistar. } \\
\text { Houaiss (2007): apossar datação } 15672 \text { tomar posse de; assenhorar-se. }\end{array}$ \\
\hline \multicolumn{2}{|c|}{$\begin{array}{l}\text { A unidade lexical apossar está registrada pelos lexicógrafos no sentido de 'tomar } \\
\text { posse, apoderar-se, assenhorar-se'. Estas definições remetem à mesma acepção buscada e } \\
\text { às apresentadas pelos informantes. Tanto Cunha como Houaiss trazem seu primeiro } \\
\text { registro a partir do século XVI, podendo-se inferir que, apesar de a lexia apossar ter } \\
\text { origem remota, sua forma ainda é bastante produtiva na linguagem oral dos informantes. } \\
\text { Portanto, há indícios do item lexical 'apossar' ser um caso de manutencão. }\end{array}$} \\
\hline
\end{tabular}

\begin{tabular}{|l|l|}
\hline \multicolumn{2}{|l|}{ 11. ARRIMAR / DOC.10, fól.1r, l.08-12 } \\
\hline $\begin{array}{l}\text { Acepção } \\
\text { buscada }\end{array}$ & Dar apoio, dar suporte. \\
\hline $\begin{array}{l}\text { Acepção(ões) } \\
\text { conhecida(s) }\end{array}$ & F1-H-EP: NSR. \\
pelos & F1-M-EP: NSR. \\
informantes & F1-M-EF: NSR. NSR. \\
& F1-H-EM: NSR. \\
\hline
\end{tabular}




\begin{tabular}{|c|c|}
\hline & $\begin{array}{l}\text { F1-M-EM: NSR. } \\
\text { F1-H-ES: NSR. } \\
\text { F1-M-ES: NSR. } \\
\text { F2-H-EP: NSR. } \\
\text { F2-M-EP: NSR. } \\
\text { F2-H-EF: É aqui fala apoiar no caso, arrimar não. } \\
\text { F2-M-EF: NSR. } \\
\text { F2-H-EM:NSR. } \\
\text { F2-M-EM: NSR. } \\
\text { F2-H-ES: Arrimar-se é ajeitar-se, dar um jeito. } \\
\text { F2-M-ES: Arrimar é quando você faz alguma frase para rimar. }\end{array}$ \\
\hline $\begin{array}{l}\text { Acepções } \\
\text { registradas } \\
\text { nos } \\
\text { dicionários: }\end{array}$ & $\begin{array}{l}\text { Bluteau (1712-1728): ARRIMAR, huma cousa a outra, para que não } \\
\text { caya. Vid. Encostar. } \\
\text { Morais Silva (1813): ARRIMÁR, v. at. Encostar. } \\
\text { Cunha (1997): rima }{ }^{3} s f \text {. 'ato ou efeito de arrimar-se'. De etimologia } \\
\text { obscura | arrimar } v b \text {. 'pôr em ordem' XIV. } \\
\text { Ferreira (2004): arrimar 3. Servir de arrimo a; amparar, escorar, } \\
\text { sustentar. } \\
\text { Houaiss (2007): arrimar datação sXIV } 5 \text { usar como arrimo, } \\
\text { sustentáculo, sustentação; valer-se, apoiar-se, socorrer-se. }\end{array}$ \\
\hline \multicolumn{2}{|c|}{$\begin{array}{l}\text { Da acepção buscada: 'dar apoio, dar suporte', para o item lexical arrimar, os } \\
\text { dicionaristas trazem acepções semelhantes: Bluteau e Morais Silva definem arrimar } \\
\text { como 'encostar'. Ferreira e Houaiss: 'servir de arrimo', 'usar como arrimo', no sentido de } \\
\text { sustentar/dar sustentação. Portanto, são definições muito próximas da acepção registrada } \\
\text { nos documentos manuscritos. Analisando o contexto de uso da unidade lexical arrimar, } \\
\text { verifica-se que seu emprego na modalidade oral tem pouca produtividade, haja vista que } \\
\text { nenhum dos informantes da faixa I conhece essa forma lexical. Dos oito informantes da } \\
\text { faixa II, somente três conhecem a lexia, mas com ressalvas: o informante F2-H-EF } \\
\text { afirmou que não fala arrimar, emprega em seu lugar outro item lexical, com o mesmo } \\
\text { significado, a forma lexical apoiar. Já a informante F2-M-ES associou o parônimo } \\
\text { rimar com arrimar. São unidades lexicais distintas e com significados também } \\
\text { diferentes. O único contexto de fala que se aproxima da acepção buscada foi empregado } \\
\text { pelo informante F2-H-ES: 'Arrimar-se é ajeitar-se, dar um jeito', ou seja, sentido } \\
\text { semelhante ao abonado por Cunha: 'por em ordem', lexicalizado no séc. XIV. } \\
\text { Dessa forma, arrimar é um item lexical desconhecido pela maioria dos entrevistados, } \\
\text { principalmente pelos informantes da faixa I, e seu emprego na modalidade oral apresenta } \\
\text { tendência ao desuso. }\end{array}$} \\
\hline
\end{tabular}




\begin{tabular}{|c|c|}
\hline \multicolumn{2}{|c|}{ 12. ARROMBAR / DOC.33, fól.1v, l.18-21 } \\
\hline $\begin{array}{l}\text { Acepção } \\
\text { buscada }\end{array}$ & Derrubar, romper. \\
\hline $\begin{array}{l}\text { Acepção(ões) } \\
\text { conhecida(s) } \\
\text { pelos } \\
\text { informantes }\end{array}$ & $\begin{array}{l}\text { F1-H-EP: Arrombar uma casa e entrar. } \\
\text { F1-M-EP: Arrombar uma cerca. } \\
\text { F1-H-EF: Arrombar uma porta, entrar em determinado lugar que tá } \\
\text { fechado. } \\
\text { F1-M-EF: Arrombar uma porta. } \\
\text { F1-H-EM: Arrombar a porta. } \\
\text { F1-M-EM: Quando rouba a tua casa, os ladrões arrombam a porta, } \\
\text { janela. } \\
\text { F1-H-ES: Arrombar é invadir, estragar. } \\
\text { F1-M-ES: Arrombar tipo abrir um lugar com muita força. } \\
\text { F2-H-EP: Derrubar uma cerca. } \\
\text { F2-M-EP: Arrombar que eu saiba é entrar numa casa, pegar e estourar a } \\
\text { porta, é isso arrombar. } \\
\text { F2-H-EF: Arrombar de rebentar, destruir, quebrar. No sentido uma porta, } \\
\text { uma janela. } \\
\text { F2-M-EF: Arrombou a casa, arrombou o armário de alguém. } \\
\text { F2-H-EM: Arrombar um supermercado. } \\
\text { F2-M-EM:NSR. } \\
\text { F2-H-ES: Tomar, quebrar, entrar. } \\
\text { F2-M-ES: Arrombar uma porta, uma janela. }\end{array}$ \\
\hline $\begin{array}{l}\text { Acepções } \\
\text { registradas } \\
\text { nos } \\
\text { dicionários: }\end{array}$ & $\begin{array}{l}\text { Bluteau (1712-1728): ARROMBAR huma porta. Quebralla com grande } \\
\text { força, \& deitala dentro. } \\
\text { Morais Silva (1813): ARROMBÁR, v. at. Fazer buraco, aberta, rombo á } \\
\text { força, com tiro, deitando abaixo portas, janellas, forçando. } \\
\text { Cunha (1997): rombo }{ }^{2} \mathrm{sm} \text {. 'furo, abertura, buraco de grandes } \\
\text { proporções' | arrombar XV. } \\
\text { Ferreira (2004): arrombar } 2 \text {. Abrir à força. } \\
\text { Houaiss (2007): arrombar datação sXV } 2 \text { abrir à força, usando de } \\
\text { violência. }\end{array}$ \\
\hline \multicolumn{2}{|c|}{$\begin{array}{l}\text { Analisando o contexto de uso da lexia arrombar pelos informantes de Paranaguá, as } \\
\text { definições apresentadas por eles evidenciam como traços comuns 'romper usando muita } \\
\text { força'. Arrombar é registrado pelos lexicógrafos com o mesmo sentido da acepção } \\
\text { buscada 'derrubar, ir abaixo, romper'. Dos dezesseis entrevistados, somente o informante } \\
\text { F2-H-EM disse desconhecer a lexia arrombar, os demais a empregam em seu contexto de } \\
\text { fala cotidianamente. Portanto, a unidade lexical arrombar parece tratar-se de um caso de } \\
\text { manutencão. }\end{array}$} \\
\hline
\end{tabular}




\begin{tabular}{|c|c|}
\hline \multicolumn{2}{|c|}{ 13. ASSENHOREAR-SE / DOC.25, fól.1r, 1.21-24 } \\
\hline $\begin{array}{l}\text { Acepção } \\
\text { buscada }\end{array}$ & Apossar-se, dominar. \\
\hline $\begin{array}{l}\text { Acepção(ões) } \\
\text { conhecida(s) } \\
\text { pelos } \\
\text { informantes }\end{array}$ & $\begin{array}{l}\text { F1-H-EP: NSR. } \\
\text { F1-M-EP: NSR. } \\
\text { F1-H-EF: NSR. } \\
\text { F1-M-EF: NSR. } \\
\text { F1-H-EM: NSR. } \\
\text { F1-M-EM: NSR. } \\
\text { F1-H-ES: NSR. } \\
\text { F1-M-ES: NSR. } \\
\text { F2-H-EP: NSR. } \\
\text { F2-M-EP: NSR. } \\
\text { F2-H-EF: Tomar posse, se tornar dono. } \\
\text { F2-M-EF: NSR. } \\
\text { F2-H-EM: NSR. } \\
\text { F2-M-EM: NSR. } \\
\text { F2-H-ES: NSR. } \\
\text { F2-M-ES: NSR. }\end{array}$ \\
\hline $\begin{array}{l}\text { Acepções } \\
\text { registradas } \\
\text { nos } \\
\text { dicionários }\end{array}$ & $\begin{array}{l}\text { Bluteau (1712-1728): [SENHOREARSE. Fazerse Senhor. Aposarse]. } \\
\text { Morais Silva (1813): ASSENHOREÁR, v. at. e netro, Dominar como } \\
\text { senhor. §. Assenhorear-se da terra; fazer-se senhor, conquista-la, e } \\
\text { dominá-la. } \\
\text { Cunha (1997): senhor sm. 'dono, patrão' | assenhorear } v b \text {. 'senhorear' } \\
\text { XIV. } \\
\text { Ferreira (2004): assenhorear 2. Tornar-se senhor; entrar no domínio; } \\
\quad \text { tomar posse; apossar-se; apoderar-se; ensenhorear-se. } \\
\text { Houaiss (2007): assenhorear datação } 13442 \text { tornar-se senhor; apossar- } \\
\quad \text { se, apoderar-se. }\end{array}$ \\
\hline \multicolumn{2}{|c|}{$\begin{array}{l}\text { A entrada assenhorear-se está registrada pelos dicionaristas com o mesmo significado } \\
\text { documentado nos manuscritos: 'apossar-se, dominar'. Esta mesma definição foi obtida da } \\
\text { resposta de um único informante F2-H-EF. Os outros quinze informantes disseram não } \\
\text { conhecer a lexia em questão. } \\
\text { Portanto, como a forma verbal assenhorear-se não é reconhecida por nenhum dos } \\
\text { informantes da faixa I, e sua ocorrência esteve presente somente na fala de um informante } \\
\text { da faixa II, supõe-se que esta unidade lexical apresenta tendência ao desuso. }\end{array}$} \\
\hline
\end{tabular}




\begin{tabular}{|c|c|}
\hline \multicolumn{2}{|c|}{ 14. ASSISTIR / DOC.25, fól.1v, l.03-05 } \\
\hline $\begin{array}{l}\text { Acepção } \\
\text { buscada }\end{array}$ & Residir, permanecer. \\
\hline $\begin{array}{l}\text { Acepção(ões) } \\
\text { conhecida(s) } \\
\text { pelos } \\
\text { informantes }\end{array}$ & $\begin{array}{l}\text { F1-H-EP: Assistir televisão. } \\
\text { F1-M-EP: Assistir filme. } \\
\text { F1-H-EF: Assistir um teatro, televisão. } \\
\text { F1-M-EF: Assistir t.v. } \\
\text { F1-H-EM: Assistir de ver uma situação. } \\
\text { F1-M-EM: Assistir t.v. } \\
\text { F1-H-ES: Assistir televisão ou de socorrer alguém. } \\
\text { F1-M-ES: Assistir a televisão. } \\
\text { F2-H-EP: Assistir, nós usa a palavra assistir assim: alguém tá enfermo o } \\
\text { pessoal vai lá assistir. } \\
\text { F2-M-EP: Assistir é quando a gente via assistir uma televisão, um jogo } \\
\text { no campo. } \\
\text { F2-H-EF: Assistir quando você vê um espetáculo, assistir uma tevê, um } \\
\text { filme: E assistir como dar uma assistência pra alguma pessoa, que tá } \\
\text { precisando de uma ajuda, aí a gente tá assistindo aquela pessoa. } \\
\text { F2-M-EF: Assistir um filme. } \\
\text { F2-H-EM: Assistir televisão, assistir filme no cinema. } \\
\text { F2-M-EM: Assistir uma televisão, uma palestra. } \\
\text { F2-H-ES: Assistir é dar amparo juridicamente, atender. Hoje se você } \\
\text { perguntar é assistir um filme, uma novela. } \\
\text { F2-M-ES: Assistir uma, televisão, uma ópera. }\end{array}$ \\
\hline $\begin{array}{l}\text { Acepções } \\
\text { registradas } \\
\text { nos } \\
\text { dicionários }\end{array}$ & $\begin{array}{l}\text { Bluteau (1712-1728): ASSISTIR. Outras vezes vem a ser o mesmo, que } \\
\text { morar. } \\
\text { Morais Silva (1813): ASSISTÍR, v. at. §. Morar em alguma casa, lugar. } \\
\text { Cunha (1997): assistir } v b \text {. 'estar presente, ver, testemunhar' 'ajudar, } \\
\quad \text { socorrer' XVI. } \\
\text { Ferreira (2004): assistir 9. Residir, morar; habitar. } \\
\text { Houaiss (2007): assistir datação } 15938 \text { residir, morar. }\end{array}$ \\
\hline \multicolumn{2}{|c|}{$\begin{array}{l}\text { Da lexia assistir buscou-se a acepção 'residir, permanecer' presente nos documentos } \\
\text { manuscritos. Das várias acepções registradas pelos dicionaristas, encontra-se lexicalizada } \\
\text { a acepção buscada (com exceção de Cunha): 'morar, residir, habitar'. Analisando o } \\
\text { contexto de uso deste item lexical pelos entrevistados de Paranaguá, observa-se o emprego } \\
\text { de dois outros significados: assistir sentido de 'ver' e 'assistir' sentido de 'ajudar, } \\
\text { socorrer'. Na faixa I, o emprego da lexia assistir no sentido de 'ver' foi unânime, havendo } \\
\text { somente uma variação de significado por parte do informante F1-H-ES. Quanto à faixa II, } \\
\text { cinco informantes (F2-M-EP, F2-M-EF, F2-H-EM, F2-M-EM e F2-M-ES) conhecem o } \\
\text { termo somente no sentido de 'ver', outros dois (F2-H-EF e F2-H-ES) no sentido de 'ver' }\end{array}$} \\
\hline
\end{tabular}


e 'ajudar', e somente o informante F2-H-EP utiliza assistir no sentido de 'ajudar': 'alguém tá enfermo o pessoal vai lá assistir'. Pelo enunciado do informante F2-H-ES constata-se que o emprego do item lexical assistir é quase que exclusivo no sentido de 'ver', e que assistir no sentido de 'dar amparo, ajuda, proteção' é uma forma lexical obsoleta: 'Assistir é dar amparo juridicamente, atender. Hoje se você perguntar, é assistir um filme, uma novela'. Esta assertiva se comprova conforme se verifica sua quase ausência na fala dos informantes da faixa I.

Pela datação do lema assistir, Cunha e Houaiss trazem seu registro no século XVI, com várias designações. Em Cunha (1997) não há a acepção no sentido de 'moradia, residência', apenas com os outros dois sentidos: 'ver, testemunhar' e 'ajudar, socorrer'. Analisando os dados apresentados, conjectura-se que em algum momento da língua, a lexia assistir teve vários sentidos concorrendo entre si, inclusive o da acepção buscada. Considerando as respostas dos informantes com relação à unidade lexical assistir, presume-se que a acepção investigada não está mais presente na memória dos falantes parnanguaras, supondo-se, portanto, que tenha caído em $\underline{\text { desuso. }}$.

\begin{tabular}{|c|c|}
\hline \multicolumn{2}{|c|}{ 15. ATALHAR / DOC.32, fól.1r, l.06-08 } \\
\hline $\begin{array}{l}\text { Acepção } \\
\text { buscada }\end{array}$ & Impedir, estorvar. \\
\hline $\begin{array}{l}\text { Acepção(ões) } \\
\text { conhecida(s) } \\
\text { pelos } \\
\text { informantes }\end{array}$ & $\begin{array}{l}\text { F1-H-EP: NSR. } \\
\text { F1-M-EP: NSR. } \\
\text { F1-H-EF: Atalhar é cortar. } \\
\text { F1-M-EF: De atalho, pegar atalho. } \\
\text { F1-H-EM: NSR. } \\
\text { F1-M-EM: NSR. } \\
\text { F1-H-ES: NSR. } \\
\text { F1-M-ES: Atalhar caminho no sentido de cortar caminho. } \\
\text { F2-H-EP: NSR. } \\
\text { F2-M-EP: NSR. } \\
\text { F2-H-EF: Atalhar usa muito no sítio, vou atalhar por aqui, desviar, } \\
\quad \text { atalhar e tal. } \\
\text { F2-M-EF: Conheço como cortar o caminho. } \\
\text { F2-H-EM: NSR. } \\
\text { F2-M-EM: NSR. } \\
\text { F2-H-ES: Talhar deve ser cortar, de talho. } \\
\text { F2-M-ES: Atalhar é no sentido de você pegar um atalho, um caminho } \\
\quad \text { mais curto. }\end{array}$ \\
\hline $\begin{array}{l}\text { Acepções } \\
\text { registradas }\end{array}$ & $\begin{array}{l}\text { Bluteau (1712-1728): ATALHAR. Cortar. Não deyxar hir por diante. } \\
\text { Atalhar os passos a alguem, para que não chegue a algum lugar. }\end{array}$ \\
\hline
\end{tabular}




\begin{tabular}{|l|l|}
\hline $\begin{array}{l}\text { nos dicionários } \\
\text { Cunha (1997): talhar } v b \text {. 'cortar' | Atalhar } v b . \text { 'talhar' | XIV. } \\
\text { fechar, impedír. } \\
\text { Ferreira (2004): atalhar' } 7 \text {. Embaraçar, estorvar, obstar. } \\
\text { Houaiss (2007): atalhar datação sXIII 1 impedir que corra, que ande, } \\
\text { que continue, que se propague etc. }\end{array}$ \\
\hline $\begin{array}{l}\text { Seis informantes (F1-H-EF, F1-M-EF e F1-M-ES / F2-H-EF, F2-M-EF e F2-M-ES) } \\
\text { reconheceram a lexia atalhar em seu contexto de uso, evidenciando como traços comuns: }\end{array}$ \\
$\begin{array}{l}\text { 'encurtar caminho', 'cortar caminho', 'diminuir caminho'. Quanto ao informante F2-H- } \\
\text { é de 'se machucar, fazer um corte'. Os lexicógrafos (com exceção de Cunha) trazem a } \\
\text { acepção de atalhar com o mesmo sentido de 'interromper, estorvar, impedir que corra, } \\
\text { não deixar prosseguir'. Quanto à datação da entrada atalhar, Houaiss a registra no século } \\
\text { XIII, enquanto Cunha traz seu primeiro registro um século depois. Por hipótese, presume- } \\
\text { se que o item lexical atalhar com o sentido de 'impedir, estorvar', tenha ocorrido em } \\
\text { algum momento da língua, perdendo o seu registro na modalidade oral conforme se } \\
\text { constata por meio das respostas dos entrevistados. Portanto supõe-se que a lexia com o } \\
\text { sentido da acepção em estudo, tenha caído em desuso. }\end{array}$ \\
\hline
\end{tabular}

\begin{tabular}{|c|c|}
\hline \multicolumn{2}{|c|}{ 16. AVANÇAR A DINHEIRO / DOC.37, fól.1v, l.20-24 } \\
\hline $\begin{array}{l}\text { Acepção } \\
\text { buscada }\end{array}$ & Conceder, dispor. \\
\hline $\begin{array}{l}\text { Acepção(ões) } \\
\text { conhecida(s) } \\
\text { pelos } \\
\text { informantes }\end{array}$ & $\begin{array}{l}\text { F1-H-EP: NSR. } \\
\text { F1-M-EP: NSR. } \\
\text { F1-H-EF: NSR. } \\
\text { F1-M-EF: NSR. } \\
\text { F1-H-EM: NSR. } \\
\text { F1-M-EM: NSR. } \\
\text { F1-H-ES: NSR. } \\
\text { F1-M-ES: NSR. } \\
\text { F2-H-EP: NSR. } \\
\text { F2-M-EP: NSR. } \\
\text { F2-H-EF: Avançar a dinheiro seria você dar uma entrada, você vai } \\
\text { comprar um negócio, então vou te dar um sinal, vou avançar um sinal. } \\
\text { F2-M-EF: NSR. } \\
\text { F2-H-EM: Pegar pagamento no final do mês. } \\
\text { F2-M-EM: NSR. } \\
\text { F2-H-ES: NSR. } \\
\text { F2-M-ES: NSR. }\end{array}$ \\
\hline
\end{tabular}




\begin{tabular}{|l|l|}
\hline $\begin{array}{l}\text { Acepções } \\
\text { registradas } \\
\text { nos } \\
\text { dicionários }\end{array}$ & $\begin{array}{l}\text { Bluteau (1712-1728): N.D. } \\
\text { Morais Silva (1813): N.D. } \\
\text { Cunha (1997): N.D. } \\
\text { Ferreira (2004): N.D. } \\
\text { Houaiss (2007): N.D. }\end{array}$ \\
\hline \multicolumn{1}{|c|}{ A expressão avançar a dinheiro não está registrada nos dicionários acima e nem possui } \\
locuções semelhantes que possam indicar caso de variação lexical. Analisando o contexto \\
de uso, somente dois informantes (F2-H-EF e F2-H-EM) utilizam a locução verbal, mas \\
com sentido diferente da acepção buscada. Considerando que nenhum informante da faixa \\
$\begin{array}{l}\text { I conhece a expressão avançar a dinheiro, e somente dois informantes da faixa II a } \\
\text { utilizam, mas com outra acepção, presume-se que esta expressão tenha caído em desuso. }\end{array}$ \\
\hline
\end{tabular}

\begin{tabular}{|c|c|}
\hline \multicolumn{2}{|c|}{ 17. AVOCAR / DOC.48, fól.1r, l.24-26 } \\
\hline $\begin{array}{l}\text { Acepção } \\
\text { buscada }\end{array}$ & Chamar, invocar. \\
\hline $\begin{array}{l}\text { Acepção(ões) } \\
\text { conhecida(s) } \\
\text { pelos } \\
\text { informantes }\end{array}$ & $\begin{array}{l}\text { F1-H-EP: NSR. } \\
\text { F1-M-EP: NSR. } \\
\text { F1-H-EF: Avocar, invocar, chamar. } \\
\text { F1-M-EF: NSR. } \\
\text { F1-H-EM: NSR. } \\
\text { F1-M-EM: NSR. } \\
\text { F1-H-ES: NSR. } \\
\text { F1-M-ES: NSR. } \\
\text { F2-H-EP: NSR. } \\
\text { F2-M-EP: NSR. } \\
\text { F2-H-EF: Avocar não sei, evocar sim, evoque fulano, evoque sicrano. } \\
\text { F2-M-EF: NSR. } \\
\text { F2-H-EM: Avocar é aquele que dá a chamada, que chama. } \\
\text { F2-M-EM: NSR. } \\
\text { F2-H-ES: É como evocar, é como solicitar, é como pedir. } \\
\text { F2-M-ES: NSR. }\end{array}$ \\
\hline $\begin{array}{l}\text { Acepções } \\
\text { registradas } \\
\text { nos } \\
\text { dicionários }\end{array}$ & $\begin{array}{l}\text { Bluteau (1712-1728): AVOCAR. Chamar. Fazer vir. Avocar a si. } \\
\text { Morais Silva (1813): AVOCÁR, v. at. Chamar; attrahir, fazer vir a si. } \\
\text { Cunha (1997): avocar } v b \text {. 'chamar, atrair' XV. } \\
\text { Ferreira (2004): avocar 5. Chamar. } \\
\text { Houaiss (2007): avocar } 1 \text { chamar, invocar; chamar a si, fazer vir. }\end{array}$ \\
\hline
\end{tabular}


Constata-se, pelo contexto de uso, que a lexia avocar tem pouca produtividade no contexto de fala, pois, dos dezesseis entrevistados, apenas quatro informantes (um da faixa I e três da faixa II) responderam a questão. Dos poucos informantes que conhecem avocar, observa-se que dois (F1-H-EF / F2-H-EM) a empregam com o sentido de 'invocar, chamar'. Já o informante F2-H-EF foi incisivo ao afirmar que não utiliza avocar, em seu lugar prefere o uso do item lexical evocar. Mesma preferência, por este item lexical demonstra o informante F2-H-ES

Os lexicógrafos registram a entrada avocar com o mesmo sentido da acepção buscada: 'chamar, invocar'. Cunha fixa a forma lexical avocar no século XV, confirmando ser uma lexia de origem antiga. Em contrapartida, Houaiss registra 1789, enquanto Cunha a lexicaliza somente no século posterior, mais precisamente em 1813. Pelas informações dadas por estes lexicógrafos, e contrastando com o contexto de utilização do item lexical avocar, presume-se que esta unidade lexical além de estar concorrendo com a lexia evocar, tem apenas uma ocorrência por parte de um informante da faixa I. Supõe-se, então, que avocar apresenta tendência ao desuso.

\begin{tabular}{|l|l|}
\hline \multicolumn{1}{|l|}{$\begin{array}{l}\text { 18. BOTAR / DOC.44, fól.1r, l.11-12 } \\
\text { buscada }\end{array}$} & Pôr, colocar. \\
\hline $\begin{array}{l}\text { Acepção(ões) } \\
\text { conhecida(s) } \\
\text { pelos } \\
\text { informantes }\end{array}$ & $\begin{array}{l}\text { F1-H-EP: É colocar, vou colocar esse copo em cima da mesa. } \\
\text { F1-H-EP: NSR. Bota uma coisa ali, pega outra aqui: bota uma xícara, bota os } \\
\text { talheres. } \\
\text { F1-M-EF: Mudar algo de lugar: pego aqui e boto lá. } \\
\text { F1-H-EM: Sentido de colocar alguma coisa, e também a galinha bota } \\
\text { ovo. } \\
\text { F1-M-EM: A galinha bota os ovos, eu coloco as coisas, eu não boto. } \\
\text { F1-H-ES Sentido de colocar. } \\
\text { F1-M-ES: Botar, colocar. } \\
\text { F2-H-EP: Conheço colocar. } \\
\text { F2-M-EP: Eu falo colocar. } \\
\text { F2-H-EF: Botar seria colocar, pôr. } \\
\text { F2-M-EF: Botar algo em algum lugar. } \\
\text { F2-H-EM: Sentido de aves, quando ela bota. } \\
\text { F2-M-EM: Hoje eu vou botar frango na panela, no sentido de colocar. } \\
\text { F2-H-ES: Pra nós hoje botar é colocar. } \\
\text { F2-M-ES: Botar as coisas no lugar. }\end{array}$ \\
\hline
\end{tabular}




\begin{tabular}{|c|c|}
\hline $\begin{array}{l}\text { Acepções } \\
\text { registradas } \\
\text { nos } \\
\text { dicionários }\end{array}$ & $\begin{array}{l}\text { Bluteau (1712-1728): BOTAR. Derivase do Francez Bouter, que he } \\
\text { deitar fora com força alguma cousa, que està dentro de outra. Botar } \\
\text { huma cousa sobre outra. } \\
\text { Morais Silva (1813): BOTÁR, v. at. §. Pòr. } \\
\text { Cunha (1997): botar } v b \text {. 'deitar em, lançar fora, pôr, colocar' XIV. } \\
\text { Ferreira (2004): botar }{ }^{1} \text { 6. Pôr, colocar. } \\
\text { Houaiss (2007): }{ }^{2} \text { botar dataçâo sXIV } 15 \text { Uso: informal: deslocar (algo) } \\
\text { de um local para outro; pôr, colocar. }\end{array}$ \\
\hline
\end{tabular}

Analisando o contexto de uso da lexia botar, verifica tratar-se de uma forma lexical bastante produtiva na fala dos informantes de Paranaguá. Quanto à acepção buscada 'pôr, colocar', a maior parte dos entrevistados disse empregar com este mesmo sentido. No caso, dois informantes, F2-H-EP e F2-M-EP, salientaram utilizar somente o item lexical colocar. Já a informante F1-M-EM foi mais taxativa: 'A galinha bota os ovos, eu coloco as coisas, eu não boto'.

A entrada botar com a acepção de 'pôr, colocar' está lexicalizada pelos dicionaristas e remonta certa antiguidade em seu registro, segundo Cunha e Houaiss, a partir do século XIV. Este último dicionarista, quando traz a definição dessa unidade lexical, no sentido de 'pôr e colocar', documenta ser esta acepção de uso informal.

Dessa forma, o emprego deste item lexical, presente na fala da maioria dos informantes com a mesma acepção em estudo, apresenta tendência à manutencão.

\begin{tabular}{|c|c|}
\hline \multicolumn{2}{|c|}{ 19. BOTAR PINGOS / DOC.42, fól.1r, l.36-38/fól.1v, l.01-04 } \\
\hline $\begin{array}{l}\text { Acepção } \\
\text { buscada }\end{array}$ & Impedir que receba chuva densa. \\
\hline $\begin{array}{l}\text { Acepção(ões) } \\
\text { conhecida(s) } \\
\text { pelos } \\
\text { informantes }\end{array}$ & $\begin{array}{l}\text { F1-H-EP: NSR. } \\
\text { F1-M-EP: NSR. } \\
\text { F1-H-EF: A gente usa mais botar pingo nos is quando a gente quer, } \\
\text { conversar alguma coisa que não foi conversado, arrumar alguma coisa } \\
\text { que a pessoa falou e desconversou de novo. } \\
\text { F1-M-EF: NSR. } \\
\text { F1-H-EM: Só por os pingos nos is. } \\
\text { F1-M-EM: NSR. } \\
\text { F1-H-ES: NSR. } \\
\text { F1-M-ES: Botar pingos nos is. } \\
\text { F2-H-EP: NSR. } \\
\text { F2-M-EP: NSR. } \\
\text { F2-H-EF: Assinalar, botar pingo na gramática pra escrever, pontuar, } \\
\text { botar um pingo. } \\
\text { F2-M-EF: NSR. }\end{array}$ \\
\hline
\end{tabular}




\begin{tabular}{|c|c|}
\hline & $\begin{array}{l}\text { F2-H-EM: NSR. } \\
\text { F2-M-EM: Só conheço botar os pingos nos is. } \\
\text { F2-H-ES: Colocar as coisas no lugar certo, botar pingos nos is, que deve } \\
\text { ser botar pingos, já começam nos is né, fazer a coisa certa. } \\
\text { F2-M-ES: Botar os pingos nos is. }\end{array}$ \\
\hline $\begin{array}{l}\text { Acepções } \\
\text { registradas } \\
\text { nos } \\
\text { dicionários }\end{array}$ & $\begin{array}{l}\text { Bluteau (1712-1728): N.D. } \\
\text { Morais Silva (1813): N.D. } \\
\text { Cunha (1997): N.D. } \\
\text { Ferreira (2004): N.D. } \\
\text { Houaiss (2007): N.D. }\end{array}$ \\
\hline \multicolumn{2}{|c|}{$\begin{array}{l}\text { A expressão botar pingos foi registrada nos documentos manuscritos com o sentido de } \\
\text { 'impedir que receba chuva densa'. Analisando as respostas dadas pelos informantes, } \\
\text { parece ter ocorrido uma relação de sinonímia entre os termos devido à semelhança pela } \\
\text { aproximação dos itens lexicais 'botar pingos' com a expressão 'botar os pingos nos is'. } \\
\text { Esta é uma expressão popular corriqueira na linguagem dos brasileiros, portanto, não } \\
\text { peculiar somente ao grupo de falantes em Paranaguá. Apenas o informante F2-H-EF } \\
\text { associou a expressão botar pingos com o 'ato de assinalar na escrita os pingos em cima } \\
\text { dos is'. Quanto ao registro nos dicionários, a expressão botar pingos não é abonada por } \\
\text { nenhum dos lexicógrafos. } \\
\text { Analisando o contexto de uso por parte dos informantes, pressupõe que, pela falta de } \\
\text { registro tanto na modalidade oral como nos dicionários gerais, pode-se deduzir que a } \\
\text { expressão botar pingos com o sentido que se encontra nos documentos manuscritos } \\
\text { configura caso de desuso. }\end{array}$} \\
\hline
\end{tabular}

\begin{tabular}{|l|l|}
\hline \multicolumn{2}{|l|}{ 20. BROTAR / DOC.32, fól.1r, l.16-18 } \\
\hline $\begin{array}{l}\text { Acepção } \\
\text { buscada }\end{array}$ & Resultar, ter como consequência. \\
\hline $\begin{array}{l}\text { Acepção(ões) } \\
\text { conhecida(s) } \\
\text { pelos } \\
\text { informantes }\end{array}$ & $\begin{array}{l}\text { F1-H-EP: Quando a planta brota. } \\
\text { F1-H-EP: Brotar uma árvore. } \\
\text { F1-M-EF: Uma planta que bota. } \\
\text { F1-H-EM: Brotar uma flor, brotar um fruto. } \\
\text { F1-M-EM: Quando planta uma semente, ela vai brotar. } \\
\text { F1-H-ES: Planta que brota. } \\
\text { F1-M-ES: Brotar feijão, e no sentido de brotar um sentimento, brotar } \\
\text { alguma coisa em você, de brotar alguma esperança, a gente usa muito. }\end{array}$ \\
\end{tabular}




\begin{tabular}{|c|c|}
\hline & $\begin{array}{l}\text { F2-H-EP: Uma planta que vai brotar. } \\
\text { F2-M-EP: Brotar é quando uma árvore tá brotando, tá saindo os } \\
\text { galhinhos. } \\
\text { F2-H-EF: Brotar é crescer. } \\
\text { F2-M-EF: Brotar uma planta. } \\
\text { F2-H-EM: Sentido de planta, a árvore tá brotando. } \\
\text { F2-M-EM: Quando a flor tá brotando. } \\
\text { F2-H-ES: Deve ser no sentido de surgir, de aparecer, como de planta } \\
\text { brotar. } \\
\text { F2-M-ES: Quanto você faz uma plantação, ela vai brotar. }\end{array}$ \\
\hline $\begin{array}{l}\text { Acepções } \\
\text { registradas } \\
\text { nos } \\
\text { dicionários }\end{array}$ & $\begin{array}{l}\text { Bluteau (1712-1728): BROTAR. Diz-se da planta, quando começa a dar } \\
\text { folha, ou fruto. } \\
\text { Morais Silva (1813): BROTÁR, v. at. Lançar a arvore folha, flores, } \\
\text { fruto. } \\
\text { Cunha (1997): brotar vb. 'lançar, produzir (o vegetal) rebentos, ramos, } \\
\text { folhas, flores' XVI. } \\
\text { Ferreira (2004): brotar 5. Proceder, derivar, resultar. } \\
\text { Houaiss (2007): brotar datação } 15522.1 \text { Derivação: sentido figurado. } \\
\text { provir, originar-se. }\end{array}$ \\
\hline \multicolumn{2}{|c|}{$\begin{array}{l}\text { Em consulta aos dicionários na procura da acepção 'resultar, ter como consequência' } \\
\text { para a entrada brotar, somente Ferreira e Houaiss trazem definições próximas à acepção } \\
\text { buscada: 'derivar, resultar, provir, originar-se'. Já Bluteau, Morais Silva e Cunha } \\
\text { apresentam como traços semelhantes 'planta quando começa a dar folha'. Pelo contexto } \\
\text { de uso dos informantes parnanguaras, brotar é empregado com o mesmo sentido } \\
\text { registrado pelos dicionaristas Bluteau, Morais Silva e Cunha. Dos dezesseis informantes, } \\
\text { houve apenas um caso de variação de significado por parte da informante F1-M-ES que } \\
\text { além de conhecer brotar com o sentido da 'planta crescer', conhece também como: } \\
\text { 'brotar um sentimento, brotar alguma coisa em você, de brotar alguma esperança, a } \\
\text { gente usa muito'. Este segundo sentido empregado por essa informante decorre da } \\
\text { associação entre a característica da planta (nascer e crescer), com o sentimento de se } \\
\text { 'aflorar', portanto, seu emprego está no sentido figurado. } \\
\text { Dessa forma, como a lexia brotar com o sentido de 'resultar, ter como consequência', } \\
\text { não se encontra mais na linguagem dos informantes parnanguaras, supõe tratar-se de um } \\
\text { item lexical em desuso. }\end{array}$} \\
\hline
\end{tabular}

\section{CESSAR / DOC.32, fól.1v, l-18-20}

\begin{tabular}{|l|l|}
\hline $\begin{array}{l}\text { Acepção } \\
\text { buscada: }\end{array}$ & Acabar, parar. \\
\hline $\begin{array}{l}\text { Acepção(ões) } \\
\text { conhecida(s) }\end{array}$ & F1-H-EP: NSR. \\
\hline
\end{tabular}




\begin{tabular}{|c|c|}
\hline & $\begin{array}{l}\text { F1-M-EP: NSR. } \\
\text { F1-H-EF: De acesso, acessar alguma coisa na internet. } \\
\text { F1-M-EF: Cessar é parar. } \\
\text { F1-H-EM: NSR. } \\
\text { F1-M-EM: Cessar um site. } \\
\text { F1-H-ES: Parar. } \\
\text { F1-M-ES: NSR. } \\
\text { F2-H-EP: NSR. } \\
\text { F2-M-EP: NSR. } \\
\text { F2-H-EF: Parar. } \\
\text { F2-M-EF: Cessou a chuva, parou. } \\
\text { F2-H-EM: Cessou o sangramento, parou o sangramento. } \\
\text { F2-M-EM: NSR. } \\
\text { F2-H-ES: Cessar é como se fosse suspender, parar, cessar, cessa o } \\
\quad \text { processo, para o processo de andar. } \\
\text { F2-M-ES: Tem uma hora que você tem que cessar um pouco, dar uma } \\
\quad \text { acalmada, uma parada. }\end{array}$ \\
\hline $\begin{array}{l}\text { las } \\
\text { os }\end{array}$ & $\begin{array}{l}\text { Bluteau (1712-1728): CESSAR. Deixar c } \\
\text { Morais Silva (1813): CESSÁR, v. n. Para } \\
\text { Cunha (1997): cessar vb. 'interromper, a } \\
\text { Ferreira (2004): cessar } 1 \text {. Não continuar } \\
\text { Houaiss (2007): cessar datação } 13441 \mathrm{~d} \\
\quad \text { existir; parar. }\end{array}$ \\
\hline \multicolumn{2}{|c|}{$\begin{array}{l}\text { O item lexical cessar no sentido de 'acabar, parar' ainda é utilizado por alguns } \\
\text { informantes de Paranaguá. Analisando o contexto de uso desta lexia, constata-se que as } \\
\text { respostas dos cinco informantes da faixa II (F2-H-EF, F2-M-EF, F2-H-EM, F2-H-ES e } \\
\text { F2-M-ES) apresentam a mesma acepção buscada neste estudo. Já nas respostas dos } \\
\text { entrevistados da faixa I, os informantes F1-M-EF e F1-H-ES utilizam cessar no sentido de } \\
\text { 'parar'; enquanto outros dois informantes F1-H-EF e F1-M-EM associam a lexia cessar } \\
\text { com o parônimo acessar, cujo sentido é 'estabelecer uma conexão, comunicação on-line'. } \\
\text { Considerando a resposta da informante F1-M-EM, que emprega o termo cessar com o } \\
\text { sentido de 'acessar a internet', demonstra ser um caso de deslocação de sentido e de } \\
\text { alteração fonética conhecida como aférese, na qual ocorre a supressão do fonema no } \\
\text { início da palavra, fenômeno muito comum na língua portuguesa. } \\
\text { Fazendo uso da informação trazida pelos informantes, observa-se que do total de oito } \\
\text { informantes da faixa I, houve o reconhecimento da lexia cessar com o sentido de 'parar' } \\
\text { apenas por dois informantes. Os demais não souberam responder ou associaram a outro } \\
\text { item lexical. Na faixa II esta unidade lexical também apresentou baixa produtividade, } \\
\text { configurando assim um caso de tendência ao desuso. }\end{array}$} \\
\hline
\end{tabular}




\begin{tabular}{|c|c|}
\hline \multicolumn{2}{|c|}{ 22. COIBIR / DOC.46, fól.1v, l.08-10 } \\
\hline $\begin{array}{l}\text { Acepção } \\
\text { buscada }\end{array}$ & Reprimir, impedir, proibir. \\
\hline $\begin{array}{l}\text { Acepção(ões) } \\
\text { conhecida(s) } \\
\text { pelos } \\
\text { informantes }\end{array}$ & $\begin{array}{l}\text { F1-H-EP: Conheço só proibir. } \\
\text { F1-M-EP: NSR. } \\
\text { F1-H-EF: A gente usa mais pra coisas que a gente almeja: vou coibir } \\
\text { aquilo para ter aquele outro, mais para satisfazer. } \\
\text { F1-M-EF: NSR. } \\
\text { F1-H-EM: Impedir que alguém fala alguma coisa. } \\
\text { F1-M-EM: NSR. } \\
\text { F1-H-ES: NSR. } \\
\text { F1-M-ES: De inibir, reprimir. } \\
\text { F2-H-EP: NSR. } \\
\text { F2-M-EP: NSR. } \\
\text { F2-H-EF: Proibir, coibir. } \\
\text { F2-M-EF: Coibir é envergonhar. } \\
\text { F2-H-EM: Quando as pessoas fazem vandalismo, daí a polícia vai coibir } \\
\text { com aquele ato de vandalismo. } \\
\text { F2-M-EM: NSR. } \\
\text { F2-H-ES: Proibir, mas que num outro sentido coibir é mais pesado do } \\
\text { que o proibir, o coibir é mais censurado, você está coibido, você está } \\
\text { proibido, uma repressão, um proibir mais forte né. } \\
\text { F2-M-ES: NSR. }\end{array}$ \\
\hline $\begin{array}{l}\text { Acepções } \\
\text { registradas } \\
\text { nos } \\
\text { dicionários: }\end{array}$ & $\begin{array}{l}\text { Bluteau (1712-1728): COHIBIR. Vid. Reprimir. } \\
\text { Morais Silva (1813): COHIBÍR, v. at. Reprimir, refreyar fisicamente ou } \\
\quad \text { moralmente. } \\
\text { Cunha (1997): coibir } v b \text {. 'reprimir, refrear, impedir' | cohi- } 1813 \text {. } \\
\text { Ferreira (2004): coibir } 1 . \text { Obstar à continuação de; reprimir, refrear. } \\
\text { Houaiss (2007): coibir datação } 16611 \text { fazer cessar; impedir que } \\
\quad \text { continue; refrear, reprimir. }\end{array}$ \\
\hline \multicolumn{2}{|c|}{$\begin{array}{l}\text { O registro da entrada coibir nos dicionários analisados traz a mesma designação } \\
\text { documentada nos manuscritos pesquisados: 'reprimir, impedir, proibir'. Em análise do } \\
\text { contexto de uso pelos informantes parnanguaras, verifica-se que somente a metade } \\
\text { conhece a lexia em estudo. A acepção buscada encontra-se presente somente na fala de } \\
\text { seis entrevistados (F1-M-EP, F1-H-EM e F1-M-ES / F2-H-EF, F2-H-EM e F2-H-ES). } \\
\text { Porém, a informante F1-M-EP salienta que utiliza somente a forma lexical proibir. Para o } \\
\text { informante F2-H-ES, o item lexical coibir carrega um sentido mais pesado do que } \\
\text { simplesmente o de 'proibir: 'Proibir, mas que num outro sentido coibir é mais pesado do } \\
\text { que o proibir, o coibir é mais censurado, você está coibido, você está proibido, uma } \\
\text { repressão, um proibir mais forte'. Outros dois informantes utilizam a lexia coibir em }\end{array}$} \\
\hline
\end{tabular}


contextos diferentes: o informante F1-H-EF emprega coibir como sinônimo de satisfazer. Já a informante F2-M-EF diz ser coibir sinônimo de envergonhar

Nesta perspectiva, a unidade lexical coibir presente na fala de alguns informantes de Paranaguá, com o mesmo sentido empregado nos manuscritos, apresenta indícios de estágio de variação com a forma proibir, supondo, então, tratar-se de um caso com tendência à manutencão.

\begin{tabular}{|c|c|}
\hline \multicolumn{2}{|c|}{ 23. COMISERAR-SE / DOC.15, fól.1r, l.17-19 } \\
\hline $\begin{array}{l}\text { Acepção } \\
\text { buscada }\end{array}$ & Ter compaixão, ter piedade. \\
\hline $\begin{array}{l}\text { Acepção(ões) } \\
\text { conhecida(s) } \\
\text { pelos } \\
\text { informantes }\end{array}$ & $\begin{array}{l}\text { F1-H-EP: NSR. } \\
\text { F1-M-EP: Ter piedade duma criança, piedade de um animal. } \\
\text { F1-H-EF: NSR. } \\
\text { F1-M-EF: NSR. } \\
\text { F1-H-EM: NSR. } \\
\text { F1-M-EM: NSR. } \\
\text { F1-H-ES: NSR. } \\
\text { F1-M-ES: NSR. } \\
\text { F2-H-EP: NSR. } \\
\text { F2-M-EP: NSR. } \\
\text { F2-H-EF: A palavra comiserar eu não uso, uso mais compadecer. } \\
\text { F2-M-EF: NSR. } \\
\text { F2-H-EM: Conheço comiseração, que é ter compaixão. } \\
\text { F2-M-EM: NSR. } \\
\text { F2-H-ES: NSR. } \\
\text { F2-M-ES: NSR. }\end{array}$ \\
\hline $\begin{array}{l}\text { Acepções } \\
\text { registradas } \\
\text { nos } \\
\text { dicionários }\end{array}$ & $\begin{array}{l}\text { Bluteau (1712-1728): [COMMISERAÇAM. Piedade]. } \\
\text { Morais Silva (1813): COMMISERÁR-SE, v. recipr. Ter commiseração } \\
\text { de alguem. [COMMISERAÇÃO, s. f. Compaixão, piedade]. } \\
\text { Cunha (1997): miséria sf. 'estado lastimoso, indigência, penúria, } \\
\quad \text { avareza' XV | comiserar | commiserar } 1873 . \\
\text { Ferreira (2004): comiserar } 1 \text {. Inspirar compaixão, piedade, pena, dó. } \\
\text { Houaiss (2007): comiserar datação } 15762 \text { sentir comiseração, piedade; } \\
\quad \text { compadecer-se. }\end{array}$ \\
\hline \multicolumn{2}{|c|}{$\begin{array}{l}\text { Dos dezesseis entrevistados em Paranaguá, somente três informantes (F1-M-EP / F2- } \\
\text { H-EF e F2-H-EM) conhecem a lexia comiserar-se no sentido de 'ter compaixão, piedade'. } \\
\text { Além de esta forma lexical ter pouca ocorrência na fala dos parnanguaras, o informante } \\
\text { F2-H-EF admite não usar comiserar, emprega em seu lugar a forma lexical compadecer, }\end{array}$} \\
\hline
\end{tabular}


ambos com o mesmo significado. Outro informante (F2-H-EM) disse conhecer somente comiseração (única forma registrada por Bluteau), substituindo, assim, o emprego do verbo pela forma substantivada. Morais Silva, Ferreira e Houaiss registram a entrada comiserar(se) com a mesma acepção buscada. Interessante que Houaiss informa o ano de 1576 para a datação da unidade léxica comiserar, enquanto Cunha traz seu primeiro registro em 1873. O documento manuscrito no qual se encontra o registro desta lexia é datado em 1725, levando a crer que seu emprego já existia antes do século XIX.

Com base nas respostas dos informantes, o item lexical, mesmo com pouca produtividade na fala dos informantes de Paranaguá, principalmente da faixa I, ainda demonstra indícios de concorrer no atual estágio de variação com as variantes compadecer e comiseração. Presume-se, então, que a unidade lexical comiserar-se apresenta tendência ao desuso.

\begin{tabular}{|c|c|}
\hline \multicolumn{2}{|c|}{ 24. DELIBERAR / DOC.47, fól.2v, 1.09-12 } \\
\hline $\begin{array}{l}\text { Acepção } \\
\text { buscada }\end{array}$ & Determinar, resolver, decidir. \\
\hline $\begin{array}{l}\text { Acepção(ões) } \\
\text { conhecida(s) } \\
\text { pelos } \\
\text { informantes }\end{array}$ & $\begin{array}{l}\text { F1-H-EP: NSR. } \\
\text { F1-M-EP: NSR. } \\
\text { F1-H-EF: É uma coisa deliberada, vou liberar você pra alguma coisa. } \\
\text { F1-M-EF: É algo que você tem que liberar. } \\
\text { F1-H-EM: NSR. } \\
\text { F1-M-EM: NSR. } \\
\text { F1-H-ES: Delegar funções, determinar. } \\
\text { F1-M-ES: NSR. } \\
\text { F2-H-EP: NSR. } \\
\text { F2-M-EP: NSR. } \\
\text { F2-H-EF: Deliberar é discutir sobre vários assuntos, sobre isso e aquilo. } \\
\text { F2-M-EF: NSR. } \\
\text { F2-H-EM: NSR. } \\
\text { F2-M-EM: NSR. } \\
\text { F2-H-ES: É decidir. } \\
\text { F2-M-ES: Liberar algumas coisas assim: vou liberar você mais cedo do } \\
\text { serviço. }\end{array}$ \\
\hline $\begin{array}{l}\text { Acepções } \\
\text { registradas } \\
\text { nos } \\
\text { dicionários }\end{array}$ & $\begin{array}{l}\text { Bluteau (1712-1728): DELIBERAR. Determinar, resolver. } \\
\text { Morais Silva (1813): DELIBERÁR, v. n. §. Resolver, determinar com } \\
\text { deliberação, e sobrepensado. } \\
\text { Cunha (1997): deliberar } v b \text {. 'decidir, resolver após exame e discussão, } \\
\quad \text { premeditar' | XV. } \\
\text { Ferreira (2004): deliberar 3. Decidir, resolver. }\end{array}$ \\
\hline
\end{tabular}




\begin{tabular}{|l|l|}
\hline $\begin{array}{r}\text { Houaiss (2007): deliberar datação } 12601 \text { decidir(-se), após reflexão } \\
\text { e/ou consultas. }\end{array}$ \\
\hline As definições registradas pelos lexicógrafos referem-se à mesma acepção buscada para \\
o item lexical deliberar: 'determinar, resolver, decidir, discutir'. Analisando o contexto de \\
uso dessa lexia na fala dos entrevistados, verifica-se que é empregado com o mesmo \\
sentido documentado no corpus escrito, presente nas respostas de três informantes: F1-H- \\
ES: Delegar funções, determinar; F2-H-EF: Deliberar é discutir sobre vários assuntos; \\
F2-H-ES: É decidir. Outros três informantes (F1-H-EF e F1-M-EF / F2-M-ES) associaram \\
a lexia deliberar com outro item lexical, liberar, porém são unidades lexicais distintas e \\
significados também diferentes. \\
Pela baixa ocorrência da unidade lexical deliberar nas respostas dos entrevistados, e \\
principalmente no que se refere ao emprego da acepção buscada, presume-se que a forma \\
lexical deliberar apresenta tendência ao desuso.
\end{tabular}

\begin{tabular}{|l|l|}
\hline \multicolumn{2}{|l|}{ 25. DEMITIR / DOC.48, fól.2r, l.11-13 } \\
\hline $\begin{array}{l}\text { Acepção } \\
\text { buscada }\end{array}$ & Deixar, abandonar. \\
\hline $\begin{array}{l}\text { Acepção(ões) } \\
\text { conhecida(s) } \\
\text { pelos } \\
\text { informantes }\end{array}$ & $\begin{array}{l}\text { F1-H-EP: Quando você tá na firma e te demitem, manda você embora. } \\
\text { F1-H-EF: Você é demitido do trabalho. } \\
\text { F1-M-EF: É quando alguém é demitido, mandado embora. } \\
\text { F1-H-EM: Perder o emprego. } \\
\text { F1-M-EM: Mandar embora do serviço. } \\
\text { F1-H-ES: Demitir, é mandar embora. } \\
\text { F1-M-ES: Demitir de demissão do trabalho. } \\
\text { F2-H-EP: A pessoa fez um troço errado o pessoal demite. É mandado } \\
\text { embora. } \\
\text { F2-M-EP: Demitir é quando faço algo coisa errada, eu tenho de demitir } \\
\text { que tá errado. } \\
\text { F2-H-EF: É retirar a pessoa de um recinto, da empresa, do trabalho. } \\
\text { F2-M-EF: Foi demitido do emprego. } \\
\text { F2-H-EM: O chefe da empresa manda o funcionário embora, demite. } \\
\text { F2-M-EM: É quando demitem, manda a gente embora do serviço, do } \\
\text { emprego. } \\
\text { F2-H-ES: No processo trabalhista é mandar embora. } \\
\text { F2-M-ES: Demitir é quando manda embora. }\end{array}$ \\
\hline
\end{tabular}




\begin{tabular}{|c|c|}
\hline & $\begin{array}{l}\text { luteau (1712-1728): DEMITIR, ou Dimitir. Largar de si. Demitir } \\
\text { (Termo militar) Despedir. } \\
\text { orais Silva (1813): DEMITTÍR, v. at. } \S \text {. Despedir, licenciar. } \\
\text { unha (1997): demitir } v b \text {. 'destituir do cargo ou emprego, despedir, }\end{array}$ \\
\hline \multicolumn{2}{|c|}{$\begin{array}{l}\text { Nota-se, pelo contexto de uso da lexia demitir por parte dos entrevistados, ser bastante } \\
\text { produtiva em Paranaguá. Porém, as definições apresentadas pelos quinze informantes que } \\
\text { reconheceram a forma lexical demitir não é a mesma registrada nos documentos } \\
\text { manuscritos. Buscou-se a acepção para este item lexical no sentido de 'deixar, abandonar'. } \\
\text { Este significado não foi registrado em nenhum contexto de fala. A definição empregada } \\
\text { pelos informantes foi unânime: demitir no sentido de 'mandar embora do emprego', 'ser } \\
\text { demitido do trabalho'. Da acepção buscada, somente Ferreira e Houaiss registraram as } \\
\text { definições: 'largar, deixar, depor, pôr de lado'. Bluteau, Morais Silva e Cunha trazem o } \\
\text { mesmo sentido empregado pelos informantes. } \\
\text { Analisando o contexto de uso da unidade lexical demitir e comparando com a acepção } \\
\text { em estudo, constata-se que sua ocorrência não foi registrada na fala de nenhum dos } \\
\text { entrevistados. Supõe-se que o conceito encontrado nos documentos manuscritos tenha } \\
\text { perdido forças com as demais acepções que hoje definem a lexia demitir. } \\
\text { Portanto, os informantes reconhecem o item lexical demitir, mas o sentido de 'deixar, } \\
\text { abandonar' provavelmente foi substituído por outra lexia distinta, configurando, assim, } \\
\text { caso de desuso. }\end{array}$} \\
\hline
\end{tabular}

\begin{tabular}{|l|l|}
\hline \multicolumn{2}{|l|}{ 26. DEPOR / DOC.31, fól.1 r, l.05-08 } \\
\hline $\begin{array}{l}\text { Acepção } \\
\text { buscada }\end{array}$ & Destituir de função, demitir. \\
\hline $\begin{array}{l}\text { Acepção(ões) } \\
\text { conhecida(s) } \\
\text { pelos } \\
\text { informantes }\end{array}$ & $\begin{array}{l}\text { F1-H-EP: Quando a gente vai depor contra uma pessoa. } \\
\text { F1-H-EP: Depor contra uma pessoa. } \\
\text { F1-M-EF: Quando vai dar depoimento de alguma coisa. } \\
\text { F1-H-EM: No sentido de convocado. } \\
\text { F1-M-EM: Depor no tribunal, num julgamento. } \\
\text { F1-H-ES: Depor de mandar embora. } \\
\text { F1-M-ES: Depor contra ou a favor, na justiça. }\end{array}$ \\
& $\begin{array}{l}\text { F2-H-EP: A gente ouve a palavra depor, se tiver um troço de um } \\
\text { julgamento, o cara tem que ir lá depor. }\end{array}$ \\
& $\begin{array}{l}\text { F2-M-EP: Depor numa causa, numa justiça, isso daí é depor. } \\
\text { F2-H-EF: Depor seria você fazer um depoimento, relatar um caso e tal }\end{array}$ \\
\hline
\end{tabular}




\begin{tabular}{|c|c|}
\hline & $\begin{array}{l}\text { que aconteceu, daí você depõe a favor ou contra. } \\
\text { F2-M-EF: Depor num processo, você tem que depor na frente do juiz e } \\
\text { de um advogado. } \\
\text { F2-H-EM: Depor é usado em audiência, num julgamento, você vai depor } \\
\text { contra fulano de tal. } \\
\text { F2-M-EM: Quando tem julgamento, alguma coisa quando a gente é } \\
\text { chamado ao fórum, na delegacia. } \\
\text { F2-H-ES: Depor tem a questão do depoente que a pessoa vai depor ou } \\
\text { vai falar, e também tem o sentido de depor contra né, falar mal } \\
\text { daquilo, daquela pessoa. } \\
\text { F2-M-ES: Depor pra mim é quando você é chamada para uma audiência, } \\
\text { depor alguma coisa. }\end{array}$ \\
\hline $\begin{array}{l}\text { Acepções } \\
\text { registradas } \\
\text { nos } \\
\text { dicionários }\end{array}$ & $\begin{array}{l}\text { Bluteau (1712-1728): DEPOR alguem de hum officio, de huma } \\
\text { dignidade. Depor a alguem, \& privalo do seu officio. } \\
\text { Morais Silva (1813): DEPÓR, v. at. Pòr de parte, deixar, apartar de si } \\
\text { alguma coisa. §. Depòr algum Rei, Soberano; despojá-lo do governo, } \\
\text { e da soberania. } \\
\text { Cunha (1997): depor } v b . \text { 'pôr de lado, despojar de cargo' | despoer } \\
\text { XIV. } \\
\text { Ferreira (2004): depor } 2 . \text { Despojar de cargo ou dignidade; destituir. } \\
\text { Houaiss (2007): depor datação sXIV } 2 \text { destituir de cargo, poder ou } \\
\text { dignidade; exonerar. }\end{array}$ \\
\hline \multicolumn{2}{|c|}{$\begin{array}{l}\text { Observando o contexto de uso da lexia depor, todos os informantes a conhecem com o } \\
\text { mesmo sentido de 'depor em audiência, em julgamento'; salvo o informante F1-H-ES que } \\
\text { empregou depor somente no sentido de 'mandar embora', portanto, este significado é o } \\
\text { mesmo da acepção registrada nos documentos manuscritos. Todos os lexicógrafos } \\
\text { pesquisados também registram a entrada depor com o sentido de 'destituir de função e } \\
\text { demitir'. Quanto ao lema depor, Houaiss registra várias designações. Na décima primeira } \\
\text { acepção 'declarar ou testemunhar em âmbito jurídico', classifica como termo jurídico. } \\
\text { Este fato é interessante, pois, das acepções registradas nos dicionários para a unidade } \\
\text { léxica depor, a maioria dos informantes, neste contexto de fala, utiliza somente a acepção } \\
\text { pertencente ao campo jurídico. } \\
\text { Analisando o contexto de uso do item lexical depor com a acepção buscada, sua } \\
\text { ocorrência foi verificada apenas na fala de um informante da faixa I. produtividade, se } \\
\text { comparada com as respostas dos outros quinze informantes. } \\
\text { Considerando os dados em análise, infere-se que tal unidade léxica apresenta } \\
\text { tendência ao desuso. }\end{array}$} \\
\hline
\end{tabular}




\begin{tabular}{|c|c|}
\hline \multicolumn{2}{|c|}{ 27. DESPEJAR / DOC.03, fól.1v, l.04-10 } \\
\hline $\begin{array}{l}\text { Acepção } \\
\text { buscada }\end{array}$ & Desocupar, evacuar. \\
\hline $\begin{array}{l}\text { Acepção(ões) } \\
\text { conhecida(s) } \\
\text { pelos } \\
\text { informantes }\end{array}$ & $\begin{array}{l}\text { F1-H-EP: Despejar é quando tá sendo despejado de casa. } \\
\text { F1-M-EP: Despejar água, comida fora. } \\
\text { F1-H-EF: Despejar determinado inquilino que tá no imóvel e ele não } \\
\text { pagou, daí ele tá sendo despejado por falta de pagamento de aluguel. } \\
\text { F1-M-EF: NSR. } \\
\text { F1-H-EM: Você jogar alguma coisa, e também uma pessoa tá sendo } \\
\text { despejada da casa. } \\
\text { F1-M-EM: Quando você não paga aluguel, a pessoa é despejada. } \\
\text { F1-H-ES: Despejar: tô despejando terra na caçamba. } \\
\text { F1-M-ES: Ser desalojado, ficar sem abrigo, ter que mudar de lugar. } \\
\text { F2-H-EP: Já ouvi a palavra despejar quando a pessoa tá numa casa, daí o } \\
\text { pessoal da casa vai despejar essa família, pra desocupar a casa. } \\
\text { F2-M-EP: NSR. } \\
\text { F2-H-EF: Despejar, desalocar, tirar a pessoa que não paga o imóvel, ou } \\
\text { qualquer lugar assim, que tem que sair dali, então ele é despejado. A } \\
\text { pessoa foi despejada da casa. } \\
\text { F2-M-EF: Alguém que não pagou o aluguel e foi despejado. } \\
\text { F2-H-EM: Despejar água da chaleira. } \\
\text { F2-M-EM: Quando o inquilino tem que sair da casa é despejado. } \\
\text { F2-H-ES: Despejar no sentido é você colocar alguma coisa no local: vou } \\
\text { despejar aqui a areia. } \\
\text { F2-M-ES: Despejar pra mim é quando a gente vai despejar tudo o que } \\
\text { está pensando, quando tá brigando. }\end{array}$ \\
\hline $\begin{array}{l}\text { Acepções } \\
\text { registradas } \\
\text { nos } \\
\text { dicionários }\end{array}$ & $\begin{array}{l}\text { Bluteau (1712-1728): DESPEJAR. Sahir de huma casa, ou de algum } \\
\text { outro lugar. Fazer despejar. Quando fazia despejar os hospedes por } \\
\text { força. } \\
\text { Morais Silva (1813): DESPEJÁR, v. at. §. Despejar a gente; fazè-la } \\
\quad \text { sair. } \\
\text { Cunha (1997): pejar } v b \text {. 'encher, impedir, embaraçar' XV. Despejar } \\
\quad 1500 . \\
\text { Ferreira (2004): despejar } 2 \text {. Desocupar; evacuar. } \\
\text { Houaiss (2007): despejar datação } 15003 \text { deixar de ocupar; desocupar, } \\
\quad \text { evacuar. }\end{array}$ \\
\hline $\begin{array}{l}\text { Analisando } \\
\text { informantes (I } \\
\text { quatorze, nove } \\
\text { EP, F2-H-EF, }\end{array}$ & $\begin{array}{l}\text { contexto de fala dos entrevistados de Paranaguá, somente dois } \\
\text { M-EF / F2-H-EP) disseram não conhecer a lexia despejar. Dos outro } \\
\text { ormantes (F1-H-EP, F1-H-EF, F1-H-EM, F1-M-EM e F1-M-ES / F2-H- } \\
\text {-M-EF e F2-M-EM) empregam o item lexical com o mesmo sentido da }\end{array}$ \\
\hline
\end{tabular}


acepção buscada: 'desocupar, evacuar'. Quanto à resposta do informante F1-H-EM, além de conhecer o sentido de 'desocupar, evacuar', emprega também a forma lexical despejar no sentido de 'jogar alguma coisa fora'. Este outro significado para a lexia despejar é utilizado também por mais quatro informantes (F1-M-EP e F1-H-ES / F2-H-EM e F2-HES). Apenas a informante F2-M-ES utilizou a unidade lexical despejar no sentido figurado: 'despejar o que tá pensando, quando tá brigando'.

Os lexicógrafos registram a entrada despejar com a mesma acepção documentada nos manuscritos. A acepção 'esvaziar, vazar um conteúdo', Houaiss a classifica como derivação: sentido figurado.

Portanto, comparando o contexto de uso da lexia despejar com a acepção investigada 'desocupar, evacuar', verifica-se que esta unidade lexical foi empregada pela maioria dos entrevistados, apontando tendência à manutencão.

\begin{tabular}{|c|c|}
\hline \multicolumn{2}{|c|}{ 28. EMBARAÇAR / DOC.37, fól.1r, l.26-30 } \\
\hline $\begin{array}{l}\text { Acepção } \\
\text { buscada }\end{array}$ & Atrapalhar, estorvar. \\
\hline $\begin{array}{l}\text { Acepção(ões) } \\
\text { conhecida(s) } \\
\text { pelos } \\
\text { informantes }\end{array}$ & $\begin{array}{l}\text { F1-H-EP: NSR. } \\
\text { F1-M-EP: Cabelo embaraçado a gente vai desembaraçar. } \\
\text { F1-H-EF: Conheço só cabelo embaraçado. } \\
\text { F1-M-EF: NSR. } \\
\text { F1-H-EM: Se a pessoa se atrapalhar, fala que a pessoa se embaraçou. } \\
\text { F1-M-EM: Uma situação embaraçosa, que te encabula. } \\
\text { F1-H-ES: Ficar envergonhado. } \\
\text { F1-M-ES: Embaraçar no sentido de ficar confuso, atrapalhado. } \\
\text { F2-H-EP: A pessoa não consegue fazer as coisas. } \\
\text { F2-M-EP: Embaraçar quando vou fazer algo e não dá certo, aí eu falo } \\
\text { que tô muito embaraçada. } \\
\text { F2-H-EF: É você atrapalhar uma pessoa, um negócio, você embaraça, } \\
\text { atrapalha, ou um negócio que tá muito difícil de resolver, tá } \\
\text { embaraçado. } \\
\text { F2-M-EF: Numa situação embaraçosa a pessoa fica chateada. } \\
\text { F2-H-EM: Quando você se embaraçou nalguma coisa, se atrapalhou, não } \\
\text { consegue fazer, então se embaraçou. } \\
\text { F2-M-EM: NSR. } \\
\text { F2-H-ES: Embaraçar, dificultar. O sentido é esse, o processo pode estar } \\
\text { embaraçado, a vida da pessoa pode estar embaraçada. } \\
\text { F2-M-ES: Quando você vai falar alguma coisa que você distorce tudo, se } \\
\text { enrola, fica tudo atrapalhado. }\end{array}$ \\
\hline $\begin{array}{l}\text { Acepções } \\
\text { registradas }\end{array}$ & $\begin{array}{l}\text { Bluteau (1712-1728): EMBARAÇAR alguem. Causarlhe embaraços } \\
\text { com algum negocio. }\end{array}$ \\
\hline
\end{tabular}




\begin{tabular}{|c|c|}
\hline $\begin{array}{l}\text { nos } \\
\text { dicionários }\end{array}$ & $\begin{array}{l}\text { Morais Silva (1813): EMBARAÇÁR, v. at. Causar embaraço. } \\
\text { [EMBARÁÇO, s. m. §. fig. Impedimento, obstáculo, dificuldade, que } \\
\text { estorva]. } \\
\text { Cunha (1997): baraço sm. | Embaraçar vb. 'impedir, estorvar' | XV, - } \\
\text { razar XVI. } \\
\text { Ferreira (2004): embaraçar } 1 \text {. Pôr embaraço(s) ou impedimento(s) a; } \\
\text { impedir, estorvar, tolher. } \\
\text { Houaiss (2007): embaraçar datação sXV } 1 \text { criar ou sentir embaraço; } \\
\text { complicar (-se); atrapalhar(-se). }\end{array}$ \\
\hline $\begin{array}{l}\text { Os dicio } \\
\text { embaraço', } \\
\text { Analisando } \\
\text { constata-se } \\
\text { seis da faix } \\
\text { lexia embar } \\
\text { informantes } \\
\text { outros quat } \\
\text { acepções d } \\
\text { Quanto ao } \\
\text { 'Emaranhar } \\
\text { acepção: ' } \\
\text { somente er } \\
\text { significado } \\
\text { significado } \\
\text { figurado qu } \\
\text { Ferreira reg } \\
\text { Analisan } \\
\text { informantes } \\
\text { outro lado, } \\
\text { 'atrapalhar, }\end{array}$ & $\begin{array}{l}\text { pesquisados registram a entrada embaraçar com o significado: 'causar } \\
\text { culo', 'dificuldade', 'estorvar', 'impedir', 'complicar', 'atrapalhar'. } \\
\text { exto de uso da lexia embaraçar pelos entrevistados de Paranaguá, } \\
\text { ve dos informantes (três da faixa I: F1-H-EM, F1-M-EM e F1-M-ES / } \\
\text {-H-EP, F2-M-EP, F2-H-EF, F2-H-EM, F2-H-ES e F2-M-ES) utilizam a } \\
\text { om o mesmo sentido da acepção buscada: 'atrapalhar, estorvar'. Três } \\
\text {-EP e F1-M-EF / F2-M-EM) disseram não conhecer o item lexical, e } \\
\text { M-EP, F1-H-EF e F1-H-ES / F2-M-EF) conheceram embaraçar com } \\
\text { s: 'cabelo embaraçado', 'ficar envergonhado' e 'pessoa chateada'. } \\
\text { ado 'cabelo embaraçado' Ferreira traz na quinta acepção a definição: } \\
\text { lear (fio[s] de lã, cabelo, etc.)'. Cunha, por sua vez, registra na terceira } \\
\text { (-se) desordenadamente', mas a referência ao traço 'cabelo' aparece } \\
\text { abonação: 'com o vento, seu cabelo embaraçou-se'. O segundo } \\
\text { nvergonhado', apenas Ferreira o classifica como sentido figurado. O } \\
\text { a chateada' foi empregado pela informante F2-M-EF no sentido } \\
\text { e referia a uma 'situação embaraçosa'. Quanto a este sentido figurado, } \\
\text { sexta acepção: 'Causar embaraço, constrangimento; constranger'. } \\
\text { ontexto de fala da lexia embaraçar, verifica-se que a maioria dos } \\
\text { ka II ainda a empregam com o sentido da acepção em estudo, mas, por } \\
\text { ormantes da faixa I, somente três a reconhecem com o significado de } \\
\text { ar', ocorrendo assim, estágio de variação entre outras designações. } \\
\text { ser um caso de tendência ao desuso. }\end{array}$ \\
\hline
\end{tabular}

29. EMPREGAR-SE / DOC.17, fól.1r, l.06-09

\begin{tabular}{|l|l|}
\hline $\begin{array}{l}\text { Acepção } \\
\text { buscada }\end{array}$ & Servir a alguém, dedicar-se. \\
\hline $\begin{array}{l}\text { Acepção(ões) } \\
\text { conhecida(s) } \\
\text { pelos }\end{array}$ & $\begin{array}{l}\text { F1-H-EP: Quando a gente consegue um emprego, daí se emprega. } \\
\text { informantes }\end{array}$ \\
$\begin{array}{l}\text { F1-H-EF: Vou empregar você em determinada função. } \\
\text { F1-M-EF: Quando alguém arranja um emprego. }\end{array}$ \\
F1-H-EM: É quando uma pessoa conseguiu um emprego.
\end{tabular}




\begin{tabular}{|c|c|}
\hline & $\begin{array}{l}\text { F1-M-EM: Conseguir um emprego, empregar-se. } \\
\text { F1-H-ES: Empregar a crase. } \\
\text { F1-M-ES: Empregar é no sentido de trabalho, emprego, arranjar um } \\
\text { emprego. } \\
\text { F2-H-EP: A pessoa vai arranjar um emprego. } \\
\text { F2-M-EP: É quando a gente vai arranjar um emprego e tá empregada. } \\
\text { F2-H-EF: Empregar seria usar alguma coisa pra fazer ou empregar-se no } \\
\text { sentido de trabalho também. } \\
\text { F2-M-EF: É admitir um funcionário, empregar ele. } \\
\text { F2-H-EM: Quando alguém consegue um emprego, se empregou. } \\
\text { F2-M-EM: Arranjar um emprego, empregar-se. } \\
\text { F2-H-ES: Utilizar. } \\
\text { F2-M-ES: Quando você vai pedir um emprego. }\end{array}$ \\
\hline $\begin{array}{l}\text { Acepções } \\
\text { registradas } \\
\text { nos } \\
\text { dicionários }\end{array}$ & $\begin{array}{l}\text { Bluteau (1712-1728): EMPREGAR o tempo em alguma cousa. Entendi, } \\
\text { que eu havia de empregar todo o meu tempo em servir os meus } \\
\text { amigos nas occasioens, que se offerecião. } \\
\text { Morais Silva (1813): EMPREGÁR, v. at. §. Empregar algum officio, ou } \\
\text { dignidade em alguem. §. Empregar-se: ocupar-se. } \\
\text { Cunha (1997): empregar vb. 'aplicar, ocupar, dar ocupação } \\
\text { remunerada' | XIII. } \\
\text { Ferreira (2004): empregar 1. Dar emprego, uso ou aplicação a. } \\
\text { Houaiss (2007): empregar datação sXIII } 1 \text { fazer uso de; utilizar, } \\
\text { aplicar. }\end{array}$ \\
\hline \multicolumn{2}{|c|}{$\begin{array}{l}\text { Da acepção buscada 'servir a alguém, dedicar-se' para a lexia empregar-se, nenhum } \\
\text { dos entrevistados a empregou com este sentido. Dos lexicógrafos pesquisados, apenas } \\
\text { Bluteau registrou a entrada empregar com o mesmo sentido registrado nos documentos } \\
\text { manuscritos: 'empregar o meu tempo em servir os meus amigos'. Os demais registraram } \\
\text { as acepções semelhantes às dos informantes. Analisando o contexto de utilização deste } \\
\text { item lexical, constata-se ser bastante produtivo na fala dos entrevistados, haja vista que } \\
\text { somente a informante F1-M-EP disse não conhecer essa lexia. As definições de maior } \\
\text { ocorrência proferidas pelos informantes referem-se a: 'conseguir emprego', 'arranjar } \\
\text { emprego', 'ser empregado', 'admitir um funcionário'. As outras ocorrências, de baixa } \\
\text { produtividade, foram no sentido de: 'empregar a crase' (F1-H-ES), 'utilizar' (F2-M-ES) e } \\
\text { 'pedir um emprego' (F2-M-ES). } \\
\text { Portanto, analisando o contexto de uso da lexia empregar-se, constatou que seu registro } \\
\text { oral denomina outros significados (referentes ao mesmo item lexical), menos a acepção } \\
\text { aqui buscada. Dessa forma, conjectura ser um caso de desuso da unidade lexical } \\
\text { empregar-se com o sentido registrado no corpus escrito. }\end{array}$} \\
\hline
\end{tabular}




\begin{tabular}{|c|c|}
\hline \multicolumn{2}{|c|}{ 30. ENJEITAR / DOC.11, fól.1r, l.10-14 } \\
\hline $\begin{array}{l}\text { Acepção } \\
\text { buscada }\end{array}$ & Rejeitar, recusar, não aceitar. \\
\hline $\begin{array}{l}\text { Acepção(ões) } \\
\text { conhecida(s) } \\
\text { pelos } \\
\text { informantes }\end{array}$ & $\begin{array}{l}\text { F1-H-EP: NSR. } \\
\text { F1-M-EP: Enjeitar é ajeitar as coisas. } \\
\text { F1-H-EF: Quando a pessoa se ajeita na vida, vai se ajeitar. } \\
\text { F1-M-EF: Quando você é enjeitado por alguém, quando você enjeita } \\
\text { alguém, eu faço de conta que essa pessoa não existe pra mim. } \\
\text { F1-H-EM: Tá se adaptando, tá se arrumando, ou tá recusando. } \\
\text { F1-M-EM: NSR. } \\
\text { F1-H-ES: NSR. } \\
\text { F1-M-ES: NSR. } \\
\text { F2-H-EP: Rejeitar. } \\
\text { F2-M-EP: É quando a gente enjeita alguma coisa, quando não aceita. } \\
\text { F2-H-EF: Seria você negar, não aceitar, uma pessoa que oferece uma } \\
\text { coisa você enjeita, não quer. } \\
\text { F2-M-EF: Enjeitar é não aceitar uma pessoa. } \\
\text { F2-H-EM: NSR. } \\
\text { F2-M-EM: No sentido que não vai com a cara daquela pessoa, daí } \\
\text { enjeita, evita, fica longe. } \\
\text { F2-H-ES: Enjeitar é rejeitar, a criança foi enjeitada, a família enjeitou, } \\
\text { quer dizer recusou. } \\
\text { F2-M-ES: É quando você não gosta de alguém, enjeita, deixa de lado, } \\
\text { não aceita. }\end{array}$ \\
\hline $\begin{array}{l}\text { Acepções } \\
\text { registradas } \\
\text { nos } \\
\text { dicionários }\end{array}$ & $\begin{array}{l}\text { Bluteau (1712-1728): ENGEITAR. He não admittir o oferecido, \& } \\
\text { particularmente com algum desdém, \& desprezo. } \\
\text { Morais Silva (1813): ENGEITÁR, v. at. Não aceitar o que se ofereceu, } \\
\text { ou deu. §. Rejeitar o juiz; recusar. } \\
\text { Cunha (1997): enjeitar vb. 'recusar, rechaçar' eniectar XIII, enyectar } \\
\text { XIII, engeitar XIV. } \\
\text { Ferreira (2004): enjeitar 1. Não aceitar; recusar; rejeitar. } \\
\text { Houaiss (2007): enjeitar datação sXIII } 1 \text { não querer; rejeitar, recusar } \\
\quad \text { (alguém, algo ou a si mesmo). }\end{array}$ \\
\hline \multicolumn{2}{|c|}{$\begin{array}{l}\text { Os dicionaristas registram a entrada enjeitar com a mesma acepção utilizada pelos } \\
\text { informantes de Paranaguá: 'rejeitar, recusar, não aceitar'. Dos dezesseis entrevistados, } \\
\text { nove informantes (dois da faixa I: F1-M-EF e F1-H-EM /sete da faixa II: F2-H-EP, F2-M- } \\
\text { EP, F2-H-EF, F2-M-EF, F2-M-EM, F2-H-ES e F2-M-ES) empregaram a lexia enjeitar } \\
\text { com o mesmo sentido documentado no corpus escrito; cinco (F1-H-EP, F1-M-EF, F1-H- } \\
\text { ES e F1-M-ES / F2-H-EM) desconhecem o item lexical enjeitar, e dois informantes (F1- } \\
\text { M-EP e F1-H-EF) conhecem apenas o seu parônimo ajeitar, item lexical de significado }\end{array}$} \\
\hline
\end{tabular}


diferente. Já o informante F1-H-EM disse que enjeitar pode significar em contextos diferentes tanto 'se adaptar' e 'se arrumar', como 'recusar'. Observa-se que este informante, pela proximidade das formas lexicais enjeitar/ajeitar, faz confusão ao denominar as unidades léxicas parônimas.

Analisando o contexto de uso da lexia enjeitar e comparando com a acepção buscada, constata-se que seu emprego ainda está presente na fala da maioria dos informantes da faixa II, enquanto que dos informantes da faixa I, apenas do is ainda reconheceram enjeitar, com o mesmo sentido de 'rejeitar, recusar, não aceitar'. Portanto, supõe-se que a lexia em estudo apresenta tendência ao desuso.

\begin{tabular}{|c|c|}
\hline \multicolumn{2}{|c|}{ 31. ERIGIR / DOC.46, fól.1r, l.26-28 } \\
\hline $\begin{array}{l}\text { Acepção } \\
\text { buscada }\end{array}$ & Fundar, elevar, constituir. \\
\hline $\begin{array}{l}\text { Acepção(ões) } \\
\text { conhecida(s) } \\
\text { pelos } \\
\text { informantes }\end{array}$ & $\begin{array}{l}\text { F1-H-EP: NSR. } \\
\text { F1-M-EP: NSR. } \\
\text { F1-H-EF: NSR. } \\
\text { F1-M-EF: NSR. } \\
\text { F1-H-EM: NSR. } \\
\text { F1-M-EM: NSR. } \\
\text { F1-H-ES: NSR. } \\
\text { F1-M-ES: NSR. } \\
\text { F2-H-EP: NSR. } \\
\text { F2-M-EP: NSR. } \\
\text { F2-H-EF: Se erguer no caso. } \\
\text { F2-M-EF: NSR. } \\
\text { F2-H-EM: Erigir é o mesmo que levantar, subir. } \\
\text { F2-M-EM: NSR. } \\
\text { F2-H-ES: Quer dizer construir, erigir, montar, constituir. } \\
\text { F2-M-ES: NSR. }\end{array}$ \\
\hline $\begin{array}{l}\text { Acepções } \\
\text { registradas } \\
\text { nos } \\
\text { dicionários }\end{array}$ & $\begin{array}{l}\text { Bluteau (1712-1728): ERIGIR. Levantar. Erigir huma provincia em } \\
\quad \text { Reino. } \\
\text { Morais Silva (1813): ERIGIR, v. at. Levantar. §. Elevar. } \\
\text { Cunha (1997): erguer vb. 'levantar, elevar, alçar' | erigir XVI (1500). } \\
\text { Ferreira (2004): erigir 3. Fundar, constituir, instituir, criar. } \\
\text { Houaiss (2007): erigir datação } 16504 \text { criar, fundar, instituir. }\end{array}$ \\
\hline $\begin{array}{l}\text { A unidade } \\
\text { entrevistados. }\end{array}$ & $\begin{array}{l}\text { xical erigir foi documentada com baixa frequência na fala dos } \\
\text { mente três informantes (F2-H-EF, F2-H-EM e F2-H-ES) disseram } \\
\text { ia. Quanto à acepção buscada 'fundar, elevar, constituir', apenas um }\end{array}$ \\
\hline
\end{tabular}


informante ainda a utiliza em seu contexto de fala: F2-H-ES: 'Quer dizer construir, erigir, montar, constituir'. Os outros dois informantes (F2-H-EF e F2-H-EM) empregam definições com significados próximos da acepção em estudo: 'erguer', 'levantar', 'subir'. Esta afirmativa é corroborada nas designações registradas pelos lexicógrafos para a entrada erigir: 'levantar', 'elevar', 'fundar', 'constituir', 'criar', 'instituir'. A semelhança entre essas definições está muito próxima aos traços semânticos [+ elevar, fundar, constituir, elevar].

Presume-se, dessa forma, que erigir é um item lexical desconhecido pela maioria dos entrevistados, principalmente pelos informantes da faixa I, que não apresentou nenhuma ocorrência. Supõe-se, pelos dados analisados, que sua utilização na modalidade oral apresenta tendência ao desuso

\begin{tabular}{|c|c|}
\hline \multicolumn{2}{|c|}{ 32. ESCUSAR / DOC.33, fól.1v, l.10-13 } \\
\hline $\begin{array}{l}\text { Acepção } \\
\text { buscada }\end{array}$ & Recusar, dispensar. \\
\hline $\begin{array}{l}\text { Acepção(ões) } \\
\text { conhecida(s) } \\
\text { pelos } \\
\text { informantes }\end{array}$ & $\begin{array}{l}\text { F1-H-EP: NSR. } \\
\text { F1-M-EP: NSR. } \\
\text { F1-H-EF: NSR. } \\
\text { F1-M-EF: Recusar. } \\
\text { F1-H-EM: NSR. } \\
\text { F1-M-EM: NSR. } \\
\text { F1-H-ES: NSR. } \\
\text { F1-M-ES: NSR. } \\
\text { F2-H-EP: No sentido de recusar. } \\
\text { F2-M-EP: NSR. } \\
\text { F2-H-EF: Se desviar de tal, não aceitar. } \\
\text { F2-M-EF: É não aceitar. } \\
\text { F2-H-EM: NSR. } \\
\text { F2-M-EM: NSR. } \\
\text { F2-H-ES: Pedir desculpas. } \\
\text { F2-M-ES: NSR. }\end{array}$ \\
\hline $\begin{array}{l}\text { Acepções } \\
\text { registradas } \\
\text { nos } \\
\text { dicionários }\end{array}$ & $\begin{array}{l}\text { Bluteau (1712-1728): ESCUSAR alguma cousa. Naõ necessitar muito } \\
\text { della. } \\
\text { Morais Silva (1813): ESCUSÁR, v. at. Escusar alguma coisa; não } \\
\quad \text { necessitar della. §. Não se servir della. §. Dispensar. } \\
\text { Cunha (1997): escusar } v b \text {. 'desculpar, perdoar, tolerar' XIII. } \\
\text { Ferreira (2004): escusar } 11 . \text { Negar-se, recusar-se. } \\
\text { Houaiss (2007): escusar datação sXIII } 9 \text { recusar-se, negar-se. }\end{array}$ \\
\hline
\end{tabular}


Os dicionaristas (com exceção de Cunha) registram o lema escusar com a mesma acepção buscada 'não necessitar', 'dispensar', 'negar', 'recusar'. Dos dezesseis entrevistados, somente quatro informantes (F1-M-EF / F2-H-EP, F2-H-EF e F2-M-EF) utilizam a lexia escusar com o mesmo sentido registrado nos documentos manuscritos. Nota-se que o informante F2-H-ES empregou a lexia escusar com o significado de 'pedir desculpas', a mesma definição registrada por Cunha. No que se refere à etimologia de escusar, Cunha informa ter procedência do latim excūsāre, registrando-a no séc. XIII.

Embora este item lexical, ainda esteja presente na fala de alguns informantes de Paranaguá, constata-se que seu uso é pouco produtivo, pois, dos onze informantes que desconhecem a unidade lexical escusar, sete são da faixa I, e apenas três entrevistados da faixa II a empregaram com o mesmo sentido da acepção em estudo. Com base nestes dados, a lexia escusar aponta tendência ao desuso.

\begin{tabular}{|c|c|}
\hline \multicolumn{2}{|c|}{ 33. EXPENDER / DOC.46, fól.1v, l.18-20 } \\
\hline $\begin{array}{l}\text { Acepção } \\
\text { buscada }\end{array}$ & Ter despesas, ter gastos. \\
\hline $\begin{array}{l}\text { Acepção(ões) } \\
\text { conhecida(s) } \\
\text { pelos } \\
\text { informantes }\end{array}$ & $\begin{array}{l}\text { F1-H-EP: NSR. } \\
\text { F1-M-EP: NSR. } \\
\text { F1-H-EF: Expender é expandir alguma coisa, deixar pra determinada } \\
\quad \text { ocasião, prolongar. } \\
\text { F1-M-EF: NSR. } \\
\text { F1-H-EM: NSR. } \\
\text { F1-M-EM: NSR. } \\
\text { F1-H-ES: NSR. } \\
\text { F1-M-ES: NSR. } \\
\text { F2-H-EP: NSR. } \\
\text { F2-M-EP: NSR. } \\
\text { F2-H-EF: Expender seria quando você entrega alguma coisa para } \\
\text { alguém. No sentido de gastar seria despendioso, muito caro, gastei } \\
\text { muito. } \\
\text { F2-M-EF: NSR. } \\
\text { F2-H-EM: NSR. } \\
\text { F2-M-EM: NSR. } \\
\text { F2-H-ES: NSR. } \\
\text { F2-M-ES: NSR. }\end{array}$ \\
\hline $\begin{array}{l}\text { Acepções } \\
\text { registradas } \\
\text { nos } \\
\text { dicionários }\end{array}$ & $\begin{array}{l}\text { Bluteau (1712-1728): EXPENDER. Gastar. } \\
\text { Morais Silva (1813): EXPENDĖR, v. at. Despender, gastar. } \\
\text { Cunha (1997): expender } v b \text {. 'despender, pagar' XVI. } \\
\text { Ferreira (2004): expender 3. Gastar, despender. }\end{array}$ \\
\hline
\end{tabular}




\begin{tabular}{l}
\hline Houaiss (2007): expender datação 15372 despender, gastar. \\
\hline Observa-se, pelo contexto de fala, por parte dos entrevistados, que a lexia expender \\
tem escassa produtividade, pois, dos dezesseis informantes, somente dois a empregaram, \\
mas em contextos distintos. O informante F1-H-EF emprega a definição 'expandir alguma \\
coisa, prolongar' para o item lexical expender, nota-se pela semelhança entre as formas \\
que este informante associou expender com o parônimo expandir, portanto, unidades \\
léxicas distintas. Já o informante F2-H-EF utilizou duas designações para denominar o a \\
forma lexical expender: 'Expender seria quando você entrega alguma coisa para alguém' \\
e 'No sentido de gastar seria despendioso, muito caro, gastei muito'. Observa-se que, a \\
segunda designação, remete ao mesmo significado registrado no corpus escrito: 'gastar, \\
despender', porém, o informante emprega a forma "dispendioso" que se refere ao verbo \\
despender, portanto, outra unidade lexical, mas que conserva o mesmo sentido para a \\
acepção buscada. Segundo Cunha e Houaiss, a unidade lexical expender teve seu primeiro \\
registro a partir do século XVI, enquanto a forma lexical despender foi datada bem antes, \\
durante o século XIII. A primeira designação informada por este morador de Paranaguá \\
não se encontra lexicalizada por nenhum dos dicionaristas acima, para o lema expender. \\
Analisando o contexto de uso desta lexia com as respostas dos informantes, constata-se \\
baixa ocorrência presente na fala dos entrevistados, apontando, assim, tendência ao \\
desuso.
\end{tabular}

\begin{tabular}{|c|c|}
\hline \multicolumn{2}{|c|}{ 34. FACULTAR / DOC.37, fól.1r, l.19-21 } \\
\hline $\begin{array}{l}\text { Acepção } \\
\text { buscada: }\end{array}$ & Permitir, conceder. \\
\hline $\begin{array}{l}\text { Acepção(ões) } \\
\text { conhecida(s) } \\
\text { pelos } \\
\text { informantes: }\end{array}$ & $\begin{array}{l}\text { F1-H-EP: NSR. } \\
\text { F1-M-EP: NSR. } \\
\text { F1-H-EF: NSR. } \\
\text { F1-M-EF: NSR. } \\
\text { F1-H-EM: NSR. } \\
\text { F1-M-EM: NSR. } \\
\text { F1-H-ES: Sentido de escolher. } \\
\text { F1-M-ES: NSR. } \\
\text { F2-H-EP: NSR. } \\
\text { F2-M-EP: NSR. } \\
\text { F2-H-EF: Facultar é quando a pessoa decide, é facultativo, se quer ou } \\
\quad \text { não quer. Eu aceito ou não aceito, vai de cada um daí no caso, se } \\
\text { quiser você faz, se não quiser fica na tua, facultativo, daí no caso. } \\
\text { F2-M-EF: NSR. } \\
\text { F2-H-EM: NSR. } \\
\text { F2-M-EM: NSR. }\end{array}$ \\
\hline
\end{tabular}




\begin{tabular}{|c|c|}
\hline & \\
\hline $\begin{array}{l}\text { ões } \\
\text { radas } \\
\text { lários: }\end{array}$ & $\begin{array}{l}\text { Bluteau (1712-1728): N.D. } \\
\text { Morais Silva (1813): N.D. } \\
\text { Cunha (1997): faculdade } s f \text {. 'capacidade, aptidão, direito'. Adapt. do fr. } \\
\text { faculté, deriv. do lat. facultas -atis | facultar } 1858 \text {. } \\
\text { Ferreira (2004): facultar 2. Pôr à disposição (de); conceder, } \\
\text { proporcionar. } \\
\text { Houaiss (2007): facultar datação } 18581 \text { dar permissão (a); facilitar, } \\
\text { permitir. }\end{array}$ \\
\hline \multicolumn{2}{|c|}{$\begin{array}{l}\text { O item lexical facultar não se encontra dicionarizado nem em Bluteau nem em Morais } \\
\text { Silva. Tanto Cunha como Houaiss informam o ano de } 1858 \text { como datação da unidade } \\
\text { léxica facultar. Mas os documentos manuscritos provam que esta lexia já era empregada } \\
\text { desde o ano de } 1798 \text {, e só no século posterior ocorreu o seu registro. Tal fato explica, } \\
\text { também, porque não consta dos dicionários de Bluteau e de Morais Silva, elaborados em } \\
\text { datação anterior à registrada por Cunha e Houaiss. Quanto ao significado, Cunha, Ferreira } \\
\text { e Houaiss registram a forma lexical facultar com as definições: 'direito', 'capacidade', } \\
\text { 'conceder', 'proporcionar', 'dar permissão', 'facilitar', 'permitir'. Tratam-se da mesma } \\
\text { acepção em estudo. Analisando o contexto de uso de facultar, verifica-se sua baixa } \\
\text { produtividade na fala dos entrevistados, uma vez que treze informantes (sete da faia I e } \\
\text { seis da faixa II) disseram desconhecer a lexia facultar. Dos três informantes que ainda } \\
\text { empregam o item lexical facultar (F1-H-ES / F2-H-EF e F2-H-ES), apenas o informante } \\
\text { F2-H-ES a utiliza com a mesma acepção buscada: 'Facultar é dar um direito a alguma } \\
\text { coisa, conceder'. Os outros dois entrevistados (F1-H-ES e F2-H-EF) a definem com } \\
\text { designações muito próximas aos constantes da acepção de facultar: 'escolher', 'decidir' } \\
\text { 'ser facultativo'. } \\
\text { Analisando a unidade lexicalfacultar, verifica-se que somente três informantes (um da } \\
\text { faixa I e dois da faixa II) a empregam em seu contexto de fala, os demais disseram } \\
\text { desconhecer a lexia em estudo, revelando, assim, tendência ao desuso. }\end{array}$} \\
\hline
\end{tabular}

\begin{tabular}{|l|l|}
\hline 35. FAISCAR / DOC.03, fól.1v, l.02-04 \\
\hline $\begin{array}{l}\text { Acepção } \\
\text { buscada }\end{array}$ & Garimpar, procurar minerais preciosos em terras anteriormente lavradas. \\
\hline $\begin{array}{l}\text { Acepção(ões) } \\
\text { conhecida(s) } \\
\text { pelos } \\
\text { informantes }\end{array}$ & $\begin{array}{l}\text { F1-H-EP: NSR. } \\
\text { F1-H-EP: NSR. } \\
\text { F1-M-EF: Conheço só faísca. } \\
\end{array}$ \\
$\begin{array}{l}\text { F1-H-EM: Tá soltando faísca. } \\
\text { F1-M-EM: NSR. }\end{array}$ \\
\hline
\end{tabular}




\begin{tabular}{|c|c|}
\hline & $\begin{array}{l}\text { F1-H-ES: NSR. } \\
\text { F1-M-ES: NSR. } \\
\text { F2-H-EP: NSR. } \\
\text { F2-M-EP: NSR. } \\
\text { F2-H-EF: Faiscar seria quem trabalha com mineração, aqueles caras que } \\
\text { fazem garimpo, faiscar. } \\
\text { F2-M-EF: Faísca de fogo. } \\
\text { F2-H-EM: Riscar um fósforo, sai faísca de fogo. } \\
\text { F2-M-EM: NSR. } \\
\text { F2-H-ES: Faiscar é o arriscar. } \\
\text { F2-M-ES: NSR. }\end{array}$ \\
\hline $\begin{array}{l}\text { Acepções } \\
\text { registradas } \\
\text { nos } \\
\text { dicionários }\end{array}$ & $\begin{array}{l}\text { Bluteau (1712-1728): N.D. } \\
\text { Morais Silva (1813): FAISCÁR, v. intransit. §. Faiscar nas minas: } \\
\text { ajuntar terra dos córregos, e lavála para colher oiro, que vai envolto } \\
\text { nella. } \\
\text { Cunha (1997): faísca sf. 'partícula que salta de uma substância cadente' } \\
\text { | faiscar XVII. } \\
\text { Ferreira (2004): faiscar 3. Bras. Procurar faíscas de ouro, ou procurar } \\
\text { diamante, em terras já anteriormente lavradas. } \\
\text { Houaiss (2007): Houaiss (2007): faiscar datação } 15625 \text { Rubrica: } \\
\text { termo de garimpo. Regionalismo: Brasil. procurar faíscas de ouro, ou } \\
\text { procurar diamante em terras já anteriormente lavradas. }\end{array}$ \\
\hline \multicolumn{2}{|c|}{$\begin{array}{l}\text { Apesar de a unidade lexical faiscar ter sido registrada por Houaiss em } 1562 \text { e por } \\
\text { Cunha em 1600, esta forma não se encontra dicionarizado em Bluteau. Em Cunha, não há } \\
\text { a definição de faiscar, somente do item lexical faísca. Os documentos manuscritos } \\
\text { atestam seu registro em 1721, provando ser uma lexia de origem antiga. Os lexicógrafos } \\
\text { Morais Silva, Ferreira e Houaiss trazem as mesmas designações para a acepção buscada: } \\
\text { 'procurar faísca de ouro ou diamante em terras já lavradas'. Ferreira e Houaiss, por sua } \\
\text { vez, classificam esta acepção como um brasileirismo/regionalismo do Brasil. Analisando } \\
\text { o contexto de uso da lexia faiscar, somente o informante F2-H-EF a conheceu com o } \\
\text { mesmo sentido registrado no corpus escrito: 'Faiscar seria quem trabalha com } \\
\text { mineração, aqueles caras que fazem garimpo, faiscar'. Quatro dos informantes (F1-H-EF } \\
\text { e F1-H-EM / F2-M-EF e F2-H-EM) conheceram a lexia faiscar apenas como sinônimo de } \\
\text { faísca. Já os informantes da faixa II foram mais específicos: 'faísca de fogo'. O } \\
\text { informante F2-H-ES empregou faiscar no sentido de arriscar, definição não registrada } \\
\text { por nenhum dos lexicógrafos acima. } \\
\text { Pelo contexto de utilização da unidade lexicalfaiscar, nota-se que seu emprego na fala } \\
\text { dos entrevistados tem pouca ocorrência. Dos dezesseis informantes, dez (seis da faixa I e } \\
\text { quatro da faixa II) não souberam dizer o significado da lexia faiscar. Da acepção buscada, } \\
\text { somente um informante da faixa II conheceu a lexia em questão, supondo, assim, ser caso } \\
\text { de tendência ao desuso. }\end{array}$} \\
\hline
\end{tabular}




\begin{tabular}{|c|c|}
\hline \multicolumn{2}{|c|}{ 36. FELICITAR / DOC.32, fól.2r, 1.01} \\
\hline $\begin{array}{l}\text { Acepção } \\
\text { buscada }\end{array}$ & Desejar felicidades. \\
\hline $\begin{array}{l}\text { Acepção(ões) } \\
\text { conhecida(s) } \\
\text { pelos } \\
\text { informantes }\end{array}$ & $\begin{array}{l}\text { F1-H-EP: NSR. } \\
\text { F1-M-EP: Quando alguém faz algo que te agrada, daí você vai felicitar } \\
\text { por aquele negócio que fizeram por você. } \\
\text { F1-H-EF: Felicitar é quando uma pessoa passou num negócio, num } \\
\quad \text { concurso, daí você felicita, parabeniza, felicita. } \\
\text { F1-M-EF: Parabenizar. } \\
\text { F1-H-EM: NSR. } \\
\text { F1-M-EM: NSR. } \\
\text { F1-H-ES: Felicitar é dar felicitações. } \\
\text { F1-M-ES: Quando está fazendo aniversário, venho felicitar você. } \\
\text { F2-H-EP: É desejar felicidades. } \\
\text { F2-M-EP: NSR. } \\
\text { F2-H-EF: Felicitar é felicidade, a pessoa tá feliz. } \\
\text { F2-M-EF: Dar o parabéns pra alguém. } \\
\text { F2-H-EM: NSR. } \\
\text { F2-M-EM: Quando alguém ganha alguma coisa, a gente vai lá e felicita. } \\
\text { F2-H-ES: Dar os parabéns. } \\
\text { F2-M-ES: Felicitar é de desejar felicidades a alguém. }\end{array}$ \\
\hline $\begin{array}{l}\text { Acepções } \\
\text { registradas } \\
\text { nos } \\
\text { dicionários }\end{array}$ & $\begin{array}{l}\text { Bluteau (1712-1728): FELICITAR. Dar Felice successo. } \\
\text { Morais Silva (1813): FELICITÁR, v. at. §. Dar o parabem, os emboras. } \\
\text { Cunha (1997): feliz adj. } 2 g \text {. 'afortunado, próspero, bem combinado, } \\
\quad \text { satisfeito, ditoso' XIV | felicitar XVIII. } \\
\text { Ferreira (2004): felicitar 2. Dirigir parabéns ou cumprimentos a; } \\
\quad \text { congratular, cumprimentar. } \\
\text { Houaiss (2007): felicitar datação } 16972 \text { congratular(-se) com (alguém } \\
\quad \text { ou consigo mesmo); aplaudir(-se). }\end{array}$ \\
\hline \multicolumn{2}{|c|}{$\begin{array}{l}\text { Analisando o contexto de uso da lexia felicitar, verifica-se ser esta bastante produtiva } \\
\text { na fala dos informantes parnanguaras. Quanto à acepção buscada 'desejar felicidades', a } \\
\text { maior parte dos entrevistados a reconheceu com este mesmo sentido. Três informantes } \\
\text { empregaram as formas lexicais parabenizar (F1-M-EF) e dar os parabéns (F2-M-EF e } \\
\text { F2-H-ES) com o mesmo sentido da acepção em estudo, portanto, tratam-se de variantes } \\
\text { sinônimas para designar o mesmo item lexical felicitar. Já para o informante F2-H-EF a } \\
\text { lexia felicitar seria sinônimo de 'felicidade', 'estar feliz'. Nos dicionários pesquisados, } \\
\text { Ferreira traz na primeira acepção do lema felicitar uma definição próxima se comparada } \\
\text { com o a acepção atribuída por este informante: 'Dar a felicidade a; tornar feliz'. }\end{array}$} \\
\hline
\end{tabular}


Os lexicógrafos Bluteau, Morais Silva, Ferreira e Houaiss registraram as definições: 'dar os parabéns', 'dirigir os parabéns ou cumprimentos', 'cumprimentar', 'congratular', 'aplaudir'.

Analisando o contexto de utilização da lexia felicitar, constata-se, no estágio atual de variação, a coocorrência das formas lexicais 'parabenizar' e 'dar os parabéns', porém em pequena proporção se comparada com as respostas dos demais informantes (quatro da faixa I e quatro da faixa II). Dessa forma, a unidade lexical felicitar apresenta tendência à manutencão

\begin{tabular}{|c|c|}
\hline \multicolumn{2}{|c|}{ 37. FOMENTAR / DOC.32, fól.1v, l.21-23 } \\
\hline $\begin{array}{l}\text { Acepção } \\
\text { buscada }\end{array}$ & Causar, provocar, incitar. \\
\hline $\begin{array}{l}\text { Acepção(ões) } \\
\text { conhecida(s) } \\
\text { pelos } \\
\text { informantes }\end{array}$ & $\begin{array}{l}\text { F1-H-EP: NSR. } \\
\text { F1-M-EP: NSR. } \\
\text { F1-H-EF: Fomentar é ter fome. } \\
\text { F1-M-EF: NSR. } \\
\text { F1-H-EM: NSR. } \\
\text { F1-M-EM: NSR. } \\
\text { F1-H-ES: Fomentar é alimentar algo. } \\
\text { F1-M-ES: NSR. } \\
\text { F2-H-EP: NSR. } \\
\text { F2-M-EP: NSR. } \\
\text { F2-H-EF: Fomentar seria você criar alguma coisa no serviço, comentar, } \\
\text { provocar pra gerar mais coisa, é fomentar uma situação. } \\
\text { F2-M-EF: Fomentar eu acho que seria assim: uma cosia que não tem } \\
\text { tanta importância e a pessoa fica ali dizendo tem que ser, tem que ser, } \\
\text { eu acho que é mais ou menos isso. } \\
\text { F2-H-EM: A palavra fomentar é de incentivo a briga, ou discórdia, } \\
\text { desordem. } \\
\text { F2-M-EM: NSR. } \\
\text { F2-H-ES: Fomentar seria a ideia de você estar criando alguma coisa, } \\
\text { fomentando, dando uma ilusão, fomentar dar uma ajuda e a pessoa } \\
\text { acreditar que vai melhorar, então eu estou fomentando. } \\
\text { F2-M-ES: Quando a pessoa está brigando, você põe mais lenha na } \\
\text { fogueira. }\end{array}$ \\
\hline $\begin{array}{l}\text { Acepções } \\
\text { registradas } \\
\text { nos } \\
\text { dicionários }\end{array}$ & $\begin{array}{l}\text { Bluteau (1712-1728): FOMENTAR. Metaphoricamente. Fomentar a } \\
\text { guerra. Prolongar a sua duraçaõ. } \\
\text { Morais Silva (1813): FOMENTÀR, v. at. §. Fomentar a guerra, a } \\
\text { amizade, a sedição, paixões, ira, discordia, amor. }\end{array}$ \\
\hline
\end{tabular}




\begin{tabular}{|l|l|}
\hline & $\begin{array}{l}\text { Cunha (1997): fomentar vb. 'promover o desenvolvimento de' XVI. } \\
\text { Ferreira (2004): fomentar 2. Excitar, incitar. } \\
\text { Houaiss (2007): fomentar datação } 1522 \text { 4 Derivação: sentido figurado: } \\
\text { provocar (reação, sentimentos); incitar, instigar. }\end{array}$ \\
\hline Analisando o contexto de uso da lexia fomentar nas respostas dos informantes, \\
constata-se a presença da acepção buscada somente na fala de quatro informantes da faixa \\
II (F2-H-EF, F2-M-EF, F2-H-EM e F2-M-ES). O informante F2-H-ES reconheceu \\
fomentar com o sentido de 'criar alguma coisa', 'dar uma ilusão' 'dar uma ajuda a \\
alguém'. Nos dicionários, o sentido mais próximo a este, para a forma lexical fomentar \\
encontra-se registrado em Cunha e em Ferreira, na primeira acepção: 'Promover o \\
desenvolvimento, o progresso de; estimular; facilitar'. Já dois informantes (F1-H-EF e F1- \\
H-ES) associaram a definição de fomentar com outros itens lexicais: fome e alimentar. \\
Quanto ao registro da acepção buscada nos dicionários, Bluteau abona 'fomentar a guerra' \\
como uma metáfora. Morais Silva amplia sua abonação: 'fomentar a guerra, a amizade, \\
discórdia, amor'. Estas abonações assemelham-se às respostas dos seguintes informantes: \\
F2-H-EM: 'A palavra fomentar é de incentivo a briga, ou discórdia, desordem'; F2-M- \\
ES: 'Quando a pessoa está brigando, você põe mais lenha na fogueira'. Ferreira e \\
Houaiss registram as definições: 'excitar', 'incitar', 'provocar', 'instigar'. Este último \\
dicionarista classifica essa designação como sentido figurado. \\
Levando em consideração que, dos dezesseis entrevistados, nove informantes (seis da \\
faixa I e três da faixa II) desconhecem a unidade lexical fomentar, e nenhum informante \\
da faixa I reconheceu este item lexical com o sentido da acepção em estudo, presume-se \\
que a lexia fomentar apresenta tendência ao desuso.
\end{tabular}

\begin{tabular}{|c|c|}
\hline \multicolumn{2}{|c|}{ 38. INCORRER / DOC.37, fól.1r, l.19-21 } \\
\hline $\begin{array}{l}\text { Acepção } \\
\text { buscada }\end{array}$ & Causar, ter como consequência. \\
\hline $\begin{array}{l}\text { Acepção(ões) } \\
\text { conhecida(s) } \\
\text { pelos } \\
\text { informantes }\end{array}$ & $\begin{array}{l}\text { F1-H-EP: NSR. } \\
\text { F1-M-EP: NSR. } \\
\text { F1-H-EF: Incorrer é ir atrás do que você almeja. } \\
\text { F1-M-EF: NSR. } \\
\text { F1-H-EM: NSR. } \\
\text { F1-M-EM: NSR. } \\
\text { F1-H-ES: NSR. } \\
\text { F1-M-ES: NSR. } \\
\text { F2-H-EP: NSR. } \\
\text { F2-M-EP: NSR. } \\
\text { F2-H-EF: Seria você cometer alguma coisa errada, você incorreu. } \\
\text { F2-M-EF: NSR. }\end{array}$ \\
\hline
\end{tabular}




\begin{tabular}{|c|c|}
\hline & $\begin{array}{l}\text { 2-H-EM: Pessoas que vão correr. } \\
\text { 2-M-EM: NSR. } \\
\text { 2-H-ES: Pode ser incorrer no erro, cometer um erro, fazer um erro. } \\
\text { 2-M-ES: NSR. }\end{array}$ \\
\hline $\begin{array}{l}\text { Acepções } \\
\text { registradas } \\
\text { nos } \\
\text { dicionários }\end{array}$ & $\begin{array}{l}\text { Bluteau (1712-1728): [ENCORRER no odio dos homens. Fazerse } \\
\text { aborrecer]. } \\
\text { Morais Silva (1813): INCORRER. Cahir, ficar sujeito. } \\
\text { Cunha (1997): correr } v b \text {. | incorrer } v b \text {. 'ficar incluído, implicado ou } \\
\text { comprometido' | en- XIV. } \\
\text { Ferreira (2004): incorrer 3. Ant. Atrair sobre si; cair em. } \\
\text { Houaiss (2007): incorrer datação sXIV } 4 \text { Estatística: pouco usado: } \\
\text { atrair sobre si; causar. }\end{array}$ \\
\hline \multicolumn{2}{|c|}{$\begin{array}{l}\text { Da acepção buscada: 'causar, ter como consequência', para o item lexical incorrer, os } \\
\text { dicionaristas registraram várias designações: 'fazer-se aborrecer', 'ficar sujeito', 'ficar } \\
\text { incluído', 'atrair sobre si', 'causar'. Dentre essas acepções, somente a definição 'causar' } \\
\text { registrada em Houaiss, remete ao mesmo sentido da acepção documentada no corpus } \\
\text { escrito, porém este lexicógrafo esclarece tratar-se de uma acepção, estatisticamente pouco } \\
\text { usada. Esta informação trazida por Houaiss se confirma nas respostas dos entrevistados: } \\
\text { dos quatro informantes que reconheceram a lexia incorrer, nenhum a emprega com o } \\
\text { mesmo sentido da acepção em estudo: 'causar, ter como consequência'. Para os } \\
\text { informantes FI-H-EF e F2-H-EM incorrer seria o mesmo que 'correr'. Talvez essa } \\
\text { associação ocorra devido à semelhança entre as duas formas lexicais correr/incorrer. Já } \\
\text { os informantes F2-H-EF e F2-H-ES empregaram incorrer no sentido de 'cometer algum } \\
\text { erro'. Houaiss registra esta definição na segunda acepção da entrada incorrer com o } \\
\text { sentido 'levar a efeito, incidir em, cometer'. } \\
\text { Analisando o contexto de uso da lexia incorrer, verifica-se que este item lexical tem } \\
\text { pouca produtividade na fala dos informantes, pois doze entrevistados (sete da faixa I e } \\
\text { cinco da faixa II) não utilizam incorrer em seu dia a dia. Os quatro informantes que ainda } \\
\text { a utilizam, empregam outro sentido para a unidade lexical incorrer, supondo, então, tratar- } \\
\text { se de uma lexia em desuso. }\end{array}$} \\
\hline
\end{tabular}

\begin{tabular}{|l|l|}
\hline \multicolumn{2}{|l|}{ 39. INTEIRAR / DOC.47, fól.1v, l.01-04 } \\
\hline $\begin{array}{l}\text { Acepção } \\
\text { buscada }\end{array}$ & Juntar o que falta, completar. \\
\hline $\begin{array}{l}\text { Acepção(ões) } \\
\text { conhecida(s) } \\
\text { pelos } \\
\text { informantes }\end{array}$ & $\begin{array}{l}\text { F1-H-EP: NSR. } \\
\text { F1-M-EP: NSR. } \\
\text { F1-H-EF: É se interagir. }\end{array}$ \\
\hline
\end{tabular}




\begin{tabular}{|c|c|}
\hline & $\begin{array}{l}\text { F1-H-EM: Inteirar-se sobre algum assunto, tá procurando saber, ou } \\
\text { vamos fazer uma intera, cada um dá um pouquinho. } \\
\text { F1-M-EM: Você quer inteirar daquilo que tá acontecendo agora, quer } \\
\text { ficar dentro do assunto. } \\
\text { F1-H-ES: Sentido de completar. } \\
\text { F1-M-ES: Inteirar de um assunto, estar por dentro e vou inteirar uma } \\
\text { garrafa que tá pela metade, como se fosse colocar mais. } \\
\text { F2-H-EP: É completar. } \\
\text { F2-M-EP: Às vezes eu falo vou inteirar o leite. } \\
\text { F2-H-EF: Inteirar é você ficar a par, saber o que tá acontecendo, por } \\
\text { exemplo: tem uma notícia ali e você não sabe, daí você vai lá pra se } \\
\text { inteirar e tal, saber. No caso de uma coisa quando não tá completa daí } \\
\text { você inteira, seja dinheiro, seja alguma coisa que não tá completa. } \\
\text { F2-M-EF: É pra saber de um assunto que você não tem tanto } \\
\text { conhecimento e então antes que você sai falando, você vai inteirar do } \\
\text { assunto pra saber. } \\
\text { F2-H-EM: Completar o litro de água. } \\
\text { F2-M-EM: Tem inteirar de algum assunto e também as crianças falam: } \\
\text { inteira o leite aí pra mim. } \\
\text { F2-H-ES: Inteirar-se é tomar conhecimento, tomar tenência sobre a } \\
\text { questão. } \\
\text { F2-M-ES: Inteirar é você querer aprender as coisas e também completar } \\
\text { um litro de leite. }\end{array}$ \\
\hline $\begin{array}{l}\text { Acepções } \\
\text { registradas } \\
\text { nos } \\
\text { dicionários }\end{array}$ & $\begin{array}{l}\text { Bluteau (1712-1728): INTEIRAR. Fazer, ou tornar a fazer inteiro. } \\
\text { Morais Silva (1813): INTEIRÁR, v. at. Fazer inteiro, ajuntando o que } \\
\text { falta para a integridade. } \\
\text { Cunha (1997): integrar } v b \text {. 'completar' | inteirar XVI. } \\
\text { Ferreira (2004): inteirar } 1 \text {. Tornar inteiro ou completo; completar; } \\
\text { perfazer; preencher. } \\
\text { Houaiss (2007): inteirar datação } 15891 \text { tornar inteiro, completar, } \\
\text { preencher. }\end{array}$ \\
\hline \multicolumn{2}{|c|}{$\begin{array}{l}\text { Os dicionaristas registram a entrada inteirar com o mesmo sentido da acepção buscada } \\
\text { 'juntar o que falta, completar'. Analisando o contexto de uso dessa unidade lexical, } \\
\text { constatou-se: (i) dos quatorze informantes que reconheceram o item lexical em estudo, } \\
\text { cinco (F1-H-EM e F1-M-ES / F2-H-EF, F2-H-EF e F2-M-ES) a utilizam com variação de } \\
\text { significados: inteirar no sentido de 'se interagir, se informar sobre determinado assunto', } \\
\text { e inteirar no sentido de 'completar, preencher'; (ii) quatro informantes (F1-H-EF e F1-M- } \\
\text { EM / F2-M-EF e F2-H-ES) utilizam o item lexical somente no sentido de 'se interagir, se } \\
\text { informar'; e (iii) cinco informantes (F1-M-EF e F1-H-ES / F2-H-EP, F2-M-EP e F2-H- } \\
\text { EM) empregam inteirar apenas com o sentido de 'completar, preencher o que falta'. O } \\
\text { informante F1-H-EM empregou uma nova forma lexical para designar o sentido de }\end{array}$} \\
\hline
\end{tabular}


completar: 'fazer uma intera'. Esse morador informou ser o mesmo sentido de 'fazer uma vaquinha'.

Analisando o contexto de utilização da lexia inteirar, averigua-se, no estágio atual de variação, considerável frequência da ocorrência dos dois significados distintos para o única forma lexical inteirar. Neste cenário linguístico, supõe-se, então, que esta unidade lexical no sentido documentado no corpus escrito, presente em quase todas as respostas dos informantes em Paranaguá, apresenta tendência à manutencão.

\begin{tabular}{|c|c|}
\hline \multicolumn{2}{|c|}{ 40. INTENTAR / DOC.10, fól.1r, l.19-21 } \\
\hline $\begin{array}{l}\text { Acepção } \\
\text { buscada }\end{array}$ & Pretender fazer algo. \\
\hline $\begin{array}{l}\text { Acepção(ões) } \\
\text { conhecida(s) } \\
\text { pelos } \\
\text { informantes }\end{array}$ & $\begin{array}{l}\text { F1-H-EP: NSR. } \\
\text { F1-M-EP: NSR. } \\
\text { F1-H-EF: Tentar novamente, coisa que você tentou e não conseguiu, } \\
\text { você vai lá intentar de novo. } \\
\text { F1-M-EF: NSR. } \\
\text { F1-H-EM: NSR. } \\
\text { F1-M-EM: NSR. } \\
\text { F1-H-ES: NSR. } \\
\text { F1-M-ES: NSR. } \\
\text { F2-H-EP: A palavra intentar é quando não sabe das coisas, mas vai lá e } \\
\text { tenta. } \\
\text { F2-M-EP: Quando você quer algo assim, vai tentar conseguir. } \\
\text { F2-H-EF: Seria você intentar contra uma pessoa, contra um cachorro, } \\
\text { contra um bem que não é teu, tá intentando alguma coisa errada, é } \\
\text { intentar. } \\
\text { F2-M-EF: NSR. } \\
\text { F2-H-EM: NSR. } \\
\text { F2-M-EM: NSR. } \\
\text { F2-H-ES: NSR. } \\
\text { F2-M-ES: É tentar alguma coisa. }\end{array}$ \\
\hline $\begin{array}{l}\text { Acepções } \\
\text { registradas } \\
\text { nos } \\
\text { dicionários }\end{array}$ & $\begin{array}{l}\text { Bluteau (1712-1728): INTENTAR. Ter algum intento. [INTENTO. O } \\
\text { que se traz no pensamento, com intenção de o executar]. } \\
\text { Morais Silva (1813): INTENTÁR, v. at. Cuidar, meditar, projectar, } \\
\text { pretender. } \\
\text { Cunha (1997): N.D. } \\
\text { Ferreira (2004): intentar 1. Tentar, tencionar, planejar; projetar. } \\
\text { Houaiss (2007): intentar datação } 15181 \text { ter uma dada intenção; } \\
\quad \text { tencionar, planejar, projetar. }\end{array}$ \\
\hline
\end{tabular}


A unidade lexical intentar está lexicalizada por todos os dicionaristas (com exceção de Cunha) com as seguintes definições: 'ter algum intento', 'ter uma dada intenção', 'projetar', 'pretender', 'tentar', 'tencionar', 'planejar'. Dos dezesseis entrevistados, apenas o informante F2-H-EF empregou a lexia intentar com o mesmo sentido da acepção buscada: 'Seria você intentar contra uma pessoa, contra um cachorro, contra um bem que não é teu, tá intentando alguma coisa errada, é intentar'. Analisando as respostas dos outros quatro informantes (F1-H-EF / F2-H-EP, F2-M-EP e F2-M-ES) em seu contexto de uso, parece ter ocorrido uma relação de sinonímia entre os itens lexicais intentar e tentar, devido à semelhança entre essas formas lexicais.

Considerando os dados em questão, constatou-se que o item lexical intentar com o sentido da acepção buscada 'pretender fazer algo', quase não se encontra mais registrada em contexto de fala dos entrevistados de Paranaguá. Das cinco ocorrências proferidas pelos informantes, apenas uma do informante da faixa II é condizente com a acepção em estudo. Portanto, a lexia intentar com o mesmo sentido registrado no corpus escrito, apresenta tendência ao desuso.

\begin{tabular}{|c|c|}
\hline \multicolumn{2}{|c|}{ 41. LANCEAR / DOC.33, Fól.1v, l.16-19 } \\
\hline $\begin{array}{l}\text { Acepção } \\
\text { buscada }\end{array}$ & Ferir com lança. \\
\hline $\begin{array}{l}\text { Acepção(ões) } \\
\text { conhecida(s) } \\
\text { pelos } \\
\text { informantes }\end{array}$ & $\begin{array}{l}\text { F1-H-EP: Lancear é o tipo de pesca que nós pescamos, a gente sai pesca } \\
\text { a sardinha a gente dá um lanço, é lancear pra nós. } \\
\text { F1-M-EP: NSR. } \\
\text { F1-H-EF: Lancear no sentido de lançar alguma coisa, alancear é jogar e } \\
\text { puxar. } \\
\text { F1-M-EF: Lancear é quando os pescadores vão pegar peixe, daí vai } \\
\text { lancear a rede. } \\
\text { F1-H-EM: NSR. } \\
\text { F1-M-EM: NSR. } \\
\text { F1-H-ES: NSR. } \\
\text { F1-M-ES: NSR. } \\
\text { F2-H-EP: Pra nós aqui lancear é pegar uma rede lancear aquela rede } \\
\text { F2-M-EP: Lancear é quando vão caçar peixe, aí vão lancear, jogam a } \\
\text { rede é um tipo de lancear. Quando eu cheguei aqui na ilha é que eu fui } \\
\text { saber o que era lancear. } \\
\text { F2-H-EF: Lancear é mais de pescador, vamos dar um lance de rede, } \\
\text { então vamos lancear. } \\
\text { F2-M-EF: NSR. } \\
\text { F2-H-EM: Lancear está ligado à rede, a pesca. É jogar a rede, espichar } \\
\text { ela no mar. }\end{array}$ \\
\hline
\end{tabular}




\begin{tabular}{|c|c|}
\hline & $\begin{array}{l}\text { F2-M-EM: Lancear aqui em Paranaguá é ir pro mar, lancear é jogar a } \\
\text { rede. Lança a rede e vem cheia de pexe, daí se fala que hoje o lance } \\
\text { foi bom. } \\
\text { F2-H-ES: NSR. } \\
\text { F2-M-ES: Lancear é lançar a rede, lançar o anzol, a vara. }\end{array}$ \\
\hline $\begin{array}{l}\text { Acepções } \\
\text { registradas } \\
\text { nos } \\
\text { dicionários }\end{array}$ & $\begin{array}{l}\text { Bluteau (1712-1728): ALANCEAR. Ferir com lança. } \\
\text { Morais Silva (1813): LANCEÁR, v. at. Ferir com lança. } \\
\text { Cunha (1997): lança } s f . \text { 'arma ofensiva' XIII. Lancear XVI. } \\
\text { Ferreira (2004): lancear }{ }^{1} 1 \text {. Ferir com lança, alancear. } \\
\text { Houaiss (2007): lancear }{ }^{1} \text { datação 1597, m.q. alancear. [alancear } 1 \\
\quad \text { ferir(-se) com lança, golpear(-se) } \\
\text { Ferreira: lancear }{ }^{2} \text {. Bras. Pescar com rede. } \\
\text { Houaiss: lancear }{ }^{2} \text { datação } 1899 \text { Regionalismo: Pará. Pescar com } \\
\quad \text { arrasto. }\end{array}$ \\
\hline \multicolumn{2}{|c|}{$\begin{array}{l}\text { Dos dezesseis entrevistados, nove dos informantes (três da faixa I e seis da faixa II) } \\
\text { empregam o termo 'lancear' com o sentido relacionado à atividade da pesca, conforme } \\
\text { atestam os seguintes informantes: F2-H-EF: 'Lancear é mais de pescador, vamos dar um } \\
\text { lance de rede, então vamos lancear'; F2-M-EP: 'Lancear é quando vão caçar peixe, ai } \\
\text { vão lancear, jogam a rede é um tipo de lancear. Quando eu cheguei aqui na ilha é que eu } \\
\text { fui saber o que era lancear'. Nos dicionários de Ferreira e Houaiss constam duas entradas } \\
\text { para lancear'. Na primeira consta da definição de 'ferir com lança, alancear' evidenciando } \\
\text { o mesmo sentido documentado no corpus escrito. Esta acepção também consta de Bluteau } \\
\text { e de Morais Silva. Houaiss, por sua vez, remete o consulente à variante lexical alancear, } \\
\text { cujo significado é o mesmo. Na segunda entrada de lancear consta o significado 'pescar } \\
\text { com rede', que, por sua vez, foi empregado pelos nove informantes de Paranaguá. Ferreira } \\
\text { marca como brasileirismo e Houaiss como regionalismo do Pará. A marca dialetal } \\
\text { informada por este dicionarista infere-se ser exclusiva da região do Pará, portanto a } \\
\text { ocorrência, de certa forma significativa, da lexia lancear com o sentido de 'pescar com } \\
\text { rede' no contexto de fala da região de Paranaguá, presume ser, talvez, uma marca dialetal } \\
\text { de região litorânea, onde há a atividade da pesca. } \\
\text { Portanto, levando em consideração que os informantes parnanguaras reconheceram } \\
\text { outro item lexical, no caso o homônimo de lancear, pressupõe-se que a unidade léxica } \\
\text { com o sentido de 'ferir com lança', configura um caso de desuso. }\end{array}$} \\
\hline
\end{tabular}

\begin{tabular}{|l|l|}
\hline \multicolumn{2}{|l|}{ 42. LAVRAR / DOC.03, fól.1v, l.04-07 } \\
\hline $\begin{array}{l}\text { Acepção } \\
\text { buscada }\end{array}$ & Explorar, trabalhar em minas. \\
\hline $\begin{array}{l}\text { Acepção(ões) } \\
\text { conhecida(s) }\end{array}$ & $\begin{array}{l}\text { F1-H-EP: NSR. } \\
\text { F1-M-EP: NSR. } \\
\text { F1-H-EF: Só conheço lavar. }\end{array}$ \\
\hline
\end{tabular}




\begin{tabular}{|c|c|}
\hline & $\begin{array}{l}\text { F1-M-EF: Lavrar se fala na roça, lavrar é trabalhar, plantar. } \\
\text { F1-H-EM: NSR. } \\
\text { F1-M-EM: Lavrar uma ata. } \\
\text { F1-H-ES: É trabalhar. } \\
\text { F1-M-ES: Trabalhar de lavrador. } \\
\text { F2-H-EP: NSR. } \\
\text { F2-M-EP: Minha sogra falava, ela lidava muito na terra, mas eu num } \\
\text { falo. } \\
\text { F2-H-EF: Lavrar é mais pra agricultura, lavrar a terra, preparar o solo. } \\
\text { F2-M-EF: Lavrar um documento no cartório. } \\
\text { F2-H-EM: Pegar na enxada e carpir o chão. } \\
\text { F2-M-EM: É trabalhar na roça. } \\
\text { F2-H-ES: Lavrar é quando você registra, lavrou a área, lavrou a ata, de } \\
\text { lavrar. } \\
\text { F2-M-ES: Conheço como lavoura. }\end{array}$ \\
\hline $\begin{array}{l}\text { Acepções } \\
\text { registradas } \\
\text { nos } \\
\text { dicionários: }\end{array}$ & $\begin{array}{l}\text { Bluteau (1712-1728): LAVRAR. Pedras que se podem lavrar. Lavrar hũ } \\
\text { diamente bruto. } \\
\text { Morais Silva (1813): LAVRÁR, v. at. §. Trabalhar. §. Lavrar as minas: } \\
\text { beneficiar. } \\
\text { Cunha (1997): labor, lavor sm. 'trabalho, faina' | lavrar XIII. } \\
\text { Ferreira (2004): lavrar 5. Explorar (minas). } \\
\text { Houaiss (2007): lavrar datação sXIII } 7 \text { Derivação: sentido figurado. } \\
\text { explorar (terreno de mineração). }\end{array}$ \\
\hline \multicolumn{2}{|c|}{$\begin{array}{l}\text { Da lexia lavrar buscou-se a acepção 'explorar, trabalhar em minas', presente nos } \\
\text { documentos manuscritos. A acepção buscada encontra-se registrada em Bluteau, Morais } \\
\text { Silva, Ferreira e Houaiss: 'lavrar um diamante', 'trabalhar, lavrar em minas', 'explorar } \\
\text { minas ou terreno de mineração'. Esta última acepção é classificada por Houaiss como } \\
\text { derivação: sentido figurado. Analisando o contexto de uso da lexia lavrar com as } \\
\text { respostas dos entrevistados de Paranaguá, verifica-se que o significado 'explorar, trabalhar } \\
\text { em minas' não ocorreu na fala de nenhum dos informantes. Os registros orais apontam } \\
\text { variação entre três significados: (i) 'lavar', (ii) 'trabalhar na roça (serviço pesado)', e (iii) } \\
\text { 'redigir, escrever uma ata'. Apenas o informante F1-H-EF associou a forma parônima de } \\
\text { lavrar com lavar, itens lexicais e significados distintos. Oito informantes (três da faixa I e } \\
\text { cinco da faixa II) utilizam o segundo sentido; e três informantes (um da faixa I e dois da } \\
\text { faixa II) empregam o terceiro significado. } \\
\text { Analisando os dados orais, observa-se que a unidade lexical lavrar tem maior } \\
\text { ocorrência com o sentido de 'trabalhar no campo, roça'. Como em Paranaguá a extração } \\
\text { de ouro deixou de existir desde o século XVII, a lexia lavrar com o sentido de 'explorar } \\
\text { minas' também deixou de ser usada em contexto de fala por parte dos informantes de } \\
\text { Paranaguá. Conjectura-se que, em algum momento da língua, essa unidade lexical tenha } \\
\text { tido vários sentidos coocorrendo entre si, inclusive o da acepção buscada. Portanto, }\end{array}$} \\
\hline
\end{tabular}


considerando as respostas dos informantes, o item lexical lavrar com o sentido de 'explorar minas' caiu em desuso.

\begin{tabular}{|c|c|}
\hline \multicolumn{2}{|c|}{ 43. LOGRAR / DOC.10, fól.1v, l.16-19 } \\
\hline $\begin{array}{l}\text { Acepção } \\
\text { buscada }\end{array}$ & Estar de posse, conseguir. \\
\hline $\begin{array}{l}\text { Acepção(ões) } \\
\text { conhecida(s) } \\
\text { pelos } \\
\text { informantes }\end{array}$ & $\begin{array}{l}\text { F1-H-EP: NSR. } \\
\text { F1-M-EP: NSR. } \\
\text { F1-H-EF: NSR. } \\
\text { F1-M-EF: NSR. } \\
\text { F1-H-EM: NSR. } \\
\text { F1-M-EM: Você vai trabalha e a pessoa não te paga, ela te logra. } \\
\text { F1-H-ES: Você tá me logrando, no sentido de passar a perna. } \\
\text { F1-M-ES: NSR. } \\
\text { F2-H-EP: É aqui a gente usa a palavra lograr, às vezes um quer lograr } \\
\text { outro. } \\
\text { F2-M-EP: Lograr é quando alguém pega algum dinheiro, alguma coisa } \\
\text { assim, que seja de outro, aí esse quer lograr a pessoa. } \\
\text { F2-H-EF: Lograr tem dois sentidos: lograr de enganar e lograr de ter } \\
\text { êxito. } \\
\text { F2-M-EF: NSR. } \\
\text { F2-H-EM: Tentar passar uma coisa que não é verdade, é mentira, eu te } \\
\text { engano. } \\
\text { F2-M-EM: Lograr é quando você quer tirar proveito de alguma pessoa. } \\
\text { F2-H-ES: Lograr é enganar ou conseguir um êxito, logrou um êxito. } \\
\text { F2-M-ES: É coisa ruim, é enganar a pessoa, passar a perna, enganar a } \\
\text { pessoa. }\end{array}$ \\
\hline $\begin{array}{l}\text { Acepções } \\
\text { registradas } \\
\text { nos } \\
\text { dicionários }\end{array}$ & $\begin{array}{l}\text { Bluteau (1712-1728): LOGRAR alguma cousa. Estar de posse, \& ter o } \\
\text { uso della. } \\
\text { Morais Silva (1813): LOGRÁR, v. at. §. fig. Estar possuindo, gozar. §. } \\
\quad \text { Conseguir, e gozar. } \\
\text { Cunha (1997): lograr } v b \text {. 'obter, alcançar' XIII. } \\
\text { Ferreira (2004): lograr } 3 \text {. Conseguir, alcançar. } \\
\text { Houaiss (2007): lograr datação sXIV } 1 \text { conseguir, alcançar (algo); } \\
\quad \text { obter (algo) a que se tem direito ou que se deseja. }\end{array}$ \\
\hline Observan & $\begin{array}{l}\text { contexto de uso da lexia lograr certifica-se que pouco mais } \\
\text { vistados (dois da faixa I e sete da faixa II) a utiliza con }\end{array}$ \\
\hline
\end{tabular}


registrada nos documentos manuscritos: 'estar de posse, conseguir'. Sete informantes (seis da faixa I e um da faixa II) disseram não conhecer a forma lexical lograr, e dois informantes (F2-H- EF e F2-H-ES) reconheceram com outro sentido: 'ter/conseguir êxito'. Os lexicógrafos registram as mesmas acepções buscadas neste estudo.

Analisando o contexto de uso da unidade lexical lograr e comparando com a acepção buscada, constatou-se a não ocorrência por parte dos entrevistados. Supõe-se que o sentido encontrado nos documentos manuscritos tenha perdido forças com as demais acepções que hoje definem a unidade léxica lograr, configurando, assim, um caso de desuso

\begin{tabular}{|c|c|}
\hline \multicolumn{2}{|c|}{ 44. MEDIANDO / DOC.10, fól.1r, l.25-29 } \\
\hline $\begin{array}{l}\text { Acepção } \\
\text { buscada }\end{array}$ & Estar próximo, entre. \\
\hline $\begin{array}{l}\text { Acepção(ões) } \\
\text { conhecida(s) } \\
\text { pelos } \\
\text { informantes }\end{array}$ & $\begin{array}{l}\text { F1-H-EP: NSR. } \\
\text { F1-M-EP: NSR. } \\
\text { F1-H-EF: Mediando é medir. } \\
\text { F1-M-EF: NSR. } \\
\text { F1-H-EM: NSR. } \\
\text { F1-M-EM: NSR. } \\
\text { F1-H-ES: NSR. } \\
\text { F1-M-ES: NSR. } \\
\text { F2-H-EP: NSR. } \\
\text { F2-M-EP: NSR. } \\
\text { F2-H-EF: Mediando você tá fazendo papel de juiz, entre duas partes, três } \\
\quad \text { partes tal daí você tá mediando pra não deixar um lado só, você vai } \\
\text { mediar, é um mediador. } \\
\text { F2-M-EF: NSR. } \\
\text { F2-H-EM: NSR. } \\
\text { F2-M-EM: NSR. } \\
\text { F2-H-ES: Mediando quer dizer que você fica controlando, duas pessoas } \\
\text { discutindo e você tá mediando uma questão, um assunto. } \\
\text { F2-M-ES: NSR. }\end{array}$ \\
\hline $\begin{array}{l}\text { Acepções } \\
\text { registradas } \\
\text { nos } \\
\text { dicionários: }\end{array}$ & $\begin{array}{l}\text { Bluteau (1712-1728): [MEDIAR. Estar no meyo de duas cousas, } \\
\text { unindo-as huma com outra]. } \\
\text { Morais Silva (1813): [MEDIÁR, v. n. Estar no meyo de duas coisas]. } \\
\text { Cunha (1997): N.D. } \\
\text { Ferreira (2004): [mediar 3. Ficar no meio de dois pontos; distar]. } \\
\text { Houaiss (2007): [mediar } 3 \text { estar entre (duas coisas), situar-se entre (dois } \\
\quad \text { extremos)]. }\end{array}$ \\
\hline
\end{tabular}


A lexia mediando não consta do registro de nenhum dos lexicógrafos acima. As definições apresentadas por eles referem-se à entrada mediar: 'estar no meio', 'ficar no meio', 'situar-se entre'. Pelo contexto de uso, essa unidade lexical tem baixa produtividade por parte dos entrevistados. Treze informantes (sete da faixa I e seis da faixa II) disseram não conhecer a forma lexical mediando. O informante F1-H-EF associou mediando e medir pela semelhança das formas, portanto são itens lexicais e significados distintos. Dois informantes (F2-H-EF e F2-H-ES) empregaram a lexia mediando com o mesmo sentido de: 'mediar uma questão, um assunto', 'fazer papel de juiz, de mediador'. Na verdade, essas definições referem-se ao item lexical mediar, e não à lexia mediando, registrada nos documentos manuscritos com o sentido de 'estar perto de algum lugar'. Como a maioria dos informantes desconhece a unidade lexical mediando, principalmente da faixa I, configura-se um caso de $\underline{\text { desuso. }}$.

\begin{tabular}{|c|c|}
\hline \multicolumn{2}{|c|}{ 45. OBRAR / DOC.25, fól.1v, l.18-19 } \\
\hline $\begin{array}{l}\text { Acepção } \\
\text { buscada }\end{array}$ & Executar, realizar, produzir. \\
\hline $\begin{array}{l}\text { Acepção(ões) } \\
\text { conhecida(s) } \\
\text { pelos } \\
\text { informantes }\end{array}$ & $\begin{array}{l}\text { F1-H-EP: NSR. } \\
\text { F1-M-EP: NSR. } \\
\text { F1-H-EF: Obrar é quando tô fazendo uma obra. } \\
\text { F1-M-EF: NSR. } \\
\text { F1-H-EM: NSR. } \\
\text { F1-M-EM: NSR. } \\
\text { F1-H-ES: NSR. } \\
\text { F1-M-ES: NSR. } \\
\text { F2-H-EP: NSR. } \\
\text { F2-M-EP: NSR. } \\
\text { F2-H-EF: Obrar seria construir, fazer alguma coisa, fazer alguma obra } \\
\quad \text { no caso trabalhar, usa nesse sentido. } \\
\text { F2-M-EF: Aqui seria no sentido de obrar uma casa. } \\
\text { F2-H-EM: NSR. } \\
\text { F2-M-EM: Pra nós é quem trabalha na obra, serviço pesado. } \\
\text { F2-H-ES: Obrar Dom Pedro fazia muito, Dom João VI também fazia } \\
\text { muito, não é de fazer obra, é de cagar mesmo. } \\
\text { F2-M-ES: Obrar pra mim é ir ao banheiro. }\end{array}$ \\
\hline $\begin{array}{l}\text { Acepções } \\
\text { registradas } \\
\text { nos } \\
\text { dicionários }\end{array}$ & $\begin{array}{l}\text { Bluteau (1712-1728): OBRAR. Fazer qualquer acção. } \\
\text { Morais Silva (1813): OBRÁR, v. at. Fazer. } \\
\text { Cunha (1997): obra } s f \text {. 'construção, trabalho, produção' XIII.| obrar } \\
\quad \text { XIII. }\end{array}$ \\
\hline
\end{tabular}




\begin{tabular}{|l|l|}
\hline & $\begin{array}{c}\text { Ferreira (2004): obrar 1. Converter em obra; fazer, executar, praticar, } \\
\text { realizar. } \\
\text { Houaiss (2007): obrar datação sXIII } 1 \text { exercer um ofício; realizar uma } \\
\text { ação; trabalhar, agir. }\end{array}$ \\
\hline Os lexicógrafos registram a entrada obrar com a mesma acepção buscada: 'executar, \\
realizar, produzir'. Dos dezesseis entrevistados, somente quatro informantes (F1-H-EF / \\
F2-H-EF, F2-M-EF e F2-M-EM) utilizaram a lexia obrar com o mesmo sentido registrado \\
no corpus escrito. Outros dois informantes (F2-H-ES e F2-M-ES) reconheceram obrar \\
apenas como sinônimo de defecar. Embora obrar ainda esteja presente na fala de alguns \\
informantes parnanguaras, constata-se que seu uso é pouco produtivo, pois, dos dezesseis \\
entrevistados, dez informantes (sete da faixa I e três da faixa II) disseram desconhecer a \\
unidade lexical obrar. Dos poucos que ainda a utilizam, somente três a reconheceram com \\
o mesmo sentido da acepção em estudo (um da faixa I e dois da II). Esses dados apontam \\
que a unidade lexical obrar revela tendência ao desuso.
\end{tabular}

\begin{tabular}{|c|c|}
\hline \multicolumn{2}{|c|}{ 46. OBVIAR / DOC.08, fól.1r, l.10-13 } \\
\hline $\begin{array}{l}\text { Acepção } \\
\text { buscada }\end{array}$ & Opor, contrapor, obstar. \\
\hline $\begin{array}{l}\text { Acepção(ões) } \\
\text { conhecida(s) } \\
\text { pelos } \\
\text { informantes }\end{array}$ & $\begin{array}{l}\text { F1-H-EP: NSR. } \\
\text { F1-M-EP: NSR. } \\
\text { F1-H-EF: É uma coisa óbvia. } \\
\text { F1-M-EF: NSR. } \\
\text { F1-H-EM: NSR. } \\
\text { F1-M-EM: NSR. } \\
\text { F1-H-ES: NSR. } \\
\text { F1-M-ES: NSR. } \\
\text { F2-H-EP: NSR. } \\
\text { F2-M-EP: NSR. } \\
\text { F2-H-EF: Obviar é você fazer alguma coisa que não tem outro jeito, é } \\
\text { aquilo mesmo, é óbvio aquilo ali. } \\
\text { F2-M-EF: NSR. } \\
\text { F2-H-EM: NSR. } \\
\text { F2-M-EM: NSR. } \\
\text { F2-H-ES: NSR. } \\
\text { F2-M-ES: O que é óbvio, verdadeiro. }\end{array}$ \\
\hline $\begin{array}{l}\text { Acepções } \\
\text { registradas }\end{array}$ & $\begin{array}{l}\text { Bluteau (1712-1728): OBVIAR. Prevenir. } \\
\text { Morais Silva (1813): OBVIÁR, v. at. Prevenir, atalhar anticipadamente } \\
\quad \text { o mal, que há-de vir. }\end{array}$ \\
\hline
\end{tabular}




\begin{tabular}{|l|l|}
\hline $\begin{array}{l}\text { nos } \\
\text { dicionários: }\end{array}$ & $\begin{array}{l}\text { Cunha (1997): obviar } v b \text {. 'remediar, obstar, desviar' XVI. } \\
\text { Ferreira (2004): obviar 2. Obstar, resistir, opor-se. } \\
\text { Houaiss (2007): obviar datação } 15822 \text { apresentar oposição; resistir, } \\
\text { opor-se. }\end{array}$ \\
\hline $\begin{array}{l}\text { Os lexicógrafos Cunha, Ferreira e Houaiss registraram as definições: 'obstar', 'opor- } \\
\text { se', 'apresentar oposição' para a entrada obviar. Já Bluteau e Morais Silva registraram } \\
\text { designações diferentes da acepção buscada. Dos dezesseis entrevistados, apenas três } \\
\text { informantes (F1-H-EF / F2-H-EF e F2-M-ES) responderam que conhecem o item lexical } \\
\text { obviar, mas, analisando o contexto de fala, verifica tratar-se do emprego de outra lexia, no } \\
\text { caso óbvio com o valor de 'verdadeiro'. } \\
\text { Levando em consideração os dados orais, constatou-se que a unidade lexical obviar } \\
\text { com o sentido documentado no corpus escrito não está mais presente na fala dos } \\
\text { entrevistados, configurando um caso de desuso. }\end{array}$
\end{tabular}

\begin{tabular}{|c|c|}
\hline \multicolumn{2}{|c|}{ 47. PATENTEAR / DOC.46, fól.1r, 1.24-25 } \\
\hline $\begin{array}{l}\text { Acepção } \\
\text { buscada }\end{array}$ & Manifestar, evidenciar. \\
\hline $\begin{array}{l}\text { Acepção(ões) } \\
\text { conhecida(s) } \\
\text { pelos } \\
\text { informantes }\end{array}$ & $\begin{array}{l}\text { F1-H-EP: NSR. } \\
\text { F1-M-EP: NSR. } \\
\text { F1-H-EF: NSR. } \\
\text { F1-M-EF: NSR. } \\
\text { F1-H-EM: Você inventa um produto e vai patentear ele. } \\
\text { F1-M-EM: Uma pessoa que sobe de cargo. } \\
\text { F1-H-ES: Patentear minha invenção. } \\
\text { F1-M-ES: NSR. } \\
\text { F2-H-EP: NSR. } \\
\text { F2-M-EP: NSR. } \\
\text { F2-H-EF: Patentear é você inventar alguma coisa, e patentear para que } \\
\text { outro não pegue sua ideia. } \\
\text { F2-M-EF: Você cria alguma coisa e vai ter que registrar, vai patentear, } \\
\text { daí quer dizer registrar. } \\
\text { F2-H-EM: NSR. } \\
\text { F2-M-EM: Quando uma pessoa inventa uma fórmula de um remédio, ou } \\
\text { música, aí tem que patentear a autoria dela. } \\
\text { F2-H-ES: Patentear é registrar. } \\
\text { F2-M-ES: Patentear é quando a pessoa inventa alguma coisa e precisa } \\
\text { registrar. }\end{array}$ \\
\hline
\end{tabular}




\begin{tabular}{|c|c|}
\hline $\begin{array}{l}\text { es } \\
\text { rios }\end{array}$ & $\begin{array}{l}\text { Bluteau (1712-1728): PATENTEAR. Manifestar. Expor à vista. } \\
\text { Morais Silva (1813): PATENTEÁR, v. at. Fazer patente; publico; } \\
\quad \text { manifestar. } \\
\text { Cunha (1997): patente adj. } 2 g \text {. 'franqueado, acessível, evidente' | } \\
\quad \text { patemte XV | patentear } 1813 \text {. } \\
\text { Ferreira (2004): patentear } 1 \text {. Tornar patente, manifesto; franquear, }\end{array}$ \\
\hline \multicolumn{2}{|c|}{$\begin{array}{l}\text { Quanto ao reconhecimento do item lexical patentear, a metade dos informantes } \\
\text { reconheceu essa lexia, mas não com o mesmo sentido da acepção buscada 'manifestar, } \\
\text { evidenciar'. Do total de dezesseis entrevistados, sete informantes (F1-H-EM e F1-H-ES / } \\
\text { F2-H-EF, F2-M-EF, F2-M-EM, F2-H-ES e F2-M-ES) empregaram a lexia patentear com } \\
\text { o sentido de 'registrar'. Esta acepção encontra-se registrada por Ferreira e Cunha com a } \\
\text { definição: 'registrar com(o) patente'. Comparando a resposta da informante F1-M-EM, } \\
\text { verifica-se que esta atribuiu um significado diferente para a forma lexical patentear: 'Uma } \\
\text { pessoa que sobe de cargo'. Nos dicionários pesquisados não consta o registro essa } \\
\text { definição. Com relação à acepção buscada, os lexicógrafos (com exceção de Cunha) } \\
\text { registraram: 'fazer patente', 'manifestar', 'mostrar', 'evidenciar', 'tornar-se manifesto'. } \\
\text { Quanto à datação, Cunha fixa a entrada patentear registrada somente em 1813. Houaiss } \\
\text { a registra no século anterior, em 1789. A unidade lexical patentear consta do documento } \\
\text { manuscrito de } 1799 \text {. Como a lexia patentear já consta do registro de Bluteau, supõe-se } \\
\text { que esta forma lexical já existia bem antes da datação registrada por Houaiss. } \\
\text { Analisando o contexto de uso da unidade lexical patentear e comparando o emprego de } \\
\text { sua acepção por parte dos informantes, constata-se que o significado 'manifestar, } \\
\text { evidenciar' não se faz presente na modalidade oral dos entrevistados em Paranaguá, } \\
\text { configurando, assim, caso de desuso. }\end{array}$} \\
\hline
\end{tabular}

\begin{tabular}{|l|l|}
\hline \multicolumn{2}{|l|}{ 48. PENDER / DOC.47, fól.1v, l.30-33 } \\
\hline $\begin{array}{l}\text { Acepção } \\
\text { buscada }\end{array}$ & Depender, estar sujeito. \\
\hline $\begin{array}{l}\text { Acepção(ões) } \\
\text { conhecida(s) } \\
\text { pelos } \\
\text { informantes }\end{array}$ & $\begin{array}{l}\text { F1-H-EP: NSR. } \\
\text { F1-M-EP: Quando a gente entra na canoa, fala assim: não pende senão a } \\
\text { gente vai cair na água, daí se pender dizem que cai na água. } \\
\end{array}$ \\
& $\begin{array}{l}\text { penso com alguma coisa. Você tá muito pensativo naquilo que vai } \\
\text { fazer. Você fica em cima do muro. }\end{array}$ \\
& $\begin{array}{l}\text { F1-H-EF: NSR. } \\
\text { pender, tá pendendo pro meu lado. }\end{array}$ \\
\hline
\end{tabular}




\begin{tabular}{|c|c|}
\hline & $\begin{array}{l}\text { F1-M-EM: Pender pro lado errado ou pro lado certo. Você vai pender } \\
\text { pra lá ou vai pender pra cá. } \\
\text { F1-H-ES: NSR. } \\
\text { F1-M-ES: Pender, pender pro lado de cá, pro lado de lá. Pender algo. } \\
\text { F2-H-EP: NSR. } \\
\text { F2-M-EP: Pender é quando uma coisa que tá meio falsa, daí eu falo ela } \\
\text { vai pender, no sentido de cair. } \\
\text { F2-H-EF: Pender é no caso você tem duas linhas, daí um pessoal tem } \\
\text { uma tendência, o outro tem outra tendência, aí você opina: ou você } \\
\text { pende praquele, ou você pende pra esse. } \\
\text { F2-M-EF: Minha sogra fala: você só pende para esse lado. } \\
\text { F2-H-EM: Pender aqui pra nóis é quando você tá no mar, daí de repente } \\
\text { a canoa pende. } \\
\text { F2-M-EM: NSR. } \\
\text { F2-H-ES: Pender quer dizer ficar de um lado ou de outro, pender uma } \\
\text { situação, um ponto de vista. } \\
\text { F2-M-ES: Pender é você ficar pendendo em alguma coisa, como que se } \\
\text { diz? Eu vou fazer uma prova, mas não sei fazer, vou ficar pendendo } \\
\text { nisso daí. }\end{array}$ \\
\hline $\begin{array}{l}\text { Acepções } \\
\text { registradas } \\
\text { nos } \\
\text { dicionários }\end{array}$ & $\begin{array}{l}\text { Bluteau (1712-1728): PENDER. Depender. } \\
\text { Morais Silva (1813): PENDÈR, v. n. §. Depender. } \\
\text { Cunha (1997): pendência sf. ‘qualidade do que está pendente' | pender } \\
\quad \text { XIV. } \\
\text { Ferreira (2004): pender 5. Depender. } \\
\text { Houaiss (2007): pender datação sXIV } 7 \text { Estar sujeito a; depender de. }\end{array}$ \\
\hline \multicolumn{2}{|c|}{$\begin{array}{l}\text { A entrada pender está lexicalizada em Bluteau, Morais Silva, Ferreira e Houaiss com a } \\
\text { mesma acepção buscada: 'depender, estar sujeito'. Do total de dezesseis entrevistados, } \\
\text { onze informantes (cinco da faixa I e seis da faixa II) disseram conhecer a lexia, mas } \\
\text { somente o informante F2-H-ES utilizou pender com a acepção mais próxima do sentido } \\
\text { empregado nos documentos manuscritos: 'Pender é você ficar pendendo em alguma } \\
\text { coisa, como que se diz? Eu vou fazer uma prova, mas não sei fazer, vou ficar pendendo } \\
\text { nisso dai'. Infere-se, portanto, por meio deste exemplo, alguém que fez a prova ficará } \\
\text { dependendo do resultado da mesma para saber se será aprovado ou não. Quanto à } \\
\text { respostas dos outros dez informantes, o contexto de uso é diferente da acepção em estudo: } \\
\text { (i) quatro informantes (F1-M-EP e F1-M-ES / F2-M-EP e F2-H-EM) utilizaram a lexia } \\
\text { pender com o sentido de 'inclinar', 'descair', e (ii) os outros seis (F1-H-EF, F1-H-EM e } \\
\text { F1-M-EM / F2-H-EF, F2-M-EF e F2-H-ES) a empregaram no sentido de 'ter tendência, } \\
\text { propensão, preferência'. } \\
\text { Analisando os dados em questão, constatou-se que o item lexical pender com o sentido } \\
\text { da acepção buscada não se encontra mais registrada em contexto de fala dos entrevistados }\end{array}$} \\
\hline
\end{tabular}


de Paranaguá. Das dez ocorrências proferidas pelos informantes, o significado atribuído por eles refere-se a outros itens lexicais.

Considerando o contexto de fala dos informantes, presume-se que a acepção buscada 'depender, estar sujeito' em concorrência com demais acepções, perdeu forças e deixou de ser utilizada, tendo sido provavelmente substituída por outra lexia para designar o significado em estudo. Conjectura-se, dessa forma, tratar-se de um caso de lexia em desuso

\begin{tabular}{|c|c|}
\hline \multicolumn{2}{|c|}{ 49. PERVERTER / DOC.45, fól.1r, l.23-28 } \\
\hline $\begin{array}{l}\text { Acepção } \\
\text { buscada: }\end{array}$ & Efetuar alteração, sofrer mudança. \\
\hline $\begin{array}{l}\text { Acepção(ões) } \\
\text { conhecida(s) } \\
\text { pelos } \\
\text { informantes }\end{array}$ & $\begin{array}{l}\text { F1-H-EP: NSR. } \\
\text { F1-M-EP: NSR. } \\
\text { F1-H-EF: Pervertido, uma pessoa perversa. } \\
\text { F1-M-EF: Perverter é a mesma coisa que pervertido. } \\
\text { F1-H-EM: Conheço só perversão. } \\
\text { F1-M-EM: Conheço pervertido, é uma pessoa que não pensa pra falar, } \\
\text { solta qualquer coisa. } \\
\text { F1-H-ES: NSR. } \\
\text { F1-M-ES: Perverter de pervertido, no sentido ruim. } \\
\text { F2-H-EP: NSR. } \\
\text { F2-M-EP: NSR. } \\
\text { F2-H-EF: É quando uma pessoa vem da perversidade, vem da perversão, } \\
\text { uma coisa errada, perverter. } \\
\text { F2-M-EF: Perverter no meu ver é uma pessoa muito certinha e de } \\
\text { repente ele se transforma. } \\
\text { F2-H-EM: É muito usado quando uma mocinha certinha e uma outra que } \\
\text { errada, quer levar ela pro caminho da maldição, perversão. } \\
\text { F2-M-EM: NSR. } \\
\text { F2-H-ES: Perverter quer dizer que sai do sentido legal, do que a lei } \\
\text { determina e ele passa a exercer uma atividade que não seja legal, } \\
\text { perverteu-se. Se utilizava muito com a meninas, quando elas viravam } \\
\text { prostitutas, elas ficaram pervertidas. } \\
\text { F2-M-ES: Perverter é perversidade, fazer perversão. }\end{array}$ \\
\hline $\begin{array}{l}\text { Acepções } \\
\text { registradas } \\
\text { nos } \\
\text { dicionários }\end{array}$ & $\begin{array}{l}\text { Bluteau (1712-1728): PERVERTER, he o contrario de converter. } \\
\text { Perverter alguem com maos exemplos, conselhos, ou documentos, he } \\
\text { ser causa de que se aparte do caminho da virtude, ou da verdade. } \\
\text { Morais Silva (1813): PERVERTĖ, v. at. §. Perverter a órdem; } \\
\text { alterando-a para má: perverter as leis da natureza, as ordens, etc. }\end{array}$ \\
\hline
\end{tabular}




\begin{tabular}{|l|l|}
\hline & $\begin{array}{c}\text { Cunha (1997): perversão sf. 'ato ou efeito de perverter' 'corrupção' } \\
\text { perverter XVI. } \\
\text { Ferreira (2004): perverter 2. Realizar mudança, alteração, em; alterar, } \\
\text { transtornar. } \\
\text { Houaiss (2007): perverter datação sXIV } 2 \text { efetuar alteração em; mudar. }\end{array}$ \\
\hline Analisando o contexto de utilização da lexia perverter presente na fala dos informantes \\
de Paranaguá, constata-se que sua ocorrência é bastante produtiva. Porém, dos dezesseis \\
entrevistados, dez informantes (cinco da faixa I e cinco da faixa II) reconheceram o item \\
lexical perverter apenas com o sentido de 'tornar perverso ou mau; corromper, depravar, \\
desmoralizar', que se encontra lexicalizado em Bluteau, Ferreira e Houaiss na primeira \\
acepção da unidade lexical perverter. Estes informantes empregaram os seguintes \\
significados: 'pessoa perversa', 'pessoa se transforma', 'pervertido', 'perversidade', \\
'perversão', 'fazer perversão', 'caminho da maldição'. A acepção investigada 'efetuar \\
alteração, sofrer mudança' encontra-se lexicalizada em Morais Silva, Cunha, Ferreira e \\
Houaiss. Analisando os dados apresentados, c o n s t a t a -se que, no contexto de fala \\
dos informantes parnanguaras, o item lexical perverter deixou de ser usado com o sentido \\
da acepção em estudo, porém é bastante produtivo quando empregado com outros \\
significados. Portanto, a unidade lexical configura um caso de desuso.
\end{tabular}

\begin{tabular}{|c|c|}
\hline \multicolumn{2}{|c|}{ 50. PÔR OS OLHOS / DOC.22, fól.1v, l.12-14 } \\
\hline $\begin{array}{l}\text { Acepção } \\
\text { buscada }\end{array}$ & Cuidar. \\
\hline $\begin{array}{l}\text { Acepção(ões) } \\
\text { conhecida(s) } \\
\text { pelos } \\
\text { informantes }\end{array}$ & $\begin{array}{l}\text { F1-H-EP: É quando a gente cobiça as coisas dos outros. } \\
\text { F1-M-EP: Põe os olhos em alguém, ficar olhando. } \\
\text { F1-H-EF: Pôr os olhos é cobiçar as coisas que é do outro, querer se } \\
\text { apossar daquilo que não é seu. } \\
\text { F1-M-EF: NSR. } \\
\text { F1-H-EM: No sentido de cobiçar e ver. } \\
\text { F1-M-EM: NSR. } \\
\text { F1-H-ES: NSR. } \\
\text { F1-M-ES: Pôr os olhos em alguém, em algo, alguma coisa. } \\
\text { F2-H-EP: Pôr os olhos é você tem um troço assim, o cara chega e põe os } \\
\text { olhos. Os olhos gordos. } \\
\text { F2-M-EP: Pôr os olhos nas crianças pra que elas não caem, não se } \\
\text { machuca. } \\
\text { F2-H-EF: Pôr os olhos, seria você ter alguma coisa e a pessoa ficar } \\
\text { admirando ou querendo ter também. } \\
\text { F2-M-EF: É ficar olhando alguma coisa, cuidando. } \\
\text { F2-H-EM: É cuidar de alguém. }\end{array}$ \\
\hline
\end{tabular}




\begin{tabular}{|c|c|}
\hline & -M-ES: No sentido de cobiçar e cuidar de alguem. \\
\hline $\begin{array}{l}\text { epções } \\
\text { yistradas } \\
\text { s } \\
\text { ionários }\end{array}$ & $\begin{array}{l}\text { Morais Silva (1813): N.D. } \\
\text { Cunha (1997): N.D. } \\
\text { Ferreira (2004): N.D. } \\
\text { Houaiss (2007): N.D. }\end{array}$ \\
\hline \multicolumn{2}{|c|}{$\begin{array}{l}\text { A expressão pôr os olhos não está lexicalizada em nenhum dos dicionários } \\
\text { pesquisados. Mas, analisando o seu contexto de uso, verifica-se ser esta expressão } \\
\text { bastante produtiva na fala dos informantes parnanguaras. Dos dezesseis entrevistados, } \\
\text { somente três informantes da faixa I (F1-M-EF, F1-M-EM e F1-H-ES) disseram } \\
\text { desconhecer a expressão. Quanto à acepção buscada, apenas cinco informantes da faixa II } \\
\text { (F2-M-EP, F2-M-EF, F2-H-EM, F2-H-ES e F2-M-ES) ainda utilizam pôr os olhos com o } \\
\text { sentido de 'cuidar', 'ficar atento'. O informante F2-M-ES, além de utilizar o mesmo } \\
\text { sentido em estudo para a expressão pôr os olhos, a emprega também com o conceito 'de } \\
\text { cobiçar'. Esta designação foi a mais produtiva, se comparada com as demais acepções } \\
\text { reconhecidas pelos entrevistados: seis informantes (três da faixa I e três da faixa II) a } \\
\text { utilizam em seu dia a dia. Já o sentido de 'ficar olhando alguém ou algo' é empregado por } \\
\text { três informantes femininas: F1-M-EP e F1-M-ES / F2-M-EM. } \\
\text { Considerando que somente cinco informantes da faixa II ainda empregam a } \\
\text { locução verbal pôr os olhos com o mesmo sentido da acepção documentada no corpus } \\
\text { escrito, e nenhum informante da faixa I a reconhece com este sentido, presume-se que } \\
\text { esta expressão apresenta tendência ao desuso. }\end{array}$} \\
\hline
\end{tabular}

\begin{tabular}{|l|l|}
\hline \multicolumn{2}{|l|}{ 51. SUBITAR / DOC.31, fól.1v, l.05-08 } \\
\hline $\begin{array}{l}\text { Acepção } \\
\text { buscada }\end{array}$ & Ir a baixo, derrubar. \\
\hline $\begin{array}{l}\text { Acepção(ões) } \\
\text { conhecida(s) } \\
\text { pelos }\end{array}$ & F1-H-EP: NSR. \\
informantes & F1-M-EP: NSR. \\
& F1-M-EF: NSR. NSR. \\
& F1-H-EM: NSR. \\
& F1-M-EM: NSR. \\
& F1-H-ES: NSR. \\
& F1-M-ES: NSR. \\
& F2-H-EP: NSR. \\
& F2-M-EP: NSR. \\
\hline
\end{tabular}




\begin{tabular}{|c|c|}
\hline & $\begin{array}{l}\text { F2-H-EF: NSR. } \\
\text { F2-M-EF: NSR. } \\
\text { F2-H-EM: NSR. } \\
\text { F2-M-EM: NSR. } \\
\text { F2-H-ES: NSR. } \\
\text { F2-M-ES: NSR. }\end{array}$ \\
\hline $\begin{array}{l}\text { Acepções } \\
\text { registradas } \\
\text { nos } \\
\text { dicionários }\end{array}$ & $\begin{array}{l}\text { Bluteau (1712-1728): N.D. } \\
\text { Morais Silva (1813): N.D. } \\
\text { Cunha (1997): súbito adj. Do lat. subitus, part. pass. de subīe 'pôr } \\
\quad \text { debaixo de'. } \\
\text { Ferreira (2004): N.D. } \\
\text { Houaiss (2007): [subit- antepositivo, ver }{ }^{2} \text { i-. }{ }^{2} \text { i- 14. v. lat. subèo, is } \\
\quad \text { propriamente 'ir para baixo de]. }\end{array}$ \\
\hline \multicolumn{2}{|c|}{$\begin{array}{l}\text { O caso da lexia subitar é pertinente por não constar seu registro nem da modalidade } \\
\text { oral, por parte dos informantes de Paranaguá, nem dos dicionários pesquisados. Porém } \\
\text { foram encontrados rastros da acepção buscada 'ir a baixo, derrubar' em Cunha e em } \\
\text { Houaiss. O primeiro registra o lema súbito de origem lat. subitus, particípio passado de } \\
\text { subire com o sentido de 'pôr debaixo de'. O segundo apresenta somente como } \\
\text { antepositivo 'subit-' e remete a 'i-', que, por sua vez, na décima quarta acepção tem o } \\
\text { valor de 'ir pra baixo'. } \\
\text { Portanto, como não há seu registro nem na modalidade oral nem nos dicionários } \\
\text { pesquisados, pressupõe-se que a unidade lexical subitar tenha caído em desuso. }\end{array}$} \\
\hline
\end{tabular}

\section{SUBSCREVER / DOC.28, fól.1r, l.13-15}

\begin{tabular}{|l|l}
\hline $\begin{array}{l}\text { Acepção } \\
\text { buscada }\end{array}$ & Aprovar, aceitar. \\
\hline $\begin{array}{l}\text { Acepção(ões) } \\
\text { conhecida(s) } \\
\text { pelos } \\
\text { informantes }\end{array}$ & $\begin{array}{l}\text { F1-H-EP: NSR. } \\
\text { F1-H-EP: NSR. } \\
\text { F1-M-EF: NSR. } \\
\text { F1-H-EM: NSR. } \\
\text { F1-M-EM: NSR. } \\
\text { F1-H-ES: NSR. } \\
\text { F1-M-ES: Subscrever é reescrever algo, escreve novamente. } \\
\\
\text { F2-H-EP: NSR. } \\
\text { F2-M-EP: NSR. } \\
\text { F2-H-EF: Seria a pessoa que escreve e você dá o teu ok, subscreve. } \\
\text { F2-M-EF: Copiar alguma coisa de alguém. }\end{array}$
\end{tabular}




\begin{tabular}{|c|c|}
\hline & $\begin{array}{l}\text {-H-EM: Aquilo que escreveu e val escrever de novo. } \\
\text {-M-EM: NSR. } \\
\text {-H-ES: É quando escreve embaixo. } \\
\text {-M-ES: NSR. }\end{array}$ \\
\hline $\begin{array}{l}\text { ções } \\
\text { rradas } \\
\text { nários }\end{array}$ & $\begin{array}{l}\text { Bluteau (1712-1728): SUBSCREVER, ou Sobscrever. Escrever hũa } \\
\text { cousa debayxo de outra. } \\
\text { Morais Silva (1813): SUBSCREVER,v. at. Escrever debaixo de outras } \\
\text { palavras; subscrever o seu nome. } \\
\text { Cunha (1997): escrever vb. 'redigir, exprimir-se por escrito, gravar' | } \\
\text { Subscrever | sobscriber XIII. } \\
\text { Ferreira (2004): subscrever 3. Aceitar ou aprovar escrito, julgamento, } \\
\text { opinião. } \\
\text { Houaiss (2007): subscrever datação } 12612 \text { Derivação: por extensão de } \\
\text { sentido: estar ou pôr-se de acordo; aceitar, aprovar, anuir. }\end{array}$ \\
\hline \multicolumn{2}{|c|}{$\begin{array}{l}\text { Analisando o contexto de uso do item lexical subscrever, constata-se baixa } \\
\text { produtividade presenta na fala dos entrevistados. Dos dezesseis entrevistados, onze } \\
\text { informantes (sete da faixa I e quatro da faixa II) disseram não conhecer a lexia subscrever, } \\
\text { e os cinco que ainda reconhecem a unidade lexical a empregam com variação de } \\
\text { significados. Para os informantes F1-M-ES e F2-H-EM, subscrever é o mesmo que } \\
\text { 'reescrever, escrever novamente'. A informante F2-M-EF a define como 'Copiar alguma } \\
\text { coisa de alguém'. Estas duas acepções não se encontram registradas em nenhum dos } \\
\text { dicionários pesquisados para o item lexical subscrever. Já o informante F2-H-ES emprega } \\
\text { a mesma acepção registrada em Bluteau e em Morais Silva: 'subscrever é quando escreve } \\
\text { embaixo'. Quanto à acepção em estudo, somente o informante F2-H-EF a utiliza em seu } \\
\text { contexto de fala: 'Seria a pessoa que escreve e você dá o teu ok, subscreve'. Dos } \\
\text { lexicógrafos, apenas Ferreira e Houaiss registram as designações com o mesmo sentido } \\
\text { documentado nos manuscritos: 'aprovar, aceitar'. Este último dicionarista documenta que } \\
\text { esta designação é uma derivação por extensão de sentido. } \\
\text { Considerando o contexto de uso desta lexia na fala dos entrevistados, verifica-se sua } \\
\text { baixa produtividade, principalmente por parte dos informantes da faixa I. A respeito da } \\
\text { acepção buscada, somente um informante da faixa II ainda a reconhece na forma lexica } \\
\text { subscrever. Dessa forma, supõe tratar-se de uma lexia com tendência ao desuso. }\end{array}$} \\
\hline
\end{tabular}

53. SUSTAR / DOC.48, fól.2r, l.15-19

\begin{tabular}{|l|l|}
\hline $\begin{array}{l}\text { Acepção } \\
\text { buscada }\end{array}$ & Parar, interromper, suspender. \\
\hline $\begin{array}{l}\text { Acepção(ões) } \\
\text { conhecida(s) }\end{array}$ & $\begin{array}{l}\text { F1-H-EP: Conheço só sustar o cheque. } \\
\text { F1-M-EP: Conheço como assustar, de dar susto. }\end{array}$ \\
\hline
\end{tabular}




\begin{tabular}{|c|c|}
\hline & $\begin{array}{l}\text { F1-H-EF: Sustar é assustar com determinada coisa. } \\
\text { F1-M-EF: Cheque sustado, quando manda cancelar. } \\
\text { F1-H-EM: Conheço sustar o cheque, pro banco não compensar. } \\
\text { F1-M-EM: Sustar alguém, dar susto. } \\
\text { F1-H-ES: Conheço no sentido de cancelar o cheque, não seguir avante. } \\
\text { F1-M-ES: Só conheço sustar um cheque, suspender a transação, outro } \\
\text { sentido não uso. } \\
\text { F2-H-EP: Assusta as pessoas, fazer brincadeira. } \\
\text { F2-M-EP: NSR. } \\
\text { F2-H-EF: Sustar é parar, tipo um cheque, você retirar, uma coisa que foi } \\
\text { colocada e você sustou, daí a pessoa não recebe, no caso do cheque e } \\
\text { tal. } \\
\text { F2-M-EF: Tipo um cheque que você deu e pagou por uma coisa que não } \\
\text { funcionou, aí susta o cheque. } \\
\text { F2-H-EM: Suspender. } \\
\text { F2-M-EM: Conheço como sustar o cheque. } \\
\text { F2-H-ES: Sustar é suspender, se susta o processo, se susta o cheque. Usa } \\
\text { assim, ainda hoje. } \\
\text { F2-M-ES: NSR. }\end{array}$ \\
\hline regis & $\begin{array}{l}\text { Bluteau (1712-1728): N.D. } \\
\text { Morais Silva (1813): N.D. } \\
\text { Cunha (1997): sustar, substar vb. 'fazer parar, interromper' | sustar } \\
\quad \text { XIX. } \\
\text { Ferreira (2004): sustar 1. Fazer parar; interromper, suspender. } \\
\text { Houaiss (2007): sustar datação 1817-1819 fazer parar ou parar; } \\
\quad \text { suspender(-se), interromper(-se). }\end{array}$ \\
\hline \multicolumn{2}{|c|}{$\begin{array}{l}\text { Analisando o contexto de uso da lexia sustar, constata-se ser bastante produtiva na fala } \\
\text { dos informantes parnanguaras, porém, a maior parte dos entrevistados reconhece nesta } \\
\text { unidade léxica o sentido de 'parar', 'interromper' correlacionada com o item lexical } \\
\text { 'cheque'. Dessa forma, sustar para os entrevistados é sinônimo de 'parar/ interromper um } \\
\text { cheque'. Essa informação é atestada na fala dos seguintes informantes: F1-H-EP: } \\
\text { 'Conheço só sustar o cheque'; F1-M-EF: 'Cheque sustado, quando manda cancelar'; F1- } \\
\text { H-EM: 'Conheço sustar o cheque, pro banco não compensar'; F1-H-ES: 'Conheço no } \\
\text { sentido de cancelar o cheque, não seguir avante'; F1-M-ES: 'Só conheço sustar um } \\
\text { cheque, suspender a transação, outro sentido não uso'; F2-M-EF: 'Tipo um cheque que } \\
\text { você deu e pagou por uma coisa que não funcionou, aí susta o cheque'; F2-M-EM: } \\
\text { 'Conheço como sustar o cheque'. Logo, os informantes F2-H-EF, F2-H-EM e F2-H-ES } \\
\text { responderam que sustar é sinônimo apenas de 'parar', 'suspender', e complementaram } \\
\text { com exemplo: 'sustar um cheque', 'sustar um processo'. O informante F2-H-ES informa, } \\
\text { por sua vez, ser a lexia sustar no sentido de 'suspender' bastante produtiva na fala dos } \\
\text { parnanguaras. Outros quatro informantes (F1-M-EP, F1-H-EF e F1-M-EM / F2-H-EP) }\end{array}$} \\
\hline
\end{tabular}


associaram o parônimo assustar com sustar, devido à semelhança entre essas formas lexicais, no entanto, são unidades léxicas distintas e com significados também diferentes. Não há o registro do termo sustar nos dicionários de Bluteau e Morais Silva. Nos demais dicionaristas consta da acepção buscada. Segundo Cunha e Ferreira, esta unidade léxica teve sua primeira entrada a partir do séc. XIX. Segundo Houaiss, especificamente em 1817-1819. O documento manuscrito datado em 1800, atesta ser o uso desta lexia anterior à datação informada pelos dicionaristas citados.

Analisando o contexto de utilização da lexia sustar, nota-se que seu emprego na fala dos informantes da faixa I e da faixa II é produtivo. Apesar de a maioria dos informantes empregar sustar o cheque, em seu contexto de fala, averigua-se que o sentido empregado com o acréscimo da forma lexical 'cheque', não altera o sentido documentado nos corpus escrito, pois se trata de uma variante sinônima. Portanto, há indícios desta unidade lexical ser um caso de manutencão.

\begin{tabular}{|c|c|}
\hline \multicolumn{2}{|c|}{ 54. VENTILAR / DOC.25, fól.1r, 1.25-27 } \\
\hline $\begin{array}{l}\text { Acepção } \\
\text { buscada }\end{array}$ & Discutir, debater um assunto, levantar hipóteses. \\
\hline $\begin{array}{l}\text { Acepção(ões) } \\
\text { conhecida(s) } \\
\text { pelos } \\
\text { informantes }\end{array}$ & $\begin{array}{l}\text { F1-H-EP: NSR. } \\
\text { F1-M-EP: NSR. } \\
\text { F1-H-EF: Ventilar de arejar ar. } \\
\text { F1-M-EF: NSR. } \\
\text { F1-H-EM: Abrir a janela pra ventilar o ar. } \\
\text { F1-M-EM: Ventilar de ventilador. } \\
\text { F1-H-ES: NSR. } \\
\text { F1-M-ES: NSR. } \\
\text { F2-H-EP: NSR. } \\
\text { F2-M-EP: O ventilador, eu deixo aí na frente pra ventilar a gente. } \\
\text { F2-H-EF: Ventilar seria você abrir uma janela, ligar um ventilador, fazer } \\
\text { alguma coisa que ventile o espaço. } \\
\text { F2-M-EF: Ventilar é um lugar arejado. } \\
\text { F2-H-EM: Tá ligado a um espaço físico, quando tá muito quente, daí } \\
\text { você liga o ventilador, ventilar. } \\
\text { F2-M-EM: Abro a janela pra ventilar. } \\
\text { F2-H-ES: Tem do ventilador e ventilou-se quer dizer que se falou sobre } \\
\text { um assunto, mas não se sabe ao certo se é verdade, é um termo } \\
\text { duvidoso, ventilou-se. } \\
\text { F2-M-ES: Ventilar é estar num lugar arejado. }\end{array}$ \\
\hline $\begin{array}{l}\text { Acepções } \\
\text { registradas }\end{array}$ & $\begin{array}{l}\text { Bluteau (1712-1728): VENTILAR. Tratar hũa materia conferindo, ou } \\
\text { disputando. Ventilar huma questão. }\end{array}$ \\
\hline
\end{tabular}




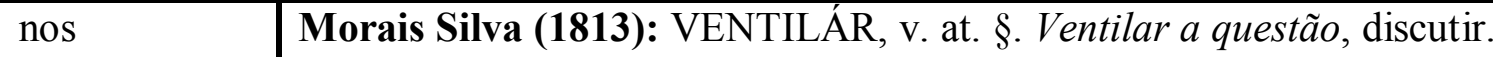 dicionários Cunha (1997): vento $\mathrm{sm}$. | ventilar $v b$. 'introduzir vento a, renovar o ar de' XVI.
Ferreira (2004): ventilar 5. Agitar, debater, discutir.
Houaiss (2007): ventilar datação sXV 7 Derivação: sentido figurado: examinar ou investigar de modo livre e aberto; discutir, debater.

Em consulta aos dicionários na procura da acepção 'discutir, debater um assunto, levantar hipóteses’ para o item lexical ventilar, todos os lexicógrafos (com exceção de Cunha) trazem as designações semelhantes à acepção buscada: 'discutir, debater um assunto, levantar hipóteses'. Houaiss assinala ser esta acepção uma derivação: sentido figurado. Analisando o contexto de uso, o informante F2-H-ES foi o único que ainda reconhece na lexia ventilar o sentido documentado no corpus escrito. Porém, em sua resposta, ele também associa a forma lexical ventilar ao objeto ventilador, cuja função é ventilar. A designação 'arejar' para a lexia ventilar foi a mais produtiva nas respostas dos informantes. Dos dezesseis entrevistados, dez informantes (três da faixa I e sete da faixa II) utilizam apenas com esse significado (com exceção do informante F2-H-ES).

Dessa forma, como a lexia ventilar com o sentido de 'discutir, debater um assunto, levantar hipóteses', não se encontra mais na linguagem dos informantes da faixa I, supõese ser uma unidade lexical com tendência ao desuso.

\section{SUBSTANTIVOS}

\begin{tabular}{|c|c|}
\hline \multicolumn{2}{|c|}{ 55. ACENO / DOC.36, fól.1r, 1.21-24 } \\
\hline $\begin{array}{l}\text { Acepção } \\
\text { buscada }\end{array}$ & Sinal, gesto. \\
\hline $\begin{array}{l}\text { Acepção(ões) } \\
\text { conhecida(s) } \\
\text { pelos } \\
\text { informantes }\end{array}$ & $\begin{array}{l}\text { F1-H-EP: NSR. } \\
\text { F1-M-EP: NSR. } \\
\text { F1-H-EF: Aceno é acenar, dar tchau. } \\
\text { F1-M-EF: NSR. } \\
\text { F1-H-EM: Acenar pra uma pessoa. Acenar indicando alguma coisa. } \\
\quad \text { Fazendo sinal a distância. } \\
\text { F1-M-EM: Acenar para ser visto, dar um aceno, um sinal. } \\
\text { F1-H-ES: NSR. } \\
\text { F1-M-ES: Conheço acenar. } \\
\text { F2-H-EP: Acenar pra pessoa. } \\
\text { F2-M-EP: NSR. } \\
\text { F2-H-EF: Seria um sinal, ou com a cabeça ou com a mão, um oi, um } \\
\quad \text { sinal. }\end{array}$ \\
\hline
\end{tabular}




\begin{tabular}{|c|c|}
\hline & $\begin{array}{l}\text { F2-M-EF: Dar um tchau. } \\
\text { F2-H-EM: Sentido de cumprimentação. } \\
\text { F2-M-EM: Vou dar um aceno pra'quela pessoa, vou acenar pra ela. } \\
\text { F2-H-ES: Aceno de acenar, mas dentro do processo aceno ele tem o } \\
\text { sentido de que tem algo que apoia. "Acena-se que vai ser possível ser } \\
\text { feito". Há uma possibilidade que seja feita, há um aceno. } \\
\text { F2-M-ES: É quando alguém passa e te cumprimenta. }\end{array}$ \\
\hline $\begin{array}{l}\text { Acepções } \\
\text { registradas } \\
\text { nos } \\
\text { dicionários }\end{array}$ & $\begin{array}{l}\text { Bluteau (1712-1728): ACENO, Acêno. Sinal, que se dà com a cabeça, } \\
\text { olhos, ou mãos. } \\
\text { Morais Silva (1813): ACENO, s. m. Sinal do olhos, cabeça, ou mãos, } \\
\text { para darmos a entender alguma coisa; qualquer leve indicio, ou sinal } \\
\text { dos conceitos, da vontade. } \\
\text { Cunha (1997): acenar } v b \text {. 'fazer acenos, sinais' | aceno XV. } \\
\text { Ferreira (2004): aceno } 1 . \text { Movimento da cabeça, dos olhos ou das } \\
\text { mãos, para exprimir idéias; gesto, sinal. } \\
\text { Houaiss (2007): aceno datação sXV } 1.1 \text { sinal que se faz com a cabeça, } \\
\text { os olhos, as mãos etc. para dar a conhecer o que se deseja; gesto. }\end{array}$ \\
\hline \multicolumn{2}{|c|}{$\begin{array}{l}\text { Analisando o contexto de utilização da lexia aceno, verifica-se ser esta bastante } \\
\text { produtiva na fala dos informantes parnanguaras. Quanto à acepção buscada 'sinal, gesto', } \\
\text { a maior parte dos entrevistados a empregam com este mesmo sentido. Sete informantes } \\
\text { (F1-H-EF, F1-H-EM- F1-M-EM e F1-M-ES / F2-H-EP, F2-M-EM e F2-H-ES) empregam } \\
\text { em suas respostas as formas lexicais aceno e acena que correspondem ao mesmo valor de } \\
\text { 'sinal' e 'gesto', portanto se tratam de variantes sinônimas cujo significado é o mesmo. O } \\
\text { informante F2-H-ES, além de conhecer a lexia aceno com o sentido 'de acenar', traz uma } \\
\text { informação nova quanto à definição deste item lexical: 'mas dentro do processo aceno, ele } \\
\text { tem o sentido de que tem algo que apoia. “Acena-se que vai ser possível ser feito". Há } \\
\text { uma possibilidade que seja feita, há um aceno'. Com relação ao emprego do item lexical } \\
\text { aceno exemplificado por este informante, em nenhum dos dicionários pesquisados consta } \\
\text { tal designação. Os lexicógrafos Bluteau, Morais Silva, Ferreira e Houaiss registram as } \\
\text { acepções: 'gesto', 'movimento da cabeça, dos olhos, das mãos'. } \\
\text { Analisando o contexto de utilização da lexia aceno, verifica-se no estágio atual de } \\
\text { variação, a coocorrência com a forma lexical acenar, porém seu emprego na fala dos } \\
\text { informantes refere-se ao mesmo sentido atribuído à unidade lexical aceno. Conjectura-se } \\
\text { dessa forma, ser uma lexia com tendência à manutenção. }\end{array}$} \\
\hline
\end{tabular}

56. AGUARDENTE / DOC.46, fól.1r, 1.35-37

\begin{tabular}{|l|l|}
\hline $\begin{array}{l}\text { Acepção } \\
\text { buscada }\end{array}$ & Bebida de teor alcoólico. \\
\hline $\begin{array}{l}\text { Acepção(ões) } \\
\text { conhecida(s) }\end{array}$ & $\begin{array}{l}\text { F1-H-EP: É a pinga. } \\
\text { F1-M-EP: Eu falo cachaça. }\end{array}$ \\
\hline
\end{tabular}




\begin{tabular}{|c|c|}
\hline $\begin{array}{l}\text { pelos } \\
\text { informantes }\end{array}$ & $\begin{array}{l}\text { F1-H-EF: Aguardente pra nós é cachaça, pinga. } \\
\text { F1-M-EF: Cachaça. } \\
\text { F1-H-EM: É pinga. } \\
\text { F1-M-EM: Aguardente é pinga, cachaça, água que passarinho não bebe. } \\
\text { F1-H-ES: Cachaça. } \\
\text { F1-M-ES: Cachaça. } \\
\text { F2-H-EP: Aguardente é uma bebida aqui. } \\
\text { F2-M-EP: Aguardente é uma bebidade de tomar, bebida de álcool. } \\
\text { F2-H-EF: A pinga que eu conheço, uma bebida de álcool, uma } \\
\text { aguardente. } \\
\text { F2-M-EF: É cachaça. } \\
\text { F2-H-EM: Pra nóis é a bebida, cachaça. } \\
\text { F2-M-EM: Aguardente pra nós é cachaça. } \\
\text { F2-H-ES: É pinga. } \\
\text { F2-M-ES: Aguardente é caipirinha com limão. }\end{array}$ \\
\hline $\begin{array}{l}\text { Acepções } \\
\text { registradas } \\
\text { nos } \\
\text { dicionários }\end{array}$ & $\begin{array}{l}\text { Bluteau (1712-1728): AGOARDENTE. He vinho destilado atè ficar a } \\
\text { sexta parte. } \\
\text { Morais Silva (1813): AGUARDÈNTE, s. f. Licor espirituoso do vinho, } \\
\text { grãos, succo de canna, borras de assucar. } \\
\text { Cunha (1997): água sf. 'líquido incolor, inodoro e insípido, essencial à } \\
\text { vida' | aguardente XVI. } \\
\text { Ferreira (2004): aguardente 1. Bebida de elevado teor alcoólico ( } 40 \% \\
\text { a } 60 \% \text { ), que se obtém por destilação de inúmeros frutos, cereais, } \\
\text { raízes, sementes, tubérculos, etc. } \\
\text { Houaiss (2007): aguardente datação sXV bebida de teor alcoólico } \\
\text { elevado, obtida pela destilação do caldo da cana-de-açúcar, do vinho, } \\
\text { do bagaço de uvas, de cereais, raízes, tubérculos, frutos e outros } \\
\text { produtos vegetais doces, depois de fermentados. }\end{array}$ \\
\hline \multicolumn{2}{|c|}{$\begin{array}{l}\text { Da lexia aguardente, a maioria dos informantes a denomina por 'cachaça' e 'pinga'. } \\
\text { Todos os informantes da faixa I apresentaram essas variantes lexicais 'cachaça' e 'pinga' } \\
\text { para a resposta desta questão. Os informantes da faixa II (F2-H-EP, F2-M-EP e F2-H-EF) } \\
\text { definiram aguardente como 'uma bebida de álcool'. E a informante F2-M-ES associou o } \\
\text { conteúdo aguardente com um tipo de bebida conhecida como 'caipirinha'. Os outros } \\
\text { quatro informantes (F2-M-EF, F2-H-EM, F2-M-EM e F2-H-ES) utilizaram as variantes } \\
\text { 'pinga' e 'cachaça' para definir o item lexical aguardente. As acepções 'vinho destilado', } \\
\text { 'licor espirituoso de vinho', 'bebida de elevador teor alcoólico', 'bebida obtida por meio } \\
\text { de destilação de vários ingredientes' presentes nas definições dos lexicógrafos (com } \\
\text { exceção de Cunha) referem-se, de certa forma, ao modo de preparo dessa bebida de teor } \\
\text { alcoólico, presentes na acepção da entrada aguardente. } \\
\text { Analisando o contexto de uso da lexia aguardente nas respostas dos informantes de } \\
\text { Paranaguá, nota-se que seu emprego está perdendo forças para as variantes concorrentes }\end{array}$} \\
\hline
\end{tabular}


'pinga' e 'cachaça', pois estes itens lexicais apresentam o mesmo valor da acepção em estudo: 'bebida de teor alcoólico'. Portanto, presume-se ser aguardente um caso de tendência ao desuso.

\begin{tabular}{|c|c|}
\hline \multicolumn{2}{|c|}{ 57. ALQUEIRE / DOC.47, fól.2r, l.01-03 } \\
\hline $\begin{array}{l}\text { Acepção } \\
\text { buscada }\end{array}$ & Unidade de medida agrária. \\
\hline $\begin{array}{l}\text { Acepção(ões) } \\
\text { conhecida(s) } \\
\text { pelos } \\
\text { informantes }\end{array}$ & $\begin{array}{l}\text { F1-H-EP: Conheço o alqueire de terra. } \\
\text { F1-M-EP: NSR. } \\
\text { F1-H-EF: NSR. } \\
\text { F1-M-EF: Alqueire é de terra, mas aqui em Paranguá quase ninguém fala } \\
\text { alqueire. } \\
\text { F1-H-EM: NSR. } \\
\text { F1-M-EM: NSR. } \\
\text { F1-H-ES: É metragem. Alqueire é uma medida igual hectare, só que uma } \\
\text { é maior que a outra. } \\
\text { F1-M-ES: NSR. } \\
\text { F2-H-EP: É medida de terra. } \\
\text { F2-M-EP: Eu não uso, mas minha sogra fala alqueire de terra. } \\
\text { F2-H-EF: Alqueire é mais pra terra, na colônia fala, trata como alqueire, } \\
\text { não sei se é 10, } 100 \text { metros quadrados, numa fazenda mede em } \\
\text { alqueire ou hectare. } \\
\text { F2-M-EF: Alqueire é quando se mede as terras numa fazenda, lá tem } \\
\text { tantos alqueires. } \\
\text { F2-H-EM: Alqueire é um lugar de marcação de terra onde vai comprar. } \\
\text { F2-M-EM: Fazem colheita de } 5 \text { alqueires de farinha, de arroz. Aqui em } \\
\text { Paranaguá é um tipo de medida. } \\
\text { F2-H-ES: É uma medição de terra. } \\
\text { F2-M-ES: Alqueires é quando tem uma fazenda. }\end{array}$ \\
\hline $\begin{array}{l}\text { Acepções } \\
\text { registradas } \\
\text { nos } \\
\text { dicionários }\end{array}$ & $\begin{array}{l}\text { Bluteau (1712-1728): ALQUEIRE. Medida de todo o genero de grãos. } \\
\text { Morais Silva (1813): ALQUEIRE, s. m. Medida de grãos: seis alqueires } \\
\text { fazem um saco. } \\
\text { Cunha (1997): alqueire sm. 'medida de área' XIII. } \\
\text { Ferreira (2004): alqueire } 2 \text {. Bras. Unidade de medida de superfície } \\
\text { agrária equivalente em MG, RJ e GO a } 10.000 \text { braças quadradas ( } 4 \text {, } \\
84 \text { hectares), e em SP a } 5.000 \text { braças quadradas ( } 2,42 \text { hectares). } \\
\text { Houaiss (2007): alqueire datação } 11112 \text { Rubrica: metrologia. } \\
\text { Regionalismo: Brasil: unidade de medida de superfície agrária. }\end{array}$ \\
\hline
\end{tabular}


Analisando o contexto de uso da lexia alqueire, verifica tratar-se de um item lexical bastante produtiva na fala dos informantes de Paranaguá. Quanto à acepção buscada 'unidade de medida agrária', a maior parte dos entrevistados (três da faixa I e cinco da faixa II) a emprega com este mesmo sentido. Porém, há quatro ocorrências a se comentar: (i) a informante F1-M-EF reconhece que a forma léxica alqueire tem relação com o campo semântico terra, mas adverte que 'em Paranaguá quase ninguém fala alqueire'; (ii) já a informante F2-M-EP foi incisiva ao afirmar que não usa a lexia alqueire, mas sabe que se refere à terra porque sua 'sogra fala'; (iii) o informante F2-H-EM atribuiu à lexia alqueire o mesmo valor de 'um lugar de marcação de terra'; enquanto que (iv) o informante F2-H-ES associou alqueire à fazenda, inferindo, dessa forma, ser a fazenda um lugar onde tem uma grande extensão de terra. Logo alqueire, segundo este informante, relaciona-se ao campo semântico terra.

A entrada alqueire com a definição de 'unidade de medida agrária' encontra-se lexicalizado por Cunha, Ferreira e Houaiss. Em Bluteau e Morais Silva o item lexical alqueire designa 'medida de gênero de grãos'. Ferreira classifica esta acepção como brasileirismo e Houaiss como Regionalismo do Brasil, pertencente ao campo da metrologia.

O emprego deste item lexical, presente na fala da maioria dos informantes com a mesma acepção em estudo, portanto, apresenta tendência à manutencão.

\begin{tabular}{|l|l|}
\hline \multicolumn{2}{|l|}{ 58. ALUGADOR / DOC.47, fól.2r, l.20-24 } \\
\hline $\begin{array}{l}\text { Acepção } \\
\text { buscada }\end{array}$ & Pessoa que aluga, locatário, locador. \\
\hline $\begin{array}{l}\text { Acepção(ões) } \\
\text { conhecida(s) } \\
\text { pelos } \\
\text { informantes }\end{array}$ & $\begin{array}{l}\text { F1-H-EP: Alugador é aquele que aluga pra mim, aluga uma casa, essas } \\
\text { coisas que tem pra alugar. }\end{array}$ \\
$\begin{array}{l}\text { F1-H-EP: NSR. } \\
\text { Tem também o alugador de um imóvel. } \\
\text { F1-M-EF: É alguém que aluga a casa, aquele que coloca pra alugar. } \\
\text { F1-H-EM: Na praia tem as cadeiras pra alugar, daí tem o alugador de } \\
\text { cadeira. } \\
\text { F1-M-EM: Quem aluga um imóvel é um alugador. } \\
\text { F1-H-ES: NSR. } \\
\text { F1-M-ES: Alugador é no lugar de locador, locatário. } \\
\text { F2-H-EP: É um inquilino. } \\
\text { F2-M-EP: Alugador quando a gente aluga um imóvel. } \\
\text { F2-H-EF: Alugador seria o cara que trabalha na imobiliária, locador no } \\
\text { caso. É o locador. } \\
\text { F2-M-EF: Conheço só inquilino. }\end{array}$ \\
\hline
\end{tabular}




\begin{tabular}{|c|c|}
\hline & $\begin{array}{l}\text { F2-H-EM: Quando alguém vai alugar alguma coisa, uma moradia, vive } \\
\text { de aluguel, ele é alugador. } \\
\text { F2-M-EM: As crianças deixam a gente de cabeça quente: aquele ali é um } \\
\text { alugador, vive alugando a gente. } \\
\text { F2-H-ES: Conheço só locatário. } \\
\text { F2-M-ES: Alugador é a pessoa que aluga alguma coisa. }\end{array}$ \\
\hline $\begin{array}{l}\text { Acepções } \\
\text { registradas } \\
\text { nos } \\
\text { dicionários }\end{array}$ & $\begin{array}{l}\text { Bluteau (1712-1728): ALUGADOR. O que toma por aluguel. O que dà } \\
\text { em aluguel. } \\
\text { Morais Silva (1813): ALUGADOR, s. m. O que dá á coisa por aluguel. } \\
\text { V. Alugador da casa. §. O que recebe a coisa para usar della por certo } \\
\text { preço, se diz hoje alugador, e se dizia alugueiro. } \\
\text { Cunha (1997): alugar vb. 'ceder (ou tomar) mediante pagamento, por } \\
\text { algum tempo, um imóvel, um objeto etc' 'arrendar' | alugador XIII. } \\
\text { Ferreira (2004): alugador } 1 \text {. Aquele que aluga. } 2 \text {. V. locatário. } \\
\text { Houaiss (2007): alugador datação sXIII que ou o que aluga } 1 \text { que ou o } \\
\text { que dá algo em aluguel; locador. }\end{array}$ \\
\hline \multicolumn{2}{|c|}{$\begin{array}{l}\text { O registro da entrada alugador nos dicionários analisados (com exceção de Cunha) traz } \\
\text { a mesma acepção documentada no corpus escrito 'pessoa que aluga', 'locatário', } \\
\text { 'locador'. Analisando o contexto de uso da lexia alugador e comparando com a acepção } \\
\text { buscada, certifica-se que seu emprego ainda está presente na fala da maioria dos } \\
\text { informantes (seis da faixa I e seis da faixa II). Quanto à variação de significado, a } \\
\text { informante F2-M-EM empregou alugar no sentido de 'enganar' e no sentido de 'alugar } \\
\text { um imóvel'. Já a informante F2-M-EM atribuiu à lexia alugar somente o valor de } \\
\text { 'incomodar', 'tomar o tempo de alguém'. Houaiss assinala ser esta última acepção como } \\
\text { um regionalismo brasileiro de uso informal. Esteve presente no enunciado dos } \\
\text { informantes (F1-M-ES / F2-H-EF e F2-H-ES) as variantes lexicais 'locador' e 'locatário' } \\
\text { cujo significado é mesmo do item lexical alugador. Para o informante F2-H-EP, a unidade } \\
\text { lexical 'inquilino' é um sinônimo de alugador. Os dicionários pesquisados registram a } \\
\text { entrada 'inquilino' com o mesmo valor semântico de 'locatário', 'locador'. Mas, para a } \\
\text { informante F2-M-EF, a única forma lexical reconhecida foi 'inquilino', que disse } \\
\text { desconhecer alugador para definir a acepção 'pessoa que aluga'. } \\
\text { Neste contexto de uso da unidade lexical alugador, verifica-se que mesmo em estágio } \\
\text { atual de variação com as formas lexicais 'locador' e 'locatário', sua ocorrência é bastante } \\
\text { produtiva na modalidade oral, visto que doze informantes (seis da faixa I e seis da faixa II) } \\
\text { reconheceram alugador com o mesmo sentido empregado no corpus escrito. Dessa forma, } \\
\text { a lexia alugador apresenta tendência à manutencão. }\end{array}$} \\
\hline
\end{tabular}

59. ARBITRAMENTO / DOC.20, fól.1v, 1.02-06

Acepção

buscada

Decisão, julgamento. 


\begin{tabular}{|c|c|}
\hline $\begin{array}{l}\text { Acepção(ões) } \\
\text { conhecida(s) } \\
\text { pelos } \\
\text { informantes }\end{array}$ & $\begin{array}{l}\text { F1-H-EP: NSR. } \\
\text { F1-M-EP: NSR. } \\
\text { F1-H-EF: NSR. } \\
\text { F1-M-EF: NSR. } \\
\text { F1-H-EM: NSR. } \\
\text { F1-M-EM: No futebol tem o arbitramento, o juiz dita as regras do jogo. } \\
\text { F1-H-ES: NSR. } \\
\text { F1-M-ES: Conheço só o livre arbítrio. } \\
\text { F2-H-EP: NSR. } \\
\text { F2-M-EP: NSR. } \\
\text { F2-H-EF: Arbitramento seria uma pessoa que opina, se tá certo, se tá } \\
\text { errado, age como árbitro, como juiz. } \\
\text { F2-M-EF: Seria alguém que corrige, tipo o juiz. } \\
\text { F2-H-EM: NSR. } \\
\text { F2-M-EM: Quando decide, determina o final, é como de juiz, árbitro. } \\
\text { F2-H-ES: Arbitramento tem no jogo, o juiz de futebol. } \\
\text { F2-M-ES: NSR. }\end{array}$ \\
\hline $\begin{array}{l}\text { Acepções } \\
\text { registradas } \\
\text { nos } \\
\text { dicionários }\end{array}$ & $\begin{array}{l}\text { Bluteau (1712-1728): ARBITRAMENTO. Vid. Arbitrio. [ARBITRIO, } \\
\text { juizo dos que foraõ nomeados arbitros he hum negocio]. } \\
\text { Morais Silva (1813): ARBITRAMÈNTRO, s. m. O juízo, sentença do } \\
\text { Juiz arbitro. } \\
\text { Cunha (1997): N.D. } \\
\text { Ferreira (2004): arbitramento 1. V. arbitragem. [arbitragem 2. O } \\
\text { julgamento, decisão ou veredicto de árbitro(s); arbítrio.]. } \\
\text { Houaiss (2007): arbitramento datação } 16001 \text { Rubrica: termo jurídico: } \\
\text { parecer de avaliação feita por peritos de coisa ou fato; decisão } \\
\text { decorrente de arbitragem. }\end{array}$ \\
\hline \multicolumn{2}{|c|}{$\begin{array}{l}\text { A entrada arbitramento consta do registro dos lexicógrafos pesquisados (com exceção } \\
\text { de Cunha). No entanto, Bluteau remete o consulente à variante lexical 'arbítrio', enquanto } \\
\text { que Ferreira remete à variante 'arbitragem'. As definições registradas por Ferreira e } \\
\text { Houaiss remetem à mesma acepção em estudo 'decisão, julgamento'. Este último } \\
\text { dicionarista informa ser o item lexical arbitramento um termo específico do campo } \\
\text { jurídico. Analisando o contexto de uso da lexia arbitramento, constata-se nas respostas a } \\
\text { não ocorrência da acepção documentada no corpus escrito. Os informantes F1-M-EM / } \\
\text { F2-M-EM e F2-H-ES associaram a forma lexical arbitramento com o jogo de futebol. } \\
\text { Para os informantes F2-H-EF e F2-M-EF arbitramento é uma espécie de juiz, cuja função } \\
\text { é corrigir. E a informante F2-M-ES empregou apenas o 'livre arbítrio', cujo significado, } \\
\text { neste contexto em estudo, não apresenta relação com o item lexical arbitramento. } \\
\text { A ausência de respostas por parte de dez informantes (seis da faixa I e quatro da faixa } \\
\text { II) indica ser esta unidade lexical pouco produtiva no contexto de fala dos entrevistados. }\end{array}$} \\
\hline
\end{tabular}


Dos seis informantes (do is da faixa I e quatro da faixa II) que reconheceram a unidade lexical arbitramento, nenhum empregou o sentido da acepção investigada, presumindo-se, assim, ser um caso de desuso.

60. ARDIL / DOC.32, fól.1v, 1.21-23

\begin{tabular}{|c|c|}
\hline $\begin{array}{l}\text { Acepção } \\
\text { buscada }\end{array}$ & Astúcia, cilada, visa iludir. \\
\hline $\begin{array}{l}\text { Acepção(ões) } \\
\text { conhecida(s) } \\
\text { pelos } \\
\text { informantes }\end{array}$ & $\begin{array}{l}\text { F1-H-EP: NSR. } \\
\text { F1-M-EP: NSR. } \\
\text { F1-H-EF: NSR. } \\
\text { F1-M-EF: NSR. } \\
\text { F1-H-EM: NSR. } \\
\text { F1-M-EM: NSR. } \\
\text { F1-H-ES: NSR. } \\
\text { F1-M-ES: NSR. } \\
\text { F2-H-EP: NSR. } \\
\text { F2-M-EP: NSR. } \\
\text { F2-H-EF: Ardil é ardiloso, no caso assim, a pessoa é esperta, tenta ser } \\
\text { melhor que os outros. } \\
\text { F2-M-EF: NSR. } \\
\text { F2-H-EM: Uma pessoa sagaz, má. } \\
\text { F2-M-EM: NSR. } \\
\text { F2-H-ES: Safado. } \\
\text { F2-M-ES: NSR. }\end{array}$ \\
\hline $\begin{array}{l}\text { Acepções } \\
\text { registradas } \\
\text { nos } \\
\text { dicionários }\end{array}$ & $\begin{array}{l}\text { Bluteau (1712-1728): ARDIL, em lingoa Franceza val o mesmo, que } \\
\text { valente, animoso. } \\
\text { Morais Silva (1813): ARDIL, s. m. O mesmo que ardileza. } \\
\text { [ARDILEZA, s. f. Manha, astucia]. } \\
\text { Cunha (1997): ardil sm. 'astúcia, manha, estratagema' } 1572 . \\
\text { Ferreira (2004): ardil 1. Meio astucioso a que se recorre para burlar } \\
\quad \text { alguém; estratagema, ardileza. } \\
\text { Houaiss (2007): ardil datação sXV } 2 \text { ação que visa iludir, lograr } \\
\quad \text { (pessoa ou animal); armação, cilada. }\end{array}$ \\
\hline \multicolumn{2}{|c|}{$\begin{array}{l}\text { Analisando as respostas dos entrevistados, constata-se que a lexia ardil tem baixa } \\
\text { frequência no contexto de fala dos parnanguaras. Os três informantes que reconheceram a } \\
\text { unidade lexical ardil, a empregaram com valores adjetivais distintos: F2-H-EF: 'Ardil é } \\
\text { ardiloso, um a pessoa é esperta'; F2-H-EM: 'Uma pessoa sagaz, má'; e F2-H-ES: } \\
\text { 'Safado'. Com relação à acepção buscada, Morais Silva, Cunha, Ferreira e Houaiss }\end{array}$} \\
\hline
\end{tabular}


registram os significados: 'astúcia', 'manha', 'estratagema', 'ardileza', 'armação', 'cilada', 'visa iludir'. Bluteau atribui à entrada ardil o mesmo sentido de 'valente', 'animoso'.

Portanto, considerando os dados orais em questão, nota-se que nenhum informante da faixa I faz uso da unidade lexical ardil. A baixa ocorrência presente ainda na fala dos informantes da faixa II apresenta um sentido próximo ao que se encontra registrado nos documentos manuscritos, mas não o mesmo. Dessa forma, a lexia em questão, configura tratar-se de um caso de desuso.

\begin{tabular}{|c|c|}
\hline \multicolumn{2}{|c|}{ 61. ARREMATAÇÃO / DOC.32, fól.1v, l.11-14 } \\
\hline $\begin{array}{l}\text { Acepção } \\
\text { buscada }\end{array}$ & Finalização, conclusão. \\
\hline $\begin{array}{l}\text { Acepção(ões) } \\
\text { conhecida(s) } \\
\text { pelos } \\
\text { informantes }\end{array}$ & $\begin{array}{l}\text { F1-H-EP: NSR. } \\
\text { F1-M-EP: NSR. } \\
\text { F1-H-EF: Arrematar algo, finalizar, concluir. } \\
\text { F1-M-EF: Arrematar o gado. } \\
\text { F1-H-EM: Leilão, arrematar alguma coisa. Uma pessoa que comprou, } \\
\text { deu o lance maior pra comprar, finalizar o lance. } \\
\text { F1-M-EM: Você põe um leilão alguma coisa e arremata. } \\
\text { F1-H-ES: Conheço arremate só, no sentido de acabamento, o fim. } \\
\text { F1-M-ES: Arrematar algo, finalizar. } \\
\text { F2-H-EP: Arrematação de leilão, vai lá e arremata. } \\
\text { F2-M-EP: Arrematação quando a gente vai arrematar alguma coisa, é o } \\
\text { final. } \\
\text { F2-H-EF: Arrematação no caso de um leilão, ou um lote, ou um pessoal } \\
\text { tem um negócio lá pra vender, várias pessoas querem comprar, mas aí } \\
\text { chega um e arremata, compra tudo. Tem no sentido também que o } \\
\text { serviço não tava bem feito e daí ele foi lá e arrumou, arrematou. } \\
\text { F2-M-EF: Num salão de costura, ela arremata a roupa, termina, dá o } \\
\text { acabamento. } \\
\text { F2-H-EM: Um leilão. } \\
\text { F2-M-EM: Os evangélicos dizem que Deus vai fazer uma arrematação } \\
\text { aqui na Terra, só para os escolhidos de Deus. } \\
\text { F2-H-ES: Quando você arremata uma propriedade que esteja em leilão, } \\
\text { então arrematou. } \\
\text { F2-M-ES: Num leilão você arremata uma casa, um quadro. }\end{array}$ \\
\hline $\begin{array}{l}\text { Acepções } \\
\text { registradas }\end{array}$ & $\begin{array}{l}\text { Bluteau (1712-1728): ARREMATAÇAM. Chamase assim, porque he o } \\
\text { Remate, \& o fim dos lanços, nas vendas, que se fazem por mandado }\end{array}$ \\
\hline
\end{tabular}




\begin{tabular}{|c|c|}
\hline , & $\begin{array}{l}\text { do julgador; ou tambem, se chama Arrematação, porque se faz acabado o } \\
\text { termo dos pregoens. } \\
\text { Morais Silva (1813): ARREMATAÇÃO, s. f. A acção de arrematar. } \\
\text { [ARREMATÁR, v. at. Pòr o remate]. } \\
\text { Cunha (1997): rematar } v b \text {. 'dar remate, concluir, completar' | } \\
\text { Arrematação XVI. } \\
\text { Ferreira (2004): arrematar 1. Ato ou efeito de arrematar². } \\
\text { Houaiss (2007): arrematar datação } 15621 \text { ato ou efeito de arrematar. } \\
\text { [arrematar } 1 \text { dar ou alcançar remate, finalização; concluir, acabar, } \\
\text { rematar]. }\end{array}$ \\
\hline $\begin{array}{r}\text { Analis } \\
\text { produtiva } \\
\text { conclusão } \\
\text { informant } \\
\text { arremata } \\
\text { enquanto } \\
\text { 'concluir' } \\
\text { 'arremata } \\
\text { pesquisad } \\
\text { presentes } \\
\text { formas le } \\
\text { item lex } \\
\text { arremata } \\
\text { arremata } \\
\text { Houaiss } \\
\text { lexicaliza } \\
\text { designaçã } \\
\text { Analis } \\
\text { fala dos } \\
\text { informant }\end{array}$ & $\begin{array}{l}\text { ntexto de uso da unidade lexical arrematação, verifica-se ser bastante } \\
\text { los informantes parnanguaras. Quanto à acepção buscada 'finalização, } \\
\text { r parte dos entrevistados a emprega com este mesmo sentido. Os } \\
\text { EF, F1-M-ES e F1-H-ES / F2-M-EP e F2-M-EF utilizam a lexia } \\
\text { o sentido de 'finalização', 'conclusão', 'dar o acabamento', 'fim', } \\
\text { rmantes (três da faixa I e cinco da faixa II) associaram o valor de } \\
\text { zar' aos itens lexicais: 'arrematação de leilão', 'arremate de leilão', } \\
\text { 'leilão'. Quanto à forma lexical leilão, observa-se que, nos dicionários } \\
\text { ignações 'venda pública', 'objetos arrematados' e 'arrematação' estão } \\
\text { ção da lexia arrematação, o que justifica, dessa forma, a associação das } \\
\text { ematação e leilão. Apenas uma informante (F2-M-EM) relacionou o } \\
\text { matação ao campo semântico da religião: 'Deus vai fazer uma } \\
i \text { na Terra'. Provavelmente, essa informante tenha associado } \\
\text { forma lexical arrematar, que é parônimo de arrebatar, registrado por } \\
\text { var, carregar consigo pelos ares'. O lema arrematação encontra-se } \\
\text { hte em Bluteau e em Morais Silva. Em Ferreira e em Houaiss a } \\
\text { efeito de arrematar' refere-se à entrada arrematar. } \\
\text { ntexto de utilização da lexia arrematação, nota-se que seu emprego na } \\
\text { es da faixa I e da faixa II é bem produtivo. Apesar de a maioria dos } \\
\text { gar 'arrematação de leilão' em seu contexto de fala, observa-se que o } \\
\text { nesta expressão é o mesmo documentado nos corpus escrito. Portanto, } \\
\text { utencão. }\end{array}$ \\
\hline
\end{tabular}

62. ARROBA / DOC.22, fól.1r, 1.20-23

\begin{tabular}{|l|l|}
\hline $\begin{array}{l}\text { Acepção } \\
\text { buscada }\end{array}$ & Unidade de medida de peso. \\
\hline $\begin{array}{l}\text { Acepção(ões) } \\
\text { conhecida(s) } \\
\text { pelos }\end{array}$ & $\begin{array}{l}\text { F1-H-EP: NSR. } \\
\text { Fi-M-EP: NSR. }\end{array}$ \\
F1-H-EF: Arroba da internet. \\
\hline
\end{tabular}




\begin{tabular}{|c|c|}
\hline & $\begin{array}{l}\text { F1-H-EM: Conheço só arroba de internet. } \\
\text { F1-M-EM: Arroba de internet. } \\
\text { F1-H-ES: Arroba do gado, arroba da internet. } \\
\text { F1-M-ES: Arroba de internet. } \\
\text { F2-H-EP: Arroba aqui é como se fosse um corte de boi, chama de } \\
\text { arroba. Tem também o peso do algodão, pesa uma arroba, um quilo. } \\
\text { F2-M-EP: Só conheço arroba da internet. } \\
\text { F2-H-EF: Arroba é peso de boi. } \\
\text { F2-M-EF: Arroba é quilo, num frigorífico tem tantas arrobas de carne. } \\
\text { F2-H-EM: Arroba conheço da tecnologia, internet. } \\
\text { F2-M-EM: NSR. } \\
\text { F2-H-ES: Arroba é medição de quilo, mas não se usa muito hoje. } \\
\text { F2-M-ES: Arroba é quando conta as cabeças de gado. }\end{array}$ \\
\hline $\begin{array}{l}\text { Acepções } \\
\text { registradas } \\
\text { nos } \\
\text { dicionários }\end{array}$ & $\begin{array}{l}\text { Bluteau (1712-1728): ARROBA. Peso de trinta, \& dous arrateis. } \\
\text { Morais Silva (1813): ARRÒBA, s. f. Peso de trinta e dois arrateis. } \\
\text { Cunha (1997): arroba } s f \text {. 'antiga medida de peso correspondente a, } \\
\text { aproximadamente, } 15 \text { quilos' | XIV. } \\
\text { Ferreira (2004): arroba } 2 \text {. Unidade ainda usada no Brasil, como } \\
\text { medida de peso de produtos agropecuários, equivalente a } 15 \mathrm{~kg} \text {. } \\
\text { Houaiss (2007): arroba datação } 1188-12301 \text { Rubrica: metrologia: } \\
\text { antiga unidade de medida de peso que corresponde a } 32 \text { arráteis } \\
\text { (cerca de } 14,7 \mathrm{~kg} \text { ). }\end{array}$ \\
\hline \multicolumn{2}{|c|}{$\begin{array}{l}\text { As definições registradas pelos lexicógrafos para a entrada arroba evidenciam os } \\
\text { traços comuns: 'peso', 'medida de peso' e 'unidade de medida de peso'. Analisando o } \\
\text { contexto de uso dessa unidade lexical, constata-se que a maioria dos informantes a utiliza, } \\
\text { porém com variação de significados: 'peso de gado e de algodão', 'arroba da internet', } \\
\text { 'corte de boi' e 'contagem de cabeça de boi'. Da acepção buscada 'unidade de medida de } \\
\text { peso', apenas quatro informantes (F1-M-EF / F2-H-EF, F2-M-EF e F2-H-ES) a } \\
\text { empregaram com este mesmo sentido. Dois informantes masculinos utilizaram a lexia } \\
\text { arroba com variação de significados: F1-H-ES: 'medida de peso' e 'arroba da internet'; } \\
\text { F2-H-EP: 'medida de peso' e 'corte de boi'. E seis informantes (quatro da faixa I e dois da } \\
\text { faixa II) conhecem somente arroba com o valor de 'arroba da internet'. A unidade lexical } \\
\text { arroba designando 'sinal gráfico usado nos endereços de correio eletrônico', teve sua } \\
\text { entrada fixada por Cunha no século XX. } \\
\text { Analisando o contexto de utilização desse item lexical, constata-se, no estágio atual } \\
\text { de variação, considerável frequência da ocorrência dos dois significados distintos ('peso } \\
\text { de gado e de algodão' e 'arroba da internet') para a única forma lexical: arroba. Mas, } \\
\text { quando se leva em consideração a baixa ocorrência da acepção 'medida de peso' } \\
\text { atribuída à lexia arroba por parte dos informantes da faixa I, pressupõe tratar-se de um } \\
\text { caso de tendência ao desuso. }\end{array}$} \\
\hline
\end{tabular}




\begin{tabular}{|c|c|}
\hline \multicolumn{2}{|c|}{ 63. ASILO / DOC.10, fól.1v, 1.09-12 } \\
\hline $\begin{array}{l}\text { Acepção } \\
\text { buscada }\end{array}$ & Proteção, amparo. \\
\hline $\begin{array}{l}\text { Acepção(ões) } \\
\text { conhecida(s) } \\
\text { pelos } \\
\text { informantes }\end{array}$ & $\begin{array}{l}\text { F1-H-EP: Onde coloca os idosos. } \\
\text { F1-M-EP: Asilo é onde põem os velhos. } \\
\text { F1-H-EF: Asilo é um lugar onde coloca os idosos. } \\
\text { F1-M-EF: Asilo onde coloca pessoas que ficam sozinhas. } \\
\text { F1-H-EM: Asilo de idosos e de você dar asilo a uma pessoa que } \\
\text { necessitada, você acolhe. } \\
\text { F1-M-EM: Asilo é pra idosos. } \\
\text { F1-H-ES: Casa de idosos. Também como refúgio. } \\
\text { F1-M-ES: Asilo lugar que abriga idosos. } \\
\text { F2-H-EP: Asilo é uma casa de gente idosa. } \\
\text { F2-M-EP: Só conheço onde ficam os idosos. } \\
\text { F2-H-EF: Asilo seria uma casa beneficente para idoso. Ou numa parte } \\
\text { política, seria você sair do seu país e ficar em outro, ficar asilado. } \\
\text { Seria esses dois tipos. } \\
\text { F2-M-EF: Tem onde ficam os velhinhos e também quando uma pessoa } \\
\text { não tem onde ficar, eu dou asilo a ele. } \\
\text { F2-H-EM: Lugar onde as pessoas vão quando têm uma certa idade ou } \\
\text { não possui parentes. } \\
\text { F2-M-EM: Asilo é abrigo de velho, de idoso. E também de dar asilo pra } \\
\text { alguém, moradia. } \\
\text { F2-H-ES: Tem dois sentidos é onde hoje a gente coloca as pessoas mais } \\
\text { velhas e dar asilo, dar proteção. } \\
\text { F2-M-ES: Onde que põe as pessoas idosas. }\end{array}$ \\
\hline $\begin{array}{l}\text { Acepções } \\
\text { registradas } \\
\text { nos } \\
\text { dicionários }\end{array}$ & $\begin{array}{l}\text { Bluteau (1712-1728): ASYLO, ou Azylo. Era hum lugar de refugio, do } \\
\text { qual ninguem podia tirar os que se acolhessem a elle, sem ofender os } \\
\text { Deoses, \& à Religiaõ. } \\
\text { Morais Silva (1813): ASÍLO, s. m. §. fig. Refugio, abrigo, acolheita. } \\
\text { Cunha (1997): asilo sm. 'guarida, proteção, abrigo' XVII. } \\
\text { Ferreira (2004): asilo 3. P. ext. Guarida, abrigo, proteção. } \\
\text { Houaiss (2007): ' } \text { asilo datação } 16232 \text { Derivação: por extensão de } \\
\text { sentido: proteção, amparo, segurança. }\end{array}$ \\
\hline \multicolumn{2}{|c|}{$\begin{array}{l}\text { Os dicionaristas registraram a entrada asilo com o mesmo sentido da acepção buscada: } \\
\text { 'proteção, amparo'. Analisando o contexto de uso dessa unidade lexical, constata-se que } \\
\text { todos os informantes a utilizam no seu dia a dia, porém com significados diferenciados: } \\
\text { asilo no sentido de 'lugar onde acolhem pessoas idosas', e asilo no sentido de } \\
\text { 'acolhimento', 'refúgio', 'proteção'. Onze informantes (seis da faixa I e cinco da faixa II) } \\
\text { utilizaram o item lexical somente na acepção de 'lugar onde acolhem pessoas idosas', e }\end{array}$} \\
\hline
\end{tabular}


quatro informantes (F1-H-EM e F1-H-ES / F2-M-EM e F2-H-ES), além dessa definição, empregaram também o sentido da acepção buscada 'acolher', 'proteção' e 'amparo'. O informante F2-H-EF atribuiu à lexia asilo os valores: 'lugar beneficente para idoso' e 'asilado'. Quanto à definição 'asilado', este informante explica ser referente ao campo político, no qual 'uma pessoa sai de seu país e fica asilada em outro'. Em consulta aos dicionários pesquisados, não consta dessa acepção para as formas lexicais asilo e asilar. Acredita-se que pela semelhança entre as formas asilado e exilado, este informante tenha feito a associação entre as formas e significados que são próximos.

Analisando o contexto de utilização do item lexical asilo pelos informantes parnanguaras e a acepção em estudo, presume-se que, num dado momento nesta comunidade linguística, estas acepções começaram a coocorrer entre si e, no estágio atual de variação, há indícios do favorecimento da acepção 'lugar onde acolhem pessoas idosas' em detrimento da acepção documentada no corpus escrito, lembrada apenas por quatro informantes (dois da faixa I e dois da faixa II) e com variação de significado. Portanto, a unidade lexical asilo no sentido de 'proteção e amparo' aponta tendência ao desuso.

\begin{tabular}{|c|c|}
\hline \multicolumn{2}{|c|}{ 64. ATRAVESSADOR / DOC.37, fól.1v, l.24-31 } \\
\hline $\begin{array}{l}\text { Acepção } \\
\text { buscada }\end{array}$ & Pessoa que compra e revende com grande margem de lucro. \\
\hline $\begin{array}{l}\text { Acepção(ões) } \\
\text { conhecida(s) } \\
\text { pelos } \\
\text { informantes }\end{array}$ & $\begin{array}{l}\text { F1-H-EP: Conheço por atravessador aquele que comprou um pescado } \\
\text { nosso, vai lá pra frente, já atravessa pro outro lado, esse é o que } \\
\text { compra e revende. } \\
\text { F1-M-EP: Quando alguém atravessa o rio de um lado para o outro, ele é } \\
\text { atravessador de barco. } \\
\text { F1-H-EF: NSR. } \\
\text { F1-M-EF: NSR. } \\
\text { F1-H-EM: Quem atravessa mercadorias, é chamado de atravessador. } \\
\text { F1-M-EM: NSR. } \\
\text { F1-H-ES: É o cara que explora os outros. Ele compra e revende } \\
\text { pensando em lucro. } \\
\text { F1-M-ES: NSR. } \\
\text { F2-H-EP: Atravessador é a pessoa que compra aqui e já revende lá na } \\
\text { frente, a gente chama de atravessador, você comprou aqui e já vende } \\
\text { lá na frente é como chama o atravessador. } \\
\text { F2-M-EP: A pessoa que compra e revende é atravessador. } \\
\text { F2-H-EF: Atravessador é o que compra do produtor e depois repassa } \\
\text { pros outros a parte comercial. Ele compra do produtor e repassa por } \\
\text { outro preço pra outro vendedor, ou ele vende, então ele é } \\
\text { atravessador, essa parte é mais comercial, atravessador. }\end{array}$ \\
\hline
\end{tabular}




\begin{tabular}{|c|c|}
\hline & $\begin{array}{l}\text { F2-M-EF: Atravessador, aquele que compra por um preço e vende por } \\
\text { um outro muito mais alto. } \\
\text { F2-H-EM: Aquele que compra a mercadoria e vai vender. Tipo aqui no } \\
\text { litoral temos o pescador, vende pro mascate, daí o cara mascate vende } \\
\text { pra Curitiba, São Paulo. Isso se chama atravessador. } \\
\text { F2-M-EM: Atravessador é quem atravessa alguma coisa ilegal. } \\
\text { F2-H-ES: Atravessador, isso tem ainda, usa, é aquele que compra e } \\
\text { vende o produto. O que antigamente se falava, eu acho muito bonito, } \\
\text { o mercador, o mercantilismo. É pejorativo o termo atravessador. } \\
\text { F2-M-ES: Atravessador pra mim é assim, que compra uma coisa errada e } \\
\text { vende, passa pra frente pra ter lucro, }\end{array}$ \\
\hline $\begin{array}{l}\text { Acepções } \\
\text { registradas } \\
\text { nos } \\
\text { dicionários }\end{array}$ & $\begin{array}{l}\text { Bluteau (1712-1728): [ATRAVESSAR mercadorias. Comprallas para } \\
\text { as revender. Comprallas barato, para as vender caro]. } \\
\text { Morais Silva (1813): ATRAVESSADÒR, s. m. O que compra toda a } \\
\text { mercadoria, ou viveres, para regatear, e vender a seu arbítrio elle só. } \\
\text { Cunha (1997): través sm. | Atravessador } 1844 \text { | Atravessar } v b \text {. 'pôr ao } \\
\text { través' 'transpor' XIII. } \\
\text { Ferreira (2004): atravessador 3. Bras. Amaz. Aquele que compra } \\
\text { mercadorias por preço baixo para revendê-las com grande lucro. } \\
\text { Houaiss (2007): atravessador datação } 16283 \text { Regionalismo: } \\
\text { Amazônia: que ou o que compra e revende com grande margem de } \\
\text { lucro (diz-se de negociante). }\end{array}$ \\
\hline \multicolumn{2}{|c|}{$\begin{array}{l}\text { A lexia atravessador é bastante produtiva no contexto de fala dos informantes } \\
\text { parnanguaras. Houve somente quatro casos de ausência de respostas (F1-H-EF, F1-M-EF, } \\
\text { F1-M-EM e F1-M-ES). Dos dezesseis entrevistados, onze informantes (três da faixa I e } \\
\text { oito da faixa II) reconhecem o item lexical atravessador com o mesmo sentido da acepção } \\
\text { buscada 'pessoa que compra e revende com grande margem de lucro'. Porém, analisando } \\
\text { as respostas de alguns informantes, nota-se que a lexia atravessador, com o tempo, } \\
\text { ganhou sentido pejorativo, conforme se atesta nos exemplos os seguir: F2-H-ES: } \\
\text { 'Atravessador, isso tem ainda, usa, é aquele que compra e vende o produto. O que } \\
\text { antigamente se falava, eu acho muito bonito, o mercador, o mercantilismo. É pejorativo o } \\
\text { termo atravessador'; F1-H-ES: 'É o cara que explora os outros. Ele compra e revende } \\
\text { pensando em lucro'; F2-M-ES: 'Atravessador pra mim é assim, que compra uma coisa } \\
\text { errada e vende, passa pra frente pra ter lucro'; F2-M-EM: 'Atravessador é quem } \\
\text { atravessa alguma coisa ilegal'. Já para a informante F1-M-EP atravessador é } \\
\text { simplesmente alguém que atravessa o rio de barco, de um lado para o outro. Os } \\
\text { lexicógrafos registraram as mesmas designações referentes ao conceito documentado no } \\
\text { corpus escrito. Com relação à acepção 'aquele que compra e revende mercadoria com } \\
\text { grande margem de lucro', Ferreira e Houaiss classificam como brasileirismo/regionalismo } \\
\text { da Amazônia. Nota-se, pois, que a marca dialetal atribuída à unidade léxica atravessador } \\
\text { pelos lexicógrafos mencionados se encontra registrada também na fala dos informantes de } \\
\text { Paranaguá. }\end{array}$} \\
\hline
\end{tabular}


Analisando o contexto de uso da lexia atravessador, constata-se ser bastante produtiva na fala dos informantes. Dos dezesseis informantes, onze (três da faixa I e oito da faixa II) ainda empregam a lexia atravessador com o mesmo sentido da acepção investigada, apontando, assim, tendência à manutencão.

\begin{tabular}{|c|c|}
\hline \multicolumn{2}{|c|}{ 65. AULISTA / DOC.48, fól.1r, l.30-32 } \\
\hline $\begin{array}{l}\text { Acepção } \\
\text { buscada }\end{array}$ & Professor, aquele que ministra aulas. \\
\hline $\begin{array}{l}\text { Acepção(ões) } \\
\text { conhecida(s) } \\
\text { pelos } \\
\text { informantes }\end{array}$ & $\begin{array}{l}\text { F1-H-EP: NSR. } \\
\text { F1-M-EP: NSR. } \\
\text { F1-H-EF: Aulista é ter aula. } \\
\text { F1-M-EF: NSR. } \\
\text { F1-H-EM: NSR. } \\
\text { F1-M-EM: NSR. } \\
\text { F1-H-ES: NSR. } \\
\text { F1-M-ES: NSR. } \\
\text { F2-H-EP: NSR. } \\
\text { F2-M-EP: NSR. } \\
\text { F2-H-EF: Seria no caso da educação, uma pessoa que tem as hora-aula, } \\
\quad \text { então ele é professor aulista, ele dá aula de manhã, aula a tarde, aula a } \\
\text { noite. } \\
\text { F2-M-EF: NSR. } \\
\text { F2-H-EM: NSR. } \\
\text { F2-M-EM: NSR. } \\
\text { F2-H-ES: NSR. } \\
\text { F2-M-ES: NSR. }\end{array}$ \\
\hline $\begin{array}{l}\text { Acepções } \\
\text { registradas } \\
\text { nos } \\
\text { dicionários }\end{array}$ & $\begin{array}{l}\text { Bluteau (1712-1728): N.D. } \\
\text { Morais Silva (1813): AULÍSTA, s. m. O que aprende em alguma Aula. } \\
\text { Cunha (1997): N.D. } \\
\text { Ferreira (2004): aulista 1. P. us. Pessoa que freqüenta aulas; estudante. } \\
\text { Houaiss (2007): aulista datação } 1813 \text { Estatística: pouco usado: que ou } \\
\quad \text { aquele que freqüenta aulas; aluno, discípulo. }\end{array}$ \\
\hline \multicolumn{2}{|c|}{$\begin{array}{l}\text { Embora a unidade lexical aulista esteja registrada em Morais Silva, Ferreira e Houaiss, } \\
\text { não consta destes dicionaristas o registro da acepção buscada 'professor, alguém que } \\
\text { ministra aulas'. Esta definição consta de um documento manuscrito datado em 1800, e } \\
\text { Houaiss, por sua vez, fixa sua entrada a partir de 1813. Os três dicionaristas citados } \\
\text { registraram a mesma acepção para a forma lexical aulista: 'aluno', 'discípulo', 'aquele } \\
\text { que frequenta aulas', e assinalam ser um termo pouco usado. Bluteau e Cunha não trazem }\end{array}$} \\
\hline
\end{tabular}


o registra da entrada aulista. No caso de Bluteau, a ausência do registro da entrada aulista justifica-se por ter sido elaborado um século anterior, se comparado com a datação de Houaiss. Analisando o contexto de uso do item lexical aulista, constata-se baixa ocorrência por parte dos entrevistados de Paranaguá. Dos dezesseis informantes, somente dois reconheceram esta lexia, mas com significado distinto da acepção em estudo. $\mathrm{O}$ informante F1-H-EF associou a lexia aulista com o valor de 'ter aula'. Já o informante F2- H-EF considerou um professor que tem hora-aula, um professor aulista. Esta acepção não está registrada nos dicio nários pesquisados.

Considerando a ausência de resposta de quatorze informantes (sete da faixa I e sete da faixa II) e a não ocorrência da acepção documentada no corpus escrito, para a unidade lexical aulista, supõe-se ser um caso de desuso.

\begin{tabular}{|c|c|}
\hline \multicolumn{2}{|c|}{ 66. AVULSÃO/EVULSÃO / DOC.12, fól.1r, l.23-27 } \\
\hline $\begin{array}{l}\text { Acepção } \\
\text { buscada }\end{array}$ & Ato de arrancar algo de forma violenta. \\
\hline $\begin{array}{l}\text { Acepção(ões) } \\
\text { conhecida(s) } \\
\text { pelos } \\
\text { informantes }\end{array}$ & $\begin{array}{l}\text { F1-H-EP: NSR. } \\
\text { F1-M-EP: NSR. } \\
\text { F1-H-EF: NSR. } \\
\text { F1-M-EF: NSR. } \\
\text { F1-H-EM: NSR. } \\
\text { F1-M-EM: NSR. } \\
\text { F1-H-ES: NSR. } \\
\text { F1-M-ES: NSR. } \\
\text { F2-H-EP: NSR. } \\
\text { F2-M-EP: NSR. } \\
\text { F2-H-EF: Avulsão aqui tem negócio de porto, portuário. Os } \\
\text { trabalhadores avulsos. } \\
\text { F2-M-EF: Avulsão seria alguém que trabalha por conta própria, avulso. } \\
\text { F2-H-EM: NSR. } \\
\text { F2-M-EM: NSR. } \\
\text { F2-H-ES: NSR. } \\
\text { F2-M-ES: NSR. }\end{array}$ \\
\hline $\begin{array}{l}\text { Acepções } \\
\text { registradas } \\
\text { nos } \\
\text { dicionários }\end{array}$ & $\begin{array}{l}\text { Bluteau (1712-1728): N.D. } \\
\text { Morais Silva (1813): N.D. } \\
\text { Cunha (1997): avulsão sf. 'ato de arrancar, de extrair violentamente' } \\
\quad 1858 . \\
\text { Ferreira (2004): evulsão 1. Ato de arrancar, de extrair violentamente; } \\
\quad \text { avulsão, ablação. }\end{array}$ \\
\hline
\end{tabular}




\begin{tabular}{|c|}
\hline $\begin{array}{l}\text { Houaiss (2007): avulsão datação } 18581 \text { ato de extrair algo } \\
\text { violentamente. }\end{array}$ \\
\hline $\begin{array}{l}\text { Quanto ao registro das formas lexicais avulsão e evulsão, Ferreira registra evulsão e } \\
\text { remete para a variante avulsão, enquanto que, Houaiss registra avulsão e remete para a } \\
\text { variante evulsão, ambas com a mesma acepção: 'ato de arrancar, de extrair } \\
\text { violentamente'. Cunha atribuiu esses mesmos valores para a designação da entrada } \\
\text { avulsão. Não consta em Bluteau e Morais Silva registro das entradas avulsão e evulsão. } \\
\text { Cunha e Houaiss fixam a entrada da forma avulsão a partir de 1858. Talvez esse fato } \\
\text { justifique o não registro em Bluteau e Morais Silva, cujas edições são anteriores a esta } \\
\text { datação. Curiosamente, a lexia avulsão consta do documento manuscrito datado em 1722, } \\
\text { e só um século depois os dicionaristas trazem a sua primeira entrada. } \\
\text { Analisando o contexto de uso desse item lexical, constata-se baixa ocorrência por parte } \\
\text { dos entrevistados de Paranaguá. Dos dezesseis informantes, somente dois (F2-H-EF e F2- } \\
\text { M-EF) reconheceram a lexia avulsão, mas associaram com a forma lexical avulso. } \\
\text { Considerando a ausência de resposta de quatorze informantes (oito da faixa I e seis da } \\
\text { faixa II) e a não ocorrência da acepção buscada: 'Ato de arrancar ou extrair algo de forma } \\
\text { violenta', para a unidade lexical avulsão, supõe-se ser um caso de desuso. }\end{array}$ \\
\hline
\end{tabular}

\begin{tabular}{|c|c|}
\hline \multicolumn{2}{|c|}{ 67. BALANDRA / DOC.22, fól.1r, l.05-07 } \\
\hline $\begin{array}{l}\text { Acepção } \\
\text { buscada }\end{array}$ & Tipo de embarcação, veleiro de um mastro. \\
\hline $\begin{array}{l}\text { Acepção(ões) } \\
\text { conhecida(s) } \\
\text { pelos } \\
\text { informantes }\end{array}$ & $\begin{array}{l}\text { F1-H-EP: NSR. } \\
\text { F1-M-EP: NSR. } \\
\text { F1-H-EF: NSR. } \\
\text { F1-M-EF: NSR. } \\
\text { F1-H-EM: NSR. } \\
\text { F1-M-EM: NSR. } \\
\text { F1-H-ES: NSR. } \\
\text { F1-M-ES: NSR. } \\
\text { F2-H-EP: NSR. } \\
\text { F2-M-EP: NSR. } \\
\text { F2-H-EF: NSR. } \\
\text { F2-M-EF: NSR. } \\
\text { F2-H-EM: NSR. } \\
\text { F2-M-EM: NSR. } \\
\text { F2-H-ES: NSR. } \\
\text { F2-M-ES: NSR. } \\
\text { Resposta de todos os informantes: desconhecem o termo. }\end{array}$ \\
\hline
\end{tabular}




\begin{tabular}{|c|c|}
\hline $\begin{array}{l}\text { Acepções } \\
\text { registradas } \\
\text { nos } \\
\text { dicionários }\end{array}$ & $\begin{array}{l}\text { Bluteau (1712-1728): N.D. } \\
\text { Morais Silva (1813): BALÁNDRA, s. f. Embarcação de tilhá, ou } \\
\text { coberta, de uma só arvore; serve de transportar mercadorias, ou de } \\
\text { andar a corso. } \\
\text { Cunha (1997): balandra sf. 'tipo de embarcação antiga' } 1813 \text {. } \\
\text { Ferreira (2004): balandra 1. Antiga embarcação, por vezes monóxila, } \\
\text { de fundo chato, com coberta, aparelhada com um mastro, e destinada } \\
\text { ao transporte de mercadorias ou ao corso. } \\
\text { Houaiss (2007): balandra datação } 1660 \text { Rubrica: termo de marinha: } 1 \\
\text { embarcação a vela, chata e de coberta, feita de um só tronco, us. } \\
\text { particularmente nos rios como meio de transporte, ou armada em } \\
\text { corso, ou seja, preparada para atacar e perseguir o tráfego mercante } \\
\text { do inimigo. }\end{array}$ \\
\hline \multicolumn{2}{|c|}{$\begin{array}{l}\text { Dos dezesseis entrevistados, todos disseram desconhecer a lexia balandra. Quanto à } \\
\text { datação da unidade lexical balandra parece não haver um consenso entre os registros dos } \\
\text { dicionaristas pesquisados. Mesmo tendo sua entrada fixada por Houaiss em } 1660 \text {, } \\
\text { balandra não consta do registro de Bluteau. Cunha, por sua vez, fixa a entrada balandra a } \\
\text { partir de } 1813 \text {, e, se comparada com a datação documentada por Houaiss, seu registro } \\
\text { ocorreu quase dois séculos depois. No documento manuscrito de } 1734 \text { encontra-se o } \\
\text { registro da lexia balandra, pressupondo, dessa forma, que sua ocorrência já existia bem } \\
\text { antes da datação informada por Cunha. } \\
\text { Considerando os dados analisados, o item lexical balandra, sem nenhuma ocorrência } \\
\text { em contexto de fala dos entrevistados, caiu em desuso, talvez por não mais existir este } \\
\text { tipo de embarcação no Brasil, restando apenas o seu registro em documentos de fase } \\
\text { pretérita, livros de história e alguns dicionários gerais. }\end{array}$} \\
\hline
\end{tabular}

\begin{tabular}{|c|c|}
\hline \multicolumn{2}{|c|}{ 68. BANDO / DOC.03, fól.1r, l.20-22 } \\
\hline $\begin{array}{l}\text { Acepção } \\
\text { buscada }\end{array}$ & Pregão, divulgação, proclamação pública. \\
\hline $\begin{array}{l}\text { Acepção(ões) } \\
\text { conhecida(s) } \\
\text { pelos } \\
\text { informantes }\end{array}$ & $\begin{array}{l}\text { F1-H-EP: Um bando de passarinho. } \\
\text { F1-M-EP: Bando de passarinho. } \\
\text { F1-H-EF: Bando é um grupo: bando de pessoas. } \\
\text { F1-M-EF: Bando de gente. } \\
\text { F1-H-EM: Um bando de pessoas. } \\
\text { F1-M-EM: Bando de ladrão. } \\
\text { F1-H-ES: Bando de aves, bando de bandido. } \\
\text { F1-M-ES: Bando é uma corja de pessoas juntas. } \\
\text { F2-H-EP: Já ouvi falar num bando de passarinho. } \\
\text { F2-M-EP: Um bando de passarinho que voa no ar. }\end{array}$ \\
\hline
\end{tabular}




\begin{tabular}{|c|c|}
\hline & $\begin{array}{l}\text { F2-H-EF: Bando já seria o sinônimo de pássaro, de gente. } \\
\text { F2-M-EF: Bando de pessoas desocupadas. } \\
\text { F2-H-EM: Bando de passarinhos. } \\
\text { F2-M-EM: Passou um bando de passarinhos. } \\
\text { F2-H-ES: Bando, grupo, pode ser bando de pessoas armadas, bando de } \\
\text { pessoas boas. } \\
\text { F2-M-ES: Um bando de pessoas na praia, um bando de pessoas fazendo } \\
\text { arrastão. }\end{array}$ \\
\hline $\begin{array}{l}\text { Acepções } \\
\text { registradas } \\
\text { nos } \\
\text { dicionários }\end{array}$ & $\begin{array}{l}\text { Bluteau (1712-1728): BANDO. Derivase do antigo vocabulo Alemão } \\
\text { Bam, que significa pregão; do Bam dos Alemaens fizeram os } \\
\text { Italianos o seu Bandire, o que quer dizer Publicar por bando, como } \\
\text { quando se declara publicamente hum decreto, huma ley. } \\
\text { Morais Silva (1813): BANDO, s. m. } \S \text {. Bando: pregão público, pelo } \\
\text { qual se faz pública alguma ordem, ou decreto; e se denuncia talvez } \\
\text { guerra. } \\
\text { Cunha (1997): bando sm. 'partido, facção' XIII. } \\
\text { Ferreira (2004): bando² } 1 . \text { P. us. Pregão público; proclamação. } \\
\text { Houaiss (2007): }{ }^{2} \text { bando datação sXVII Estatística: pouco usado: } \\
\text { anúncio público; proclamação. }\end{array}$ \\
\hline \multicolumn{2}{|c|}{$\begin{array}{l}\text { Da lexia bando buscou-se a acepção 'pregão, divulgação, proclamação pública', } \\
\text { presente nos documentos manuscritos. Das várias designações registradas pelos } \\
\text { dicionaristas constam: 'pregão', 'publicação por bando', 'declaração pública de um } \\
\text { decreto', 'pregão público', 'anúncio público' e 'proclamação'. Houaiss assinala a lexia } \\
\text { bando com o sentido de 'pregão, divulgação, proclamação pública' estatisticamente pouco } \\
\text { usada. } \\
\text { Analisando o contexto de uso deste item lexical pelos entrevistados de Paranaguá, } \\
\text { verifica-se que todos os entrevistados a empregam no seu dia a dia, mas com o significado } \\
\text { de 'grupo de pessoas ou animais'. Esta definição refere-se ao homônimo bando de } \\
\text { procedência do lat. tar. bandum, enquanto que a lexia de etim. it. bando no sentido de } \\
\text { 'anúncio público, proclamação, divulgação' é desconhecida por todos os informantes. } \\
\text { Dessa forma, os informantes parnanguaras fazem uso de outro item lexical homônimo de } \\
\text { bando, cujos significados são distintos. Portanto, a lexia bando com o sentido da acepção } \\
\text { em estudo configura um caso de desuso. }\end{array}$} \\
\hline
\end{tabular}

69. BARRA / DOC.12, fól.1r, l.16-19

\begin{tabular}{|l|l|}
\hline $\begin{array}{l}\text { Acepção } \\
\text { buscada }\end{array}$ & Entrada estreita de porto. \\
\hline $\begin{array}{l}\text { Acepção(ões) } \\
\text { conhecida(s) }\end{array}$ & $\begin{array}{l}\text { F1-H-EP: NSR. } \\
\text { F1-M-EP: NSR. }\end{array}$ \\
\hline
\end{tabular}




\begin{tabular}{|c|c|}
\hline $\begin{array}{l}\text { pelos } \\
\text { informantes }\end{array}$ & $\begin{array}{l}\text { F1-H-EF: Quando alguma coisa tá difícil: é uma barra! } \\
\text { F1-M-EF: Quando você tá passando por um problema, por uma barra. } \\
\text { F1-H-EM: Barra de ferro, de chocolate. } \\
\text { F1-M-EM: Barra da calça. } \\
\text { F1-H-ES: Barra da calça, barra do cais. } \\
\text { F1-M-ES: NSR. } \\
\text { F2-H-EP: Barra é um negócio do mar, barra de rio: aquela barra de rio } \\
\text { ali. } \\
\text { F2-M-EP: NSR. } \\
\text { F2-H-EF: Barra daí tem vários sentidos, barra de chocolate, barra de } \\
\text { código, barra do mar, por exemplo: aonde o navio passa é barra, dali } \\
\text { pra dentro é barra, dali pra fora então é, eles falam no sentido de } \\
\text { barra, fora de barra, daquele trecho ali pra fora é mar, alto-mar. } \\
\text { Então tá dentro da barra, seria a baía já. } \\
\text { F2-M-EF: Tem a barra de ferro, barra portuária. } \\
\text { F2-H-EM: Barra aqui tem uma certa altura de mar que é chamada de } \\
\text { barra. } \\
\text { F2-M-EM: Barra do navio, tipo entrada. } \\
\text { F2-H-ES: Aqui se usa entrada da barra e não do porto, que é o canal da } \\
\text { Galheta que é a entrada da barra. } \\
\text { F2-M-ES: Tem a barra de ferro e a barra do porto, entrada de navio. }\end{array}$ \\
\hline $\begin{array}{l}\text { Acepções } \\
\text { registradas nos } \\
\text { dicionários }\end{array}$ & $\begin{array}{l}\text { Bluteau (1712-1728): BARRA, he huma entrada de Porto, que por } \\
\text { nenhuma outra parte se pode entrar, nem sahir dele, senão por ella. } \\
\text { Morais Silva (1813): BÁRRA, s. f. t. de Naut. Entrada para algum } \\
\text { porto por entre dois lados de terra firme. } \\
\text { Cunha (1997): barra sf. 'entrada estreita de um porto' XIII. } \\
\text { Ferreira (2004): barra 18. Bras. Foz do rio ou de riacho. } \\
\text { Houaiss (2007): barra datação } 11751 \text { Rubrica: geografia, termo de } \\
\text { marinha: entrada de um porto, entre duas porções avançadas de terra } \\
\text { firme. }\end{array}$ \\
\hline \multicolumn{2}{|c|}{$\begin{array}{l}\text { A lexia barra foi lembrada pela maioria dos informantes (cinco da faixa I e sete da } \\
\text { faixa II) com vários significados: 'situação difícil', 'passar por um problema', 'barra de } \\
\text { ferro, de chocolate', 'barra da calça', 'código de barras', 'barra do cais', 'barra do mar', } \\
\text { 'barra portuária', 'barra do navio', 'entrada da barra', 'barra do porto'. Dentre essas } \\
\text { designações, os informantes atribuíram algumas específicas ao campo semântico } \\
\text { marítimo: ' barra do cais', 'barra do mar', 'barra portuária', 'barra do navio', 'entrada } \\
\text { da barra' e 'barra do porto'. Estas definições, de certa forma, apresentam certa } \\
\text { proximidade de relação com a acepção buscada 'entrada estreita de porto'. Analisando o } \\
\text { contexto de uso da lexia barra, verifica-se que sete informantes da faixa II associaram a } \\
\text { forma lexical barra ao sentido de 'entrada de porto', enquanto que da faixa I, apenas o } \\
\text { informante F1-H-ES reconheceu em barra o sentido relacionado à entrada do porto. }\end{array}$} \\
\hline
\end{tabular}


Dentre as várias designações registradas nos dicionários para a entrada barra, os lexicógrafos Bluteau, Morais Silva, Cunha e Houaiss trazem a mesma acepção documentada no corpus escrito. Em Ferreira, a designação mais próxima do sentido 'entrada estreita de porto' foi registrada na décima oitava acepção, classificada como brasileirismo: 'Foz do rio ou de riacho'.

Considerando os dados orais, verifica-se que as ocorrências mais próximas com o sentido da acepção em estudo, encontram-se no contexto de fala dos informantes da faixa II, presumindo, dessa forma, que a lexia barra com o sentido da acepção documentada no corpus escrito revela tendência ao desuso.

\begin{tabular}{|c|c|}
\hline \multicolumn{2}{|c|}{ 70. BOTICA / DOC.46, fól.1r, l.09-11 } \\
\hline $\begin{array}{l}\text { Acepção } \\
\text { buscada }\end{array}$ & Loja de produtos farmacêuticos. \\
\hline $\begin{array}{l}\text { Acepção(ões) } \\
\text { conhecida(s) } \\
\text { pelos } \\
\text { informantes }\end{array}$ & $\begin{array}{l}\text { F1-H-EP: NSR. } \\
\text { F1-M-EP: NSR. } \\
\text { F1-H-EF: NSR. } \\
\text { F1-M-EF: NSR. } \\
\text { F1-H-EM: NSR. } \\
\text { F1-M-EM: NSR. } \\
\text { F1-H-ES: É farmácia, minha mãe fala até hoje. } \\
\text { F1-M-ES: NSR. } \\
\text { F2-H-EP: Assim o cara abre assim uma venda qualquer chama de botica. } \\
\text { Comércio de alguém chama de botica do cara. } \\
\text { F2-M-EP: NSR. } \\
\text { F2-H-EF: Botica seria uma farmácia antiga assim, que vende vários tipos } \\
\text { de remédio e tal. Uma farmácia de manipulação, no caso seria botica. } \\
\text { F2-M-EF: NSR. } \\
\text { F2-H-EM: NSR. } \\
\text { F2-M-EM: NSR. } \\
\text { F2-H-ES: É farmácia. } \\
\text { F2-M-ES: Botica pra mim é uma vasilha para pôr algo, minha mãe de } \\
\text { primeiro falava: põe na botica pra mim. Tem também a botica de } \\
\text { venda, onde a gente vai lá comprar um fósforo. }\end{array}$ \\
\hline $\begin{array}{l}\text { Acepções } \\
\text { registradas } \\
\text { nos } \\
\text { dicionários }\end{array}$ & $\begin{array}{l}\text { Bluteau (1712-1728): BOTICA do Francez Boutique, que he o nome } \\
\text { geral de todas as lojas, em que estão mercancias em venda, \& como } \\
\text { as drogas preparadas para a conservação da saude, [...] razão era que } \\
\text { as lojas, em que se distrubuem estas salutíferas drogas, se chamassem } \\
\text { antomasticamente Boticas. }\end{array}$ \\
\hline
\end{tabular}




\begin{tabular}{|l|l|}
\hline & $\begin{array}{c}\text { Morais Silva (1813): BOTÍCA, s. f. §. De ordinario se diz botica, por } \\
\text { casa onde se vendem remedios, e drogas medicináes. } \\
\text { Cunha (1997): bodega sf. | botica } s f . \text { 'farmácia' | bu- XV | Divergente } \\
\text { de bodega, talvez pelo fr. boutique. } \\
\text { Ferreira (2004): botica 1. Desus. Farmácia. } \\
\text { Houaiss (2007): botica datação 1460 1.3 Diacronismo: antigo: lugar } \\
\text { onde se vendiam remédios e afins; farmácia. }\end{array}$ \\
\hline $\begin{array}{l}\text { A lexia botica tem pouca produtividade na fala dos informantes parnanguaras. Os cinco } \\
\text { informantes que ainda utilizam esta unidade lexical a empregam com variação de } \\
\text { significados: 'farmácia', 'venda de comércio', 'vasilha'. A acepção buscada 'loja de } \\
\text { produtos farmacêuticos' encontra-se nas respostas de apenas três informantes (F1-H-ES / } \\
\text { F2-H-EF e F2-H-ES). Os outros dois informantes (F2-H-EP e F2-M-ES) reconheceram } \\
\text { botica com o valor de 'venda' e 'armazém'. Esta acepção encontra-se registrada em } \\
\text { Houaiss na primeira acepção. A informante F2-M-ES além de empregar o sentido de } \\
\text { 'venda' para a lexia botica, atribui também o valor de objeto: 'vasilha para pôr algo'. Nos } \\
\text { dicionários gerais, esta acepção não se encontra dicionarizada para a entrada botica. } \\
\text { As designações registradas pelos lexicógrafos referem-se à mesma acepção } \\
\text { investigada. Quanto à acepção 'lugar onde se vende remédios' para a entrada botica, } \\
\text { Ferreira e Houaiss indicam ser um diacronismo antigo. } \\
\text { Analisando o contexto de uso desta lexia e comparando com as respostas dos } \\
\text { informantes, constata-se baixa produtividade, principalmente pelos informantes da faixa I, } \\
\text { pois dos oito entrevistados dessa faixa etária, sete disseram não conhecer a lexia botica, e } \\
\text { apenas um informante (F1-H-ES) que a reconheceu atribuiu o mesmo valor da acepção em } \\
\text { estudo. Infere-se dessa forma, ser um caso de tendência ao desuso. }\end{array}$ \\
\hline
\end{tabular}

\begin{tabular}{|c|c|}
\hline \multicolumn{2}{|c|}{ 71. BRAÇA / DOC.25, fól.1r, l.12-13 } \\
\hline $\begin{array}{l}\text { Acepção } \\
\text { buscada }\end{array}$ & Medida de extensão. \\
\hline $\begin{array}{l}\text { Acepção(ões) } \\
\text { conhecida(s) } \\
\text { pelos } \\
\text { informantes: }\end{array}$ & $\begin{array}{l}\text { F1-H-EP: NSR. } \\
\text { F1-M-EP: NSR. } \\
\text { F1-H-EF: NSR. } \\
\text { F1-M-EF: NSR. } \\
\text { F1-H-EM: NSR. } \\
\text { F1-M-EM: NSR. } \\
\text { F1-H-ES: NSR. } \\
\text { F1-M-ES: NSR. } \\
\text { F2-H-EP: Pra nós aqui a rede de pesca, mede com braça. Pra fazer uma } \\
\quad \text { rede aqui, eu cobro por braça. } \\
\text { F2-M-EP: NSR. }\end{array}$ \\
\hline
\end{tabular}




\begin{tabular}{|c|c|}
\hline & $\begin{array}{l}\text { F2-H-EF: Braça é medida que os pescadores usam, uma braça seria um } \\
\text { metro, dois metros, metro e meio, então eles usam pra medir, daí eles } \\
\text { usam braça. } \\
\text { F2-M-EF: Braça, meu pai falava pra medir. } \\
\text { F2-H-EM: Pro cabroco aqui, ele vai fazer a rede e vai medir as braça. } \\
\text { Sentido de metragem. } \\
\text { F2-M-EM: No sítio ainda se fala, se ouve, quando eles fazem a rede. } \\
\text { F2-H-ES: Braça é medida, pode ser também por mar, tantas braças pra } \\
\text { chegar. } \\
\text { F2-M-ES: Braça é pra medir alguma coisa, uma braçada. }\end{array}$ \\
\hline $\begin{array}{l}\text { Acepções } \\
\text { registradas } \\
\text { nos } \\
\text { dicionários: }\end{array}$ & $\begin{array}{l}\text { Bluteau (1712-1728): BRAÇA. Medida, que contem o comprimento dos } \\
\text { dous braços abertos, \& estendidos, juntamente com a parte do corpo, } \\
\text { que està no meyo deles, atè à extremidade dos dedos do meyo de cada } \\
\text { mão. } \\
\text { Morais Silva (1813): BRÁÇA, s. f. Medida longa de 7. pés geometricos, } \\
\text { e 10. palmos de craveira. } \\
\text { Cunha (1997): braço } \mathrm{sm} \text {. 'cada um dos membros superiores do corpo } \\
\text { humano' | braça XIII. } \\
\text { Ferreira (2004): braça } 1 \text {. Antiga unidade de medida de comprimento } \\
\text { equivalente a dez palmos [v. palmo (2)], ou seja, } 2,2 \mathrm{~m} \text {. } \\
\text { Houaiss (2007): braça datação } 12531 \text { Rubrica: metrologia: antiga } \\
\text { medida (ainda em uso no Brasil), com variações de país para país, } \\
\text { equivalente à extensão que vai de um punho ao outro, ou da } \\
\text { extremidade de uma mão aberta à outra, ou da ponta de um polegar } \\
\text { em abdução ao outro, num adulto com os braços estendidos } \\
\text { horizontalmente para os lados (em Portugal e no Brasil, } 2,2 \mathrm{~m} \\
\text { lineares). }\end{array}$ \\
\hline \multicolumn{2}{|c|}{$\begin{array}{l}\text { A unidade lexical braça com o sentido de 'medida antiga de extensão', apesar de ser } \\
\text { utilizada por quase todos os informantes da faixa II, não é reconhecida por nenhum dos } \\
\text { informantes da faixa I. Os lexicógrafos Bluteau, Morais Silva, Ferreira e Houaiss } \\
\text { registraram a entrada braça com o mesmo sentido documentado no corpus escrito. } \\
\text { Houaiss informa ser o termo braça referente ao campo da metrologia. } \\
\text { Analisando o contexto de uso do item lexical braça na fala dos informantes da faixa II, } \\
\text { constata-se ser bastante produtiva. Do ponto de vista diageracional, braça com o valor de } \\
\text { 'medição' é uma lexia típica de informantes mais velhos, visto que nenhum informante da } \\
\text { faixa I reconhece esta unidade lexical. Portanto, braça revela tendência ao desuso. }\end{array}$} \\
\hline
\end{tabular}




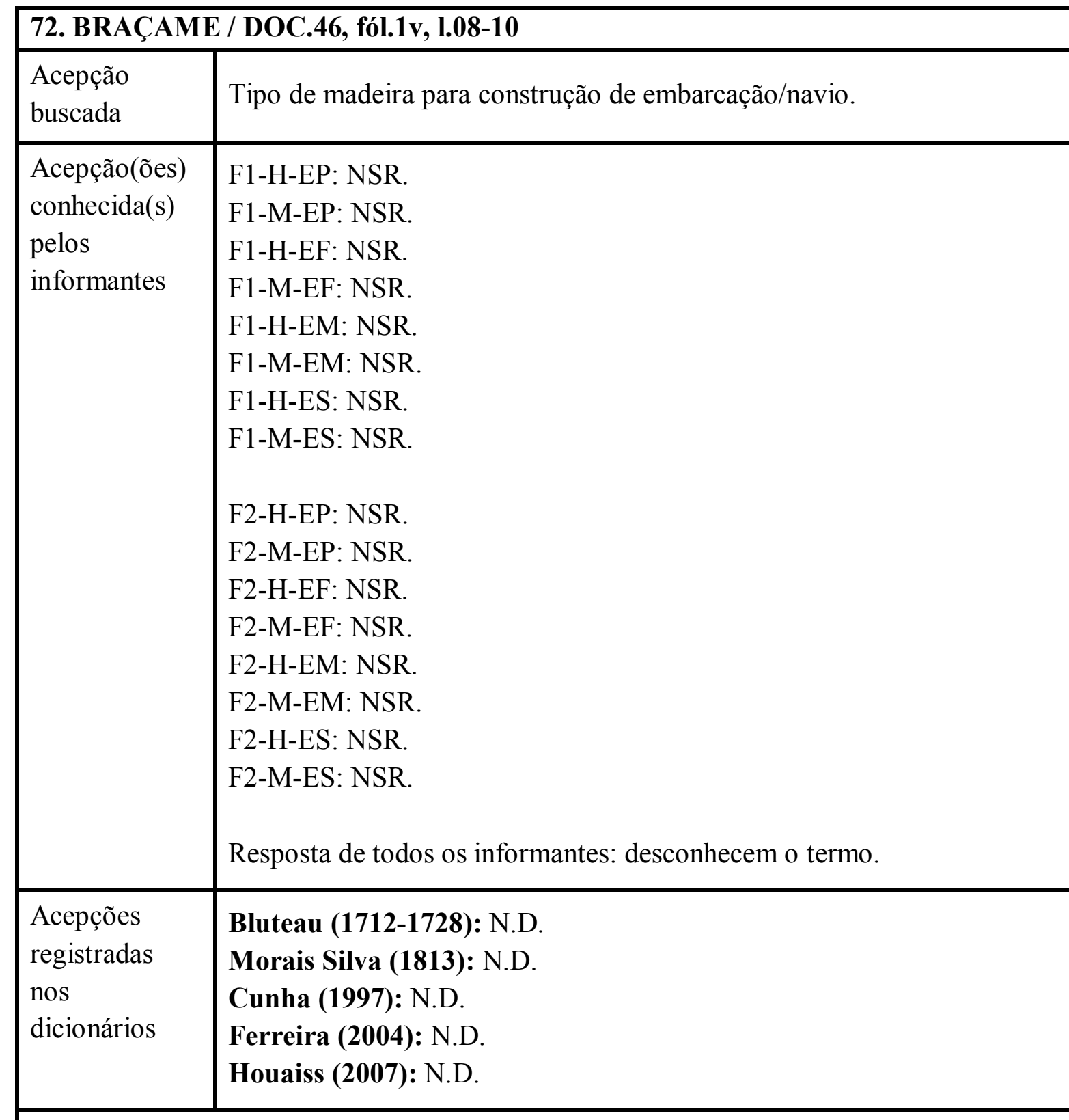

A lexia braçame não consta dicionarizada por nenhum dos lexicógrafos pesquisados. Nos registros orais também não houve sua ocorrência. Dos dezesseis entrevistados, todos disseram nunca ter ouvido braçame. No contexto do documento manuscrito, a unidade lexical braçame parece referir-se a 'um tipo de madeira para construção de embarcação/navio'. Em pesquisas a outras fontes, o item lexical braçame encontra-se registrado no poema intitulado "Ensinando navegar", que faz parte de uma coletânea de poesias publicadas, em 2008, no livro Vaqueiro marajoara: encantarias, chulas $e$ ladainhas, de autoria de Marcos Quinan ${ }^{39}$. Segue como exemplo a primeira estrofe do poema: 'Esqueleto de paricá / Braçame de pracuíba / Forro de sapucaia / Agrado pra toda vida'. A lexia braçame no contexto do poema "Ensinando navegar" relaciona-se ao Ver o sítio: $<$ http://parlamaz.tnx.com.br/conteudo.php?pageNum_Pagina=1\&sid=246\&cid=868\&
totalRows_Pagina $=11>$. 
campo semântico navegação, sugerindo os traços [mar, embarcação, madeira].

Portanto, como não houve o registro desse item lexical no contexto de oralidade dos informantes parnanguaras, configura-se em caso de desuso.

\begin{tabular}{|c|c|}
\hline \multicolumn{2}{|c|}{ 73. CAMARISTA / DOC.32, fól.1r, l.22-24 } \\
\hline $\begin{array}{l}\text { Acepção } \\
\text { buscada }\end{array}$ & $\begin{array}{l}\text { Membro de uma câmara legislativa municipal, função de vereador } \\
\text { municipal. }\end{array}$ \\
\hline $\begin{array}{l}\text { Acepção(ões) } \\
\text { conhecida(s) } \\
\text { pelos } \\
\text { informantes }\end{array}$ & $\begin{array}{l}\text { F1-H-EP: NSR. } \\
\text { F1-M-EP: NSR. } \\
\text { F1-H-EF: NSR. } \\
\text { F1-M-EF: NSR. } \\
\text { F1-H-EM: NSR. } \\
\text { F1-M-EM: NSR. } \\
\text { F1-H-ES: NSR. } \\
\text { F1-M-ES: Camarista é quem trabalha na câmara. } \\
\text { F2-H-EP: NSR. } \\
\text { F2-M-EP: NSR. } \\
\text { F2-H-EF: Camarista seria a pessoa que trabalha em hotel será, } \\
\text { camareira. } \\
\text { F2-M-EF: Pessoa que trabalha no hotel. } \\
\text { F2-H-EM: Camarista é quem arruma a cama. } \\
\text { F2-M-EM: NSR. } \\
\text { F2-H-ES: Era vereador. } \\
\text { F2-M-ES: Acho que é arrumar a cama. }\end{array}$ \\
\hline $\begin{array}{l}\text { Acepções } \\
\text { registradas } \\
\text { nos } \\
\text { dicionários }\end{array}$ & $\begin{array}{l}\text { Bluteau (1712-1728): CAMARISTA del-Rey. Hoje em Palacio se } \\
\text { chamaõ Camaristas os Fidalgos, que servem o officio de Camareiro } \\
\text { mór. } \\
\text { Morais Silva (1813): CAMARÍSTA, s. m. Oficial do Senado da } \\
\text { Camara. } \\
\text { Cunha (1997): N.D. } \\
\text { Ferreira (2004): camarista 1. Vereador municipal. } \\
\text { Houaiss (2007): camarista datação } 16493 \text { Regionalismo: Portugal: } \\
\text { membro de uma câmara legislativa municipal. }\end{array}$ \\
\hline \multicolumn{2}{|c|}{$\begin{array}{l}\text { Para a pergunta sobre o conhecimento ou não da lexia camarista, a informante F1-M- } \\
\text { ES respondeu genericamente 'ser qualquer funcionário que trabalha na câmara'. Já o } \\
\text { informante F2-H-ES respondeu: 'era vereador'. Pelo emprego do verbo no pretérito } \\
\text { imperfeito, presume-se pela resposta dada por este informante que, hoje em dia, o item } \\
\text { lexical camarista refere-se a outro conceito, e não mais a um 'membro de uma câmara }\end{array}$} \\
\hline
\end{tabular}


legislativa municipal'. Talvez esse outro significado seja referente à unidade lexical 'camareiro/camareira', no sentido de 'arrumar cama em hotel', presente nas respostas de quatro informantes (F2-H-EF, F2-M-EF, F2-H-EM e F2-M-ES). Quanto ao registro nos dicionários pesquisados, assim como Bluteau, Ferreira registra na segunda acepção, da entrada camarista, a designação 'camareiro'. Este mesmo dicionarista registra, na terceira acepção da entrada camareiro, a designação 'empregado que atende o serviço dos quartos e os arruma (em hotéis, navios de passageiros)', e a classifica como um brasileirismo.

Analisando esses dados, supõe-se que esses quatro informantes da faixa II, pela semelhança entre as formas lexicais camarista e camareiro, tenham associado o mesmo significado para as duas formas distintas. Quanto à acepção buscada, encontra-se lexicalizada em Morais Silva, Ferreira e Houaiss. Este último dicionarista informa ser a designação 'membro de uma câmara legislativa municipal' um regionalismo de Portugal. Em Cunha, não há o registro desta entrada.

Considerando o contexto de uso da lexia camarista, constata-se baixa produtividade na fala dos informantes de Paranaguá. Dos dezesseis entrevistados, dez informantes (sete da faixa I e três da faixa II) disseram não conhecer o item lexical camarista. E os cinco informantes (um da faixa I e quatro da faixa II) que ainda reconhecem essa lexia, não a empregam com o conceito da acepção em estudo. Portanto, a unidade lexical camarista com o sentido de 'vereador municipal' configura um caso de $\underline{\text { desuso }}$.

\begin{tabular}{|l|l|}
\hline \multicolumn{2}{|l|}{ 74. CEIFA / DOC.22, fól.1 r, l.09-11 } \\
\hline $\begin{array}{l}\text { Acepção } \\
\text { buscada }\end{array}$ & Ato de cortar, colher. \\
\hline $\begin{array}{l}\text { Acepção(ões) } \\
\text { conhecida(s) }\end{array}$ & $\begin{array}{l}\text { F1-H-EP: NSR. } \\
\text { F1-M-EP: NSR. } \\
\text { Felos } \\
\text { informantes }\end{array}$ \\
$\begin{array}{l}\text { F1-M-EF: Ceifar é colher alguma coisa: vou ceifar uma soja. } \\
\text { F1-H-EM: NSR. } \\
\text { F1-M-EM: NSR. } \\
\text { F1-H-ES: NSR. } \\
\text { F1-M-ES: De cortar, de colher } \\
\text { F2-H-EP: NSR. } \\
\text { F2-M-EP: NSR. } \\
\text { F2-H-EF: Ceifa é o ato de você colher, cortar. } \\
\text { F2-M-EF: Colher. } \\
\text { F2-H-EM: Plantação de trigo, feijão. } \\
\text { F2-M-EM: NSR. } \\
\text { F2-H-ES: Vem do verbo ceifar que é cortar. } \\
\text { F2-M-ES: Ceifa é uma plantação de trigo, de arroz. }\end{array}$ \\
\hline
\end{tabular}




\begin{tabular}{|c|c|}
\hline $\begin{array}{l}\text { Acepções } \\
\text { registradas } \\
\text { nos } \\
\text { dicionários: }\end{array}$ & $\begin{array}{l}\text { Bluteau (1712-1728): N.D. } \\
\text { Morais Silva (1813): CEIFA, s. f. Acção, e tempo de ceifar. [CEIFÁR, } \\
\quad \text { v. at. Cortar os pães maduros]. } \\
\text { Cunha (1997): ceifa } s f . \text { 'ação de cortar, segar' | ceypha XV. } \\
\text { Ferreira (2004): ceifa } 1 \text {. Ato de ceifar; sega. [ceifar 5. Colher]. } \\
\text { Houaiss (2007): ceifa datação sXIV } 1 \text { ação ou efeito de ceifar; aceifa, } \\
\quad \text { sega. }\end{array}$ \\
\hline
\end{tabular}

A unidade lexical ceifa com o sentido de 'ato de cortar, colher' encontra-se presente nas respostas de cinco informantes (F1-H-EF e F1-M-ES / F2-H-EF, F2-M-EF e F2-HES). Já os informantes F2-H-EM e F2-M-ES atribuíram à forma lexical ceifa o sentido de 'plantação de trigo, feijão etc.'. Esta designação não se encontra lexicalizada nos dicionários gerais. Talvez estes informantes tenham associado o sema 'plantação' aos traços semânticos [roça, plantação, colheita]. Quanto ao registro da acepção buscada nos dicionários pesquisados, Bluteau não traz o registro da entrada ceifa. Em Cunha, Ferreira e Houaiss a entrada ceifa apresenta o mesmo sentido da acepção em estudo.

Analisando o contexto de uso do item lexical ceifar, constata-se baixa produtividade na fala dos entrevistados. Dos dezesseis entrevistados, nove informantes (seis da faixa I e quatro da faixa II) disseram não conhecer a lexia ceifa. E da faixa I, apenas dois informantes ainda a empregam com o sentido de 'cortar' e 'colher'. Portanto, essa lexia revela tendência ao desuso, , pela baixa produtividade presente na fala dos informantes da faixa I.

\begin{tabular}{|l|l|}
\hline \multicolumn{2}{|l|}{ 75. CIRCUITO / DOC.32, fól. 1r, l.22-24 } \\
\hline $\begin{array}{l}\text { Acepção } \\
\text { buscada }\end{array}$ & Ao redor, periferia. \\
\hline $\begin{array}{l}\text { Acepção(ões) } \\
\text { conhecida(s) } \\
\text { pelos } \\
\text { informantes }\end{array}$ & $\begin{array}{l}\text { F1-H-EP: NSR. } \\
\text { F1-M-EP: NSR. } \\
\text { F1-M-EF: Conheço o circuito de carro, corrida. } \\
\text { F1-H-EM: Tem o curto-circuito e também de corrida. } \\
\text { F1-M-EM: Curto-circuito. } \\
\text { F1-H-ES: Conheço no sentido de ao redor. } \\
\text { F1-M-ES: Circuito elétrico e também em volta da cidade. } \\
\end{array}$ \\
$\begin{array}{l}\text { F2-H-EP: O cara vai fazer uma ligação de linha, vai fazer um circuito. } \\
\text { F2-M-EP: É quando dá um circuito na luz de casa. } \\
\text { F2-H-EF: Circuito seria, por exemplo: uma corrida, tem um circuito, } \\
\text { seria um roteiro para turismo, vamos supor, um circuito. } \\
\text { F2-M-EF: NSR. } \\
\text { F2-H-EM: Algo que é redondo, ao redor. }\end{array}$ \\
\hline
\end{tabular}




\begin{tabular}{|l|l|}
\hline & $\begin{array}{l}\text { F2-M-EM: NSR. } \\
\text { F2-H-ES: É o local, por exemplo: o circuito de Fórmula 1 ou por onde o } \\
\text { processo deve tramitar, o circuito de tramitação. } \\
\text { F2-M-ES: Conheço como curto circuito, de eletricidade. }\end{array}$ \\
\hline $\begin{array}{l}\text { Acepções } \\
\text { registradas } \\
\text { nos } \\
\text { dicionários }\end{array}$ & $\begin{array}{l}\text { Bluteau (1712-1728): CIRCUITO. O espaço de hum lugar em redoado. } \\
\text { Morais Silva (1813): CIRCUITO, s. m. O espaço, ou área circular, em } \\
\text { redondo: } \text { o circuito da cidade é de tres leguas. } \\
\text { Cunha (1997): circuito } \text { sm. 'contorno, periferia, circunferência' | XVI. } \\
\text { Ferreira (2004): circuito 1. Contorno, periferia, circunferência. } \\
\text { Houaiss (2007): circuito } 1 \text { linha fechada que limita uma superfície, um } \\
\text { espaço; contorno, perímetro. }\end{array}$ \\
\hline
\end{tabular}

As definições apresentadas pelos lexicógrafos para a entrada circuito evidenciam o mesmo sentido da acepção buscada 'ao redor', 'periferia', 'contorno', 'circunferência'. Dentre as várias designações empregadas pelos informantes: 'curto-circuito', 'circuito de carro', 'circuito de tramitação do processo', 'ao redor, 'em volta da cidade'; somente três informantes (F1-H-ES e F1-M-ES / F2-H-EM) empregaram o item lexical circuito (além de outros significados) com o valor de 'ao redor', 'periferia'. Seis informantes (F1-H-EM, F1-H-ES e F1-M-ES / F2-H-EP, F2-M-EP e F2-M-ES) associaram a lexia circuito com outro item lexical 'curto-circuito' de significado distinto. Quatro informantes (F1-H-EF e F1-H-EM / F2-H-EF e F2-H-ES) utilizaram circuito para designar também 'corrida e competição de carro'. Houaiss informa ser esta acepção 'percurso a ser cumprido em certas provas, esp. as automobilísticas e congêneres', pertencente ao campo semântico esportivo.

Considerando os dados em análise, há indícios de que a lexia circuito, com o sentido da acepção buscada, seja esquecida com o passar do tempo, pois somente três informantes (dois da faixa I e um da faixa II) reconheceram nesta unidade lexical a acepção em estudo, revelando, dessa forma, tendência ao desuso.

\begin{tabular}{|l|l|}
\hline \multicolumn{2}{|l|}{ 76. CIRCUNVIZINHANÇA / DOC.11, fól.1r, 1.24-27 } \\
\hline $\begin{array}{l}\text { Acepção } \\
\text { buscada }\end{array}$ & Arredor de uma povoação. \\
\hline $\begin{array}{l}\text { Acepção(ões) } \\
\text { conhecida(s) } \\
\text { pelos } \\
\text { informantes }\end{array}$ & F1-H-EP: NSR. \\
& $\begin{array}{l}\text { F1-M-EP: NSR. } \\
\text { F1-M-EF: Algo que está vizinho. }\end{array}$ \\
& $\begin{array}{l}\text { F1-H-EM: NSR. } \\
\text { F1-M-EM: NSR. }\end{array}$ \\
& F1-H-ES: No sentido de ao redor, circunvizinhança da igreja. \\
& F1-M-ES: NSR. \\
\hline
\end{tabular}




\begin{tabular}{|c|c|}
\hline & $\begin{array}{l}\text { F2-H-EP: NSR. } \\
\text { F2-M-EP: NSR. } \\
\text { F2-H-EF: Seria... tem a zona urbana e tem a metropolitana, daí no caso } \\
\text { os bairros em volta, seria a circunvizinhança, no caso daqui tem a } \\
\text { Alexandra, Valadares. } \\
\text { F2-M-EF: NSR. } \\
\text { F2-H-EM: Aquele que tá ao nosso redor. } \\
\text { F2-M-EM: NSR. } \\
\text { F2-H-ES: É sentido de periferia. } \\
\text { F2-M-ES: A gente tem um ônibus aqui que anda circulando pela } \\
\quad \text { vizinhança, que circula ao redor, na circunvizinhança. }\end{array}$ \\
\hline $\begin{array}{l}\text { Acepções } \\
\text { registradas } \\
\text { nos } \\
\text { dicionários: }\end{array}$ & $\begin{array}{l}\text { Bluteau (1712-1728): [CIRCUNVESINHO. Cousa, que está na } \\
\text { vizinhança, \& nos contornos de outra]. } \\
\text { Morais Silva (1813): [CIRCUNVISÍNHO, adj. Que está proximamente } \\
\text { visinho]. } \\
\text { Cunha (1997): circunvizinho adj. 'que está próximo ou em redor' | } \\
\text { circunvizinhança | circumvisi- } 1844 \text {. } \\
\text { Ferreira (2004): circunvizinhança } 2 \text {. Arredores de uma povoação; } \\
\text { arredores, cercania(s). } \\
\text { Houaiss (2007): circunvizinhança datação } 1836 \text { território ou } \\
\text { população adjacente a um determinado núcleo. }\end{array}$ \\
\hline \multicolumn{2}{|c|}{$\begin{array}{l}\text { Apesar da lexia circunvizinhança não ser reconhecida por dez entrevistados (seis } \\
\text { da faixa I e quatro da faixa II), os seis informantes (F1-H-EF e F1-H-ES / F2-H-EF, F2- } \\
\text { H- EM, F2-H-ES e F2-M-ES) que responderam a questão a utilizaram com o mesmo } \\
\text { sentido da acepção buscada 'arredor de uma povoação'. Observa-se que o informante F2- } \\
\text { H-ES atribuiu o sinônimo de periferia para a unidade lexical circunvizinhança. Em } \\
\text { Ferreira esta constatação se confirma, po is, no registro da unidade lexical periferia (na } \\
\text { quinta acepção), define como sentido figurado a acepção: 'contorno, vizinhança, } \\
\text { proximidade'. Segundo Houaiss, a unidade lexical circunvizinhança tem sua forma fixada } \\
\text { a partir de } 1836 \text {. Talvez esse fato justifique o não registro em Bluteau e em Morais } \\
\text { Silva, cujas edições são anteriores a esta datação. Porém, Bluteau e Morais Silva } \\
\text { registram a entrada circunvizinho como sinônimo de circunvizinhança. } \\
\text { Analisando o contexto de uso deste item lexical, nota-se que seu emprego pelos } \\
\text { informantes da faixa I tem pouca produtividade, presumindo tratar-se de uma lexia com } \\
\text { tendência ao desuso. }\end{array}$} \\
\hline
\end{tabular}

\section{CôMPUTO / DOC.48, fól.2r, l.01-02}

Acepção

buscada

Soma, conta, resultado. 


\begin{tabular}{|c|c|}
\hline $\begin{array}{l}\text { Acepção(ões) } \\
\text { conhecida(s) } \\
\text { pelos } \\
\text { informantes }\end{array}$ & $\begin{array}{l}\text { F1-H-EP: NSR. } \\
\text { F1-M-EP: NSR. } \\
\text { F1-H-EF: NSR. } \\
\text { F1-M-EF: NSR. } \\
\text { F1-H-EM: NSR. } \\
\text { F1-M-EM: NSR. } \\
\text { F1-H-ES: NSR. } \\
\text { F1-M-ES: NSR. } \\
\text { F2-H-EP: NSR. } \\
\text { F2-M-EP: NSR. } \\
\text { F2-H-EF: Seria a contagem de alguma coisa, voto, material qualquer. } \\
\quad \text { Você vai conferir, no final tem que dar o resultado, faz a computação } \\
\text { para ver quanto deu o resultado. } \\
\text { F2-M-EF: NSR. } \\
\text { F2-H-EM: NSR. } \\
\text { F2-M-EM: NSR. } \\
\text { F2-H-ES: Computar vem do computador, estou computando a sua conta. } \\
\text { F2-M-ES: NSR. }\end{array}$ \\
\hline $\begin{array}{l}\text { Acepções } \\
\text { registradas } \\
\text { nos } \\
\text { dicionários: }\end{array}$ & $\begin{array}{l}\text { Bluteau (1712-1728): COMPUTO. Vid. Computaçaõ. } \\
\text { [COMPUTAÇAM. Acção de computar. Computo. Conta]. } \\
\text { Morais Silva (1813): COMPUTO, s. m. Cálculo, conta. } \\
\text { Cunha (1997): computar vb. | cômputo sm. 'contagem, cálculo’ XVII. } \\
\text { Ferreira (2004): cômputo 3. Cálculo. } \\
\text { Houaiss (2007): cômputo datação } 1708-17101 \text { cálculo, conta, } \\
\text { contagem. }\end{array}$ \\
\hline \multicolumn{2}{|c|}{$\begin{array}{l}\text { Cômputo é uma lexia com baixa produtividade na fala dos entrevistados. Dos } \\
\text { dezesseis, apenas dois informantes (F2-H-EF e F2-H-ES) empregam este item lexical com } \\
\text { o mesmo sentido da acepção buscada 'soma, conta, resultado'. Os lexicógrafos Morais } \\
\text { Silva, Cunha, Ferreira e Houaiss registraram as designações: 'cálculo', 'conta', } \\
\text { 'contagem', para a entrada cômputo. Para Bluteau as formas lexicais cômputo e } \\
\text { computação apresentam a mesma definição. } \\
\text { Analisando o contexto de uso da unidade lexical cômputo, constata-se a ausência de } \\
\text { resposta por parte de todos os informantes da faixa I, e apenas duas respostas por parte da } \\
\text { faixa II, revelando, dessa forma, tendência ao desuso. }\end{array}$} \\
\hline
\end{tabular}

78. CONJUNTURA / DOC.43, fól.1r, l.04-07

Acepção

buscada

Circunstância, situação. 


\begin{tabular}{|c|c|}
\hline $\begin{array}{l}\text { Acepção(ões) } \\
\text { conhecida(s) } \\
\text { pelos } \\
\text { informantes }\end{array}$ & $\begin{array}{l}\text { F1-H-EP: NSR. } \\
\text { F1-M-EP: NSR. } \\
\text { F1-H-EF: NSR. } \\
\text { F1-M-EF: NSR. } \\
\text { F1-H-EM: NSR. } \\
\text { F1-M-EM: NSR. } \\
\text { F1-H-ES: Acho que em Paranaguá fala demais essa palavra, no sentido } \\
\text { de atual situação. } \\
\text { F1-M-ES: NSR. } \\
\text { F2-H-EP: NSR. } \\
\text { F2-M-EP: NSR. } \\
\text { F2-H-EF: Conjuntura seria junto, mais ou menos nos termos da lei. E } \\
\text { tem também na atual conjuntura das coisas, tudo o que tá } \\
\text { acontecendo. } \\
\text { F2-M-EF: NSR. } \\
\text { F2-H-EM: NSR. } \\
\text { F2-M-EM: NSR. } \\
\text { F2-H-ES: Conjuntura é quadro, a situação, a situação política, os } \\
\text { acontecimentos que compõe aquela época. } \\
\text { F2-M-ES: NSR. }\end{array}$ \\
\hline $\begin{array}{l}\text { Acepções } \\
\text { registradas } \\
\text { nos } \\
\text { dicionários }\end{array}$ & $\begin{array}{l}\text { Bluteau (1712-1728): CONJUNTURA. He o estado dos negocios, boa, } \\
\text { ou má disposição delles. } \\
\text { Morais Silva (1813): CONJUNCTÚRA. V. Conjuncção. Ensejo, em } \\
\text { que concorrem diversas acções, circunstancias. } \\
\text { Cunha (1997): junto adj. 'unido, pegado, próximo, chegado, anexo' | } \\
\text { Do lat. conjunctus -us | conjuntura XIII. } \\
\text { Ferreira (2004): conjuntura } 1 \text {. Situação nascida de um encontro de } \\
\text { determinadas circunstâncias, e que se considera como o ponto de } \\
\text { partida de uma evolução, uma ação, um fato. } \\
\text { Houaiss (2007): conjuntura datação sXIII } 1 \text { combinação ou } \\
\text { concorrência de acontecimentos ou circunstâncias num dado } \\
\text { momento; circunstância, situação. }\end{array}$ \\
\hline \multicolumn{2}{|c|}{$\begin{array}{l}\text { A lexia conjuntura apresentou baixa produtividade no contexto de fala das entrevistas } \\
\text { em Paranaguá. Dos dezesseis informantes, treze (sete da faixa I e seis da faixa II) disseram } \\
\text { não conhecer o item lexical conjuntura. Quanto à acepção buscada 'circunstância, } \\
\text { situação', apenas três informantes (F1-H-ES / F2-H-EF e F2-H-ES) a reconheceram. O } \\
\text { informante F2-H-EF, além de empregar o sentido 'circunstância, situação' para a unidade } \\
\text { lexical conjuntura, atribui também o valor de 'junto', talvez pela semelhança entre essas } \\
\text { formas lexicais: conjuntura/junto. Os lexicógrafos Bluteau, Ferreira e Houaiss registraram } \\
\text { o lema conjuntura com o mesmo sentido da acepção em estudo. }\end{array}$} \\
\hline
\end{tabular}


Analisando o contexto de uso do item lexical conjuntura, constata-se baixa produtividade na fala dos informantes, pois, do total de dezesseis entrevistados, apenas um informante da faixa I e dois da faixa II ainda empregam conjuntura com o mesmo sentido da acepção investigada, configurando, assim, tendência ao desuso.

\begin{tabular}{|c|c|}
\hline \multicolumn{2}{|c|}{ 79. CONSTERNAÇÃO / DOC.22, fól.1r, l.21-25 } \\
\hline $\begin{array}{l}\text { Acepção } \\
\text { buscada }\end{array}$ & Abatimento, desolação, tristeza. \\
\hline $\begin{array}{l}\text { Acepção(ões) } \\
\text { conhecida(s) } \\
\text { pelos } \\
\text { informantes }\end{array}$ & $\begin{array}{l}\text { F1-H-EP: NSR. } \\
\text { F1-M-EP: NSR. } \\
\text { F1-H-EF: Quando a pessoa fica constrangida. } \\
\text { F1-M-EF: NSR. } \\
\text { F1-H-EM: NSR. } \\
\text { F1-M-EM: NSR. } \\
\text { F1-H-ES: NSR. } \\
\text { F1-M-ES: NSR. } \\
\text { F2-H-EP: NSR. } \\
\text { F2-M-EP: NSR. } \\
\text { F2-H-EF: Consternação seria você ver um como aconteceu, por } \\
\quad \text { exemplo: o vendaval que arrasou as colônias, então você fica } \\
\text { consternado com aquilo. } \\
\text { F2-M-EF: Alguém que está triste. } \\
\text { F2-H-EM: NSR. } \\
\text { F2-M-EM: NSR. } \\
\text { F2-H-ES: NSR. } \\
\text { F2-M-ES: NSR. }\end{array}$ \\
\hline $\begin{array}{l}\text { Acepções } \\
\text { registradas } \\
\text { nos } \\
\text { dicionários }\end{array}$ & $\begin{array}{l}\text { Bluteau (1712-1728): CONSTERNAÇAM, val o mesmo, que grande } \\
\text { desalento, \& medo, como sucede nas calamidades publicas, ruinas, } \\
\text { estragos, \& derrotas de exercitos. } \\
\text { Morais Silva (1813): CONSTERNAÇÃO, s. f. Grande perturbação, e } \\
\text { quebra de animo. } \\
\text { Cunha (1997): consternar vb. 'desalentar' | consternação XVIII. } \\
\text { Ferreira (2004): consternação 1. Ato ou efeito de consternar(-se). } \\
\text { [consternar 1. Causar funda aflição e abatimento a; lançar em } \\
\text { consternação; desalentar.] } \\
\text { Houaiss (2007): consternação datação } 16832 \text { grande tristeza; pesar } \\
\text { profundo; contristação, dor, desolação. }\end{array}$ \\
\hline
\end{tabular}


Dos dezesseis entrevistados em Paranaguá, três informantes reconheceram a lexia consternação, mas apenas dois informantes (F2-H-EF e F2-M-EF) empregam o item lexical consternação no sentido de 'abatimento, desolação, tristeza'. Para o informante F1-H-EF, consternação seria sinônimo de 'uma pessoa constrangida'. Em pesquisa aos dicionários acima, não há o registro dessa acepção para a lexia em questão. Os lexicógrafos registraram a entrada consternação com a mesma acepção buscada.

Analisando o contexto de uso do item lexical consternação, constata-se baixa produtividade na fala dos informantes, pois apenas do is informantes da faixa II ainda empregam conjuntura com o mesmo sentido da acepção investigada, e nenhum informante da faixa I reconheceu-o com o sentido de 'abatimento, desolação, tristeza', indicando, assim, tendência ao desuso.

\begin{tabular}{|c|c|}
\hline$\overline{0 .}($ & $\overline{03}$ \\
\hline $\begin{array}{l}\text { Acepção } \\
\text { buscada }\end{array}$ & Plantação, cultivo. \\
\hline $\begin{array}{l}\text { Acepção(ões) } \\
\text { conhecida(s) } \\
\text { pelos } \\
\text { informantes }\end{array}$ & $\begin{array}{l}\text { F1-H-EP: NSR. } \\
\text { F1-M-EP: Cultura é plantação de tomate, cebola. } \\
\text { F1-H-EF: Cultura conheço mais pra arte, cultura da cidade. } \\
\text { F1-M-EF: Cultura são os costumes de um lugar. Em Paranaguá o } \\
\text { barreado é cultura daqui. } \\
\text { F1-H-EM: Sentido da própria cultura do local. } \\
\text { F1-M-EM: Cultura de plantação. } \\
\text { F1-H-ES: Cultura de vegetais, cultura de plantação. } \\
\text { F1-M-ES: Como plantação. } \\
\text { F2-H-EP: Uso cultura de arroz de milho. } \\
\text { F2-M-EP: Cultura é quando você tem uma cultura e sabe mais que os } \\
\text { outros. } \\
\text { F2-H-EF: Cultura seria o que as pessoas sabem, ou você cultiva alguma } \\
\text { coisa, por exemplo: o que você tem na sua propriedade? Ah, eu tenho } \\
\text { uma cultura de milho, mandioca. } \\
\text { F2-M-EF: Acho que cultura é a nossa cultura que nem aqui em } \\
\text { Paranaguá tem fandango, tem outras coisas também. } \\
\text { F2-H-EM: Costumes, hábitos, vestimenta, comida, e plantação também. } \\
\text { F2-M-EM: É tudo que diz respeito a cidade, as festas da Nossa Senhora } \\
\text { do Rocio, do Rosário, dos Navegantes, a linguagem da gente que } \\
\text { dizem que é diferente. } \\
\text { F2-H-ES: São costumes, tradições de um povo, de um local. Tem } \\
\text { também a agricultura, a cultura da soja, a cultura do arroz, produto } \\
\text { daí. }\end{array}$ \\
\hline
\end{tabular}




\begin{tabular}{|c|c|}
\hline & $\begin{array}{l}\text { F2-M-ES: Cultura é quando você conversa com uma pessoa que ela tem } \\
\text { uma cultura pra falar, se expressa bem. }\end{array}$ \\
\hline $\begin{array}{l}\text { Acepções } \\
\text { registradas } \\
\text { nos } \\
\text { dicionários }\end{array}$ & $\begin{array}{l}\text { Bluteau (1712-1728): CULTURA. O modo, a arte, a acçaõ de cultivar a } \\
\text { terra. } \\
\text { Morais Silva (1813): CULTÚRA, s. f. O modo, e arte, o trabalho de } \\
\text { cultivar a terra. } \\
\text { Cunha (1997): De culto }{ }^{1} \text { | cultura sf. 'orig. ato, efeito ou modo de } \\
\text { cultivar' 'ext. civilização' XVI. } \\
\text { Ferreira (2004): cultura } 1 \text {. Ato, efeito ou modo de cultivar; cultivo. } \\
\text { Houaiss (2007): cultura datação sXV } 1 \text { Rubrica: agricultura: ação, } \\
\text { processo ou efeito de cultivar a terra; lavra, cultivo. }\end{array}$ \\
\hline
\end{tabular}

Dentre as várias designações para a entrada cultura, os lexicógrafos registraram a acepção buscada: 'plantação, cultivo'. Analisando o contexto de uso dessa unidade lexical, constata-se que praticamente todos os informantes (com exceção do informante F1-H-EP, que disse não saber o significado de cultura) utilizam a lexia cultura no seu dia a dia, porém com variação de significados: 'pessoa instruída', 'costume de um povo', 'tradição local', 'plantação', 'ação de cultivar gêneros alimentícios'. Seis informantes (F1H-EF, F1-M-EF e F1-H-EM / F2-M-EP, F2-M-EF e F2-M-ES) utilizaram o item lexical somente nas acepções de 'pessoa instruída', 'costume de um povo', 'tradição local'. Outros seis informantes (F1-M-EP, F1-M-EM, F1-H-ES e F1-M-ES / F2-H-EP e F2-MEM) empregaram cultura apenas na acepção de 'plantação', 'ação de cultivar gêneros alimentícios', e três informantes (F2-H-EF, F2-H-EM e F2-H-ES) atribuíram à unidade lexical os significados apresentados anteriormente.

Analisando o contexto de utilização do item lexical cultura, observa-se, no estágio atual de variação, o emprego de diversos significados, tanto por da parte dos informantes da faixa I como da faixa II. Neste cenário linguístico, conclui-se, então, que a unidade lexical cultura no sentido de 'plantação, cultivo', presente nas respostas de oito informantes de Paranaguá (quatro da faixa I e quatro da faixa II), apresenta tendência à manutencão.

\begin{tabular}{|l|l|}
\hline \multicolumn{2}{|l|}{ 81. DATA / DOC.25, fól.1r, l.22-2 } \\
\hline $\begin{array}{l}\text { Acepção } \\
\text { buscada }\end{array}$ & Pedaço de terra, faixa de terreno. \\
\hline $\begin{array}{l}\text { Acepção(ões) } \\
\text { conhecida(s) } \\
\text { pelos } \\
\text { informantes }\end{array}$ & F1-H-EP: Data de nascimento. \\
& $\begin{array}{l}\text { F1-H-EF: Dat Conheço data só de calendário. } \\
\text { F1-M-EF: Data do pagamento, de um dia importante. } \\
\end{array}$ \\
& F1-H-EM: Data do dia. \\
\hline
\end{tabular}




\begin{tabular}{|c|c|}
\hline & $\begin{array}{l}\text { F1-H-ES: Data só do calendário. } \\
\text { F1-M-ES: Data de calendário. } \\
\text { F2-H-EP: Data de validade. } \\
\text { F2-M-EP: Aquele arroz tem aquela data pra colher, data do aniversário. } \\
\text { F2-H-EF: Data é mais lá no norte que fala, quando você tem uma } \\
\text { propriedade daí, fala eu tenho uma data, mas aqui no litoral não usa. } \\
\text { F2-M-EF: Já faz uma data que eu não ouço isso, faz um tempo. } \\
\text { F2-H-EM: Muito usada no sentido de aniversário, pessoal, país, estado. } \\
\text { F2-M-EM: Data é todo o dia. } \\
\text { F2-H-ES: Data é marcação de terra, mas aqui em Paranaguá não se usa. } \\
\text { F2-M-ES: Uma data de aniversário. }\end{array}$ \\
\hline $\begin{array}{l}\text { Acepções } \\
\text { registradas } \\
\text { nos } \\
\text { dicionários }\end{array}$ & $\begin{array}{l}\text { Bluteau (1712-1728): DATA. O que se acrescenta a hum papel, para } \\
\text { declarar, \& assinalar o dia, em que foy escrito. } \\
\text { Morais Silva (1813): DÁTA, s. f. O dia do mez, e o anno, em que se fez } \\
\text { qualquer carta. } \\
\text { Cunha (1997): data sf. 'tempo assinalado, indicação da época, ano, mês } \\
\text { ou dia em que se realizou algum fato' XIII. } \\
\text { Ferreira (2004): data } 8 \text {. Bras. MG SP PR Porção de terreno com } 20 \text { a } \\
22 \text { metros por } 40 \text { a } 44 \text { metros. } \\
\text { Houaiss (2007): ' data datação sXIII } 12 \text { Regionalismo: Minas Gerais, } \\
\text { São Paulo, Paraná: terreno retangular de } 20 \text { m a } 22 \text { m por } 40 \text { m a } \\
44 \text { m. }\end{array}$ \\
\hline \multicolumn{2}{|c|}{$\begin{array}{l}\text { Analisando o contexto de uso da lexia data, constata-se ser esta bastante produtiva na } \\
\text { fala dos entrevistados. Todos os informantes utilizam o item lexical data, mas somente } \\
\text { com o conceito de 'dia do ano', 'período de tempo'. Os informantes (F2-H-EF e F2-H-ES), } \\
\text { chegaram a identificar na unidade lexical o sentido de 'propriedade', 'marcação de terra' } \\
\text { no entanto, advertiram que no litora1/Paranaguá não é comum o emprego deste significado } \\
\text { para a lexia data. Os lexicógrafos Bluteau, Morais Silva e Cunha registraram a mesma } \\
\text { acepção que os informantes parnanguaras utilizam, enquanto Ferreira (na oitava acepção) } \\
\text { e Houaiss (na décima segunda acepção) trazem a designação 'porção de terreno', 'terreno } \\
\text { retangular'. O primeiro classifica como brasileirismo, e o segundo como regionalismo } \\
\text { Ambos indicam ser marca dialetal dos estados de Minas Gerais, São Paulo e Paraná } \\
\text { Levando em consideração a classificação cunhada por Ferreira e Houaiss, presume-se, em } \\
\text { toda região do Paraná há o registro oral da acepção 'pedação de terra, lote, terreno' para a } \\
\text { forma lexical data. } \\
\text { Portanto, por meio dos dados apresentados, essa classificação se torna um tanto } \\
\text { questionável, haja vista o não reconhecimento por parte dos informantes parnanguaras, } \\
\text { desta acepção. Dessa forma, supõe-se ser um caso de desuso. }\end{array}$} \\
\hline
\end{tabular}




\begin{tabular}{|c|c|}
\hline \multicolumn{2}{|c|}{ 82. DEMASIA / DOC.36, fól.1v, l.02-04 } \\
\hline $\begin{array}{l}\text { Acepção } \\
\text { buscada }\end{array}$ & Abuso, desregramento. \\
\hline $\begin{array}{l}\text { Acepção(ões) } \\
\text { conhecida(s) } \\
\text { pelos } \\
\text { informantes }\end{array}$ & $\begin{array}{l}\text { F1-H-EP: NSR. } \\
\text { F1-M-EP: NSR. } \\
\text { F1-H-EF: NSR. } \\
\text { F1-M-EF: NSR. } \\
\text { F1-H-EM: NSR. } \\
\text { F1-M-EM: NSR. } \\
\text { F1-H-ES: Uma pessoa que fala bastante. } \\
\text { F1-M-ES: NSR. } \\
\text { F2-H-EP: NSR. } \\
\text { F2-M-EP: NSR. } \\
\text { F2-H-EF: Demasia é coisa que é além, que extrapola. Se você precisa de } \\
\text { trinta, daí te dão quarenta, cinquenta, é em demasia, é além do que } \\
\text { você precisa no caso. } \\
\text { F2-M-EF: Demais, alguma coisa que passa dos limites. } \\
\text { F2-H-EM: NSR. } \\
\text { F2-M-EM: NSR. } \\
\text { F2-H-ES: Demasia demais, abuso. } \\
\text { F2-M-ES: NSR. }\end{array}$ \\
\hline $\begin{array}{l}\text { Acepções } \\
\text { registradas } \\
\text { nos } \\
\text { dicionários }\end{array}$ & $\begin{array}{l}\text { Bluteau (1712-1728): DEMASIA, as vezes se toma por pouco respeyto } \\
\text { do Inferior para com o seu superior, ou pelo contrario do orgulho, } \\
\text { com que os grandes trataõ aos pequenos. Em hum, \& outro sentido } \\
\text { poderás usar da palavra. } \\
\text { Morais Silva (1813): DEMASÍA, s. f. Excesso, superfluidade. } \\
\text { Cunha (1997): demais } a d v \text {. 'excessivamente, em demasia' | demasia } \\
\text { XV. } \\
\text { Ferreira (2004): demasia } 3 \text {. Abuso, temeridade. } \\
\text { Houaiss (2007): demasia datação } 14221 \text { o que está em excesso; o que } \\
\text { ultrapassa a média ou o bom senso. }\end{array}$ \\
\hline \multicolumn{2}{|c|}{$\begin{array}{l}\text { Dos dezesseis informantes entrevistados, doze (sete da faixa I e cinco da faixa II) } \\
\text { disseram não conhecer a lexia demasia. Dos quatro informantes que ainda utilizam este } \\
\text { item lexical, apenas o informante F2-H-ES empregaram com o mesmo sentido da acepção } \\
\text { buscada: 'abuso, desregramento'. Os outros três informantes (F1-H-ES / F2-H-EF e F2- } \\
\text { M-EF) reconheceram demasia com o sentido 'o que está em excesso; o que ultrapassa a } \\
\text { média ou o bom senso'. Este conceito está registro em Ferreira e em Houaiss na primeira } \\
\text { acepção. As definições apresentadas por Bluteau, Morais Silva, Ferreira e Houaiss } \\
\text { evidenciam o mesmo sentido da acepção buscada. }\end{array}$} \\
\hline
\end{tabular}


Analisando o contexto de uso da unidade lexical demasia e comparando com as respostas dos informantes, percebe-se baixa produtividade dessa lexia na fala dos entrevistados, principalmente, os da faixa I. Portanto, demasia apresenta tendência ao desuso.

\begin{tabular}{|c|c|}
\hline \multicolumn{2}{|c|}{ 83. DESARRANJO / DOC.33, fól.1r, l.14-16 } \\
\hline $\begin{array}{l}\text { Acepção } \\
\text { buscada }\end{array}$ & Desordem, confusão. \\
\hline $\begin{array}{l}\text { Acepção(ões) } \\
\text { conhecida(s) } \\
\text { pelos } \\
\text { informantes }\end{array}$ & $\begin{array}{l}\text { F1-H-EP: NSR. } \\
\text { F1-M-EP: Conheço só desarranjo de flor. } \\
\text { F1-H-EF: Desarranjo é dor de barriga. } \\
\text { F1-M-EF: NSR. } \\
\text { F1-H-EM: NSR. } \\
\text { F1-M-EM: Desarranjo é dor de barriga. } \\
\text { F1-H-ES: Desarrumado. } \\
\text { F1-M-ES: Desarranjo intestinal, dor de barriga. } \\
\text { F2-H-EP: Às vezes tem um desarranjo assim, um bate boca com outro, } \\
\text { confusão. } \\
\text { F2-M-EP: NSR. } \\
\text { F2-H-EF: Desarranjo é quando alguma coisa que tá certa, de repente } \\
\text { desarranja, sai do lugar, exemplo: o trem que descarila. } \\
\text { F2-M-EF: Quando a gente faz alguma coisa pra uma pessoa e de repente } \\
\text { a pessoa volta atrás, fez um desarranjo. } \\
\text { F2-H-EM: Estava arranjado, ou tava tudo no lugar, tudo certinho, chega } \\
\text { alguém e bagunçou tudo, daí desarranja. } \\
\text { F2-M-EM: Quando eu tô com desarranjo na minha barriga. } \\
\text { F2-H-ES: Dor de barriga. E aqui dor de barriga é chorrilho, aquela que } \\
\text { não para nunca. } \\
\text { F2-M-ES: Quando você está com desarranjo e precisa ir ao banheiro. }\end{array}$ \\
\hline $\begin{array}{l}\text { Acepções } \\
\text { registradas } \\
\text { nos } \\
\text { dicionários }\end{array}$ & $\begin{array}{l}\text { Bluteau (1712-1728): DESARRANJO. Desordem, confuso, ou } \\
\text { perturbação. } \\
\text { Morais Silva (1813): DESARRANJO, s. m. Desordem na guerra, } \\
\text { perturbação. } \\
\text { Cunha (1997): arranjar vb. 'pôr em ordem, arrumar, compor' | } \\
\text { Desarranjo XVI. } \\
\text { Ferreira (2004): desarranjo 1. Falta de arranjo; desordem, confusão. } \\
\text { Houaiss (2007): desarranjo datação sXVI } \mathbf{1 . 1} \text { desordem decorrente da } \\
\text { falta de disciplina, de competência, de comando etc. }\end{array}$ \\
\hline
\end{tabular}


Pelas respostas dos entrevistados observa-se que a lexia desarranjo é bastante produtiva no contexto de fala. Dos dezesseis informantes, somente quatro (três da faixa I e um da faixa II) disseram não conhecer desarranjo. Observou-se que desarranjo, nas respostas dos informantes, é um item lexical com várias acepções. Da acepção buscada 'desordem, confusão', apenas o informante F2-H-EP reconheceu a lexia desarranjo com este sentido. Seis informantes (F1-H-EF, F1-M-EM e F1-M-ES / F2-M-EM, F2-H-ES e F2-M-ES) definiram desarranjo como sinônimo de 'dor de barriga'. Ferreira e Houaiss informam essa acepção como uso popular, e o último dicionarista faz remissão ao termo diarreia. O informante F2-H-ES informou também ser a variante lexical chorrilho um tipo de 'dor de barriga que não para nunca'. Dos dicionários pesquisados, Cunha é o único que registra a designação 'disenteria, diarréia', na quarta acepção para a entrada chorrilho e a classifica como de uso informal, relacionada ao campo semântico da veterinária. Os informantes (F1-H-ES / F2-M-EF e F2-H-EM) utilizaram a unidade lexical desarranjo como sinônimo de 'desarrumado/desarrumar'. A informante F1-M-EP associou 'arranjo de flor' com a lexia desarranjo, devido à semelhança entre essas formas lexicais. Já para o informante F2-H-EF, desarranjo seria 'alguma coisa que sai do lugar, exemplo o trem que descarrila'. Nos dicionários pesquisados não há o registro dessa acepção para a entrada desarranjo. As definições registradas por Bluteau, Morais Silva, Ferreira e Houaiss evidenciam como designações comuns: 'desordem', 'perturbação', 'confusão', 'falta de arranjo'.

No estágio atual de variação, a verig u a -se que a unidade lexical desarranjo com o sentido documentado no corpus escrito, apresenta baixa produtividade. Aparentemente, a acepção 'dor de barriga' é a designação mais lembrada para este item lexical e, consequentemente, está concorrendo com maior índice de frequência na fala dos entrevistados. Portanto, há indícios de tendência ao desuso, uma vez que nenhum dos informantes da faixa I emprega a forma lexical desarranjo com a acepção em estudo.

\begin{tabular}{|l|l|}
\hline \multicolumn{2}{|l|}{ 84. DESCONSOLAÇÃO / DOC.46, fól.1v, l.13-16 } \\
\hline $\begin{array}{l}\text { Acepção } \\
\text { buscada }\end{array}$ & Tristeza, frustração. \\
\hline $\begin{array}{l}\text { Acepção(ões) } \\
\text { conhecida(s) } \\
\text { pelos } \\
\text { informantes }\end{array}$ & $\begin{array}{l}\text { F1-H-EP: NSR. } \\
\text { F1-M-EP: NSR. } \\
\text { F1-M-EF: É Uma pessoa desconsolada, triste. } \\
\text { F1-H-EM: É tipo uma tristeza. } \\
\text { F1-M-EM: Pessoa que tá desconsolada, triste. } \\
\text { F1-H-ES: NSR. } \\
\text { F1-M-ES: Tá desconsolado, tá triste. }\end{array}$ \\
& $\begin{array}{l}\text { F2-H-EP: É quando a pessoa tá desconsolada, tá triste. } \\
\text { F2-M-EP: Quando você tá triste, vem alguém te consolar. }\end{array}$ \\
\hline
\end{tabular}




\begin{tabular}{|c|c|}
\hline & $\begin{array}{l}\text { F2-H-EF: Desconsolação é uma pessoa que tá desconsolada com alguma } \\
\text { coisa assim, com algum evento que não deu certo, tá desconsolada. } \\
\text { F2-M-EF: Alguém que está muito pra baixo, está desconsolado. } \\
\text { F2-H-EM: Alguém que sofreu uma decepção. } \\
\text { F2-M-EM: NSR. } \\
\text { F2-H-ES: Desconsolado, que tá triste. } \\
\text { F2-M-ES: Quando a pessoa está triste, deprimida. }\end{array}$ \\
\hline $\begin{array}{l}\text { Acepções } \\
\text { registradas } \\
\text { nos } \\
\text { dicionários }\end{array}$ & $\begin{array}{l}\text { Bluteau (1712-1728): DESCONSOLAÇAM, desconsolado. } V \text {. afflicçaõ. } \\
\text { Vid. Tristeza. } \\
\text { Morais Silva (1813): DESCONSOLAÇÃO, s. f. Falta de consolação. } \\
\text { [CONSOLAÇÃO, s. f. O estado de animo do consolado]. } \\
\text { Cunha (1997): consolar vb. 'aliviar ou suavizar o sofrimento de' | } \\
\text { Desconsolação | -çam } 1570 . \\
\text { Ferreira (2004): desconsolação } 1 . \text { Falta de consolação; desconsolo. } \\
\text { Houaiss (2007): desconsolação datação sXIV } 1 \text { ausência de } \\
\text { consolação; desconsolo, tristeza, aflição. }\end{array}$ \\
\hline \multicolumn{2}{|c|}{$\begin{array}{l}\text { Os lexicógrafos Morais Silva, Ferreira e Houaiss registraram a entrada desconsolação } \\
\text { com a mesma acepção buscada neste estudo: 'tristeza, frustração'. Para a definição do } \\
\text { lema desconsolação, Bluteau remete à variante lexical tristeza. Analisando o contexto de } \\
\text { uso na fala dos informantes, verifica-se que, dos doze informantes que conhecem a lexia } \\
\text { desconsolação, oito deles (F1-H-EF, F1-M-EF, F1-M-EM e F1-M-ES / F2-H-EP, F2-H- } \\
\text { EF, F2-M-EF e F2-H-ES) a empregam com valor adjetival: desconsolado/desconsolada. } \\
\text { Para esses informantes, a qualidade de desconsolado é sinônimo de alguém 'estar triste', } \\
\text { 'desanimada', 'decepcionada', 'estar pra baixo'. Portanto, essas designações referem-se à } \\
\text { mesma acepção em estudo: 'tristeza, frustração'. } \\
\text { Presume-se, pelos dados analisados, que a maioria dos informantes parnanguaras ainda } \\
\text { conserva o conceito 'tristeza', 'frustração', 'desconsolo' para o item lexical } \\
\text { desconsolação, porém seu emprego no registro oral se manifesta por meio do adjetivo } \\
\text { desconsolado, havendo indícios do favorecimento desta forma, em detrimento da lexia } \\
\text { desconsolação. Portanto a unidade lexical em estudo apresenta tendência ao desuso. }\end{array}$} \\
\hline
\end{tabular}

\begin{tabular}{|l|l|}
\hline \multicolumn{2}{|l|}{ 85. DESMEMBRAÇÃO / DOC.48, fól.1v, l.33-37 } \\
\hline $\begin{array}{l}\text { Acepção } \\
\text { buscada }\end{array}$ & Separação, desagregação. \\
\hline $\begin{array}{l}\text { Acepção(ões) } \\
\text { conhecida(s) } \\
\text { pelos }\end{array}$ & F1-H-EP: NSR. \\
informantes & F1-H-EP: NSR. \\
& F1-M-EF: NSR. \\
\hline
\end{tabular}




\begin{tabular}{|c|c|}
\hline & $\begin{array}{l}\text { F1-H-EM: Desmembramento que seria tirada de um membro, excluir um } \\
\text { membro, tirar definitivo. } \\
\text { F1-M-EM: É separar. } \\
\text { F1-H-ES: Desmembrou, separou. } \\
\text { F1-M-ES: NSR. } \\
\text { F2-H-EP: NSR. } \\
\text { F2-M-EP: NSR. } \\
\text { F2-H-EF: Desmembração no caso de município, você separa um } \\
\text { município um do outro tal. } \\
\text { F2-M-EF: Alguém que sai de um grupo, tinha um grupo e o grupo se } \\
\text { dividiu. } \\
\text { F2-H-EM: Alguém do contexto familiar que saiu e foi pra uma outro } \\
\text { lugar. } \\
\text { F2-M-EM: Desmembração é quando tira um membro do corpo. } \\
\text { F2-H-ES: Desmembrar é quando se pega uma área e reparte essa área em } \\
\text { vários lotes, isso se usa muito nas prefeituras, na questão das } \\
\text { medições de casas, ruas e tem que ter o registro do imóvel } \\
\text { desmembrado. Desmembrar é a mesma coisa que lotear, você loteia. } \\
\text { F2-M-ES: Desmembrar é separar. Tinha um terreno enorme, foi } \\
\text { desmembrado, agora cada um tem seu lote. }\end{array}$ \\
\hline $\begin{array}{l}\text { Acepções } \\
\text { registradas } \\
\text { nos } \\
\text { dicionários }\end{array}$ & $\begin{array}{l}\text { Bluteau (1712-1728): DESMEMBRAÇAM. (Termo politico) Separaçaõ } \\
\text { de alguma parte de hum Estado, terra, ou provicia, incorporada com } \\
\text { outra. } \\
\text { Morais Silva (1813): DESMEMBRAÇÃO, s. f. §. Separação, desunião } \\
\text { de parte de algum Estado, rendas. } \\
\text { Cunha (1997): N.D. } \\
\text { Ferreira (2004): desmembração 4. Separação, desagregação. } \\
\text { Houaiss (2007): desmembração datação } 1713 \text { m.q. desmembramento. } \\
\text { [desmembramento } 2 \text { divisão, em várias partes, daquilo que formava } \\
\text { uma unidade; divisão, partilha, separação, loteamento]. }\end{array}$ \\
\hline \multicolumn{2}{|c|}{$\begin{array}{l}\text { A lexia desmembramento com o sentido de 'separação, desagregação' foi reconhecida } \\
\text { por sete informantes (F1-M-EM e F1-H-ES / F2-H-EF, F2-M-EF, F2-H-EM, F2-H-ES e } \\
\text { F2-M-ES). Outros dois informantes (F1-H-EM / F2-M-EM) atribuíram à unidade lexical } \\
\text { desmembramento o valor de 'amputar'. Os lexicógrafos Bluteau, Morais e Ferreira } \\
\text { registram as designações: 'separação de um Estado, terra', 'desunião de parte de um } \\
\text { Estado' e 'desagregação'. Houaiss registra a entrada desmembração e remete à variante } \\
\text { lexical desmembramento com a mesma acepção registra em Bluteau, Morais Silva e } \\
\text { Ferreira. Cunha não traz o registro da entrada desmembração. } \\
\text { Analisando o contexto de uso dessa unidade lexical, observa ser bastante produtiva na } \\
\text { fala dos informantes da faixa II, enquanto, dos informantes da faixa I, apenas dois } \\
\text { utilizaram a lexia com a mesma acepção documentada no corpus escrito. Portanto, a }\end{array}$} \\
\hline
\end{tabular}


forma lexical desmembração com o sentido de 'separação, desagregação' revela tendência ao desuso.

\begin{tabular}{|c|c|}
\hline \multicolumn{2}{|c|}{ 86. DETRIMENTO / DOC.22, fól.1r, l.10-12 } \\
\hline $\begin{array}{l}\text { Acepção } \\
\text { buscada }\end{array}$ & Prejuízo, dano. \\
\hline $\begin{array}{l}\text { Acepção(ões) } \\
\text { conhecida(s) } \\
\text { pelos } \\
\text { informantes: }\end{array}$ & $\begin{array}{l}\text { F1-H-EP: NSR. } \\
\text { F1-M-EP: NSR. } \\
\text { F1-H-EF: NSR. } \\
\text { F1-M-EF: NSR. } \\
\text { F1-H-EM: NSR. } \\
\text { F1-M-EM: NSR. } \\
\text { F1-H-ES: NSR. } \\
\text { F1-M-ES: NSR. } \\
\text { F2-H-EP: NSR. } \\
\text { F2-M-EP: NSR. } \\
\text { F2-H-EF: Detrimento é quando você faz alguma coisa em detrimento a } \\
\text { alguém, por exemplo: vou fazer isso para aquela pessoa, que pode ser } \\
\text { para os dois lados: pro bem e pro mal. Eu fiz em detrimento para bem, } \\
\text { ou fiz em detrimento para mal, isso aí pode ser usado para os dois } \\
\text { sentidos. } \\
\text { F2-M-EF: NSR. } \\
\text { F2-H-EM: Atrelação de duas pedras. Quando você toca duas pedras. } \\
\text { F2-M-EM: NSR. } \\
\text { F2-H-ES: Detrimento é quando se faz algo quando você retira em } \\
\text { detrimento, "eu estou fazendo isso aqui em detrimento àquilo", quer } \\
\text { dizer pode ser em razão, pode ser em resultado ou eu acho que nesse } \\
\text { sentido em que você favorece ou desfavorece alguém no detrimento. } \\
\text { Todo detrimento causa prejuízo a alguém e vantagem a outro. } \\
\text { F2-M-ES: NSR. }\end{array}$ \\
\hline $\begin{array}{l}\text { Acepções } \\
\text { registradas } \\
\text { nos } \\
\text { dicionários: }\end{array}$ & $\begin{array}{l}\text { Bluteau (1712-1728): DETRIMENTO. Dano. Perda. } \\
\text { Morais Silva (1813): DETRIMÈNTO, s. m. Perda, prejuízo de alguma } \\
\text { parte, diminuição. } \\
\text { Cunha (1997): detrição } s f \text {. 'decomposição por atrito' | detrimento } \\
\text { 1525. } \\
\text { Ferreira (2004): detrimento } 1 \text {. Dano, perda, prejuízo. } \\
\text { Houaiss (2007): detrimento datação } 1505 \text { dano moral ou material; } \\
\quad \text { prejuízo, perda. }\end{array}$ \\
\hline
\end{tabular}


Os dicionaristas Bluteau, Morais Silva, Ferreira e Houaiss registraram a entrada detrimento com a mesma acepção utilizada pelos informantes parnanguaras: 'prejuízo, dano'. Dos dezesseis entrevistados, treze informantes (oito da faixa I e cinco da faixa II) disseram não conhecer a unidade léxica detrimento. Com relação à acepção buscada, dois informantes (F2-H-EF e F2-H-ES) a empregaram com o mesmo sentido registrado nos documentos manuscritos, porém com uma ressalva: o informante F2-H-EF, talvez ao afirmar que detrimento 'é fazer alguma coisa a alguém tanto pro bem, como pro mal', estava querendo exemplificar o indício do favorecimento de um e desvantagem de outro, conforme ficou bem esclarecido na resposta do informante F2-H-ES, quando exemplifica o que ele entende por detrimento: 'Detrimento é quando se faz algo, quando você retira em detrimento, "eu estou fazendo isso aqui em detrimento àquilo", quer dizer pode ser em razão, pode ser em resultado ou eu acho que nesse sentido em que você favorece ou desfavorece alguém no detrimento. Todo detrimento causa prejuizo a alguém e vantagem a outro'. Já o informante F2-H-EM atribuiu a detrimento o valor de 'atrelação entre duas pedras'. Esta acepção não se encontra lexicalizada nos dicionários pesquisados para a entrada detrimento.

Embora este item lexical ainda esteja presente na fala de alguns moradores de Paranaguá, verifica-se que seu uso é pouco produtivo. Nenhum informante da faixa I reconheceu a lexia detrimento, e apenas do is informantes faixa II ainda a empregam com o mesmo sentido documentado no corpus escrito. Dessa forma, detrimento revela tendência ao desuso.

\begin{tabular}{|c|c|}
\hline \multicolumn{2}{|c|}{ 87. DILIGÊNCIA / DOC.11, fól.1r, l.12-14 } \\
\hline $\begin{array}{l}\text { Acepção } \\
\text { buscada }\end{array}$ & Providência, zelo, presteza. \\
\hline $\begin{array}{l}\text { Acepção(ões) } \\
\text { conhecida(s) } \\
\text { pelos } \\
\text { informantes }\end{array}$ & $\begin{array}{l}\text { F1-H-EP: NSR. } \\
\text { F1-M-EP: NSR. } \\
\text { F1-H-EF: NSR. } \\
\text { F1-M-EF: Quando a polícia vai fazer uma diligência, uma ocorrência. } \\
\text { F1-H-EM: NSR. } \\
\text { F1-M-EM: NSR. } \\
\text { F1-H-ES: NSR. } \\
\text { F1-M-ES: NSR. } \\
\text { F2-H-EP: NSR. } \\
\text { F2-M-EP: NSR. } \\
\text { F2-H-EF: Diligência é você tá investigando alguma coisa, ou procurando } \\
\text { alguém que fez alguma coisa, você tá mais ou menos numa diligência. } \\
\text { F2-M-EF: Tipo assim, a polícia tem que ir num bairro fazer uma vistoria } \\
\text { lá, pegar alguém com diligência. } \\
\text { F2-H-EM: Uma comitiva de bastante pessoa nômade, bastante carroça. }\end{array}$ \\
\hline
\end{tabular}




\begin{tabular}{|c|c|}
\hline & $\begin{array}{l}\text { F2-M-EM: Quando há um denúncia, o policial vai fazer uma diligência. } \\
\text { F2-H-ES: Diligência hoje se usa ainda acho que na polícia, quando se } \\
\text { vai fazer uma verificação no local. } \\
\text { F2-M-ES: O delegado saiu pra fazer uma diligência. }\end{array}$ \\
\hline $\begin{array}{l}\text { Acepções } \\
\text { registradas } \\
\text { nos } \\
\text { dicionários }\end{array}$ & $\begin{array}{l}\text { Bluteau (1712-1728): DILIGENCIA. Attençaõ, \& cuidado, com que } \\
\text { devemos acudir a cousas da nossa obrigaçaõ. Promptidaõ. } \\
\text { Morais Silva (1813): DILIGĖNCIA, s. f. A aplicação, cuidado, que se } \\
\text { põe em conseguir alguma coisa. } \\
\text { Cunha (1997): diligência sf. 'zelo, cuidado, atividade, providência, } \\
\text { pesquisa, investigação' XIV. } \\
\text { Ferreira (2004): diligência }{ }^{1} \text { 2. Atividade, rapidez, presteza. } 3 \text {. } \\
\text { Providência; medida. } \\
\text { Houaiss (2007): }{ }^{1} \text { diligência datação sXIII } 1 \text { interesse ou cuidado } \\
\text { aplicado na execução de uma tarefa; zelo. } 2 \text { urgência ou presteza em } \\
\text { fazer alguma coisa. }\end{array}$ \\
\hline \multicolumn{2}{|c|}{$\begin{array}{l}\text { A lexia diligência com o sentido da acepção buscada 'providência, zelo, presteza' não } \\
\text { foi reconhecida por nenhum informante, nem da faixa I e nem da faixa II. Os sete } \\
\text { informantes que reconheceram o item lexical diligência o empregam com outros } \\
\text { significados. A maioria dos informantes (F1-M-EF / F2-H-EF, F2-M-EF, F2-M-EM, F2- } \\
\text { H-ES e F2-M-ES) emprega o sentido de 'busca minuciosa, pesquisa, averiguação, } \\
\text { investigação'. Esta acepção encontra-se lexicalizada em Ferreira e Houaiss na quarta } \\
\text { acepção da entrada diligência. O informante F2-H-EM definiu diligência como 'Uma } \\
\text { comitiva de bastante pessoa nômade, bastante carroça'. Nos dicionários de Ferreira e } \\
\text { Houaiss encontra-se registrado o homônimo de diligência }{ }^{2} \text { com o sentido de: ' } 1 . \\
\text { Carruagem puxada a cavalos, com suspensão de molas, que servia para o transporte } \\
\text { coletivo de passageiros antes dos trens de ferro e do automóvel; carruagem'. Talvez este } \\
\text { informante, tenha ainda na memória a lembrança desse tipo de transporte coletivo puxado } \\
\text { a cavalos, por isso tenha feito a associação entre comitiva de bastante pessoa (coletivo de } \\
\text { passageiros) e carroça (carruagem). Nos dicionários pesquisados encontram-se o registro } \\
\text { da acepção em estudo. } \\
\text { Analisando o contexto de uso da unidade lexical diligência, verifica-se a não } \\
\text { ocorrência da acepção documentada no corpus escrito. Os poucos informantes que ainda } \\
\text { reconheceram a lexia diligência a utilizam com outro sentido, configurando, portanto, um } \\
\text { caso de desuso. }\end{array}$} \\
\hline
\end{tabular}

\section{DISCÍPULO / DOC.46, fól.1 r, l.19-20}

\begin{tabular}{|l|l}
\hline $\begin{array}{l}\text { Acepção } \\
\text { buscada }\end{array}$ & Aquele que aprende, aluno. \\
\hline
\end{tabular}




\begin{tabular}{|c|c|}
\hline $\begin{array}{l}\text { Acepção(ões) } \\
\text { conhecida(s) } \\
\text { pelos } \\
\text { informantes }\end{array}$ & $\begin{array}{l}\text { F1-H-EP: Discípulo da igreja. } \\
\text { F1-M-EP: NSR. } \\
\text { F1-H-EF: Díscipulo ligado à religião. } \\
\text { F1-M-EF: Discípulo é de igreja. } \\
\text { F1-H-EM: Discípulo de Jesus. } \\
\text { F1-M-EM: NSR. } \\
\text { F1-H-ES: Um aprendiz. } \\
\text { F1-M-ES: Discípulo da bíblia. } \\
\text { F2-H-EP: NSR. } \\
\text { F2-M-EP: Discípulo de Jesus. } \\
\text { F2-H-EF: Discípulo é um seguidor, uma pessoa que segue alguém, um } \\
\text { pastor. } \\
\text { F2-M-EF: Na igreja tem o pastor, seus membros que é seus discípulos. } \\
\text { F2-H-EM: Discípulo só para apóstolo. } \\
\text { F2-M-EM: Algo relacionado à igreja. } \\
\text { F2-H-ES: Discípulo é aquele que segue o mestre. } \\
\text { F2-M-ES: Discípulo é de religião. }\end{array}$ \\
\hline $\begin{array}{l}\text { Acepções } \\
\text { registradas } \\
\text { nos } \\
\text { dicionários: }\end{array}$ & $\begin{array}{l}\text { Bluteau (1712-1728): DISCIPULO. Estudante, que toma liçaõ de hum } \\
\text { mestre. } \\
\text { Morais Silva (1813): DISCÍPULO, s. m. O que aprende alguma Arte, } \\
\text { ou Sciencia. } \\
\text { Cunha (1997): discípulo sm. 'o que recebe ensino de alguém, aluno' | } \\
\text { XIII. } \\
\text { Ferreira (2004): discípulo 3. Aquele que aprende ou estuda qualquer } \\
\text { disciplina; aluno. } \\
\text { Houaiss (2007): discípulo datação sXIII } 1 \text { quem estuda; aluno. }\end{array}$ \\
\hline \multicolumn{2}{|c|}{$\begin{array}{l}\text { Analisando as respostas dos informantes quanto ao reconhecimento da lexia discípulo } \\
\text { com o sentido de 'aluno, aquele que aprende', as respostas mais próximas quanto a esse } \\
\text { significado foram dadas pelos informantes F1-H-ES e F2-H-ES. Para o informante da } \\
\text { faixa I, discípulo é sinônimo de 'aprendiz'. Houaiss registra na segunda acepção, da } \\
\text { entrada discípulo: 'aprendiz, aluno receptivo a ensinamentos'. Para o informante da faixa } \\
\text { II, discípulo 'é aquele que segue o mestre'. Esta definição é registra por Houaiss na } \\
\text { terceira acepção: 'aluno, seguidor disposto a dar prosseguimento ao trabalho (de seu } \\
\text { mestre); epígono'. As acepções apresentadas pelos lexicógrafos pesquisados evidenciam } \\
\text { as mesmas designações atribuídas pelos informantes e também à acepção em estudo. Com } \\
\text { relação às respostas da maioria dos informantes, constata-se a relação do item lexical } \\
\text { discípulo ao campo semântico religião. Dos dezesseis entrevistados, onze informantes } \\
\text { (cinco da faixa I e seis da faixa II) atribuíram à lexia discípulo o valor de: seguidor devoto } \\
\text { da igreja/de um pastor. }\end{array}$} \\
\hline
\end{tabular}


Portanto, analisando o contexto de uso da unidade lexical discípulo, constata-se que essa lexia não foi reconhecida pelos informantes com o sentido da acepção documentada no corpus escrito, configurando, assim, um caso de desuso.

\begin{tabular}{|c|c|}
\hline \multicolumn{2}{|c|}{ 89. DITO / DOC.20, fól.1v, l.10-12 } \\
\hline $\begin{array}{l}\text { Acepção } \\
\text { buscada }\end{array}$ & Referido, mencionado. \\
\hline $\begin{array}{l}\text { Acepção(ões) } \\
\text { conhecida(s) } \\
\text { pelos } \\
\text { informantes: }\end{array}$ & $\begin{array}{l}\text { F1-H-EP: NSR. } \\
\text { F1-M-EP: NSR. } \\
\text { F1-H-EF: Só conheço a expressão: ficou dito pelo não dito. } \\
\text { F1-M-EF: NSR. } \\
\text { F1-H-EM: Ela tinha dito que viria. Como se tivesse falado alguma coisa. } \\
\text { F1-M-EM: O dito poder ser um fulano. } \\
\text { F1-H-ES: O dito-cujo. } \\
\text { F1-M-ES: O dito fulano. } \\
\text { F2-H-EP: NSR. } \\
\text { F2-M-EP: Dito é quando você fala algo pra outra pessoa, tá dito. } \\
\text { F2-H-EF: Dito seria no popular que o pessoal fala: o dito pelo não dito. } \\
\text { F2-M-EF: Conheço só o dito pelo não dito. } \\
\text { F2-H-EM: Foi dito tal coisa. } \\
\text { F2-M-EM: Foi dito isso na reunião. } \\
\text { F2-H-ES: A gente falava ficou o dito pelo não dito, o dito o que foi } \\
\text { falado. O dito-cujo pode ser a pessoa. } \\
\text { F2-M-ES: Dito é quando você fala alguma coisa, tá dito e não se fala } \\
\text { mais nisso. }\end{array}$ \\
\hline $\begin{array}{l}\text { Acepções } \\
\text { registradas } \\
\text { nos } \\
\text { dicionários }\end{array}$ & $\begin{array}{l}\text { Bluteau (1712-1728): DITTO, ou Dito. Cousa ditta. } \\
\text { Morais Silva (1813): DITO, p. pass. de Dizer. } \\
\text { Cunha (1997): dizer } v b \text {. 'expor, exprimir por palavras, proferir, } \\
\quad \text { enunciar' | dito adj. XIII. } \\
\text { Ferreira (2004): dito } 1 . \text { Que se disse; mencionado, referido. } \\
\text { Houaiss (2007): }{ }^{1} \text { dito datação } 12141 \text { que se diz ou disse; aludido, } \\
\quad \text { mencionado, referido. }\end{array}$ \\
\hline \multicolumn{2}{|c|}{$\begin{array}{l}\text { Considerando o contexto de uso do item lexical dito, verifica-se considerável } \\
\text { frequência nas respostas dos entrevistados. Os conceitos atribuídos pelos informantes } \\
\text { quanto à utilização da lexia dito foram diversos: (i) cinco informantes (F1-H-EM / F2-M- } \\
\text { EP, F2-H-EM, F2-M-EM e F2-M-ES) empregaram como particípio do verbo dizer 'dito', } \\
\text { no sentido de 'ter dito', 'ter falado'; (ii) quatro informantes (F1-H-EF / F2-H-EF, F2-M- } \\
\text { EF e F2-H-ES) reconheceram apenas como expressão idiomática "o dito pelo não dito", a } \\
\text { qual significa 'considerar sem efeito o que se disse'; (iii) três informantes (F1-M-EM, F1- }\end{array}$} \\
\hline
\end{tabular}


M-ES e F1-H-ES) mencionaram 'o dito-cujo', 'o dito fulano'. Houaiss registra a entrada dito-cujo com a acepção: 'ser de que já se falou, quando não se quer, não se sabe ou não se pode dizer seu nome; cujo, fulano, sujeito', e a classifica como um regionalismo do Brasil de uso informal e jocoso; (iv) o informante F2-H-ES denominou a forma léxica dito como: 'dito pelo não dito', 'foi falado' e 'o dito-cujo'. Quanto ao registro da entrada dito nos dicionários pesquisados, Bluteau e Morais Silva a registram como 'particípio passado do verbo dizer', 'coisa dita'. Os lexicógrafos Ferreira e Houaiss, por sua vez, trazem o registro da entrada dito com a mesma acepção buscada: 'mencionado', 'referido', 'aludido'.

Observando os dados apresentados, presume-se que a unidade lexical dito com o mesmo sentido documentado no corpus escrito não se encontra mais nos enunciados dos entrevistados, principalmente pelos informantes da faixa $\mathrm{I}$, que empregaram mais 'o dito-cujo', 'o dito fulano'. Portanto, supõe-se ser um caso de desuso.

\begin{tabular}{|c|c|}
\hline \multicolumn{2}{|c|}{ 90. EMBARGO / DOC.32, fól.1r, l.18-20 } \\
\hline $\begin{array}{l}\text { Acepção } \\
\text { buscada }\end{array}$ & Impedimento, obstáculo, empecilho. \\
\hline $\begin{array}{l}\text { Acepção(ões) } \\
\text { conhecida(s) } \\
\text { pelos } \\
\text { informantes }\end{array}$ & $\begin{array}{l}\text { F1-H-EP: NSR. } \\
\text { F1-M-EP: NSR. } \\
\text { F1-H-EF: Embargar um bar, fechar, impedir de funcionar. } \\
\text { F1-M-EF: NSR. } \\
\text { F1-H-EM: Conheço como parar, impedir, embargo da obra, embargo de } \\
\text { alguma coisa por alguma situação que não esteja legal. } \\
\text { F1-M-EM: NSR. } \\
\text { F1-H-ES: Embargar de parar, paralisar: a prefeitura embargou a obra ali, } \\
\text { porque é um parimônio histórico. } \\
\text { F1-M-ES: Embargo é algo que tá empacado, impedido de acontecer, de } \\
\text { ir adiante. } \\
\text { F2-H-EP: Alguém tá fazendo um troço errado ali, o cara vai lá e } \\
\text { embarga, impede. } \\
\text { F2-M-EP: Embargo é quando alguém tá na sua terra e você vem e } \\
\text { embarga, pra tirar alguém que tá na tua terra. } \\
\text { F2-H-EF: Embargo se a pessoa tá fazendo alguma coisa, você vai lá e } \\
\text { manda parar. } \\
\text { F2-M-EF: Você tem que passar alguma coisa pro teu chefe, ele olha e } \\
\text { diz não, esse não vai, embargou. } \\
\text { F2-H-EM: Quando alguém começou uma construção, não consultou o } \\
\text { CREA, aí vem a fiscalização e embarga. } \\
\text { F2-M-EM: Embargar é quando você compra um terreno e outra pessoa } \\
\text { vai lá e embarga, impede, porque não tá certo. }\end{array}$ \\
\hline
\end{tabular}




\begin{tabular}{|c|c|}
\hline & $\begin{array}{l}\text { F2-H-ES: Embargo é quando você suspende um processo, você } \\
\text { embarga, você dificulta o processo de estar tramitando. } \\
\text { F2-M-ES: Embargo é quando alguém impede de construir num terreno. }\end{array}$ \\
\hline $\begin{array}{l}\text { Acepções } \\
\text { registradas } \\
\text { nos } \\
\text { dicionários }\end{array}$ & $\begin{array}{l}\text { Bluteau (1712-1728): EMBARGO de sentença por ordem do juiz. } \\
\text { Impedimento, que se põem à execução de huma sentença. } \\
\text { Morais Silva (1813): EMBÁRGO, s. m. §. Impedimento, ou suspensão } \\
\text { da execução de alguma sentença; do uso livre de alguns bens. } \\
\text { Cunha (1997): embargar vb. 'tolher, estorvar, pôr obstáculos' } \\
\text { embargo XIII. } \\
\text { Ferreira (2004): embargo 1. Impedimento, estorvo, obstáculo, } \\
\text { embaraço, empecilho. } \\
\text { Houaiss (2007): embargo datação sXIII } 1 \text { aquilo que impede, } \\
\text { embaraça; empecilho, obstáculo, dificuldade. }\end{array}$ \\
\hline \multicolumn{2}{|c|}{$\begin{array}{l}\text { A entrada embargo é registrada pelos lexicógrafos com o sentido de 'impedimento de } \\
\text { uma execução', 'suspensão de alguma ação', 'obstáculo', 'empecilho' e 'dificuldade'. } \\
\text { Estas definições remetem à mesma acepção buscada e às apresentadas pelos doze } \\
\text { informantes. Alguns informantes empregaram também as formas lexicais embargar e } \\
\text { embarga, mas referindo-se ao mesmo sentido da unidade lexical embargo. } \\
\text { Analisando o contexto de uso desta lexia, constata-se ser ainda bastante produtiva na } \\
\text { linguagem oral dos informantes parnanguaras, havendo, assim, indícios de manutencão. }\end{array}$} \\
\hline
\end{tabular}

\begin{tabular}{|l|l|}
\hline \multicolumn{2}{|l|}{ 91. EMOLUMENTO / DOC.15, fól.1r, l.10-13 } \\
\hline $\begin{array}{l}\text { Acepção } \\
\text { buscada }\end{array}$ & Lucro, proveito, gratificação. \\
\hline $\begin{array}{l}\text { Acepção(ões) } \\
\text { conhecida(s) }\end{array}$ & F1-H-EP: NSR. \\
pelos & F1-M-EP: NSR. \\
informantes & F1-H-EF: NSR. \\
& F1-M-EF: NSR. \\
& F1-H-EM: NSR. \\
& F1-M-EM: NSR. \\
& F1-H-ES: NSR. \\
& F1-M-ES: NSR. \\
& F2-H-EP: NSR. \\
& F2-M-EP: NSR. \\
& F2-H-EF: NSR. \\
& F2-M-EF: NSR. \\
& F2-H-EM: NSR. \\
& F2-M-EM: NSR. \\
\hline
\end{tabular}




\begin{tabular}{|c|c|}
\hline & $\begin{array}{l}\text { F2-H-ES: NSR. } \\
\text { F2-M-ES: NSR. } \\
\text { Resposta de todos os informantes: desconhecem o termo. }\end{array}$ \\
\hline $\begin{array}{l}\text { Acepções } \\
\text { registradas } \\
\text { nos } \\
\text { dicionários }\end{array}$ & $\begin{array}{l}\text { Bluteau (1712-1728): EMOLUMENTO. Lucro. Proveito. } \\
\text { Morais Silva (1813): EMOLUMĖNTO, s. m. Lucro, proveito. } \\
\text { Cunha (1997): emolumento sm. 'lucro, gratificação, rendimento' XVII. } \\
\text { Ferreira (2004): emolumento 1. Lucro, proveito. 2. Retribuição, } \\
\quad \text { gratificação. } \\
\text { Houaiss (2007): emolumento datação sXV } 1 \text { aquilo que se ganha; } \\
\quad \text { vantagem, lucro. }\end{array}$ \\
\hline \multicolumn{2}{|c|}{$\begin{array}{l}\text { Dos dezesseis entrevistados, todos disseram desconhecer a lexia emolumento. Todos os } \\
\text { lexicógrafos pesquisados trazem o registro da entrada emolumento com o mesmo sentido } \\
\text { da acepção em estudo: 'lucro, proveito, gratificação'. } \\
\text { Levando em consideração os dados em análise, constata-se que o item lexical } \\
\text { emolumento não faz parte do léxico dos informantes de Paranaguá, pois, dos dezesseis } \\
\text { entrevistados, nenhum reconheceu esta lexia, configurando, assim, um caso de desuso. }\end{array}$} \\
\hline
\end{tabular}

\begin{tabular}{|l|l|}
\hline \multicolumn{2}{|l|}{ 92. ENFERMO / DOC.33, fól.1v, l.15-16 } \\
\hline $\begin{array}{l}\text { Acepção } \\
\text { buscada }\end{array}$ & Doente, sem saúde. \\
\hline $\begin{array}{l}\text { Acepção(ões) } \\
\text { conhecida(s) } \\
\text { pelos } \\
\text { informantes }\end{array}$ & $\begin{array}{l}\text { F1-H-EP: Quando uma pessoa tá enferma, doente. } \\
\text { F1-H-EF: Pessoa enferma, tá doente. } \\
\text { F1-M-EF: Quando a pessoa tá doente. } \\
\text { F1-H-EM: Quando a pessoa está doente. } \\
\text { F1-M-EM: Quando você tem uma doença que não se cura. } \\
\text { F1-H-ES: Doente. } \\
\text { F1-M-ES: Doente. } \\
\text { F2-H-EP: Se a pessoa tá assim, tá doente a gente fala que ela tá enferma. } \\
\text { F2-M-EP: Quando a pessoa está doente. } \\
\text { F2-H-EF: É doente, não tá bom de saúde ou tá internado. } \\
\text { F2-M-EF: Alguém doente. } \\
\text { F2-H-EM: Ligada a pessoa, tá enferma, tá doente. } \\
\text { F2-M-EM: Quando a pessoa está doente, bem enferma. } \\
\text { F2-H-ES: Enfermo é doente. } \\
\text { F2-M-ES: Quando a pessoa está doente, enferma. }\end{array}$ \\
\hline
\end{tabular}




\begin{tabular}{|l|l|}
\hline $\begin{array}{l}\text { Acepções } \\
\text { registradas } \\
\text { nos } \\
\text { dicionários }\end{array}$ & $\begin{array}{l}\text { Bluteau (1712-1728): ENFERMO. O que tem pouca saude. Enfermo. } \\
\text { Morais Silva (1813): ENFÈRMO, adj. Doente. } \\
\text { Cunha (1997): enfermar vb. 'ficar doente' | enfermo XIII. } \\
\text { Ferreira (2004): enfermo 3. Aquele que está enfermo; doente. } \\
\text { Houaiss (2007): enfermo datação sXIII } 1 \text { que ou aquele que se encontra } \\
\text { doente, achacado. }\end{array}$ \\
\hline $\begin{array}{l}\text { A entrada enfermo é registrada pelos lexicógrafos com as designações: 'o que tem } \\
\text { pouca saúde', 'aquele que está doente' e 'aquele que se encontra enfermo'. Estas } \\
\text { definições remetem à mesma acepção buscada e às apresentadas pelos dezesseis } \\
\text { informantes. } \\
\text { Analisando o contexto de uso dessa lexia, consta-se ser bastante produtiva na } \\
\text { linguagem oral dos informantes parnanguaras, revelando, assim, indícios de manutencão. }\end{array}$ \\
\hline
\end{tabular}

\begin{tabular}{|c|c|}
\hline \multicolumn{2}{|c|}{ 93. ENGENHO / DOC.46, fól.1r, 1.35-37 } \\
\hline $\begin{array}{l}\text { Acepção } \\
\text { buscada }\end{array}$ & $\begin{array}{l}\text { Propriedade/estabelecimento destinado a cultura da cana e a fabricação } \\
\text { do açúcar. }\end{array}$ \\
\hline $\begin{array}{l}\text { Acepção(ões) } \\
\text { conhecida(s) } \\
\text { pelos } \\
\text { informantes }\end{array}$ & $\begin{array}{l}\text { F1-H-EP: NSR. } \\
\text { F1-M-EP: NSR. } \\
\text { F1-H-EF: É engenharia. } \\
\text { F1-M-EF: Engenho de açúcar. } \\
\text { F1-H-EM: NSR. } \\
\text { F1-M-EM: NSR. } \\
\text { F1-H-ES: De cana. } \\
\text { F1-M-ES: Engenho é uma obra. } \\
\text { F2-H-EP: Antigamente usava falar essa palavra engenho, esses moinho } \\
\text { de fazer cachaça falava engenho. Hoje não se usa mais. } \\
\text { F2-M-EP: Engenho de açúcar. } \\
\text { F2-H-EF: Engenho seria alguma coisa que um engenheiro fez, uma casa } \\
\text { ou um engenho para fabricar pinga, cachaça, essas coisas. } \\
\text { F2-M-EF: Onde se mói cana. } \\
\text { F2-H-EM: Hoje não usa mais, antigamente se usava muito para aquelas } \\
\text { fábrica de cana-de-açúcar. } \\
\text { F2-M-EM: NSR. } \\
\text { F2-H-ES: Engenho é o local a onde se produz, no caso da história, o } \\
\text { açúcar. Hoje tem engenho, tem engenho do açúcar, tem engenho da } \\
\text { cachaça, tinha o engenho da farinha de mandioca, na verdade o } \\
\text { engenho é a primeira fábrica, antes mesmo da Revolução Industrial, o } \\
\text { Brasil já tinha fábrica, que era o engenho. }\end{array}$ \\
\hline
\end{tabular}




\begin{tabular}{|c|c|}
\hline & $\begin{array}{l}\text { F2-M-ES: Antigamente tinha engenho de fazer farinha, hoje não usa } \\
\text { mais. }\end{array}$ \\
\hline $\begin{array}{l}\text { Acepções } \\
\text { registradas } \\
\text { nos } \\
\text { dicionários }\end{array}$ & $\begin{array}{l}\text { Bluteau (1712-1728): ENGENHO de açucar. Vid. Açucar. } \\
\text { Morais Silva (1813): ENGĖNHO, s. m. A Faculdade, com que a alma } \\
\text { concebe facilmente as connexões das coisas; inventa maquinas com } \\
\text { facilidade. } \\
\text { Cunha (1997): engenho } \mathrm{sm} \text {. 'máquina' 'oficina' | XIV. } \\
\text { Ferreira (2004): engenho 8. Bras. Estabelecimento agrícola destinado à } \\
\text { cultura da cana e à fabricação do açúcar. } \\
\text { Houaiss (2007): engenho datação sXIII 6.2 Regionalismo: Brasil: todo } \\
\text { o conjunto relativo à cultura e ao processamento da cana-de-açúcar, } \\
\text { incluindo as terras cultivadas, as instalações para moagem e as } \\
\text { residências de proprietários, colonos e trabalhadores. }\end{array}$ \\
\hline
\end{tabular}

A lexia engenho foi reconhecida por onze informantes parnanguaras. Quanto à acepção buscada 'propriedade/estabelecimento destinado à cultura da cana e à fabricação do açúcar', quatro informantes (F1-M-EF e F1-H-ES / F2-M-EP e F2-M-EF) atribuíram ao item lexical engenho as designações: 'açúcar' e 'cana', respostas um tanto genéricas quanto ao significado da lexia em estudo. Outros quatro informantes (F2-H-EP, F2-H-EM, F2-H-ES e F2-M-ES) atribuíram a acepção documentada no corpus escrito ao item lexical engenho, mas advertiram que 'antigamente se usava falar a palavra engenho para denominar fábrica, porém hoje não se usa mais'. O informante F2-H-ES complementou que 'antes mesmo da Revolução Industrial, no Brasil já tinha fábrica, que era o engenho'. Para os informantes F1-M-ES e F2-H-EF, engenho é 'um tipo de obra, uma construção feita por um engenheiro'. E para o informante F1-H-EF, engenho é sinônimo de 'engenharia'. Os lexicógrafos Morais Silva e Cunha definem a entrada engenho como 'invenção de máquina', 'oficina'. Ferreira e Houaiss registram a acepção em estudo e classificam como brasileirismo, e Bluteau como 'engenho de açúcar'.

Tomando por base as respostas dos quatro informantes da faixa II (F2-H-EP, F2-HEM, F2-H-ES e F2-M-ES) que afirmaram ser de uso antigo a unidade lexical engenho, e comparando com as respostas dos informantes da faixa I, constata-se que tal afirmativa se comprova, pois, dos informantes jovens entrevistados, somente quatro reconheceram a lexia engenho, mas a relacionaram a definições genéricas. Portanto, o item lexical em estudo configura um caso de $\underline{\text { desuso. }}$.

\begin{tabular}{|l|l|}
\hline 94. ESTERILIDADE / DOC.33, fól.1r, l.26-28 \\
\hline $\begin{array}{l}\text { Acepção } \\
\text { buscada }\end{array}$ & Escassez, penúria. \\
\hline $\begin{array}{l}\text { Acepção(ões) } \\
\text { conhecida(s) }\end{array}$ & $\begin{array}{l}\text { F1-H-EP: NSR. } \\
\text { F1-M-EP: NSR. }\end{array}$ \\
\hline
\end{tabular}




\begin{tabular}{|c|c|}
\hline $\begin{array}{l}\text { pelos } \\
\text { informantes }\end{array}$ & $\begin{array}{l}\text { F1-H-EF: NSR. } \\
\text { F1-M-EF: NSR. } \\
\text { F1-H-EM: Uma pessoa que fica estéril. } \\
\text { F1-M-EM: NSR. } \\
\text { F1-H-ES: Infertilidade. Já ouvi: essa terra é estéril. } \\
\text { F1-M-ES: NSR. } \\
\text { F2-H-EP: NSR. } \\
\text { F2-M-EP: NSR. } \\
\text { F2-H-EF: Esterilidade seria o ato de você esterilizar uma ferramenta, um } \\
\quad \text { negócio que vai trabalhar com ela. Ou também, castrar um animal, } \\
\text { deixar ele estéril tal, esterilizar. } \\
\text { F2-M-EF: Alguém que não pode ter filho, estéril. } \\
\text { F2-H-EM: Uma pessoa que fica estéril, que não pode ter filhos. } \\
\text { F2-M-EM: Ligado a mulher que não pode ter filho. Ou a um aparelho } \\
\text { que você esteriliza. } \\
\text { F2-H-ES: De estéril. Ou então de que não produz nenhum efeito. } \\
\text { F2-M-ES: Quando a pessoa é estéril. }\end{array}$ \\
\hline $\begin{array}{l}\text { Acepções } \\
\text { registradas } \\
\text { nos } \\
\text { dicionários }\end{array}$ & $\begin{array}{l}\text { Bluteau (1712-1728): ESTERILIDADE. Carencia, ou inopia de frutos } \\
\text { em causa productiva. Esterilidade nos campos, ou nas molheres. } \\
\text { Morais Silva (1813): ESTERILIDÁDE, s. f. O contrario da fertilidade, } \\
\text { e da fecundidade; carência, ou pobreza de fructos; esterilidade da } \\
\text { terra: que não gerão. } \\
\text { Cunha (1997): estéril adj. } 2 g \text {. 'que não produz, árido' | esterilidade | } \\
\text { estrallidade XV, estrelidade } 1532 \text {. } \\
\text { Ferreira (2004): esterilidade } 2 \text {. Escassez, falta, penúria. } \\
\text { Houaiss (2007): esterilidade } 4 \text { Derivação: sentido figurado: escassez, } \\
\text { falta. }\end{array}$ \\
\hline \multicolumn{2}{|c|}{$\begin{array}{l}\text { Dos dezesseis entrevistados, oito informantes reconheceram a lexia esterilidade, mas } \\
\text { om acepções diferentes: cinco informantes (F1-H-EM e F1-H-ES / F2-M-EF, F2-H-EM e } \\
\text { 2-M-ES) atribuíram ao item lexical esterilidade o valor de 'pessoa estéril', 'alguém que } \\
\text { ao pode ter filhos'. Dois informantes (F2-H-EF e F2-M-EM) além do sentido de 'não } \\
\text { cocriação', utilizaram também para essa lexia o sentido de 'esterilizar uma ferramenta, } \\
\text { m aparelho'. O informante F1-H-ES disse conhecer apenas o item lexical infertilidade, } \\
\text { ando como exemplo 'terra estéril'. Todas essas acepções encontram-se registradas nos } \\
\text { icionários pesquisados. A acepção de esterilidade empregada pelo informante F2-H-ES, } \\
\text { le que não produz nenhum efeito', não consta registrada nos dicionários pesquisados. } \\
\text { uanto ao registro da acepção buscada, Bluteau e Morais Silva definem a entrada } \\
\text { terilidade tanto no sentido de 'terra incapaz de produzir', como também 'o contrário de } \\
\text { cundidade, fertilidade nas mulheres'. Cunha traz a designação da entrada estéril como } \\
\text { jue não produz, árido', referindo-se ao campo terra. Ferreira e Houaiss registram o }\end{array}$} \\
\hline
\end{tabular}


mesmo sentido da acepção em estudo: 'escassez, penúria'. O último dicionarista informa ser esta essa acepção uma derivação: sentido figurado.

Considerando os dados em análise, há indícios de que a lexia esterilidade, lembrada apenas com outros sentidos, sem nenhuma ocorrência da acepção documentada no corpus escrito, seja um caso de desuso.

\begin{tabular}{|c|c|}
\hline \multicolumn{2}{|c|}{ 95. EXCRETO / DOC.42, fól.1r, l.18-21 } \\
\hline $\begin{array}{l}\text { Acepção } \\
\text { buscada }\end{array}$ & Dejeto, excremento. \\
\hline $\begin{array}{l}\text { Acepção(ões) } \\
\text { conhecida(s) } \\
\text { pelos } \\
\text { informantes }\end{array}$ & $\begin{array}{l}\text { F1-H-EP: NSR. } \\
\text { F1-M-EP: NSR. } \\
\text { F1-H-EF: NSR. } \\
\text { F1-M-EF: NSR. } \\
\text { F1-H-EM: NSR. } \\
\text { F1-M-EM: NSR. } \\
\text { F1-H-ES: NSR. } \\
\text { F1-M-ES: NSR. } \\
\text { F2-H-EP: NSR. } \\
\text { F2-M-EP: NSR. } \\
\text { F2-H-EF: NSR. } \\
\text { F2-M-EF: NSR. } \\
\text { F2-H-EM: NSR. } \\
\text { F2-M-EM: NSR. } \\
\text { F2-H-ES: NSR. } \\
\text { F2-M-ES: NSR. }\end{array}$ \\
\hline $\begin{array}{l}\text { Acepções } \\
\text { registradas } \\
\text { nos } \\
\text { dicionários }\end{array}$ & $\begin{array}{l}\text { Bluteau (1712-1728): EXCRETO, he o que a natureza separa da, } \\
\text { substancia alimentosa. } \\
\text { Morais Silva (1813): EXCRÉTO, adj. t. de Med. Separado pelos vasos } \\
\quad \text { excretorios. } \\
\text { Cunha (1997): excreto adj. 'espelido, evacuado, segregado' XVII. } \\
\text { Ferreira (2004): excreto } 2 \text {. V. excreção. [escreção 2. Matéria excretada; } \\
\quad \text { excreto, excreta]. } \\
\text { Houaiss (2007): excreto datação } 16422 \text { matéria excretada; excreção. }\end{array}$ \\
\hline $\begin{array}{l}\text { Dos dezes } \\
\text { lexicógrafos } \mathrm{p} \\
\text { acepção em } \\
\text { consulente à v }\end{array}$ & $\begin{array}{l}\text { is entrevistados, todos disseram desconhecer a lexia excreto. Os } \\
\text { quisados trazem o registro da entrada excreto com o mesmo sentido da } \\
\text { tudo: 'dejeto, excremento'. } \mathrm{Na} \text { entrada excreto, Ferreira remete o } \\
\text { lante lexical excreção. }\end{array}$ \\
\hline
\end{tabular}


Considerando os dados apresentados, observa-se que a unidade lexical excreto não faz mais parte do acervo lexical dos informantes parnanguaras na modalidade oral, visto que, dos dezesseis entrevistados, nenhum reconheceu esta lexia, revelando, dessa forma, um caso de desuso.

\begin{tabular}{|c|c|}
\hline \multicolumn{2}{|c|}{ 96. EXPEDIÇÃO / DOC.08, fól.1r, l.08-11 } \\
\hline $\begin{array}{l}\text { Acepção } \\
\text { buscada }\end{array}$ & Despacho, remessa. \\
\hline $\begin{array}{l}\text { Acepção(ões) } \\
\text { conhecida(s) } \\
\text { pelos } \\
\text { informantes }\end{array}$ & $\begin{array}{l}\text { F1-H-EP: NSR. } \\
\text { F1-M-EP: NSR. } \\
\text { F1-H-EF: Vamos fazer uma expedição pra tal lugar, vamos conhecer } \\
\text { línguas, culturas. } \\
\text { F1-M-EF: Quando fazem aquela reunião pra ir viajar, daí tem uma } \\
\text { expedição de pessoas. } \\
\text { F1-H-EM: Sair pra conhecer um local, fazer uma expedição. } \\
\text { F1-M-EM: De viajar, fazer uma expedição. } \\
\text { F1-H-ES: Uma viagem. } \\
\text { F1-M-ES: Expedição é uma viagem. } \\
\text { F2-H-EP: Já ouvi falar, é quando vai fazer mandar, enviar alguma coisa, } \\
\text { daí eu faço uma expedição. } \\
\text { F2-M-EP: NSR. } \\
\text { F2-H-EF: Expedição é você expedir, por exemplo: tem uma } \\
\text { transportadora, tem uma parte dela que é de expedição, mandar pra } \\
\text { fora. Você entregar, expedir. } \\
\text { F2-M-EF: Expedição é montar um grupo de pessoas e sair pesquisando } \\
\text { uma caverna. } \\
\text { F2-H-EM: Um grupo de pessoas que foi pra África ou pra algum lugar } \\
\text { do país ou do mundo, foram pra uma expedição. } \\
\text { F2-M-EM: Quando umas pessoa se reúne e vão fazer uma expedição em } \\
\text { outra cidade. } \\
\text { F2-H-ES: Expedição é quando os navios saem para o mar, é uma } \\
\text { expedição. Tem também de expedir processo, fazer o processo sair de } \\
\text { um local e ir pro outro, um despacho. } \\
\text { F2-M-ES: NSR. }\end{array}$ \\
\hline $\begin{array}{l}\text { Acepções } \\
\text { registradas } \\
\text { nos } \\
\text { dicionários }\end{array}$ & $\begin{array}{l}\text { Bluteau (1712-1728): EXPEDIÇAM dos negocios. } \\
\text { Morais Silva (1813): EXPEDIÇÃO, s. f. Despacho breve: expedição } \\
\quad \text { dos negocios cotidianos. } \\
\text { Cunha (1997): expedição } \text { sf. 'despacho, remessa, expediência' XVI. }\end{array}$ \\
\hline
\end{tabular}




\begin{tabular}{|l|l|}
\hline Ferreira (2004): expedição 1. Ato ou efeito de expedir; despacho, \\
remessa; expediência. \\
Houaiss (2007): expedição datação 1501 1 ato ou efeito de expedir, de \\
enviar, de fazer com que algo chegue a seu destino; despacho, \\
remessa.
\end{tabular}

A lexia expedição com o sentido de 'despacho, remessa' foi reconhecida na fala de apenas três informantes (F2-H-EP, F2-H-EF e F2-H-ES). A maioria dos informantes (seis da faixa I e três da faixa II) reconheceu o item lexical com o sentido de 'viagem', 'excursão', 'turismo'. Enquanto que, para a informante F2-M-EF, 'expedição é montar um grupo de pessoas e sair pesquisando uma caverna'. Neste sentido, Ferreira registra na quinta acepção, por extensão de sentido: 'grupo que se destina a explorar, pesquisar, estudar uma região, ger. em caráter científico'. Quanto ao registro da acepção em estudo nos dicionários pesquisados, Cunha, Ferreira e Houaiss registraram as designações: 'despacho', 'remessa', 'ato de expedir', 'efeito de enviar', evidenciando o mesmo sentido documentado no corpus escrito. Bluteau definiu apenas 'expedição dos negócios', enquanto Morais Silva foi mais específico e exemplificou expedição dos negócios como um 'despacho breve'.

Analisando o contexto de uso da unidade lexical expedição nas respostas dos informantes, certifica-se ser bastante produtiva. Dos dezesseis entrevistados, somente quatro informantes (do is da faixa I e do is da faixa II) disseram não conhecer a lexia em questão. Com relação ao reconhecimento do item lexical expedição com o mesmo sentido registrado no documento manuscrito, constata-se baixa ocorrência, apenas três informantes da faixa II ainda a utilizam. Portanto, esse item lexical, no contexto de fala dos informantes parnanguaras, revela tendência ao desuso.

\begin{tabular}{|l|l|}
\hline \multicolumn{2}{|l|}{ 97. FAISQUEIRA / DOC.46, fól.1r, l.28-30 } \\
\hline $\begin{array}{l}\text { Acepção } \\
\text { buscada }\end{array}$ & Lugar onde se encontrava faísca de ouro. \\
\hline $\begin{array}{l}\text { Acepção(ões) } \\
\text { conhecida(s) } \\
\text { pelos } \\
\text { informantes }\end{array}$ & $\begin{array}{l}\text { F1-H-EP: NSR. } \\
\text { F1-M-EP: Faisqueira é a chama do isqueiro. } \\
\text { F1-M-EF: Conheço só faísca de fogo. } \\
\text { F1-H-EM: NSR. } \\
\text { F1-M-EM: NSR. } \\
\text { F1-H-ES: NSR. } \\
\text { F1-M-ES: NSR. } \\
\\
\text { F2-H-EP: NSR. } \\
\text { F2-M-EP: NSR. } \\
\text { F2-H-EF: Faisqueira é alguma coisa com garimpeiro. }\end{array}$ \\
\hline
\end{tabular}




\begin{tabular}{|c|c|}
\hline & $\begin{array}{l}\text { F2-M-EF: NSR. } \\
\text { F2-H-EM: Faisqueira é um lugar que tem lá em Morretes, lá tinha faísca } \\
\quad \text { de ouro. } \\
\text { F2-M-EM: NSR. } \\
\text { F2-H-ES: NSR. } \\
\text { F2-M-ES: NSR. }\end{array}$ \\
\hline $\begin{array}{l}\text { Acepções } \\
\text { registradas } \\
\text { nos } \\
\text { dicionários }\end{array}$ & $\begin{array}{l}\text { Bluteau (1712-1728): N.D. } \\
\text { Morais Silva (1813): N.D. } \\
\text { Cunha (1997): N.D. } \\
\text { Ferreira (2004): faisqueira 1. Lugar onde se acham faíscas. [faíscas } 5 . \\
\quad \text { Palheta de ouro que se perde na terra ou areia das minas]. } \\
\text { Houaiss (2007): faisqueira datação } 1753 \text { local onde se encontram } \\
\quad \text { faíscas (gar). }\end{array}$ \\
\hline \multicolumn{2}{|c|}{$\begin{array}{l}\text { Analisando o contexto de uso da lexia faisqueira constata-se baixa produtividade por } \\
\text { parte dos entrevistados. Doze informantes (seis da faixa I e seis da faixa II) disseram não } \\
\text { conhecer a unidade lexical faisqueira. Para a informante F1-M-EP, faisqueira é sinônimo } \\
\text { de 'chama do isqueiro'. Provavelmente, esta informante tenha associado a forma lexical } \\
\text { faisqueira aos traços semânticos [faísca, labareda, chama]. Já o informante F1-H-EF disse } \\
\text { conhecer somente o item lexical faisca. Quanto à acepção buscada 'lugar onde se } \\
\text { encontrava faísca de ouro', os informantes F2-H-EF e F2-H-ES mencionaram que a lexia } \\
\text { faisqueira tem relação com o 'garimpo'. O informante de grau superior, foi mais } \\
\text { específico, definiu faisqueira como 'um lugar que tem lá em Morretes, lá tinha faísca de } \\
\text { ouro'. Os lexicógrafos Bluteau, Morais Silva e Cunha não trazem o registro da forma } \\
\text { lexicalfaisqueira. Ferreira registra na primeira acepção da entrada faisqueira: 'lugar onde } \\
\text { se acham faíscas'. Houaiss, por sua vez, registra faisqueira com a mesma acepção } \\
\text { registrada por Ferreira, mas informa entre parênteses ser um termo referente ao campo do } \\
\text { garimpo. Com relação à datação, Houaiss fixa a entrada faisqueira a partir de } 1753 \text {. } \\
\text { Talvez este fato explique porque não consta do dicionário Bluteau, mas não justifica o não } \\
\text { registro em Morais Silva, cuja edição é de } 1813 \text {. } \\
\text { Considerando os dados orais apresentados pelos informantes, observa-se que a } \\
\text { unidade lexical faisqueira, mesmo lembrada apenas por dois informantes da faixa II, não } \\
\text { é uma lexia utilizada em contexto de fala. Como a atividade de mineração deixou de } \\
\text { existir há mais de séculos no município de Paranaguá, a forma lexical, } \\
\text { consequentemente, também está deixando de ser lembrada e usada, conforme se constata } \\
\text { nas respostas dos informantes. Portanto, considerando o contexto de uso do item lexical } \\
\text { faisqueira com o sentido de 'lugar onde se encontrava faísca de ouro', configura-se um } \\
\text { caso de desuso. }\end{array}$} \\
\hline
\end{tabular}




\begin{tabular}{|c|c|}
\hline \multicolumn{2}{|c|}{ 98. FIEL / DOC.47, fól.2r, 1.31-34 } \\
\hline $\begin{array}{l}\text { Acepção } \\
\text { buscada }\end{array}$ & $\begin{array}{l}\text { Pessoa provida em cargo público responsável em cobrar, guardar e } \\
\text { receber dinheiro. }\end{array}$ \\
\hline $\begin{array}{l}\text { Acepção(ões) } \\
\text { conhecida(s) } \\
\text { pelos } \\
\text { informantes }\end{array}$ & $\begin{array}{l}\text { F1-H-EP: Ser fiel a uma pessoa. } \\
\text { F1-M-EP: NSR. } \\
\text { F1-H-EF: Pessoa fiel a alguém. } \\
\text { F1-M-EF: Uma pessoa fiel a outra, de confiança. } \\
\text { F1-H-EM: NSR. } \\
\text { F1-M-EM: Fiel é uma pessoa que é comprometida, leal, tem um } \\
\text { compromisso. } \\
\text { F1-H-ES: Fiel da igreja membro de uma igreja, namorodo fiel } \\
\text { F1-M-ES: NSR. } \\
\text { F2-H-EP: Ser fiel a alguém. } \\
\text { F2-M-EP: Eu dou dízimo todo mês na igreja, daí eu sou fiel. } \\
\text { F2-H-EF: Fiel é uma pessoa que acompanha as outras, ela é fiel. No } \\
\text { porto tinha o cargo de fiel, seria o chefe de lá que tá fazendo as } \\
\text { coisas, então ele é o fiel. } \\
\text { F2-M-EF: Alguém que é muito amigo da gente, que você pode confiar. } \\
\text { F2-H-EM: Termo ligado à religiosidade, Jesus é fiel. } \\
\text { F2-M-EM: Quando um colega é fiel a nós. } \\
\text { F2-H-ES: Fiel é você ser uma pessoa íntegra, correta, de confiança. } \\
\text { Antigamente o meu pai era fiel de armazém, trabalhava no porto, hoje } \\
\text { se diz conferente. } \\
\text { F2-M-ES: Pode ser o fiel de armazém que é aquele que cuida, fiel de } \\
\text { armazém teve muito, era o cara que cuidava do armazém, ele era } \\
\text { responsável. }\end{array}$ \\
\hline $\begin{array}{l}\text { Acepções } \\
\text { registradas } \\
\text { nos } \\
\text { dicionários: }\end{array}$ & $\begin{array}{l}\text { Bluteau (1712-1728): FIEL. Officio da Camara de Barcellos. He o que } \\
\text { serve de apontar os preços de paõ, \& vinho por todo o anno, \& se } \\
\text { fazem as liquidaçoens pelas certidoens, que passa, tiradas do livro, em } \\
\text { que vay escrevendo, dandolhe por cada huma dous vintens. } \\
\text { Morais Silva (1813): FIÉL, s. m. O fiel de d'alguem; a pessoa de sua } \\
\text { confiança, de quem se fia. §. Fiel do Thesoureiro mor: o que guarda, } \\
\text { e recebe, e entrega dinheiros ás partes. } \\
\text { Cunha (1997): fiel } \text { adj. } 2 g \text {. 'seguro, leal, sólido' XIII. } \\
\text { Ferreira (2004): fiel } 10 \text {. Ajudante de tesoureiro. } \\
\text { Houaiss (2007): }{ }^{1} \text { fiel datação sXIII } 14 \quad \text { Rubrica: termo de marinha: } \\
\text { marinheiro ou outra praça encarregado de alguns serviços especiais, } \\
\text { compartimentos ou materiais (fiel do navio, da aguada, do óleo, de } \\
\text { mantimentos, do porão etc.). }\end{array}$ \\
\hline
\end{tabular}


Analisando o contexto de uso da lexia fiel, constatou-se que: (i) dos treze informantes que reconheceram o item lexical em estudo, sete informantes (F1-H-EP, F1-H-EF e F1-MEF, F1-H-EM / F2-H-EP, F2-M-EF e F2-M-EM) utilizaram a lexia fiel somente com o sentido de 'aquele que é digno de confiança'; (ii) três informantes (F1-H-ES / F2-M-EP e F2-H-EM) empregaram fiel com o sentido relacionado ao campo religioso: 'membro de uma igreja'; (iii) três informantes (F2-H-EF, F2-H-ES e F2-M-ES) mencionaram que antigamente existia o 'cargo de fiel'. Os informantes F2-H-ES e F2-M-ES se recordaram do cargo 'fiel de armazém'. A informante F2-M-ES, quando menciona ter havido 'muito fiel de armazém', subentende que hoje em dia este cargo não existe mais. Porém, analisando a resposta do informante F2-H-ES, este explica que o termo 'fiel' foi substituído pela variante lexical 'conferente'. Já o informante F2-H-EF se recorda que no porto também havia o cargo de fiel, cuja função era semelhante à de um chefe. Quanto à acepção buscada 'pessoa provida em cargo público responsável em cobrar, guardar e receber dinheiro', não se sabe, pelas respostas desses informantes, se o cargo de fiel do porto era oferecido por meio de concurso ou não. Os lexicógrafos Bluteau, Morais Silva, Ferreira e Houaiss registraram as designações próximas ao conceito da acepção em estudo. Houaiss acrescenta ser essa acepção pertencente ao campo da marinha. Cunha registra apenas a designação 'seguro, leal, sólido' para a entrada fiel.

Levando em consideração os dados analisados, observa-se que os informantes da faixa I reconheceram o item lexical fiel somente com o sentido de 'digno de confiança' e 'membro de uma igreja'. A lembrança da acepção documentada no corpus escrito permanece na memória de apenas três informantes da faixa II, porém, conforme assinala o informante F2-H-ES, o cargo de 'fiel do porto' foi substituído pela função de conferente, ou seja, deixou de existir, configurando, assim, um caso de $\underline{\text { desuso }}$ da lexia fiel com o sentido da acepção buscada.

\begin{tabular}{|c|c|}
\hline \multicolumn{2}{|c|}{ 99. FINTA / DOC.48, fól.1r, l.32-35 } \\
\hline $\begin{array}{l}\text { Acepção } \\
\text { buscada }\end{array}$ & Tributo, imposto extraordinário. \\
\hline $\begin{array}{l}\text { Acepção(ões) } \\
\text { conhecida(s) } \\
\text { pelos } \\
\text { informantes }\end{array}$ & $\begin{array}{l}\text { F1-H-EP: NSR. } \\
\text { F1-M-EP: NSR. } \\
\text { F1-H-EF: NSR. } \\
\text { F1-M-EF: NSR. } \\
\text { F1-H-EM: Finta de futebol, driblar. } \\
\text { F1-M-EM: NSR. } \\
\text { F1-H-ES: A gente só ouve no futebol } \\
\text { F1-M-ES: NSR. } \\
\text { F2-H-EP: NSR. } \\
\text { F2-M-EP: NSR. } \\
\text { F2-H-EF: Finta no futebol, um drible. }\end{array}$ \\
\hline
\end{tabular}




\begin{tabular}{|c|c|}
\hline & $\begin{array}{l}\text { F2-M-EF: NSR. } \\
\text { F2-H-EM: NSR. } \\
\text { F2-M-EM: NSR. } \\
\text { F2-H-ES: É o futebol, fintar é jogo de corpo você engana que vai de um } \\
\quad \text { lado pro outro, sentido de enganar. } \\
\text { F2-M-ES: NSR. }\end{array}$ \\
\hline $\begin{array}{l}\text { Acepções } \\
\text { registradas } \\
\text { nos } \\
\text { dicionários: }\end{array}$ & $\begin{array}{l}\text { Bluteau (1712-1728): FINTA. Tributo, que se paga ao Principe do } \\
\text { rendimento da fazenda de cada subdito. } \\
\text { Morais Silva (1813): FÍNTA, s. f. Tributo Real, pago do rendimento da } \\
\text { fazenda de cada súbdito; de ordinário se impõe para obra pública. } \\
\text { Cunha (1997): finta sf. 'imposto extraordinário' XIII. } \\
\text { Ferreira (2004): finta } 1 \text {. Contribuição extraordinária, ou encargo } \\
\text { pecuniário. } \\
\text { Houaiss (2007): }{ }^{1} \text { finta datação sXIV } 1 \text { tributo proporcional aos } \\
\text { rendimentos de cada cidadão; derrama, imposto. }\end{array}$ \\
\hline \multicolumn{2}{|c|}{$\begin{array}{l}\text { A lexia finta com a acepção buscada 'tributo, imposto extraordinário' não foi } \\
\text { reconhecida por nenhum dos informantes entrevistados. Para quatro informantes (F1-H- } \\
\text { EM e F1-H-ES / F2-H-EF e F2-H-ES) o item lexical finta é sinônimo de 'driblar'. Na } \\
\text { segunda entrada de finta, Cunha registra na primeira acepção: 'ação que visa enganar ou } \\
\text { ludibriar; logro', e na segunda acepção registra por extensão de sentido, 'driblar' que } \\
\text { passou a designar o conceito de 'enganar', em razão do movimento que o corpo do } \\
\text { jogador de futebol faz para enganar seu adversário. Cunha traz a datação desta acepção a } \\
\text { partir de 1958, portanto, parece tratar-se de uma forma inovadora no contexto de fala. As } \\
\text { definições registradas pelos lexicógrafos evidenciam a mesma acepção buscada. } \\
\text { A ausência de respostas por parte de doze informantes (seis da faixa I e seis da faixa II) } \\
\text { indica ser esta unidade lexical pouco produtiva no contexto de fala dos entrevistados. } \\
\text { Aparentemente, a forma lexical finta, com o sentido de 'driblar', presente nas respostas de } \\
\text { dois informantes da faixa I e dois informantes da faixa II, possa ser um indício de que o } \\
\text { item lexical finta continuará a existir nos registros orais. Portanto, como nenhum } \\
\text { informante reconheceu nesta unidade lexical a acepção documentada no corpus escrito, } \\
\text { presume-se ser um caso de desuso. }\end{array}$} \\
\hline
\end{tabular}

\begin{tabular}{|l|l|}
\hline 100. FOGO / DOC.19, fól.1r, l.15-19 \\
\hline $\begin{array}{l}\text { Acepção } \\
\text { buscada }\end{array}$ & Casa, residência, família. \\
\hline $\begin{array}{l}\text { Acepção(ões) } \\
\text { conhecida(s) } \\
\text { pelos } \\
\text { informantes }\end{array}$ & $\begin{array}{l}\text { F1-H-EP: Fogo é fogo. } \\
\text { F1-H-EP: Conheço só o fogo de queimar. } \\
\text { F1-M-EF: Fogo, queimada. }\end{array}$ \\
\hline
\end{tabular}




\begin{tabular}{|c|c|}
\hline & $\begin{array}{l}\text { F1-H-EM: Fogo no sentido de queimar. } \\
\text { F1-M-EM: Fogo de queimar. } \\
\text { F1-H-ES: Fogo é fogo. } \\
\text { F1-M-ES: Fogo de chama, queimar. } \\
\text { F2-H-EP: Conheço fogo normal, que queima. } \\
\text { F2-M-EP: As criançadas são fogo, atentadas. } \\
\text { F2-H-EF: Fogo é fogo mesmo, de incendiar. } \\
\text { F2-M-EF: Chama, lavareda. } \\
\text { F2-H-EM: O fogo aquece e muito mais. } \\
\text { F2-M-EM: Sentido de queimar. } \\
\text { F2-H-ES: Fogo é chama. Antigamente fogo era família, era uma casa, } \\
\text { porque tinha um fogão dentro de casa, então representava uma } \\
\text { residência. } \\
\text { F2-M-ES: Fogo é incêndio. }\end{array}$ \\
\hline $\begin{array}{l}\text { Acepções } \\
\text { registradas } \\
\text { nos } \\
\text { dicionários }\end{array}$ & $\begin{array}{l}\text { Bluteau (1712-1728): FOGO. Familia. Villa, que tem cem, ou duzentos } \\
\quad \text { fogos. } \\
\text { Morais Silva (1813): FÓGO, s. m. §. Casa, ou familia. } \\
\text { Cunha (1997): fogo } s f . \text { 'desenvolvimento simultâneo de calor e luz } \\
\quad \text { produzido pela combustão de certos corpos' 'lume, incêndio' XIII. } \\
\text { Ferreira (2004): fogo } 6 \text {. Residência de uma família; lar, casa. } \\
\text { Houaiss (2007): fogo datação } 9946 \text { casa de habitação; lar, residência. }\end{array}$ \\
\hline \multicolumn{2}{|c|}{$\begin{array}{l}\text { Dentre as várias designações registradas nos dicionários para a entrada fogo, os } \\
\text { lexicógrafos Bluteau, Morais Silva, Ferreira e Houaiss trazem a mesma acepção } \\
\text { documentada no corpus escrito: 'casa, residência, família'. Para o lema fogo, Cunha } \\
\text { registra as seguintes designações: 'calor', 'luz', 'combustão', 'lume' e 'incêndio', } \\
\text { evidenciando o mesmo sentido atribuído pelos informantes de Paranaguá. Analisando o } \\
\text { contexto de uso da unidade lexical fogo e o conceito empregado pelos informantes, } \\
\text { constata-se que, das dezesseis respostas, quinze informantes atribuíram à lexia fogo as } \\
\text { designações: 'chama', 'queimada', 'incêndio', 'labareda'. Quanto à acepção buscada, } \\
\text { somente o informante F2-H-ES mencionou ser de uso antigo: 'Antigamente fogo era } \\
\text { família, era uma casa, porque tinha um fogão dentro de casa, então representava uma } \\
\text { residência'. Já a informante F2-M-EP utilizou a unidade lexical fogo no sentido figurado: } \\
\text { 'As criançadas são fogo, atentadas'. Esta acepção para a unidade lexical fogo não se } \\
\text { encontra lexicalizada nos dicionários pesquisados. } \\
\text { Considerando os dados analisados, constata-se que o item lexicalfogo com o sentido da } \\
\text { acepção em estudo foi apenas lembrado por um informante da faixa II, como uma acepção } \\
\text { que não se usa mais, apontando, assim, um caso de desuso. }\end{array}$} \\
\hline
\end{tabular}




\begin{tabular}{|c|c|}
\hline \multicolumn{2}{|c|}{ 101. FORTUNA / DOC.10, fól.1v, l.15-18 } \\
\hline $\begin{array}{l}\text { Acepção } \\
\text { buscada }\end{array}$ & Sorte, fado. \\
\hline $\begin{array}{l}\text { Acepção(ões) } \\
\text { conhecida(s) } \\
\text { pelos } \\
\text { informantes }\end{array}$ & $\begin{array}{l}\text { F1-H-EP: Fortuna é quando você pega muito dinheiro. } \\
\text { F1-M-EP: Fortuna é o que alguém recebe de outra que morreu. } \\
\text { F1-H-EF: Relacionado a dinheiro: ganhei uma fortuna ou paguei uma } \\
\text { fortuna por aquilo. } \\
\text { F1-M-EF: Quem ganha na mega sena, ganha uma fortuna. } \\
\text { F1-H-EM: Sentido de riqueza. } \\
\text { F1-M-EM: Pessoa que é rica. } \\
\text { F1-H-ES: Afortunado. } \\
\text { F1-M-ES: De dinheiro. } \\
\text { F2-H-EP: O cara tem muita fortuna, é rico. } \\
\text { F2-M-EP: Quando você tem muito dinheiro, tem uma fortuna. } \\
\text { F2-H-EF: Dinheiro, e também afortunado é a pessoa que se dá bem em } \\
\text { alguma coisa, sempre dá certo as coisas, é afortunado no caso e tem a } \\
\text { fortuna. } \\
\text { F2-M-EF: É grana. } \\
\text { F2-H-EM: Tem muito dinheiro. } \\
\text { F2-M-EM: A pessoa ganhou uma fortuna, dinheiro. } \\
\text { F2-H-ES: Dinheiro. } \\
\text { F2-M-ES: É você correr atrás do seu trabalho, pra fazer sua fortuna. }\end{array}$ \\
\hline $\begin{array}{l}\text { Acepções } \\
\text { registradas } \\
\text { nos } \\
\text { dicionários: }\end{array}$ & $\begin{array}{l}\text { Bluteau (1712-1728): FORTUNA. Fabulosa Deidade, que os Antigos } \\
\text { adoravaõ como causa de todos os acontecimentos prosperos, \& } \\
\text { adversos. } \\
\text { Morais Silva (1813): FORTUNA, s. f. Sorte, destino, dita, ventura, boa } \\
\text { ou má, felicidade ou desgraça, sucesso bom ou máo; de ordinario se } \\
\text { toma por boa fortuna. } \\
\text { Cunha (1997): fortuna } s f \text {. 'sucesso, imprevisto, ventura, revés da sorte' } \\
\text { | XV. } \\
\text { Ferreira (2004): fortuna } 2 . \text { Destino, fado, sorte. } \\
\text { Houaiss (2007): fortuna datação sXIV } 3 \text { destino, fado. } 4 \text { boa sorte; } \\
\text { felicidade, ventura; êxito. }\end{array}$ \\
\hline \multicolumn{2}{|c|}{$\begin{array}{l}\text { Analisando o contexto de utilização da lexia fortuna, verifica-se ser bastante produtiva } \\
\text { na fala dos informantes parnanguaras. No entanto, dos dezesseis entrevistados, doze } \\
\text { informantes (cinco da faixa I e sete da faixa II) utilizam o item lexical fortuna apenas com } \\
\text { o sentido de 'ter dinheiro', 'ganhar dinheiro'. Dois informantes F1-H-EM e F1-M-EM } \\
\text { atribuíram à lexia fortuna os valores de 'riqueza', 'pessoa rica'. Dentre as várias } \\
\text { designações para a entrada rico, Houaiss registra na primeira acepção: 'que ou aquele que } \\
\text { possui muitos bens, muito dinheiro e/ou muitas coisas de valor'. Para os informantes (F1- }\end{array}$} \\
\hline
\end{tabular}


H-ES / F2-H-EF) fortuna é sinônimo de 'afortunado', que significa segundo Houaiss: ‘que ou quem foi abençoado com a boa sorte, êxito, felicidade, abastança; bem-aventurado'.

Partindo desta reflexão, constata-se que a acepção documentada no corpus escrito para a unidade lexical fortuna não se encontra mais nos registros orais dos informantes parnanguaras. Dessa forma, configura um caso de $\underline{\text { desuso. }}$.

\begin{tabular}{|c|c|}
\hline \multicolumn{2}{|c|}{ 102. HABITADOR / DOC.10, fól.1r, l.24-27 } \\
\hline $\begin{array}{l}\text { Acepção } \\
\text { buscada }\end{array}$ & Habitante, morador. \\
\hline $\begin{array}{l}\text { Acepção(ões) } \\
\text { conhecida(s) } \\
\text { pelos } \\
\text { informantes }\end{array}$ & $\begin{array}{l}\text { F1-H-EP: Falo só habitante. } \\
\text { F1-M-EP: NSR. } \\
\text { F1-H-EF: Conheço só habitante. } \\
\text { F1-M-EF: Pessoa que habita, que mora num lugar. } \\
\text { F1-H-EM: Conheço só habitante. } \\
\text { F1-M-EM: De habitar, morador. } \\
\text { F1-H-EP: NSR. } \\
\text { F1-M-ES: Morador. } \\
\text { F2-H-EP: Eu falo só habitante. } \\
\text { F2-M-EP: Quando você é habitador de um lugar, mora lá. } \\
\text { F2-H-EF: É morador. } \\
\text { F2-M-EF: Habitador é alguém que monta uma vila pequena e vai } \\
\text { fazendo suas casinhas, habitando ali. } \\
\text { F2-H-EM: Aquele que habita em algum lugar. } \\
\text { F2-M-EM: NSR. } \\
\text { F2-H-ES: NSR. } \\
\text { F2-M-ES: É quando você tá num lugar onde você habita, eu habito ali. } \\
\quad \text { No sentido de morador. }\end{array}$ \\
\hline $\begin{array}{l}\text { Acepções } \\
\text { registradas } \\
\text { nos } \\
\text { dicionários }\end{array}$ & $\begin{array}{l}\text { Bluteau (1712-1728): HABITADOR. Vid. Morador. } \\
\text { Morais Silva (1813): HABITADÒR, s. m. O que habita algum lugar. } \\
\text { Cunha (1997): habitar } v b \text {. 'ocupar como morada, residir ou viver em' } \\
\text { habitador XVI. } \\
\text { Ferreira (2004): habitador 1. P. us. V. habitante. [habitante 1. Que ou } \\
\text { quem reside habitualmente num lugar]. } \\
\text { Houaiss (2007): habitador datação } 1553 \text { Estatística: pouco usado: m.q. } \\
\text { habitante. [habitante que ou o que habita, reside ou vive em } \\
\text { determinado lugar; residente]. }\end{array}$ \\
\hline Analisanc & $\begin{array}{l}\text { contexto de utilização da lexia habitador pelos informantes de } \\
\text { ta-se que sua ocorrência é bastante produtiva, pois, do total de dezesseis }\end{array}$ \\
\hline
\end{tabular}


entrevistados, apenas quatro (dois da faixa I e dois da faixa II) disseram não conhecer a forma lexical habitador. Quanto à acepção buscada 'habitante, morador', oito informantes (F1-M-EF, F1-M-EM e F1-M-ES / F2-M-EP, F2-H-EF, F2-M-EF, F2-H-EM e F2-M-ES) atribuíram à lexia habitador esse mesmo conceito, enquanto outros quatro informantes (F1-H-EP, F1-H-EF e F1-H-EM / F2-H-EP) disseram empregar somente o item lexical habitante. O lexicógrafo Bluteau, na entrada habitador, remete o consulente à variante morador. Ferreira e Houaiss registraram a entrada habitador marcando-a como um termo pouco usado e remetem o consulente à variante lexical habitante.

Verificando o contexto de uso da unidade lexical habitador na fala dos entrevistados, dados apontam indícios da substituição da lexia habitador pela variante lexical habitante. Porém, no estágio atual de variação, o item lexical habitador ainda representa maior ocorrência na fala dos entrevistados, revelando, assim, tendência à manutencão.

\begin{tabular}{|c|c|}
\hline \multicolumn{2}{|c|}{ 103. IMINENTE / DOC.33, fól.1r, l.13-16 } \\
\hline $\begin{array}{l}\text { Acepção } \\
\text { buscada }\end{array}$ & Prestes a acontecer. \\
\hline $\begin{array}{l}\text { Acepção(ões) } \\
\text { conhecida(s) } \\
\text { pelos } \\
\text { informantes }\end{array}$ & $\begin{array}{l}\text { F1-H-EP: NSR. } \\
\text { F1-M-EP: NSR. } \\
\text { F1-H-EF: NSR. } \\
\text { F1-M-EF: NSR. } \\
\text { F1-H-EM: NSR. } \\
\text { F1-M-EM: NSR. } \\
\text { F1-H-ES: Conheço perigo iminente. } \\
\text { F1-M-ES: NSR. } \\
\text { F2-H-EP: NSR. } \\
\text { F2-M-EP: NSR. } \\
\text { F2-H-EF: Que tá prestes a acontecer no caso, tá na iminência de } \\
\text { acontecer. } \\
\text { F2-M-EF: Alguém importante. } \\
\text { F2-H-EM: Aquilo que tá por vir, por acontecer. } \\
\text { F2-M-EM: NSR. } \\
\text { F2-H-ES: O que vai acontecer. } \\
\text { F2-M-ES: NSR. }\end{array}$ \\
\hline $\begin{array}{l}\text { Acepções } \\
\text { registradas } \\
\text { nos } \\
\text { dicionários }\end{array}$ & $\begin{array}{l}\text { Bluteau (1712-1728): IMMINENTE, ou Iminente, ou (como outros } \\
\text { dizem) Eminente. O que brevemente há de suceder. } \\
\text { Morais Silva (1813): IMMINÈNTE, V. Eminente. §. Perigo imminente, } \\
\text { instante, que está sobrevindo. } \\
\text { Cunha (1997): iminente adj. } 2 g \text {. 'que está por acontecer, pedente' | } \\
\text { imminente XVII. }\end{array}$ \\
\hline
\end{tabular}




\begin{tabular}{|l|l|}
\hline $\begin{array}{c}\text { Ferreira (2004): iminente 1. Que ameaça acontecer breve; que está } \\
\text { sobranceiro; que está em via de efetivação imediata; impendente. } \\
\text { Houaiss (2007): iminente datação } 1541 \text { que ameaça se concretizar, que } \\
\text { está a ponto de acontecer; próximo, imediato. }\end{array}$ \\
\hline $\begin{array}{l}\text { Analisando o contexto de uso da lexia iminente, constata-se baixa ocorrência por parte } \\
\text { dos entrevistados de Paranaguá. Dos dezesseis informantes, cinco reconhecem o item }\end{array}$ \\
lexical em estudo, mas apenas três informantes F2-H-EF, F2-H-EM e F2-H-ES \\
empregaram iminente com a mesma acepção buscada, 'prestes a acontecer'. Quanto aos \\
outros significados, para a informante F2-M-EF, iminente é sinônimo de 'alguém \\
importante'. Provavelmente, esta informante tenha associado o parônimo eminente, cujo \\
significado é 'que é superior aos demais; excelente', com a forma lexical iminente devido \\
à semelhança entre essas formas lexicais. Por conseguinte, eminente provém do lat. \\
éminnēns - entis, enquanto que iminente provém do lat. imminens -entis. O informante F1- \\
H-ES respondeu de forma genérica: 'conheço perigo iminente', sem detalhar qual seria o \\
significado iminente. Os lexicógrafos registram a acepção da entrada iminente com o \\
mesmo sentido da acepção em estudo. \\
Considerando aos dados analisados, verifica-se que a unidade lexical iminente com o \\
mesmo sentido documentado no corpus escrito, não ocorreu na fala de nenhum dos \\
informantes da faixa I, somente nas respostas de três informantes da faixa II. Dessa forma, \\
revela tendência ao desuso.
\end{tabular}

\begin{tabular}{|c|c|}
\hline \multicolumn{2}{|c|}{ 104. INCONVENIENTE / DOC.08, fól.1r, l.07-10 } \\
\hline $\begin{array}{l}\text { Acepção } \\
\text { buscada }\end{array}$ & Dificuldade em executar algo. \\
\hline $\begin{array}{l}\text { Acepção(ões) } \\
\text { conhecida(s) } \\
\text { pelos } \\
\text { informantes }\end{array}$ & $\begin{array}{l}\text { F1-H-EP: NSR. } \\
\text { F1-M-EP: NSR. } \\
\text { F1-H-EF: É uma pessoa chata. } \\
\text { F1-M-EF: Inconveniente é uma pessoa insuportável. } \\
\text { F1-H-EM: Uma pessoa inconveniente no caso de só falar o que não } \\
\text { deve. } \\
\text { F1-M-EM: A gente tá conversando aqui, vem alguém e para a conversa, } \\
\text { essa pessoa é inconveniente. } \\
\text { F1-H-ES: NSR. } \\
\text { F1-M-ES: Eu sei no sentido: não vou fazer aquilo que é inconveniente, } \\
\text { que é difícil, é complicado de se fazer. } \\
\text { F2-H-EP: Quando uma pessoa é inconveniente. } \\
\text { F2-M-EP: Quando você não faz seu serviço certo, você é inconveniente. } \\
\text { F2-H-EF: Inconveniente é uma coisa que não convém ou uma pessoa } \\
\text { que é inconveniente também. }\end{array}$ \\
\hline
\end{tabular}




\begin{tabular}{|c|c|}
\hline & $\begin{array}{l}\text { F2-M-EF: É alguém chato que incomoda você. } \\
\text { F2-H-EM: Quando você vai a uma festa sem ser convidado, você é } \\
\text { inconveniente. } \\
\text { F2-M-EM: Inconveniente é uma pessoa que se mete onde não é } \\
\text { chamada. } \\
\text { F2-H-ES: Inconveniente é aquele que é chato, que fala na hora que não } \\
\text { deve. } \\
\text { F2-M-ES: Inconveniente é uma pessoa que vem sempre numa hora } \\
\text { errada, num momento que você não espera. }\end{array}$ \\
\hline $\begin{array}{l}\text { Acepções } \\
\text { registradas } \\
\text { nos } \\
\text { dicionários }\end{array}$ & $\begin{array}{l}\text { Bluteau (1712-1728): INCONVENIENTE. Dificuldade, que impede a } \\
\text { execução de hum negocio. Obstaculo a algum intento. } \\
\text { Morais Silva (1813): INCONVENIĖNTE, s. m. Obstaculo, estorvo, que } \\
\text { desvia o exito de alguma negociação, obra, trabalho, negocio. } \\
\text { Cunha (1997): convir vb. 'concordar, admitir' | inconveniente XV. } \\
\text { Ferreira (2004): inconveniente 7. Obstáculo, incômodo, objeção, } \\
\text { estorvo, transtorno, embaraço. } \\
\text { Houaiss (2007): inconveniente datação sXV } 2 \text { acontecimento } \\
\text { desagradável ou inesperado, que importuna, incomoda, estorva; } \\
\text { dificuldade, obstáculo, objeção, embaraço. }\end{array}$ \\
\hline \multicolumn{2}{|c|}{$\begin{array}{l}\text { As designações registradas pelos lexicógrafos, com exceção de Cunha, referem-se à } \\
\text { mesma acepção buscada para a unidade lexical inconveniente: 'dificuldade em executar } \\
\text { algo'. Analisando o contexto de uso da lexia inconveniente na fala dos entrevistados, } \\
\text { constata-se ser um item lexical bastante produtivo, pois, dos dezesseis entrevistados, } \\
\text { apenas três informantes (três da faixa I) disseram não conhecer a forma lexical } \\
\text { inconveniente. Quanto à acepção em estudo, somente uma informante (F2-M-ES) } \\
\text { reconheceu a lexia com o mesmo sentido documentado no corpus escrito. O item lexical } \\
\text { inconveniente empregado com o sentido de 'pessoa chata', 'pessoa insuportável', 'aquele } \\
\text { que fala demais', 'aquele que atrapalha', 'alguém que incomoda', esteve presente no } \\
\text { contexto de fala de doze informantes (quatro da faixa I e oito da faixa II). Estas } \\
\text { designações encontram-se registrados em Houaiss na quarta acepção: 'que ou quem fala } \\
\text { ou age de forma inconveniente; que ou quem tem comportamento contrário às } \\
\text { conveniências'. O informante F2-H-EF, além de utilizar a lexia inconveniente como valor } \\
\text { de adjetivo 'pessoa inconveniente', atribui também o sentido de 'uma coisa que não } \\
\text { convém'. Esta definição encontra-se registrada em Houaiss na primeira acepção: 'que não } \\
\text { traz vantagem, que não é útil, proveitoso; desvantajoso'. } \\
\text { Considerando a baixa ocorrência da unidade lexical inconveniente com o sentido da } \\
\text { acepção investigada, presente apenas na fala de um informante da faixa I, presume } \\
\text { tratar-se de um caso de tendência ao desuso. }\end{array}$} \\
\hline
\end{tabular}




\begin{tabular}{|c|c|}
\hline \multicolumn{2}{|c|}{ 105. INCUMBÊNCIA / DOC.22, fól.1v, l.03-05 } \\
\hline $\begin{array}{l}\text { Acepção } \\
\text { buscada: }\end{array}$ & Obrigação imposta. \\
\hline $\begin{array}{l}\text { Acepção(ões) } \\
\text { conhecida(s) } \\
\text { pelos } \\
\text { informantes }\end{array}$ & $\begin{array}{l}\text { F1-H-EP: NSR. } \\
\text { F1-M-EP: NSR. } \\
\text { F1-H-EF: NSR. } \\
\text { F1-M-EF: NSR. } \\
\text { F1-H-EM: NSR. } \\
\text { F1-M-EM: NSR. } \\
\text { F1-H-ES: Sentido de estar incumbido de fazer alguma coisa, como se } \\
\quad \text { fosse uma obrigação, tá com a responsabilidade. } \\
\text { F1-M-ES: NSR. } \\
\text { F2-H-EP: NSR. } \\
\text { F2-M-EP: NSR. } \\
\text { F2-H-EF: É que tá encarregado de fazer alguma coisa, tá incumbido. } \\
\text { F2-M-EF: É quando alguém me incumbiu de fazer tal tarefa. } \\
\text { F2-H-EM: Incumbência é quando te manda fazer alguma tarefa. } \\
\text { F2-M-EM: NSR. } \\
\text { F2-H-ES: O que você deve fazer, é sua incumbência. } \\
\text { F2-M-ES: É você incumbir alguém de alguma coisa, impor um dever. }\end{array}$ \\
\hline $\begin{array}{l}\text { Acepções } \\
\text { registradas } \\
\text { nos } \\
\text { adicionários }\end{array}$ & $\begin{array}{l}\text { Bluteau (1712-1728): INCUMBENCIA. Encargo. Obrigaçaõ de oficio. } \\
\text { Tenho esta incumbencia. } \\
\text { Morais Silva (1813): INCUMBÈNCIA, s. f. Encargo, obrigação } \\
\text { imposta de fazer alguma coisa. } \\
\text { Cunha (1997): incumbir } v b \text {. 'encarregar, cometer, confiar' | } \\
\text { incumbência } 1844 \text {. } \\
\text { Ferreira (2004): incumbência } 1 \text {. Ato ou efeito de incumbir(-se); } \\
\text { encargo. } \\
\text { Houaiss (2007): incumbência datação } 17241.1 \text { aquilo de que se é } \\
\text { incumbido, encarregado; encargo, missão. }\end{array}$ \\
\hline \multicolumn{2}{|c|}{$\begin{array}{l}\text { A entrada incumbência está registrada por Bluteau, Morais Silva, Ferreira e Houaiss } \\
\text { com o mesmo sentido da acepção buscada: 'obrigação imposta'. As definições } \\
\text { empregadas pelos seis informantes (F1-H-ES / F2-H-EF, F2-M-EF, F2-H-EM, F2-H-ES e } \\
\text { F2-M-ES) evidenciam o mesmo sentido registrado no corpus escrito. No entanto, nota-se } \\
\text { baixa ocorrência da lexia incumbência em contexto de fala dos informantes. Dos } \\
\text { dezesseis entrevistados, dez informantes (sete da faixa I e três da faixa II) disseram não } \\
\text { conhecer a lexia incumbência. Dos informantes que reconheceram com o mesmo sentido } \\
\text { da acepção investigada, seis informantes são da faixa II e apenas um da faixa I. Portanto, } \\
\text {.. }\end{array}$} \\
\hline
\end{tabular}


levando em consideração esses dados apresentados, supõe-se que incumbência apresenta tendência ao desuso.

\begin{tabular}{|c|c|}
\hline \multicolumn{2}{|c|}{ 106. LAVRA / DOC.22, fól.1r, l.28-29 } \\
\hline $\begin{array}{l}\text { Acepção } \\
\text { buscada }\end{array}$ & Terreno de mineração. \\
\hline $\begin{array}{l}\text { Acepção(ões) } \\
\text { conhecida(s) } \\
\text { pelos } \\
\text { informantes }\end{array}$ & $\begin{array}{l}\text { F1-H-EP: NSR. } \\
\text { F1-M-EP: NSR. } \\
\text { F1-H-EF: Conheço só o lavrador. } \\
\text { F1-M-EF: Quando tá pegando fogo na roça, tem lavra de fogo. } \\
\text { F1-H-EM: NSR. } \\
\text { F1-M-EM: NSR. } \\
\text { F1-H-ES: Tá queimando, tocaram fogo na roça, aí tem uma lavra de } \\
\quad \text { fogo. } \\
\text { F1-M-ES: NSR. } \\
\text { F2-H-EP: Lavra aqui é o negócio do peixe, tirar a lavra do peixe. } \\
\text { F2-M-EP: NSR. } \\
\text { F2-H-EF: É trabalho. } \\
\text { F2-M-EF: Lavra seria montar um documento. } \\
\text { F2-H-EM: Sentido de arar a terra. } \\
\text { F2-M-EM: NSR. } \\
\text { F2-H-ES: Trabalho, lavrar, virar a terra, de arar. } \\
\text { F2-M-ES: NSR. }\end{array}$ \\
\hline $\begin{array}{l}\text { Acepções } \\
\text { registradas } \\
\text { nos } \\
\text { dicionários }\end{array}$ & $\begin{array}{l}\text { Bluteau (1712-1728): LAVRA, ou Lavoura. O cultivar, o lavrar a terra. } \\
\text { Morais Silva (1813): LAVRA, s. f. A terra que se lavra. §. O trabalho } \\
\text { de minar a terra, para extrair metáes. } \\
\text { Cunha (1997): labor, lavor sm. 'trabalho, faina' | lavra XIV. } \\
\text { Ferreira (2004): lavra 3. Bras. Terreno de mineração; lugar onde se } \\
\text { extrai ouro ou diamante. } \\
\text { Houaiss (2007): 1lavra datação } 13662.2 \text { Derivação: por metonímia. } \\
\text { Rubrica: mineralogia. Regionalismo: Brasil: local de onde se extrai } \\
\text { metal ou pedras preciosas; terreno de mineração. }\end{array}$ \\
\hline \multicolumn{2}{|c|}{$\begin{array}{l}\text { Da lexia lavra buscou-se a acepção ‘terreno de mineração' presente no corpus escrito. } \\
\text { A acepção buscada encontra-se registrada em Morais Silva, na segunda acepção: ‘trabalho } \\
\text { de minar a terra, para extrair metáes'. Ferreira a classifica na terceira acepção como um } \\
\text { brasileirismo: 'terreno de mineração'. E Houaiss classifica esta mesma acepção como } \\
\text { regionalismo do Brasil pertencente ao campo da mineralogia. Analisando o contexto de } \\
\text { uso da lexia lavra com as respostas dos informantes de Paranaguá, verifica-se que a }\end{array}$} \\
\hline
\end{tabular}


acepção 'terreno de mineração' não ocorreu na fala de nenhum dos informantes. Os registros orais apontam variação entre cinco significados: (i) 'trabalhar/arar a terra', (ii) 'lavra de fogo', (iii) 'lavrador', (iv) 'lavrar um documento', e (v) 'lavra do peixe'. Três informantes (F2-H-EF, F2-H-EM e F2-H-ES) utilizaram a primeira designação. Em Bluteau encontra-se o registro da entrada lavra como sinônimo de lavoura, 'onde se cultiva e lavra a terra'. Dois informantes (F1-M-EF e F1-H-ES) empregaram a segunda designação: 'lavra de fogo'. Provavelmente esses informantes tenham associado o parônimo lavra com lava, devido à semelhança entre essas formas lexicais. Já no caso do emprego de lava para denominar 'lava de fogo' quando há 'fogo na roça', parece ter sido motivado por um processo metonímico, onde ocorre a associação dos semas: 'fogo', 'chama', 'ardor' e 'calor'. O informante F1-H-EF disse conhecer somente o item lexical lavrador referente ao campo semântico terra/roça. A informante F2-M-EF empregou lavra no sentido de 'lavrar um documento'. Esta acepção encontra-se registrada nos dicionários pesquisados. Já o informante F2-H-EP afirmou que 'lavra aqui é o negócio do peixe, tirar a lavra do peixe'. Esta designação não consta do registro de nenhum dos dicionários pesquisados.

Analisando os dados orais, percebe-se que a unidade lexical lavra foi reconhecida pela metade dos entrevistados em contexto de uso com significados distintos. Possivelmente, a lexia lavra com o sentido de 'terreno de mineração' tenha deixado de ser usada, por não haver mais em Paranaguá a extração de ouro (desde o século XVII). Portanto, o item lexical lavra com o sentido de 'terreno de mineração' provavelmente tenha caído em desuso.

\begin{tabular}{|l|l|}
\hline 107. LÉGUA / DOC.10, fól.1r, l.25-29 \\
\hline $\begin{array}{l}\text { Acepção } \\
\text { buscada }\end{array}$ & Antiga unidade brasileira de medida itinerária. \\
\hline $\begin{array}{l}\text { Acepção(ões) } \\
\text { conhecida(s) } \\
\text { pelos } \\
\text { informantes }\end{array}$ & $\begin{array}{l}\text { F1-H-EP: NSR. } \\
\text { F1-M-EP: NSR. } \\
\text { F1-M-EF: Conheço só a bota sete léguas. } \\
\text { quilômetros. } \\
\text { F1-H-EM: Conheço o pessoal fala: andar muitas léguas, quer dizer muitos } \\
\text { F1-M-EM: Sentido de muito longe. } \\
\text { F1-H-ES: Distância. } \\
\text { F1-M-ES: Andar mil léguas. }\end{array}$ \\
& $\begin{array}{l}\text { F2-H-EP: É uma medida, daqui no compadre tem tantas léguas de } \\
\text { comprimento. }\end{array}$ \\
& $\begin{array}{l}\text { F2-M-EP: NSR. } \\
\text { F2-H-EF: Distância de um lugar pro outro, isso é mais no sítio, Morretes } \\
\text { tá a tantas léguas daqui, se falava assim antigamente. }\end{array}$ \\
\hline
\end{tabular}




\begin{tabular}{|c|c|}
\hline & $\begin{array}{l}\text { F2-M-EF: Légua também é medição. } \\
\text { F2-H-EM: Caminhei tantas léguas. } \\
\text { F2-M-EM: NSR. } \\
\text { F2-H-ES: Légua é medida, que tem mudança de um lugar pra outro. } \\
\text { F2-M-ES: Légua é caminhar bastante, quilômetros. }\end{array}$ \\
\hline $\begin{array}{l}\text { Acepções } \\
\text { registradas } \\
\text { nos } \\
\text { dicionários }\end{array}$ & $\begin{array}{l}\text { Bluteau (1712-1728): LEGOA, no Grego quer dizer Branca; e } \\
\text { antigamente com pedras brancas se marcavaõ as distancias de hum } \\
\text { lugar a outro. } \\
\text { Morais Silva (1813): LÈGOA, s. f. Medida itineraria, que contèm } 3.755 \\
\text { passos geometricos. } \\
\text { Cunha (1997): légua } s f \text {. 'medida itinerária' | XIII. } \\
\text { Ferreira (2004): légua 1.Antiga unidade brasileira de medida itinerária, } \\
\text { equivalente a } 3.000 \text { braças, ou seja, } 6.600 \mathrm{~m} \text {; légua brasileira. } \\
\text { Houaiss (2007): légua datação sXIII } 1 \text { Rubrica: metrologia: medida de } \\
\text { distância em vigor antes da adoção do sistema métrico, cujo valor } \\
\text { varia de acordo com a época, país ou região; no Brasil, vale } \\
\text { proximadamente } 6.600 \text { m, em Portugal, } 5.572 \text { m. }\end{array}$ \\
\hline
\end{tabular}

Analisando o contexto de utilização da lexia légua pelos informantes de Paranaguá, constata-se que sua ocorrência é bastante produtiva, pois, do total de dezesseis entrevistados, apenas quatro (dois da faixa I e dois da faixa II) disseram não conhecer a lexia em questão. Quanto à acepção buscada 'antiga unidade brasileira de medida it inerária', dez informantes (cinco da faixa I: F1-M-EF, F1-H-EM, F1-M-EM, F1-H-ES e F1-M-ES / cinco da faixa II: F2-H-EP, F2-H-EF, F2-M-EF, F2-H-EM, F2-H-ES e F2-MES) atribuíram à lexia légua designações próximas da acepção buscada: 'andar muitas léguas', 'léguas de comprimento', 'distância de um lugar para outro', 'caminhar bastante', 'tipo de medida', 'muitos quilômetros' e 'muito longe'. Apenas o informante F1-H-EF associou, por meio do processo metonímico, a marca da bota 'sete léguas' com o item lexical léguas. Analisando as respostas desses dois informantes: F1-M-EF: 'No sítio o pessoal fala: andar muitas léguas, quer dizer muitos quilometros' e F2-H-EF: 'Distância de um lugar pro outro, isso é mais no sítio, Morretes tá a tantas léguas daqui, se falava assim antigamente', supõe-se ser o item lexical légua uma marca dialetal de pessoas que habitam no meio rural. Entretanto, essa informação não se encontra registrada por nenhum dos dicionários pesquisados. As designações registradas pelos lexicógrafos evidenciam o mesmo sentido da acepção buscada. Ainda segundo Houaiss, essa acepção refere-se ao campo da metrologia.

Portanto, verificando o contexto de uso da unidade lexical légua na fala dos entrevistados, dados apontam indícios de tendência à manutencão, com relação ao sentido da acepção em estudo. 


\begin{tabular}{|c|c|}
\hline \multicolumn{2}{|c|}{ 108. LETRA / DOC.15, fól.1r, l.07-09 } \\
\hline $\begin{array}{l}\text { Acepção } \\
\text { buscada }\end{array}$ & Documento, carta. \\
\hline $\begin{array}{l}\text { Acepção(ões) } \\
\text { conhecida(s) } \\
\text { pelos } \\
\text { informantes }\end{array}$ & $\begin{array}{l}\text { F1-H-EP: De escrever. } \\
\text { F1-M-EP: Escrever uma letra bonita. } \\
\text { F1-H-EF: Quando vou conversar com alguém, vou trocar uma letra. } \\
\text { F1-M-EF: Escrever. } \\
\text { F1-H-EM: Letra de alfabeto, de texto, de música. } \\
\text { F1-M-EM: Letra de escrever. } \\
\text { F1-H-ES: Escrita. } \\
\text { F1-M-ES: Letra de documento ninguém fala aqui. } \\
\text { F2-H-EP: Letra é documento, faz um documento, eu faço uma letra. } \\
\text { F2-M-EP: Só sei letra de algarismo. } \\
\text { F2-H-EF: Conheço só a letra da escrita. } \\
\text { F2-M-EF: Letra de caligrafia. } \\
\text { F2-H-EM: Letra de escrever. } \\
\text { F2-M-EM: Letra é a escrita, letra boa. } \\
\text { F2-H-ES: Letra alfabeto ou então letra como título bancário, } \\
\text { empréstimo. } \\
\text { F2-M-ES: Letra é a escrita. }\end{array}$ \\
\hline $\begin{array}{l}\text { Acepções } \\
\text { registradas } \\
\text { nos } \\
\text { dicionários }\end{array}$ & $\begin{array}{l}\text { Bluteau (1712-1728): LETRA. Modo de escrever, \& caracter proprio, \& } \\
\text { particular de qualquer pessoa. } \\
\text { Morais Silva (1813): LETTRA, s. f. Caracter de mão, ou tipo, que } \\
\text { representa as vogáes, ou sons. } \\
\text { Cunha (1997): letra } s f . \text { 'carta' | XIII. } \\
\text { Ferreira (2004): letra } 8 \text {. Econ. Título da dívida pública. } \\
\text { Houaiss (2007): 'letra datação sXIII } 12 \text { Uso: informal. Diacronismo: } \\
\text { antigo: carta, missiva, epístola. }\end{array}$ \\
\hline \multicolumn{2}{|c|}{$\begin{array}{l}\text { Analisando o contexto de uso da lexia letra na fala dos entrevistados, constata-se ser } \\
\text { um item lexical bastante produtivo. Dos dezesseis entrevistados, todos reconherem a } \\
\text { unidade lexical, porém com sentidos diversos. A acepção em estudo foi empregada } \\
\text { somente pelo informante F2-H-EP. A maioria dos informantes (seis da faixa I e sete da } \\
\text { faixa II) atribuiu ao item lexical letra o sentido de 'ato de escrever', 'letra do alfabeto' e } \\
\text { 'escrita'. Esta acepção encontra-se registrada por Bluteau e Morais Silva. Já os } \\
\text { informantes (F1-H-EM / F2-H-ES), além de atribuírem o significado 'letra de alfabeto', } \\
\text { acrescentaram 'letra de música' e 'letra como um título bancário, empréstimo'. Esta } \\
\text { última designação encontra-se registrada em Ferreira, na o itava acepção referente ao } \\
\text { campo da economia. O informante F1-H-EF informou ser letra sinônimo de um 'bate- } \\
\text { papo': 'quando vou conversar com alguém, vou trocar uma letra'. Esta acepção não se } \\
\text { encontra registrada por nenhum dos dicionaristas pesquisados. Com relação à acepção }\end{array}$} \\
\hline
\end{tabular}


buscada, Cunha registra a designação 'carta' para a entrada letra, e Houaiss, por sua vez, a classifica como um diacronismo antigo de uso informal, na acepção de 'carta, missiva, epístola'.

Analisando o contexto de uso da unidade lexical letra com o sentido da acepção investigada, constata-se somente uma ocorrência na fala do informante F2-H-ES. Esta constatação vem, de certa forma, corroborar a resposta da informante F1-M-ES: 'Letra de documento ninguém fala aqui'. Portanto, presume-se neste contexto de utilização tendência ao desuso.

\begin{tabular}{|c|c|}
\hline \multicolumn{2}{|c|}{ 109. LIBRA / DOC.42, fól.1r, l.14-16 } \\
\hline $\begin{array}{l}\text { Acepção } \\
\text { buscada }\end{array}$ & Medida de peso. \\
\hline $\begin{array}{l}\text { Acepção(ões) } \\
\text { conhecida(s) } \\
\text { pelos } \\
\text { informantes }\end{array}$ & $\begin{array}{l}\text { F1-H-EP: NSR. } \\
\text { F1-M-EP: NSR. } \\
\text { F1-H-EF: NSR. } \\
\text { F1-M-EF: NSR. } \\
\text { F1-H-EM: Conheço como uma comunicação por gesto e também como } \\
\quad \text { uma moeda da Inglaterra. } \\
\text { F1-M-EM: Libra de sinais. } \\
\text { F1-H-ES: NSR. } \\
\text { F1-M-ES: NSR. } \\
\text { F2-H-EP: NSR. } \\
\text { F2-M-EP: Libra é dinheiro porque antigamente se falava assim: pô, você } \\
\text { tem bastante libra! Com sentido de dinheiro. } \\
\text { F2-H-EF: Libra seria a libra em dinheiro. Medida também é libra: tantas } \\
\text { libras. E tem a libra de falar em libras. } \\
\text { F2-M-EF: É dinheiro. } \\
\text { F2-H-EM: Moeda. } \\
\text { F2-M-EM: NSR. } \\
\text { F2-H-ES: Libra é moeda. } \\
\text { F2-M-ES: Libra é dinheiro. }\end{array}$ \\
\hline $\begin{array}{l}\text { Acepções } \\
\text { registradas } \\
\text { nos } \\
\text { dicionários }\end{array}$ & $\begin{array}{l}\text { Bluteau (1712-1728): LIBRA, ou Livra. Antigamente entre Romanos } \\
\text { era moeda de doze onças de peso, \& valor. He a moeda mais antiga de } \\
\text { que se achão memorias, como se vèda Ordenação velha livro. } \\
\text { Morais Silva (1813): LIBRA, s. f. Peso de doze onças dos Boticarios. } \\
\text { Cunha (1997): libra } s f . \text { 'peso, moeda' | XIII. } \\
\text { Ferreira (2004): libra Unidade de medida de massa, igual a } \\
\text { 0,45359237kg, utilizada no sistema inglês de pesos e medidas; libra- } \\
\text { massa. }\end{array}$ \\
\hline
\end{tabular}




\begin{tabular}{|c|c|c|}
\hline $\begin{array}{c}\text { Houaiss (2007): libra datação sXIII 1 } \\
\text { unidade de massa utilizada no sistema inglês de pesos e medidas } \\
\text { equivalente a 0,4535923 quilogramas; libra-massa. }\end{array}$ \\
\hline A única ocorrência da acepção 'medida de peso' para o item lexical libra fo i \\
mencionada na resposta do informante F2-H-EF: 'Libra seria a libra em dinheiro. Medida \\
também é libra: tantas libras. E tem a libra de falar em libras'. Outros cinco informantes \\
da faixa II (F2-M-EP, F2-M-EF, F2-H-EM, F2-H-ES e F2-M-ES) atribuíram o sentido de \\
'moeda', 'dinheiro'. Esta acepção encontra-se na entrada libra lexicalizada em Bluteau, \\
Morais Silva e Cunha. Com relação ainda ao sentido monetário, o informante F1-H-EM \\
conhece libra como 'moeda específica da Inglaterra'. Dois informantes (F1-H-EM e F1- \\
M-EM) associaram a forma lexical 'libra' à sigla Libras (língua brasileira de sinais), por \\
serem itens lexicais parônimos. Os lexicógrafos Ferreira e Houaiss definem o termo libra \\
como 'unidade de medida/massa utilizada no sistema inglês de pesos e medidas'. O último \\
dicionarista assinala que esta acepção pertencente ao campo da física, metrologia. \\
Analisando o contexto de uso da unidade lexical libra com o sentido específico de \\
'medida de peso', constata-se sua menção pelo informante da faixa II, dentre vários outros \\
significados atribuídos por ele. Dos oito informantes da faixa I, apenas dois reconheceram \\
a lexia libra, mas com significados diferentes. Conjectura-se, portanto, indícios de \\
tendência ao desuso.
\end{tabular}

\begin{tabular}{|l|l|}
\hline \multicolumn{1}{|l|}{$\begin{array}{l}\text { 110. LONGES / DOC.17, fól.1r, l.15-17 } \\
\text { buscada }\end{array}$} & Grande distância. \\
\hline $\begin{array}{l}\text { Acepção(ões) } \\
\text { conhecida(s) } \\
\text { pelos } \\
\text { informantes }\end{array}$ & $\begin{array}{l}\text { F1-H-EP: Longes quando uma pessoa tá distante. } \\
\text { F1-H-EP: NSR. } \\
\text { F1-M-EF: É distante. distante de alguém. } \\
\text { F1-H-EM: NSR. } \\
\text { F1-M-EM: NSR. } \\
\text { F1-H-ES: NSR. } \\
\text { F1-M-ES: NSR. } \\
\\
\text { F2-H-EP: Longes pra nós aqui é distância. } \\
\text { F2-M-EP: Longes é distância. } \\
\text { F2-H-EF: NSR. } \\
\text { F2-M-EF: Longes seria o povo muito antigo. } \\
\text { F2-H-EM: NSR. } \\
\text { F2-M-EM: NSR. } \\
\text { F2-H-ES: De longe, distância. } \\
\text { F2-M-ES: Longes é quando você está distante. }\end{array}$ \\
\hline
\end{tabular}




\begin{tabular}{|l|l|}
\hline $\begin{array}{l}\text { Acepções } \\
\text { registradas } \\
\text { nos } \\
\text { dicionários }\end{array}$ & $\begin{array}{l}\text { Bluteau (1712-1728): LONGE. O contrario de perto. } \\
\text { Morais Silva (1813): LÒNGES, s. m. pl. Na pintura, os objetos, que por } \\
\text { meyo da perspectiva se representão no painel distantes da vista. } \\
\text { Cunha (1997): longo adj. | longe adj. adv. 'distante, afastado' 'a grande } \\
\text { distância' XIII. } \\
\text { Ferreira (2004): longes 3. Grandes distâncias de tempo ou de espaço. } \\
\text { Houaiss (2007): longe datação } 1258 \text { 5 Derivação: por analogia: } \\
\text { afastado no tempo, distante de determinado momento (freq. us. no pl.) }\end{array}$ \\
$\begin{array}{l}\text { Analisando o contexto de uso da lexia longes constata-se que, dos dezesseis } \\
\text { entrevistados, a metade a utiliza em seu contexto de fala. Apenas uma informante (F2-M- }\end{array}$ \\
$\begin{array}{l}\text { EF) associou o item lexical longes ao 'povo muito antigo'. Os demais informantes (três da } \\
\text { faixa I: F1-H-EP, F1-H-EF e, F1-M-EF / quatro da faixa II: F2-H-EP, F2-M-EP, F2-H-ES, } \\
\text { F2-M-ES) empregaram longes no sentido de 'estar distante' e 'distância', evidenciando, } \\
\text { assim, o sentido documentado no corpus escrito. Os lexicógrafos Morais Silva e Ferreira } \\
\text { registraram também a mesma definição em estudo para a entrada longes e Bluteau, Cunha } \\
\text { e Houaiss, longe. Houaiss, apesar de registrar a entrada longe no singular, informa entre } \\
\text { parênteses ser comum o emprego desta lexia no plural para designar a acepção em } \\
\text { questão. } \\
\text { Dessa forma, o emprego da unidade lexical longes, presente na fala de sete informantes } \\
\text { (três da faixa I e quatro da faixa II), referente à acepção em estudo, apresenta tendência à } \\
\text { manutencão. }\end{array}$ \\
\hline
\end{tabular}

\begin{tabular}{|l|l|}
\hline \multicolumn{2}{|l|}{ 111. MANTIMENTO / DOC.47, fól.2r, l.28-30 } \\
\hline $\begin{array}{l}\text { Acepção } \\
\text { buscada }\end{array}$ & Alimento para sustento próprio. \\
\hline $\begin{array}{l}\text { Acepção(ões) } \\
\text { conhecida(s) } \\
\text { pelos } \\
\text { informantes }\end{array}$ & $\begin{array}{l}\text { F1-H-EP: Mantimento é tipo alimento. } \\
\text { F1-M-EP: Mantimento é comida, alimento. } \\
\text { F1-M-EF: Comida é mantimento. } \\
\text { F1-H-EM: É comida. } \\
\text { F1-M-EM: Mantimento é fazer um estoque de alimento. } \\
\text { F1-H-ES: De comida, alimento. } \\
\text { F1-M-ES: De alimento. } \\
\text { F2-H-EP: É mantimento a gente usa em casa, faltou tal coisa, estamos } \\
\text { sem mantimento, sem alimento. } \\
\text { F2-M-EP: Mantimento é comida. } \\
\text { F2-H-EF: É comida, mais na matéria de se manter. } \\
\text { F2-M-EF: Mantimento é comida, arroz, feijão essas coisas. } \\
\text { F2-H-EM: Sentido de estocar alimento. }\end{array}$ \\
\hline
\end{tabular}




\begin{tabular}{|c|c|}
\hline & $\begin{array}{l}\text { F2-M-EM: As pessoas do sítio vão até a cidade comprar mantimentos, } \\
\text { comida. } \\
\text { F2-H-ES: Mantimento é comida. } \\
\text { F2-M-ES: É alimentação. }\end{array}$ \\
\hline $\begin{array}{l}\text { Acepções } \\
\text { registradas } \\
\text { nos } \\
\text { dicionários }\end{array}$ & $\begin{array}{l}\text { Bluteau (1712-1728): MANTIMENTO, ou mantimentos. Alimentos } \\
\text { necessarios para o sustento da vida. } \\
\text { Morais Silva (1813): MANTIMÈNTO, s. m. Os comeres, víveres, } \\
\text { vitualhas, alimento. } \\
\text { Cunha (1997): manter } v b \text {. 'sustentar, prover do que é necessário à } \\
\text { subsistência, conservar'| mantimento } \mid \text { XIV. } \\
\text { Ferreira (2004): mantimento } 2 \text {. V. mantença. [mantença } 1 \text {. Aquilo } \\
\text { que mantém ou sustenta; sustento, alimento, mantimento]. } \\
\text { Houaiss (2007): mantimento datação } 13651 \text { conjunto de gêneros } \\
\text { alimentícios; víveres. }\end{array}$ \\
\hline \multicolumn{2}{|c|}{$\begin{array}{l}\text { As definições apresentadas pelos lexicógrafos evidenciam o sentido próximo da } \\
\text { acepção buscada 'alimento para sustento próprio'. Ferreira registra a entrada mantimento } \\
\text { remetendo o consulente à variante lexical mantença. Analisando o contexto de uso da } \\
\text { lexia mantimento por parte dos informantes parnanguaras, constata-se ser um item lexical } \\
\text { bastante produtivo. Quinze informantes reconhecem o sentido de 'alimento', 'comida' } \\
\text { para a unidade lexical mantimento. Apenas o informante F2-H-EM associou mantimento } \\
\text { com o sentido de 'estocar alimento', os demais informantes a empregaram com o mesmo } \\
\text { sentido documentado no corpus escrito. } \\
\text { Analisando o contexto de uso desta unidade lexical com as respostas dos informantes, } \\
\text { verifica-se que a acepção buscada é bastante produtiva na fala dos entrevistados, supondo } \\
\text { tratar-se, então, de um caso de manutencão. }\end{array}$} \\
\hline
\end{tabular}

\begin{tabular}{|l|l|}
\hline \multicolumn{2}{|l|}{ 112. MEIRINHO / DOC.40, fól.1r, l.08-11 } \\
\hline $\begin{array}{l}\text { Acepção } \\
\text { buscada }\end{array}$ & Funcionário judicial. \\
\hline $\begin{array}{l}\text { Acepção(ões) } \\
\text { conhecida(s) }\end{array}$ & F1-H-EP: NSR. \\
pelos & F1-M-EP: NSR. \\
informantes & F1-H-EF: NSR. \\
& F1-M-EF: NSR. \\
& F1-H-EM: NSR. \\
& F1-M-EM: NSR. \\
& F1-H-ES: NSR. \\
& F1-M-ES: NSR. \\
& F2-H-EP: NSR. \\
\hline
\end{tabular}




\begin{tabular}{|c|c|}
\hline & $\begin{array}{l}\text { F2-M-EP: NSR. } \\
\text { F2-H-EF: NSR. } \\
\text { F2-M-EF: NSR. } \\
\text { F2-H-EM: NSR. } \\
\text { F2-M-EM: NSR. } \\
\text { F2-H-ES: Meirinho é o auxiliar do juiz. O meirinho é obrigado a fazer a } \\
\text { abertura do julgamento, indo lá e gritando "processo tal, contra fulano } \\
\quad \text { de tal, nos autos tal, começa agora com a juíza tal etc.. O meirinho faz } \\
\text { isso aí. } \\
\text { F2-M-ES: NSR. }\end{array}$ \\
\hline $\begin{array}{l}\text { Acepções } \\
\text { registradas } \\
\text { nos } \\
\text { dicionários }\end{array}$ & $\begin{array}{l}\text { Bluteau (1712-1728): MEIRINHO. Homem que tem mayoria, \& poder } \\
\text { para administrar, \& fazer justiça em alguma Villa, ou terra, etc. } \\
\text { Meirinho do Alcaide, que o acompanha, \& ajuda a executar actos de } \\
\text { justiça. } \\
\text { Morais Silva (1813): MEIRÍNHO, s. m. Official da Justiça, que prende, } \\
\text { cita, penhora, e executa outros mandados judiciaes; é oficial de } \\
\text { Ouvidores; Corregedores, Provedores; e dos Vigarios Geraes. } \\
\text { Cunha (1997): meirinho } \mathrm{sm} \text {. 'antigo funcionário judicial } \\
\text { correspondente ao oficial de diligências atual' | XV. } \\
\text { Ferreira (2004): meirinho }{ }^{1} 1 \text {. Antigo funcionário judicial, } \\
\text { correspondente ao oficial de justiça de hoje. } \\
\text { Houaiss (2007): ' }{ }^{1} \text { meirinho dataçâo } 12721 \text { Diacronismo: antigo: } \\
\text { funcionário da justiça. }\end{array}$ \\
\hline \multicolumn{2}{|c|}{$\begin{array}{l}\text { Analisando o contexto de utilização da lexia meirinho, constata-se que este item lexical } \\
\text { foi reconhecido apenas pelo informante F2-H-ES. Segundo este informante, 'meirinho é o } \\
\text { auxiliar do juiz. O meirinho é obrigado a fazer a abertura do julgamento, indo lá e } \\
\text { gritando 'processo tal, contra fulano de tal, nos autos tal, começa agora com a juíza tal } \\
\text { etc. O meirinho faz isso ai'. Verifica-se, por meio do exemplo dado por este informante, } \\
\text { que o sentido atribuído hoje para a unidade lexical meirinho não corresponde ao sentido } \\
\text { empregado no corpus escrito. Nota-se que a relação ainda existente entre as duas } \\
\text { acepções ('funcionário judicial' e 'auxiliar de juiz') encontra-se no campo jurídico. Os } \\
\text { lexicógrafos registraram a mesma acepção em estudo: 'funcionário judicial'. Houaiss traz } \\
\text { a marca de diacronismo antigo para esta acepção. } \\
\text { Levando em consideração a não resposta de quinze informantes e nenhuma ocorrência } \\
\text { da acepção documentada no corpus escrito por parte dos informantes parnanguaras, } \\
\text { supõe-se que a unidade lexical tenha caído em desuso. }\end{array}$} \\
\hline
\end{tabular}

\begin{tabular}{|c|c|}
\hline \multicolumn{2}{|c|}{ 113. MERCÊ / FAZER MERCÊ / DOC.16, fól.1r, l.03-05 } \\
\hline $\begin{array}{l}\text { Acepção } \\
\text { buscada }\end{array}$ & Conceder benefício. \\
\hline
\end{tabular}




\begin{tabular}{|c|c|}
\hline $\begin{array}{l}\text { Acepção(ões) } \\
\text { conhecida(s) } \\
\text { pelos } \\
\text { informantes }\end{array}$ & $\begin{array}{l}\text { F1-H-EP: NSR. } \\
\text { F1-M-EP: NSR. } \\
\text { F1-H-EF: NSR. } \\
\text { F1-M-EF: Você está a mercê de alguém. Quando você está na mão de } \\
\text { alguém. } \\
\text { F1-H-EM: Conheço como ficou a mercê de fulano, como se ficasse } \\
\text { dependendo. } \\
\text { F1-M-EM: NSR. } \\
\text { F1-H-ES: Tá jogando baralho, tá a mercê, tá se arriscando, está sujeito a } \\
\text { alguma coisa. } \\
\text { F1-M-ES: Estou a sua mercê. } \\
\text { F2-H-EP: NSR. } \\
\text { F2-M-EP: Antigamente se falava mercê, hoje não fala mais. } \\
\text { F2-H-EF: Mercê é estar a mercê de alguma coisa. } \\
\text { F2-M-EF: Fico a mercê da decisão de alguém. } \\
\text { F2-H-EM: Quando a gente vai na casa dos parentes, a gente fica a mercê } \\
\text { deles. } \\
\text { F2-M-EM: NSR. } \\
\text { F2-H-ES: Estar a mercê ou estar a disposição. } \\
\text { F2-M-ES: Mercê eu acho, isso tá tudo a mercê, ninguém liga pra isso } \\
\text { daí, tá jogado, tá a mercê mesmo, quer levar, pode leva, ninguém quer } \\
\text { mesmo. }\end{array}$ \\
\hline $\begin{array}{l}\text { Acepções } \\
\text { registradas } \\
\text { nos } \\
\text { dicionários }\end{array}$ & $\begin{array}{l}\text { Bluteau (1712-1728): MERCÈ. Na língua portuguesa não se costuma } \\
\text { nesta significação de salario, premio, remuneração, senão de graça, ou } \\
\text { beneficio, como os que Deos faz às suas creaturas, ou os senhores aos } \\
\text { seus criados. Fazer mercê a alguem de algũa cousa. } \\
\text { Morais Silva (1813): MERCĖ, s. f. Graça, beneficio, dom gratuito; } \\
\text { obra, acção por bemfeitoria. } \\
\text { Cunha (1997): mercê sf. 'graça, benefício, proteção' | XIII, mercee } \\
\text { XIII. } \\
\text { Ferreira (2004): mercê } 2 \text {. Favor, graça, benefício. } \\
\text { Houaiss (2007): mercê datação } 12692 \text { favor, gosto, graça, benefício } \\
\text { que alguém faz ou concede a outro. }\end{array}$ \\
\hline \multicolumn{2}{|c|}{$\begin{array}{l}\text { Analisando as respostas dos informantes parnanguaras, constata-se que a lexia mercê é } \\
\text { empregada como locução verbal: 'estar à mercê de', 'ficar à mercê de'. Quanto ao sentido } \\
\text { dessas locuções verbais empregadas pelos informantes, verifica-se que cada informante a } \\
\text { emprega em contextos diferentes: F1-M-EF: 'estar à mercê de alguém = estar na mão de } \\
\text { alguém'; F1-H-EM: 'ficar à mercê de fulano = ficar dependente dele'; F1-H-ES: 'estar à } \\
\text { mercê = estar sujeito a alguma coisa'; F2-M-EF: 'Ficou à mercê da decisão de alguém'; } \\
\text { F2-H-EM: 'ficar na casa dos parentes = ficar à mercê deles'; F2-H-ES: 'estar à mercê = }\end{array}$} \\
\hline
\end{tabular}


estar à disposição'; F2-M-ES: 'estar tudo à mercê = ninguém liga, ninguém se importa, ninguém quer'. A acepção buscada 'conceder benefício' para a entrada mercê consta do registro dos dicionários pesquisados.

Com relação ao registro oral da unidade lexical mercê, em contexto de fala, o informante F2-H-EP se recorda que 'antigamente se falava mercê, hoje não fala mais. Levando em consideração este contexto e a não ocorrência da acepção em estudo nas respostas dos demais informantes, pressupõe-se um caso de $\underline{\text { desuso. }}$.

\begin{tabular}{|c|c|}
\hline \multicolumn{2}{|c|}{ 114. MESTRE / DOC.48, fól.1v, l.16-19 } \\
\hline $\begin{array}{l}\text { Acepção } \\
\text { buscada }\end{array}$ & Comandante de embarcação. \\
\hline $\begin{array}{l}\text { Acepção(ões) } \\
\text { conhecida(s) } \\
\text { pelos } \\
\text { informantes }\end{array}$ & $\begin{array}{l}\text { F1-H-EP: Tem o mestre de obra e de embarcação também. } \\
\text { F1-M-EP: NSR. } \\
\text { F1-H-EF: É professor. } \\
\text { F1-M-EF: NSR. } \\
\text { F1-H-EM: Sentido de professor, pessoa que tá passando certo } \\
\text { ensinamento. } \\
\text { F1-M-EM: Mestre de obras ou mestre que dá aula. } \\
\text { F1-H-ES: De professor. } \\
\text { F1-M-ES: Professor. } \\
\text { F2-H-EP: Pra nós aqui sair numa embarcação tem que ter um mestre. } \\
\text { F2-M-EP: Você é mestre de obra, é um mestre como professor, mestre } \\
\text { de embarcação. } \\
\text { F2-H-EF: Mestre seria uma pessoa que lidera os outros é mestre, mestre } \\
\text { de obras. Tem também o mestre piloto de barco. } \\
\text { F2-M-EF: Professor. } \\
\text { F2-H-EM: Mestre é uma pessoa que é justamente um perito na área que } \\
\text { faz, que sabe aquilo que faz. } \\
\text { F2-M-EM: Pra nós é professor. } \\
\text { F2-H-ES: Tem o mestre de obra, o mestre das corporações, aqui por hora } \\
\text { ninguém lembra disso, é a titulação de mestre. } \\
\text { F2-M-ES: Mestre quem ensina, o professor. }\end{array}$ \\
\hline $\begin{array}{l}\text { Acepções } \\
\text { registradas } \\
\text { nos } \\
\text { dicionários }\end{array}$ & $\begin{array}{l}\text { Bluteau (1712-1728): MESTRE da nao. } \\
\text { Morais Silva (1813): MÉSTRE, s. m. §. Mestre da náo; o que tem á sua } \\
\text { conta o velame, cordoalha, palamenta, e aparelhos da náo. } \\
\text { Cunha (1997): mestre } s m \text {. 'homem que ensina, professor, homem muito } \\
\quad \text { sabedor' | XIII. } \\
\text { Ferreira (2004): mestre 14. Ant. Capitão. [capitão 4. Mar. Merc. } \\
\quad \text { Comandante de navio mercante]. }\end{array}$ \\
\hline
\end{tabular}




\begin{tabular}{l}
\hline $\begin{array}{l}\text { Houaiss (2007): mestre datação 1255 15 Rubrica: termo de marinha. } \\
\text { Diacronismo: antigo: comandante de navio mercante; capitão. }\end{array}$ \\
\hline $\begin{array}{l}\text { Analisando o contexto de uso do item lexical mestre pelos entrevistados de Paranaguá, } \\
\text { averigua-se o emprego de vários significados. A maior parte dos informantes da faixa I, } \\
\text { empregou a lexia mestre no sentido de 'professor', havendo variação de significado por } \\
\text { parte de dois informantes: F1-H-EP: 'mestre de obra', 'mestre de embarcação'; F1-M- } \\
\text { EM: 'mestre de obras', 'professor'. Quanto à faixa II, três informantes (F2-M-EF, F2-M- } \\
\text { EM e F2-M-ES) conheceram a forma lexical mestre somente no sentido de 'professor'. E } \\
\text { o informante F2-H-EM utilizou-a apenas no sentido de 'aquele que domina um } \\
\text { conhecimento específico'. Cunha registra estas duas acepções para a unidade léxica } \\
\text { mestre. Outros três informantes empregam a lexia mestre com variação de significado: } \\
\text { F2- M-EP: 'mestre de obra', 'professor', 'mestre de embarcação'; F2-H-EF: 'mestre de } \\
\text { obras', 'mestre de embarcação'; F2-H-ES: 'mestre de obra', 'mestre das corporações', } \\
\text { 'titulação de mestre'. Constam dos lexicógrafos Bluteau, Morais Silva, Ferreira e Houaiss } \\
\text { a acepção em estudo: 'comandante de embarcação'. Ferreira registra a entrada mestre e } \\
\text { define como 'Ant. Capitão'. Na quarta acepção da entrada capitão, Ferreira designa } \\
\text { 'comandante de navio mercante'. Houaiss registra a entrada mestre, marcando-a como } \\
\text { diacronismo antigo pertencente ao termo da marinha. } \\
\text { Analisando o contexto de fala do item lexical mestre, constata-se que somente um } \\
\text { informante (F2-H-EP) empregou mestre com o sentido da acepção em estudo: 'mestre de } \\
\text { embarcação'. Três outros informantes da faixa II, além de vários significados atribuídos à } \\
\text { unidade lexical mestre, empregaram também o sentido relacionado a 'mestre de } \\
\text { embarcação'. No estágio atual de variação entre essas várias designações, observa-se que } \\
\text { a maioria dos informantes da faixa I tem preferência pelo emprego da forma lexical } \\
\text { mestre com o sentido de 'professor' e 'mestre de obra'. Portanto, presume-se ser mestre } \\
\text { com o sentido da acepção documentado no corpus escrito uma lexia com tendência ao } \\
\text { desuso. }\end{array}$ \\
\hline
\end{tabular}

\begin{tabular}{|l|l|}
\hline \multicolumn{1}{|l|}{ 115. MILICIANO / DOC.47, fól.2v, l.16-19 } \\
\hline $\begin{array}{l}\text { Acepção } \\
\text { buscada }\end{array}$ & O mesmo que soldado militar. \\
\hline $\begin{array}{l}\text { Acepção(ões) } \\
\text { conhecida(s) } \\
\text { pelos } \\
\text { informantes }\end{array}$ & $\begin{array}{l}\text { F1-H-EP: NSR. } \\
\text { F1-M-EP: NSR. } \\
\end{array}$ \\
& $\begin{array}{l}\text { F1-M-EF: NSR. Miliciano é o cabo. } \\
\text { F1-H-EM: Seria um soldado que tá fazendo outro tipo de serviço fora. } \\
\end{array}$ \\
& $\begin{array}{l}\text { F1-H-ES: Tem a ver com polícia. } \\
\text { F1-M-ES: No sentido de tropa de soldados. }\end{array}$ \\
\hline
\end{tabular}




\begin{tabular}{|c|c|}
\hline & $\begin{array}{l}\text { F2-H-EP: NSR. } \\
\text { F2-M-EP: NSR. } \\
\text { F2-H-EF: Miliciano é soldado. } \\
\text { F2-M-EF: Alguém que forma um grupo e sai sendo justiceiro. } \\
\text { F2-H-EM: NSR. } \\
\text { F2-M-EM: NSR. } \\
\text { F2-H-ES: Soldado. } \\
\text { F2-M-ES: Miliciano tem a ver com a polícia. }\end{array}$ \\
\hline $\begin{array}{l}\text { Acepções } \\
\text { registradas } \\
\text { nos } \\
\text { dicionários }\end{array}$ & $\begin{array}{l}\text { Bluteau (1712-1728): MILICIÂNO. Gente miliciana, he a gente } \\
\text { bisonha, \& soldados de Ordenança, em que estão sapateiros, } \\
\text { alfayates, \& outros officiaes mecanicos. Tropas milicianas. (Onde } \\
\text { com outra gente miliciana, recolhida para defensa da praça). } \\
\text { Morais Silva (1813): MILICIÁNO, adj. Gente miliciana; bisonha, de } \\
\text { ordenança, indisciplinada, como os paisanos de recluta. } \\
\text { Cunha (1997): militar' } v b \text {. | Do lat. milĭtāre, de miles - ittis 'soldado' | } \\
\text { miliciano XVII. } \\
\text { Ferreira (2004): miliciano 2. Soldado de milícias. } \\
\text { Houaiss (2007): miliciano datação } 16341 \text { relativo a ou próprio de } \\
{ }^{1} \text { milícia. }\end{array}$ \\
\hline \multicolumn{2}{|c|}{$\begin{array}{l}\text { Analisando o contexto de uso da unidade lexical miliciano constata-se que, dos } \\
\text { dezesseis entrevistados, sete informantes (três da faixa I e quatro da faixa II) disseram não } \\
\text { conhecer esse item lexical. Dos nove informantes que reconheceram, quatro (F1-H-EM e } \\
\text { F1-M-EM / F2-H-EF e F2-H-ES) a empregaram com o sentido da acepção em estudo: } \\
\text { 'soldado'. Para os informantes F1-M-EF e F1-M-EM, miliciano é o mesmo que 'cabo'. } \\
\text { Segundo os dicionaristas, cabo é um militar com posição hierárquica acima do soldado, } \\
\text { que pertence ao corpo das tropas milicianas. Como a relação de significado entre as } \\
\text { formas lexicais 'soldado' e 'cabo' são muito próximas, será considerado neste contexto } \\
\text { de fala a lexia 'cabo' como uma variante lexical de 'miliciano', porque ambos pertencem } \\
\text { à milícia. Outros dois informantes (F1-H-ES / F2-M-ES) responderam apenas que } \\
\text { miliciano tem a ver com a polícia. Já para a informante F2-M-EF, 'miliciano é alguém que } \\
\text { forma um grupo e sai sendo justiceiro'. Esta acepção não consta registrada por nenhum } \\
\text { dos dicionaristas pesquisados. Com relação à acepção buscada, os lexicógrafos Cunha, } \\
\text { Ferreira e Houaiss registraram as designações: 'soldado', 'soldado de milícias', 'relativo } \\
\text { ou próprio de milícia'. Bluteau e Morais Silva, por seu turno, descrevem miliciano como } \\
\text { um soldado de ordenança com pouca ou nenhum experiência recolhido para a defesa da } \\
\text { praça. } \\
\text { Considerando os dados analisados, verifica-se baixa produtividade da unidade lexical } \\
\text { miliciano no contexto de utilização dos informantes de Paranaguá. Mesmo comparando o } \\
\text { emprego da acepção buscada para o item lexical miliciano, constata-se sua ocorrência nas } \\
\text { respostas de quatro informantes da faixa I e dois da faixa II. Considerando, então, esses }\end{array}$} \\
\hline
\end{tabular}


dados de maior ocorrência por parte dos informantes da faixa I, presume-se que a lexia miliciano apresenta tendência à manutencão.

\begin{tabular}{|c|c|}
\hline \multicolumn{2}{|c|}{ 116. MOLÉSTIA / DOC.43, fól.1r, l.12-13 } \\
\hline $\begin{array}{l}\text { Acepção } \\
\text { buscada }\end{array}$ & Doença, enfermidade. \\
\hline $\begin{array}{l}\text { Acepção(ões) } \\
\text { conhecida(s) } \\
\text { pelos } \\
\text { informantes }\end{array}$ & $\begin{array}{l}\text { F1-H-EP: NSR. } \\
\text { F1-M-EP: NSR. } \\
\text { F1-H-EF: NSR. } \\
\text { F1-M-EF: NSR. } \\
\text { F1-H-EM: É uma doença que não tem cura. } \\
\text { F1-M-EM: NSR. } \\
\text { F1-H-ES: Doença. } \\
\text { F1-M-ES: Moléstia de doença, ter alguma enfermidade. } \\
\text { F2-H-EP: Chama de moléstia quando o cara que tem uma doença, diz } \\
\text { que o cara tem uma moléstia. } \\
\text { F2-M-EP: Moléstia é quando alguém quer molestar alguém. } \\
\text { F2-H-EF: Doença. } \\
\text { F2-M-EF: Doença. } \\
\text { F2-H-EM: Molestou alguém, passou a perna. } \\
\text { F2-M-EM: NSR. } \\
\text { F2-H-ES: Dor, doença. } \\
\text { F2-M-ES: É doença. }\end{array}$ \\
\hline $\begin{array}{l}\text { Acepções } \\
\text { registradas } \\
\text { nos } \\
\text { dicionários: }\end{array}$ & $\begin{array}{l}\text { Bluteau (1712-1728): MOLÊSTIA. Enfado. Pena do animo. } \\
\text { Inquietação. } \\
\text { Morais Silva (1813): MOLÉSTIA, s. f. Enfado, incommodo, trabalho } \\
\text { do corpo, e do animo; doença. } \\
\text { Cunha (1997): molestar vb. 'afetar, maltratar, magoar' |moléstia XVI. } \\
\text { Ferreira (2004): moléstia 2. Doença. } \\
\text { Houaiss (2007): moléstia } 1 \text { disfunção orgânica, ger. manifestada por } \\
\quad \text { uma série de sintomas; mal, doença, enfermidade. }\end{array}$ \\
\hline $\begin{array}{l}\text { Analisand } \\
\text { entrevistados } \\
\text { (três da faixa } \\
\text { F2-M-EF e } \\
\text { 'doença, enfe } \\
\text { Outros dois } \\
\text { informantes }\end{array}$ & $\begin{array}{l}\text { contexto de uso da lexia moléstia constata-se que, dos dezesseis } \\
\text { informantes a utilizam em seu contexto de fala. Estes oito informantes } \\
\text { 1-H-EM, F1-H-ES e F1-M-ES / cinco da faixa II: F2-H-EP, F2-H-EF, } \\
\text { [-ES, F2-M-ES) empregaram o item lexical moléstia no sentido de } \\
\text { lade', evidenciando, assim, o sentido documentado no corpus escrito. } \\
\text { rmantes empregaram essa unidade lexical com outro significado. Os } \\
\text { M-EP e F2-H-EM) associaram a lexia moléstia com a forma lexical }\end{array}$ \\
\hline
\end{tabular}


molestar'. Etimo logicamente, essas duas formas são distintas e com significados também diferentes. O item lexical moléstia vem do lat. molestia, enquanto que molestar vem do lat. molestare. Quanto ao registro nos dicionários pesquisados, Bluteau, Morais Silva, Ferreira e Houaiss registraram a mesma acepção em estudo para a entrada moléstia.

Dessa forma, o emprego da unidade lexical moléstia, presente na fala de sete informantes (três da faixa I e quatro da faixa II), referente à acepção em estudo apresenta tendência à manutencão.

\begin{tabular}{|c|c|}
\hline \multicolumn{2}{|c|}{ 117. MOLHADO / DOC.45, fól.1r, l.12-14 } \\
\hline $\begin{array}{l}\text { Acepção } \\
\text { buscada }\end{array}$ & Gênero alimentício líquido. \\
\hline $\begin{array}{l}\text { Acepção(ões) } \\
\text { conhecida(s) } \\
\text { pelos } \\
\text { informantes }\end{array}$ & $\begin{array}{l}\text { F1-H-EP: Quando alguma coisa tá molhado. } \\
\text { F1-M-EP: Quando chove a terra fica molhada. } \\
\text { F1-H-EF: Quando joga água, a gente fica molhado. } \\
\text { F1-M-EF: Molhado da chuva. } \\
\text { F1-H-EM: NSR. } \\
\text { F1-M-EM: Minha filha fica molhada quando faz xixi. } \\
\text { F1-H-ES: NSR. } \\
\text { F1-M-ES: Conheço só a vendinha de secos e molhados. } \\
\text { F2-H-EP: Conheço um comércio de secos e molhados, é de alimento. } \\
\text { F2-M-EP: Aquele chão tá molhado. } \\
\text { F2-H-EF: Molhado mesmo de molhar. Já ouvi secos e molhados. } \\
\text { F2-M-EF: Conheço secos e molhados, onde vende de tudo. } \\
\text { F2-H-EM: Quando joga água, você molha, fica molhado. } \\
\text { F2-M-EM: NSR. } \\
\text { F2-H-ES: Secos e molhados é no sentido de mercadinho. } \\
\text { F2-M-ES: Quando a gente entra na água fica molhado. }\end{array}$ \\
\hline $\begin{array}{l}\text { Acepções } \\
\text { registradas } \\
\text { nos } \\
\text { dicionários }\end{array}$ & $\begin{array}{l}\text { Bluteau (1712-1728): MOLHADO em agua, ou em outro qualquer licor. } \\
\text { Morais Silva (1813): MOLHÁDO, p. pass. de Molhar. §. Jogar } \\
\text { dinheiros molhados; i. é, para pagar comida, ou bebida aquelle que } \\
\text { perdeu, ou jogar coisas de comer, e beber, e não dinheiros secos, ou } \\
\text { em moeda. } \\
\text { Cunha (1997): molhar } v b \text {. 'embeber em líquido, banhar, umedecer' | } \\
\text { molhado XV. } \\
\text { Ferreira (2004): molhado } 1 \text {. Umedecido, banhado ou embebido de } \\
\text { qualquer líquido. } \\
\text { Houaiss (2007): molhado datação sXIII } 4 \text { gêneros alimentícios } \\
\text { líquidos. }\end{array}$ \\
\hline
\end{tabular}


A lexia molhado foi reconhecida pela maioria dos entrevistados com o sentido de 'umedecido', 'banhado de água'. Quatro informantes (F1-M-ES / F2-H-EP, F2-M-EF e F2-H-ES), porém, associaram o item lexical molhado com a expressão 'secos e mo lhados' para designar local de 'venda', 'comércio' e 'mercadinho'. Ao contrário da informante F2-M-EF, que disse ser 'secos e molhados' um local 'onde se vende de tudo', o informante F2-H-EP especificou ser 'um comércio destinado a alimento'. A acepção buscada, 'gênero alimentício líquido', encontra-se lexicalizada apenas em Houaiss, na quarta acepção da entrada molhado. Morais Silva registra o lema molhado como p. pass. do verbo molhar e, curiosamente, exemplifica a expressão jogar dinheiros molhados com o sentido de 'para pagar comida, ou bebida aquelle que perdeu, ou jogar coisas de comer, e beber', fazendo a relação entre 'dinheiros molhados' e 'paga de comida ou bebida'. Os demais lexicógrafos designaram molhado como 'umedecido, banhado por qualquer líquido'.

Considerando os dados analisados, constata-se que a acepção em estudo não foi empregada por nenhum dos informantes parnanguaras. Sua lembrança se conserva apenas na expressão 'secos e molhados' com o sentido de 'um local de venda de produtos alimentícios ou não'. Dessa forma, esta lexia configura um caso de desuso.

\begin{tabular}{|l|l|}
\hline \multicolumn{1}{|l|}{$\begin{array}{l}\text { 118. NAU / DOC.11, fól.1v, l.15-17 } \\
\text { buscada }\end{array}$} & Navio de porte grande. \\
\hline $\begin{array}{l}\text { Acepção(ões) } \\
\text { conhecida(s) } \\
\text { pelos } \\
\text { informantes }\end{array}$ & $\begin{array}{l}\text { F1-H-EP: NSR. } \\
\text { F1-M-EP: NSR. } \\
\text { F1-M-EF: NSR. NSR. } \\
\text { F1-H-EM: A nau do descobrimento do Brasil, é um tipo de embarcação } \\
\text { ou navio, mas não uso. } \\
\text { F1-M-EM: É navio ou embarcação, mas não falo nau. } \\
\text { F1-H-ES: É navio, mas não uso. } \\
\text { F1-M-ES: NSR. } \\
\text { F2-H-EP: NSR. } \\
\text { F2-M-EP: NSR. } \\
\text { F2-H-EF: Nau ninguém usa mais, seria no caso um barco, uma nau, mas } \\
\text { ninguém usa. } \\
\text { F2-M-EF: Nau é alguém que tá naufragando. } \\
\text { F2-H-EM: NSR. } \\
\text { F2-M-EM: NSR. } \\
\text { F2-H-ES: Nau é navio, embarcação, não se usa mais. } \\
\text { F2-M-ES: NSR. }\end{array}$ \\
\hline
\end{tabular}




\begin{tabular}{|l|l|}
\hline $\begin{array}{l}\text { Acepções } \\
\text { registradas } \\
\text { nos } \\
\text { dicionários }\end{array}$ & $\begin{array}{c}\text { Bluteau (1712-1728): NAÕ. Embarcação grande, de alto bordo, mais } \\
\text { comprida, que larga. Anda com velas, \& he mercantil, ou de guerra. } \\
\text { Morais Silva (1813): NÁO, s. f. Embarcação d'altobordo, são os } \\
\text { mayores navios, e mayores que as fragatas. } \\
\text { Cunha (1997): nau sf. 'navio de casco e velame redondos' | náao XIII. } \\
\text { Ferreira (2004): nau 1. Antigo navio redondo, tanto na forma do casco } \\
\text { quanto no velame, de grande tamanho, com acastelamentos na proa e } \\
\text { na popa. } \\
\text { Houaiss (2007): nau datação sXIV } 2 \text { designação dada desde o sXVII a } \\
\text { navio de grande porte, com três mastros, velas redondas, fortemente } \\
\text { armado, integrante ger. de uma linha de batalha. }\end{array}$ \\
\hline $\begin{array}{l}\text { Analisando o contexto de uso do item lexical nau nas respostas dos informantes de } \\
\text { informantes (F1-H-EM, F1-M-EM e F1-H-ES / F2-H-EF e F2-H-ES) reconheceram a }\end{array}$ \\
$\begin{array}{l}\text { coxia nau com o sentido da acepção buscada. Entretanto, todos salientaram ser uma forma } \\
\text { lexical que 'ninguém usa mais'. A informante F2-M-EF associou a forma nau com a 'ação } \\
\text { de naufragar', talvez esta relação se explique pela relação existente entre o traço } \\
\text { semântico [mar] contido nas duas formas lexicais nau e naufragar. Os lexicógrafos } \\
\text { registram as acepções com o mesmo sentido documentado no corpus escrito. } \\
\text { Considerando os dados apresentados, constata-se que a unidade lexical nau continua } \\
\text { presente apenas na memória de alguns informantes parnanguaras, haja vista que os } \\
\text { próprios informantes evidenciaram não usar mais essa forma lexical para se referir a um } \\
\text { navio de grande porte. Portanto, o item lexical nau configura um caso de desuso. }\end{array}$ \\
\hline
\end{tabular}

\begin{tabular}{|l|l|}
\hline \multicolumn{2}{|l|}{ 119. OBSERVÂNCIA / DOC.12, fól.1r, l.10-12 } \\
\hline $\begin{array}{l}\text { Acepção } \\
\text { buscada }\end{array}$ & Cumprimento de uma norma, execução fiel. \\
\hline $\begin{array}{l}\text { Acepção(ões) } \\
\text { conhecida(s) } \\
\text { pelos } \\
\text { informantes }\end{array}$ & $\begin{array}{l}\text { F1-H-EP: NSR. } \\
\text { F1-M-EP: NSR. } \\
\text { F1-M-EF: É ficar observando. É observar alguma coisa. } \\
\text { F1-H-EM: Uma pessoa que fica observando. } \\
\text { F1-M-EM: NSR. } \\
\text { F1-H-ES: NSR. } \\
\text { F1-M-ES: De observar. } \\
\text { F2-H-EP: É fazer uma observação. } \\
\text { F2-M-EP: É quando você fica observando alguma coisa. } \\
\text { F2-H-EF: O ato de você verificar, observar as coisas do seu lugar e tal. } \\
\text { F2-M-EF: Aquele que tá de longe olhando, fica observando. }\end{array}$ \\
\hline
\end{tabular}




\begin{tabular}{|c|c|}
\hline & $\begin{array}{l}\text { F2-H-EM: Quando estamos observando tal coisa. } \\
\text { F2-M-EM: NSR. } \\
\text { F2-H-ES: De observar. } \\
\text { F2-M-ES: Ficar só observando certas coisas. }\end{array}$ \\
\hline $\begin{array}{l}\text { Acepções } \\
\text { registradas } \\
\text { nos } \\
\text { dicionários }\end{array}$ & $\begin{array}{l}\text { Bluteau (1712-1728): OBSERVÂNCIA das leys, quer dizer, Cuydado } \\
\text { da observanvia das leys. } \\
\text { Morais Silva (1813): OBSERVÁNCIA, s. f. O acto de observar as Leis, } \\
\text { Ordens, Decretos, Regra, Instituto, etc. } \\
\text { Cunha (1997): observação sf. 'advertência, cumprimento, prática' | } \\
\text { observância | observamça XV. } \\
\text { Ferreira (2004): observância } 1 . \text { Execução fiel; prática, uso. } \\
\text { Houaiss (2007): observância datação sXV } 1 \text { cumprimento rigoroso de } \\
\text { uma regra; submissão a uma lei. }\end{array}$ \\
\hline \multicolumn{2}{|c|}{$\begin{array}{l}\text { Dos dezesseis entrevistados, cinco informantes (quatro da faixa I e um da faixa II) } \\
\text { disseram não conhecer a lexia observância e onze informantes (quatro da faixa I e sete da } \\
\text { faixa II) a reconheceram com o sentido de 'observar' e 'ficar observando'. A acepção } \\
\text { buscada 'cumprimento de uma norma, execução fiel' consta do registro dos lexicógrafos } \\
\text { Ferreira e Houaiss. Bluteau e Morais Silva registraram a designação 'observância das } \\
\text { leis', 'o ato de observar as leis, ordens, decretos, regra' no sentido de cumpri-las. } \\
\text { Analisando o contexto de uso da unidade lexical observância por parte dos informantes } \\
\text { parnanguaras, constata-se sua ocorrência, porém não com o sentido da acepção em estudo. } \\
\text { Conjectura-se, dessa forma, ser a unidade lexical observância um caso de desuso. }\end{array}$} \\
\hline
\end{tabular}

\begin{tabular}{|l|l|}
\hline \multicolumn{2}{|l|}{ 120. OPULÊECIA / DOC.46, fól.1r, l.06-08 } \\
\hline $\begin{array}{l}\text { Acepção } \\
\text { buscada }\end{array}$ & Abundância, acúmulo de bens. \\
\hline $\begin{array}{l}\text { Acepção(ões) } \\
\text { conhecida(s) }\end{array}$ & F1-H-EP: NSR. \\
pelos & F1-M-EP: NSR. \\
informantes & F1-H-EF: NSR. \\
& F1-M-EF: NSR. \\
& F1-H-EM: NSR. \\
& F1-M-EM: NSR. \\
& F1-H-ES: NSR. \\
& F1-M-ES: NSR. \\
& F2-H-EP: NSR. \\
& F2-M-EP: NSR. \\
& F2-H-EF: Riqueza. \\
& F2-M-EF: NSR. \\
\hline
\end{tabular}




\begin{tabular}{|c|c|}
\hline & $\begin{array}{l}\text { F2-H-EM: NSR. } \\
\text { F2-M-EM: NSR. } \\
\text { F2-H-ES: É coisa muito grande, onde o cara tem muita opulência, } \\
\text { abundância. } \\
\text { F2-M-ES: NSR. }\end{array}$ \\
\hline $\begin{array}{l}\text { Acepções } \\
\text { registradas } \\
\text { nos } \\
\text { dicionários: }\end{array}$ & $\begin{array}{l}\text { Bluteau (1712-1728): OPULENCIA. Grandes riquezas. } \\
\text { Morais Silva (1813): OPULĖNCIA, s. f. Riqueza grande. } \\
\text { Cunha (1997): opulência sf. 'abundância de riquezas, luxo, fausto' } \\
\quad \text { XVII. } \\
\text { Ferreira (2004): opulência } 1 \text {. Abundância de riquezas; grande riqueza. } \\
\text { Houaiss (2007): opulência datação } 15731 \text { grande quantidade de bens; } \\
\quad \text { riqueza. }\end{array}$ \\
\hline \multicolumn{2}{|c|}{$\begin{array}{l}\text { A lexia opulência foi registrada pelos lexicógrafos com o mesmo significado } \\
\text { documentado nos manuscritos: 'abundância, acúmulo de bens'. Os informantes F2-H-EF e } \\
\text { F2-H-ES reconheceram o item lexical opulência com o mesmo sentido da acepção } \\
\text { buscada. Os outros quatorze informantes (oito da faixa I e seis da faixa I) disseram não } \\
\text { conhecer a forma lexical opulência. } \\
\text { Portanto, como esta não foi reconhecida por nenhum dos informantes da faixa I e sua } \\
\text { ocorrência apresenta baixa produtividade no contexto de fala dos informantes de } \\
\text { Paranaguá, supõe-se que esta unidade lexical apresenta tendência ao desuso. }\end{array}$} \\
\hline
\end{tabular}

\begin{tabular}{|c|c|}
\hline \multicolumn{2}{|c|}{ 121. ORDENAÇÃO / DOC.04, fól.1r, l.04-06 } \\
\hline $\begin{array}{l}\text { Acepção } \\
\text { buscada }\end{array}$ & Ato ou efeito de ordenar, mandado. \\
\hline $\begin{array}{l}\text { Acepção(ões) } \\
\text { conhecida(s) } \\
\text { pelos } \\
\text { informantes }\end{array}$ & $\begin{array}{l}\text { F1-H-EP: NSR. } \\
\text { F1-M-EP: NSR. } \\
\text { F1-H-EF: É ordenar. } \\
\text { F1-M-EF: Quando se ordena alguma coisa. } \\
\text { F1-H-EM: NSR. } \\
\text { F1-M-EM: Ordenar alguém a fazer alguma coisa. } \\
\text { F1-H-ES: NSR. } \\
\text { F1-M-ES: De ordenar, designar algo. } \\
\text { F2-H-EP: NSR. } \\
\text { F2-M-EP: Quando você dá ordem pra alguém. } \\
\text { F2-H-EF: Na parte religiosa seria o padre que se ordena tal, ou uma } \\
\text { pessoa que a gente recebe ordem, ordenança. } \\
\text { F2-M-EF: Ordenação é tipo um encarregado de uma obra, ele ordena as } \\
\text { pessoas a fazerem determinadas coisas, dá o mandado. } \\
\text { F2-H-EM: Quando a gente estuda teologia é ordenado pra pastor. }\end{array}$ \\
\hline
\end{tabular}




\begin{tabular}{|c|c|}
\hline & $\begin{array}{l}\text { F2-M-EM: NSR. } \\
\text { F2-H-ES: Ordenação são ordens, por exemplo que o Pardinho fez, são } \\
\text { determinações, ordens, mandado. } \\
\text { F2-M-ES: É quando você dá ordem pra alguém. }\end{array}$ \\
\hline $\begin{array}{l}\text { Acepções } \\
\text { registradas } \\
\text { nos } \\
\text { dicionários }\end{array}$ & $\begin{array}{l}\text { Bluteau (1712-1728): ORDENAÇAÕ. Estatuto, ou Decreto ordenado } \\
\text { para o bom governo de hum Reyno, Republica, etc. } \\
\text { Morais Silva (1813): ORDENAÇÃO, s. f. §. O acto de ordenar, dar o } \\
\text { Sacramento da Ordem. } \\
\text { Cunha (1997): ordem } s f \text {. 'disposição, regra, disciplina' |ordenação | - } \\
\quad \text { çom XIV. } \\
\text { Ferreira (2004): ordenação 1. Ato ou efeito de ordenar; ordenamento. } \\
\text { Houaiss (2007): ordenação datação } 1390 \text { ato ou efeito de ordenar(-se); } \\
\quad \text { ordenamento. }\end{array}$ \\
\hline \multicolumn{2}{|c|}{$\begin{array}{l}\text { Analisando o contexto de uso da lexia ordenação constata-se que, dos dezesseis } \\
\text { entrevistados, dez informantes a utilizam em seu contexto de fala. Oito informantes } \\
\text { (quatro da faixa I: F1-H-EF, F1-M-EF, F1-M-EM e F1-M-ES / quatro da faixa II: F2-M- } \\
\text { EP, F2-M-EF, F2-H-ES e F2-M-ES) empregaram o sentido de 'ato ou efeito de mandado, } \\
\text { ordenamento', evidenciando, assim, a acepção documentada no corpus escrito. Os outros } \\
\text { informantes (F2-H-EF e F2-H-EM) empregaram o item lexical ordenação com o sentido } \\
\text { de 'co lação de ordens sacras'. Esta acepção encontra-se lexicalizada nos dicionários } \\
\text { pesquisados. Quanto ao registro nos dicionários pesquisados, Bluteau, Morais Silva, } \\
\text { Ferreira e Houaiss registraram a mesma definição em estudo para a entrada ordenação. } \\
\text { Portanto, o emprego da unidade lexical ordenação, presente na fala de oito informantes } \\
\text { (quatro da faixa I e quatro da faixa II), referente à acepção em estudo apresenta tendência } \\
\underline{\text { à manutencão. }}\end{array}$} \\
\hline
\end{tabular}

\begin{tabular}{|l|l|}
\hline 122. ORDENADO / DOC.24, fól.1 r, l.14-17 \\
\hline $\begin{array}{l}\text { Acepção } \\
\text { buscada }\end{array}$ & Salário, remuneração. \\
\hline $\begin{array}{l}\text { Acepção(ões) } \\
\text { conhecida(s) } \\
\text { pelos } \\
\text { informantes }\end{array}$ & $\begin{array}{l}\text { F1-H-EP: Na firma onde eu trabalha falava: dia cinco o ordenado tá na } \\
\text { conta. }\end{array}$ \\
& $\begin{array}{l}\text { F1-M-EP: NSR. } \\
\text { F1-H-EF: Ordenado é salário. } \\
\text { F1-H-EM: Ordenado no sentido da pessoa ter ordenado. }\end{array}$ \\
& $\begin{array}{l}\text { F1-M-EM: Mandado fazer aquilo, foi ordenado. } \\
\text { F1-H-ES: Salário. } \\
\text { F1-M-ES: De dinheiro, pagamento, meu avô falava. }\end{array}$ \\
\hline
\end{tabular}




\begin{tabular}{|c|c|}
\hline & $\begin{array}{l}\text { F2-H-EP: O cara tá empregado ganha um ordenado bom. } \\
\text { F2-M-EP: Hoje vou receber meu ordenado. } \\
\text { F2-H-EF: Seria o pagamento, o salário. } \\
\text { F2-M-EF: Salário, grana. } \\
\text { F2-H-EM: Foi ordenado fazer aquilo. } \\
\text { F2-M-EM: Trabalho na escola e ganho meu ordenado. } \\
\text { F2-H-ES: Ordenado é o que vem no final do mês, salário. } \\
\text { F2-M-ES: É quem recebe tua ordem. Conheço como salário também. }\end{array}$ \\
\hline $\begin{array}{l}\text { Acepções } \\
\text { registradas } \\
\text { nos } \\
\text { dicionários }\end{array}$ & $\begin{array}{l}\text { Bluteau (1712-1728): ORDENADO, que se dà a alguem para seu } \\
\text { sustento. } \\
\text { Morais Silva (1813): ORDENÁDO, s. m. O mantimento, ou salario } \\
\text { certo, e determinado. } \\
\text { Cunha (1997): ordem } s f \text {. 'disposição, regra, disciplina' |ordenado XIV. } \\
\text { Ferreira (2004): ordenado 5. Vencimento dum funcionário, ou } \\
\text { empregado qualquer, pago periodicamente. } \\
\text { Houaiss (2007): ordenado datação sXIII } 2 \text { retribuição certa de um } \\
\text { servidor público ou empregado, paga periodicamente, por seu } \\
\text { trabalho; vencimento, salário. }\end{array}$ \\
\hline \multicolumn{2}{|c|}{$\begin{array}{l}\text { A unidade lexical ordenado é bastante produtiva no contexto de fala dos informantes } \\
\text { parnanguaras. Houve somente um caso de ausência de resposta por parte da informante } \\
\text { F2-M-EP. Dos dezesseis entrevistados, dez informantes (quatro da faixa I: F1-H-EP, F1- } \\
\text { M-EF, F1-H-ES e F1-M-ES / seis da faixa II: F2-H-EP, F2-M-EP, F2-H-EF, F2-M-EF, } \\
\text { F2-M-EM e F2-H-ES) reconhecem a lexia ordenado com o mesmo sentido da acepção } \\
\text { buscada: 'salário, remuneração'. Outros quatro informantes (F1-H-EF, F1-H-EM e F1-M- } \\
\text { EM / F2-H-EM) a utilizaram no sentido de 'dar e receber uma ordem' e também como } \\
\text { particípio do verbo ordenar: 'ordenado'. A informante F1-M-ES empregou estes dois } \\
\text { sentidos para a lexia em questão. Os lexicógrafos Bluteau, Morais Silva, Ferreira e } \\
\text { Houaiss registraram a entrada ordenado com o mesmo sentido da acepção investigada. } \\
\text { Analisando o contexto de utilização da lexia ordenado, certifica-se, no estágio atual de } \\
\text { variação, considerável frequência da ocorrência dos dois significados distintos para o } \\
\text { único item lexical ordenado. No entanto, comparando a ocorrência das duas acepções } \\
\text { distintas nas respostas dos informantes da faixa I, observa-se o reconhecimento da lexia } \\
\text { ordenado com o valor de 'salário, remuneração', presente na fala de quatro informantes, } \\
\text { enquanto o sentido de 'dar ordem' ocorreu na fala de três informantes. Dessa forma, } \\
\text { pressupõe que ordenado apresenta tendência à manutencão. }\end{array}$} \\
\hline
\end{tabular}

\begin{tabular}{|l|l|}
\hline \multicolumn{2}{|l|}{ 123. PARAGEM / DOC.25, fól.1r, l.22-24 } \\
\hline $\begin{array}{l}\text { Acepção } \\
\text { buscada }\end{array}$ & Ponto, lugar de parada. \\
\hline
\end{tabular}




\begin{tabular}{|c|c|}
\hline $\begin{array}{l}\text { Acepção(ões) } \\
\text { conhecida(s) } \\
\text { pelos } \\
\text { informantes }\end{array}$ & $\begin{array}{l}\text { F1-H-EP: NSR. } \\
\text { F1-M-EP: NSR. } \\
\text { F1-H-EF: É onde para, um ponto. } \\
\text { F1-M-EF: NSR. } \\
\text { F1-H-EM: Um local onde as pessoas param. } \\
\text { F1-M-EM: NSR. } \\
\text { F1-H-ES: NSR. } \\
\text { F1-M-ES: NSR. } \\
\text { F2-H-EP: NSR. } \\
\text { F2-M-EP: NSR. } \\
\text { F2-H-EF: Paragem seria um lugar onde tem sempre assim um horizonte, } \\
\text { um lugar bonito, daí se diz: ah, aquelas paragens! No sentido de } \\
\text { ônibus é parada e não paragem. } \\
\text { F2-M-EF: Tipo uma rodoviária. } \\
\text { F2-H-EM: Conheço só como ponto. } \\
\text { F2-M-EM: NSR. } \\
\text { F2-H-ES: Paragem é o local onde se para, pode ser uma estalagem, aí } \\
\quad \text { depende do tropeirismo todo. } \\
\text { F2-M-ES: Uma paragem de caminhão, quando ele tá parado. }\end{array}$ \\
\hline $\begin{array}{l}\text { Acepções } \\
\text { registradas } \\
\text { nos } \\
\text { dicionários }\end{array}$ & $\begin{array}{l}\text { Bluteau (1712-1728): PARÂGEM. Termo Nautico. He esta, ou aquella } \\
\text { parte do mar, em tal sitio, em tal altura, ou lugar, donde o bayxel que } \\
\text { parou, \& lançou ferro, possa aparelhar, \& porse à vela, quando quiser. } \\
\text { Morais Silva (1813): PARÁGEM, s. f. Altura limitada, onde o navio } \\
\text { anda cruzando, esperando outros, ou o inimigo. } \\
\text { Cunha (1997): parar vb. 'cessar, deter-se'. | paragem XVI. } \\
\text { Ferreira (2004): paragem } 2 \text {. V. parada. [parada 2. Local onde se pára; } \\
\text { estância, paragem]. } \\
\text { Houaiss (2007): paragem datação } 15522.1 \text { lugar em que se pára; } \\
\text { parada. }\end{array}$ \\
\hline \multicolumn{2}{|c|}{$\begin{array}{l}\text { A lexia paragem com o sentido de 'ponto, lugar de parada' foi reconhecida na fala de } \\
\text { apenas quatro informantes (F1-H-EF e F1-H-E / F2-M-ES e F2-H-ES). Dois informantes } \\
\text { disseram não utilizar a forma lexical paragem para o sentido de 'lugar de parada', mas por } \\
\text { sua vez, empregam as variantes lexicais ponto (F2-H-EM) e parada (F2-H-EF). A } \\
\text { informante F2-M-EF associou a lexia paragem com 'um terminal de embarque e } \\
\text { desembarque de ônibus': 'tipo uma rodoviária'. O informante F2-H-EF atribuiu também o } \\
\text { valor de 'um lugar bonito, onde tem sempre um horizonte' para a lexia paragem. Esta } \\
\text { acepção não consta do registro dos dicionários pesquisados. Com relação ao registro nos } \\
\text { dicionários acima, Bluteau e Morais Silva definiram a entrada paragem como 'certo lugar } \\
\text { no mar onde o navio se fixa/para a espera de outros navios'. Ferreira registra a entrada } \\
\text { paragem e remete o consulente à variante lexical parada, designando-a como um 'local }\end{array}$} \\
\hline
\end{tabular}


onde se pára, paragem'. Houaiss define o termo paragem com o mesmo sentido da acepção em estudo.

Considerando os dados analisados, verifica-se a baixa produtividade da unidade lexical paragem no contexto de fala dos informantes de Paranaguá. Das quatro ocorrências, a acepção buscada esteve presente na fala de apenas dois informantes da faixa I e dois da faixa II. No estágio atual de variação, as variantes lexicais ponto e parada concorrem o item lexical paragem. Pressupõe-se, dessa forma, que a lexia em estudo revela tendência ao desuso.

\begin{tabular}{|c|c|}
\hline \multicolumn{2}{|c|}{ 124. PARIDADE / DOC.15, fól.1r, l.14-17 } \\
\hline $\begin{array}{l}\text { Acepção } \\
\text { buscada }\end{array}$ & Igualdade, analogia, semelhança. \\
\hline $\begin{array}{l}\text { Acepção(ões) } \\
\text { conhecida(s) } \\
\text { pelos } \\
\text { informantes }\end{array}$ & $\begin{array}{l}\text { F1-H-EP: NSR. } \\
\text { F1-M-EP: NSR. } \\
\text { F1-H-EF: Acho que é parir. } \\
\text { F1-M-EF: Paridade é quando a mulher pariu, paridade. } \\
\text { F1-H-EM: NSR. } \\
\text { F1-M-EM: Conheço só parir. } \\
\text { F1-H-ES: Igualdade. } \\
\text { F1-M-ES: De parir. } \\
\text { F2-H-EP: NSR. } \\
\text { F2-M-EP: NSR. } \\
\text { F2-H-EF: Paridade é parecido, alguma coisa que é igual, é parecido é } \\
\text { paridade. } \\
\text { F2-M-EF: NSR. } \\
\text { F2-H-EM: NSR. } \\
\text { F2-M-EM: NSR. } \\
\text { F2-H-ES: Quer dizer igual, tem semelhança. } \\
\text { F2-M-ES: NSR. }\end{array}$ \\
\hline $\begin{array}{l}\text { Acepções } \\
\text { registradas } \\
\text { nos } \\
\text { dicionários }\end{array}$ & $\begin{array}{l}\text { Bluteau (1712-1728): PARIDADE. Igualdade. } \\
\text { Morais Silva (1813): PARIDÁDE, s. f. Semelhança, ou igualdade, ou } \\
\quad \text { analogia. } \\
\text { Cunha (1997): par adj. sm. 'igual, semelhante' | paridade XVII. } \\
\text { Ferreira (2004): paridade 2. Semelhança, parecença, analogia. } \\
\text { Houaiss (2007): paridade datação } 16442 \text { qualidade de ser parecido; } \\
\quad \text { semelhança, parecença, similaridade. }\end{array}$ \\
\hline $\begin{array}{l}\text { As definiçc̃ } \\
\text { evidenciam o }\end{array}$ & $\begin{array}{l}\text { la entrada paridade registradas por Bluteau, Morais Silva e Ferre } \\
\text { smo sentido documentando no corpus escrito: 'igualdade, analog }\end{array}$ \\
\hline
\end{tabular}


semelhança'. Analisando o contexto de utilização da lexia paridade, dos dezesseis entrevistados, somente três (F1-H-ES / F2-H-EF e F2-H-ES) a reconheceram com o mesmo sentido da acepção buscada. Outros quatro informantes (F1-H-EF, F1-M-EF, F1M-EM e F1-M-ES) associaram o item lexical paridade com parir, devido à semelhança entre essas formas lexicais. Na verdade, tratam-se de formas etimologicamente distintas: paridade vem do lat. paritas, atis, e parir do lat. parere.

Embora paridade ainda esteja presente na fala de alguns informantes de Paranaguá, verifica-se que seu uso é pouco produtivo. Dos três informantes que reconheceram essa lexia com o sentido da acepção em estudo, somente um informante é da faixa I. Pressupõe-se, dessa forma, que a unidade lexical paridade apresenta tendência ao desuso.

\begin{tabular}{|c|c|}
\hline \multicolumn{2}{|c|}{ 125. PENÚRIA / DOC.46, fól.1r, l.31-34 } \\
\hline $\begin{array}{l}\text { Acepção } \\
\text { buscada }\end{array}$ & Extrema pobreza, miséria. \\
\hline $\begin{array}{l}\text { Acepção(ões) } \\
\text { conhecida(s) } \\
\text { pelos } \\
\text { informantes }\end{array}$ & $\begin{array}{l}\text { F1-H-EP: NSR. } \\
\text { F1-M-EP: NSR. } \\
\text { F1-H-EF: Penúria no sentido de pena. } \\
\text { F1-M-EF: NSR. } \\
\text { F1-H-EM: Penúria é muita dificuldade, pobreza. } \\
\text { F1-M-EM: Miséria. } \\
\text { F1-H-ES Sofrimento, miséria. } \\
\text { F1-M-ES: Penúria vive sempre mal, sempre pobre, miserenta coitada. } \\
\text { F2-H-EP: Tá sem dinheiro, o cara tá numa penúria desgraçada. } \\
\text { F2-M-EP: Quando você tá triste, passando por uma penúria. } \\
\text { F2-H-EF: Penúria quando você tá passando mal de dinheiro, mal de } \\
\text { situação, tá na penúria. } \\
\text { F2-M-EF: É alguém que tá muito sem dinheiro, tá na penúria. } \\
\text { F2-H-EM: NSR. } \\
\text { F2-M-EM: NSR. } \\
\text { F2-H-ES: Dó e sofrimento. } \\
\text { F2-M-ES: Penúria quando a pessoa tá passando uma necessidade muito } \\
\quad \text { grande, tá numa pindaíba, miséria. }\end{array}$ \\
\hline $\begin{array}{l}\text { Acepções } \\
\text { registradas } \\
\text { nos } \\
\text { dicionários }\end{array}$ & $\begin{array}{l}\text { Bluteau (1712-1728): PENÚRIA, val o mesmo que Despensa. Toma-se } \\
\text { por falta do necessario, pobreza, indigencia, pouco provimento. } \\
\text { Morais Silva (1813): PENÚRIA, s. f. Falta do necessário, indigência, } \\
\text { mingoa. } \\
\text { Cunha (1997): pena' }{ }^{1} s f \text {. 'castigo, punição, sofrimento' | penúria } 1813 \text {. } \\
\text { Ferreira (2004): penúria } 1 \text {. Pobreza extrema; indigência, miséria. }\end{array}$ \\
\hline
\end{tabular}




\begin{tabular}{|c|c|}
\hline & $\begin{array}{l}\text { Houaiss (2007): penúria datação } 16601 \text { estado de extrema pobreza; } \\
\text { miséria. }\end{array}$ \\
\hline $\begin{array}{l}\text { Analisando o } \\
\text { constata-se cons } \\
\text { da faixa I: F1-H } \\
\text { H-EF, F2-M-EF } \\
\text { da acepção busc } \\
\text { M-EP / F2-H-ES } \\
\text { 'so frimento'. Co } \\
\text { Ferreira e Hou } \\
\text { 'indig'ncia', 'mí } \\
\text { penúria em } 166 \\
\text { consta do registr } \\
\text { de Bluteau, supõ } \\
\text { Cunha. } \\
\text { Verificando o } \\
\text { apontam para o } \\
\text { permanência da } \\
\text { de oito informan }\end{array}$ & $\begin{array}{l}\text { contexto de utilização da lexia penúria pelos informantes de Paranaguá, } \\
\text { iderável frequência na fala desses entrevistados. Oito informantes (quatro } \\
\text {-EM, F1-M-EM, F1-H-ES e F1-M-ES / quatro da faixa II: F2-H-EP, F2- } \\
\text { e F2-M-ES) reconheceram o item lexical penúria com o mesmo sentido } \\
\text { ada: 'extrema pobreza, miséria'. Outros três informantes (F1-H-EF e F2- } \\
\text { S) o conheceram com variação de significado: 'pena', 'estar triste', 'dó' e } \\
\text { m relação à acepção em estudo, os lexicógrafos Bluteau, Morais Silva, } \\
\text { uaiss registraram as designações: 'falta do necessário', 'pobreza', } \\
\text { ngua', 'miséria' e 'pobreza extrema'. Houaiss, por sua vez, fixa a entrada } \\
0 \text {, enquanto Cunha registra a partir de 1813. A unidade lexical penúria } \\
\text { o do documento manuscrito de } 1799 \text {. Como penúria já consta do registro } \\
\text { se-se que esta forma lexical já existia bem antes da datação registrada por } \\
\text { contexto de uso da lexia penúria na fala dos entrevistados, os dados } \\
\text { estágio atual de variação, com os demais significados, e indícios de } \\
\text { acepção buscada para o item lexical penúria presente no contexto de fala } \\
\text { ates (quatro da faixa I e quatro da faixa II). Dessa forma, há indícios de } \\
\text { nutencão. }\end{array}$ \\
\hline
\end{tabular}

\begin{tabular}{|c|c|}
\hline \multicolumn{2}{|c|}{ 126. PRIVANÇA / DOC.25, fól.1v, l.16-18 } \\
\hline $\begin{array}{l}\text { Acepção } \\
\text { buscada }\end{array}$ & Desfavorecimento, destituição. \\
\hline $\begin{array}{l}\text { Acepção(ões) } \\
\text { conhecida(s) } \\
\text { pelos } \\
\text { informantes }\end{array}$ & $\begin{array}{l}\text { F1-H-EP: NSR. } \\
\text { F1-M-EP: NSR. } \\
\text { F1-H-EF: Privança é quando uma pessoa fica sem aquilo, sem alguma } \\
\text { coisa, ela é privada de alguma coisa. } \\
\text { F1-M-EF: NSR. } \\
\text { F1-H-EM: NSR. } \\
\text { F1-M-EM: NSR. } \\
\text { F1-H-ES: NSR. } \\
\text { F1-M-ES: NSR. } \\
\text { F2-H-EP: NSR. } \\
\text { F2-M-EP: NSR. } \\
\text { F2-H-EF: Privança seria um privativo, seria só pra um pessoal, um } \\
\text { privativo. Mas não fala, o pessoal não usa privança aqui. } \\
\text { F2-M-EF: Privança é quando você fica sem alguma coisa que você quer, } \\
\text { precisa, é privar você disso. }\end{array}$ \\
\hline
\end{tabular}




\begin{tabular}{|c|c|}
\hline & $\begin{array}{l}\text { F2-H-EM: NSR. } \\
\text { F2-M-EM: NSR. } \\
\text { F2-H-ES: NSR. } \\
\text { F2-M-ES: Privança é cuidar, guardar alguma coisa, se prevenir. }\end{array}$ \\
\hline $\begin{array}{l}\text { Acepções } \\
\text { registradas } \\
\text { nos } \\
\text { dicionários }\end{array}$ & $\begin{array}{l}\text { Bluteau (1712-1728): PRIVANÇA. Valimento. } \\
\text { Morais Silva (1813): PRIVANÇA, s. f. Valimento, trato, conversação } \\
\text { do valido, e favorecido do Soberano. } \\
\text { Cunha (1997): privar } v b \text {. 'despojar, destituir, tolher' | privança XIII. } \\
\text { Ferreira (2004): privança } 1 \text {. Estado de quem é favorito, valido, } \\
\quad \text { privado. } \\
\text { Houaiss (2007): privança datação sXIII } 1 \text { característica de quem é } \\
\quad \text { favorito; regalia, favoritismo. }\end{array}$ \\
\hline \multicolumn{2}{|c|}{$\begin{array}{l}\text { Dos dezesseis informantes entrevistados, doze (sete da faixa I e cinco da faixa II) } \\
\text { disseram não conhecer a lexia privança. Dos quatro informantes que ainda utilizam este } \\
\text { item lexical, dois informantes (F1-H-EF / F2-M-EF) o empregaram com o mesmo sentido } \\
\text { da acepção buscada: 'desfavorecimento, destituição'. Os outros dois informantes (F2-H- } \\
\text { EF / F2-H-EF e F2-M-ES) reconheceram privança com o sentido de 'privativo, exclusivo' } \\
\text { e 'se prevenir'. O informante F2-H-EF informou também que 'o pessoal não usa privança' } \\
\text { em Paranaguá. Das definições apresentadas pelos lexicógrafos pesquisados, a designação } \\
\text { que mais se aproxima da acepção em estudo encontra-se registrada por Cunha na entrada } \\
\text { privar: 'despojar, destituir, tolher'. Os demais dicionaristas definem o lema privança com } \\
\text { o sentido de 'valimento', 'favorecimento', 'favoritismo'. } \\
\text { Analisando o contexto de uso da unidade lexical privança e comparando com as } \\
\text { respostas dos informantes, observa-se baixa produtividade dessa lexia na fala dos } \\
\text { entrevistados, principalmente os da faixa I. Portanto, privança apresenta tendência ao } \\
\text { desuso. }\end{array}$} \\
\hline
\end{tabular}

\begin{tabular}{|l|l|}
\hline \multicolumn{2}{|l|}{ 127. PROPINA / DOC.21, fól.1r, l.11-13 } \\
\hline $\begin{array}{l}\text { Acepção } \\
\text { buscada }\end{array}$ & Pagamento, gratificação em dinheiro. \\
\hline $\begin{array}{l}\text { Acepção(ões) } \\
\text { conhecida(s) } \\
\text { pelos } \\
\text { informantes }\end{array}$ & $\begin{array}{l}\text { F1-H-EP: NSR. } \\
\text { F1-M-EP: NSR. } \\
\text { F1-H-EF: Propina é dinheiro sujo: coisas que os governantes fazem. } \\
\end{array}$ \\
& $\begin{array}{l}\text { F1-H-EM: Pagamento de propina, como coisa irregular. } \\
\text { dinheiro. } \\
\text { F1-H-ES: Políticos gostam de propina. } \\
\text { F1-M-ES: Receber um dinheiro que é ilegal. }\end{array}$ \\
\hline
\end{tabular}




\begin{tabular}{|c|c|}
\hline & $\begin{array}{l}\text { F2-H-EP: NSR. } \\
\text { F2-M-EP: NSR. } \\
\text { F2-H-EF: Propina seria você pagar alguma coisa pra alguém pra ficar } \\
\text { livre de alguma coisa, por exemplo: você fez alguma coisa de errado e } \\
\text { alguém descobriu, então você paga uma propina pra usufruir alguma } \\
\text { coisa. } \\
\text { F2-M-EF: Dinheiro sujo. } \\
\text { F2-H-EM: Alguém que fez alguma cachorrada, burlou o negócio de } \\
\text { alguém, fez uma propina. } \\
\text { F2-M-EM: Propina é quando faz alguma coisa errada e paga um } \\
\text { dinheiro, uma coisa que não é legal. } \\
\text { F2-H-ES: Dinheiro, quando você compra alguém, algo ilegal. } \\
\text { F2-M-ES: Propina é comprar pessoas com dinheiro sujo, pra tentar se } \\
\text { dar bem. }\end{array}$ \\
\hline $\begin{array}{l}\text { Acepções } \\
\text { registradas } \\
\text { nos } \\
\text { dicionários }\end{array}$ & $\begin{array}{l}\text { Bluteau (1712-1728): PROPINA, val o mesmo que Brindar à saúde de } \\
\text { alguem. Antigamente era hũa merenda, que se dava em algumas } \\
\text { juntas. Hoje se dá propina em dinheyro, ou em tantas varas de pano, } \\
\text { \& outras cousas usuaes. } \\
\text { Morais Silva (1813): PROPÍNA, s. f. Presente, ou dom em dinheiro, } \\
\text { panno, ou peça, que se dá a alguns officiaes, Ministros, Lentes por } \\
\text { assistencia, ou trabalho. } \\
\text { Cunha (1997): propinar } v b \text {. 'dar a beber, ministrar' XVI. propina } \\
\text { XVIII. } \\
\text { Ferreira (2004): propina 1. Gratificação, gorjeta. } \\
\text { Houaiss (2007): propina datação } 16191 \text { gratificação extra por serviço } \\
\text { normal prestado a alguém; gorjeta, emolumento. }\end{array}$ \\
\hline \multicolumn{2}{|c|}{ 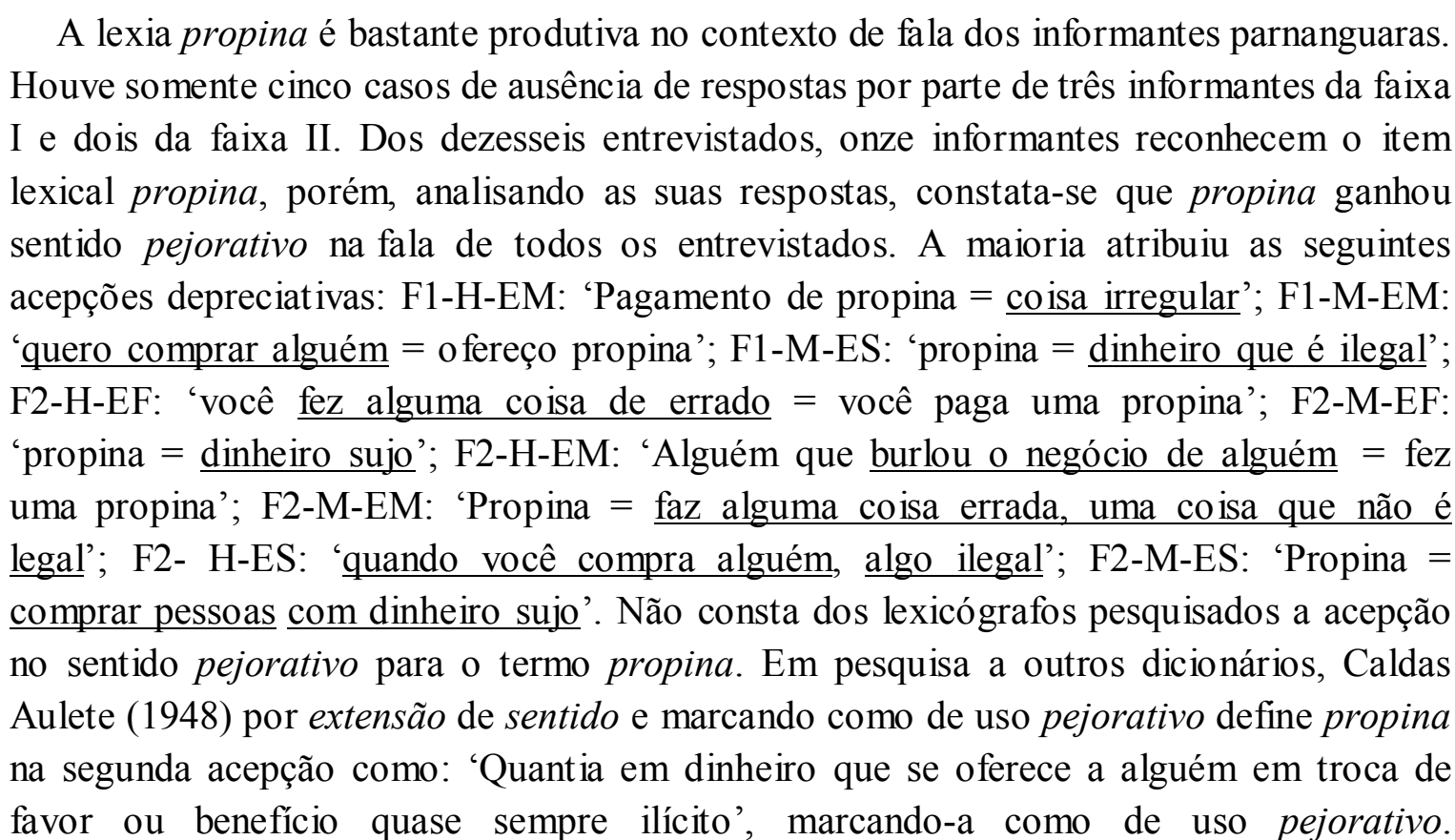 } \\
\hline
\end{tabular}


Constantemente, noticiários brasileiros divulgam informações sobre práticas ilícitas da propina entre políticos corruptos, fato que talvez explique a associação entre a forma propina com os itens lexicais governantes e políticos mencionados nas respostas dos seguintes informantes da faixa I: F1-H-EF: 'Propina é dinheiro sujo: coisas que os governantes fazem'; F1-H-ES: 'Políticos gostam de propina'.

Analisando o contexto de uso da unidade lexical propina, constata-se ser bastante produtiva na fala dos entrevistados, porém com o emprego no sentido pejorativo. Dessa forma, supõe-se, neste contexto linguístico, que a lexia propina com o sentido da acepção buscada 'pagamento, gratificação em dinheiro', tenha caído em $\underline{\text { desuso. }}$.

\begin{tabular}{|c|c|}
\hline \multicolumn{2}{|c|}{ 128. RÁBULA / DOC.31, fól.1v, l.05-08 } \\
\hline $\begin{array}{l}\text { Acepção } \\
\text { buscada }\end{array}$ & Indivíduo trapaceiro, ardiloso. \\
\hline $\begin{array}{l}\text { Acepção(ões) } \\
\text { conhecida(s) } \\
\text { pelos } \\
\text { informantes }\end{array}$ & $\begin{array}{l}\text { F1-H-EP: NSR. } \\
\text { F1-M-EP: NSR. } \\
\text { F1-H-EF: NSR. } \\
\text { F1-M-EF: NSR. } \\
\text { F1-H-EM: NSR. } \\
\text { F1-M-EM: NSR. } \\
\text { F1-H-ES: NSR. } \\
\text { F1-M-ES: NSR. } \\
\text { F2-H-EP: NSR. } \\
\text { F2-M-EP: NSR. } \\
\text { F2-H-EF: NSR. } \\
\text { F2-M-EF: NSR. } \\
\text { F2-H-EM: NSR. } \\
\text { F2-M-EM: NSR. } \\
\text { F2-H-ES: Já ouvi isso no jurídico entre advogados, mas não sei o que é. } \\
\text { F2-M-ES: NSR. }\end{array}$ \\
\hline $\begin{array}{l}\text { Acepções } \\
\text { registradas } \\
\text { nos } \\
\text { dicionários }\end{array}$ & $\begin{array}{l}\text { Bluteau (1712-1728): RÂBULA, he Advogado de pouca estimação, } \\
\text { ignorante, \& grande fallador. } \\
\text { Morais Silva (1813): RÁBULA, s. m. Advogado ignorante, e mui } \\
\text { fallador. } \\
\text { Cunha (1997): rábula sm. 'advogado de limitada cultura e chicaneiro' } \\
\text { XVII. } \\
\text { Ferreira (2004): rábula 1. Advogado de limitada cultura e chicaneiro; } \\
\text { leguleio, pegas. 2. Indivíduo que fala muito, mas não conclui nem } \\
\text { prova nada. }\end{array}$ \\
\hline
\end{tabular}




\begin{tabular}{|c|}
\hline $\begin{array}{l}\text { Houaiss (2007): rábula datação } 16522 \text { Uso: pejorativo: advogado } \\
\text { muito falador, porém de poucos conhecimentos; incompetente. } 4 \\
\text { indivíduo que fala muito mas não chega às conclusões do seu } \\
\text { arrazoado. }\end{array}$ \\
\hline $\begin{array}{l}\text { A lexia rábula em contexto de uso foi reconhecida por um único informante (F2-H- } \\
\text { ES), mas o mesmo salientou não saber o significado deste item lexical, apenas ter ouvido } \\
\text { 'no jurídico entre advogados'. Todas as definições trazidas pelos lexicógrafos para a } \\
\text { entrada rábula referem-se a um 'advogado ignorante, de cultura limitada e muito falador'. } \\
\text { Ferreira na segunda acepção e Houaiss na quarta acepção (marcando como uso pejorativo) } \\
\text { designam também rábula como um 'indivíduo que fala muito, mas não conclui e nem } \\
\text { prova nada'. Observa-se, por meio dos registros das acepções lexicalizadas nos } \\
\text { dicionários pesquisados e pela resposta desse informante, ser a lexia rábula um termo } \\
\text { relacionado ao campo semântico jurídico. No entanto, a acepção presente no corpus } \\
\text { escrito está mais próxima ao sentido de 'indivíduo trapaceiro, ardiloso', por se tratar de } \\
\text { uma ofensa do Ouvidor Geral Antônio Barbosa de Matos Coutinho quando se referia ao } \\
\text { vereador José Joaquim Pinto de Castro. } \\
\text { Como não houve nenhuma ocorrência da unidade lexical rábula com o sentido da } \\
\text { acepção em estudo por parte dos informantes parnanguaras, supõe-se ser um caso de } \\
\text { desuso. }\end{array}$ \\
\hline
\end{tabular}

\begin{tabular}{|c|c|}
\hline \multicolumn{2}{|c|}{ 129. REBATE / DOC.12, fól.1r, l.23-27 } \\
\hline $\begin{array}{l}\text { Acepção } \\
\text { buscada }\end{array}$ & Ataque repentino, sinal de alarme, aviso. \\
\hline $\begin{array}{l}\text { Acepção(ões) } \\
\text { conhecida(s) } \\
\text { pelos } \\
\text { informantes }\end{array}$ & $\begin{array}{l}\text { F1-H-EP: NSR. } \\
\text { F1-M-EP: NSR. } \\
\text { F1-H-EF: Rebater: numa briga eu rebato, pra não brigar mais. Reprimir, } \\
\text { conter. } \\
\text { F1-M-EF: Quando um falo uma coisa, você vai lá e rebate o que eu } \\
\text { disse. Contestar, refutar } \\
\text { F1-H-EM: De rebater. } \\
\text { F1-M-EM: NSR. } \\
\text { F1-H-ES: NSR. } \\
\text { F1-M-ES: NSR. } \\
\text { F2-H-EP: NSR. } \\
\text { F2-M-EP: NSR. } \\
\text { F2-H-EF: Rebate seria você fazer alguma pergunta e a pessoa rebate com } \\
\text { outra. contestar } \\
\text { F2-M-EF: Rebate eu falo alguma coisa, retruco pra você, te devolvo. } \\
\text { F2-H-EM: Uma bola rebatida. }\end{array}$ \\
\hline
\end{tabular}




\begin{tabular}{|c|c|}
\hline & $\begin{array}{l}\text { F2-M-EM: NSR. } \\
\text { F2-H-ES: É bater novamente e tem outro sentido que é de devolver ou } \\
\text { de rebate falso, tipo um sinal, alarme falso, algo que não aconteceu. } \\
\text { F2-M-ES: Rebate é quando fazem alguma coisa pra você e você já rebate } \\
\text { em cima: já dá-lhe outro em cima.. }\end{array}$ \\
\hline $\begin{array}{l}\text { Acepções } \\
\text { registradas } \\
\text { nos } \\
\text { dicionários }\end{array}$ & $\begin{array}{l}\text { Bluteau (1712-1728): REBÃTE. O sinal, que se faz com gritos, ou } \\
\text { sinos, ou instrumentos de guerra para juntar gente, tomar armas, \& } \\
\text { resistir ao improviso acometimento do inimigo, porque vem a ferir, } \\
\text { que he bater, \& sahe se a rebatello. } \\
\text { Morais Silva (1813): REBÁTE, s. m. Sinal com sino, caixa, grito, ou } \\
\text { ataque do inimigo. } \\
\text { Cunha (1997): bater } v b \text {. 'dar pancadas em' 'dar choques ou pancadas } \\
\text { com' | rebate }{ }^{2} \text { XVI. } \\
\text { Ferreira (2004): rebate } 2 \text {. Ataque imprevisto. } 4 \text {. Chamamento ou sinal } \\
\text { para avisar um acontecimento repentino e perigoso. } \\
\text { Houaiss (2007): rebate datação sXV } 1 \text { assalto repentino; ataque, } \\
\text { incursão. } 2 \text { grito, chamamento ou sinal com que se alerta sobre ataque } \\
\text { do inimigo. }\end{array}$ \\
\hline \multicolumn{2}{|c|}{$\begin{array}{l}\text { Considerando o contexto de uso do item lexical rebate, averigua-se considerável } \\
\text { frequência nas respostas dos entrevistados. Os significados atribuídos pelos informantes } \\
\text { quanto à utilização da lexia rebate foram diversos: (i) três informantes (F1-M-EF / F2-H- } \\
\text { EF e F2-M-ES) empregaram com o sentido de 'contestar, refutar'; (ii) do is informantes } \\
\text { (F2-M-EF, F2-H-ES) atribuíram o valor 'retrucar' e 'devolver'; (iii) dois informantes (F2- } \\
\text { H-EM, F2-H-ES) empregaram com o sentido de 'bater novamente'; (iv) um informante } \\
\text { (F1-H-EF) empregou com o sentido de 'reprimir, 'conter'; (v) o informante F1-H-EM } \\
\text { associou ao verbo rebater; e (vi) o informante F2-H-ES, além de outros significados } \\
\text { reconheceu na forma lexical rebate o sentido próximo da acepção em estudo: 'rebate de } \\
\text { rebate falso, tipo um sinal, alarme falso, algo que não aconteceu'. Apesar de este } \\
\text { informante ter acrescido o sema 'falso' à unidade lexical rebate, o sentido da acepção } \\
\text { buscada 'sinal de alarme' encontra-se presente nesta lexia exemplificada em seu contexto } \\
\text { de fala. Quanto ao registro da entrada rebate nos dicionários pesquisados, Bluteau, Morais } \\
\text { Silva, Ferreira e Houaiss registraram as designações que evidenciam a mesma acepção em } \\
\text { estudo: 'sinal', 'grito', 'ataque imprevisto', 'sinal para avisar'. } \\
\text { Considerando os dados apresentados, nota-se que a unidade lexical rebate com o } \\
\text { mesmo sentido documentado no corpus escrito esteve presente apenas na resposta de um } \\
\text { informante da faixa II. Portanto, há indícios de tendência ao desuso. }\end{array}$} \\
\hline
\end{tabular}

130. RÉDITO / DOC.42, fól.1r, 1.23-26

Acepção

buscada

Rendimento, ganho, lucro. 


\begin{tabular}{|c|c|}
\hline $\begin{array}{l}\text { Acepção(ões) } \\
\text { conhecida(s) } \\
\text { pelos } \\
\text { informantes }\end{array}$ & $\begin{array}{l}\text { F1-H-EP: NSR. } \\
\text { F1-M-EP: NSR. } \\
\text { F1-H-EF: NSR. } \\
\text { F1-M-EF: NSR. } \\
\text { F1-H-EM: NSR. } \\
\text { F1-M-EM: NSR. } \\
\text { F1-H-ES: NSR. } \\
\text { F1-M-ES: NSR. } \\
\text { F2-H-EP: NSR. } \\
\text { F2-M-EP: NSR. } \\
\text { F2-H-EF: NSR. } \\
\text { F2-M-EF: NSR. } \\
\text { F2-H-EM: NSR. } \\
\text { F2-M-EM: NSR. } \\
\text { F2-H-ES: NSR. } \\
\text { F2-M-ES: NSR. }\end{array}$ \\
\hline $\begin{array}{l}\text { Acepções } \\
\text { registradas } \\
\text { nos } \\
\text { dicionários }\end{array}$ & $\begin{array}{l}\text { Bluteau (1712-1728): RÊDITO. Rendimento. } \\
\text { Morais Silva (1813): RÉDDITO, s. m. Renda. Lucro do dinheiro, usura. } \\
\text { Cunha (1997): rédito sm. 'lucro, ganho' XVII. } \\
\text { Ferreira (2004): rédito 2. Lucro, ganho. 3. Rendimento, juro. } \\
\text { Houaiss (2007): rédito datação } 16852 \text { qualquer vantagem material que } \\
\quad \text { se pode tirar de alguma coisa; lucro. }\end{array}$ \\
\hline \multicolumn{2}{|c|}{$\begin{array}{l}\text { Dos dezesseis entrevistados, todos disseram desconhecer a lexia rédito. Os lexicógrafos } \\
\text { pesquisados trazem o registro da entrada rédito com o mesmo sentido da acepção em } \\
\text { estudo: 'rendimento, ganho, lucro'. Considerando os dados apresentados, constata-se que } \\
\text { o item lexical rédito não faz mais parte do vocabulário dos informantes parnanguaras na } \\
\text { modalidade oral, haja vista que dos dezesseis entrevistados, nenhum reconheceu esta } \\
\text { unidade lexical, revelando, dessa forma, um caso de desuso. }\end{array}$} \\
\hline
\end{tabular}

\begin{tabular}{|l|l|}
\hline 131. REMÉDIO DA SUA FOME / DOC.32, fól.1r, l.29-31 \\
\hline $\begin{array}{l}\text { Acepção } \\
\text { buscada }\end{array}$ & Plantação que serve para alimento. \\
\hline $\begin{array}{l}\text { Acepção(ões) } \\
\text { conhecida(s) } \\
\text { pelos }\end{array}$ & $\begin{array}{l}\text { F1-H-EP: É a comida. } \\
\text { informantes: }\end{array}$ \\
& $\begin{array}{l}\text { F1-H-EP: NSR. NSR. } \\
\text { F1-M-EF: NSR. } \\
\end{array}$ \\
& F1-H-EM: NSR. \\
& F1-M-EM: NSR. \\
\hline
\end{tabular}




\begin{tabular}{|c|c|}
\hline & $\begin{array}{l}\text { F1-H-ES: NSR. } \\
\text { F1-M-ES: NSR. } \\
\text { F2-H-EP: NSR. } \\
\text { F2-M-EP: NSR. } \\
\text { F2-H-EF: Remédio da fome seria alimento. } \\
\text { F2-M-EF: NSR. } \\
\text { F2-H-EM: NSR. } \\
\text { F2-M-EM: Moeda antiga, hoje não usa mais. } \\
\text { F2-H-ES: Comida. } \\
\text { F2-M-ES: NSR. }\end{array}$ \\
\hline $\begin{array}{l}\text { Acepções } \\
\text { registradas } \\
\text { nos } \\
\text { dicionários }\end{array}$ & $\begin{array}{l}\text { Bluteau (1712-1728): N.D. } \\
\text { Morais Silva (1813): N.D. } \\
\text { Cunha (1997): N.D. } \\
\text { Ferreira (2004): N.D. } \\
\text { Houaiss (2007): N.D. }\end{array}$ \\
\hline \multicolumn{2}{|c|}{$\begin{array}{l}\text { A expressão remédio da sua fome não está registrada nos dicionários pesquisados e } \\
\text { nem possui locuções semelhantes que possam indicar caso de variação lexical. Parece } \\
\text { tratar-se de um caso de metáfora do qual remédio da sua fome deve ser algo que serve } \\
\text { para matar a fome, neste caso, o alimento/a plantação que produz alimento. A passagem } \\
\text { no documento manuscrito em que se encontra esta expressão refere-se às plantações } \\
\text { destruídas pelo gado, logo, o gado destruiu o remédio da sua fome. Analisando o contexto } \\
\text { de uso desta expressão por parte dos entrevistados, houve o seu reconhecimento por parte } \\
\text { de quatro informantes. Para três informantes (F1-H-EP / F2-H-ES e F2-H-EF) a expressão } \\
\text { remédio da sua fome é sinônima de 'comida', 'alimento', evidenciando assim, uma } \\
\text { relação muito próxima com a acepção em estudo: 'plantação que serve para alimento'. Já } \\
\text { para a informante F2-M-EM, a expressão tem o sentido de 'moeda antiga', mas, em } \\
\text { seguida, informou que hoje não se usa mais. Esta acepção não consta do registro de } \\
\text { nenhum dos dicionaristas pesquisados. } \\
\text { Levando em consideração os dados analisados, verifica-se que, dos dezesseis } \\
\text { entrevistados, apenas três informantes (um da faixa I e dois da faixa II) associaram a } \\
\text { expressão remédio da sua fome com o sentido da acepção investigada, revelando dessa } \\
\text { forma tendência ao desuso. }\end{array}$} \\
\hline
\end{tabular}

132. RIPA / DOC.46, fól.1v, l.09-12

\begin{tabular}{|l|l|}
\hline $\begin{array}{l}\text { Acepção } \\
\text { buscada }\end{array}$ & Pedaço de madeira estreito e comprido. \\
\hline $\begin{array}{l}\text { Acepção(ões) } \\
\text { conhecida(s) }\end{array}$ & F1-H-EP: Um caibro que tem uma ripa, só de madeira. \\
\hline
\end{tabular}




\begin{tabular}{|c|c|}
\hline $\begin{array}{l}\text { pelos } \\
\text { informantes }\end{array}$ & $\begin{array}{l}\text { F1-M-EP: Ripa é o pau que vai no telhado. As tirinhas da parede são } \\
\text { sarrafos. } \\
\text { F1-H-EF: Ripa é madeira, um sarrafo, caibro. } \\
\text { F1-M-EF: Ripa é tábua. } \\
\text { F1-H-EM: Ripa é uma madeira. } \\
\text { F1-M-EM: Ripa é madeira fina. } \\
\text { F1-H-ES: É tábua, madeira. } \\
\text { F1-M-ES: Ripa de pau. } \\
\text { F2-H-EP: Aqui é madeira que a gente usa pra fazer casa. } \\
\text { F2-M-EP: Viga de madeira. } \\
\text { F2-H-EF: Ripa é um pedaço de tábua. } \\
\text { F2-M-EF: É madeira. } \\
\text { F2-H-EM: Uma ripa, um pedaço de pau de madeira. } \\
\text { F2-M-EM: Ripa é de construção. É aquele sarrafo, tira comprida de } \\
\text { madeira. } \\
\text { F2-H-ES: Ripa é madeira fina. } \\
\text { F2-M-ES: Ripa é uma madeira comprida, para construir casa. }\end{array}$ \\
\hline $\begin{array}{l}\text { Acepções } \\
\text { registradas } \\
\text { nos } \\
\text { dicionários }\end{array}$ & $\begin{array}{l}\text { Bluteau (1712-1728): RIPA. Fasquia comprida, \& estreyta de madeyra, } \\
\text { que se assenta nos barrotes dos telhados, para ter mão nas telhas. } \\
\text { Morais Silva (1813): RÍPA, s. f. Fasquia de taboa, que se atravessa } \\
\text { sobre os barrotes, e faz huma grade com elles, sobre o que se assentão } \\
\text { as telhas nos telhados. } \\
\text { Cunha (1997): ripa' }{ }^{1} s f \text {. 'pedaço de madeira, comprido e estreito, } \\
\text { sarrafo' XVII. } \\
\text { Ferreira (2004): ripa 1. Pedaço de madeira comprido e estreito; fasquia, } \\
\text { verga, sarrafo. } \\
\text { Houaiss (2007): ripa datação } 1209 \text { 1 Rubrica: materiais: qualquer peça } \\
\text { de madeira, esp. quando longa e estreita. }\end{array}$ \\
\hline \multicolumn{2}{|c|}{$\begin{array}{l}\text { Analisando o contexto de utilização do item lexical ripa presente na fala dos } \\
\text { informantes de Paranaguá, constata-se que é bastante produtiva, pois os dezesseis } \\
\text { entrevistados reconheceram este item lexical com o mesmo sentido documentado no } \\
\text { corpus escrito. No entanto, estes informantes, ao atribuírem à unidade lexical ripa o } \\
\text { sentido de 'pedaço de madeira estreito e comprido', empregaram as seguintes variantes } \\
\text { lexicais: 'caibro', 'pau', 'sarrafo', 'viga', 'pedaço de tábua', 'pedaço de pau'. Com relação } \\
\text { à acepção investigada, encontra-se lexicalizada em Bluteau, Morais Silva, Ferreira e } \\
\text { Houaiss. } \\
\text { Nota-se, ainda, que seu emprego na fala dos informantes da faixa I e da faixa II é } \\
\text { bastante produtivo. As variantes lexicais presentes nas respostas dos informantes } \\
\text { serviram de base para a descrição do objeto, no caso, 'pedaço de madeira', e não }\end{array}$} \\
\hline
\end{tabular}


como indício de concorrência entre essas formas lexicais. Portanto, a unidade lexical ripa apresenta indícios de manutencão.

\begin{tabular}{|c|c|}
\hline \multicolumn{2}{|c|}{ 133. ROSSIO / DOC.32, fól.1r, l.22-25 } \\
\hline $\begin{array}{l}\text { Acepção } \\
\text { buscada }\end{array}$ & Praça larga, espaçosa. \\
\hline $\begin{array}{l}\text { Acepção(ões) } \\
\text { conhecida(s) } \\
\text { pelos } \\
\text { informantes: }\end{array}$ & $\begin{array}{l}\text { F1-H-EP: Rocio pra nós é um bairro. } \\
\text { F1-M-EP: Conheço só a igreja do Rocio. } \\
\text { F1-H-EF: É um bairro. } \\
\text { F1-M-EF: Temos a Santa do Rocio, e tem o bairro } \\
\text { F1-H-EM: É um bairro e uma Santa também, a Nossa Senhora do Rocio. } \\
\text { F1-M-EM: Tem a festa do Rocio, homenagem à Santa. } \\
\text { F1-H-ES: Rocio é um bairro, só que é escrito com 'c'. } \\
\text { F1-M-ES: Rocio é um bairro em Paranaguá. } \\
\text { F2-H-EP: NSR. } \\
\text { F2-M-EP: É um bairro que eu conheço. } \\
\text { F2-H-EF: Rocio com c é o lugar grande onde faz uma roçada seria um } \\
\text { rocio. Aqui em Paranaguá usa mais pra igreja. } \\
\text { F2-M-EF: Acho que é um Santa. } \\
\text { F2-H-EM: Teve um tempo em que o bairro Nossa Senhora do Rossio era } \\
\text { escrito com dois 's'. Depois de mil oitocentos e alguma coisa mudou } \\
\text { para Rocio com 'c'. Lá é o bairro do Rocio. Lá fica a padroeira do } \\
\text { Paraná. } \\
\text { F2-M-EM: NSR. } \\
\text { F2-H-ES: Aqui em Paranaguá rocio tem o sentido de orvalho. Já o meu } \\
\text { sentido de rossio com dois "esses" que é róssio, que é a palavra } \\
\text { principal, ele quer dizer campo, local aberto. É que a igreja hoje } \\
\text { monta muito rocio como orvalho que achou a santa, com c. Mas na } \\
\text { verdade a escrita original é com dois "esses” que significa praça } \\
\text { aberta, espaçosa. } \\
\text { F2-M-ES: Rocio é um bairro onde temos festa. }\end{array}$ \\
\hline $\begin{array}{l}\text { Acepções } \\
\text { registradas } \\
\text { nos } \\
\text { dicionários }\end{array}$ & $\begin{array}{l}\text { Bluteau (1712-1728): ROCIO. Algũas vezes val o mesmo que Praça. } \\
\text { Morais Silva (1813): ROCIO, s. m. §. V. Recio, ou Ressio; posto que } \\
\text { hoje dizemos o rocio, ou a praça, e por excellencia huma praça de } \\
\text { Lisboa. } \\
\text { Cunha (1997): rossio } \mathrm{sm} \text {. 'praça largar' | XVI. } \\
\text { Ferreira (2004): rossio 1.Praça larga; largo espaçoso. } \\
\text { Houaiss (2007): rossio datação } 1 \text { terreno ou largo bastante espaçoso; } \\
\quad \text { grande praça. }\end{array}$ \\
\hline
\end{tabular}


Analisando as respostas dos informantes de Paranaguá, nota-se que os itens lexicais rossio e rocio referem-se a contextos distintos, conforme esclarece o informante F2-H-ES: 'Aqui em Paranaguá rocio tem o sentido de orvalho. Já o meu sentido de rossio com dois "esses" que é róssio, que é a palavra principal, ele quer dizer campo, local aberto. É que a igreja hoje monta muito rocio com c como orvalho que achou a santa. Mas na verdade a escrita original é com dois "esses" que significa praça aberta, espaçosa'. Através desta informação compreende-se que o lugar onde foi encontrada a Santa havia muito rocio, ou seja, 'orvalho' e por extensão de sentido o nome rocio passou a designar a Santa do Rocio, a igreja do Rocio e o bairro do Rocio, lugar onde se encontra a Padroeira da cidade. Portanto, dos dezesseis entrevistados, treze informantes (oito da faixa I e cinco da faixa II) reconheceram o item lexical rocio com o sentido de: 'bairro', 'Santa', 'igreja'. Já o informante F2-H-EF atribuiu à lexia rocio o sentido de 'lugar onde faz uma roçada seria um rocio'. Esta acepção encontra-se registrada por Ferreira e Houaiss na segunda entrada para rocio marcada como brasileirismo, em Ferreira, e regionalismo de São Paulo, em Houaiss. Em seguida, esse mesmo informante acrescenta que, em Paranaguá, rocio se usa mais para denominar a igreja. Quanto à acepção buscada 'praça larga, espaçosa', apenas o informante F2-H-ES reconheceu a unidade lexical rossio com o valor de 'campo, local aberto, praça aberta, espaçosa'. Nos dicionários pesquisados, os lexicógrafos Cunha, Ferreira e Houaiss fixam o registro das entradas rossio, rocio ${ }^{1} e$ rocio $^{2}$, atribuindo-lhe os valores: 'praça larga, espaçosa' (rossio); 'm.q. orvalho' (rocio ${ }^{l}$ ); 'antiga roça' $\left(\right.$ rocio $\left.^{2}\right)$.

Analisando o contexto de uso da unidade lexical rossio e comparando com a acepção buscada, presume tratar-se de uma lexia com tendência ao desuso, visto que apenas um informante da faixa II reconheceu rossio com o sentido documentado no corpus escrito. O item lexical que apresenta considerável produtividade na fala dos parnanguaras refere-se, na verdade, ao seu homônimo rocio e não ao mesmo item lexical em estudo.

\begin{tabular}{|c|c|}
\hline \multicolumn{2}{|c|}{ 134. SEARA / DOC.22, fól.1r, l.09-11 } \\
\hline $\begin{array}{l}\text { Acepção } \\
\text { buscada }\end{array}$ & Plantação, terra cultivada. \\
\hline $\begin{array}{l}\text { Acepção(ões) } \\
\text { conhecida(s) } \\
\text { pelos } \\
\text { informantes }\end{array}$ & $\begin{array}{l}\text { F1-H-EP: NSR. } \\
\text { F1-M-EP: NSR. } \\
\text { F1-H-EF: Alimento. } \\
\text { F1-M-EF: NSR. } \\
\text { F1-H-EM: Conheço como o local onde os agricultores vendem seu } \\
\quad \text { produto. Um local de revenda de produtos. } \\
\text { F1-M-EM: NSR. } \\
\text { F1-H-ES: NSR. } \\
\text { F1-M-ES: Seara de alimentos. }\end{array}$ \\
\hline
\end{tabular}




\begin{tabular}{|c|c|}
\hline & $\begin{array}{l}\text { F2-H-EP: NSR. } \\
\text { F2-M-EP: NSR. } \\
\text { F2-H-EF: Seara seria colheita. } \\
\text { F2-M-EF: Colheita. } \\
\text { F2-H-EM: Onde tem plantação de alguma coisa, é uma seara. } \\
\text { F2-M-EM: NSR. } \\
\text { F2-H-ES: É uma plantação. } \\
\text { F2-M-ES: NSR. }\end{array}$ \\
\hline $\begin{array}{l}\text { Acepções } \\
\text { registradas } \\
\text { nos } \\
\text { dicionários }\end{array}$ & $\begin{array}{l}\text { Bluteau (1712-1728): SEARA. Os pães, em quanto estão em pé, no } \\
\text { campo. } \\
\text { Morais Silva (1813): SEÁRA, s. f. §. Fazer seara, plantar em terra } \\
\quad \text { alheya, não abegado nella, com bois alheyos. } \\
\text { Cunha (1997): seara } s f \text {. 'extensão de terra semeada' | XIII. } \\
\text { Ferreira (2004): seara } 2 \text {. Extensão de terra semeada, cultivada. } \\
\text { Houaiss (2007): seara datação } 9332 \text { Rubrica: agricultura: extensão de } \\
\quad \text { terra cultivada. }\end{array}$ \\
\hline \multicolumn{2}{|c|}{$\begin{array}{l}\text { A lexia seara com o sentido da acepção em estudo 'plantação, terra cultivada' fo i } \\
\text { reconhecida por apenas do is informantes (F2-H-EM e F2-H-ES). Os demais informantes } \\
\text { empregaram diversos significados: (i) do is informantes da faixa I (F1-H-EF, F1-M-ES) } \\
\text { definiram seara com o sentido de 'alimento'; (ii) dois informantes da faixa II (F2-H-EF, } \\
\text { F2-M-EF) a definiram como 'colheita'; (iii) e o informante F1-H-EM associou seara a um } \\
\text { 'local de revenda de produtos'. Estes novos significados atribuídos para a forma lexical } \\
\text { seara não constam do registro dos dicionários pesquisados. Talvez a associação entre os } \\
\text { semas 'alimento', 'colheita' para a forma lexical seara, seja devido à proximidade dos } \\
\text { traços semânticos [+plantar, plantação, colheita, alimento]. Os lexicógrafos Cunha, } \\
\text { Ferreira e Houaiss trazem o registro da acepção buscada. Já Bluteau define a entrada seara } \\
\text { de forma vaga: 'os pães enquanto de pé no campo'. Morais Silva, por sua vez, refere-se à } \\
\text { locução fazer seara com o sentido de 'plantar em terra alheia'. } \\
\text { Analisando o contexto de uso da unidade lexical seara no estágio atual de variação, } \\
\text { constata-se que este item lexical apresenta tendência ao desuso, visto que apenas dois } \\
\text { informantes da faixa II ainda empregam seara com o sentido de 'plantação' e 'terra } \\
\text { cultivada'. }\end{array}$} \\
\hline
\end{tabular}

\begin{tabular}{|l|l|}
\hline 135. SOLDO / DOC.47, fól.1v, l.14-17 \\
\hline $\begin{array}{l}\text { Acepção } \\
\text { buscada }\end{array}$ & Salário, remuneração de militar. \\
\hline $\begin{array}{l}\text { Acepção(ões) } \\
\text { conhecida(s) } \\
\text { pelos }\end{array}$ & $\begin{array}{l}\text { F1-H-EP: NSR. } \\
\text { F1-M-EP: NSR. }\end{array}$ \\
\hline
\end{tabular}




\begin{tabular}{|c|c|}
\hline antes & $\begin{array}{l}\text { F1-M-EF: NSR. } \\
\text { F1-H-EM: NSR. } \\
\text { F1-M-EM: Soldador. } \\
\text { F1-H-ES: NSR. } \\
\text { F1-M-ES: NSR. } \\
\text { F2-H-EP: NSR. } \\
\text { F2-M-EP: NSR. } \\
\text { F2-H-EF: Salário. } \\
\text { F2-M-EF: NSR. } \\
\text { F2-H-EM: NSR. } \\
\text { F2-M-EM: NSR. } \\
\text { F2-H-ES: Soldo é salário dos soldados. Os militares mais antigos falam: } \\
\quad \text { vou ao banco pegar meu soldo. Meus alunos dizem: o meu pai falam } \\
\text { isso. } \\
\text { F2-M-ES: Soldo vem de soldar, metalúrgico. }\end{array}$ \\
\hline $\begin{array}{l}\text { Acepções } \\
\text { registradas } \\
\text { nos } \\
\text { dicionários }\end{array}$ & $\begin{array}{l}\text { Bluteau (1712-1728): SOLDO. A paga do Soldado. } \\
\text { Morais Silva (1813): SÓLDO, s. m. A paga do soldado, commummente } \\
\text { pronunciamos sóldo, o pré dos soldados; a moeda antiga é sóldo. } \\
\text { Cunha (1997): soldar } v b \text {. | soldo sm. 'salário' XV. } \\
\text { Ferreira (2004): soldo } 2 \text {. Bras. Mil. Quantia básica, de referência, para } \\
\text { pagamento de militar, à qual se acrescentam percentuais que variam } \\
\text { com a categoria hierárquica, especialidade, tempo de serviço, etc. } \\
\text { Houaiss (2007): soldo datação } 9335 \text { Derivação: por extensão de } \\
\text { sentido: vencimento de militares de qualquer posto ou graduação. }\end{array}$ \\
\hline \multicolumn{2}{|c|}{$\begin{array}{l}\text { Analisando o contexto de uso do item lexical soldo constata-se baixa produtividade na } \\
\text { fala dos entrevistados. Dos dezesseis informantes, onze (seis da faixa I e cinco da faixa II) } \\
\text { disseram não conhecer essa lexia. Dos cinco que a reconheceram, dois informantes f2-H- } \\
\text { EF e F2-H-ES atribuíram a soldo o valor de salário. Da acepção em estudo 'salário, } \\
\text { remuneração de militar', apenas o informante F2-H-ES especificou o conceito: 'Soldo é } \\
\text { salário dos soldados. Os militares mais antigos falam: vou ao banco pegar meu soldo. } \\
\text { Meus alunos dizem: o meu pai falam isso'. Neste enunciado, as passagens 'militares mais } \\
\text { antigos falam' e 'o meu pai falam isso' parecem evidenciar a marca diageracional } \\
\text { exclusiva a esta lexia. Outros três informantes (F1-H-EF e F1-M-EM / F2-M-ES) } \\
\text { associaram a forma lexical soldo com o parônimo soldar devido à semelhança entre essas } \\
\text { formas. Etimologicamente, soldo vem do lat. solidus, a, um, e soldar do lat. solidare. } \\
\text { Portanto, trata-se de itens lexicais e significados distintos. Os lexicógrafos Bluteau, } \\
\text { Morais Silva, Ferreira e Houaiss trazem o registro da acepção buscada para a unidade } \\
\text { lexical soldo. Ferreira marca brasileirismo na segunda acepção, a designação 'pagamento } \\
\text { de militar'. Houaiss, na quinta acepção, informa ser essa designação derivação por } \\
\text { extensão de sentido. Cunha define a entrada soldo como sinônimo de salário. } \\
\text { Analisando o contexto de uso da unidade lexical soldo, constata-se que seu emprego é }\end{array}$} \\
\hline
\end{tabular}


escasso. O único informante que atribuiu o sentido de 'salário de soldados' informou ser típico da fala de pessoas mais antigas. As respostas dos informantes da faixa I confirmam esta assertiva, haja vista que nenhum reconheceu soldo com o valor de 'salário'. Portanto, no estágio atual de variação, esta unidade lexical apresenta tendência ao desuso.

\begin{tabular}{|c|c|}
\hline \multicolumn{2}{|c|}{ 136. SUMACA / DOC.11, fól.1r, l.10-14 } \\
\hline $\begin{array}{l}\text { Acepção } \\
\text { buscada: }\end{array}$ & Navio a vela, pequena embarcação. \\
\hline $\begin{array}{l}\text { Acepção(ões) } \\
\text { conhecida(s) } \\
\text { pelos } \\
\text { informantes }\end{array}$ & $\begin{array}{l}\text { F1-H-EP: NSR. } \\
\text { F1-M-EP: NSR. } \\
\text { F1-H-EF: NSR. } \\
\text { F1-M-EF: NSR. } \\
\text { F1-H-EM: NSR. } \\
\text { F1-M-EM: NSR. } \\
\text { F1-H-ES: NSR. } \\
\text { F1-M-ES: NSR. } \\
\text { F2-H-EP: NSR. } \\
\text { F2-M-EP: NSR. } \\
\text { F2-H-EF: NSR. } \\
\text { F2-M-EF: NSR. } \\
\text { F2-H-EM: NSR. } \\
\text { F2-M-EM: NSR. } \\
\text { F2-H-ES: NSR. } \\
\text { F2-M-ES: NSR. }\end{array}$ \\
\hline $\begin{array}{l}\text { Acepções } \\
\text { registradas } \\
\text { nos } \\
\text { dicionários }\end{array}$ & $\begin{array}{l}\text { Bluteau (1712-1728): N.D. } \\
\text { Morais Silva (1813): N.D. } \\
\text { Cunha (1997): sumaca sf. 'antigo navio a vela' XVII. } \\
\text { Ferreira (2004): sumaca 1. Bras. Antigo navio à vela, muito usado na } \\
\quad \text { costa do Brasil, semelhante ao patacho, porém menor, de mastreação } \\
\text { constituída de gurupés e dois mastros inteiriços: o de vante, que cruza } \\
\text { duas vergas, e o de ré, que enverga vela latina. } \\
\text { Houaiss (2007): }{ }^{1} \text { sumaca datação } 1660 \text { Rubrica: termo de marinha. } \\
\text { Diacronismo: antigo: pequena embarcação de dois mastros, us. } \\
\text { outrora esp. no Brasil e na América do Sul. }\end{array}$ \\
\hline \multicolumn{2}{|c|}{$\begin{array}{l}\text { Dos dezesseis entrevistados, todos disseram desconhecer a lexia sumaca. Supõe-se, } \\
\text { pela não ocorrência desta unidade lexical no contexto de fala dos informantes } \\
\text { parnanguaras, que seu registro consta somente dos documentos manuscritos, livros de } \\
\text { história e dos dicionários gerais. Quanto ao registro nos dicionários pesquisados, Cunha e }\end{array}$} \\
\hline
\end{tabular}


Ferreira definem a entrada sumaca como 'antigo navio à vela'. Houaiss a define como 'pequena embarcação de dois mastros, usado esp. no Brasil e na América do Sul', marcando como diacronismo antigo pertencente ao termo da marinha. Curiosamente, o item lexical sumaca não consta do registro dos dicionários de Bluteau e de Morais Silva, mesmo tendo sua entrada fixada por Cunha a partir do séc. XVII, e, mais especificamente, por Houaiss em 1660, e também registrado no documento manuscrito datado de 1721, cujo significado é o mesmo registrado por Cunha, Ferreira e Houaiss.

Considerando os dados analisados, a lexia sumaca, sem nenhuma ocorrência em contexto de fala dos entrevistados, caiu em $\underline{\text { desuso, }}$, justamente por não existir mais este tipo de embarcação no Brasil.

\begin{tabular}{|c|c|}
\hline \multicolumn{2}{|c|}{ 137. SUSTENTAÇÃO / DOC.48, fól.1r, l.35-39 } \\
\hline $\begin{array}{l}\text { Acepção } \\
\text { buscada }\end{array}$ & Abastecimento de alimento, sustento. \\
\hline $\begin{array}{l}\text { Acepção(ões) } \\
\text { conhecida(s) } \\
\text { pelos } \\
\text { informantes }\end{array}$ & $\begin{array}{l}\text { F1-H-EP: Quando você faz um pilar pra sustentar uma viga. } \\
\text { F1-M-EP: NSR. } \\
\text { F1-H-EF: É sustentar. } \\
\text { F1-M-EF: NSR. } \\
\text { F1-H-EM: A pessoa que sustenta, mantém ou faz a sustentação da casa. } \\
\text { F1-M-EM: Sustentando alguém, que me dá sustentação. } \\
\text { F1-H-ES: Sentido de dinheiro, que sustenta. } \\
\text { F1-M-ES: Algo que se sustenta, sustentável, sustentabilidade. } \\
\text { F2-H-EP: NSR. } \\
\text { F2-M-EP: Eu vou pôr esse pau aqui nessa casa pra sustentar. } \\
\text { F2-H-EF: Alguma coisa que sustenta alguma coisa, um pilar e tal. } \\
\text { F2-M-EF: Uma viga de concreto por exemplo serve de sustentação pro } \\
\text { telhado. } \\
\text { F2-H-EM: A coluna serve como sustentação de uma casa. } \\
\text { F2-M-EM: Aquela pessoa é a cabeça da família, é a sustentação da casa. } \\
\text { F2-H-ES: Sustentação é que dá apoio. } \\
\text { F2-M-ES: A gente trabalha para levar sustentação para casa, ganhar o } \\
\text { sustento. }\end{array}$ \\
\hline $\begin{array}{l}\text { Acepções } \\
\text { registradas } \\
\text { nos } \\
\text { dicionários }\end{array}$ & $\begin{array}{l}\text { Bluteau (1712-1728): SUSTENTAÇÃO, ou Sustento. Vid. Sustento. } \\
\text { Morais Silva (1813): SUSTENTAÇÃO, s. f. O acto de sustentar. §. O } \\
\quad \text { sustento. } \\
\text { Cunha (1997): sustentar } v b . \text { 'alimentar física ou moralmente' | } \\
\quad \text { sustentação | -çõ XIII. } \\
\text { Ferreira (2004): sustentação 3. Alimento, sustento. }\end{array}$ \\
\hline
\end{tabular}




\begin{tabular}{|l|l|}
\hline $\begin{array}{l}\text { Houaiss (2007): sustentação datação } 1 \text { abastecimento renovado do } \\
\text { conjunto das substâncias necessárias à conservação da vida; nutrição, } \\
\text { alimentação, sustento. }\end{array}$ \\
\hline $\begin{array}{l}\text { Analisando o contexto de utilização da lexia sustentação presente na fala dos } \\
\text { informantes de Paranaguá, constata-se que sua ocorrência é bastante produtiva. Dos } \\
\text { dezesseis entrevistados, treze informantes reconheceram o item lexical com variação de } \\
\text { significado: (i) cinco informantes (F1-H-EP / quatro da faixa II: F2-M-EP, F2-H-EF, F2- } \\
\text { M-EF e F2-H-EM), ao atribuírem à lexia sustentação o sentido de 'aquilo que sustenta, } \\
\text { sustentáculo, apoio', empregaram as seguintes variantes lexicais: 'pilar', 'pau', 'viga de } \\
\text { concreto', 'coluna'; (ii) três informantes (F1-H-EF e F1-M-ES / F2-H-ES) responderam } \\
\text { em contexto mais genérico: 'sustentar', 'algo que sustenta, sustentável, sustentabilidade', } \\
\text { 'que dá apoio'; (iii) o informante F1-H-ES associou sustentação ao sentido de 'dinheiro, } \\
\text { que sustenta'. Esta acepção não consta do registro dos dicionaristas pesquisados. Com } \\
\text { relação à acepção buscada 'abastecimento de alimento, sustento' para a unidade lexical } \\
\text { sustentação, quatro informantes (F1-H-EM e F1-M-EM / F2-M-EM e F2-M-ES) disseram } \\
\text { empregá-la em seu contexto de fala. A acepção investigada encontra-se lexicalizada em } \\
\text { Bluteau, Morais Silva, Ferreira e Houaiss. Para a designação da entrada sustentação, o } \\
\text { primeiro dicionarista remete o consulente à variante lexical sustento. } \\
\text { Analisando os dados apresentados, observa-se que a forma lexical sustentação com o } \\
\text { sentido da acepção em estudo está perdendo forças para o emprego das demais acepções } \\
\text { atribuídas para esta lexia. No estágio atual de variação, o item lexical sustentação } \\
\text { apresenta tendência ao desuso, uma vez que dos seis informantes da faixa I que a } \\
\text { reconheceram, apenas dois a empregam com o mesmo sentido documentado no corpus } \\
\text { escrito. }\end{array}$ \\
\hline
\end{tabular}

\begin{tabular}{|c|c|}
\hline \multicolumn{2}{|c|}{ 138. TABUADO / DOC.46, fól.1v, l.09-10 } \\
\hline $\begin{array}{l}\text { Acepção } \\
\text { buscada }\end{array}$ & Conjunto de tábuas, de peças de madeira. \\
\hline $\begin{array}{l}\text { Acepção(ões) } \\
\text { conhecida(s) } \\
\text { pelos } \\
\text { informantes }\end{array}$ & $\begin{array}{l}\text { F1-H-EP: NSR. } \\
\text { F1-M-EP: Conheço só tabuada de conta. } \\
\text { F1-H-EF: Conheço só tabuada da escola. } \\
\text { F1-M-EF: NSR. } \\
\text { F1-H-EM: Conheço só tábua. } \\
\text { F1-M-EM: Conheço tábua. } \\
\text { F1-H-ES: NSR. } \\
\text { F1-M-ES: NSR. } \\
\text { F2-H-EP: Tabuado pra nós aqui é negócio de madeira. } \\
\text { F2-M-EP: NSR. } \\
\text { F2-H-EF: NSR. }\end{array}$ \\
\hline
\end{tabular}




\begin{tabular}{|c|c|}
\hline & $\begin{array}{l}\text { F2-M-EF: Tabuado antigamente no meu tempo era um brejo onde tinha } \\
\text { uma taboa, uma planta que daquela planta se fazia travesseiro, isso } \\
\text { seria o tabuado, era um lugar difícil pra entrar porque era muita lama, } \\
\text { muito brejo. } \\
\text { F2-H-EM: NSR. } \\
\text { F2-M-EM: NSR. } \\
\text { F2-H-ES: Tabuado que tá marcado. } \\
\text { F2-M-ES: NSR. }\end{array}$ \\
\hline $\begin{array}{l}\text { Acepções } \\
\text { registradas } \\
\text { nos } \\
\text { dicionários }\end{array}$ & $\begin{array}{l}\text { Bluteau (1712-1728): TABOADO. As taboas de hum soalhado, ou } \\
\text { muytas taboas desta, ou daquela casta. } \\
\text { Morais Silva (1813): TABOÁDO, s. m. Multidão de taboas. } \\
\text { Cunha (1997): tábua, tábula, távola, tabla sf. 'orig. mesa' 'ext. peça } \\
\text { plana de madeira' | tabuado, tabulado sm. | tauolado XVII. } \\
\text { Ferreira (2004): tabuado 1. Conjunto de peças de madeira, unidas entre } \\
\text { si ou colocadas lado a lado, que constituem forro de assoalho, o } \\
\text { próprio assoalho, revestimento de parede, a própria parede, etc.; } \\
\text { tabuame. } \\
\text { Houaiss (2007): tabuado datação sXIV Rubrica: carpintaria. } 1 \text { conjunto } \\
\text { de tábuas agrupadas, us. para revestir telhado, assoalho, paredes, } \\
\text { pontes etc.; tabuame, tabulado. }\end{array}$ \\
\hline \multicolumn{2}{|c|}{$\begin{array}{l}\text { A unidade lexical tabuado está registrada por todos os lexicógrafos acima com a } \\
\text { mesma acepção buscada: 'conjunto de tábuas, de peças de madeira'. Dos dezesseis } \\
\text { entrevistados, sete informantes reconheceram essa lexia, mas a empregaram com variação } \\
\text { de significados: (i) do is informantes (F1-H-EP e F1-M-EP) disseram conhecer somente o } \\
\text { item lexical tabuada, cujo significado pertence ao campo da aritmética: 'tabela das quatro } \\
\text { operações elementares de números'; (ii) a informante F2-M-EF reconheceu tabuado como } \\
\text { um conjunto da planta 'taboa' que servia para confeccionar o travesseiro. Segundo esta } \\
\text { informante, a 'taboa' é uma planta típica de lugares úmidos, de difícil acesso, onde há } \\
\text { muito brejo. O dicionarista Ferreira registra a entrada taboa e remete o consulente à } \\
\text { variante lexical tabua, inserindo essa unidade léxica ao campo semântico da botânica, } \\
\text { concebendo-a, também, como um brasileirismo na acepção: 'Grande erva da família das } \\
\text { tifáceas, que vive em águas paradas e rasas, pois se radica no fundo lemacento por meio } \\
\text { de um rizoma, que é comestível. [...] As folhas servem para tecer esteiras e cestos, e } \\
\text { podem dar celulose para papel'; (iii) o informante F2-H-ES informou de forma genérica: } \\
\text { 'Tabuado que tá marcado'; (iv) somente três informantes (F1-H-EM e F1-M-EM / F2-H- } \\
\text { EP) atribuíram à lexia tabuado designações próximas ao sentido documentado no corpus } \\
\text { escrito: 'tábua', 'negócio de madeira'. } \\
\text { Analisando os dados em questão, constatou-se que o item lexical tabuado com } \\
\text { o sentido da acepção investigada, não se encontra mais registrada em contexto de fala dos } \\
\text { entrevistados de Paranaguá, pressupondo, desta forma, tratar-se de um caso de desuso. }\end{array}$} \\
\hline
\end{tabular}




\begin{tabular}{|c|c|}
\hline \multicolumn{2}{|c|}{ 139. TABULARIA / DOC.42, fól.1r, l.28-31 } \\
\hline $\begin{array}{l}\text { Acepção } \\
\text { buscada }\end{array}$ & Uma espécie de tábua. \\
\hline $\begin{array}{l}\text { Acepção(ões) } \\
\text { conhecida(s) } \\
\text { pelos } \\
\text { informantes }\end{array}$ & $\begin{array}{l}\text { F1-H-EP: NSR. } \\
\text { F1-M-EP: NSR. } \\
\text { F1-H-EF: Conheço só tabuleiro de xadrez. } \\
\text { F1-M-EF: NSR. } \\
\text { F1-H-EM: NSR. } \\
\text { F1-M-EM: NSR. } \\
\text { F1-H-ES: NSR. } \\
\text { F1-M-ES: NSR. } \\
\text { F2-H-EP: NSR. } \\
\text { F2-M-EP: NSR. } \\
\text { F2-H-EF: NSR. } \\
\text { F2-M-EF: Seria uma marcenaria onde se fazem móveis. } \\
\text { F2-H-EM: NSR. } \\
\text { F2-M-EM: NSR. } \\
\text { F2-H-ES: NSR. } \\
\text { F2-M-ES: NSR. }\end{array}$ \\
\hline $\begin{array}{l}\text { Acepções } \\
\text { registradas } \\
\text { nos } \\
\text { dicionários }\end{array}$ & $\begin{array}{l}\text { Bluteau (1712-1728): N.D. } \\
\text { Morais Silva (1813): N.D. } \\
\text { Cunha (1997): N.D. } \\
\text { Ferreira (2004): N.D. } \\
\text { Houaiss (2007): N.D. }\end{array}$ \\
\hline \multicolumn{2}{|c|}{$\begin{array}{l}\text { A lexia tabularia encontra-se registrada no corpus escrito com o sentido de 'uma } \\
\text { espécie de tábua'. Nos dicionários pesquisados não consta do registro desta unidade } \\
\text { lexical. Em contexto de fala, somente dois informantes responderam a questão referente à } \\
\text { tabularia. O informante F1-H-EF disse conhecer somente 'tabuleiro de xadrez'. Já a } \\
\text { informante F2-M-EF associou tabularia com uma 'marcenaria onde se fazem móveis'. } \\
\text { Há, portanto, uma relação entre os semas das formas lexicais tabularia e marcenaria, pois } \\
\text { ambas possuem os traços [tábua, madeira]. } \\
\text { Considerando os dados apresentados, constata-se a não ocorrência da acepção buscada } \\
\text { por nenhum dos entrevistados, portanto, infere-se ser o item lexical tabularia um caso de } \\
\text { desuso. }\end{array}$} \\
\hline
\end{tabular}

\begin{tabular}{|l|l|}
\hline 140. VERAS / DOC.11, fól.1r, l.05-06 \\
\hline $\begin{array}{l}\text { Acepção } \\
\text { buscada }\end{array}$ & Coisas verdadeiras, verdade. \\
\hline
\end{tabular}




\begin{tabular}{|c|c|}
\hline $\begin{array}{l}\text { Acepção(ões) } \\
\text { conhecida(s) } \\
\text { pelos } \\
\text { informantes }\end{array}$ & $\begin{array}{l}\text { F1-H-EP: NSR. } \\
\text { F1-M-EP: NSR. } \\
\text { F1-H-EF: NSR. } \\
\text { F1-M-EF: NSR. } \\
\text { F1-H-EM: NSR. } \\
\text { F1-M-EM: NSR. } \\
\text { F1-H-ES: NSR. } \\
\text { F1-M-ES: De verdade. } \\
\text { F2-H-EP: NSR. } \\
\text { F2-M-EP: NSR. } \\
\text { F2-H-EF: Veras é verdade, é vero. } \\
\text { F2-M-EF: NSR. } \\
\text { F2-H-EM: NSR. } \\
\text { F2-M-EM: NSR. } \\
\text { F2-H-ES: NSR. } \\
\text { F2-M-ES: NSR. }\end{array}$ \\
\hline $\begin{array}{l}\text { Acepções } \\
\text { registradas } \\
\text { nos } \\
\text { dicionários }\end{array}$ & $\begin{array}{l}\text { Bluteau (1712-1728): VERAS. Às vezes val o mesmo que verdade, \& e } \\
\quad \text { cousa de proposito. } \\
\text { Morais Silva (1813): VÉRAS, s. f. pl. Devéras, adv. Com verdade. } \\
\text { Cunha (1997): verdade } s f . \mid \text { veras } s f . p l \text {. 'coisas verdadeiras' XVII. } \\
\text { Ferreira (2004): veras } 1 \text {. Coisas verdadeiras; realidade, verdade. } \\
\text { Houaiss (2007): vera datação } 15431 \text { verdade. }\end{array}$ \\
\hline \multicolumn{2}{|c|}{$\begin{array}{l}\text { Observa-se pelo contexto de uso que a lexia veras tem escassa produtividade no dia } \\
\text { a dia dos informantes parnanguaras, pois, dos dezesseis entrevistados, somente dois } \\
\text { informantes (F1-M-ES / F2-H-EF) a reconheceram com o sentido da acepção buscada: } \\
\text { 'co isas verdadeiras, verdade'. O informante F2-H-EF acrescentou em sua resposta a } \\
\text { variante lexical vero, cujo significado é o mesmo de 'verdadeiro'. Os lexicógrafos } \\
\text { Bluteau, Morais Silva e Ferreira registraram a designação em estudo para a entrada veras. } \\
\text { Houaiss registra somente o lema vera com o sentido de 'verdade'. Cunha registra a } \\
\text { entrada verdade e em seguida conceitua veras com a acepção: 'coisas verdadeiras'. } \\
\text { Considerando os dados analisados, verifica-se que a unidade lexical veras tem baixa } \\
\text { produtividade na fala dos entrevistados. Dos dezesseis entrevistados, quatorze informantes } \\
\text { (sete da faixa I e sete da faixa II) disseram desconhecer a lexia em questão, tendo o seu } \\
\text { reconhecimento apenas por parte de dois informantes: um da faixa I e outro da faixa II. } \\
\text { Portanto, a forma lexical veras apresenta tendência ao desuso. }\end{array}$} \\
\hline
\end{tabular}

\begin{tabular}{|l|l|}
\hline \multicolumn{2}{|l|}{ 141. VIGÁRIO / DOC.06, fól.1r, l.03-04 } \\
\hline $\begin{array}{l}\text { Acepção } \\
\text { buscada }\end{array}$ & Padre que substitui o pároco. \\
\hline
\end{tabular}




\begin{tabular}{|c|c|}
\hline $\begin{array}{l}\text { Acepção(ões) } \\
\text { conhecida(s) } \\
\text { pelos } \\
\text { informantes }\end{array}$ & $\begin{array}{l}\text { F1-H-EP: NSR. } \\
\text { F1-M-EP: NSR. } \\
\text { F1-H-EF: Só a expressão: não caio no conto do vigário. } \\
\text { F1-M-EF: É o padre. } \\
\text { F1-H-EM: É da igreja. } \\
\text { F1-M-EM: Vigarista. } \\
\text { F1-H-ES: NSR. } \\
\text { F1-M-ES: De padre. } \\
\text { F2-H-EP: Vigário é uma pessoa que tá na igreja, você é um vigário. } \\
\text { F2-M-EP: Antes falavam que era padre. } \\
\text { F2-H-EF: Vigário é o padre. } \\
\text { F2-M-EF: Padre. } \\
\text { F2-H-EM: Título eclesiástico da igreja católica. } \\
\text { F2-M-EM: Vigário é padre. } \\
\text { F2-H-ES: Padre. } \\
\text { F2-M-ES: É o padre. }\end{array}$ \\
\hline $\begin{array}{l}\text { Acepções } \\
\text { registradas } \\
\text { nos } \\
\text { dicionários }\end{array}$ & $\begin{array}{l}\text { Bluteau (1712-1728): VIGAIRO, ou Vigario, ou Vicario. O que faz as } \\
\text { vezes, \& funçoens do Prelado na sua ausencia. Vigairo, Cura d'almas. } \\
\text { Morais Silva (1813): VIGÁRIO, s. m. O Cura d'almas. } \\
\text { Cunha (1997): vigário sm. 'orig. vicário' 'ext. padre que faz as vezes do } \\
\text { prelado, ou que substitui o pároco' XIII. } \\
\text { Ferreira (2004): vigário 3. Padre que substitui o pároco em uma } \\
\text { paróquia. } \\
\text { Houaiss (2007): vigário datação sXIII } 2.2 \text { padre que substitui o pároco } \\
\text { de uma paróquia. }\end{array}$ \\
\hline \multicolumn{2}{|c|}{$\begin{array}{l}\text { Analisando o contexto de uso da lexia vigário pelos entrevistados de Paranaguá, } \\
\text { constata-se ser bastante produtiva, mas com variação de significados. Para a maioria dos } \\
\text { informantes, principalmente da faixa II (F1-M-EF e F1-M-ES / seis da faixa II: F2-M-EP, } \\
\text { F2-H-EF, F2-M-EF, F2-M-EM, F2-H-ES, F2-M-ES), vigário é sinônimo de 'padre'. A } \\
\text { informante F2-M-EP respondeu que 'antes falavam que era padre', levando a entender que } \\
\text { hoje o item lexical vigário talvez tenha adquirido outro sentido. Outros três informantes } \\
\text { (F1-H-EM / F2-H-EP e F2-H-EM) associaram a unidade léxica vigário ao local 'igreja', à } \\
\text { 'pessoa que frequenta uma igreja' e ao 'título eclesiástico da igreja católica'. Já do is } \\
\text { informantes da faixa I atribuíram a vigário sentido pejorativo: (i) para a informante F1-M- } \\
\text { EM, vigário é sinônimo de 'vigarista'. Houaiss registra a entrada vigário atribuindo-lhe na } \\
\text { quinta acepção, a marca dialetal de regionalismo de Minas Gerais de uso informal e a } \\
\text { define: 'aquele que engana outrem com trapaças; vigarista, velhaco'; (ii) o informante F1- } \\
\text { H-EF recordou-se apenas da expressão idiomática: 'não caio no conto do vigário', cujo } \\
\text { significado é sinônimo de 'falcatrua e malandragem'. Constam dos lexicógrafos } \\
\text { pesquisados a acepção em estudo: 'padre que substitui o pároco'. }\end{array}$} \\
\hline
\end{tabular}


Analisando o contexto de fala da lexia vigário, verifica-se que nenhum dos informantes a reconheceu com o mesmo sentido documentado no corpus escrito. No entanto, a designação de 'padre' atribuída para a unidade lexical vigário foi o mais próximo da acepção investigada e esteve presente na fala de dois informantes da faixa I e seis da faixa II. Presume-se que, com o tempo, a acepção 'padre que substitui o pároco' para o item lexical vigário, foi se perdendo, restando apenas a sentido de 'padre', conhecido pelos informantes como sinônimo de vigário. Portanto, o item lexical vigário com o sentido da acepção documentada no corpus escrito não se encontra mais no contexto de fala dos informantes de Paranaguá, pressupondo, então, ser um caso de desuso.

\section{ADJETIVOS}

\begin{tabular}{|c|c|}
\hline \multicolumn{2}{|c|}{ 142. ABASTADO / DOC.47, fól.2r, 1.06-09 } \\
\hline $\begin{array}{l}\text { Acepção } \\
\text { buscada }\end{array}$ & Rico, possuidor de bens. \\
\hline $\begin{array}{l}\text { Acepção(ões) } \\
\text { conhecida(s) } \\
\text { pelos } \\
\text { informantes }\end{array}$ & $\begin{array}{l}\text { F1-H-EP: NSR. } \\
\text { F1-M-EP: NSR. } \\
\text { F1-H-EF: NSR. } \\
\text { F1-M-EF: NSR. } \\
\text { F1-H-EM: NSR. } \\
\text { F1-M-EM: NSR. } \\
\text { F1-H-ES: NSR. } \\
\text { F1-M-ES: NSR. } \\
\text { F2-H-EP: NSR. } \\
\text { F2-M-EP: NSR. } \\
\text { F2-H-EF: Bem de dinheiro. } \\
\text { F2-M-EF: É alguém que tem muitos bens. } \\
\text { F2-H-EM: Uma pessoa que tem muitas posses de terreno ou de dinheiro. } \\
\text { F2-M-EM: NSR. } \\
\text { F2-H-ES: Abastado é rico. } \\
\text { F2-M-ES: NSR. }\end{array}$ \\
\hline $\begin{array}{l}\text { Acepções } \\
\text { registradas } \\
\text { nos } \\
\text { dicionários }\end{array}$ & $\begin{array}{l}\text { Bluteau (1712-1728): ABASTADO. Homem abastado. Aquelle, que } \\
\text { tem, o que lhe basta. Bastantemente rico. } \\
\text { Morais Silva (1813): ABASTÁDO, part. Pass. de Abastar. Que tem o } \\
\text { que é bastante, e suficiente. } \\
\text { Cunha (1997): bastar } v b \text {. 'ser bastante, suficiente' 'satisfazer' | } \\
\text { abastado XIV. } \\
\text { Ferreira (2004): abastado } 2 \text {. Endinheirado, dinheiroso, rico, abastoso. } \\
\text { Houaiss (2007): abastado datação sXIV } 2 \text { rico, opulento. }\end{array}$ \\
\hline
\end{tabular}


A acepção em estudo 'rico, possuidor de bens' para a entrada abastado encontra-se registrada em Bluteau, Morais Silva, Ferreira e Houaiss. Analisando o contexto de uso da lexia abastado, verifica-se baixa produtividade. Dos dezesseis entrevistados, apenas quatro informantes da faixa II (F2-H-EF, F2-M-EF, F2-H-EM e F2-H-ES) reconheceram o item lexical abastado com o sentido da acepção buscada e outros doze informantes (oito da faixa I e quatro da faixa II) disseram não conhecê-lo.

Portanto, como a forma lexical abastado não foi reconhecida por nenhum dos informantes da faixa I e sua ocorrência esteve presente somente na fala de quatro informantes da faixa II, supõe tratar-se de um caso de tendência ao desuso.

\begin{tabular}{|c|c|}
\hline \multicolumn{2}{|c|}{ 143. ACOMETIDO / DOC.36, fól.1r, l.06-07 } \\
\hline $\begin{array}{l}\text { Acepção } \\
\text { buscada }\end{array}$ & Entregue, confiado. \\
\hline $\begin{array}{l}\text { Acepção(ões) } \\
\text { conhecida(s) } \\
\text { pelos } \\
\text { informantes }\end{array}$ & $\begin{array}{l}\text { F1-H-EP: NSR. } \\
\text { F1-M-EP: NSR. } \\
\text { F1-H-EF: NSR. } \\
\text { F1-M-EF: NSR. } \\
\text { F1-H-EM: NSR. } \\
\text { F1-M-EM: NSR. } \\
\text { F1-H-ES: NSR. } \\
\text { F1-M-ES: NSR. } \\
\text { F2-H-EP: NSR. } \\
\text { F2-M-EP: NSR. } \\
\text { F2-H-EF: É uma pessoa controlada. } \\
\text { F2-M-EF: NSR. } \\
\text { F2-H-EM: Quando alguém está doente, está acometida por uma } \\
\quad \text { enfermidade. } \\
\text { F2-M-EM: NSR. } \\
\text { F2-H-ES: No sentido que ele foi acometido de uma doença, ele foi } \\
\text { infectado, ele teve um mal súbito. } \\
\text { F2-M-ES: NSR. }\end{array}$ \\
\hline $\begin{array}{l}\text { Acepções } \\
\text { registradas } \\
\text { nos } \\
\text { dicionários }\end{array}$ & $\begin{array}{l}\text { Bluteau (1712-1728): ACOMETIDO. Provocado. Irritado. } \\
\text { Morais Silva (1813): ACOMMETTÍDO, part. pass. de Acommetter. } \\
\text { [ACOMMETTÈR, v. at. Assaltar, investir, principiar a batalha, } \\
\text { briga]. } \\
\text { Cunha (1997): N.D. } \\
\text { Ferreira (2004): N.D. } \\
\text { Houaiss (2007): acometido datação sXV } 5 \text { Derivação: sentido figurado. } \\
\quad \text { afetado, atacado (por doença, sentimento etc.). }\end{array}$ \\
\hline
\end{tabular}


Analisando o contexto de uso da lexia acometido constata-se baixa produtividade por parte dos informantes de Paranaguá. Dos dezesseis entrevistados, apenas três informantes da faixa II reconheceram a unidade lexical em estudo. $\mathrm{O}$ informante F2-H-EF atribuiu à lexia acometido o valor de 'pessoa controlada'. Outros dois informantes (F2-H-EM e F2H-ES) definiram acometido como 'alguém estar acometida por uma doença, uma enfermidade'. Houaiss registra esta definição na quinta acepção por derivação: sentido figurado: 'afetado, atacado (por doença, sentimento etc.)'. Não consta o registro da acepção buscada dos dicionários de Bluteau e Morais Silva. Cunha e Ferreira, por sua vez, não trazem o registro da unidade lexical acometido.

Considerando os dados analisados, constata-se que nenhum dos informantes da faixa I reconheceu o item lexical acometido, e os três informantes da faixa II a empregam com o sentido diferente da acepção investigada. Conclui-se, dessa forma, ser um caso de desuso.

\begin{tabular}{|c|c|}
\hline $\begin{array}{l}\text { Acepção } \\
\text { buscada }\end{array}$ & Instalado, alojado. \\
\hline $\begin{array}{l}\text { Acepção(ões) } \\
\text { conhecida(s) } \\
\text { pelos } \\
\text { informantes }\end{array}$ & $\begin{array}{l}\text { F1-H-EP: NSR. } \\
\text { F1-M-EP: Quando você vai para casa de alguém é fica bem acomodado } \\
\text { lá. } \\
\text { F1-H-EF: Pessoa tranquila, que se acomoda, fica acomodado e não faz } \\
\text { nada, é preguiçoso. } \\
\text { F1-M-EF: Aquela pessoa acomodada, que não sai do lugar, não faz nada. } \\
\text { F1-H-EM: Tem muita gente aqui acomodada e também ficar num lugar } \\
\text { acomodada, instalada. } \\
\text { F1-M-EM: Uma pessoa sossegada. } \\
\text { F1-H-ES: Sentido de preguiçoso, pessoa acomodada. } \\
\text { F1-M-ES: De acomodar-se, de se estabelecer em algum lugar. } \\
\text { F2-H-EP: Acomodado é a pessoa é muito paradão assim, fica } \\
\text { acomodado. } \\
\text { F2-M-EP: Um marido que não trabalho é acomodado. } \\
\text { F2-H-EF: Acomodado é bem pacata, calma, parada ela é cômoda. } \\
\text { F2-M-EF: Alguém tranquilo e também alguém que se acomoda no hotel. } \\
\text { F2-H-EM: É uma pessoa que ficou pacato, tem talento na vida, mas } \\
\text { ficou acomodada. } \\
\text { F2-M-EM: Fulano é acomodado, não quer nada com o serviço. } \\
\text { F2-H-ES: Acomodado é tranquilo. Também podemos pergunta se } \\
\text { alguém está bem acomodado, se está confortável, mesmo sentido de } \\
\text { estar instalado. }\end{array}$ \\
\hline
\end{tabular}




\begin{tabular}{|c|c|}
\hline & \\
\hline $\begin{array}{l}\text { s } \\
\text { as }\end{array}$ & $\begin{array}{l}\text { honestamente o que hà mister. Estou accomodao em caza do Conde, } \\
\text { etc. } \\
\text { Morais Silva (1813): ACCOMODÁDO, part. pass. de Accommodar. §. } \\
\text { Casa ; que tem commodos de vivenda. } \\
\text { Cunha (1997): comodidade } s f \text {. 'qualidade ou caráter do que é cômodo' | } \\
\text { acomodado } 1572 \text {. } \\
\text { Ferreira (2004): acomodado } 2 \text {. Tranquilo, quieto, sossegado. } \\
\text { Houaiss (2007): acomodado datação } 15702 \text { instalado, alojado. }\end{array}$ \\
\hline \multicolumn{2}{|c|}{$\begin{array}{l}\text { Analisando o contexto de utilização da lexia acomodado presente na fala dos } \\
\text { informantes de Paranaguá, constata-se que sua ocorrência é bastante produtiva. Dos } \\
\text { dezesseis entrevistados, nove informantes (quatro da faixa I e cinco da faixa II) atribuíram } \\
\text { à lexia acomodado as seguintes designações: 'preguiçoso', 'sossegado', 'não faz nada', } \\
\text { 'parada', 'não trabalha', 'pacata, 'calma' e 'cômoda'. Ferreira registra estas designações } \\
\text { na segunda acepção da entrada acomodado. Quanto à acepção buscada 'instalado } \\
\text { alojado', seis informantes reconheceram a unidade lexical acomodado com este sentido } \\
\text { (i) dois informantes F1-H-EP e F1-H-ES empregaram apenas com o sentido da acepção } \\
\text { em estudo; e (ii) quatro informantes (F1-H-EM / F2-M-EF, F2-H-ES e F2-M-ES) } \\
\text { empregaram com variação de significados: 'pessoa tranquila, não quer nada na vida' } \\
\text { 'instalado, alojado'. A acepção investigada encontra-se lexicalizada em Bluteau, Morais } \\
\text { Silva e Houaiss. Cunha e Ferreira, por sua vez, não trazem o registro da acepção em } \\
\text { estudo. } \\
\text { Analisando os dados apresentados, constata-se que a lexia acomodado com o sentido } \\
\text { da acepção investigada está perdendo forças para o emprego das demais acepções } \\
\text { empregadas pelos noves informantes (quatro da faixa I e cinco da faixa II). No estágio } \\
\text { atual de variação, a unidade lexical acomodado apresenta tendência ao desuso, uma vez } \\
\text { que, dos seis informantes da faixa I que a reconheceram, apenas do is a empregam com o } \\
\text { sentido documentado no corpus escrito. }\end{array}$} \\
\hline
\end{tabular}

\begin{tabular}{|l|l|}
\hline \multicolumn{1}{|l|}{ 145. AFETO / DOC.32, fól.1v, l.17-18 } \\
\hline $\begin{array}{l}\text { Acepção } \\
\text { buscada }\end{array}$ & Partidário, adepto. \\
\hline $\begin{array}{l}\text { Acepção(ões) } \\
\text { conhecida(s) } \\
\text { pelos }\end{array}$ & $\begin{array}{l}\text { F1-H-EP: Afeto é quando a gente gosta de alguém. } \\
\text { informantes }\end{array}$ \\
& $\begin{array}{l}\text { F1-H-EF: É carinho. } \\
\text { F1-M-EF: Afeto é carinho, atenção. } \\
\text { F1-H-EM: Afeto é gostar de alguém. }\end{array}$ \\
\hline
\end{tabular}




\begin{tabular}{|c|c|}
\hline & $\begin{array}{l}\text { F1-M-EM: Você querer expressar um sentimento. } \\
\text { F1-H-ES: NSR. } \\
\text { F1-M-ES: De amor, carinho. } \\
\text { F2-H-EP: NSR. } \\
\text { F2-M-EP: Eu tenho afeto por alguém, é gostar de alguém. } \\
\text { F2-H-EF: É carinho, sei lá amor. } \\
\text { F2-M-EF: É alguém que te faz um carinho, que gosta de você. } \\
\text { F2-H-EM: É um carinho. } \\
\text { F2-M-EM: Afeto é quanto eu gosto de alguém. } \\
\text { F2-H-ES: Carinho. } \\
\text { F2-M-ES: É querer bem a pessoa. }\end{array}$ \\
\hline $\begin{array}{l}\text { Acepções } \\
\text { registradas } \\
\text { nos } \\
\text { dicionários }\end{array}$ & $\begin{array}{l}\text { Bluteau (1712-1728): AFFECTO. Amor. Boa vontade. } \\
\text { Morais Silva (1813): AFFÉCTO, adj. Affeiçoado, que tem affeição a } \\
\quad \text { alguem. } \\
\text { Cunha (1997): afecção } s f . \mid \text { afeto }^{1} \text { adj. 'sujeito a, dependente de' } \\
\text { 'afeiçoado a' XVII. } \\
\text { Ferreira (2004): afeto }{ }^{2} \text { 2. Partidário, sectário. } \\
\text { Houaiss (2007): }{ }^{2} \text { afeto datação } 16111 \text { que demonstra inclinação ou } \\
\quad \text { estima por; afeiçoado, dedicado; partidário de, simpatizante. }\end{array}$ \\
\hline \multicolumn{2}{|c|}{$\begin{array}{l}\text { A busca da acepção 'partidário, adepto' para a lexia afeto, constatou o não } \\
\text { reconhecimento por parte de todos os entrevistados. Dos dezesseis informantes, treze } \\
\text { reconheceram esta lexia, mas com as seguintes designações: 'carinho', 'gostar de alguém', } \\
\text { 'querer bem', 'expressar um sentimento'. A acepção empregada pelos informantes refere- } \\
\text { se ao homônimo afeto registrado na primeira entrada dos dicionários de Cunha, Ferreira e } \\
\text { Houaiss, cuja etimo logia vem do lat. affectus, us, enquanto a acepção buscada 'partidário, } \\
\text { adepto' refere-se ao outro item lexical afeto, registrado na segunda entrada dos dicionários } \\
\text { de Ferreira e Houaiss, de procedência lat. affectus, a, um. } \\
\text { Analisando o contexto de uso da unidade lexical afeto e comparando com a acepção } \\
\text { investigada, presume tratar-se de uma lexia em desuso, visto que a ocorrência do item } \\
\text { lexical afeto registrada na fala dos treze informantes (seis da faixa I e sete da faixa II) } \\
\text { refere-se a seu homônimo, e não ao mesmo item lexical em estudo. }\end{array}$} \\
\hline
\end{tabular}

\begin{tabular}{|l|l|}
\hline \multicolumn{1}{|l|}{ 146. APONTADO / DOC.46, fól.1r, l.28-30 } \\
\hline $\begin{array}{l}\text { Acepção } \\
\text { buscada }\end{array}$ & Indicado, referido, citado. \\
\hline $\begin{array}{l}\text { Acepção(ões) } \\
\text { conhecida(s) }\end{array}$ & $\begin{array}{l}\text { F1-H-EP: Apontado pra nós, é quando aponta alguma pessoa, para } \\
\text { algum serviço. } \\
\text { F1-M-EP: Quando alguém é apontado para trabalhar em tal lugar. }\end{array}$ \\
\hline
\end{tabular}




\begin{tabular}{|c|c|}
\hline $\begin{array}{l}\text { pelos } \\
\text { informantes }\end{array}$ & $\begin{array}{l}\text { F1-H-EF: NSR. } \\
\text { F1-M-EF: Fulana foi apontada, de mostrar. } \\
\text { F1-H-EM: Apontado é uma pessoa que foi citada, alguém falou, foi } \\
\text { apontada ali. } \\
\text { F1-M-EM: Acusado. } \\
\text { F1-H-ES: Sentido de indicado. } \\
\text { F1-M-ES: De indicar alguém, algo. } \\
\text { F2-H-EP: Apontado é quando você aponta uma pessoa por qualquer } \\
\text { coisa. } \\
\text { F2-M-EP: Quando alguém é apontado por alguém para trabalhar em } \\
\text { algum serviço. } \\
\text { F2-H-EF: Uma pessoa que a gente indica para algum cargo, pode ser } \\
\text { apontado também. } \\
\text { F2-M-EF: Fulano foi apontado pra um trabalho, pra um cargo melhor. } \\
\text { F2-H-EM: Você vai fazer um concurso, fulano me apontou pra tal cargo, } \\
\text { me indicou. } \\
\text { F2-M-EM: NSR. } \\
\text { F2-H-ES: Apontado foi acusado, foi mostrado. } \\
\text { F2-M-ES: Quando alguém te aponta para um emprego, você é uma } \\
\text { pessoa apontada por ele. }\end{array}$ \\
\hline $\begin{array}{l}\text { Acepções } \\
\text { registradas } \\
\text { nos } \\
\text { dicionários }\end{array}$ & $\begin{array}{l}\text { Bluteau (1712-1728): APONTADO por este, ou por aquelle Author. } \\
\text { Morais Silva (1813): APONTÁDO, part. pass. de Apontar. } \S \text {. } \\
\text { Designado para cargo, officio. } \S . \text { Prevenido, e apontado para alguma } \\
\text { coisa. } \\
\text { Cunha (1997): N.D. } \\
\text { Ferreira (2004): apontado }{ }^{1} \text { 2. Mostrado, indicado, indigitado. } \\
\text { Houaiss (2007): }{ }^{1} \text { apontado datação sXV } 3 \text { indicado (por algum motivo } \\
\text { específico); designado, nomeado, citado. }\end{array}$ \\
\hline \multicolumn{2}{|c|}{$\begin{array}{l}\text { Analisando o contexto de utilização da lexia apontado pelos informantes parnanguaras, } \\
\text { constata-se ser bastante produtiva na fala dos entrevistados. A maior parte dos informantes } \\
\text { (cinco da faixa I e seis da faixa II) reconheceu o item lexical apontado com o mesmo } \\
\text { sentido da acepção buscada 'indicado, referido, citado'. Outros três informantes (F1-M-EF } \\
\text { e F1-M-EM / F2-H-ES) o reconheceram com variação de significado: 'mostrar' e 'acusar'. } \\
\text { Com relação à acepção em estudo, todos os lexicógrafos pesquisados (com exceção de } \\
\text { Cunha) trazem o seu registro para o item lexical apontado. } \\
\text { Levando em consideração os dados analisados, no estágio atual de variação com os } \\
\text { demais significados, há indícios de permanência da acepção buscada para esta unidade } \\
\text { lexical, presente no contexto de fala de onze informantes (cinco da faixa I e seis da faixa } \\
\text { II). Portanto, a lexia apontado revela tendência à manutencão. }\end{array}$} \\
\hline
\end{tabular}




\begin{tabular}{|c|c|}
\hline \multicolumn{2}{|c|}{ 147. ASSENTADO / DOC.13, fól.1r, l.09-11 } \\
\hline $\begin{array}{l}\text { Acepção } \\
\text { buscada }\end{array}$ & Estabelecido, decidido. \\
\hline $\begin{array}{l}\text { Acepção(ões) } \\
\text { conhecida(s) } \\
\text { pelos } \\
\text { informantes }\end{array}$ & $\begin{array}{l}\text { F1-H-EP: NSR. } \\
\text { F1-M-EP: NSR. } \\
\text { F1-H-EF: NSR. } \\
\text { F1-M-EF: NSR. } \\
\text { F1-H-EM: Assentar um terreno, tijolo. } \\
\text { F1-M-EM: NSR. } \\
\text { F1-H-ES: NSR. } \\
\text { F1-M-ES: NSR. } \\
\text { F2-H-EP: NSR. } \\
\text { F2-M-EP: Assentado é quando a gente se senta. } \\
\text { F2-H-EF: Assentado é, por exemplo: assentar um tijolo. } \\
\text { F2-M-EF: Assentou cerâmica, assentou o tijolo. } \\
\text { F2-H-EM: NSR. } \\
\text { F2-M-EM: É quando eu vou me assentar num lugar. } \\
\text { F2-H-ES: Assentar quer dizer juntar os processos num alto. } \\
\text { F2-M-ES: Assentado é quando a gente coloca as coisas todas em ordem, } \\
\quad \text { elas ficam todas assentadas. }\end{array}$ \\
\hline $\begin{array}{l}\text { Acepções } \\
\text { registradas } \\
\text { nos } \\
\text { dicionários }\end{array}$ & $\begin{array}{l}\text { Bluteau (1712-1728): ASSENTADO. Resolvido. Determinado. } \\
\text { Morais Silva (1813): ASSENTÁDO, p. pss. De ASSENTÁR, v. at. } \S \text {. } \\
\quad \text { Estabelecér. } \\
\text { Cunha (1997): assentar } v b \text {. 'apor, anotar' | assentado XIV. } \\
\text { Ferreira (2004): assentado 3. Firmado, resolvido, deliberado. } \\
\text { Houaiss (2007): assentado datação sXIII } 3 \text { estabelecido com firmeza; } \\
\quad \text { resolvido, decidido, fixado. }\end{array}$ \\
\hline \multicolumn{2}{|c|}{$\begin{array}{l}\text { Dentre as várias designações registradas nos dicionários pesquisados para a entrada } \\
\text { assentado, os lexicógrafos Bluteau, Morais Silva, Ferreira e Houaiss registraram a mesma } \\
\text { acepção documentada no corpus escrito: 'estabelecido, decidido'. Observando o contexto } \\
\text { de uso dessa lexia, verifica-se considerável frequência na fala dos entrevistados de } \\
\text { Paranaguá. Os sete informantes que reconheceram o item lexical assentado o empregam } \\
\text { com variação de significados: (i) três informantes (F1-H-EM / F2-H-EF e F2-M-EF) } \\
\text { atribuíram o sentido de assentar: 'um terreno', 'tijolo', 'cerâmica'. Para a entrada } \\
\text { assentado Ferreira registra na segunda acepção: 'colocar ou dispor de modo que fique } \\
\text { seguro'; (ii) duas informantes F2-M-EP e F2-M-EM atribuíram o sentido de 'sentar, } \\
\text { assentar num lugar'. Ferreira registra na primeira acepção: 'flexionar, ou fazer flexionar, } \\
\text { os membros inferiores, apoiando as nádegas e coxas em assento; assentar-se, sentar'; (iii) } \\
\text { já para o informante F2-H-ES 'assentar quer dizer juntar os processos num alto'; e (iv) } \\
\text { para a informante F2-M-ES 'Assentado é quando a gente coloca as coisas todas em }\end{array}$} \\
\hline
\end{tabular}


ordem, elas ficam todas assentadas'. Estas duas acepções não constam do registro dos dicionários pesquisados.

Analisando o contexto de uso desta lexia e comparando com as respostas dos informantes, constata-se a não ocorrência da acepção em estudo 'estabelecido, decidido' para o item lexical assentado, inferindo, dessa forma, ser um caso de desuso.

\begin{tabular}{|c|c|}
\hline \multicolumn{2}{|c|}{ 148. ASSOMBRADO / DOC.33, fól.1v, l.07-10 } \\
\hline $\begin{array}{l}\text { Acepção } \\
\text { buscada }\end{array}$ & Coberto, cheio de sombras. \\
\hline $\begin{array}{l}\text { Acepção(ões) } \\
\text { conhecida(s) } \\
\text { pelos } \\
\text { informantes }\end{array}$ & $\begin{array}{l}\text { F1-H-EP: Quando um lugar é assombrado, de medo. } \\
\text { F1-M-EP: Casa mal assombrada. } \\
\text { F1-H-EF: Medo, susto. } \\
\text { F1-M-EF: Casa assombrada. } \\
\text { F1-H-EM: Lugar mal assombrado. } \\
\text { F1-M-EM: Lugar vazio, mal assombrado. } \\
\text { F1-H-ES: Lugar assustado. } \\
\text { F1-M-ES: Assombrado de assombração. } \\
\text { F2-H-EP: Coisa de antiguidade, não vai naquele lugar que tem } \\
\text { assombração assombrado. } \\
\text { F2-M-EP: Lugar assombrado, de medo. } \\
\text { F2-H-EF: Assombrado é o lugar que é assombrado, só assim. } \\
\text { F2-M-EF: Assombrado é alguém medroso, que tem medo de tudo. Eu } \\
\text { sou muito assombrado. } \\
\text { F2-H-EM: NSR. } \\
\text { F2-M-EM: Conheço como casa assombrada, de medo. } \\
\text { F2-H-ES: Assombrado como assombração sim. Antigamente, nos textos } \\
\text { se encontravam as casas eram assombradadas porque tinha muita } \\
\text { sombra ou árvores na frente, mas só nos textos, não se usa como } \\
\text { sombra de árvore e nem com casa com sombra. } \\
\text { F2-M-ES: De vez em quando uso: tem um árvore assombrada naquele } \\
\text { lugar, cheia de sombras. }\end{array}$ \\
\hline $\begin{array}{l}\text { Acepções } \\
\text { registradas } \\
\text { nos } \\
\text { dicionários }\end{array}$ & $\begin{array}{l}\text { Bluteau (1712-1728): ASSOMBRADO. Espantado com medo. } \\
\text { Morais Silva (1813): ASSOMBRÁDO, p. pass. de Assombrar. Cheyo } \\
\quad \text { de sombra, por se metter em meyo coisa, que impida a luz. } \\
\text { Cunha (1997): N.D. } \\
\text { Ferreira (2004): assombrado } 1 \text {. Coberto de sombra; sombrio. } \\
\text { Houaiss (2007): assombrado datação sXIV } 1 \text { coberto de sombra. }\end{array}$ \\
\hline
\end{tabular}


Analisando o contexto de utilização da lexia assombrado pelos informantes parnanguaras, constata-se que sua ocorrência é bastante produtiva, pois do total de dezesseis entrevistados, houve apenas a não resposta do informante F2-H-EM. Quanto à acepção buscada 'coberto, cheio de sombras', apenas do is informantes (F2-M-ES e F2-HES) atribuíram o sentido da acepção documentada no corpus escrito para o item lexical assombrado. Porém, o informante F2-H-ES, além do reconhecimento de outro significado: 'asso mbração', salientou que o sentido de 'cheio de sombras' não se encontra mais em registros orais: 'Antigamente, nos textos se encontravam as casas eram assombradadas porque tinha muita sombra ou árvores na frente, mas só nos textos, não se usa como sombra de árvore e nem com casa com sombra'. Os outros treze informantes (oito da faixa I e cinco da faixa II) conhecem a lexia assombrado somente com o sentido de 'medo', 'terror', 'susto', 'assombração'. Em Bluteau há somente o registro desta acepção para a entrada assombrado. Já em Morais Silva, Ferreira e Houaiss consta do registro a designação 'coberto de sombra', 'cheio de sombra' para a unidade lexical em questão. Cunha não traz o registro do item lexical assombrado.

Analisando o contexto de utilização desta unidade lexical pelos informantes de Paranaguá e a acepção buscada, presume-se que, no estágio atual de variação, há o favorecimento da acepção 'medo', 'terror', 'susto', 'assombração' em detrimento da acepção documentada no corpus escrito, lembrada apenas por dois informantes da faixa II. Portanto, a unidade lexical assombrado no sentido de 'coberto, cheio de sombras' aponta tendência ao desuso.

\begin{tabular}{|l|l|}
\hline \multicolumn{1}{|l|}{$\begin{array}{l}\text { 149. BRIOSO / DOC.47, fól.3r, l.09-11 } \\
\text { buscada }\end{array}$} & Que tem brio, valoroso. \\
\hline $\begin{array}{l}\text { Acepção(ões) } \\
\text { conhecida(s) } \\
\text { pelos } \\
\text { informantes }\end{array}$ & F1-H-EP: NSR. \\
& F1-M-EP: NSR. \\
& F1-M-EF: NSR. NSR. \\
& F1-H-EM: NSR. \\
& F1-H-EM: NSR. NSR. \\
& F1-M-ES: NSR. \\
& F2-H-EP: NSR. \\
& F2-M-EP: NSR. \\
& F2-H-EF: NSR. \\
& F2-M-EF: NSR. \\
& F2-H-EM: Que tem garra. \\
& F2-M-EM: NSR. \\
\hline
\end{tabular}




\begin{tabular}{|l|l|}
\hline & $\begin{array}{l}\text { F2-H-ES: Brioso é tinhoso. } \\
\text { F2-M-ES: NSR. }\end{array}$ \\
\hline $\begin{array}{l}\text { Acepções } \\
\text { registradas } \\
\text { nos } \\
\text { dicionários }\end{array}$ & $\begin{array}{l}\text { Bluteau (1712-1728): BRIOSO. Cioso de seu credito, cuidadoso, \& } \\
\text { zeloso da sua honra. } \\
\text { Morais Silva (1813): BRIÒSO, adj. Dotado de briyo: diz-se das } \\
\text { pessoas, e suas acções, em que se mostra o briyo do animo. } \\
\text { Cunha (1997): brio } \text { sm. 'sentimento da própria dignidade' | brioso XIII. } \\
\text { Ferreira (2004): brioso 1. Que tem brio; pundonoroso. } \\
\text { Houaiss (2007): brioso datação sXIII que tem brio(s). }\end{array}$ \\
\hline
\end{tabular}

Brioso é uma lexia com escassa produtividade no contexto de fala dos informantes parnanguaras. Dos dezesseis entrevistados, apenas dois informantes da faixa II reconheceram a lexia, mas com significados distintos da acepção buscada 'que tem brio, valoroso'. Para o informante F2-H-EM 'brioso é quem tem garra'. E para o informante F2-H-ES 'brioso é tinhoso'. Estas acepções não constam do registro dos dicionários pesquisados. Os lexicógrafos Morais Silva, Ferreira e Houaiss registram a mesma acepção 'que tem brio', 'pundonoroso', 'dotado de brio' para a entrada brioso. Em Bluteau e Cunha não consta o registro da acepção em estudo.

Analisando os dados em questão, constatou-se que a unidade lexical brioso com o sentido da acepção investigada não se encontra mais registrada em contexto de fala dos entrevistados de Paranaguá, pressupondo, desta forma, tratar-se de um caso de desuso.

\begin{tabular}{|c|c|}
\hline \multicolumn{2}{|c|}{ 150. CABAL / DOC.01, fól.1v, l.02-03 } \\
\hline $\begin{array}{l}\text { Acepção } \\
\text { buscada }\end{array}$ & Completo, perfeito, pleno. \\
\hline $\begin{array}{l}\text { Acepção(ões) } \\
\text { conhecida(s) } \\
\text { pelos } \\
\text { informantes }\end{array}$ & $\begin{array}{l}\text { F1-H-EP: NSR. } \\
\text { F1-M-EP: NSR. } \\
\text { F1-H-EF: Pessoa que é completa em tudo, é perfeita. } \\
\text { F1-M-EF: NSR. } \\
\text { F1-H-EM: NSR. } \\
\text { F1-M-EM: NSR. } \\
\text { F1-H-ES: NSR. } \\
\text { F1-M-ES: NSR. } \\
\text { F2-H-EP: NSR. } \\
\text { F2-M-EP: NSR. } \\
\text { F2-H-EF: NSR. } \\
\text { F2-M-EF: NSR. } \\
\text { F2-H-EM: Tem integridade. } \\
\text { F2-M-EM: NSR. }\end{array}$ \\
\hline
\end{tabular}




\begin{tabular}{|c|c|}
\hline & $\begin{array}{l}\text { F2-H-ES: Cabal é uma coisa normal, uma coisa cabal, não usa mais } \\
\text { também. } \\
\text { F2-M-ES: NSR. }\end{array}$ \\
\hline $\begin{array}{l}\text { Acepções } \\
\text { registradas } \\
\text { nos } \\
\text { dicionários }\end{array}$ & $\begin{array}{l}\text { Bluteau (1712-1728): CABAL. Pêrfeyto, o a que naõ falta nada para a } \\
\text { perfeyçaõ. } \\
\text { Morais Silva (1813): CABÁL, adj. Perfeito, completo. } \\
\text { Cunha (1997): cabo } s m \mid \text { acabado adj. 'pronto, perfeito' | cabal XVII. } \\
\text { Ferreira (2004): cabal 1. Completo, pleno, inteiro, perfeito. } \\
\text { Houaiss (2007): cabal datação } 1697 \text { que vai ou chega ao fim; que é ou } \\
\quad \text { está como deve ser; completo, inteiro, pleno. }\end{array}$ \\
\hline \multicolumn{2}{|c|}{$\begin{array}{l}\text { A lexia cabal em contexto de fala apresentou baixa produtividade por parte dos } \\
\text { informantes parnanguaras. Dos dezesseis entrevistados, apenas três informantes } \\
\text { reconheceram essa unidade léxica. Para o informante F2-H-EM, cabal refere-se à } \\
\text { 'integridade'. Já para o informante F2-H-ES, 'Cabal é uma coisa normal, uma coisa } \\
\text { cabal, não usa mais também'. Sua resposta, apesar de ser um tanto genérica quanto ao } \\
\text { significado da lexia cabal, traz a informação de que cabal não é mais usada em contexto } \\
\text { de fala em Paranaguá. Quanto à acepção buscada 'completo, perfeito, pleno', o informante } \\
\text { F1-H-EF foi o único que reconheceu este sentido no item lexical cabal. As designações } \\
\text { registradas nos dicionários pesquisados para a entrada cabal evidenciam o mesmo sentido } \\
\text { documentado no corpus escrito. } \\
\text { Considerando os dados analisados, supõe-se, pela escassa produtividade do item lexical } \\
\text { cabal em contexto de fala, ser um caso de tendência ao desuso, pois treze informantes } \\
\text { (sete da faixa I e seis da faixa II) disseram não conhecer essa unidade léxica. }\end{array}$} \\
\hline
\end{tabular}

\begin{tabular}{|c|c|}
\hline \multicolumn{2}{|c|}{ 151. DE BOA NOTA / DOC.46, fól.1r, l.08-11 } \\
\hline $\begin{array}{l}\text { Acepção } \\
\text { buscada }\end{array}$ & Alguém experiente, reconhecido. \\
\hline $\begin{array}{l}\text { Acepção(ões) } \\
\text { conhecida(s) } \\
\text { pelos } \\
\text { informantes }\end{array}$ & $\begin{array}{l}\text { F1-H-EP: NSR. } \\
\text { F1-M-EP: Quando o aluno tem boa nota na escola. } \\
\text { F1-H-EF: Inteligente. } \\
\text { F1-M-EF: Nota boa na escola. } \\
\text { F1-H-EM: Aluno que tem boa nota. } \\
\text { F1-M-EM: Que tira boas notas na escola. } \\
\text { F1-H-ES: NSR. } \\
\text { F1-M-ES: NSR. } \\
\text { F2-H-EP: NSR. } \\
\text { F2-M-EP: NSR. } \\
\text { F2-H-EF: Boa nota, excelente, uma pessoa excelente. }\end{array}$ \\
\hline
\end{tabular}




\begin{tabular}{|c|c|}
\hline & $\begin{array}{l}\text { F2-M-EF: NSR. } \\
\text { F2-H-EM: Alguém que tirou nota máxima na escola. } \\
\text { F2-M-EM: NSR. } \\
\text { F2-H-ES: De bom dinheiro, mas não uso. } \\
\text { F2-M-ES: Fulano de boa nota é uma pessoa que vive de bem com a vida. }\end{array}$ \\
\hline $\begin{array}{l}\text { Acepções } \\
\text { registradas } \\
\text { nos } \\
\text { dicionários }\end{array}$ & $\begin{array}{l}\text { Bluteau (1712-1728): N.D. } \\
\text { Morais Silva (1813): N.D. } \\
\text { Cunha (1997): N.D. } \\
\text { Ferreira (2004): N.D. } \\
\text { Houaiss (2007): N.D. }\end{array}$ \\
\hline
\end{tabular}

A expressão de boa nota não está registrada nos dicionários pesquisados e nem possui locuções semelhantes que possam indicar caso de variação lexical. Analisando o contexto de uso dessa expressão, verifica-se que a maior parte dos informantes da faixa I associou o sentido 'de boa nota' com as notas obtidas por meio de avaliações aplicadas em escolas. Parece que, neste caso, a expressão de boa nota passou a significar, em contexto escolar, por processo de derivação de extensão de sentido, um aluno que 'tem boa nota', 'tira boa nota'. Os demais informantes atribuíram a esta expressão outros significados distintos: F1H-EF: 'Inteligente'; F2-H-EF: 'Boa nota, excelente, uma pessoa excelente'; F2-H-ES: 'De bom dinheiro, mas não uso'; F2-M-ES: 'Fulano de boa nota é uma pessoa que vive de bem com a vida'.

Considerando os dados apresentados, constata-se que, apesar de cinco informantes da faixa I e quatro da faixa II reconhecerem a expressão de boa nota, o significado atribuído por eles não é o mesmo evidenciado no corpus escrito. Presume-se, então, ser um caso de desuso.

\begin{tabular}{|l|l|}
\hline \multicolumn{2}{|l|}{ 152. DECOROSO / DOC.10, fól.1v, l.02-06 } \\
\hline $\begin{array}{l}\text { Acepção } \\
\text { buscada }\end{array}$ & Digno, honrado, decente. \\
\hline $\begin{array}{l}\text { Acepção(ões) } \\
\text { conhecida(s) } \\
\text { pelos } \\
\text { informantes }\end{array}$ & $\begin{array}{l}\text { F1-H-EP: NSR. } \\
\text { F1-MP: Quando você decora um lugar, faz desenhos bonitos, você } \\
\text { F1-H-EF: NSR. } \\
\end{array}$ \\
& $\begin{array}{l}\text { F1-M-EF: NSR. } \\
\text { F1-H-EM: NSR. } \\
\text { F1-M-EM: NSR. } \\
\text { F1-H-ES: NSR. } \\
\text { F1-M-ES: NSR. }\end{array}$ \\
\end{tabular}




\begin{tabular}{|c|c|}
\hline & $\begin{array}{l}\text { F2-H-EP: NSR. } \\
\text { F2-M-EP: NSR. } \\
\text { F2-H-EF: NSR. } \\
\text { F2-M-EF: Alguém que estuda muito. } \\
\text { F2-H-EM: NSR. } \\
\text { F2-M-EM: NSR. } \\
\text { F2-H-ES: NSR. } \\
\text { F2-M-ES: É uma pessoa que gosta de fazer decoração, tudo ele decora, } \\
\quad \text { faz desenhos. }\end{array}$ \\
\hline $\begin{array}{l}\text { Acepções } \\
\text { registradas } \\
\text { nos } \\
\text { dicionários }\end{array}$ & $\begin{array}{l}\text { Bluteau (1712-1728): DECOROSO. Modesto. } \\
\text { Morais Silva (1813): DECORÒSO, adj. Conforme ao decóro, honroso, } \\
\text { decente. } \\
\text { Cunha (1997): decoro sm. 'decência, honra, pundonor' | decoroso } \\
\text { XVII. } \\
\text { Ferreira (2004): decoroso 1. Conforme ao decoro; decente, honesto, } \\
\text { digno. } \\
\text { Houaiss (2007): decoroso datação } 1647 \text { de conformidade com o } \\
\text { decoro; decente, digno, honrado. }\end{array}$ \\
\hline \multicolumn{2}{|c|}{$\begin{array}{l}\text { Analisando o contexto de uso da unidade lexical decoroso, verifica-se que seu emprego } \\
\text { na modalidade oral é de baixa produtividade. Dos dezesseis entrevistados, apenas três } \\
\text { informantes reconheceram essa lexia. Dois informantes (F1-M-EP / F2-M-ES) associaram } \\
\text { a forma léxica decoroso a alguém que 'decora um lugar', 'fazer desenhos', 'faz } \\
\text { decorações'. Esta acepção reconhecida por estes informantes refere-se ao item lexical } \\
\text { decorar de procedência latina: decorare. Já a informante F2-M-EF definiu decoroso como } \\
\text { 'alguém que estuda muito'. Este conceito refere-se ao homônimo decorar, também de } \\
\text { origem latina: de cor + ar. Os lexicógrafos Bluteau, Morais Silva, Ferreira e Houaiss } \\
\text { registram a designação de decoroso com o mesmo sentido da acepção em estudo 'digno, } \\
\text { honrado, decente'. } \\
\text { Considerando os dados em análise, presume-se que a unidade lexical decoroso é } \\
\text { desconhecida pela maioria dos entrevistados e seu uso na modalidade oral encontra-se } \\
\text { em desuso. }\end{array}$} \\
\hline
\end{tabular}

\begin{tabular}{|l|l|}
\hline \multicolumn{2}{|l|}{ 153. DEPOSTO / DOC.03, fól.1v, l.24-27 } \\
\hline $\begin{array}{l}\text { Acepção } \\
\text { buscada }\end{array}$ & Destituído do cargo, demitido. \\
\hline $\begin{array}{l}\text { Acepção(ões) } \\
\text { conhecida(s) }\end{array}$ & F1-H-EP: NSR. \\
pelos & F1-M-EP: NSR. \\
informantes & F1-M-EF: Quando alguém é tirado de um lugar. \\
\hline
\end{tabular}




\begin{tabular}{|c|c|}
\hline & $\begin{array}{l}\text { F1-H-EM: NSR. } \\
\text { F1-M-EM: NSR. } \\
\text { F1-H-ES: NSR. } \\
\text { F1-M-ES: NSR. } \\
\text { F2-H-EP: NSR. } \\
\text { F2-M-EP: NSR. } \\
\text { F2-H-EF: Deposto é quando é tirado de algum lugar. } \\
\text { F2-M-EF: Mandado embora, despedido. } \\
\text { F2-H-EM: Alguém que tinha um lugar, um posto, um cargo e foi } \\
\quad \text { deposto, demitido. } \\
\text { F2-M-EM: NSR. } \\
\text { F2-H-ES: Deposto foi tirado, destituído. } \\
\text { F2-M-ES: NSR. }\end{array}$ \\
\hline $\begin{array}{l}\text { Acepções } \\
\text { registradas } \\
\text { nos } \\
\text { dicionários: }\end{array}$ & $\begin{array}{l}\text { Bluteau (1712-1728): DEPOSTO. Privado do officio, da dignidade. } \\
\text { Morais Silva (1813): DEPÒSTO, p. pass. de Depòr. Privados do officio. } \\
\text { Cunha (1997): depor } v b \text {. 'pôr de lado, despojar de cargo' } \mid \text { deposto } \mid \\
\quad \text { XVI. } \\
\text { Ferreira (2004): N.D. } \\
\text { Houaiss (2007): deposto datação sXIV } 1.1 \text { destituído de cargo ou } \\
\quad \text { dignidade; desempossado. }\end{array}$ \\
\hline \multicolumn{2}{|c|}{$\begin{array}{l}\text { Dos dezesseis entrevistados, sete informantes reconheceram a lexia deposto com o } \\
\text { mesmo sentido da acepção em estudo 'destituído do cargo, demitido'. Para a entrada } \\
\text { deposto, os lexicógrafos Bluteau e Morais Silva trazem uma definição próxima do sentido } \\
\text { documentado no corpus escrito: 'privado do ofício, da dignidade'. Consta do registro de } \\
\text { Houaiss a designação 'destituído do cargo ou dignidade'. Em Ferreira não consta do } \\
\text { registro a unidade lexical deposto. } \\
\text { Analisando o contexto de uso deste item lexical com as respostas dos entrevistados, } \\
\text { verificou-se que a acepção 'destituído do cargo, demitido' foi empregada por apenas um } \\
\text { informante da faixa I, os demais não souberam responder, supondo-se, dessa forma, ser } \\
\text { um caso de tendência ao desuso. }\end{array}$} \\
\hline
\end{tabular}

\begin{tabular}{|l|l|}
\hline \multicolumn{2}{|l|}{ 154. DERROGADO / DOC.27, fól.1r, l.11-14 } \\
\hline $\begin{array}{l}\text { Acepção } \\
\text { buscada }\end{array}$ & Sem validade, anulado. \\
\hline $\begin{array}{l}\text { Acepção(ões) } \\
\text { conhecida(s) }\end{array}$ & F1-H-EP: NSR. \\
pelos & F1-M-EP: NSR. \\
informantes & F1-M-EF: NSR. \\
\hline
\end{tabular}




\begin{tabular}{|c|c|}
\hline & $\begin{array}{l}\text { F1-H-EM: NSR. } \\
\text { F1-M-EM: NSR. } \\
\text { F1-H-ES: NSR. } \\
\text { F1-M-ES: NSR. } \\
\text { F2-H-EP: NSR. } \\
\text { F2-M-EP: NSR. } \\
\text { F2-H-EF: NSR. } \\
\text { F2-M-EF: NSR. } \\
\text { F2-H-EM: NSR. } \\
\text { F2-M-EM: NSR. } \\
\text { F2-H-ES: NSR. } \\
\text { F2-M-ES: NSR. }\end{array}$ \\
\hline $\begin{array}{l}\text { Acepções } \\
\text { registradas } \\
\text { nos } \\
\text { dicionários: }\end{array}$ & $\begin{array}{l}\text { Bluteau (1712-1728): [DEROGAR. (Termo forense) Desfazer a ley em } \\
\text { parte. } \\
\text { Morais Silva (1813): DEROGÁDO, p. pass. de Derogar. [DEROGÁR, } \\
\text { v. at. Annullar, abolir algum capitulo, ou sentença da Lei. } \\
\text { Cunha (1997): N.D. } \\
\text { Ferreira (2004): [derrogar 1. Anular, abolir]. } \\
\text { Houaiss (2007): [derrogar } 3.1 \text { tornar nulo; invalidar, desfazer, } \\
\text { suprimir]. }\end{array}$ \\
\hline \multicolumn{2}{|c|}{$\begin{array}{l}\text { Dos dezesseis entrevistados, todos disseram desconhecer a lexia derrogado. Quanto ao } \\
\text { registro dessa unidade léxica nos dicionários pesquisados, consta apenas em Morais Silva } \\
\text { a forma derogado como particípio passado de derogar. Os demais dicionaristas (com } \\
\text { exceção de Cunha) registraram as designações: 'desfazer a lei em parte', 'anular', 'tornar } \\
\text { nulo', 'invalidar', 'desfazer' para a entrada derrogado. } \\
\text { Supõe-se, pela falta de registro da forma lexical derrogado nos dicionários pesquisados } \\
\text { (com exceção de Morais Silva) e pela não ocorrência desta lexia no contexto de fala dos } \\
\text { informantes parnanguaras, que seu resquício encontra-se registrado em textos datados de } \\
\text { séculos anteriores. Portanto, derrogado, sem nenhuma ocorrência na modalidade oral dos } \\
\text { informantes de Paranaguá, configura um caso de desuso. }\end{array}$} \\
\hline
\end{tabular}

\begin{tabular}{|l|l|}
\hline \multicolumn{2}{|l|}{ 155. DESCONCERTADO / DOC.32, fól.1r, l.31-33 } \\
\hline $\begin{array}{l}\text { Acepção } \\
\text { buscada }\end{array}$ & Confuso, desordenado. \\
\hline $\begin{array}{l}\text { Acepção(ões) } \\
\text { conhecida(s) }\end{array}$ & $\begin{array}{l}\text { F1-H-EP: NSR. } \\
\text { pelos } \\
\text { informantes }\end{array}$ \\
$\begin{array}{l}\text { F1-H-EP: NSR. Pessoa confusa, não tá bem orientada. } \\
\text { F1-M-EF: Quando você tá sem jeito de alguma coisa, atrapalhado. }\end{array}$ \\
\hline
\end{tabular}




\begin{tabular}{|c|c|}
\hline & $\begin{array}{l}\text { F1-H-EM: Uma pessoa desconcertada é que não tem juízo, meio louca. } \\
\text { F1-M-EM Envergonhado, encabulado. } \\
\text { F1-H-ES: Sentido de envergonhado. } \\
\text { F1-M-ES: Confuso, meio desordenado. } \\
\text { F2-H-EP: Quando um troço num tá bem feito, num tá bem consertado } \\
\text { ainda. } \\
\text { F2-M-EP: É alguém confuso. } \\
\text { F2-H-EF: NSR. } \\
\text { F2-M-EF: Algo que quebrou. } \\
\text { F2-H-EM: Um pessoa desregrada na vida, sem moral. } \\
\text { F2-M-EM: NSR. } \\
\text { F2-H-ES: Esse usa muito, num sentido que ele tá todo mal arrumado, tá } \\
\text { torto, quebrado, esse sentido. } \\
\text { F2-M-ES: Desconcertada é quando a gente fica confusa, embaralhada. }\end{array}$ \\
\hline $\begin{array}{l}\text { Acepções } \\
\text { registradas } \\
\text { nos } \\
\text { dicionários }\end{array}$ & $\begin{array}{l}\text { Bluteau (1712-1728): DESCONCERTADO. Posto sem ordem. Homem } \\
\text { desconcertado, como aquelle que não trata do aceo da sua pessoa, \& } \\
\text { anda com o cabello empeçado; a volta suja, a meya arrugada. } \\
\text { Morais Silva (1813): DESCONCERTÁDO, p. pass. de Desconcertar. } \\
\text { [DESCONCERTÁR. V. at. §. Desconcertar, n. não fallar certo, como } \\
\text { quem está fora de seu siso. } \\
\text { Cunha (1997): N.D. } \\
\text { Ferreira (2004): desconcertado 2. Embaraçado, contrafeito, perturbado, } \\
\text { sem jeito. } \\
\text { Houaiss (2007): desconcertado datação sXV } 3 \text { cheio de embaraço; } \\
\text { atrapalhado, confuso. }\end{array}$ \\
\hline \multicolumn{2}{|c|}{$\begin{array}{l}\text { Analisando o contexto de uso da lexia desconcertado pelos entrevistados de Paranaguá, } \\
\text { registra-se o emprego de variação de significados: (i) os informantes (F1-M-EM e F1-H- } \\
\text { ES) atribuíram o valor de 'envergonhado' e 'encabulado'; (ii) o informante F1-H-EM } \\
\text { atribuiu a qualidade de insano: 'não tem juízo', 'meio louca'; (iii) para o informante F2-H- } \\
\text { EP: 'desconcertado é quando um troço num tá bem feito, num tá bem consertado ainda'; } \\
\text { (iii) para a informante F2-M-EF: 'desconcertado é algo que quebrou'; (iv) o informante } \\
\text { F2-H-EM atribuiu a qualidade de 'desregrada' e 'sem moral'; (i) para o informante F2-H- } \\
\text { ES desconcertado no sentido de 'tá todo mal arrumado' se usa muito em Paranaguá. } \\
\text { Quanto à acepção em estudo, 'confuso, desordenado', cinco informantes (F1-H-EF, F1- } \\
\text { M-EF e F1-M-ES/ F2-M-EP e F2-M-ES) atribuíram à lexia desconcertado esse sentido. } \\
\text { Consta do registro da acepção investigada nos dicionários pesquisados (com exceção de } \\
\text { Cunha). } \\
\text { Analisando o contexto de fala da unidade lexical desconcertado, constata-se que } \\
\text { apenas cinco informantes (três da faixa I e do is da faixa II) empregam essa lexia com o } \\
\text { mesmo sentido documentado no corpus escrito. Os demais informantes (três da faixa I e } \\
\text { quatro da faixa II) empregaram desconcertado com variação de significados. No estágio }\end{array}$} \\
\hline
\end{tabular}


atual de variação entre essas várias designações, presume-se que o item lexical desconcertado com o sentido de 'confuso, desordenado', apresenta tendência ao desuso.

\begin{tabular}{|c|c|}
\hline \multicolumn{2}{|c|}{ 156. DILATADO / DOC.12, fól.1v, l.08-09 } \\
\hline $\begin{array}{l}\text { Acepção } \\
\text { buscada }\end{array}$ & Longo, vasto, extenso. \\
\hline $\begin{array}{l}\text { Acepção(ões) } \\
\text { conhecida(s) } \\
\text { pelos } \\
\text { informantes }\end{array}$ & $\begin{array}{l}\text { F1-H-EP: Uma pessoa muito magra, é uma pessoa que tá dilatada. } \\
\text { F1-M-EP: NSR. } \\
\text { F1-H-EF: NSR. } \\
\text { F1-M-EF: NSR. } \\
\text { F1-H-EM: Conheço o estômago dilatado. } \\
\text { F1-M-EM: Pupila dilatada. } \\
\text { F1-H-ES: NSR. } \\
\text { F1-M-ES: De aumentar. } \\
\text { F2-H-EP: Dilatado aqui é uma peça de qualquer coisa, já tá dilatado. } \\
\text { F2-M-EP: NSR. } \\
\text { F2-H-EF: Quando tem uma peça, alguma coisa que tá maior que o } \\
\text { tamanho normal, dilatado. } \\
\text { F2-M-EF: NSR. } \\
\text { F2-H-EM: Algo que está elástico. } \\
\text { F2-M-EM: NSR. } \\
\text { F2-H-ES: Dilatado usa quando o calor dilata, mas nesse sentido de } \\
\text { dilatar. } \\
\text { F2-M-ES: Dilatado é longo, comprido. }\end{array}$ \\
\hline $\begin{array}{l}\text { Acepções } \\
\text { registradas } \\
\text { nos } \\
\text { dicionários }\end{array}$ & $\begin{array}{l}\text { Bluteau (1712-1728): DILATADO. Comprido, largo, cousa que dura } \\
\text { muito tempo. } \\
\text { Morais Silva (1813): DILATÁDO, p. pass. de Dilatar. [DILATÁR, v. } \\
\text { at. §. Allongar, fazer longo. §. Prolongar em tempo. §. Estender } \\
\text { largamente. } \\
\text { Cunha (1997): dilatar } v b \text {. 'aumentar as dimensões ou o volume de, } \\
\text { estender, espalhar, demorar' | dilatado } 1813 . \\
\text { Ferreira (2004): dilatado } 1 \text {. Amplo, largo, extenso. } \\
\text { Houaiss (2007): dilatado datação sXV } 1 \text { que se ampliou; largo, longo, } \\
\text { extenso. }\end{array}$ \\
\hline $\begin{array}{l}\text { Analisanc } \\
\text { o emprę } \\
\text { sponderan } \\
\text { spostas, f }\end{array}$ & $\begin{array}{l}\text { ntexto de uso da lexia dilatado pelos entrevistados de Paranaguá, no } \\
\text { variação de significados: (i) os informantes F1-H-EM e F1-M- H } \\
\text { as 'estômago dilatado' e 'pupila dilatada'. Em seguida a es } \\
\text { perguntado qual o significado de dilatado e os informantes r }\end{array}$ \\
\hline
\end{tabular}


souberam responder; (ii) o informante F1-H-ES respondeu apenas que dilatado é 'quando o calor dilata'; (iii) a informante F2-H-EM definiu como 'algo elástico'; e (iv) para o informante F1-H-EP dilatada é 'uma pessoa que tá magra'. Enfim, as definições apresentadas pelos informantes acima referem-se a definições vagas, e não constam do registro de nenhum dos dicionários pesquisados. Já os informantes F2-H-EP e F2-H-EM reconheceram o item lexical dilatado como uma 'peça de qualquer/alguma coisa que tá maior que o tamanho normal, tá dilatada'. Parece que estes informantes fizeram uso do sentido figurado, no qual o significado de dilatado se ampliou para o contexto de uma peça muito usada e gasta. Quanto à acepção buscada 'longo, vasto, extenso, duradouro', apenas do is informantes (F1-M-ES e F2-M-ES) atribuíram este valor à unidade lexical dilatado. A acepção em estudo encontra-se registrada pelos lexicógrafos pesquisados.

Analisando o contexto de uso da lexia dilatado, constata-se que somente dois informantes (um da faixa I e um da faixa II) empregaram este item lexical com o mesmo sentido documentado no corpus escrito. Os demais informantes (três da faixa I e quatro da faixa II) a reconheceram com variação de significados. No estágio atual de variação entre essas várias deginações, presume-se que a unidade léxica dilatado com o sentido de 'longo, vasto, extenso' apresentada tendência ao desuso.

\begin{tabular}{|l|l|}
\hline \multicolumn{2}{|l|}{ 157. DIMINUTO / DOC.31, fól.1r, l.09-12 } \\
\hline $\begin{array}{l}\text { Acepção } \\
\text { buscada }\end{array}$ & Insuficiente, reduzido. \\
\hline $\begin{array}{l}\text { Acepção(ões) } \\
\text { conhecida(s) } \\
\text { pelos } \\
\text { informantes }\end{array}$ & $\begin{array}{l}\text { F1-H-EP: NSR. } \\
\text { F1-M-EP: NSR. } \\
\text { F1-M-EF: É diminuir, reduzir. } \\
\text { F1-H-EM: NSR. } \\
\text { F1-M-EM: NSR. } \\
\text { F1-H-ES: É pequeno. } \\
\text { F1-M-ES: De diminuir, encurtar alguma coisa. } \\
\\
\text { F2-H-EP: Quando é muito pequeno. } \\
\text { F2-M-EP: NSR. } \\
\text { F2-H-EF: Quando é muito pequeno. } \\
\text { F2-M-EF: NSR. } \\
\text { F2-H-EM: NSR. } \\
\text { F2-M-EM: NSR. } \\
\text { F2-H-ES: NSR. } \\
\text { F2-M-ES: NSR. }\end{array}$ \\
\hline
\end{tabular}




\begin{tabular}{|l|l|}
\hline $\begin{array}{l}\text { Acepções } \\
\text { registradas } \\
\text { nos } \\
\text { dicionários }\end{array}$ & $\begin{array}{l}\text { Bluteau (1712-1728): DIMINUTO. Falto, não inteiro. } \\
\text { Morais Silva (1813): DIMINUTO, adj. Falto de alguma parte. §. Obra } \\
\text { diminuta, falta do necessario para sua inteireza. } \\
\text { Cunha (1997): diminuir vb. 'tornar menor, reduzir a menos, encurtar, } \\
\text { encolher' | diminuto XVII. } \\
\text { Ferreira (2004): diminuto 2. Muito pouco. } \\
\text { Houaiss (2007): diminuto datação } 16442 \text { em pouquíssima quantidade; } \\
\text { reduzido. }\end{array}$ \\
\hline $\begin{array}{l}\text { Analisando o contexto de uso da lexia diminuto verifica-se baixa produtividade na fala } \\
\text { dos entrevistados. Dos dezesseis informantes, cinco reconheceram o item lexical diminuto. }\end{array}$ \\
$\begin{array}{l}\text { I (F1-H-EF e F1-M-ES) atribuíram este significado à lexia diminuto. Os outros três } \\
\text { informantes (F1-H-ES / F2-H-EP e F2-H-EF) atribuíram o valor de 'pequeno/muito } \\
\text { pequeno'. As definições apresentadas pelos lexicógrafos evidenciam o mesmo sentido da } \\
\text { acepção investigada. } \\
\text { Considerando os dados em análise, pressupõe-se que a unidade lexical diminuto com o } \\
\text { significado da acepção 'insuficiente, reduzido', revela tendência ao desuso, pois somente } \\
\text { dois informantes da faixa I (F1-H-EF e F1-M-ES ) a utilizam em contexto de fala. }\end{array}$ \\
\hline
\end{tabular}

\begin{tabular}{|l|l|}
\hline 158. EMBRENHADO / DOC.13, fól.1r, l.14-17 \\
\hline $\begin{array}{l}\text { Acepção } \\
\text { buscada }\end{array}$ & Escondido, metido dentro de matos. \\
\hline $\begin{array}{l}\text { Acepção(ões) } \\
\text { ponhecida(s) } \\
\text { pelos } \\
\text { informantes }\end{array}$ & $\begin{array}{l}\text { F1-H-EP: NSR. } \\
\text { F1-M-EP: NSR. } \\
\text { F1-H-EF: NSR. } \\
\text { F1-H-EM: Embrenhado no meio do mato, tá escondido. } \\
\text { F1-M-EM: Embrenhado no meio do mato, você não sai de lá. } \\
\text { F1-H-ES: Embrenhado no mato, sempre ouço e falo. } \\
\text { F1-M-ES: Embrenhado no mato, fica lá no meio do mato. } \\
\text { F2-H-EP: Pra nós aqui é diferente a palavra, fala tá perdido. } \\
\text { F2-M-EP: Quando alguém fica embranhado no mato. } \\
\text { F2-H-EF: Quando tá escondido, uma pessoa que tá escondida, foge daí, } \\
\text { se embrenha. } \\
\text { F2-M-EF: Embrenhou pelo mato. } \\
\text { F2-H-EM: Se usa se lançar no mato, embrenhado no mato. } \\
\text { F2-M-EM: NSR. } \\
\text { F2-H-ES: Quando entra no mato, se embrenha. } \\
\text { F2-M-ES: Embrenhado é você se esconder no mato, como os bandidos. }\end{array}$ \\
\hline
\end{tabular}




\begin{tabular}{|c|c|}
\hline $\begin{array}{l}\text { Acepções } \\
\text { registradas } \\
\text { nos } \\
\text { dicionários }\end{array}$ & $\begin{array}{l}\text { Bluteau (1712-1728): [EMBRENHARSE. Metterse em huma brenha, } \\
\text { ou num mato, muyto para dentro] } \\
\text { Morais Silva (1813): EMBRENHÁDO, p. pass. de Embrenhar-se. } \\
\text { Embrenhado nos matos. [EMBRENHÁR, v. at. Metter, esconder por } \\
\text { dentro de brenha, mato, ou bosque]. } \\
\text { Cunha (1997): N.D. } \\
\text { Ferreira (2004): [embrenhar 1. Meter, esconder (nas brenhas, no } \\
\text { mato)]. } \\
\text { Houaiss (2007): embrenhado datação sXV } 1 \text { que se embrenhou; } \\
\text { escondido dentro de brenha; abrenhado. }\end{array}$ \\
\hline \multicolumn{2}{|c|}{$\begin{array}{l}\text { Analisando o contexto de uso de embrenhado, verifica-se tratar-se de uma lexia } \\
\text { bastante produtiva na fala dos entrevistados de Paranaguá. Quanto à acepção buscada } \\
\text { 'escondido, metido dentro de matos', a maior parte dos informantes (quatro da faixa I: } \\
\text { F1-H-EM, F1- M-EM, F1-H-ES e F1-M-ES / cinco da faixa II: F2-M-EP, F2-M-EF, F2- } \\
\text { H-EM, F2-H-ES e F2-M-ES) reconheceu o item lexical embrenhado com este mesmo } \\
\text { sentido. Já o informante F2-H-EP disse utilizar apenas a locução verbal 'tá perdido'. } \\
\text { Com relação ao registro da forma lexical embrenhado, encontra-se lexicalizada em } \\
\text { Morais Silva e em Houaiss. Os demais lexicógrafos (com exceção de Cunha) registraram } \\
\text { entrada embrenhar' com a mesma acepção em estudo. } \\
\text { Dessa forma, o emprego deste item lexical, presente na fala da maioria dos informantes } \\
\text { com o mesmo sentido documentado no corpus escrito, revela tendência à manutencão. }\end{array}$} \\
\hline
\end{tabular}

\begin{tabular}{|c|c|}
\hline \multicolumn{2}{|c|}{ 159. ENFADONHO / DOC.36, fól.1r, l.08-09 } \\
\hline $\begin{array}{l}\text { Acepção } \\
\text { buscada: }\end{array}$ & Que enfada, cansa, aborrece, fastidioso. \\
\hline $\begin{array}{l}\text { Acepção(ões) } \\
\text { conhecida(s) } \\
\text { pelos } \\
\text { informantes }\end{array}$ & $\begin{array}{l}\text { F1-H-EP: NSR. } \\
\text { F1-M-EP: NSR. } \\
\text { F1-H-EF: É fadiga. } \\
\text { F1-M-EF: NSR. } \\
\text { F1-H-EM: NSR. } \\
\text { F1-M-EM: NSR. } \\
\text { F1-H-ES: NSR. } \\
\text { F1-M-ES: NSR. } \\
\text { F2-H-EP: NSR. } \\
\text { F2-M-EP: NSR. } \\
\text { F2-H-EF: Enfadonho, uma coisa que causa espanto e tal. } \\
\text { F2-M-EF: É quando você tá cansado de alguma coisa, aquilo te cansa. } \\
\text { F2-H-EM: Professor fala muito, pessoa que começa a contar história, } \\
\text { coisa que não interessa, começa a cansar . }\end{array}$ \\
\hline
\end{tabular}




\begin{tabular}{|c|c|}
\hline & $\begin{array}{l}\text { F2-M-EM: NSR. } \\
\text { F2-H-ES: Coisa chata, que aborrece. } \\
\text { F2-M-ES: NSR. }\end{array}$ \\
\hline $\begin{array}{l}\text { Acepções } \\
\text { registradas } \\
\text { nos } \\
\text { dicionários }\end{array}$ & $\begin{array}{l}\text { Bluteau (1712-1728): ENFADONHO. Cousa, que molesta. } \\
\text { Morais Silva (1813): ENFADÒNHO, adj. Que causa enfado, coisa, ou } \\
\text { pessoa. [ENFÁDO, s. m. Enfadamento, molestia, fadiga, trabalho, que } \\
\text { se dá a alguem]. } \\
\text { Cunha (1997): enfadar } v b \text {. 'entediar, irritar, desgostar-se' | enfadonho } \\
\text { XVI. } \\
\text { Ferreira (2004): enfadonho 1. Que enfada, cansa, aborrece; cansativo, } \\
\text { aborrecido, maçante, fastidioso. } \\
\text { Houaiss (2007): enfadonho datação } 15431 \text { que causa enfado; que é } \\
\text { monótono, cansativo }\end{array}$ \\
\hline \multicolumn{2}{|c|}{$\begin{array}{l}\text { Analisando o contexto de uso da lexia enfadonho verifica-se baixa produtividade na } \\
\text { fala dos entrevistados. Dos dezesseis informantes, apenas quatro (F1-H-EF / F2-M-EF, } \\
\text { F2-H-EM e F2-H-ES) reconheceram o item lexical enfadonho com o mesmo sentido da } \\
\text { acepção buscada 'que enfada, cansa, aborrece, fastidioso'. Já o informante F2-H-EF } \\
\text { atribuiu a esta lexia o sentido de 'uma coisa que causa espanto e tal'. Esta acepção não } \\
\text { consta do registro de nenhum dos dicionários pesquisados. Os lexicógrafos trazem o } \\
\text { registro das acepções que evidenciam o mesmo sentido documentado no corpus escrito. } \\
\text { Considerando os dados em análise, pressupõe-se que a unidade lexical enfadonho } \\
\text { revela tendência ao desuso, pois, de dezesseis informantes, apenas quatro (um da faixa I } \\
\text { e três da faixa II) ainda utilizam esta lexia em contexto de fala. }\end{array}$} \\
\hline
\end{tabular}

\begin{tabular}{|l|l|}
\hline $\mathbf{1 6 0 .}$ FALTO / DOC.36, fól.1r, l.29-31 \\
\hline $\begin{array}{l}\text { Acepção } \\
\text { buscada }\end{array}$ & Necessitado, carente. \\
\hline $\begin{array}{l}\text { Acepção(ões) } \\
\text { conhecida(s) } \\
\text { pelos } \\
\text { informantes }\end{array}$ & F1-H-EP: NSR. \\
& F1-M-EP: NSR. \\
& F1-M-EF: NSR. \\
& F1-H-EM: NSR. \\
& F1-M-EM: Que tá faltando. \\
& F1-H-ES: NSR. \\
& F1-M-ES: NSR. \\
& F2-H-EP: NSR. \\
& F2-M-EP: NSR. \\
& F2-H-EF: NSR. \\
\hline
\end{tabular}




\begin{tabular}{|l|l|}
\hline & F2-M-EF: NSR. \\
& F2-H-EM: NSR. \\
& F2-M-EM: NSR. \\
& F2-H-ES: Falto, de faltar. \\
& F2-M-ES: NSR. \\
\hline $\begin{array}{l}\text { Acepções } \\
\text { registradas } \\
\text { nos } \\
\text { dicionários }\end{array}$ & $\begin{array}{l}\text { Bluteau (1712-1728): FALTO. Necessitado. Falto de alguma cousa. } \\
\text { Morais Silva (1813): FÁLTO, adj. Carecido, necessitado. } \\
\text { Cunha (1997): falta } \text { sf. 'ato ou efeito de faltar, ausência' | falto XVI. } \\
\end{array}$ \\
$\begin{array}{l}\text { Ferreira (2004): falto } 1 . \text { Necessitado, carecido. } \\
\text { Houaiss (2007): falto datação } 15561 \text { carente, necessitado. }\end{array}$ \\
\hline
\end{tabular}

Analisando as respostas dos informantes quanto ao reconhecimento da unidade lexical falto com o sentido de 'necessitado, carente', verificou-se sua não ocorrência no contexto de fala dos informantes. Dos dezesseis entrevistados, apenas três informantes (F1-H-EF e F1-M-EM / F2-H-ES) reconheceram essa unidade lexical atribuindo-lhe a definição genérica de 'faltar', 'que está faltando'. Foi perguntado, em seguida, se eles utilizam a lexia falto. Todos disseram que empregam para este sentido apenas a locução verbal estar faltando. Os lexicógrafos pesquisados registraram a mesma acepção em estudo para a entrada falto.

Considerando os dados apresentados, constata-se a não ocorrência da acepção buscada por nenhum dos entrevistados, pressupondo, dessa forma, ser o item lexical falto com o sentido 'necessitado, carente' um caso de $\underline{\text { desuso }}$.

\begin{tabular}{|c|c|}
\hline \multicolumn{2}{|c|}{ 161. FINDO / DOC.45, fól.1r, l.30-32 } \\
\hline $\begin{array}{l}\text { Acepção } \\
\text { buscada }\end{array}$ & Concluído, acabado. \\
\hline $\begin{array}{l}\text { Acepção(ões) } \\
\text { conhecida(s) } \\
\text { pelos } \\
\text { informantes }\end{array}$ & $\begin{array}{l}\text { F1-H-EP: NSR. } \\
\text { F1-M-EP: NSR. } \\
\text { F1-H-EF: É o fim, acabou. } \\
\text { F1-M-EF: NSR. } \\
\text { F1-H-EM: NSR. } \\
\text { F1-M-EM: Que tá acabado. } \\
\text { F1-H-ES: NSR. } \\
\text { F1-M-ES: NSR. } \\
\text { F2-H-EP: NSR. } \\
\text { F2-M-EP: Quando termina uma obra, algum serviço, tá terminado. } \\
\text { F2-H-EF: Quando você termina o trabalho, findo o trabalho. Mas } \\
\text { também é bem pouca gente que fala. } \\
\text { F2-M-EF: Alguma coisa que acabou, está findo, acabado. } \\
\text { F2-H-EM: Findou a lição, a matéria. Findo, acababo, acabou. }\end{array}$ \\
\hline
\end{tabular}




\begin{tabular}{|l|l|}
\hline & $\begin{array}{l}\text { F2-M-EM: NSR. } \\
\text { F2-H-ES: Findo é acabado. } \\
\text { F2-M-ES: É o final de alguma coisa, foi concluído. }\end{array}$ \\
\hline $\begin{array}{l}\text { Acepções } \\
\text { registradas } \\
\text { nos } \\
\text { dicionários }\end{array}$ & $\begin{array}{l}\text { Bluteau (1712-1728): FINDO. Acabado. Pleito findo. } \\
\text { Morais Silva (1813): FÍNDO, part. de Findar. Antiq. Acabado. } \\
\text { Ferreira (2004): findo 2. Concluído, acabado. } \\
\text { Houaiss (2007): findo datação sXIV } 2 \text { que se considera pronto; } \\
\text { concluído, acabado. }\end{array}$ \\
\hline $\begin{array}{l}\text { Dos dezesseis entrevistados, oito informantes (dois da faixa I e seis da faixa II) } \\
\text { reconheceram a lexia findo com o mesmo sentido da acepção em estudo 'concluído, } \\
\text { acabado'. Para a entrada findo, os lexicógrafos pesquisados registram a designação com o } \\
\text { mesmo sentido da acepção investigada. } \\
\text { Analisando o contexto de uso do item lexical findo e comparando com as respostas dos }\end{array}$ \\
$\begin{array}{l}\text { entrevistados, constata-se baixa frequência no contexto de fala dos informantes da faixa I, } \\
\text { pois, dos oito informantes, apenas do is reconheceram tal lexia. Portanto, supõe-se pela } \\
\text { baixa produtividade desta unidade lexical por parte dos informantes da faixa I, ser um } \\
\text { caso de tendência ao desuso. }\end{array}$ \\
\hline
\end{tabular}

\begin{tabular}{|c|c|}
\hline \multicolumn{2}{|c|}{ 162. FRÍVOLO / DOC.37, fól.1v, l.20-24 } \\
\hline $\begin{array}{l}\text { Acepção } \\
\text { buscada }\end{array}$ & Fútil, pouca ou nenhuma importância, em vão. \\
\hline $\begin{array}{l}\text { Acepção(ões) } \\
\text { conhecida(s) } \\
\text { pelos } \\
\text { informantes }\end{array}$ & $\begin{array}{l}\text { F1-H-EP: NSR. } \\
\text { F1-M-EP: NSR. } \\
\text { F1-H-EF: Pessoa fria. } \\
\text { F1-M-EF: NSR. } \\
\text { F1-H-EM: NSR. } \\
\text { F1-M-EM: NSR. } \\
\text { F1-H-ES: NSR. } \\
\text { F1-M-ES: NSR. } \\
\text { F2-H-EP: NSR. } \\
\text { F2-M-EP: NSR. } \\
\text { F2-H-EF: Um cara frívolo, é um cara alegre, cheio de manha, história, } \\
\text { então fala é frívolo. } \\
\text { F2-M-EF: É alguém que não é um bom caráter, é um frívolo. } \\
\text { F2-H-EM: NSR. } \\
\text { F2-M-EM: NSR. }\end{array}$ \\
\hline
\end{tabular}




\begin{tabular}{|c|c|}
\hline & $\begin{array}{l}\text { F2-H-ES: É uma coisa sem importância, é uma coisa frívola, fútil. } \\
\text { F2-M-ES: NSR. }\end{array}$ \\
\hline $\begin{array}{l}\text { Acepções } \\
\text { registradas } \\
\text { nos } \\
\text { dicionários }\end{array}$ & $\begin{array}{l}\text { Bluteau (1712-1728): FRÎVOLO. Vaõ. Inutil. Que naõ he solido, nem } \\
\text { bem fundado, etc. } \\
\text { Morais Silva (1813): FRÍVOLO, adj. Vão, inutil, sem fundamento. } \\
\text { Cunha (1997): frívolo adj. 'sem importância, sem valor, vão, fútil' } \\
\text { XVI. } \\
\text { Ferreira (2004): frívolo 1. Sem importância; sem valor; vão. } \\
\text { Houaiss (2007): frívolo datação } 15611 \text { que é ou tem pouca } \\
\quad \text { importância; inconsistente, inútil, superficial. }\end{array}$ \\
\hline
\end{tabular}

As definições apresentadas pelos lexicógrafos para a entrada frívolo evidenciam o mesmo sentido da acepção buscada, 'fútil, pouca ou nenhuma importância, em vão'. Analisando o contexto de uso, nota-se que a lexia frívolo apresenta baixa produtividade na fala dos informantes parnanguaras. Dos dezesseis entrevistados, quatro informantes reconheceram o item lexical frívolo, mas com variação de significados: (i) para o informante F1-H-EF 'frívolo é uma pessoa fria'; (ii) para o informante $\mathrm{F} 2-\mathrm{H}-\mathrm{EF}$ 'um cara frívolo, é um cara alegre, cheio de manha, história, então fala é frívolo'; (iii) para a informante F2-M-EF 'alguém que não tem um bom caráter, é um frívolo'. Esta acepção consta do registro em Ferreria e Houaiss. Com relação à acepção em estudo, apenas o informante F2-H-ES atribuiu o mesmo sentido: 'frívolo é uma coisa sem importância, é uma coisa frívola, fútil'. Quanto ao registro nos dicionários pesquisados, as definições registradas pelos lexicógrafos evidenciam o mesmo sentido documentado no corpus escrito.

Analisando o contexto de uso da unidade lexical frívolo e comparando com a acepção buscada, constata-se baixa ocorrência, o que presume tratar-se de uma lexia com tendência ao desuso, pois apenas um informante da faixa I empregou frívolo com o sentido de 'fútil, pouca ou nenhuma importância, em vão'.

\begin{tabular}{|l|l|}
\hline \multicolumn{2}{|l|}{ 163. INDECOROSO / DOC.32, fól.1r, l.31-33 } \\
\hline $\begin{array}{l}\text { Acepção } \\
\text { buscada }\end{array}$ & Indecente, vergonhoso. \\
\hline $\begin{array}{l}\text { Acepção(ões) } \\
\text { conhecida(s) }\end{array}$ & F1-H-EP: NSR. \\
pelos & F1-M-EP: NSR. \\
informantes & F1-H-EF: NSR. \\
& F1-M-EF: NSR. \\
& F1-H-EM: NSR. \\
& F1-M-EM: NSR. \\
& F1-H-ES: NSR. \\
& F1-M-ES: De vergonha. \\
\hline
\end{tabular}




\begin{tabular}{|c|c|}
\hline & $\begin{array}{l}\text { F2-H-EP: NSR. } \\
\text { F2-M-EP: NSR. } \\
\text { F2-H-EF: Indecoroso seria uma pessoa que não respeita as coisas que } \\
\quad \text { não deveria fazer em certos lugar, é indecoroso, é vergonhoso eu } \\
\text { acho. } \\
\text { F2-M-EF: Alguém triste. } \\
\text { F2-H-EM: Quando não decora direito. } \\
\text { F2-M-EM: NSR. } \\
\text { F2-H-ES: No sentido que não tem respeito, indecente, não tem decoro. } \\
\text { F2-M-ES: NSR. }\end{array}$ \\
\hline $\begin{array}{l}\text { Acepções } \\
\text { registradas } \\
\text { nos } \\
\text { dicionários }\end{array}$ & $\begin{array}{l}\text { Bluteau (1712-1728): INDECOROSO. De que se houvera de ter } \\
\text { vergonha. Que he contra a honra. } \\
\text { Morais Silva (1813): INDECORÒSO, adj. Contra o decóro, indecente; } \\
\text { immodesto, torpe, feyo; vergonhoso, opprobrioso. } \\
\text { Cunha (1997): N.D. } \\
\text { Ferreira (2004): indecoroso 1. Não decoroso; indecente, indigno, } \\
\quad \text { vergonhoso; indecoro. } \\
\text { Houaiss (2007): indecoroso datação } 1708 \text { que avilta; ignominioso, } \\
\quad \text { vergonhoso, vil. }\end{array}$ \\
\hline \multicolumn{2}{|c|}{$\begin{array}{l}\text { Analisando o contexto de uso da lexia indecoroso, constata-se baixa ocorrência na fala } \\
\text { dos informantes de Paranaguá. Dos dezesseis entrevistados, somente cinco informantes } \\
\text { reconheceram o item lexical indecoroso com variação de significados: (i) para a } \\
\text { informante F2-M-EF 'indecoroso é quando não decora direito'. Neste caso a informante } \\
\text { associou o item lexical decorar com indecoroso devido às semelhanças entre essas } \\
\text { formas. Tratam-se de unidades lexicais e significados distintos; (ii) para a informante } \\
\text { F2- M-EF indecoroso é alguém triste. Esta acepção não consta do registro de nenhum } \\
\text { dos dicionários pesquisados; (iii) já os informantes F1-M-ES / F2-H-EF e F2-H-ES } \\
\text { reconheceram a lexia indecoroso com o mesmo sentido da acepção em estudo 'indecente, } \\
\text { vergonhoso'. As definições apresentadas pelos lexicógrafos (com exceção de Bluteau) } \\
\text { evidenciam o mesmo sentido documentado no corpus escrito. } \\
\text { Embora a unidade lexical indecoroso ainda esteja presente na fala de alguns } \\
\text { informantes de Paranaguá, c e rt i i i c a -se que seu uso é pouco produtivo. Dos } \\
\text { dezesseis entrevistados, onze informantes (sete da faixa I e quatro da faixa II) disseram } \\
\text { não conhecer esta lexia, e dos poucos que a utilizaram com o sentido da acepção em } \\
\text { estudo, um é da faixa I e dois são faixa II. Pressupõe-se, dessa forma, que o item lexical } \\
\text { indecoroso revela tendência ao desuso. }\end{array}$} \\
\hline
\end{tabular}

164. IRRESOLUTO / DOC.47, fól.2r, 1.02-05

Acepção

buscada

Indeciso, hesitante. 


\begin{tabular}{|c|c|}
\hline $\begin{array}{l}\text { Acepção(ões) } \\
\text { conhecida(s) } \\
\text { pelos } \\
\text { informantes }\end{array}$ & $\begin{array}{l}\text { F1-H-EP: NSR. } \\
\text { F1-M-EP: NSR. } \\
\text { F1-H-EF: NSR. } \\
\text { F1-M-EF: Sem solução. } \\
\text { F1-H-EM: NSR. } \\
\text { F1-M-EM: NSR. } \\
\text { F1-H-ES: NSR. } \\
\text { F1-M-ES: NSR. } \\
\text { F2-H-EP: NSR. } \\
\text { F2-M-EP: NSR. } \\
\text { F2-H-EF: É o mesmo que irredutível, uma pessoa que não aceita nada, é } \\
\text { irresoluto, não adianta você querer falar com a pessoa que é } \\
\text { irredutível, é irresoluto. } \\
\text { F2-M-EF: NSR. } \\
\text { F2-H-EM: NSR. } \\
\text { F2-M-EM: NSR. } \\
\text { F2-H-ES: Aquele que não muda de opinião. } \\
\text { F2-M-ES: NSR. }\end{array}$ \\
\hline $\begin{array}{l}\text { Acepções } \\
\text { registradas } \\
\text { nos } \\
\text { dicionários }\end{array}$ & $\begin{array}{l}\text { Bluteau (1712-1728): IRRESOLUTO. Que não se sabe resolver, que } \\
\text { naõ sabe, que resolução haja de tomar. } \\
\text { Morais Silva (1813): IRRESOLÚTO, adj. Que hesita; indeterminado. §. } \\
\text { Não resolvido. } \\
\text { Cunha (1997): resolução } s f . \text { 'decisão, deliberação' | irresoluto } 1813 . \\
\text { Ferreira (2004): irresoluto } 1 . \text { Não resoluto; hesitante, indeciso. } \\
\text { Houaiss (2007): irresoluto datação } 15342 \text { que ou aquele que } \\
\text { dificilmente toma uma resolução; indeciso. }\end{array}$ \\
\hline \multicolumn{2}{|c|}{$\begin{array}{l}\text { Analisando as respostas dos informantes quanto ao reconhecimento da lexia irresoluto } \\
\text { com o sentido de 'indeciso, hesitante', verificou-se sua não ocorrência no contexto de fala } \\
\text { dos entrevistados. Dos dezesseis entrevistados, apenas três informantes (F1-M-EF / F2-H- } \\
\text { EF e F2-H-ES) reconheceram essa lexia com o sentido de 'que não se resolveu, que não } \\
\text { teve resolução', 'sem solução', evidenciando, dessa forma, baixa ocorrência desta unidade } \\
\text { lexical na modalidade oral. A entrada irresoluto consta do registro dos lexicógrafos } \\
\text { Bluteau, Morais Silva, Ferreira e Houaiss com a mesma acepção em estudo. Quanto à } \\
\text { datação, Cunha fixa o registro do termo irresoluto em } 1813 \text {. Houaiss registra esse mesmo } \\
\text { termo no ano de 1534. Esta unidade lexical consta do registro do documento manuscrito } \\
\text { de } 1800 \text {. Logo, pelo fato de a entrada irresoluto constar do registro de Bluteau, supõe-se } \\
\text { que esta forma lexical já existia antes da datação registrada por Cunha. } \\
\text { Considerando os dados apresentados, constata-se a não ocorrência da acepção buscada } \\
\text { entre os entrevistados, inferindo-se, portanto, ser o item lexical irresoluto com o sentido } \\
\text { da acepção em estudo um caso de desuso. }\end{array}$} \\
\hline
\end{tabular}




\begin{tabular}{|c|c|}
\hline $\begin{array}{l}\text { Acepção } \\
\text { buscada }\end{array}$ & $\begin{array}{l}\text { Indivíduo que apresentava certo grau de aculturação, intelectualmente } \\
\text { fino. }\end{array}$ \\
\hline $\begin{array}{l}\text { Acepção(ões) } \\
\text { conhecida(s) } \\
\text { pelos } \\
\text { informantes }\end{array}$ & $\begin{array}{l}\text { F1-H-EP: NSR. } \\
\text { F1-M-EP: Os mais velhos falam ladino, mas eu nem sei o que é. } \\
\text { F1-H-EF: É um chato. } \\
\text { F1-M-EF: Pessoa ladina é uma pessoa esperta, passa os outros pra trás } \\
\text { também. } \\
\text { F1-H-EM: NSR. } \\
\text { F1-M-EM: NSR. } \\
\text { F1-H-ES: Pessoa esperta, falam muito aqui. } \\
\text { F1-M-ES: Ladino é esperto. } \\
\text { F2-H-EP: A gente usa bastante pra dizer quando a pessoa é esperta. } \\
\text { F2-M-EP: Ladino é uma pessoa esperta. } \\
\text { F2-H-EF: É esperto, muito esperto. } \\
\text { F2-M-EF: É gente esperta. } \\
\text { F2-H-EM: Ladino é uma pessoa que tem estudo, certo grau de } \\
\text { inteligência. Na época, tempo que eu morava em sítio, meu pai dizia } \\
\text { que uma pessoa mais instruída, era ladina. Meu pai sempre falava } \\
\text { assim. Hoje ladino é espertinho. } \\
\text { F2-M-EM: Uma pessoa ladina é bem inteligente, sabe das coisas. } \\
\text { F2-H-ES: Ladino é uma pessoa que tem muito conhecimento, é } \\
\text { inteligente, mas usam mais no sentido de esperteza, cheia de manha. } \\
\text { F2-M-ES: É uma pessoa muito esperta, que passa conversa, é uma } \\
\text { pessoa ladina. }\end{array}$ \\
\hline $\begin{array}{l}\text { Acepções } \\
\text { registradas } \\
\text { nos } \\
\text { dicionários }\end{array}$ & $\begin{array}{l}\text { Bluteau (1712-1728): LADINO. Hoje dão os Portuguezes este mesmo } \\
\text { nome aos Estrangeiros, que fallão melhor a sua lingua, ou a Negros } \\
\text { que são mais espertos, \& mais capazes para o que se lhes encomenda. } \\
\text { Morais Silva (1813): LADÍNO, adj. §. Homem ladino; não rude, } \\
\text { esperto, fino, passado. §. Escravo ladino, oppõe-se a boçal, e é o que } \\
\text { já sabe a lingua, e o serviço ordinario de casa. Sabião o Portuguez } \\
\text { (derivado do Latino Idioma). } \\
\text { Cunha (1997): latim sm. | ladino adj. sm. 'latino' | ladinho ‘esperto, } \\
\text { vivo, finório' XV. } \\
\text { Ferreira (2004): ladino 1. Intelectualmente fino. 3. Nos séculos XVII e } \\
\text { XVIII, dizia-se de estrangeiros e de negros que falavam bem o } \\
\text { português. } \\
\text { Houaiss (2007): ladino datação } 2 \text { sXV } 6 \text { Regionalismo: Brasil: dizia-se } \\
\text { do índio ou do escravo negro que já apresentava certo grau de } \\
\text { aculturação. }\end{array}$ \\
\hline
\end{tabular}


Analisando o contexto de uso da lexia ladino, verifica tratar-se de uma forma lexical bastante produtiva na fala dos informantes de Paranaguá. Dos dezesseis entrevistados, dez informantes (três da faixa I e sete da faixa II) reconheceram a unidade lexical ladino com o sentido de 'esperto', 'manhoso', 'astuto'. Ferreira e Houaiss registraram este significado na segunda acepção da entrada ladino. Em Cunha também se encontra esta designação. $\mathrm{O}$ informante F1-H-EF atribuiu a ladino o valor de 'chato'. Já a informante F1-M-EP disse não conhecer o significado da lexia ladino, mas informou ser usada por pessoas mais velhas. Com relação à acepção buscada 'indivíduo que apresentava certo grau de aculturação, intelectualmente fino', apenas três informantes da faixa II reconheceram a unidade lexical ladino com este significado: F2-M-EM: 'Uma pessoa ladina é bem inteligente, sabe das coisas'; F2-H-ES: 'Ladino é uma pessoa que tem muito conhecimento, é inteligente'; F2-H-EM: 'Ladino é uma pessoa que tem estudo, certo grau de inteligência. Na época, tempo que eu morava em sítio, meu pai dizia que uma pessoa mais instruída, era ladina. Meu pai sempre falava assim'. Porém, mesmo os informantes F2-H-ES e F2-H-EM reconhecendo a acepção em estudo, salientaram que a designação mais usada para ladino é 'espertinho', 'cheio de manha'. Segundo Bluteau a denominação ladino foi atribuída pelos portugueses aos estrangeiros que falavam melhor a língua portuguesa e também aos negros considerados mais espertos e capazes a determinadas funções. Morais Silva define o homem ladino como não rude, esperto e fino, e o escravo ladino aquele que já sabia a língua portuguesa, opondo-se ao boçal. Ferreira e Houaiss dentre as várias acepções, trazem o registro da definição que evidencia o mesmo significado documentado no corpus escrito: 'indivíduo (negro, índio, estrangeiro) que apresentava certo grau de aculturação'. Houaiss marca esta definição como regionalismo do Brasil.

Analisando o contexto de fala dos informantes, averigua-se que, com o passar do tempo, a designação 'pessoal intelectualmente fina, aculturada, mais esperta e capaz a certos atributos' foi se perdendo, permanecendo na memória das pessoas apenas a qualidade de 'esperto'. Tal constatação se verifica na fala dos informantes da faixa I, dos cinco informantes, três atribuíram o valor de 'pessoa esperta'. Portanto, a lexia ladino com o sentido da acepção em estudo apresenta tendência ao desuso.

\begin{tabular}{|l|l|}
\hline \multicolumn{2}{|l|}{ 166. LIMITADO / DOC.24, fól.1r, l.13-15 } \\
\hline $\begin{array}{l}\text { Acepção } \\
\text { buscada }\end{array}$ & De pouco valor, baixo. \\
\hline $\begin{array}{l}\text { Acepção(ões) } \\
\text { conhecida(s) }\end{array}$ & F1-H-EP: NSR. \\
pelos & F1-M-EP: NSR. \\
informantes & F1-H-EF: Que tem limite. \\
& F1-H-EM: Tem um certo limite pra cada coisa, não pode passar daquilo. \\
& F1-M-EM: Limitações, hora de saber até onde você vai. \\
& F1-H-ES: Curto, pequeno. \\
\hline
\end{tabular}




\begin{tabular}{|c|c|}
\hline & $\begin{array}{l}\text { F1-M-ES: Limitado é baixo, valor baixo. } \\
\text { F2-H-EP: NSR. } \\
\text { F2-M-EP: NSR. } \\
\text { F2-H-EF: Limitado é se for pessoa seria no caso que não passa além } \\
\text { daquilo, só sabe aquilo mesmo, não adianta você querer que ele faça } \\
\text { outras coisas que ele não sabe, uma pessoa limitada, só vai até ali } \\
\text { mesmo. } \\
\text { F2-M-EF: Limitado é tipo você ter um limite pra uma coisa. } \\
\text { F2-H-EM: Alguém que chegou ao ponto máximo, no limite. } \\
\text { F2-M-EM: NSR. } \\
\text { F2-H-ES: Limitado é aquela pessoa que não pode passar daquele ponto. } \\
\text { Ela está limitada, é uma pessoa burra. } \\
\text { F2-M-ES: É quando você precisa parar porque tem um limite. }\end{array}$ \\
\hline $\begin{array}{l}\text { Acepções } \\
\text { registradas } \\
\text { nos } \\
\text { dicionários }\end{array}$ & $\begin{array}{l}\text { Bluteau (1712-1728): LIMITADO. De pouco valor, de pouca } \\
\text { consideração. } \\
\text { Morais Silva (1813): LIMITÁDO, p. pass. de Limitar. Que tem certos } \\
\text { termos, limites em grandeza, extensão, quantidade, número, copia, } \\
\text { intensão. } \\
\text { Cunha (1997): N.D. } \\
\text { Ferreira (2004): limitado 3. Restrito, reduzido. } \\
\text { Houaiss (2007): limitado datação } 14461 \text { que tem limites, que é pouco } \\
\text { extenso; em quantidade reduzida; pouco considerável. }\end{array}$ \\
\hline \multicolumn{2}{|c|}{$\begin{array}{l}\text { Para a maioria dos informantes (quatro da faixa I: F1-H-EF, F1-M-EF, F1-H-EM e } \\
\text { F1- M-EM / três da faixa II: F2-M-EF, F2-H-EM e F2-M-ES) limitado refere-se a } \\
\text { 'limites ou limitações'. E para os dois informantes (F2-H-EF e F2-H-ES) limitado refere- } \\
\text { se a 'insuficiente capacidade intelectual'. O informante F2-H-ES chegou a comparar } \\
\text { uma 'pessoa limitada' a uma 'pessoa burra'. Já para o informante F1-H-ES limitado é } \\
\text { sinônimo de 'curto', 'pequeno'. Quanto à acepção buscada 'de pouco valor, baixo', } \\
\text { apenas a informante F1-M-ES atribuiu este valor à lexia limitado. As definições } \\
\text { apresentadas pelos lexicógrafos (com exceção de Bluteau) evidenciam o mesmo sentido } \\
\text { documentado no corpus escrito. } \\
\text { Analisando o contexto de utilização do item lexical limitado pelos informantes } \\
\text { parnanguaras e a acepção buscada, presume-se que, em dado momento, nesta } \\
\text { comunidade linguística, estas acepções começaram a concorrer entre si, e, no estágio atual } \\
\text { de variação, há indícios do favorecimento da acepção 'limites ou limitações' em } \\
\text { detrimento da acepção documentada no corpus escrito, lembrada apenas por um } \\
\text { informante da faixa I. Portanto, a unidade lexical limitado no sentido 'de pouco valor, } \\
\text { baixo' aponta tendência ao desuso. }\end{array}$} \\
\hline
\end{tabular}




\begin{tabular}{|c|c|}
\hline \multicolumn{2}{|c|}{ 167. LUZIDO / DOC.47, fól.3r, l.25-27 } \\
\hline $\begin{array}{l}\text { Acepção } \\
\text { buscada }\end{array}$ & Brilhante, ilustre. \\
\hline $\begin{array}{l}\text { Acepção(ões) } \\
\text { conhecida(s) } \\
\text { pelos } \\
\text { informantes }\end{array}$ & $\begin{array}{l}\text { F1-H-EP: NSR. } \\
\text { F1-M-EP: NSR. } \\
\text { F1-H-EF: NSR. } \\
\text { F1-M-EF: NSR. } \\
\text { F1-H-EM: NSR. } \\
\text { F1-M-EM: NSR. } \\
\text { F1-H-ES: NSR. } \\
\text { F1-M-ES: Brilho, a minha avó falava: "nossa a estrela é muito luzida". } \\
\quad \text { Luzida de brilho. Eu também uso. } \\
\text { F2-H-EP: NSR. } \\
\text { F2-M-EP: NSR. } \\
\text { F2-H-EF: Luzido no popular antigamente falava brilhoso, luzido, eu } \\
\text { ainda falo, mas quase não se ouve mais. } \\
\text { F2-M-EF: NSR. } \\
\text { F2-H-EM: NSR. } \\
\text { F2-M-EM: NSR. } \\
\text { F2-H-ES: NSR. } \\
\text { F2-M-ES: NSR. }\end{array}$ \\
\hline $\begin{array}{l}\text { Acepções } \\
\text { registradas } \\
\text { nos } \\
\text { dicionários }\end{array}$ & $\begin{array}{l}\text { Bluteau (1712-1728): LUZIDO. Diz-se de hum verniz, ou de qualquer } \\
\text { outra cousa muito liza, que tem alguma luz. } \\
\text { Morais Silva (1813): LUZÍDO, adj. Lustroso, pomposo, brilhante, bem } \\
\quad \text { arrayado. } \\
\text { Cunha (1997): luz } s f \text {. 'brilho, fulgor' | luzido XVI. } \\
\text { Ferreira (2004): luzido } 1 . \text { Vistoso, brilhante, pomposo. } \\
\text { Houaiss (2007): luzido datação sXIII } 1 \text { cheio de luz; brilhante, luzidio. }\end{array}$ \\
\hline \multicolumn{2}{|c|}{$\begin{array}{l}\text { Dos dezesseis entrevistados em Paranaguá, somente dois informantes (F1-M-ES / F2- } \\
\text { H-EF) reconheceram a lexia luzido com o sentido de 'brilhante, ilustre'. Os lexicógrafos } \\
\text { pesquisados trazem o registro das acepções que evidenciam o mesmo sentido } \\
\text { documentado no corpus escrito. } \\
\text { Com base nos dados analisados, constata-se que o item lexical luzido apresenta pouca } \\
\text { produtividade na fala dos informantes de Paranaguá e a não resposta por parte dos } \\
\text { quatorzes informantes (sete da faixa I e sete da faixa II) pressupõe tratar-se de um caso de } \\
\text { tendência ao desuso. }\end{array}$} \\
\hline
\end{tabular}




\begin{tabular}{|c|c|}
\hline \multicolumn{2}{|c|}{ 168. MÓDICO / DOC.31, fól.1v, l.03-05 } \\
\hline $\begin{array}{l}\text { Acepção } \\
\text { buscada }\end{array}$ & Modesto, de pouco valor. \\
\hline $\begin{array}{l}\text { Acepção(ões) } \\
\text { conhecida(s) } \\
\text { pelos } \\
\text { informantes }\end{array}$ & $\begin{array}{l}\text { F1-H-EP: NSR. } \\
\text { F1-M-EP: NSR. } \\
\text { F1-H-EF: NSR. } \\
\text { F1-M-EF: NSR. } \\
\text { F1-H-EM: NSR. } \\
\text { F1-M-EM: NSR. } \\
\text { F1-H-ES: NSR. } \\
\text { F1-M-ES: NSR. } \\
\text { F2-H-EP: NSR. } \\
\text { F2-M-EP: NSR. } \\
\text { F2-H-EF: Barato, coisa barata, módica. } \\
\text { F2-M-EF: NSR. } \\
\text { F2-H-EM: NSR. } \\
\text { F2-M-EM: NSR. } \\
\text { F2-H-ES: Preços módicos, baratos. } \\
\text { F2-M-ES: NSR. }\end{array}$ \\
\hline $\begin{array}{l}\text { Acepções } \\
\text { registradas } \\
\text { nos } \\
\text { dicionários }\end{array}$ & $\begin{array}{l}\text { Bluteau (1712-1728): MÔDICO. Cousa pequena, \& de pouca } \\
\text { consideração. } \\
\text { Morais Silva (1813): MÓDICO, adj. Pequeno, de pouco momento. } \\
\text { Cunha (1997): modo sm. 'maneira, forma, método, disposição'। } \\
\text { módico XVIII. } \\
\text { Ferreira (2004): módico 3. Moderado, limitado, restrito; modesto. } \\
\text { Houaiss (2007): módico datação } 16801 \text { que é pouco, escasso; cujo } \\
\text { valor é baixo. }\end{array}$ \\
\hline \multicolumn{2}{|c|}{$\begin{array}{l}\text { Dos dezesseis entrevistados em Paranaguá, somente dois informantes (F2-H-EF e } \\
\text { F2- H-ES) reconheceram a lexia módico no sentido de 'modesto, de pouco valor'. Os } \\
\text { lexicógrafos Bluteau, Morais Silva, Ferreira e Houaiss registram a entrada módico com a } \\
\text { mesma acepção buscada. Interessante que Houaiss informa o ano de } 1680 \text { para a datação } \\
\text { do termo módico, enquanto Cunha traz seu primeiro registro no século seguinte. } \\
\text { Com base nos dados analisados, constata-se que o item lexical módico apresenta pouca } \\
\text { produtividade na fala dos informantes de Paranaguá, e a não resposta por parte dos } \\
\text { informantes da faixa I pressupõe tratar-se de um caso de tendência ao desuso. }\end{array}$} \\
\hline
\end{tabular}




\begin{tabular}{|c|c|}
\hline \multicolumn{2}{|c|}{ 169. OB-REPTÍCIO / DOC.27, fól.1r, l.12-15 } \\
\hline $\begin{array}{l}\text { Acepção } \\
\text { buscada }\end{array}$ & Algo obtido por meio de dissimulação, astúcia. \\
\hline $\begin{array}{l}\text { Acepção(ões) } \\
\text { conhecida(s) } \\
\text { pelos } \\
\text { informantes }\end{array}$ & $\begin{array}{l}\text { F1-H-EP: NSR. } \\
\text { F1-M-EP: NSR. } \\
\text { F1-H-EF: NSR. } \\
\text { F1-M-EF: NSR. } \\
\text { F1-H-EM: NSR. } \\
\text { F1-M-EM: NSR. } \\
\text { F1-H-ES: NSR. } \\
\text { F1-M-ES: NSR. } \\
\text { F2-H-EP: NSR. } \\
\text { F2-M-EP: NSR. } \\
\text { F2-H-EF: NSR. } \\
\text { F2-M-EF: NSR. } \\
\text { F2-H-EM: NSR. } \\
\text { F2-M-EM: NSR. } \\
\text { F2-H-ES: NSR. } \\
\text { F2-M-ES: NSR. }\end{array}$ \\
\hline $\begin{array}{l}\text { Acepções } \\
\text { registradas } \\
\text { nos } \\
\text { dicionários }\end{array}$ & $\begin{array}{l}\text { Bluteau (1712-1728): OBREPTICIO. (Termo Forense). Cousa } \\
\text { conseguida por obreção. [OBREPÇÃO. A sutileza com que se } \\
\text { alcança de pessoa superior huma graça, ou dignidade, calando alguma } \\
\text { circunstancia, cuja noticia houvera sido impedimento, \& obstaculo } \\
\text { para a dita graça]. } \\
\text { Morais Silva (1813): ÓBRÉPTÍCIO, adj. Conseguido por ob-repção. } \\
\text { [ÓBRÉPÇÃO, s. f. O acto de calar alguma circumstancia de facto, ou } \\
\text { direito, para se obter algum despacho, que se não obtivéra ou não } \\
\text { devèra dar, declarada a tal circumstancia encoberta dolosamente]. } \\
\text { Cunha (1997): ob-reptício adj. 'ardiloso, astucioso, doloso' } 1813 . \\
\text { Ferreira (2004): ob-reptício } 1 . \text { Obtido por ob-repção. [ob-repção } 1 . \\
\text { Ação de obter algo por surpresa, ardil, astúcia, ou outro processo } \\
\text { doloso, por se julgar impossível consegui-lo por meios ordinários]. } \\
\text { Houaiss (2007): ob-reptício datação } 17201 \text { conseguido por ob-repção. } \\
\text { [ob-repção ação de ocultar a verdade, de dissimular um fato para } \\
\text { obter qualquer coisa]. }\end{array}$ \\
\hline \multicolumn{2}{|c|}{$\begin{array}{l}\text { A lexia ob-repticio não foi reconhecida por nenhum dos informantes entrevistados. } \\
\text { Quanto ao registro nos dicionários pesquisados, a unidade lexical ob-reptício encontra-se } \\
\text { lexicalizada com o mesmo sentido da acepção em estudo 'algo obtido por meio de } \\
\text { dissimulação, astúcia'. Cunha fixa o registro da unidade lexical ob-repitício em } 1813 \text {, } \\
\text { enquanto Houaiss a registra em } 1720 \text {. Como ob-repitício encontra-se registrado no }\end{array}$} \\
\hline
\end{tabular}


documento manuscrito de 1767, supõe-se que esta forma lexical já existia antes da datação registrada por Cunha.

Portanto, como não houve o registro do item lexical ob-reptício em contexto oral dos informantes parnanguaras, configura-se um caso de $\underline{\text { desuso. }}$.

\begin{tabular}{|c|c|}
\hline \multicolumn{2}{|c|}{ 170. OBSEQUIOSO / DOC.13, fól.1r, l.25-26 } \\
\hline $\begin{array}{l}\text { Acepção } \\
\text { buscada }\end{array}$ & Que presta favores, obséquios, revela ter boa vontade. \\
\hline $\begin{array}{l}\text { Acepção(ões) } \\
\text { conhecida(s) } \\
\text { pelos } \\
\text { informantes }\end{array}$ & $\begin{array}{l}\text { F1-H-EP: NSR. } \\
\text { F1-M-EP: NSR. } \\
\text { F1-H-EF: NSR. } \\
\text { F1-M-EF: NSR. } \\
\text { F1-H-EM: NSR. } \\
\text { F1-M-EM: NSR. } \\
\text { F1-H-ES: Só conheço por obséquio, por favor. } \\
\text { F1-M-ES: Conheço só obséquio, de favor. } \\
\text { F2-H-EP: NSR. } \\
\text { F2-M-EP: NSR. } \\
\text { F2-H-EF: NSR. } \\
\text { F2-M-EF: Por favor. } \\
\text { F2-H-EM: NSR. } \\
\text { F2-M-EM: NSR. } \\
\text { F2-H-ES: É aquele que interfere, por obséquio, você vive pedindo, } \\
\text { interferindo. } \\
\text { F2-M-ES: NSR. }\end{array}$ \\
\hline $\begin{array}{l}\text { Acepções } \\
\text { registradas } \\
\text { nos } \\
\text { dicionários }\end{array}$ & $\begin{array}{l}\text { Bluteau (1712-1728): OBSEQUIOSO. Cortezão, serviçal, amigo de } \\
\text { fazer a vontade dos mayores, ou dos iguaes. } \\
\text { Morais Silva (1813): OBSEQUIÒSO, adj. Amigo de obsequiar, ou fazer } \\
\text { obséquios. [OBSÉQUIO, s. m. Obra, palavra, com que cortèz, e } \\
\text { urbanamente grangeamos a vontade de alguem]. } \\
\text { Cunha (1997): obséquio sm. 'favor, serviço, benefício' | obsequioso } \\
1813 \text {. } \\
\text { Ferreira (2004): obsequioso 1. Que presta obséquios; serviçal; } \\
\text { benévolo; afável no trato. } \\
\text { Houaiss (2007): obsequioso datação } 16321 \text { que gosta ou tem o hábito } \\
\text { de ajudar, de prestar um favor. }\end{array}$ \\
\hline H & contexto de uso da lexia ob \\
\hline
\end{tabular}


informantes F1-H-ES e F1-M-ES / F2-M-EF são pelas formas preposicionadas 'por obséquio', 'por favor'. Para o informante F2-H-ES, a lexia obsequioso refere-se ao sentido de 'interferência', seria alguém que 'por obséquio, vive pedindo, interferindo'. Os lexicógrafos pesquisados trazem a mesma acepção documentada no corpus escrito 'que presta favores, obséquios, revela ter boa vontade'. Cunha fixa o registro da unidade lexical obsequioso em 1813, enquanto Houaiss a registra em 1632. Como obsequioso encontra-se registrado no documento manuscrito de 1723, supõe-se que esta unidade lexical já existia antes da datação registra por Cunha.

Portanto, analisando as respostas dos informantes, nota-se que o sentido atribuído pelos informantes é o de 'pedir favores', 'pedir obséquios', enquanto o significado documentado nos documentos manuscritos seria o de 'alguém que presta favores' e não que 'pede'. Considerando esses dados, pressupõe-se que a lexia obsequioso com a mesma acepção em estudo configura um caso de $\underline{\text { desuso }}$.

\begin{tabular}{|c|c|}
\hline \multicolumn{2}{|c|}{ 171. PERNICIOSO / DOC.32, fól.1 r, l.06-08 } \\
\hline $\begin{array}{l}\text { Acepção } \\
\text { buscada }\end{array}$ & Que causa dano, nocivo, perigoso. \\
\hline $\begin{array}{l}\text { Acepção(ões) } \\
\text { conhecida(s) } \\
\text { pelos } \\
\text { informantes }\end{array}$ & $\begin{array}{l}\text { F1-H-EP: NSR. } \\
\text { F1-M-EP: NSR. } \\
\text { F1-H-EF: NSR. } \\
\text { F1-M-EF: NSR. } \\
\text { F1-H-EM: NSR. } \\
\text { F1-M-EM: NSR. } \\
\text { F1-H-ES: NSR. } \\
\text { F1-M-ES: NSR. } \\
\text { F2-H-EP: NSR. } \\
\text { F2-M-EP: NSR. } \\
\text { F2-H-EF: É uma coisa ruim, que causa estrago, é pernicioso } \\
\text { F2-M-EF: NSR. } \\
\text { F2-H-EM: Mau, ruim, que prejudica. } \\
\text { F2-M-EM: NSR. } \\
\text { F2-H-ES: Perigoso. } \\
\text { F2-M-ES: NSR. }\end{array}$ \\
\hline $\begin{array}{l}\text { Acepções } \\
\text { registradas } \\
\text { nos } \\
\text { dicionários }\end{array}$ & $\begin{array}{l}\text { Bluteau (1712-1728): PERNICIOSO. Cousa que causa dano, ou ruina } \\
\text { espiritual, ou temporal. } \\
\text { Morais Silva (1813): PERNICIÒSO, adj. Que traz dano, ruina; } \\
\text { mortifero, ruinoso, natural, ou moralmente. } \\
\text { Cunha (1997): pernície } S f . \text { 'estrago, destruição, ruína' | pernicioso XVI. } \\
\text { Ferreira (2004): pernicioso } 1 \text {. Mau, nocivo, ruinoso; perigoso. }\end{array}$ \\
\hline
\end{tabular}




\begin{tabular}{|l|l|}
\hline $\begin{array}{c}\text { Houaiss (2007): pernicioso datação sXV que ocorre, sucede; } \\
\text { sobreveniente; superveniente. }\end{array}$ \\
\hline $\begin{array}{l}\text { Dos dezesseis entrevistados em Paranaguá, apenas três informantes (F2-H-EF, F2-H- } \\
\text { EM e F2-H-ES) reconheceram a lexia pernicioso com o mesmo sentido da acepção em } \\
\text { estudo 'que causa dano, nocivo, perigoso'. As acepções registradas pelos lexicógrafos } \\
\text { pesquisados evidenciam o mesmo sentido documentado no corpus escrito. } \\
\text { Com base nos dados analisados constata-se que o item lexical pernicioso apresenta } \\
\text { pouca produtividade na fala dos informantes de Paranaguá, e a não resposta por parte dos } \\
\text { informantes da faixa I pressupõe tratar-se de um caso de tendência ao desuso. }\end{array}$ \\
\hline
\end{tabular}

\begin{tabular}{|c|c|}
\hline \multicolumn{2}{|c|}{ 172. PERVENCIDO / DOC.33, fól.1r, l.03-05 } \\
\hline $\begin{array}{l}\text { Acepção } \\
\text { buscada }\end{array}$ & Vencida a validade, caducado. \\
\hline $\begin{array}{l}\text { Acepção(ões) } \\
\text { conhecida(s) } \\
\text { pelos } \\
\text { informantes }\end{array}$ & $\begin{array}{l}\text { F1-H-EP: NSR. } \\
\text { F1-M-EP: NSR. } \\
\text { F1-H-EF: NSR. } \\
\text { F1-M-EF: NSR. } \\
\text { F1-H-EM: NSR. } \\
\text { F1-M-EM: NSR. } \\
\text { F1-H-ES: NSR. } \\
\text { F1-M-ES: NSR. } \\
\text { F2-H-EP: NSR. } \\
\text { F2-M-EP: NSR. } \\
\text { F2-H-EF: NSR. } \\
\text { F2-M-EF: NSR. } \\
\text { F2-H-EM: NSR. } \\
\text { F2-M-EM: NSR. } \\
\text { F2-H-ES: NSR. } \\
\text { F2-M-ES: Coisa ruim. }\end{array}$ \\
\hline $\begin{array}{l}\text { Acepções } \\
\text { registradas } \\
\text { nos } \\
\text { dicionários }\end{array}$ & $\begin{array}{l}\text { Bluteau (1712-1728): N.D. } \\
\text { Morais Silva (1813): N.D. } \\
\text { Cunha (1997): N.D. } \\
\text { Ferreira (2004): N.D. } \\
\text { Houaiss (2007): N.D. }\end{array}$ \\
\hline
\end{tabular}

A unidade lexical pervencido não consta registrada por nenhum dos lexicógrafos pesquisados. Quanto ao contexto de uso, dos dezesseis entrevistados, apenas o informante F2-M-ES reconheceu a lexia pervencido, atribuindo-lhe o valor de 'coisa ruim'. Este significado não é o mesmo da acepção buscada 'vencida a validade, caducado'. Pode-se 
concluir, pela não resposta de quinze informantes e pela ausência da ocorrência da unidade lexical pernicioso com o mesmo sentido da acepção em estudo, que seja um caso de desuso.

\begin{tabular}{|c|c|}
\hline \multicolumn{2}{|c|}{ 173. PRINCIPIADO / DOC.46, fól.1v, l.05-07 } \\
\hline $\begin{array}{l}\text { Acepção } \\
\text { buscada }\end{array}$ & Iniciado, começado. \\
\hline $\begin{array}{l}\text { Acepção(ões) } \\
\text { conhecida(s) } \\
\text { pelos } \\
\text { informantes }\end{array}$ & $\begin{array}{l}\text { F1-H-EP: NSR. } \\
\text { F1-M-EP: NSR. } \\
\text { F1-H-EF: Princípio, início } \\
\text { F1-M-EF: NSR. } \\
\text { F1-H-EM: Um princípio, que começou. } \\
\text { F1-M-EM: NSR. } \\
\text { F1-H-ES: Adiantado. } \\
\text { F1-M-ES: NSR. } \\
\text { F2-H-EP: NSR. } \\
\text { F2-M-EP: NSR. } \\
\text { F2-H-EF: É começado. } \\
\text { F2-M-EF: Começado. } \\
\text { F2-H-EM: Principiado é referente ao futuro príncipe. } \\
\text { F2-M-EM: NSR. } \\
\text { F2-H-ES: Começado. } \\
\text { F2-M-ES: NSR. }\end{array}$ \\
\hline $\begin{array}{l}\text { Acepções } \\
\text { registradas } \\
\text { nos } \\
\text { dicionários }\end{array}$ & $\begin{array}{l}\text { Bluteau (1712-1728): PRINCIPIADO. Começado. } \\
\text { Morais Silva (1813): PRINCIPIÁDO, p. pass. de Principiar. } \\
\quad \text { [PRINCIPIÁR, v. at. Dar principio, começar]. } \\
\text { Cunha (1997): N.D. } \\
\text { Ferreira (2004): [principiar 3. Dar princípio; começar]. } \\
\text { Houaiss (2007): [principiar } 1 \text { dar início a; começar, iniciar, abrir]. }\end{array}$ \\
\hline \multicolumn{2}{|c|}{$\begin{array}{l}\text { Analisando o contexto de uso da lexia principiado verifica-se baixa produtividade na } \\
\text { fala dos entrevistados. Dos dezesseis informantes, sete disseram conhecer o item lexical } \\
\text { principiado. Cinco informantes (F1-H-EF e F1-H-EM / F2-H-EF, F2-M-EF e F2-H-ES) } \\
\text { reconhecem essa lexia com o sentido da acepção buscada 'iniciado, começado'. Outros } \\
\text { dois informantes (F1-H-ES / F2-H-EM) atribuíram os sentidos de 'adiantado' e 'futuro } \\
\text { príncipe'. A forma lexical principiado encontra-se lexicalizada somente por Bluteau e } \\
\text { Morais Silva. Ferreira e Houaiss registram a entrada principiar atribuindo as designações } \\
\text { 'dar princípio, começar, iniciar'. Cunha não traz o registro deste item lexical. }\end{array}$} \\
\hline
\end{tabular}


Considerando os dados em análise, pressupõe-se que a unidade lexical principiado revela tendência ao desuso, pois, de dezesseis informantes, apenas cinco (da faixa I e três da faixa II) ainda utilizam esta lexia em contexto de fala.

\begin{tabular}{|c|c|}
\hline \multicolumn{2}{|c|}{ 174. PROFITENTE / DOC.27, fól.1r, l.19-21 } \\
\hline $\begin{array}{l}\text { Acepção } \\
\text { buscada }\end{array}$ & Aquele que professsa. \\
\hline $\begin{array}{l}\text { Acepção(ões) } \\
\text { conhecida(s) } \\
\text { pelos } \\
\text { informantes }\end{array}$ & $\begin{array}{l}\text { F1-H-EP: NSR. } \\
\text { F1-M-EP: NSR. } \\
\text { F1-H-EF: NSR. } \\
\text { F1-M-EF: NSR. } \\
\text { F1-H-EM: NSR. } \\
\text { F1-M-EM: NSR. } \\
\text { F1-H-ES: NSR. } \\
\text { F1-M-ES: NSR. } \\
\text { F2-H-EP: NSR. } \\
\text { F2-M-EP: NSR. } \\
\text { F2-H-EF: NSR. } \\
\text { F2-M-EF: NSR. } \\
\text { F2-H-EM: NSR. } \\
\text { F2-M-EM: NSR. } \\
\text { F2-H-ES: NSR. } \\
\text { F2-M-ES: NSR. }\end{array}$ \\
\hline $\begin{array}{l}\text { Acepções } \\
\text { registradas } \\
\text { nos } \\
\text { dicionários }\end{array}$ & $\begin{array}{l}\text { Bluteau (1712-1728): PROFITENTE. Judeo profitente, he o que } \\
\text { professa a ley de Moysés. } \\
\text { Morais Silva (1813): PROFITÉNTE, adj. Que professa alguma Lei, } \\
\text { Religião; o que professa. } \\
\text { Cunha (1997): professar } v b \text {. 'reconhecer publicamente' | profitente } \\
\quad 1813 . \\
\text { Ferreira (2004): profitente } 1 . \text { Que professa. } \\
\text { Houaiss (2007): profitente datação } 1720 \text { que professa; professor. }\end{array}$ \\
\hline \multicolumn{2}{|c|}{$\begin{array}{l}\text { Dos dezesseis entrevistados, todos disseram desconhecer a lexia profitente. A acepção } \\
\text { buscada, 'aquele que professsa', encontra-se registrada em Bluteau, Morais Silva, Ferreira } \\
\text { e Houaiss. Cunha, por sua vez, fixa a unidade léxica profitente em 1813, enquanto que } \\
\text { Houaiss a registra em } 1720 \text {. Como profitente encontra-se registrado no documento } \\
\text { manuscrito de } 1767 \text {, supõe-se que esta forma lexical já existia antes da datação registra } \\
\text { por Cunha. }\end{array}$} \\
\hline
\end{tabular}


Levando em consideração os dados analisados, constata-se que o item lexical profitente não apresentou nenhuma ocorrência em contexto de fala dos entrevistados de Paranaguá. O seu registro, portanto, encontra-se apenas na modalidade escrita, configurando dessa forma, um caso de $\underline{\text { desuso }}$.

\begin{tabular}{|c|c|}
\hline \multicolumn{2}{|c|}{ 175. RELAVADO / DOC.03, fól.1v, l.04-09 } \\
\hline $\begin{array}{l}\text { Acepção } \\
\text { buscada }\end{array}$ & Explorado, exaurido. \\
\hline $\begin{array}{l}\text { Acepção(ões) } \\
\text { conhecida(s) } \\
\text { pelos } \\
\text { informantes }\end{array}$ & $\begin{array}{l}\text { F1-H-EP: NSR. } \\
\text { F1-M-EP: NSR. } \\
\text { F1-H-EF: NSR. } \\
\text { F1-M-EF: NSR. } \\
\text { F1-H-EM: A pessoa já lavou e tá lavando de novo, relavando. } \\
\text { F1-M-EM: Lavar e relavar uma roupa. } \\
\text { F1-H-ES: NSR. } \\
\text { F1-M-ES: NSR. } \\
\text { F2-H-EP: NSR. } \\
\text { F2-M-EP: NSR. } \\
\text { F2-H-EF: É o ato de lavar e relavar. } \\
\text { F2-M-EF: Alguma coisa que tava suja e foi lavada de novo. } \\
\text { F2-H-EM: É lavar a roupa novamente. } \\
\text { F2-M-EM: NSR. } \\
\text { F2-H-ES: Que foi lavado outra vez. } \\
\text { F2-M-ES: NSR. }\end{array}$ \\
\hline $\begin{array}{l}\text { Acepções } \\
\text { registradas } \\
\text { nos } \\
\text { dicionários }\end{array}$ & $\begin{array}{l}\text { Bluteau (1712-1728): N.D. } \\
\text { Morais Silva (1813): N.D. } \\
\text { Cunha (1997): N.D. } \\
\text { Ferreira (2004): N.D. } \\
\text { Houaiss (2007): N.D. }\end{array}$ \\
\hline \multicolumn{2}{|c|}{$\begin{array}{l}\text { Nos dicionários pesquisados não consta registro da unidade léxica relavado. Quanto ao } \\
\text { reconhecimento desta lexia no contexto de fala dos entrevistados de Paranaguá, apenas } \\
\text { seis informantes (F1-H-EM e F1-M-EM / quatro da faixa I: F2-H-EF, F2-M-EF, F2-H- } \\
\text { EM e F2-H-ES) a reconheceram, mas empregaram o sentido de 'lavar de novo', 'lavar } \\
\text { outra vez' para o item lexical relavar. Portanto, a unidade lexical relavado com o sentido } \\
\text { da acepção em estudo 'explorado, exaurido' (mina de ouro), revela um caso de } \\
\text { desuso, pois não se encontra mais presente na modalidade oral dos informantes } \\
\text { parnanguaras e nem nos registros dos dicionários. Presume-se, dessa forma, que o }\end{array}$} \\
\hline
\end{tabular}


resquício desta forma lexical encontra-se apenas em documentos manuscritos datados de época anteriores.

\section{ADVÉRBIO}

\begin{tabular}{|c|c|}
\hline \multicolumn{2}{|c|}{ 176. DEBALDE / DOC.13, fól.1r, l.06-11 } \\
\hline $\begin{array}{l}\text { Acepção } \\
\text { buscada }\end{array}$ & Inutilmente, em vão. \\
\hline $\begin{array}{l}\text { Acepção(ões) } \\
\text { conhecida(s) } \\
\text { pelos } \\
\text { informantes }\end{array}$ & $\begin{array}{l}\text { F1-H-EP: Quando uma pessoa tá devarde é quando tem trabalho e ela } \\
\text { não quer trabalhar, então tá devarde. Aqui todo mundo usa, tô } \\
\text { devarde. } \\
\text { F1-M-EP: NSR. } \\
\text { F1-H-EF: Devarde é estar devagar, sem fazer nada, tô com preguiça. } \\
\text { F1-M-EF: NSR. } \\
\text { F1-H-EM: Devarde é uma coisa inútil, não serva pra muita coisa, como } \\
\text { uma pessoa que não faz nada. } \\
\text { F1-M-EM: NSR. } \\
\text { F1-H-ES: Debalde não conheço, só falo devarde que é ficar sem fazer } \\
\text { nada, ficar descansando, vagabundando, não vou trabalhar, tô } \\
\text { devarde. } \\
\text { F1-M-ES: NSR. } \\
\text { F2-H-EP: É quando não quer fazer alguma coisa, diz: tô devarde. } \\
\text { F2-M-EP: Eu tô devarde, não tô fazendo nada. } \\
\text { F2-H-EF: O pessoal fala devarde, debalde não, é mais devarde. É uma } \\
\text { coisa que num serve pra nada, não faz nada, é inútil. } \\
\text { F2-M-EF: Devarde é ficar de boa: essa pessoa só fica devarde, não faz } \\
\text { nada. } \\
\text { F2-H-EM: Devarde é quando uma pessoa não faz nada. E Debalde é } \\
\text { quando tem alguma coisa sobrando. } \\
\text { F2-M-EM: Devarde é sem fazer nada. Aqui se usa bastante. } \\
\text { F2-H-ES: Devarde tá fazendo nada, fica devarde, esse é o braguenhes. } \\
\text { Debalde não, é debarde porque debalde parece areia, então é debarde } \\
\text { ou devarde, esse tá certo, os dois, porque o indivíduo não tá fazendo } \\
\text { nada, então ele foi preso por vagabundagem, foi preso porque tava } \\
\text { devarde. } \\
\text { F2-M-ES: A gente usa: aquela pessoa não trabalha, é uma pessoa que taí } \\
\text { debarde, não trabalha. }\end{array}$ \\
\hline
\end{tabular}




\begin{tabular}{|c|c|}
\hline $\begin{array}{l}\text { Acepções } \\
\text { registradas } \\
\text { nos } \\
\text { dicionários }\end{array}$ & $\begin{array}{l}\text { Bluteau (1712-1728): DEBALDE. Inutilmente. } \\
\text { Morais Silva (1813): DEBÁLDE, V. Balde. [BÁLDE, s. m. §. De } \\
\quad \text { balde, adv. em vão, inutilmente]. } \\
\text { Cunha (1997): balde }{ }^{2} \text { loc. adv. 'em vão, inutilmente'. As locs. Debalde } \\
\quad \text { e embalde já se documentam no séc. XIV. } \\
\text { Ferreira (2004): debalde } 1 \text {. Inutilmente, em vão; baldadamente, } \\
\quad \text { embalde. } \\
\text { Houaiss (2007): debalde datação sXIV em vão, inutilmente; embalde. }\end{array}$ \\
\hline $\begin{array}{l}\text { Na busca } \\
\text { da faixa I e } \\
\text { devarde e n } \\
\text { H-ES: 'Del } \\
\text { descansand } \\
\text { devarde, de } \\
\text { nada, é inú } \\
\text { quando tem } \\
\text { esse é o br } \\
\text { debarde ou } \\
\text { ele foi presc } \\
\text { forma deva } \\
\text { fenômenos } \\
\text { de } l \text { para } r \\
\text { formação d } \\
\text { característic } \\
\text { pois, para o } \\
\text { 'co isa inútil } \\
\text { sobrando', } \\
\text { que evideno } \\
\text { Cunha, por } \\
\text { significado } \\
\text { Analisan } \\
\text { sua ocorrên } \\
\text { a maioria d } \\
\text { escrito, pres }\end{array}$ & $\begin{array}{l}\text { cepção 'inutilmente, em vão' para a lexia debalde, os informantes (quatro } \\
\text { da faixa II) que reconheceram a acepção disseram ser a pronúncia certa } \\
\text { ebalde, conforme se constata nas respostas dos informantes a seguir: F1- } \\
\text { não conheço, só falo devarde que é ficar sem fazer nada, ficar } \\
\text { gabundando, não vou trabalhar, tô devarde'; F2-H-EF: 'O pessoal fala } \\
\text { e não, é mais devarde. É uma coisa que num serve pra nada, não faz } \\
\text { F2-H-EM: 'Devarde é quando uma pessoa não faz nada. E Debalde é } \\
\text { ıma coisa sobrando'; F2-H-ES: 'Devarde tá fazendo nada, fica devarde, } \\
\text { nhes. Debalde não, é debarde porque debalde parece areia, então é } \\
\text { rde, esse tá certo, os dois, porque o indivíduo não tá fazendo nada, então } \\
\text { vagabundagem, foi preso porque tava devarde'. Portanto, o emprego da } \\
\text { não significa tratar-se de outro item lexical. Na história da língua, os } \\
\text { ecidos como degeneração (alteração de } v \text { para b) e rotacismo (alteração } \\
\text { trava silábica) é uma alteração fonética comum dentro do processo de } \\
\text { sua portuguesa. Na maioria das vezes, esses fenômenos revelam marcas } \\
\text { falar rural, mas que não é o caso do item lexical devarde em Paranaguá, } \\
\text { rmantes, devarde significa 'estar à toa', 'sem fazer nada', 'não faz nada', } \\
\text { n vão'. Enquanto que debalde apresenta outros valores: 'ter alguma coisa } \\
\text { oarecido com areia'. Os lexicógrafos pesquisados registraram a acepção } \\
\text { o mesmo sentido empregado no corpus escrito: 'inutilmente, em vão'. } \\
\text { ez, registrou a entrada balde } \text {, informando ser de balde uma loc. adv. cujo } \\
\text { esmo registrado pelos demais dicionaristas. } \\
\text { contexto de utilização da unidade lexical debalde/devarde nota-se que } \\
\text { bastante produtiva na fala dos informantes parnanguaras. Portanto, como } \\
\text { formantes reconheceu a lexia com o sentido semelhante ao do corpus } \\
\text { e-se ser um caso de manutencão. }\end{array}$ \\
\hline
\end{tabular}




\subsection{Distribuição dos Itens LeXiCais POR Manutenção, TendênCia À Manutenção,} Desuso e TendênCia ho Desuso

Após a análise semântico-lexical dos 176 itens lexicais, chegou-se ao resultado de quais lexias apontam caso de manutenção, tendência à manutenção, desuso e tendência ao desuso. Para maior clareza desse resultado, segue o quadro contendo os itens lexicais e suas respectivas classificações:

Quadro 5 - Distribuição dos itens lexicais por manutenção, tendência à manutenção, desuso e tendência ao desuso

\begin{tabular}{|c|c|c|c|}
\hline Manutenção & $\begin{array}{l}\text { Tendência à } \\
\text { Manutenção }\end{array}$ & Desuso & $\begin{array}{c}\text { Tendência ao } \\
\text { Desuso }\end{array}$ \\
\hline $\begin{array}{l}\text { Acudir } \\
\text { Apossar } \\
\text { Arrematação } \\
\text { Arrombar } \\
\text { Debalde } \\
\text { Embargo } \\
\text { Enfermo } \\
\text { Mantimento } \\
\text { Ripa } \\
\text { Sustar }\end{array}$ & $\begin{array}{l}\text { Aceno } \\
\text { Alqueire } \\
\text { Alugador } \\
\text { Apanhar } \\
\text { Apontado } \\
\text { Atravessador } \\
\text { Botar } \\
\text { Coibir } \\
\text { Cultura } \\
\text { Despejar } \\
\text { Embrenhado } \\
\text { Felicitar } \\
\text { Habitador } \\
\text { Inteirar } \\
\text { Légua } \\
\text { Longes } \\
\text { Miliciano } \\
\text { Moléstia } \\
\text { Ordenação } \\
\text { Ordenado } \\
\text { Penúria }\end{array}$ & $\begin{array}{l}\text { Acometido } \\
\text { Admoestar } \\
\text { Afeto } \\
\text { Arbitramento } \\
\text { Ardil } \\
\text { Assentado } \\
\text { Assistir } \\
\text { Atalhar } \\
\text { Aulista } \\
\text { Avançar a dinheiro } \\
\text { Avulsão } \\
\text { Balandra } \\
\text { Bando } \\
\text { Botar pingos } \\
\text { Braçame } \\
\text { Brioso } \\
\text { Brotar } \\
\text { Camarista } \\
\text { Data } \\
\text { De boa nota } \\
\text { Decoroso } \\
\text { Demitir } \\
\text { Desconcertado } \\
\text { Dilatado }\end{array}$ & $\begin{array}{l}\text { Abastado } \\
\text { Acautelar } \\
\text { Acomodado } \\
\text { Acompanhar } \\
\text { Acordar } \\
\text { Aguardente } \\
\text { Alentar } \\
\text { Ansiar } \\
\text { Apenar } \\
\text { Arrimar } \\
\text { Arroba } \\
\text { Asilo } \\
\text { Assenhorear-se } \\
\text { Assombrado } \\
\text { Avocar } \\
\text { Barra } \\
\text { Botica } \\
\text { Braça } \\
\text { Cabal } \\
\text { Ceifa } \\
\text { Cessar } \\
\text { Circuito } \\
\text { Circunvizinhança } \\
\text { Comiserar-se }\end{array}$ \\
\hline
\end{tabular}


continuação

\begin{tabular}{|c|c|c|c|}
\hline Manutenção & $\begin{array}{l}\text { Tendência à } \\
\text { Manutenção }\end{array}$ & Desuso & $\begin{array}{c}\text { Tendência ao } \\
\text { Desuso }\end{array}$ \\
\hline & & $\begin{array}{l}\text { Diligência } \\
\text { Discípulo } \\
\text { Dito } \\
\text { Emolumento } \\
\text { Empregar-se } \\
\text { Enfadonho } \\
\text { Engenho } \\
\text { Esterilidade } \\
\text { Excreto } \\
\text { Faisqueira } \\
\text { Falto } \\
\text { Fiel } \\
\text { Finta } \\
\text { Fogo } \\
\text { Fortuna } \\
\text { Incorrer } \\
\text { Irresoluto } \\
\text { Lancear } \\
\text { Lavra } \\
\text { Lavrar } \\
\text { Lograr } \\
\text { Mediando } \\
\text { Meirinho } \\
\text { Mercê } \\
\text { Molhado } \\
\text { Nau } \\
\text { Ob-reptício } \\
\text { Obsequioso } \\
\text { Observância } \\
\text { Obviar } \\
\text { Patentear } \\
\text { Pender } \\
\text { Pervencido } \\
\text { Perverter } \\
\text { Profitente } \\
\text { Propina } \\
\text { Rábula } \\
\text { Rédito } \\
\end{array}$ & $\begin{array}{l}\text { Cômputo } \\
\text { Conjuntura } \\
\text { Consternação } \\
\text { Deliberar } \\
\text { Demasia } \\
\text { Depor } \\
\text { Deposto } \\
\text { Derrogado } \\
\text { Desarranjo } \\
\text { Desconsolação } \\
\text { Desmembração } \\
\text { Detrimento } \\
\text { Diminuto } \\
\text { Embaraçar } \\
\text { Enjeitar } \\
\text { Erigir-se } \\
\text { Escusar } \\
\text { Expedição } \\
\text { Expender } \\
\text { Facultar } \\
\text { Faiscar } \\
\text { Findo } \\
\text { Fomentar } \\
\text { Frívolo } \\
\text { Iminente } \\
\text { Inconveniente } \\
\text { Incumbência } \\
\text { Indecoroso } \\
\text { Intentar } \\
\text { Ladino } \\
\text { Letra } \\
\text { Libra } \\
\text { Limitado } \\
\text { Luzido } \\
\text { Mestre } \\
\text { Módico } \\
\text { Obrar } \\
\text { Opulência }\end{array}$ \\
\hline
\end{tabular}


continuação

\begin{tabular}{|l|l|l|l|}
\hline Manutenção & \multicolumn{1}{|c|}{$\begin{array}{c}\text { Tendência à } \\
\text { Manutenção }\end{array}$} & \multicolumn{1}{|c|}{ Desuso } & \multicolumn{1}{|c|}{$\begin{array}{c}\text { Desuesuso ao } \\
\text { Desuso }\end{array}$} \\
\hline & & Subitar & Paridade \\
& & Sumaca & Pernicioso \\
& & Tabuado & Pôr os olhos \\
& & Principiado \\
& & Tabularia & Privança \\
& & & Rebate \\
\hline
\end{tabular}

O gráfico 1 apresenta a distribuição em porcentagem do total de ocorrências por manutenção, tendência à manutenção, desuso e tendência ao desuso.

Gráfico 1 - Índice de porcentagem de ocorrência por manutenção, tendência à manutenção, desuso e tendência ao desuso

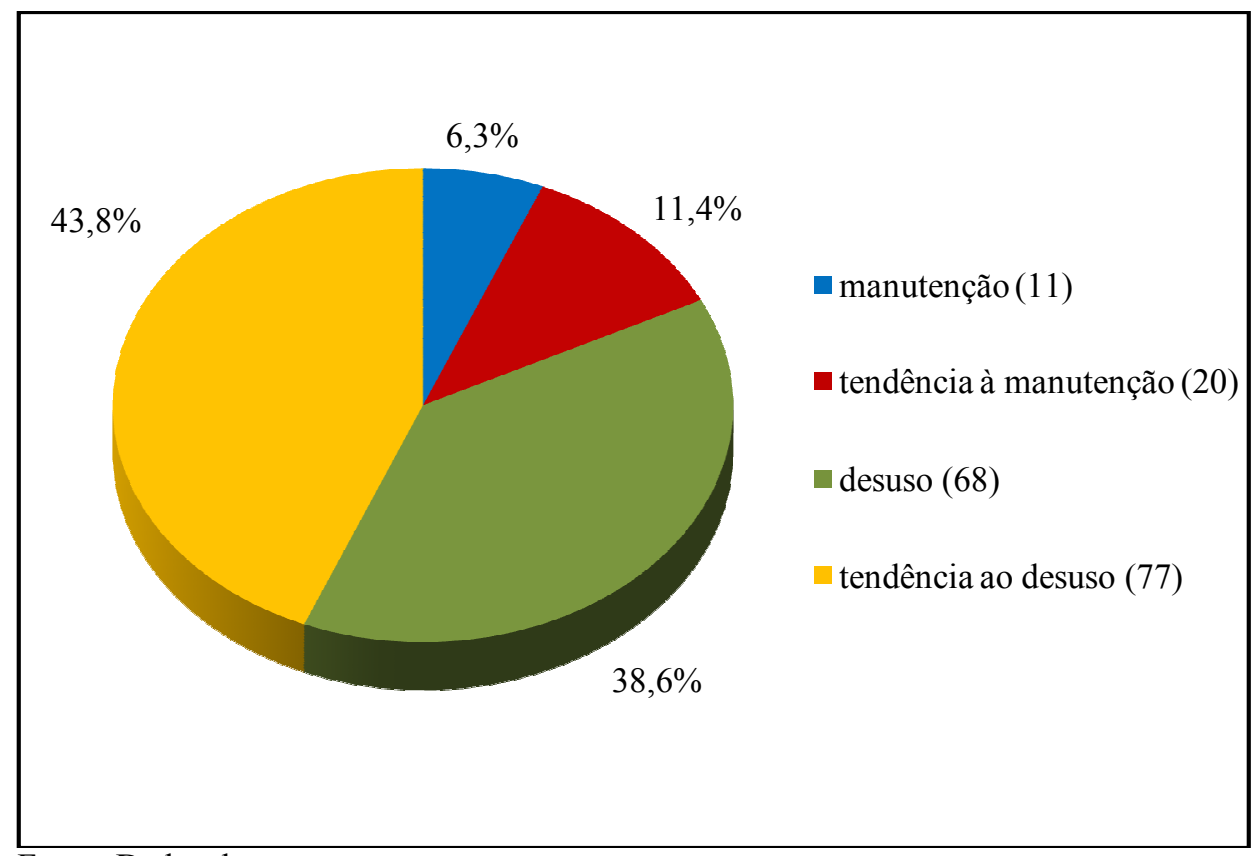

Fonte: Dados do corpus.

O gráfico 1 mostra que, do total de 176 lexias estudadas, a grande maioria, 77 casos, apresenta tendência ao desuso totalizando $43,8 \%$ do número de ocorrências. O caso de desuso vem em seguida, com 38,6\%. Depois, tendência à manutenção, com 11,4\% e, por último, o caso de manutenção com apenas $6,3 \%$ de ocorrências. Estes dados evidenciam que o 
vocabulário dos parnanguaras revela traços de inovação, pois, somando a porcentagem de manutenção e tendência à manutenção $(17,7 \%)$, o resultado é bem menor que as porcentagens de desuso e tendência ao desuso (82,4\%). Talvez, a razão deste resultado esteja correlacionada à natureza oficial dos documentos manuscritos, cujos vocábulos, em sua maior parte, compõem um vocabulário oficial da época. Mas, por outro lado, como tem discutido Toniolo (2007, p. 25), observa-se, por meio da leitura destes manuscritos, que, apesar de oficiais (documentos notariais), "muitos destes documentos manuscritos estão muito próximos de uma modalidade de língua provavelmente falada por boa parte dos brasileiros no tempo da Colônia e do Império”. Portanto, deve-se levar em consideração que, na época destes documentos manuscritos, o número de pessoas instruídas no Brasil era muito pequeno e, no caso do Paraná, após a expulsão dos jesuítas, o sistema educacional continuou tão precário durante todo o período setecentista que quase todos os moradores de pequenas vilas,

como Paranaguá, eram analfabetos (TRINDADE; ANDREAZZA, 2003, p. 408). É de se considerar, no entanto, que estes documentos manuscritos foram quase todos escritos por pessoas cultas, mas, conforme salienta Toniolo (2007, p. 25), "não se sabe com exatidão o que era ser culto no passado, tampouco se o que sentimos como formal, fosse, para eles, informalidade". Partindo deste princípio, de que textos oficiais talvez não sejam o único fator motivador pelo alto índice de porcentagem dos casos de tendência ao desuso e desuso, podese pensar, também, no processo de transformação socioeconômica do município de Paranaguá, onde, nas últimas três décadas, segundo dados do IBGE, o crescimento demográfico quase dobrou, provavelmente devido ao fluxo de imigrantes para esta região, proporcionando aos moradores dessa cidade o contanto com outras variedades linguísticas, resultando na ocorrência de fatores que condicionam as modificações e inovação da linguagem, principalmente no eixo lexical.

\subsection{ANÁLISE DAS VARIÁVEIS: FAIXA ETÁRIA, GÊNERO E ESCOLARIDADE}

A análise e o cotejo dos dados das variáveis foram feitos com o auxílio do programa Systemic Coder ${ }^{40}$. Com esse programa montou-se o esquema seguinte, que traz as dezesseis

\footnotetext{
${ }^{40}$ Systemic Coder 4.68 .
} 
variáveis referentes: à faixa etária (primeira faixa: F1 e segunda etária: F2), ao sexo (masculino: M e feminino: F) e à escolaridade (ensino primário: EP, ensino fundamental: EF, ensino médio: EM e ensino superior: ES). Destas variáveis, investigou-se o conhecimento da lexia com a acepção buscada (manutenção), o conhecimento da lexia com outra acepção (desuso) e o não conhecimento da lexia (NSR: não soube responder).

Figura 5 - Esquema de enquadramento das variáveis

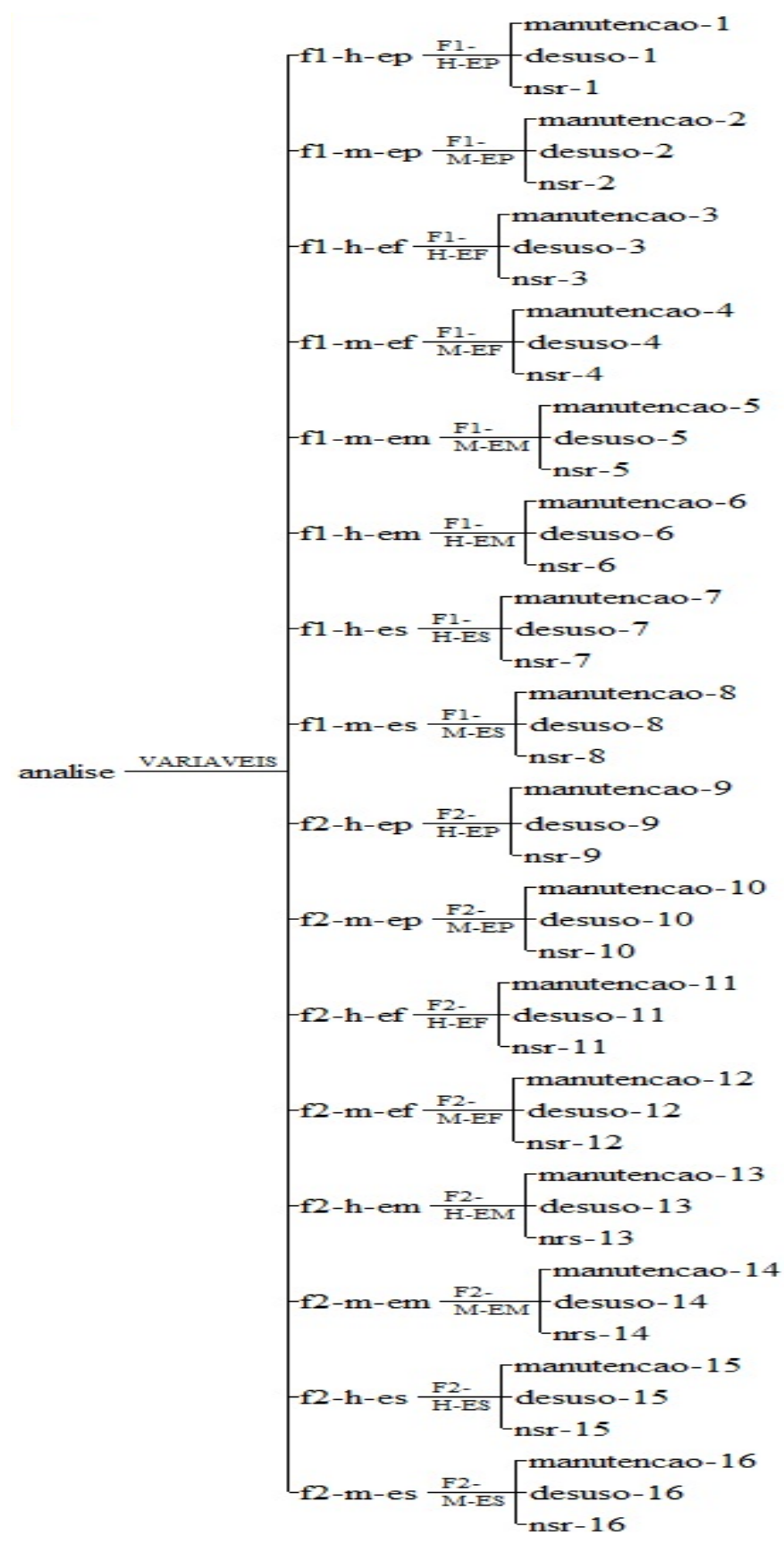


Por meio deste esquema, foi feito o enquadramento das variáveis, resultando no esquema abaixo (figura 2), com as informações seguintes: Faixa etária 1: oito variáveis: F1H-EP, F1-M-EP, F1-H-EF, F1-M-EF, F1-H-EM, F1-M-EM, F1-H-ES e F1-M-ES; Faixa etária II: oito variáveis: F2-H-EP, F2-M-EP, F2-H-EF, F2-M-EF, F2-H-EM, F2-M-EM, F2H-ES e F2-M-ES; Número de ocorrências por: manutenção, desuso e NSR; e Porcentagem de ocorrência por: manutenção, desuso e NSR (não soube responder).

Quadro 6 - Quadro descritivo da porcentagem local das variáveis

\begin{tabular}{|c|c|c|c|c|c|c|c|}
\hline \multicolumn{8}{|c|}{ Porcentagem local } \\
\hline \multicolumn{4}{|c|}{ Faixa etária 1} & \multicolumn{4}{|c|}{ Faixa etária 2} \\
\hline \multirow[t]{3}{*}{ F1-H-EP } & manutencao- 1 & 20 & $11.1 \%$ & F2-H-EP & manutencao-9 & 34 & $19.5 \%$ \\
\hline & desuso-1 & 27 & $15.0 \%$ & & desuso-9 & 37 & $21.3 \%$ \\
\hline & nsr-1 & 133 & $73.9 \%$ & & nsr-9 & 103 & $59.2 \%$ \\
\hline \multirow[t]{3}{*}{ F1-M-EP } & manutencao-2 & 12 & $6.9 \%$ & F2-M-EP & manutencao-10 & 31 & $17.5 \%$ \\
\hline & desuso-2 & 25 & $14.3 \%$ & & desuso-10 & 43 & $24.3 \%$ \\
\hline & nsr-2 & 138 & $78.9 \%$ & & nsr -10 & 103 & $58.2 \%$ \\
\hline \multirow[t]{3}{*}{ F1-H-EF } & manutencao-3 & 34 & $19.1 \%$ & F2-H-EF & manutencao-11 & 76 & $43.7 \%$ \\
\hline & desuso-3 & 76 & $42.7 \%$ & & desuso-11 & 76 & $43.7 \%$ \\
\hline & nsr-3 & 68 & $38.2 \%$ & & nST -11 & 22 & $12.6 \%$ \\
\hline \multirow[t]{3}{*}{ F1-M-EF } & manutencao- 4 & 28 & $16.1 \%$ & F2-M-EF & manutencao-12 & 50 & $28.6 \%$ \\
\hline & desuso-4 & 45 & $25.9 \%$ & & desuso-12 & 66 & $37.7 \%$ \\
\hline & nsr-4 & 101 & $58.0 \%$ & & nsr- 12 & 59 & $33.7 \%$ \\
\hline \multirow[t]{3}{*}{ F1-M-EM } & manutencao-5 & 22 & $12.5 \%$ & F2-H-EM & manutencao-13 & 42 & $24.3 \%$ \\
\hline & desuso-5 & 56 & $31.8 \%$ & & desuso-13 & 70 & $40.5 \%$ \\
\hline & nsr-5 & 98 & $55.7 \%$ & & nrs -13 & 61 & $35.3 \%$ \\
\hline \multirow[t]{3}{*}{ F1-H-EM } & manutencao- 6 & 36 & $20.8 \%$ & F2-M-EM & manutencao-14 & 29 & $16.3 \%$ \\
\hline & desuso- 6 & 47 & $27.2 \%$ & & desuso-14 & 41 & $23.0 \%$ \\
\hline & ust -6 & 90 & $52.0 \%$ & & nrs-14 & 108 & $60.7 \%$ \\
\hline \multirow[t]{3}{*}{ F1-H-ES } & manutencao-7 & 35 & $20.0 \%$ & F2-H-ES & manutencao- 15 & 77 & $43.8 \%$ \\
\hline & desuso-7 & 45 & $25.7 \%$ & & desuso-15 & 71 & $40.3 \%$ \\
\hline & nsr -7 & 95 & $54.3 \%$ & & nsr-15 & 28 & $15.9 \%$ \\
\hline \multirow[t]{3}{*}{ F1-M-ES } & manutencao-8 & 43 & $24.3 \%$ & F2-M-ES & manutencao-16 & 44 & $25.0 \%$ \\
\hline & desuso-8 & 43 & $24.3 \%$ & & desuso-16 & 66 & $37.5 \%$ \\
\hline & nsr- 8 & 91 & $51.4 \%$ & & nst- 16 & 66 & $37.5 \%$ \\
\hline
\end{tabular}

Como se vê no quadro, o maior número de ocorrência por conhecimento da lexia com a acepção buscada (manutenção) e por conhecimento da lexia com outra acepção 
(desuso) se concentra na segunda faixa etária, enquanto o maior número de ocorrência por não conhecimento da lexia (não soube responder) se concentra na primeira faixa etária.

Com o intuito de melhor explicitar, dentro de cada faixa etária, em quais grupos se concentra o maior índice de manutenção, desuso e NSR, as porcentagens constantes do quadro 9 foram organizadas e dispostas nos gráficos seguintes:

Gráfico 2 - FAIXA ETÁRIA I: Porcentagem de ocorrência por manutenção

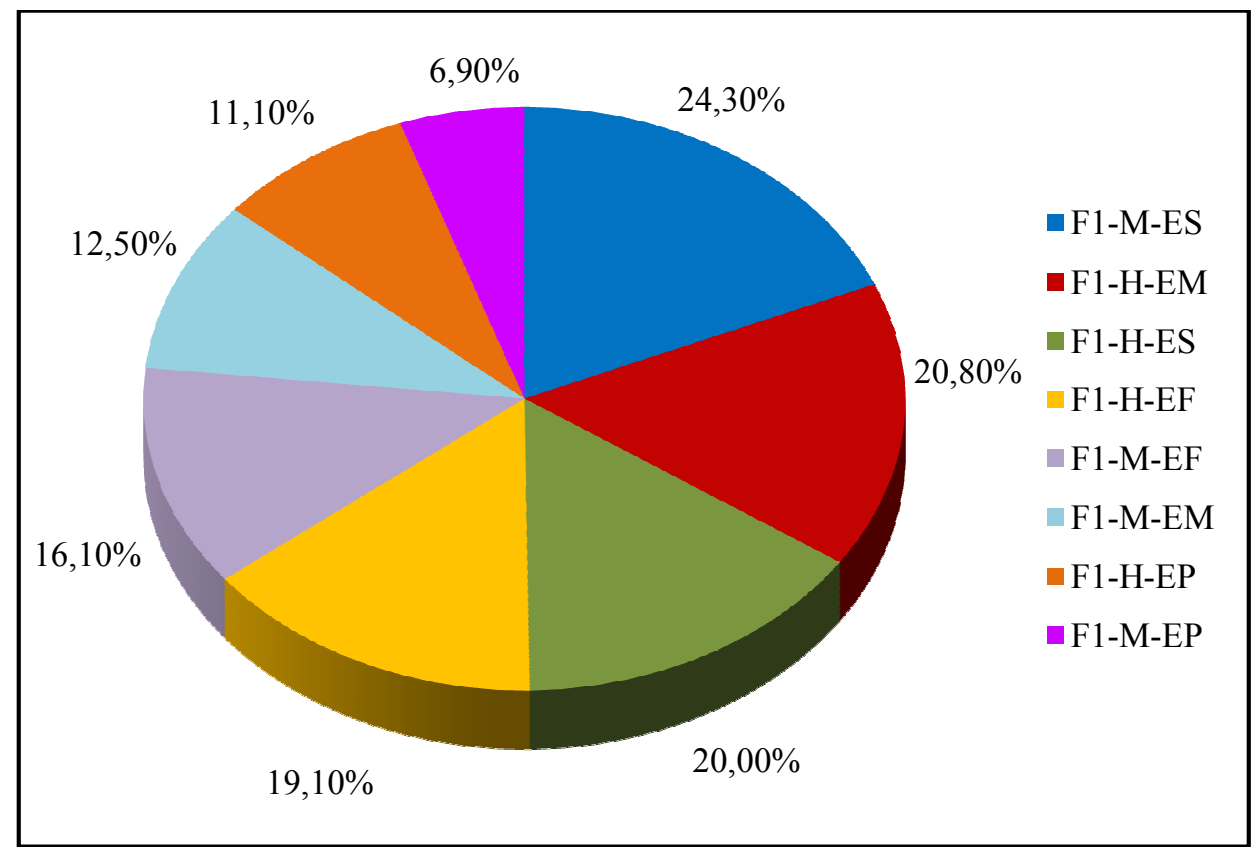

Fonte: Dados do corpus.

Como se nota no gráfico 2, a maior concentração de manutenção da faixa I ocorre na fala da informante feminina do ensino superior (24,3\%); em seguida concentra-se na fala do informante masculino do ensino médio $(20,8 \%)$, coocorrendo com o informante masculino do ensino superior (20\%). Os informantes do ensino fundamental vêm em seguida: 19,1\% para o informante masculino e $16,1 \%$ para a informante feminina. O menor índice de ocorrência por manutenção concentra-se na fala dos informantes do ensino primário: 11,1\% para o informante masculino e $6,9 \%$ para a informante feminina. Observando a concentração de manutenção da faixa I por variável escolaridade, constata-se que sua maior produtividade se encontra na fala dos informantes do ensino superior $(45,1 \%)$; em seguida, na dos informantes do ensino fundamental $(35,2 \%)$ e, depois, na fala dos informantes do ensino médio $(33,3 \%)$. Por último, os informantes do ensino primário com $18 \%$. 
Gráfico 3 - FAIXA ETÁRIA I: Porcentagem de ocorrência por desuso

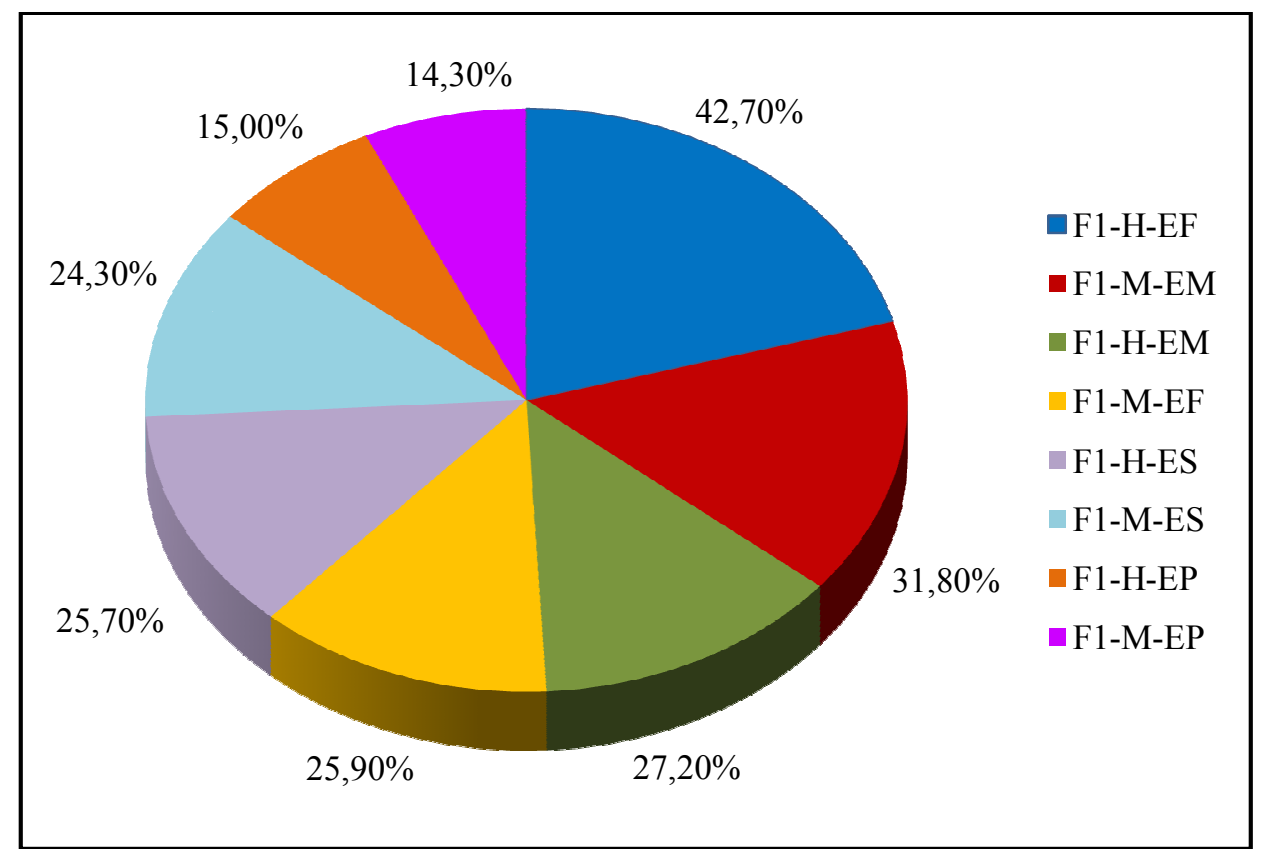

Fonte: Dados do corpus.

Com relação à ocorrência de desuso da faixa I, o gráfico 3 mostra que a maior concentração se encontra na fala do informante masculino do ensino fundamental (42,7\%). Os informantes do ensino médio vêm em seguida: $31,8 \%$ para a informante feminina e $27,2 \%$ para o informante masculino. A informante feminina do ensino fundamental apresenta $25,9 \%$ de desuso, coocorrendo com $25,7 \%$ do informante masculino do ensino superior. Ainformante feminina do ensino superior conserva $24,3 \%$ de frequência de desuso, e os informantes do ensino primário apresentam a menor taxa de ocorrência, 15\% para o informante masculino e $14,3 \%$ para a informante feminina. A maior concentração de desuso da faixa I por escolaridade se concentra na fala dos informantes do ensino fundamental (68,6\%); em seguida, vêm os informantes do ensino médio (59\%); depois, os informantes do ensino superior (50\%) e, por último, os informantes do ensino primário $(29,3 \%)$. 
Gráfico 4 - FAIXA ETÁRIA I: Porcentagem de ocorrência por NSR

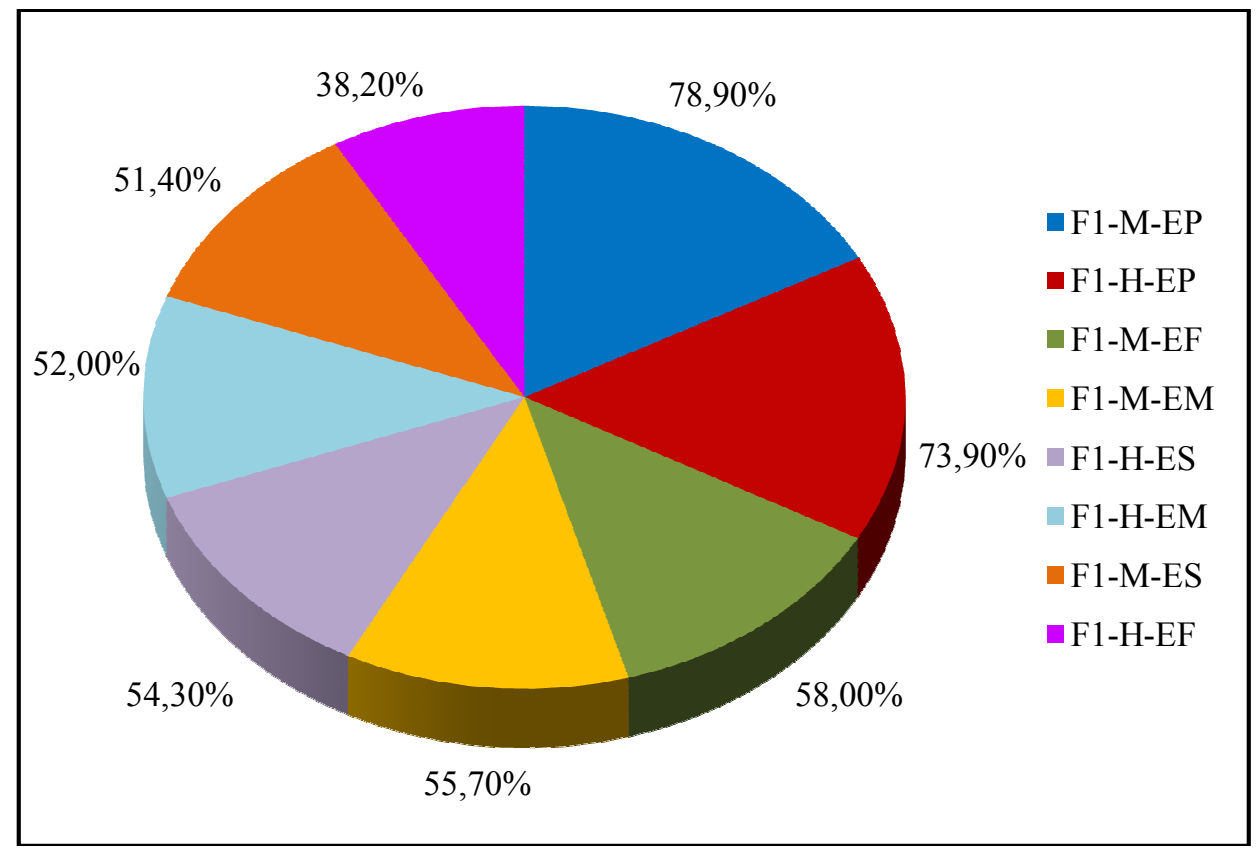

Fonte: Dados do corpus.

Pelo gráfico 4, pode-se observar que o maior índice de ausência de respostas da faixa I se encontra nos informantes do ensino primário: $78,9 \%$ para a informante feminina e $73,9 \%$ para o informante masculino. $\mathrm{Na}$ casa dos $50 \%$ de desconhecimento da lexia investigada encontram-se a informante feminina do ensino fundamental (58\%), depois a informante feminina do ensino médio $(55,7 \%)$, o informante masculino do ensino superior $(54,3 \%)$, o informante masculino do ensino médio (52\%), e a informante feminina do ensino superior $(51,4 \%)$. O informante masculino do ensino fundamental apresentou a menor taxa de ocorrência de ausência de respostas $(38,2 \%)$. Com base nos dados mostrados pelo gráfico, constata-se que, na variável escolaridade, os informantes do ensino primário foram os que menos reconheceram os itens lexicais estudados, apresentado 152,8\% de ausência de respostas. Em seguida, com 107,7\%, encontram-se os informantes do ensino médio, depois vêm os informantes do ensino superior $(105,7 \%)$ e, por último, os informantes do ensino fundamental apresentando a taxa de $96,2 \%$ de NSR.

Com base nos dados mostrados nos gráficos 2,3 e 4, referentes à primeira faixa etária, conclui-se que o maior número de ocorrência por: (i) conhecimento da lexia com a acepção buscada (manutenção) concentra-se no grupo de informantes do ensino superior (45,1\%); (ii) conhecimento da lexia com outra acepção (desuso) concentra-se no grupo de 
informantes do ensino fundamental (68,6\%); e (iii) desconhecimento da lexia (não soube responder) está presente no grupo de informantes do ensino primário $(152,8 \%)$.

Gráfico 5 - FAIXA ETÁRIA II: Porcentagem de ocorrência por manutenção

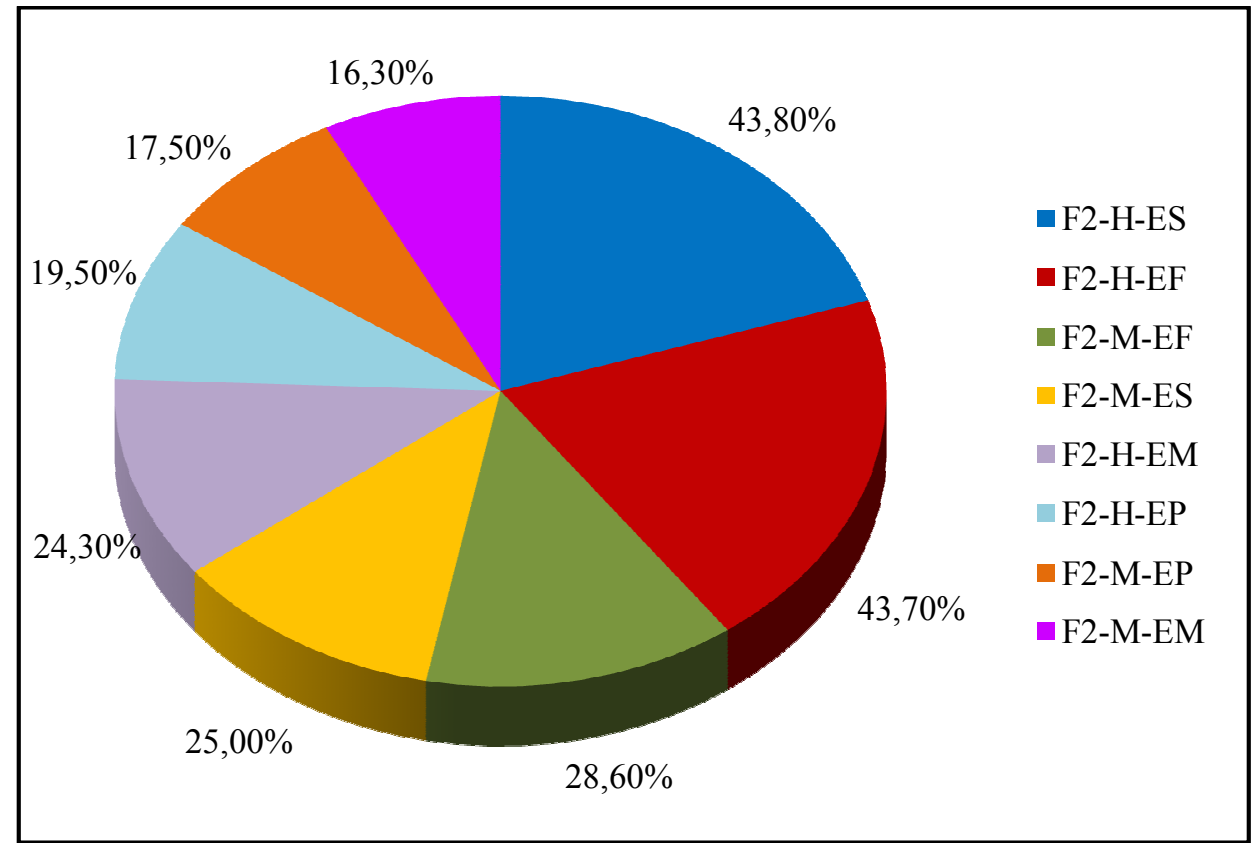

Fonte: Dados do corpus.

O gráfico 5 mostra que a maior concentração de manutenção da faixa II ocorre na fala do informante masculino do ensino superior (43,8\%), coocorrendo com $43,7 \%$ do informante masculino do ensino fundamental. Em seguida encontra-se na fala da informante feminina do ensino fundamental $(28,6 \%)$, depois da informante feminina do ensino superior (25\%), do informante masculino do ensino médio (24,3\%), do informante masculino do ensino primário (19,5\%), da informante feminina do ensino primário $(17,5 \%)$. Com o menor índice de manutenção encontra-se a informante feminina do ensino médio (16,3\%). Observando a concentração de manutenção da faixa II por variável escolaridade, constata-se que sua maior produtividade se encontra na fala dos informantes do ensino fundamental (72,3\%), seguida dos informantes do ensino superior (68,8\%). Depois, os informantes do ensino médio (40,6\%) e, por último, os informantes do ensino primário (37\%). 
Gráfico 6 - FAIXA ETÁRIA II: Porcentagem de ocorrência por desuso

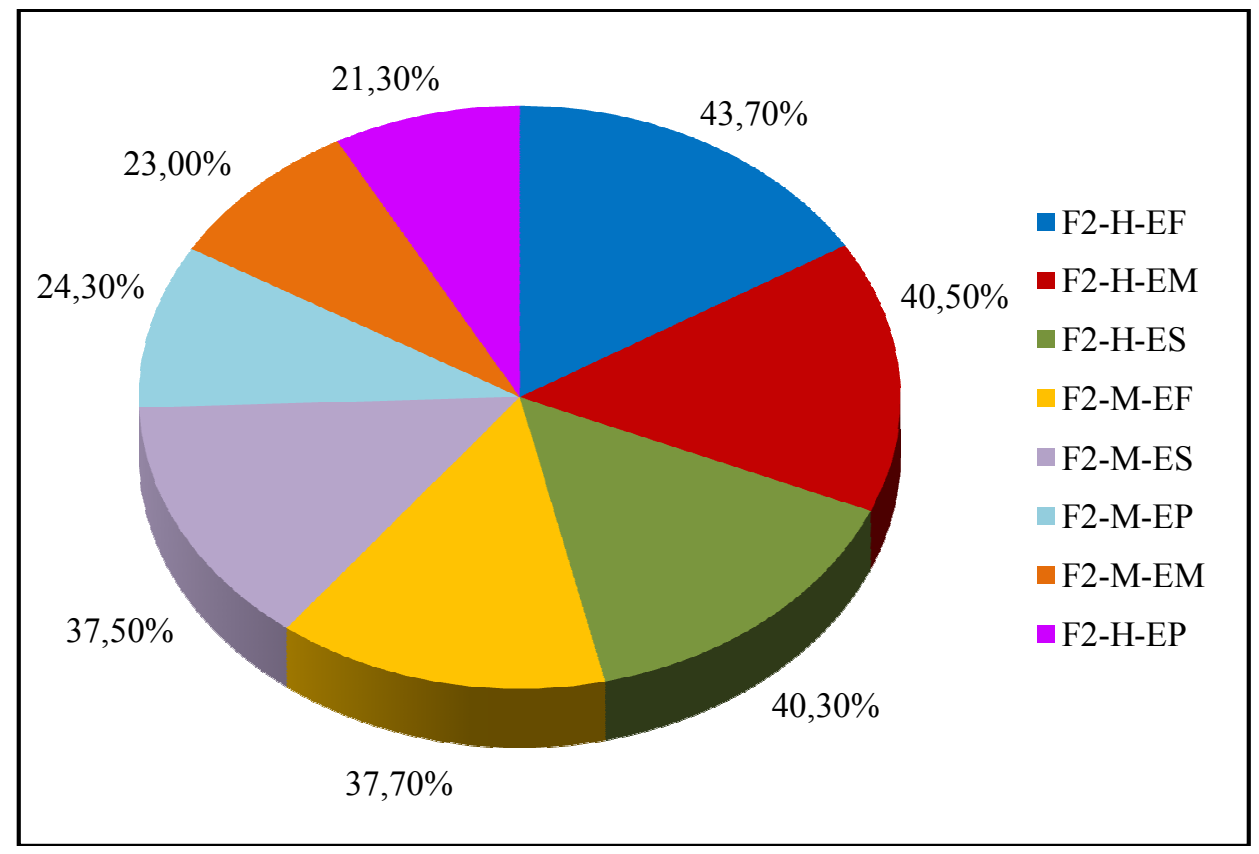

Fonte: Dados do corpus.

Como se observa no gráfico 6 , o maior índice de ocorrência de desuso da faixa II se concentra no contexto de fala do informante masculino do ensino fundamental $(43,7 \%)$; em seguida, com 40,5\%, vem o informante masculino do ensino médio, coocorrendo com o informante masculino do ensino superior $(40,3 \%)$. Ainformante feminina do ensino fundamental apresenta $37,7 \%$ de ocorrência de desuso, coocorrendo com os $37,5 \%$ da informante feminina do ensino superior. O informante do ensino primário mantém $24,3 \%$ de desuso, a informante feminina do ensino médio $23 \%$ e o informante masculino do ensino primário, com a taxa de 21,3\%, registra o menor índice de desuso desta faixa etária. Quanto à variável escolaridade, faixa II, os dados apontam maior concentração de desuso na fala dos informantes do ensino fundamental $(81,4 \%)$, em seguida vêm os informantes do ensino superior $(77,8 \%)$, depois os informantes do ensino médio $(63,5 \%)$ e, por último, os informantes do ensino primário $(45,6 \%)$. 
Gráfico 7 - FAIXA ETÁRIA II: Porcentagem de ocorrência por NSR

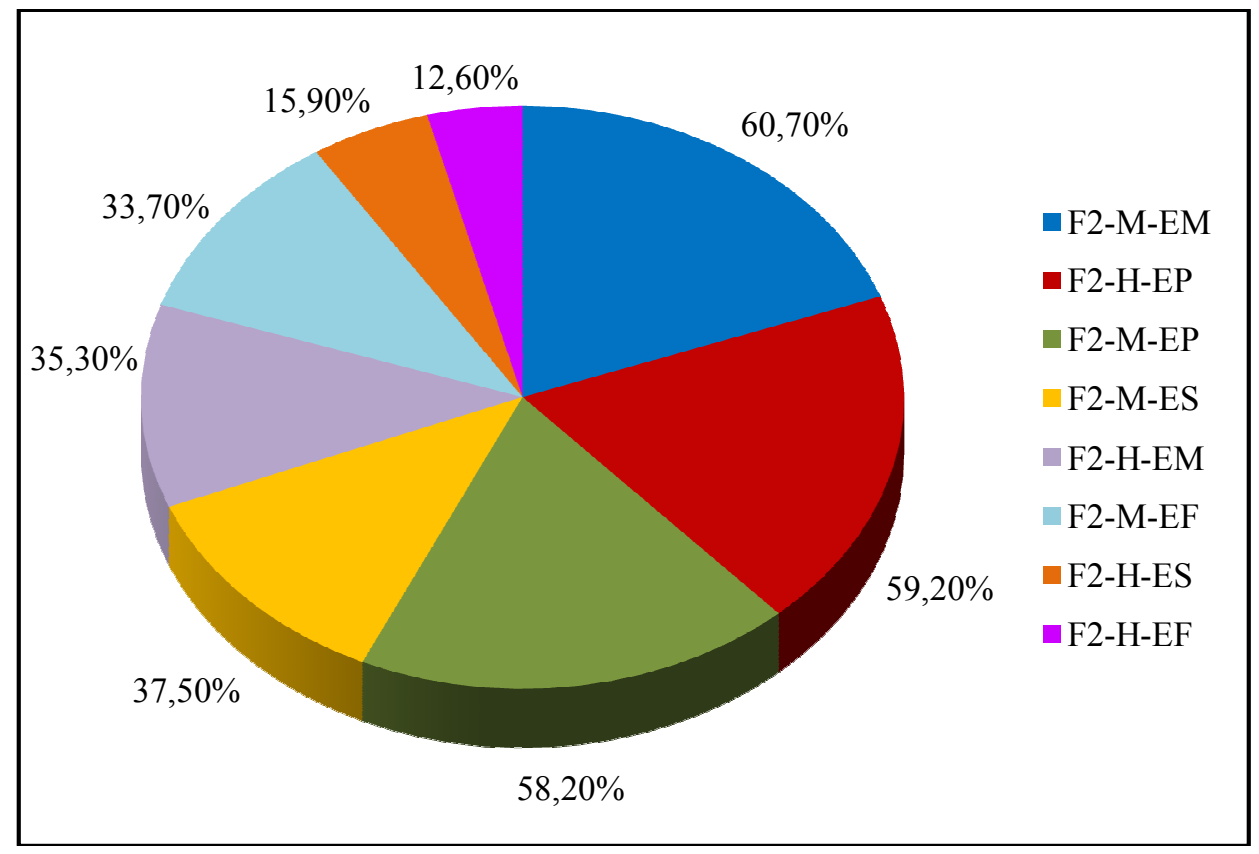

Fonte: Dados do corpus.

Verifica-se, no gráfico 7, que o maior índice de ausência de respostas da faixa II se concentra na fala da informante feminina do ensino médio (60,7\%); em seguida, vêm os informantes do ensino primário: $59,2 \%$ para o informante masculino e 58,2\% para a informante feminina. Depois, vem a informante feminina do ensino superior $(37,5 \%)$, o informante masculino do ensino médio $(35,3 \%)$, a informante feminina do ensino fundamental $(33,7 \%)$, o informante masculino do ensino superior $(15,9 \%)$ e o informante masculino do ensino fundamental $(12,6 \%)$, apresentando a menor taxa de ausência de respostas. Baseando-se nos dados mostrados pelo gráfico, observa-se que na variável escolaridade os informantes do ensino primário foram os que menos reconheceram as lexias investigadas, apresentando 117,4\% de ausência de respostas. Em seguida, com 96\%, encontram-se os informantes do ensino médio. Depois, aparecem os informantes do ensino superior, com 53,4\%, e, por último, os informantes do ensino fundamental, apresentando a taxa de $46,3 \%$ de NSR.

Ao observar o resultado dos dados constantes nos gráficos 5,6 e 7, referentes à segunda faixa etária, constata-se que o maior número de ocorrência por: (i) conhecimento da lexia com a acepção buscada (manutenção) concentra-se no grupo de informantes do ensino fundamental (72,3\%); (ii) conhecimento da lexia com outra acepção (desuso) concentra-se 
também no grupo de informantes do ensino fundamental $(81,4 \%)$; e (iii) não conhecimento da lexia (não soube responder) está presente no grupo de informantes do ensino primário $(117,4 \%)$.

Por meio da leitura e análise dos dados obtidos pelas tabelas e pelos gráficos, foi possível concluir que, no grupo de informantes do ensino primário, tanto na faixa I como na faixa II, concentra-se o menor índice de ocorrências por manutencão e $\underline{\text { desuso }}$, e o maior índice de ocorrência por não respostas. Talvez esse resultado seja o reflexo do contexto socioeconômico e cultural destes falantes, uma vez que o baixo nível de escolaridade pode favorecer a inibição da realização do contexto de produção de fala por parte desses informantes. Segundo Bortoni-Ricardo (1986, p. 10-11), "Numa situação de fala em que uma professora universitária e alunos de graduação e pós-graduação entrevistam pessoas analfabetas ou semi-analfabetas, de classe baixa e origem rural, são postas em contato variedade distintas da língua, o que naturalmente, enseja dificuldades de comunicação". De acordo com esta autora, em uma entrevista estruturada a relação entre entrevistado e inquiridor é assimétrica, ou seja, de um lado temos o pesquisador universitário e de outro lado o informante pertencente a uma classe social inferior. Nestas circunstâncias é comum ocorrer o problema de 'insegurança linguística' por parte do informante rural ou de origem rural. $\mathrm{O}$ fato dele não responder às questões pode ser porque o entrevistado não entendeu a pergunta, e conforme observa Bortoni-Ricardo (1986, p.16), "muitas vezes os informantes de classe baixa evidenciam dificuldades em entender o português padrão”. Mais adiante, esta autora esclarece que

\begin{abstract}
A maioria dos problemas de comunicação durante as entrevistas parecem derivar de diferenças dialetais nos níveis fonológico, gramatical e semântico. Em outras palavras, o ouvinte deixa de compreender o sentido do enunciado do falante num contexto específico porque não está familiarizado com: a) determinada regra fonológica que altera a forma de uma palavra conhecida; b) determinada variante gramatical; c) o significado que determinada palavra assume no dialeto do interlocutor e d) o objeto ou estado de coisas a que a palavra se refere (BORTONI-RICARDO, 1986, p. 17).
\end{abstract}

Portanto, é importante deixar claro, que problemas desta natureza linguística podem causar um alto índice de não resposta por parte desses entrevistados de origem rural, muitas vezes analfabetos ou semi-alfabetizados. 


\section{Considenacōes Frinais}




\section{CONSIDERAÇÕES FINAIS}

Inicialmente, essa pesquisa procurou mostrar que muito material manuscrito, ainda não manuseado, pode ter seu valor científico, a partir do momento em que determinado pesquisador resolva aplicar a ele regras e critérios confiáveis, como as normas de edições, para uma futura investigação linguística.

A edição semidiplomática de textos antigos brasileiros se faz necessária na medida em que preserva todo o documento, seja linguístico ou histórico. Ambos são extremamente importantes, quando se leva em conta que o primeiro preserva a língua, sua variedade, suas nuances, e traça uma linha evolutiva, apontando todos os momentos do desenvolvimento da língua. O segundo ponto é, incondicionalmente, tão importante quanto o primeiro, pois mostra a história como realmente aconteceu, permitindo ao historiador um retrato fiel da época.

Dessa forma, ficou provado que os documentos manuscritos são fonte direta, preciosa e inesgotável de informação histórica, visto que a atuação do filólogo em conjunto com o trabalho do historiador permite a reconstrução de grande parte da história nacional desse e de outros períodos, como foi o caso da Ordem dos Jesuítas em Paranaguá. A história narrada em livros sobre a figura dos jesuítas foca somente a importância desses padres para o desenvolvimento educacional e cultural do Brasil na era colonial. Mas, por outro lado, estudando a história de Paranaguá através dos documentos manuscritos, constatou-se que no doc. 25 (fol.1r/fol.1v), datado em 27 de janeiro de 1743, os representantes da Câmara de Paranaguá redigiram uma carta oficial contra os padres jesuítas, acusando-os de se apropriarem ilegalmente de 100 braças de terras no Ribanceira. Cronistas de Paranaguá, como Leão (1926), Nascimento Junior (1929) e Boutin (2005), relatam que a coroa portuguesa, sentindo-se ameaçada pelo processo de fortalecimento das instituições jesuíticas, expulsam os padres do território brasileiro, sob o pretexto de representarem um atraso na sociedade colonial.

Quanto aos aspectos linguísticos, o exame filológico do corpus escrito mostrou ser produtivo para o conhecimento da linguagem do período setecentista. Os textos escritos, apesar de serem redigidos de acordo com a norma culta daquela época, revelam, por meio da escrita pouco hábil de seus escribas, uma grande incidência de marcas de oralidade. Portanto, todo estudioso da língua que se proponha analisar textos dos séculos XVIII e XIX, encontra características comuns e marcantes, próprias dos manuscritos desse período, uma vez que a 
adaptação do alfabeto latino ao alfabeto português provocou alguns problemas, que persistem até os dias de hoje. Como afirma Teyssier (1994, p. 148), “esses problemas podem tanto evidenciar traços da comunicação oral, como representar, de uma maneira explícita, a trajetória da língua para a separação entre os falantes do português europeu e do português brasileiro".

Após a edição semidiplomática do corpus escrito, foi realizada a seleção de 176 lexias que serviram de base tanto para a elaboração do glossário, cuja finalidade se destinou a facilitar a compreensão da acepção dos itens lexicais dentro do contexto documental analisado e caracterizar o léxico do período setecentista, como também para a elaboração do questionário semântico-lexical que teve por objetivo auxiliar na investigação do grau de manutenção, tendência à manutenção, desuso e tendência ao desuso em relação às acepções registradas nos documentos manuscritos, e testá-las no município de Paranaguá com informantes pré-selecionados de acordo com os critérios adotados em pesquisas de dialetologia e sociolinguística.

Realizada a pesquisa de campo que teve por objetivo a recolha dos dados orais, o próximo passo consistiu em organizá-los por meio de tabelas contendo: (i) a lexia em estudo; (ii) o registro das acepções buscadas; (iii) o contexto de utilização dos itens lexicais conhecidos pelos informantes; e (iv) as acepções dicionarizadas. De posse desses dados, procedeu-se a análise do contexto de fala de cada informante selecionado, sendo possível identificar quais informantes ainda empregam determinado item lexical com a mesma acepção buscada.

Com base nos dados mostrados nas tabelas e nos gráficos do capítulo 6, constatou-se que a porcentagem de desuso e tendência ao desuso dos 176 itens lexicais é bem maior que a porcentagem de manutenção e tendência à manutenção. Quanto ao conhecimento da lexia com a acepção buscada (manutenção), na primeira faixa etária, a maior ocorrência recai no grupo de informantes do ensino superior, e na segunda faixa etária, no grupo de informantes do ensino fundamental. O grupo de informantes do ensino fundamental, tanto da faixa I, como da faixa II, teve maior conhecimento da lexia com outra acepção (desuso). E o grupo de informantes do ensino primário, tanto da faixa I como da faixa II, teve maior índice de não conhecimento da lexia investigada.

Comparando o resultado da porcentagem entre as duas faixas etárias, observa-se que os informantes da segunda faixa etária ainda preservam traços linguísticos próximos de seus antecedentes, conforme evidenciam os dados das respostas desses informantes. Parece que a 
rememoração do passado faz parte de seu discurso, tecido por alusão e comparação de alguns itens lexicais utilizados no passado e no presente momento. Por outro lado, os informantes da primeira faixa etária apontam para um provável desaparecimento da lexia e/ou da acepção buscada neste trabalho. Tal fator pode ser em decorrência da influência da escola e dos avanços dos meios de comunicação, que possibilitam a ampliação dos conhecimentos gerais da população.

Com base no que foi apresentado, conclui-se, de modo geral, que os itens lexicais e as acepções investigadas neste trabalho tendem ao desuso com o tempo. Na medida em que pesquisas de natureza geolinguísticas vêm se desenvolvendo no campo da linguagem, constata-se o registro de diferentes designações para um único referente, e isso prova que, em uma dada comunidade linguística, mesmo havendo fatores que possam contribuir para a cristalização da linguagem, estão sujeitos a mudanças, resultando no processo de desuso ou inovação de algumas lexias em contexto de fala.

Em suma, os dados apresentados e analisados durante todo trabalho cumpre com seu objetivo maior, que foi realizar o estudo do léxico no município de Paranaguá-PR, propondo uma discussão sobre manutenção, tendência à manutenção, desuso e tendência ao desuso de lexias extraídas de fontes manuscritas setecentistas, datadas da mesma localidade. Dessa forma, espera-se que os resultados da análise possam contribuir e, ao mesmo tempo, fornecer dados confiáveis aos estudos linguísticos sobre o estado de língua no período setecentista produzidos no Paraná. 
Oreferências 


\section{REFERÊNCIAS ${ }^{41}$}

ABREU, João Capistrano de. Capítulos de História Colonial (1500-1800) \& Os caminhos antigos e o povoamento do Brasil. 5. ed. Brasília: Ed. Universidade de Brasília, 1963.

ACIOLI, Vera Lúcia Costa. A escrita no Brasil Colônia: um guia para a leitura de documentos manuscritos. Recife: UFPE: Massangana, 1994.

AGUILERA, Vanderci Andrade; VASCONCELOS, Celciane Alves. Para uma abordagem histórico-social da fala rural de Castro-PR: a presença de tupinismos. Signum: Estudos da Linguagem, Londrina, v. 6, n. 1, p. 11-42, dez. 2003.

AGUILERA, Vanderci de Andrade; FIGUEIREDO, Maria Beatriz Tozetti. A composição de um questionário sobre o léxico do gado. Signum: Estudos da Linguagem, Londrina, v. 5, p. 9-50, dez. 2002.

ALI, Manuel Said. Gramática histórica da língua portuguesa. São Paulo: Melhoramentos, 1964.

ARAÚJO, Emanuel. Publicação de documentos históricos. Rio de Janeiro: Ministério da Justiça: Arquivo Nacional, 1985.

AZEVEDO, Aroldo de. Vilas e cidades do Brasil Colonial: ensaio de geografia urbana retrospectiva. Boletim da Faculdade de Filosofia, Letras e Ciências Humanas da Universidade de São Paulo, São Paulo, n. 208, Geografia, n. 11, p. 1-96, 1956.

BELLOTO, Heloísa Liberalli. Como fazer análise diplomática e análise tipológica de documento de arquivo. v. 8. São Paulo: Arquivo do Estado: Imprensa Oficial do Estado, 2002.

BENVENISTE, Émile. Problemas de Lingüística Geral II. Trad. Eduardo Guimarães et al. Campinas: Pontes, 1989.

BICALHO, Maria Fernanda. As Câmaras municipais no Império Português: o exemplo do Rio de Janeiro. Revista Brasileira de História, São Paulo, n. 36, p. 251-280, 1998.

BIDERMAN, Maria Tereza Camargo. A ciência da Lexicografia. Alfa, São Paulo, n. 28, p. 126, 1984. Suplemento.

\footnotetext{
41 De acordo com a Associação Brasileira de Normas Técnicas, NBR 6023 (apud UNIVERSIDADE DE SÃO PAULO, 2009)
} 
BIDERMAN, Maria Tereza Camargo. Teoria lingüística: teoria lexical e lingüística computacional. São Paulo: Martins Fontes, 2001.

BLANCO, Ricardo Román. Estudos paleográficos. São Paulo: Laserprint, 1987.

BLUTEAU, Padre Raphael. Vocabulário portuguez e latino. Coimbra: Collegio das Artes da Companhia de Jesus, 1712-1728. 8 v.

BORGES NUNES, Eduardo A. Abreviaturas paleográficas portuguesas. 3. ed. Lisboa: Faculdade de Letras, 1981.

BORTONI-RICARDO, Stella Maris. Problemas de comunicação interdialetal. In: Tempo Brasileiro, Rio de Janeiro, n. 78/79, p. 9-31, jul./dez. 1984.

BOTELHO, Angela Vianna; REIS, Liana Maria. Dicionário histórico Brasil: Colônia e Império. 6. ed. Belo Horizonte: Autêntica, 2008.

BOUTIN, Leônidas. Os jesuítas históricos em Paranaguá. Boletim do Instituto Histórico e Geográfico do Paraná, Curitiba, v. 1-LVI, p. 187-190, 2005.

BRAGA, Alencar S. O poder político do município no Brasil Colônia. Revista Brasileira de Direito Constitucional - RBDC, n. 12, p. 169-232, jul./dez. 2008. Disponível em:

$<$ http://www.esdc.com.br/RBDC/RBDC-12/RBDC-12-169-

Alencar_Santana_Braga_(municipio).pdf $>$. Acesso em: 15 dez. 2011.

CAGLIARI, Luiz Carlos. O que é a ortografia? Estudos Lingüísticos XXIII - Anais de Seminários do GEL, São Paulo, v. 1, p. 552-559, 1994.

CALDAS AULETE, Francisco Júlio. Dicionário contemporâneo da Língua Portuguesa. 2. ed. Rio de Janeiro: Delta, 1948.

CALLOU, Dinah; SERRA, Carolina. Norma e escolarização no Rio de Janeiro: a nova realidade social como reflexo de antigos problemas. In: LOBO, Tânia et al. (Orgs.). Para a história do português brasileiro. Salvador: Edufba, 2006. v. 6. t. 1-2. p. 675-687.

CALMON, Pedro. História do Brasil. v. I-VII. Rio de Janeiro: José Olympio, 1961.

CAMBRAIA, César Nardelli. Introdução à Crítica Textual. São Paulo: Martins Fontes, 2005.

CARDOSO, Jayme Antonio; WESTPHALEN, Cecília Maria. Atlas Histórico do Paraná. 2. ed. rev. ampl. Curitiba: Livraria do Chain, 1986.

COMITÊ NACIONAL DO PROJETO ALIB. Projeto Atlas Lingüístico do Brasil (ALiB). Questionário 2001. Londrina: Eduel, 2001. 
CORREA, Hugo Pereira. Fundação de Paranaguá. Boletim do Instituto Histórico, Geográfico e Etnográfico Paranaense - Gente e fatos de Paranaguá: comemorativo ao Sesquicentenário da Independência do Brasil, Curitiba, v. XVII, p. 219-222, 1972.

CÔRTES, Saboya. Paranaguá, berço da civilização paranaense. Boletim do Instituto

Histórico, Geográfico e Etnográfico Paranaense - Gente e fatos de Paranaguá: comemorativo ao Sesquicentenário da Independência do Brasil, Curitiba, v. XVII, p. 235-246, 1972.

COUTINHO, Ismael de Lima. Gramática histórica. 5. ed. Rio de Janeiro: Acadêmica, 1967.

CUNHA, Antônio Geraldo da. Dicionário Etimológico Nova Fronteira da Língua

Portuguesa. 2. ed. Rio de Janeiro: Nova Fronteira, 1997.

CUNHA, Antônio Geraldo da; CAMBRAIA, César Nardelli; MEGALE, Heitor. A carta de Pero Vaz de Caminha: reprodução fac-similar do manuscrito com leitura justalinear. 2. ed. v. 1. São Paulo: Humanitas: FFLCH/USP, 2001. (Série Diachronica).

CUNHA, Celso. Conservação e inovação no português do Brasil. O Eixo e a Roda, Belo Horizonte, v. 5, p. 199-230, nov. 1986.

DIAS, Madalena Marques; BIVAR, Vanessa dos Santos Bodstein. 1. ${ }^{\text {a }}$ Parte - Paleografia para o período colonial. In: SAMARA, Eni de Mesquita; DIAS, Madalena Marques; BIVAR, Vanessa dos Santos Bodstein. Paleografia e fontes do período colonial brasileiro. São Paulo: Humanitas: FFLCH/USP, 1986. p. 11-38. (Estudos CEDHAL, Nova Série, n. 11).

DICIONÁRIO HISTÓRICO-BIOGRÁFICO DO ESTADO DO PARANÁ. Curitiba: Livraria do Chain: Banco do Estado do Paraná, 1991.

FERREIRA, Aurélio Buarque de Holanda. Novo Dicionário Aurélio da Língua Portuguesa. Versão 5.0, rev. e atual. do Aurélio Século XXI. Rio de Janeiro: Positivo, 2004. 1 CD-ROM.

FERREIRA, Carlota da Silveira; CARDOSO, Suzana Alice Marcelino. A Dialetologia no Brasil. São Paulo: Contexto, 1994.

FLEXOR, Maria Helena Ochi. Abreviaturas: manuscritos dos séculos XVI ao XIX. 2. ed. aum. São Paulo: Arquivo do Estado, 1990.

FREITAS, Waldomiro Ferreira de. História de Paranaguá: das origens à atualidade. Paranaguá: IHGP, 1999.

FURTADO, Celso. Formação econômica do Brasil. Brasília: Ed. Universidade de Brasília, 1963.

GONÇALVES, Janice. Como classificar e ordenar documentos de arquivo. v. 2. São Paulo: Arquivo do Estado, 1998. 
GOULART, José Alípio. O cavalo na formação do Brasil. Rio de Janeiro: Letras e Artes, 1964.

HOUAISS, Antônio. Dicionário eletrônico Houaiss da Língua Portuguesa. Versão 2.0.a. Rio de Janeiro: Objetiva, 2007. 1 CD-ROM.

HOUAISS, Antônio. Elementos de bibliologia. v. I. Rio de Janeiro: Instituto Nacional do Livro: MEC, 1967.

INSTITUTO BRASILEIRO DE GEOGRAFIA E ESTATÍSTICA - IBGE. Disponível em: $<$ www.ibge.gov.br>. Vários acessos.

ISQUERDO, Aparecida Negri. Léxico regional: análise de algumas "marcas" de conservadorismo lingüístico. Estudos Lingüísticos, Taubaté, n. 25, p. 568-574, 1996.

KRAEMER, Marília. Malhas da pobreza: exploração do trabalho de pescadores artesanais na Baía de Paranaguá. Curitiba: Lítero-Técnica, 1983. (Série Estante Paranista, v. 22).

KUBO, Mari Elvira. A legislação e a instrução pública de primeiras letras na $5^{\text {a }}$ Comarca da Província de São Paulo. Curitiba: Biblioteca Pública do Paraná: Secretaria de Estado da Cultura e do Esporte, 1986. (Coleção Paraná Memória Momento).

LADEIRA, Maria Inês. YY PAh ou YVA PAh "Espaço Mbya entre as águas ou o caminho aos céus" - os índios guarani e as ilhas do Paraná. In: Centro de Trabalho Indigenista, nov. 1990. Disponível em:

$<$ http://bd.trabalhoindigenista.org.br/sites/default/files/LaderiaMI_Mbya-aguas-ceus_b.pdf $>$. Acesso em: 11 dez. 2011.

LEÃO, Ermelino Agostinho. Dicionário Histórico e Geográfico do Paraná. v. III. Curityba: Empresa Graphica Paranaense, 1926.

LEITE, Marli Quadros. Aspectos de uma língua na cidade: marcas da transformação social no léxico. In: PRETI, Dino (Org.). Léxico na língua oral e na escrita. São Paulo: Humanitas: FFLCH/USP, 2003. p. 17-45.

MAACK, Reinhard. Geografia física do Estado do Paraná. Curitiba: Banco de Desenvolvimento do Paraná: UFPR: Instituto de Biologia e Pesquisas Tecnológicas, 1968.

MAACK, Reinhard. Geografia física do Estado do Paraná. 2. ed. São Paulo: José Olympio, 1981.

MACEDO, Rafael Greca. A Justiça no Paraná na Colônia e no Império. Boletim Trimestral, Instituto Histórico e Geográfico de Paranaguá, v. IV, p. 6-23, abr./jun. 1999.

MARTINET, André. Elementos de Linguística Geral. Tradução de Jorge Barbosa. Lisboa: Sá da Costa, 1973. 
MARTINS, Romário. História do Paraná. Curitiba: Travessa dos Editores, 1995.

MASSANI-CAGLIARI, Gladis. Escrita do Cancioneiro da Biblioteca Nacional de Lisboa: fonética ou ortográfica? Filologia e Linguística Portuguesa, n. 2, p. 159-178, 1998.

Disponível em:

$<$ http://www.fflch.usp.br/dlcv/lport/site/images/arquivos/FLP2/MassiniCagliari1998.pdf $>$. Acesso em: 2 jun. 2012.

MELO, Gladstone Chaves de. Iniciação à filologia e à lingüística portuguesa. 4. ed. Rio de Janeiro: Acadêmica, 1971.

MIRANDA, Lílian Lisboa. Embates sociais cotidianos na São Paulo setecentistas: o papel da Câmara Municipal e dos homens livres pobres. Revista História, São Paulo, n. 147, p. 53-69, 2002.

MORAIS SILVA, Antônio de. Diccionario da língua portuguesa - recompilado dos vocabulários impressos ate agora, e nesta segunda edição novamente emendado e muito acrescentado. Lisboa: Typographia Lacerdina, 1813.

MORAIS SILVA, Antônio de. Grande dicionário da língua portuguesa. 10. ed. Lisboa: Confluência, 1945.

NASCIMENTO JUNIOR, Vicente. I Parte - História: o nosso litoral. História, Crônicas e Lendas. Curitiba: Gráfica Vicentina, 1980a. p. 35-39.

NASCIMENTO JUNIOR, Vicente. II Parte - Crônicas e Lendas. O despotismo dum Ouvidor. História, Crônicas e Lendas. Curitiba: Gráfica Vicentina, 1980b. p. 266-268.

NASCIMENTO JUNIOR, Vicente. Os jesuítas em Paranaguá. O Itiberê. Arquivos do Instituto Histórico Geográfico de Paranaguá, Paranaguá, a. 11, n. 127, [s.p.], nov. 1929.

NASCIMENTO JUNIOR, Vicente. Paranaguá no Continente. Boletim do Instituto Histórico, Geográfico e Etnográfico Paranaense - Gente e fatos de Paranaguá: comemorativo ao Sesquicentenário da Independência do Brasil, Curitiba, v. XVII, p. 167-174, 1972.

NEGRÃO, Francisco. Genealogia paranaense. v. I. Curitiba: Imprensa Oficial Estado do Paraná, 1926.

NEGRÃO, Francisco. Memória histórica paranaense. Curitiba: Impressora Paranaense, 1934.

OLIVEIRA, Ana Maria Pinto P. de; ISQUERDO, Aparecida Negri (Orgs.). As ciências do léxico: lexicologia, lexicografia, terminologia. Campo Grande: UFMS, 1998. 
PAIVA, Dulce de Faria. História da língua portuguesa. Século XV e meados do século XVI. São Paulo: Ática, 1988. (Série Fundamentos, 2).

PARANÁ. Documentos. A que se refere o relatório oficial do presidente da Província do Paranã, na abertura da Assembléa Legislativa Provincial em 15 de julho de 1854. Curitiba. 1854. Disponível em: <http://brazil.crl.edu/bsd/bsd/614/000003.html $>$. Acesso em: 1 maio 2012.

PINTO, Rolando Morel. História da língua portuguesa. Século XVIII. São Paulo: Ática, 1988. (Série Fundamentos, 4).

PREFEITURA DE PARANAGUÁ. Disponível em: <www.paranagua.pr.gov.br/>. Vários acessos.

RIBEIRO FILHO, Anibal. Paranaguá na história de Portugal: suas relações com a monarquia portuguêsa, 1648-1822. Paranaguá: Marinho, 1967.

SAMARA, Eni de Mesquita. $2^{\text {a }}$ Parte - Fontes coloniais. In: SAMARA, Eni de Mesquita; DIAS, Madalena Marques; BIVAR, Vanessa dos Santos Bodstein. Paleografia e fontes do período colonial brasileiro. São Paulo: Humanitas: FFLCH/USP, 1986. p. 39-85. (Estudos CEDHAL, Nova Série, n. 11).

SANTIAGO-ALMEIDA, Manoel Mourivaldo. Manuscrito do séc. XVIII para estudo linguístico. Polifonia, Cuiabá, v. 4, p. 1-14, 2002.

SANTOS, Antonio Vieira dos. Memória histórica da cidade de Paranaguá e seu município. v. I. Curitiba: Vicentina, 2001 [1850].

SANTOS, Irenilde Pereira dos. Técnicas de transcrição grafemática para o ALIB. In: Workshop de preparação de inquiridores para o Atlas Lingüístico do Brasil, 3. , Londrina, 11 a 15 nov. 2002. Palestra.

SÃO VICENTE. s.d. Disponível em:

$<$ http://www2.crb.ucp.pt/Historia/abced\%C3\%A1rio/As\%20Capitanias\%20Heredit\%C3\%A1 rias\%20do\%20Brasil/saovicente.htm>. Acesso em: 14 dez. 2012.

SILVA NETO, Serafim da. Textos medievais portugueses e seus problemas. Rio de Janeiro: Casa de Rui Barbosa, 1956.

SILVA NETO, Serafim da. Guia para estudos dialectológicos. 2. ed. Belém: Instituto Nacional de Pesquisas da Amazônia: CNPq, 1957.

SIMONSEN, Roberto Cochrane. História Econômica do Brasil: 1500/1820. São Paulo: Companhia Editora Nacional, 1977. 
SPINA, Segismundo. Introdução à Edótica: crítica textual. São Paulo: Cultrix: Ed. da Universidade de São Paulo, 1977.

SPINA, Segismundo. História da língua portuguesa. Segunda metade do século XVI e século XVII. São Paulo: Ática, 1987. (Série Fundamentos, 3).

STECA, Lucinéia Cunha; FLORES, Mariléia Dias. História do Paraná: do século XVI à década de 1950. Londrina: Ed. UEL, 2002.

TEYSSIER, Paul. História da língua portuguesa. 6. ed. Tradução Celso Cunha. Lisboa: Sá da Costa, 1994.

TONIOLO, Ênio J. Manuscritos da Vila Nova de Castro: um estudo filológico de documentos dos séculos XVIII e XIX. 2007. Tese (Doutorado em Estudos da Linguagem) Universidade Estadual de Londrina, Londrina. 2007.

TRINDADE, Etelvina Maria de C.; ANDREAZZA, Maria L. Paraná no século XIX: cultura e sociedade. Boletim do Instituto Histórico e Geográfico do Paraná, Curitiba, v. LIV, p. 401-427, 2003. Edição comemorativa do Sesquicentenário do Paraná.

UNIVERSIDADE DE SÃO PAULO. Sistema Integrado de Bibliotecas da USP. Diretrizes para apresentação de dissertações e teses da USP: documento eletrônico e impresso Parte I (ABNT). 2. ed. rev. ampl. São Paulo: Sistema Integrado de Bibliotecas da USP, 2009.

(Cadernos de Estudos, 9).

VASCONCELOS, Celciane Alves; AGUILERA, Vanderci de Andrade. As variantes lexicais para a montaria feminina: um estudo semântico-lexical em corpora geolinguísticos. Revista do GELNE. p. 347-365, número especial 2012.

VIANA, Gonçalvez. Ortografia nacional: simplificação e uniformização sistemática das ortografias portuguesas. Lisboa: Livraria, 1904.

VIANA, Manoel. Paranaguá na história e na tradição. Paranaguá: Conselho Municipal de Cultura, 1976.

WACHOWICZ, Ruy Christovan. História do Paraná. Curitiba: Editora dos Professores, 1967.

WESTPHALEN, Cecília Maria. Alfaias e jóias do antigo Colégio dos Jesuítas em Paranaguá. Boletim da Universidade do Paraná - História Moderna e Contemporânea, Curitiba, n. 1, jun. 1902.

WILLIAMS, Edwin B. Do latim ao português: fonologia e morfologia históricas da língua portuguesa. 2. ed. Rio de Janeiro: Tempo Brasileiro, 1973. 
Bibliografia Consultada 


\section{BIBLIOGRAFIA CONSULTADA}

ARAGÃO, Maria do Socorro Silva de. (Org.). Estudos em Lexicologia, Lexicografia, Terminologia e Terminografia. Fortaleza: UFC, 2009.

BARBOSA, Maria Aparecida. Dicionário, vocabulário, glossário: concepções. In: ALVES, Ieda Maria (Org.). A constituição da normalização terminológica no Brasil. 2. ed. São Paulo: FFLCH/USP: CITRAT, 2001. p. 23-45. (Cadernos de Terminologia 1).

BIDERMAN, Maria Tereza Camargo. O léxico, testemunha de uma cultura. In: LORENZO, Ramón. II Lexicoloxía e Metalexicografía. Acta do XIX Congresso Internacional de Linguística e Filoloxía Románicas. Universidade de Santiago de Compostela, 1989. p. 397405.

BIDERMAN, Maria Tereza Camargo. Dimensão da palavra. Filologia e Lingüística Portuguesa, Araraquara, n. 2, p. 81-118, 1998.

CARNEIRO, David. Algumas considerações em torno da história e da origem do colégio dos Jesuítas de Paranaguá. Boletim do Instituto Histórico, Geográfico e Etnográfico Paranaense - Gente e fatos de Paranaguá: comemorativo ao Sesquicentenário da Independência do Brasil, Curitiba, v. XVII, p. 277-298, 1972.

CIGOLINI, Adilar; MELLO, Laércio de; LOPES, Nelci. Paraná: quadro natural, transformações territoriais e economia. 2. ed. São Paulo: Saraiva, 2001.

FERREIRA, Tito Lívio. História da educação lusobrasileira. São Paulo: Saraiva, 1966. HIGOUNET, Charles. História concisa da escrita. São Paulo: Parábola, 2003.

LEITE, Pe. Serafim. História da Companhia de Jesus no Brasil. São Paulo: Loyola, 2004. $10 \mathrm{v}$.

LUCCHESI, Dante; ARAÚJO, Silvana. A Teoria da Variação Linguística. [s.d.]. Disponível em: $<$ http://www.vertentes.ufba.br/a-teoria-da-variacao-linguistica $>$. Acesso em: 12 nov. 2012.

MORENO FERNÁNDEZ, Francisco. Principios de sociolingüística y sociología del lenguaje. Barcelona: Ariel, 1998.

MORGENSTERN, Algacyr. Porto de Paranaguá: Contribuição à História. Período: 1648/1935. Paranaguá: Administração dos Portos de Paranaguá e Antonina, 1985.

NEGRÃO, Francisco. Genealogia paranaense. v. II. Curitiba: Imprensa Oficial Estado do Paraná, 1927. 
NEGRÃO, Francisco. Genealogia paranaense. v. III. Curitiba: Imprensa Oficial Estado do Paraná, 1928.

NEGRÃO, Francisco. Genealogia paranaense. v. IV. Curitiba: Imprensa Oficial Estado do Paraná, 1929.

NEGRÃO, Francisco. Genealogia paranaense. v. V. Curitiba: Imprensa Oficial Estado do Paraná, 1946.

NEGRÃO, Francisco. Genealogia paranaense. v. VI. Curitiba: Imprensa Oficial Estado do Paraná, 1950.

OLIVEIRA, Ana Maria Pinto P. de; ISQUERDO, Aparecida Negri (Orgs.). As ciências do léxico: lexicologia, lexicografia, terminologia. v. I. Campo Campo Grande: UFMS, 2000.

SEABRA, Maria Cândida Trindade Costa de (org.). O Léxico em Estudo. Belo Horizonte: Faculdade de Letras da UFMG: 2006.

SILVA NETO, Serafim. Introdução ao Estudo da Língua Portuguesa no Brasil. 3.ed. Rio de Janeiro: Presença; Brasília, INL/MEC, 1976.

SOARES, Carlos Roberto; LANA, Paulo da Cunha. Baía de Paranaguá: mapas e história. Curitiba: Ed. da UFPR, 1994.

TARALlO, Fernando. A pesquisa Sócio-lingüística. Série Princípios. São Paulo: Ática, 1985. VILELA, Mário. Estudos de Lexicologia do Português. Coimbra: Livraria Almedina, 1994.

WEINREICH, Uriel; LABOV, Willian; HERZOG, Marvin I. Fundamentos empíricos para uma teoria da mudança lingüística. Tradução Marcos Bagno. Revisão Carlos Alberto Faraco. São Paulo: Parábola, 2006. 
Apêndices 
APÊNDICE A - Listagem completa de vocábulos

\begin{tabular}{|c|c|c|c|c|}
\hline A & acordo & alegadas & andre & aprezentaraõ \\
\hline$a$ & acreçimo & alegria & anechos & aprezente \\
\hline á & acrescimo & aleluyas & anexo & aprezentou \\
\hline abaiçho & acrescimos & alem & anexos & aprezenttado \\
\hline abaixo & acteuidade & alentarce & animais & aproueitado \\
\hline abastados & acto & aleva & animal & aprouidençia \\
\hline aberta & actuais & alferes & animamos & aprovaçaõ \\
\hline abertas & actual & algua & anjos & aprovados \\
\hline abertos & actuaraõ & alguã & anno & aprovar \\
\hline abertura & ad & alguãs & annos & aproveitar \\
\hline abilegível & ademoestandonos & algum & annoz & apuraçaõ \\
\hline abitadores & adjunto & algúm & ano & aquela \\
\hline abrangem & adjuntos & alguma & anos & aquelas \\
\hline abrigo & admite & algumas & ante & aqueles \\
\hline abril & admitido & alguns & anteçeçor & aquella \\
\hline abrio & adverte & alguns & antepasados & aquellas \\
\hline abrir & advertidos & alias & antes & aquelle \\
\hline abrirem & afastar & almas & anteseçores & aqui \\
\hline absurdo & afecto & almeida & antesesores & araujo \\
\hline absurdos & afetuosas & almeyda & antiga & arbitra \\
\hline abundancias & afim & almoxarife & antigas & arbitracem \\
\hline acabada & afirma & alqueire & antigo & arbitramento \\
\hline acabe & afliçam & alqueres & antipaçados & arbitrar \\
\hline acabou & afonço & alta & antonio & arbitraraõ \\
\hline acautelar & agente & alteza & anttes & ardentes \\
\hline aceitala & agiar & alto & anttonio & ardil \\
\hline aceite & agoaardente & alugadores & antunina & arecadaçaõ \\
\hline acenos & agoardente & aluguel & anuais & arecadasaõ \\
\hline acentaraõ & agoas & aluguem & anualmente & arecadassam \\
\hline acentavam & agora & alvara & ao & arombada \\
\hline acha & agostinho & alvará & aodiante & arombar \\
\hline acham & agosto & alvarâ & aos & aroz \\
\hline achandoce & agradavel & alvares & aoz & arranxar \\
\hline achaõ & agradece & amabellicima & apanhou & arremataçaõ \\
\hline achar & agrado & amado & apareçe & arrematar \\
\hline acharem & agregar & amaro & apenar & arrimaõ \\
\hline achassem & aguardente & ambos & apenas & arrobas \\
\hline achava & aguas & ameasar & aplaudimos & arros \\
\hline achem & aguiar & amor & aplica & artes \\
\hline achou & ahi & amparar & aplicados & as \\
\hline acistencia & ainda & amparo & aplicar & ás \\
\hline acodem & ajnda & ampla & apoçar & âs \\
\hline acomodados & ajudante & anastacio & apontados & asegurando \\
\hline acompanhamento & ajustes & ancehar & apostolicum & asenhoreavaõ \\
\hline acompanhava & albertim & anda & appareceo & asentado \\
\hline aconselhando & albitrarce & andaçem & applicada & asignada \\
\hline acontesa & alcaide & andam & apresentamos & asignado \\
\hline acordaõ & alcança & andar & apresente & asignados \\
\hline acordão & alcanssem & andauaõ & apresentou & asignalladoz \\
\hline acordaram & alega & andrade & aprezenciar & asignam \\
\hline
\end{tabular}




\begin{tabular}{|c|c|c|c|c|}
\hline asignar & aumento & benemeritas & cananeya & centos \\
\hline asignaram & aumentou & benignidade & cancellas & cerca \\
\hline asignaraõ & autoridade & bens & canha & cercar \\
\hline asignei & auxilares & bento & canoas & cercarem \\
\hline asigney & auxiliados & bernardo & capas & certa \\
\hline asigno & auxiliar & bestas & capazes & certamente \\
\hline asignou & auxiliares & bignidade & capella & certeficamos \\
\hline asilo & auxilio & boa & capitais & certefico \\
\hline asim & auzencia & bobadella & capital & certeza \\
\hline asima & avançado & bondade & capitam & certidam \\
\hline asinada & aver & bordo & capitania & çertidam \\
\hline asistem & avermos & botandose & capitaniá & certidao \\
\hline asobrados & avia & botelho & capitanias & certidaõ \\
\hline assestidas & aviam & botem & capitans & certidão \\
\hline assignada & avistado & botica & capitaó & certifico \\
\hline assignei & avizo & braçame & capitaõ & certo \\
\hline assim & avocar & braças & capitullos & cessenta \\
\hline assinada & âvulssam & braga & capitulo & cetera \\
\hline assinado & axaõ & branco & cappitam & chamou \\
\hline assino & az & bras & cappitania & chaons \\
\hline assistencia & áz & brasas & cappitulos & chaons \\
\hline associacoins & azamor & brejos & carecese & chaons' \\
\hline atalhar & Azeite & breuidade & caregada & chaves \\
\hline atalharem & & breve & carga & chegada \\
\hline ate & B & brevidade & cargas & chegando \\
\hline atençaõ & bahia & briozos & cargo & chegou \\
\hline atendendo & bahyas & brotaria & carneiro & chegue \\
\hline atendivel & bairro & & carnes & chrissostomo \\
\hline atensaõ & bairros & C & caro & christo \\
\hline atento & ballandra & cá & carregar & christovaõ \\
\hline atentos & baltezar & câ & carta & chryzostomo \\
\hline athe & balthazar & cabais & cartas & cidade \\
\hline atolarem & bando & cabeça & carvalho & cinaõ \\
\hline atraueçe & baptizados & cabeças & casanova & cinco \\
\hline atrazados & barbosa & cabo & casas & circuito \\
\hline attençaõ & barboza & cada & case & circunstancia \\
\hline attender & barcos & cadeya & caso & circunstancias \\
\hline attendido & barra & caetano & castigou & clamaraõ \\
\hline attentas & barras & caldeyra & castro & clareza \\
\hline attentos & barrete & camara & catharina & coadra \\
\hline attraveçadores & barrette & camaras & catolico & coais \\
\hline atual & bastante & camargo & causa & coando \\
\hline aubzençia & bebidas & camaristas & cauza & coanto \\
\hline augusto & begnino & camera & caza & coatro \\
\hline auia & beija & cameras & cazamentos & coaze \\
\hline auiamos & beijaõ & caminho & cazo & cobrada \\
\hline auisou & bejaõ & caminhos & cede & cobradas \\
\hline aulistas & bem & campo & cegue & cobrador \\
\hline aumentando & beneficio & cana & cegundo & cobrança \\
\hline aumentar & benefiçio & canaes & cento & cobransa \\
\hline
\end{tabular}




\begin{tabular}{|c|c|c|c|c|}
\hline coedando & complimento & conhecemos & copia & cujo \\
\hline cofre & compra & conhecer & copiados & cujos \\
\hline cohibido & compraçem & conheci & copias & cultura \\
\hline cohibir & comprados & conhecimento & copie & cumprimento \\
\hline coitinho & comprar & conjuntura & copiei & cumprindo \\
\hline colegio & comprarem & conselho & coraje & cunha \\
\hline colheitas & compre & consentir & corea & curbas \\
\hline colhetas & compreende & consequencia & coritiba & curitiba \\
\hline colleçaõ & compreendidos & consequencias & coroa & custa \\
\hline colleção & comprimento & conserva & coronel & custando \\
\hline collegio & comprimentto & conservaçaõ & corpo & custodio \\
\hline collejo & comprometemos & conservandose & corporasaõ & custtuma \\
\hline collocamos & comseda & considerasaõ & corpos & custuma \\
\hline collonia & comservando & consignace & corram & custumado \\
\hline $\mathrm{com}$ & comtemplão & consta & corre & custumaõ \\
\hline comarca & comum & coñsta & correa & custume \\
\hline comarcas & comveniente & constante & corregedor & cuyas \\
\hline comarqua & comvocado & constantes & correia & \\
\hline combinados & comvocemos & constantez & correiçaõ & D \\
\hline comciderada & con & constar & correição & da \\
\hline comercio & conçeder & consternaçaõ & corrente & dado \\
\hline comerçio & conceguinte & cónstetuhiam & corresponder & dahi \\
\hline comércio & concelho & constetuindo & correycaõ & dalos \\
\hline comesam & concertado & conta & cortar & dando \\
\hline cómettidos & concerto & contador & corte & dandoçe \\
\hline comferi & conceruarlhe & contadores & cortes & daõ \\
\hline comferido & concervam & contaraõ & costa & daqueles \\
\hline comfiri & conçervar & contas & costumes & daquella \\
\hline comfirmados & concervara & contentamento & cousa & daquelle \\
\hline comforme & concervaram & contento & cousas & daquelles \\
\hline comformes & concetido & contesto & coutinho & dar \\
\hline commarca & concideraçaõ & conteves & couverem & dár \\
\hline commarcas & concluir & contheudo & couza & dará \\
\hline commizeraçonins & concordou & continha & couzas & darem \\
\hline commizerar & concorra & continua & creaçam & darlhes \\
\hline commu' & concorrer & continuando & creaçaõ & das \\
\hline commum & conde & continue & creador & data \\
\hline communicar & conduçam & contra & creador & datada \\
\hline commúns & conduzir & contraria & creçaõ & dava \\
\hline como & conferençia & contrario & crecimento & davam \\
\hline comô & conferido & contrato & criado & de \\
\hline comos & confiado & contribuicam & criados & debaicho \\
\hline compadecersse & confirmação & contribuir & criarem & debaixo \\
\hline companhauaõ & confirmada & contribuisaõ & criou & debalde \\
\hline companheiro & confirmar & contribuissaõ & cruzados & decadencia \\
\hline companheiros & conforme & contribuissão & cuidado & decisaõ \\
\hline companhia & conformidade & contta & cuidados & declarados \\
\hline companhias & confraternidades & convenha & cuidavam & declarar \\
\hline compito & conheça & convenientes & cuja & decorozo \\
\hline completala & conheçaõ & copear & cujas & decreto \\
\hline
\end{tabular}




\begin{tabular}{|c|c|c|c|c|}
\hline deduzir & derrama & determinação & diminuto & doze \\
\hline defender & derrubarem & determinaçoens & dinheiro & duarte \\
\hline defenssam & des & determinaraõ & dinis & duas \\
\hline deferio & desacete & determinou & diogo & dum \\
\hline defesa & desanimados & detreminaçam & direita & duma \\
\hline defeza & descarga & detreminamos & direitos & duuida \\
\hline degradâdo & desconcertadas & detrimento & direyto & duvida \\
\hline deixa & desconcolacam & detriminado & dis & duvidas \\
\hline deixamos & descuido & detriminará & disculpará & duvidosa \\
\hline deixando & desde & dettreminaçaô & disimulaçam & duvidosas \\
\hline deixar & dese & dettreminado & dispeza & duvidozas \\
\hline deixaraõ & desempenha & deu & disposto & duzentos \\
\hline deixaremos & desemteresado & deuiamos & distançia & \\
\hline deixo & deseseis & deuida & disto & E \\
\hline deixou & desfalques & deus & distrito & e \\
\hline deliberar & desipolos & devassa & dita & edefficios \\
\hline deligencia & desizaõ & deve & ditas & editaes \\
\hline deligençia & desmembrasam & devem & dito & editais \\
\hline deligencias & desmerece & devemos & ditos & edital \\
\hline della & desnecessariamente & dever & ditto & edraulicos \\
\hline dellas & desneçessario & deviamos & dittos & eexselençia \\
\hline delle & despacho & deviaõ & diverços & efeijtos \\
\hline delles & despachos & devo & diversoz & efeito \\
\hline dem & despedido & dez & diviaõ & efeitos \\
\hline demais & despejado & dezaçeis & divinâ & efeittos \\
\hline demazia & despeza & dezacete & divisão & effeitem \\
\hline demetir & despezas & dezamparem & diz & effeito \\
\hline deminuta & despois & dezanove & dizem & effeittos \\
\hline demónstrasoins & despoticamente & dezarranxo & dizemos & efficacia \\
\hline demora & despozição & dezaseis & dizendo & egricultores \\
\hline demorar & desprezos & dezasete & dizimos & egriculturas \\
\hline demos & dessa & dezassete & do & eleição \\
\hline demulir & desta & dezayamos & doãçaõ & ella \\
\hline denisimo & désta & dezejamos & doarte & ellas \\
\hline denominados & destante & dezejar & dobrado & elle \\
\hline dentro & destas & dezembargador & doce & ellegendo \\
\hline deo & deste & dezembro & dois & elleger \\
\hline deos & destes & dezempenho & dom & ellegerão \\
\hline deploraveis & destinado & dezenbro & dominante & elles \\
\hline deplorável & destinaria & dezignios & domingos & elleyçaõ \\
\hline depois & destinguiram & dezistirem & dominios & elogios \\
\hline depor & destinos & dezpacho & donde & em \\
\hline depostos & destribuicaõ & dia & doo & embarcaçam \\
\hline derama & destricto & diante & doô & embarcacoins \\
\hline deraõ & destrictos & dias & dôo & embarcasons \\
\hline deregida & destrito & differença & dos & embarcassonins \\
\hline deregidas & destruidas & difficuldade & dou & embargo \\
\hline derige & destruido & digne & dous & embrenados \\
\hline derigio & destta & digo & doutor & emclinaram \\
\hline derogado & determina & dilatados & douttor & emclusas \\
\hline
\end{tabular}




\begin{tabular}{|c|c|c|c|c|}
\hline emcómodo & en & escrivaõ & estymado & expresey \\
\hline emcomodos & enbargo & escrivão & et & expressada \\
\hline emcontrarmos & encarregaõ & especialmentte & eu & expulso \\
\hline emcuulcam & encidente & esperam & europa & exselco \\
\hline emfermidades & encompativel & esperamos & europêos & exselencia \\
\hline emformado & enformanos & esperamosnos & euzébio & exselençia \\
\hline emformar & engenheiros & esperando & evangelhos & exselensia \\
\hline emgeitaçe & enginheiros & espero & evitar & exselenssia \\
\hline emgenhoz & enquanto & espirito & exactamente & exselentissimo \\
\hline emparo & ensoportavel & esquivo & examinar & exselinssia \\
\hline empedimento & entaõ & essa & excelenca & exsiste \\
\hline empenho & enteiramente & essas & excelencia & extabelecese \\
\hline empidido & enteressado & esse & excelençia & extabelecidas \\
\hline empor & enterior & esses & excelenctissimo & extabelecido \\
\hline emporçe & enterros & esta & excelentissima & extençam \\
\hline emportar & entes & está & excelentissimmo & extrahido \\
\hline emposebelitado & enteyro & estâ & excelentissimo & extraordinarios \\
\hline emposiuel & entrace & estado & excelenttissimo & extrasam \\
\hline empósta & entrada & estam & excellencia & extraviada \\
\hline emposto & entram & estamos & excellençia & extrucoins \\
\hline empostos & entraõ & estando & excellentissimo & exzecutar \\
\hline empoziçaõ & entrar & estaõ & excessivo & eztaõ \\
\hline empregarmos & entrarem & estão & excilencia & eztes \\
\hline empregarnos & entre & estar & exclusam & \\
\hline emprego & entregar & estarem & excuzar & $\mathbf{F}$ \\
\hline empregou & entregava & estas & execuçaõ & faça \\
\hline empulço & entregue & estaua & execusam & factos \\
\hline empuzição & entridozirem & estauaõ & executado & faculdades \\
\hline empuzisaõ & enviado & estava & executamos & facultár \\
\hline empuzissaõ & enviarmos & estavam & executar & faiscar \\
\hline emquanto & era & este & exelencia & faisqueiras \\
\hline emquantto & erario & esterelidade & exelentissimo & falescido \\
\hline emsino & eregio & estes & exenta & fallar \\
\hline emsinuarnos & errar & esteues & exentos & fallavaõ \\
\hline emtanto & esa & estevaõ & exercer & falta \\
\hline emteiro & escolher & esteve & exercia & faltando \\
\hline emtento & escravas & estilo & exercicio & faltaõ \\
\hline emtercençaõ & escretos & estilos & exercissio & faltar \\
\hline emtradas & escreuam & estimaveiz & exercitar & faltara \\
\hline emtrado & escreueo & estipulando & exersendo & faltas \\
\hline emtram & escreuer & estiueçem & exêrsendo & faltavaõ \\
\hline emtrega & escreui & estiver & expecializa & falto \\
\hline emtregar & escreuy & estou & expedisam & fara \\
\hline emtreseder & escrevi & estrada & expendido & faremos \\
\hline emullumento & escrevy & estradas & experamos & faria \\
\hline emventario & escrita & estrangeiros & experauamos & fariamos \\
\hline emviandolhe & escrito & estranharâ & experiençia & fariaõ \\
\hline emviar & escriuam & estta & experimentado & farinha \\
\hline emviassemos & escriuaõ & esttá & expoem & farinhas \\
\hline emvolumentos & escrivam & esttes & exposto & fartos \\
\hline
\end{tabular}




\begin{tabular}{|c|c|c|c|c|}
\hline fartto & fevereiro & fome & genio & havera \\
\hline fas & fevereiro de & fomentar & gente & haviaõ \\
\hline fás & feyta & fomos & geral & havido \\
\hline fasa & feyto & for & gerbazio & he \\
\hline fasiaõ & fez & fora & girava & hé \\
\hline fassa & ffazendo & foram & giro & hê \\
\hline fassão & ffizer & foraõ & gloria & hiaõ \\
\hline fauor & ffizeraõ & força & goardaçe & hido \\
\hline fauoreçer & fica & forem & goarniçaõ & hidraulicos \\
\hline favoráveis & ficam & forma & goarniçâo & hir \\
\hline faz & ficamos & formalidade & golpe & hjronimo \\
\hline fazem & ficando & formando & gomes & hoitto \\
\hline fazemos & ficar & formarce & gonçalves & hoje \\
\hline fazenda & ficara & foros & gonçalvez & homenins \\
\hline fazendas & ficarâ & fortaleza & gonsalves & homens \\
\hline fazendo & ficaremos & forte & gora & homéns \\
\hline fazer & ficava & fortificaçam & gosto & homens \\
\hline fazermos & fico & fortificaçaõ & gostosos & homes \\
\hline fazia & ficou & fortuna & gouernador & homes \\
\hline faziam & fidalgia & foy & gouerno & homildes \\
\hline fé & fidelidade & franca & governador & honra \\
\hline fê & fidillissima & frança & governança & honrra \\
\hline fedelidade & fiel & francisco & governao' & horroroso \\
\hline fedellissimo & fielmente & françisco & governo & hú \\
\hline fedilissima & fies & freguesia & graça & $h u^{\sim}$ \\
\hline fee & filhos & freguesias & graces & hua \\
\hline feijaõ & fim & freguezia & grande & huá \\
\hline feita & findo & freire & grandes & huã \\
\hline feito & finta & frequentam & grandeza & huas \\
\hline feitto & fintas & frivolo & grapuaba & hum \\
\hline feittos & fique & froixamente & grãtuoza & huma \\
\hline feitura & fiquemos & frota & grave & humas \\
\hline feixadas & firmeza & fumos & grosseira & humildade \\
\hline felecite & fis & fundaçaõ & guarda & humilde \\
\hline felescidade & fixado & fundado & guardando & humildemente \\
\hline felescite & fixar & fundamento & guarde & humildes \\
\hline felicidade & fiz & fundaõ & guimarans & humildez \\
\hline felicidades & fizemos & futuro & & huñs \\
\hline felicitado & fizeram & & H & huns \\
\hline felicite & fizeraõ & G & ha & \\
\hline felis & fizesemos & gado & há & 1 \\
\hline felix & foce & gamito & hâ & $i$ \\
\hline fellisbento & foçe & gamitto & habeis & ida \\
\hline fernandes & fogem & gaspar & habitantes & iesu \\
\hline ferreira & fogidos & gastaõ & habitasons & iesus \\
\hline ferruge & fogo & generais & haja & igalmente \\
\hline fes & fogos & general & hajaõ & igínjo \\
\hline festejo & foi & genero & haõ & ignacio \\
\hline festividades & folha & generos & havendo & ignorauamos \\
\hline feuereiro & folhas & gêneros & haver & igreja \\
\hline
\end{tabular}




\begin{tabular}{|c|c|c|c|c|}
\hline igualmente & inquieta & josé & leite & logar \\
\hline igualmentte & inquietação & joseph & lemitada & $\log 0$ \\
\hline iguape & inquietaçoens & joze & lemitadas & lograr \\
\hline ilha & inquieto & jozé & lemitado & longes \\
\hline illustre & instante & jozê & lemos & lopes \\
\hline illustrissima & institutu & jozeph & lenha & Iorena \\
\hline illustrissimmo & instruídos & judicial & letra & lugar \\
\hline illustrissimo & instruir & juis & leuaçem & luis \\
\hline ilostrisimo & instruirce & juiz & leuantar & luiz \\
\hline ilustre & inteiramente & juizes & leuar & luminarias \\
\hline ilustrisimo & inteirarem & julho & leva & lutasonz \\
\hline ilustrissima & inteiro & junho & levado & luzes \\
\hline imbarasem & intencam & junta & levantaram & luzido \\
\hline imcumbençia & intençam & juntamente & levantarem & \\
\hline imitando & intençaõ & juntamos & levar & $M$ \\
\hline imminentes & intendente & juntas & levarem & machado \\
\hline impedimentto & intenta & junto & levava & maciel \\
\hline impedir & intentaõ & juntta & ley & madeiras \\
\hline impeto & intentavaõ & jurado & leyte & magestade \\
\hline impidimento & intento & juramento & Ihe & maior \\
\hline imposição & intereces & justa & Ihes & mais \\
\hline impostta & interesez & justiça & Ihez & majo \\
\hline impreça & interino & justissa & liais & manda \\
\hline incerto & intersençaõ & justo & liberdade & mandado \\
\hline incertos & intervensaõ & justto & libro & mandados \\
\hline incidente & intiedade & & licenca & mandamos \\
\hline inçinua & intteiro & $\mathbf{L}$ & licença & mandando \\
\hline inclusa & inviada & la & licensa & mandanos \\
\hline incluza & iresoluptos & lâ & licensas & mandar \\
\hline incluzo & irracionais & ladino & lida & mandara \\
\hline inconciderados & isso & laguna & lido & mandará \\
\hline inconuinientes & isto & laines & lima & mandaraõ \\
\hline incorrer & istto & lamentavel & limitado & mandarem \\
\hline inda & izentando & lanceadas & limitados & mandarnos \\
\hline indecorozas & izentto & lanoya & limpa & mandaros \\
\hline indeviduos & & largura & limpo & mande \\
\hline individuos & J & lastimavel & linha & mandemos \\
\hline indo & ja & lauouras & liquido & mandeoca \\
\hline infadonha & já & lauraçe & lissenca & mandioca \\
\hline infante & jamais & laurando & lista & mandiocas \\
\hline infermo & janeiro & lavouras & listou & mando \\
\hline informamos & jente & lavradores & literal & mandou \\
\hline informar & jezus & lavrar & literario & manefestar \\
\hline informemos & jguape & lavras & literarios & maneira \\
\hline injustissa & joam & laynes & liuro & manifestaõ \\
\hline innovar & joao & leaes & livra & manoel \\
\hline inoramos & joaõ & leais & livro & mantimentos \\
\hline inposiuel & joão & leal & livros & manttimenttos \\
\hline inpoziçam & joaquim & lealdade & Io & manuel \\
\hline inpusibilidade & jose & legoas & lobo & maõ \\
\hline
\end{tabular}




\begin{tabular}{|c|c|c|c|c|}
\hline mão & mendes & molestia & nam & ninhum \\
\hline maons & mendez & molhados & naó & ninhuma \\
\hline maos & mendonca & monarquia & naõ & no \\
\hline maõs & mendonça & monopollio & não & nobre \\
\hline mapa & menezes & mor & naos & nome \\
\hline maquinas & menistra & morador & naquele & nomeaçaõ \\
\hline marchar & menores & moradores & naquilo & nomeadas \\
\hline marco & menos & moraez & nas & nomeado \\
\hline março & menoz & morais & nascido & nomeados \\
\hline marinha & mente & moraiz & natural & nomeasam \\
\hline marinho & meo & moral & natureza & nomeasão \\
\hline marso & merce & moreira & nauios & nomeassam \\
\hline martins & merces & morrendo & navios & nomeassoens \\
\hline martinz & mereçer & morretes & nececidade & nomes \\
\hline mas & meresamos & mostra & necessario & norte \\
\hline más & mereseram & mostrar & necessidade & nos \\
\hline mascarenhas & meresser & mostremos & necessitando & nós \\
\hline masedo & meritissimo & motiuo & neçiçita & nôs \\
\hline massedo & merse & motivo & negado & nõs \\
\hline materia & mersses & motivos & negocio & nosas \\
\hline maternal & mes & mottivos & negocios & nosos \\
\hline matheus & mês & mourão & negoçios & nossa \\
\hline matos & meses & movel & negossios & nossas \\
\hline matozo & mesma & moyor & negra & nossaz \\
\hline matris & mesmo & mudace & nella & nosso \\
\hline mattos & mesmos & mudada & nelle & nossos \\
\hline mattoso & mestre & mudala & nelles & nota \\
\hline $\operatorname{maxa}$ & mestres & mudanca & nem & notesiarnos \\
\hline maxado & metamaticos & mudão & nemhuma & noticia \\
\hline maximas & metodo & mudar & nenhum & notisia \\
\hline mayo & meya & mudarem & nescecidade & notisias \\
\hline mayor & meyor & mui & nescecidades & notoria \\
\hline mayores & meyos & muita & nescessario & nottas \\
\hline me & meyrinho & muitas & nesesario & noua \\
\hline mediando & mez & muito & nesesidade & nouos \\
\hline medico & mezes & muitos & nessa & nova \\
\hline medicos & miguel & multiplicaçaõ & nessas & nove \\
\hline mejo & $\mathrm{mil}$ & multiplicaõ & nesse & novembro \\
\hline melecianna & milhor & munhons & nesseçario & noventa \\
\hline melecianno & $\operatorname{mim}$ & munido & nessecidades & noventta \\
\hline melecianos & minas & muntas & nesta & novidade \\
\hline melhor & minha & munto & nestas & novidades \\
\hline melhores & ministerios & muy & neste & novo \\
\hline melitares & ministro & muyto & nestes & nullo \\
\hline mello & ministtro & muytoz & nestta & numca \\
\hline membro & miranda & & néstta & numero \\
\hline membros & mizeraveis & $\mathbf{N}$ & neto & nunca \\
\hline mençaõ & mizeravel & na & neves & nunes \\
\hline mencionada & modico & nacimento & ninguem & \\
\hline mencionados & modo & nada & ninhua & 0 \\
\hline
\end{tabular}




\begin{tabular}{|c|c|c|c|c|}
\hline 0 & ofertas & ordinaria & pagarem & pasos \\
\hline ô & offeciaes & ordinariamente & pago & pasose \\
\hline obedecer & offeçiais & ordinario & pagos & passa \\
\hline obedeçer & offeçial & orffans ${ }^{\sim}$ & pagou & passada \\
\hline obedecermos & offecio & orfons & pague & passado \\
\hline obedeçido & offerece & orphaos & pais & passados \\
\hline obedeser & offereçe & os & panagoá & passagens \\
\hline obediencia & offerecem & oservar & papel & passar \\
\hline obedientes & offesiais & ostante & para & passei \\
\hline objecto & officiaes & otra & paragrafo & passo \\
\hline obra & officiaez & otras & paraje & passos \\
\hline obramos & officiais & otro & paranagoa & passou \\
\hline obrar & offiçiais & otrossim & paranagoá & pasto \\
\hline obrará & officio & ou & paranagua & patente \\
\hline obras & officios & ouro & pardinho & patentea \\
\hline obreptício & offiçios & outra & parece & patenteamoz \\
\hline õbrigaçam & offrece & outras & pareçe & paternal \\
\hline obrigaçaõ & ofonço & outro & parecer & paula \\
\hline obrigação & oie & outros & pareceres & paullo \\
\hline obrigado & oitenta & outrosim & paresseo & paulo \\
\hline obrigados & oito & outtros & paridade & paus \\
\hline obrigaõ & oitocentos & outubro & parnagoa & paxcaria \\
\hline obrigaram & oje & ouneçe & parnagoá & pé \\
\hline obrigarão & ojtoçentos & ouuidor & parnagoâ & peçoa \\
\hline obrigarem & olhos & ouuidos & parnagua & peçuhiaõ \\
\hline obrigasoens & oliueira & ouve & parnaguá & peçuido \\
\hline obrigou & oliveira & ouver & parnaguâ & pede \\
\hline obsequioso & oliveyra & ouvidas & paroquos & pedem \\
\hline observado & omildade & ouvido & parroquial & pedimos \\
\hline observancia & omildes & ouvidor & parte & pedindo \\
\hline observanssia & onde & ouvidoria & partes & pedir \\
\hline observar & onus & ouzadia & partesipantes & pedro \\
\hline observaremos & opreçam & & particular & pela \\
\hline observarmos & opulençia & $\mathbf{P}$ & particulares & pelas \\
\hline observe & ordem & pacheco & partida & pella \\
\hline obstaculo & ordena & pacifica & partido & pellas \\
\hline obuiarmos & ordenaçam & pacificada & partindo & pelles \\
\hline ocaseois & ordenaçaõ & padecer & partio & pelllo \\
\hline ocaziaõ & ordenado & padeciaõ & partir & pello \\
\hline occasião & ordenança & padecido & pas & pellos \\
\hline occaziaõ & ordenanças & padre & pasa & pelo \\
\hline occazião & ordenansas & padres & pasada & pelos \\
\hline occurrentez & ordenar & paga & pasado & pelouro \\
\hline oculta & ordenassaõ & pagace & pasagens & pelouros \\
\hline ocupados & ordenaua & pagaçe & pasam & pencam \\
\hline ocuparnos & ordene & pagacem & pasamos & pençam \\
\hline ocuppacão & ordens & pagando & pasar & pencionado \\
\hline ocuppasaõ & ordeñs & pagaõ & pasarem & pencionados \\
\hline ofeçina & ordens ${ }^{\sim}$ & pagao' & pascendi & pendem \\
\hline oferese & ordinaremos & pagar & pascua & penna \\
\hline
\end{tabular}




\begin{tabular}{|c|c|c|c|c|}
\hline pennas & pessoa & ponho & precizo & procedemos \\
\hline pensam & pessoas & ponta & preço & procederaõ \\
\hline pensamos & pessuiçem & ponto & preços & procedermos \\
\hline pensar & peste & pontual & predicto & procurador \\
\hline penuria & petiçam & por & predita & procurando \\
\hline penurias & petição & porcoanto & preditas & procuravam \\
\hline pequena & petiçoens & porem & prefassa & produzem \\
\hline pequeno & petiçonins & porhebirse & prefazer & profeçor \\
\hline pequenos & pettiçaõ & porlhe & prejuizo & proferião \\
\hline per & pettição & pormos & prejuizos & proferido \\
\hline pera & pettisaõ & pornos & premio & proficoins \\
\hline perante & pez & porquanto & prende & profitentes \\
\hline percionada & pezado & porque & prender & profundo \\
\hline perciza & pezar & porsam & prenderaõ & prohibe \\
\hline percizam & piadozo & portanto & presença & prohibiçam \\
\hline percizarem & pillar & portaria & presensa & prohibicaõ \\
\hline percizas & pillares & porteiro & presente & prohibisam \\
\hline percizava & pimentel & portendem & presisa & prohibisão \\
\hline percizo & pingos & porto & preso & prohiuimos \\
\hline perda & pinheiro & portos & presteza & prohiuiram \\
\hline perdendo & pinixe & pos & preterito & projecto \\
\hline perder & pinto & pôs & pretexto & projectos \\
\hline pereira & pipa & poses & prettexo & projetos \\
\hline perejra & pires & posibilidades & prevenciados & prometem \\
\hline pereyra & pirez & posivel & prezenca & prometer \\
\hline perfeita & planta & possa & prezença & promette \\
\hline perfeyta & plantaçam & póssa & prezensa & prometteo \\
\hline perjuiso & plantas & posse & prezente & promptidaõ \\
\hline perjuizo & plantasaõ & posseçaõ & prezentemente & promptos \\
\hline pernagoa & pobo & possivel & prezentes & promta \\
\hline pernagua & pobres & posta & prezenttes & pronpta \\
\hline pernaguá & pobrezas & posto & prezidencia & pronptos \\
\hline pernaguâ & poçe & pouca & prezidente & prontidam \\
\hline pernaguã & poçes & poucas & prezumivel & prontos \\
\hline perniciosos & pocibillidade & pouco & primeira & propençaõ \\
\hline persuadir & pocibillidades & poucos & primeiro & propias \\
\hline pertence & poçiuel & pouoaçaõ & princepe & propina \\
\hline pertencer & pocivel & povo & princepez & propinas \\
\hline pertenciaõ & pode & povos & principais & propio \\
\hline pertende & podem & povoz & principalmente & propostos \\
\hline pertendem & podemos & praça & principe & proprio \\
\hline pertenderaõ & poder & praças & principiado & proprios \\
\hline pertendia & podera & pragmatica & principiar & prosesarem \\
\hline pertendo & poderam & prassa & prinçipio & prosimo \\
\hline perterito & poderem & praticado & prinçipios & prospere \\
\hline perturbaçaõ & poderemos & praticando & principiou & prospére \\
\hline perverteo & poderençe & praticarem & prinssipiou & prossedimento \\
\hline pes & poderes & preciza & priuança & proteçaõ \\
\hline pés & poderia & precizada & privados & protestando \\
\hline pesoa & podermos & precizava & pro & prouedor \\
\hline
\end{tabular}




\begin{tabular}{|c|c|c|c|c|}
\hline prouençial & queira & recorre & remeter & respeito \\
\hline proueo & queisxas & recorrer & remeternos & respetivas \\
\hline prouizam & quem & recorrido & remettemos & respetivo \\
\hline prouizaõ & quen & recurço & remetter & responder \\
\hline prouizoins & quer & redditos & rendem & resulluçaõ \\
\hline providencia & querem & redito & renderá & resurreiçaõ \\
\hline providente & queremos & reduzido & rendidos & reteficados \\
\hline provido & querer & refazer & rendimento & retemos \\
\hline provimento & questaõ & refere & rendimentos & retirada \\
\hline provimentos & quinhentos & referida & reparaçaõ & retirados \\
\hline provinssial & quinze & referido & reparar & retirandoçe \\
\hline provisam & & referidos & reperar & retirar \\
\hline provisaõ & $\mathbf{R}$ & refferido & repitidas & reverendo \\
\hline provizão & rabula & reflexoens & replica & reverendos \\
\hline provoca & rainha & reformado & reporto & reverente \\
\hline proximamente & rainno & reformem & reposta & reverentes \\
\hline proximo & ramo & refutar & reprehendido & reverentez \\
\hline prudente & rangel & regente & representado & revestidos \\
\hline publicaçaõ & rapaz & reges & representamos & revi \\
\hline publicace & raphael & regestado & representante & revisto \\
\hline publicado & razoéns & regia & representar & reyno \\
\hline publicar & reais & regias & reprezentado & rezaõ \\
\hline publicas & real & regimento & reprezentamos & rezignados \\
\hline publicei & reays & regio & reprezentantes & rezistar \\
\hline publico & rebates & registada & reprezentar & rezois \\
\hline publicos & rebello & registar & reprezentou & rezoluçam \\
\hline puçuir & recadasaõ & registo & reprezentta & rezoluçaõ \\
\hline pudece & recadassam & registos & reprezsentallos & rezolução \\
\hline puderia & recebe & registouçe & reprezsentar & rezolupsão \\
\hline punidos & recebem & registrada & republica & rezulupsaõ \\
\hline pustturas & recebemos & registro & republicanos & ribançeyra \\
\hline \multirow[t]{2}{*}{ puzeraõ } & reçebemos & reino & reputarão & ribas \\
\hline & reçebemosnos & reis & requeremos & ribeiro \\
\hline $\mathbf{Q}$ & reçebendo & réis & requerente & ricardo \\
\hline quais & recebeo & reiz & requereo & rigistado \\
\hline qual & reçeber & rej & requereraõ & rio \\
\hline qualquer & recebera & relação & requerido & ripas \\
\hline quando & receberâ & relassam & requerimento & ripitidas \\
\hline quantia & receberam & relauadas & requerimentos & riscos \\
\hline quanto & receberaõ & religiozos & requerimenttos & rocha \\
\hline quarenta & receberia & rellaçaõ & residencia & rocio \\
\hline quarta & recebidas & rellação & resoluçam & rodigues \\
\hline quarto & reçebido & relligioins & resoluçaõ & rodrigo \\
\hline quase & recessão & rematada & resoluemonos & rodrigues \\
\hline quatorze & recibida & rematados & resolupsam & rogamos \\
\hline quatro & recibo & rematassaõ & respectivas & rogando \\
\hline quatrocentos & reçibo & remeça & respectivo & rogar \\
\hline quatroçentoz & recolhaõ & remedio & respeita & roiz \\
\hline quaze & reconcavo & remessa & respeitar & rosario \\
\hline que & reconhecemos & remetemos & respeitavel & rozairo \\
\hline
\end{tabular}




\begin{tabular}{|c|c|c|c|c|}
\hline rozario & sego & séria & silva & sua \\
\hline ruas & segueira & serie & $\operatorname{sim}$ & suas \\
\hline rubricados & seguinte & sermos & simons & subaõ \\
\hline \multirow[t]{2}{*}{ ruina } & seguintes & serra & sinal & subcidio \\
\hline & seguio & serranos & sinaõ & subcidios \\
\hline$S$ & seguirem & serteza & sinco & subdito \\
\hline sabem & segunda & sertificamos & sinos & subditos \\
\hline sabemos & segundo & serto & sintimentoz & subditoz \\
\hline saber & segura & seruiaõ & siqueira & subescrevy \\
\hline sabermos & segurança & seruiço & siqujra & subgeito \\
\hline sabias & segurando & seruido & sircumvezinhas & subitar \\
\hline sabio & segurar & seruimos & sircunstancia & submissos \\
\hline sacerdotes & seguraraõ & seruir & sircunstancias & subscrevido \\
\hline sachristons & seifa & seruirmos & sirra & subscrito \\
\hline sacristaõ & seis & seruisso & sirvo & subssidios \\
\hline sae & seja & seruos & sitado & substituto \\
\hline sahe & sejaõ & serurgiam & sitio & suçedeçe \\
\hline sahem & sem & serurgiaõ & situassam & suçedendo \\
\hline sahida & semblea & serurgião & so & suceder \\
\hline sahio & semelhantes & serurgións & só & sucedidos \\
\hline sahirem & sempre & seruus & sô & sucego \\
\hline saida & sena & serve & soares & suçesivos \\
\hline saira & senado & servem & soberana & suçesores \\
\hline sal & senaõ & servia & soberanos & sucessaõ \\
\hline salarios & senão & servico & sobral & sucessor \\
\hline salgado & sencivel & serviço & sobre & sucidios \\
\hline saluo & sendo & serviços & sobredita & suditos \\
\hline sam & senhor & servido & sobreditos & sufficientes \\
\hline sange & senhor' & servidores & sobrescrito & sufiçiente \\
\hline sangue & senhora & servidos & socede & sugeita \\
\hline santa & senhores & servisso & soçedia & sugeitas \\
\hline santos & senhoria & servos & socego & sugeitos \\
\hline santtos & sennado & sesado & sócorreo & sumaca \\
\hline saõ & sentido & sessa & socorriaõ & super \\
\hline são & sentimento & sessenta & socõrro & superior \\
\hline sao' & seo & sete & sogeiçam & suplicamos \\
\hline sardinha & seos & setecentos & soldados & suplicante \\
\hline sargento & septembro & sette & soldos & suplicantes \\
\hline sarzedas & sequeira & settecentos & soma & suplicantte \\
\hline satisfazendo & ser & settecenttos & somente & suplicar \\
\hline satisfeito & sera & setuada & somentes & suplicas \\
\hline satisfeitos & será & seu & somos & suposto \\
\hline saude & serâ & seuiram & sorte & supplicantes \\
\hline sauemos & seram & seus & sortte & supplicaz \\
\hline sauermos & serão & sezar & sousa & supposto \\
\hline se & serca & si & souza & supra \\
\hline searas & serconuezinhas & siencias & ssilua & supremo \\
\hline secando & serem & significado & ssilueira & suprio \\
\hline secretaria & serenissimo & significava & ssilva & suscestençia \\
\hline secretario & seria & silua & ssua & suspençaõ \\
\hline
\end{tabular}




\begin{tabular}{|c|c|c|c|c|}
\hline suspender & tenhaõ & toprograficos & um & veneradores \\
\hline sussistencia & tenho & toques & unanime & veneramos \\
\hline sussistençia & ter & tornamos & uniaõ & veneranda \\
\hline sustava & tera & total & unica & venha \\
\hline suste & terca & toucinho & unido & ver \\
\hline sustentasão & terça & trabalhar & uniformemente & vera \\
\hline sy & terce & trabalharem & uniformes & verá \\
\hline sylua & terço & trabalho & urgencias & verâ \\
\hline \multirow[t]{2}{*}{ sylva } & terem & transporte & usos & verança \\
\hline & termo & trato & usque & veras \\
\hline$T$ & termos & traxesse & utilidade & verdade \\
\hline tã & terra & trebutos & uzo & verdadeira \\
\hline tabeliam & terras & tres & & vereador \\
\hline tabeliaõ & terreno & treseiro & V & vereadores \\
\hline taboado & terretorio & trez & vacantes & vereança \\
\hline tabularia & territorios & treze & vacas & vereanças \\
\hline tais & testamentos & trezentos & vacuos & vereansa \\
\hline tal & testemunhos & tributamos & vai & vereansas \\
\hline talentos & teue & tributar & vaj & veriditos \\
\hline talves & the & tributo & valendome & verissimo \\
\hline tam & thé & tributos & valentim & verso \\
\hline tambem & thê & trienio & valernomos & ves \\
\hline tanbem & theor & trieno & valle & veyo \\
\hline tantas & thesoureiro & trigo & valor & vezes \\
\hline tanto & thimotio & trimestre & vam & VI \\
\hline tantos & thomas & trinta & vamos & vi \\
\hline tantoz & thome & trioraçam & vaõ & via \\
\hline taõ & tibagi & tropa & vão & vianna \\
\hline tão & tido & ttem & vara & viaõ \\
\hline tao'bem & tinha & tteor & varios & vias \\
\hline taõbem & tinham & tter & vas & vicente \\
\hline tara & tinhamos & ttodo & vasalos & vida \\
\hline tauora & tinhaõ & ttodos & vassallos & vieira \\
\hline tavares & tipograficos & tudo & vasta & viér \\
\hline taxa & tiradas & & vay & vieria \\
\hline taxas & tiralla & $\mathbf{U}$ & ve & vieyra \\
\hline te & tirar & ueiga & vê & vigario \\
\hline té & tire & ueigua & veiga & vigarios \\
\hline teixeira & tirem & uejga & velas & vigor \\
\hline teixera & tiueçem & uejgua & velha & vigorosa \\
\hline tem & tiveraõ & uer & velhas & vila \\
\hline temem & tivesse & uerdade & velho & villa \\
\hline temos & toda & uida & vella & villas \\
\hline tempo & todas & uiga & vem & vimos \\
\hline tempos & todo & uindo & vemos & vinagre \\
\hline tendo & todos & uinte & venda & vinculado \\
\hline tenente & tomado & ujga & vender & vinda \\
\hline tenentte & tomamos & ultima & venderce & vindas \\
\hline tenha & tomar & ultimo & vendo & vindo \\
\hline tenhao & tomas & ultramarinos & veneraçaõ & vinha \\
\hline
\end{tabular}




\begin{tabular}{|l|l|l|l|l|}
\hline vinhaõ & virlhe & vizivel & voto & Y \\
\hline vinho & virtude & vmildes & votos & ya \\
\hline vinta & vise & vnico & votto & \\
\hline vinte & vista & voça & vozes & Z \\
\hline Vintém & visto & volumptaria & vsado & zelar \\
\hline vintillasem & viuendo & voluntario & & zello \\
\hline vintte & vive & vontade & X & zellozo \\
\hline viollençia & viver & vosa & xavier & \\
\hline vir & viveram & vossa & xega & \\
\hline virem & viviam & vossas & xoravão & \\
\hline
\end{tabular}


APÊNDICE B - Listagem resumida de vocábulos

\begin{tabular}{|c|c|c|c|c|}
\hline A & aleluia & arrimar & barra & casamento \\
\hline abastado & alentar & arroba & barrete & caso \\
\hline aberto & alferes & arrombada & batizado & castigar \\
\hline abertura & alma & arrombar & bebida & católico \\
\hline abranger & almoxarife & arroz & beijar & causa \\
\hline abrigo & alqueire & arte & benefício & cego \\
\hline abrir & alta & asilo & benemérito & cegueira \\
\hline absurdo & alteza & assegurar & benignidade & ceifa \\
\hline abundância & alto & assembleia & benigno & cento \\
\hline acabar & alugador & assenhorear & besta & cerca \\
\hline acautelar & alugar & assentado & bondade & cercar \\
\hline aceitar & aluguel & assestido & bordo & certidão \\
\hline aceite & alvará & assinado & botar & certificar \\
\hline aceno & amabilíssimo & assinar & botica & cessado \\
\hline achar & amado & assistência & braça & cessar \\
\hline acometido & ameaçar & assistir & braçame & cetera \\
\hline acomodado & amparar & associação & brejo & chamar \\
\hline acompanhamento & amparo & assombrado & brioso & chão \\
\hline acompanhar & andar & atalhar & brotar & chave \\
\hline aconselhar & anexo & atenção & & chegada \\
\hline acontecer & animal & atender & C & chegar \\
\hline acordar & animar & atendível & cabal & chorar \\
\hline acordo & ano & atento & cabeça & cidade \\
\hline acréscimo & ansiar & atividade & caber & ciência \\
\hline acudir & antecessor & ato & cabo & circuito \\
\hline adjunto & antepassado & atolar & cadeia & circunstância \\
\hline admitir & antigo & atrasado & câmara & circunvizinhança \\
\hline admoestar & anual & atravessador & camarista & cirurgião \\
\hline advertir & apanhar & atravessar & câmera & clamar \\
\hline afastar & aparecer & atual & caminho & clareza \\
\hline afeto & apenar & atuar & campo & cobrador \\
\hline afetuoso & aplaudir & aulista & cana & cobrança \\
\hline aflição & aplicado & aumentar & canal & cobrar \\
\hline agente & aplicar & aumento & cancela & coedando \\
\hline agradável & apontado & ausência & canoa & cofre \\
\hline agradecer & apossar & autoridade & capaz & coibir \\
\hline agrado & apostolicum & auxiliar & capela & coisa \\
\hline agregar & apresentar & auxílio & capital & coleção \\
\hline agricultor & aprovação & avançado & capitania & colégio \\
\hline agricultura & aprovado & avisar & capitão & colheita \\
\hline água & aprovar & avistado & capítulo & colocar \\
\hline aguardente & aproveitar & avocar & carecer & colônia \\
\hline ajudante & apuração & avulsar & carga & comarca \\
\hline ajuste & arbitramento & azeite & cargo & combinado \\
\hline alancear & arbitrar & & carne & começar \\
\hline alcaide & ardil & B & carneiro & comércio \\
\hline alcançar & arranchar & bairro & caro & comiseração \\
\hline alegado & arrecadação & balandra & carregado & comiserar \\
\hline alegar & arrematação & bando & carregar & compadecer \\
\hline alegria & arrematar & barco & carta & companheiro \\
\hline
\end{tabular}




\begin{tabular}{|c|c|c|c|c|}
\hline companhia & conteúdo & declarado & despreso & embarcação \\
\hline cômpito & continuar & declarar & destinado & embargo \\
\hline completa & contrariar & decoroso & destinar & embrenhado \\
\hline compra & contrário & decreto & destino & emolumento \\
\hline comprar & contrato & deduzir & destruído & empenho \\
\hline compreender & contribuição & defender & determinação & empregar \\
\hline compreendido & contribuir & defensão & determinar & emprego \\
\hline comprometer & conveniente & deferir & detrimento & encarregar \\
\hline comunicar & convir & defesa & Deus & encontrar \\
\hline conceder & convocado & degradado & devassa & enfadonho \\
\hline concetido & cópia & deixar & dever & enfermidade \\
\hline concluir & copiado & deliberar & diferença & enfermo \\
\hline concordar & copiar & demasia & dificuldade & engenheiro \\
\hline concorrer & coragem & demitir & dignar & engenho \\
\hline condução & coroa & demolir & digníssimo & enjeitar \\
\hline conduzir & coronel & dissimulação & dilatado & ensino \\
\hline conferência & corpo & demonstração & diligência & enterro \\
\hline conferir & corporação & demora & diminuto & entrada \\
\hline conferir & corregedor & demorar & dinheiro & entrar \\
\hline confiar & correição & denominar & dirigido & entrega \\
\hline confirmação & corrente & deplorável & dirigir & entregar \\
\hline confirmar & correr & depor & discípulo & enviar \\
\hline conformidade & corresponder & deposto & disposição & erário \\
\hline confraternidade & cortar & derrama & disposto & erigir \\
\hline conhecer & corte & derrogar & distância & errar \\
\hline conhecimento & costa & derrubar & distante & escolher \\
\hline conjuntura & costumado & desamparar & distinguir & escrava \\
\hline conselho & costumar & desanimado & distribuição & escrever \\
\hline consentir & costume & desarranjo & distrito & escrita \\
\hline consequência & crescer & descarga & dito & escrito \\
\hline consertar & crescimento & desconcertado & divisão & escrivão \\
\hline conserto & criação & desconsolação & dizer & escusar \\
\hline conserva & criado & descuido & dízimo & especializar \\
\hline conservação & criador & desculpar & doação & esperar \\
\hline conservar & criar & desejar & dobrado & espero \\
\hline consideração & cruzado & desembargador & doce & espírito \\
\hline considerado & cuidado & desempenhar & dominante & esquivar \\
\hline consignar & cuidar & desempenho & doutor & estabelecer \\
\hline consta & cultura & desfalque & dúvida & estado \\
\hline constar & cumprimento & desígnio & & esterilidade \\
\hline consternação & curbas & desinteressado & $E$ & estilo \\
\hline constituir & custa & desistir & edifício & estimável \\
\hline conta & custar & desmembração & edital & estipular \\
\hline contador & & desmerecer & efeito & estrada \\
\hline contar & D & desnecessário & eficácia & estrangeiro \\
\hline contemplar & dado & despacho & eleger & estranhar \\
\hline contentamento & data & despedido & eleição & europeu \\
\hline contento & datado & despejado & elevar & evangelho \\
\hline conter & decadência & despesa & elogio & evitar \\
\hline contestar & decisão & despotismo & embaraçar & examinar \\
\hline
\end{tabular}




\begin{tabular}{|c|c|c|c|c|}
\hline excelência & fidelidade & governança & incompatível & lanceada \\
\hline excessivo & fidelíssimo & governar & inconsiderado & lastimável \\
\hline exclusão & fiel & governo & inconveniente & lavoura \\
\hline excreto & filho & graça & incorrer & lavrador \\
\hline execução & fim & gratuoso & inculcar & lavrar \\
\hline executado & findo & grave & incumbência & leal \\
\hline executar & finta & grosseira & indecoroso & lealdade \\
\hline exercer & firmeza & guarda & indivíduo & légoa \\
\hline exercício & fixado & guardar & infante & lei \\
\hline exercitar & fixar & guarnição & informado & leite \\
\hline existir & fogo & & informar & lenha \\
\hline expedição & folha & H & injustiça & letra \\
\hline expender & fome & habitador & inovar & levantar \\
\hline experiência & fomentar & habitação & inquietação & levar \\
\hline experimentado & força & habitantes & inquieto & liberdade \\
\hline expor & formalidade & haver & insinuar & libra \\
\hline exposto & formando & hidráulico & instituto & licença \\
\hline expressado & formar & hoje & instruído & limitado \\
\hline expressar & foro & homem & instruir & limpo \\
\hline \multirow[t]{2}{*}{ expulso } & fortaleza & honra & insuportável & linha \\
\hline & fortificação & horroroso & inteirar & líquido \\
\hline $\mathbf{F}$ & fortuna & humildade & intendente & lista \\
\hline faculdade & freguesia & humilde & intentar & listar \\
\hline facultar & frequentar & & interceder & literal \\
\hline faiscar & frívolo & I & interessado & literário \\
\hline faisqueira & frota & ignorar & interino & livro \\
\hline falar & frouxar & igreja & intervensaõ & lograr \\
\hline falecido & fugido & ilha & intiedade & lugar \\
\hline falta & fugir & ilustre & introduzir & luminária \\
\hline faltar & fumo & iminente & inventário & lotação \\
\hline falto & fundação & imitar & irracional & luz \\
\hline farinha & fundado & impedimento & irresoluto & luzido \\
\hline farto & fundamento & impedir & isento & \\
\hline fato & fundar & ímpeto & & M \\
\hline favorável & futuro & impor & J & madeira \\
\hline favorecer & & importar & Jesus & majestade \\
\hline fazenda & G & imposição & judicial & mandado \\
\hline fé & gado & impossibilidade & juiz & mandar \\
\hline fechar & gastar & impossibilitar & junta & mandioca \\
\hline feijão & general & impossível & juntamos & manifestar \\
\hline feito & gênero & imposta & junto & mantimento \\
\hline feitura & gênio & imposto & jurar & mão \\
\hline felicidade & gente & impresso & juramento & mapa \\
\hline felicitar & geral & impulso & justa & máquinas \\
\hline feliz & girar & incerto & justiça & marchar \\
\hline ferrugem & giro & incidente & justo & marinha \\
\hline festejo & golpe & inclinar & & matemático \\
\hline festividade & gosto & inclusa & $\mathbf{L}$ & matéria \\
\hline ficar & gostoso & incluzo & ladino & maternal \\
\hline fidalgia & governador & incômodo & lamentável & matriz \\
\hline
\end{tabular}




\begin{tabular}{|c|c|c|c|c|}
\hline máximo & notícia & pacífico & peste & presidente \\
\hline mediando & noticiar & padecer & petição & preso \\
\hline médico & notório & padecido & piedoso & presteza \\
\hline meirinho & novidade & padre & pilar & presumível \\
\hline membro & nulo & pagar & pingo & pretender \\
\hline menção & número & país & pipa & pretérito \\
\hline mencionar & & papel & planta & pretexto \\
\hline mente & 0 & paragem & plantação & principal \\
\hline mercê & obedecer & parecer & pobre & príncipe \\
\hline meritíssimo & obediência & paridade & pobresa & principiado \\
\hline mestre & obediente & pároco & poder & principiar \\
\hline método & objeto & paroquial & poderoso & princípio \\
\hline miliciano & obra & participante & polícia & privado \\
\hline militar & obrar & particular & ponderado & privança \\
\hline minas & ob-reptício & partida & ponderar & proceder \\
\hline ministério & obrigação & partido & ponta & procedimento \\
\hline ministro & obrigado & partir & ponto & processar \\
\hline miserável & obrigar & pascendi & pontual & procurador \\
\hline módico & obsequioso & páscoa & pôr & procurar \\
\hline moléstia & observância & passada & porção & produzir \\
\hline molhados & observar & passado & portaria & proferir \\
\hline monarquia & obviar & passagem & porteiro & professor \\
\hline monopólio & ocasião & passar & porto & profissão \\
\hline morador & ocorrente & passos & posse & profitente \\
\hline mostrar & ocupação & pasto & posseçaõ & profundo \\
\hline motivo & ocupado & patente & possibilidade & proibição \\
\hline móvel & ocupar & patentear & possível & proibir \\
\hline mudança & oferecer & paternal & possuído & projeto \\
\hline mudar & oferta & pau & possuir & prometer \\
\hline multiplicação & oficial & paz & posta & prontidão \\
\hline multiplicar & oficina & pé & posto & propensão \\
\hline \multirow[t]{2}{*}{ munido } & ofício & pedir & postura & propina \\
\hline & olho & pelouro & povo & prosperar \\
\hline $\mathbf{N}$ & ônus & pena & povoação & proteção \\
\hline nascido & opressão & pender & praça & protestar \\
\hline nascimento & opulência & pensão & pragmática & provedor \\
\hline natural & ordem & pensionado & praticado & provençal \\
\hline natureza & ordenação & penúria & praticar & prover \\
\hline navio & ordenado & perda & precionado & providência \\
\hline necessário & ordenança & perder & precisar & providente \\
\hline necessidade & ordenar & perfeito & preço & provido \\
\hline necessitar & ordinário & pernicioso & predito & provimento \\
\hline negado & órfão & persuadir & prefazer & provincial \\
\hline negócio & ouro & pertencer & prejuízo & provisão \\
\hline negra & ousadia & perturbação & prêmio & provocar \\
\hline nobre & ouvir & pervencido & prender & prudente \\
\hline nome & ouvidor & perverter & presença & publicação \\
\hline nomeação & ouvidoria & pesado & presenciar & publicar \\
\hline nomeado & & pesar & presente & público \\
\hline nota & P & pessoa & presidência & punido \\
\hline
\end{tabular}




\begin{tabular}{|c|c|c|c|c|}
\hline & reparar & sair & submisso & topográfico \\
\hline $\mathbf{Q}$ & repetir & sal & subscrever & toque \\
\hline quadra & réplica & salário & subscrevido & tornar \\
\hline queixa & reportar & salgado & subscrito & total \\
\hline querer & reposta & salvo & subsídio & toucinho \\
\hline \multirow[t]{2}{*}{ questaõ } & repreender & sangue & substituto & trabalhar \\
\hline & representado & sardinha & suceder & trabalho \\
\hline $\mathbf{R}$ & representante & sargento & sucedido & transporte \\
\hline rábula & representar & satisfazer & sucego & trato \\
\hline rainha & república & satisfeito & sucessão & traxesse \\
\hline razão & republicano & saúde & sucessor & tributar \\
\hline real & reputar & seara & súdito & tributo \\
\hline rebate & requerente & secar & suficiente & triênio \\
\hline receber & requerer & secretaria & sujeição & trigo \\
\hline recessão & requerido & secretário & sujeito & trimestre \\
\hline recibo & requerimento & seguir & sumaca & trioraçam \\
\hline recolher & residência & segurança & súplica & tropa \\
\hline recôncavo & resignado & segurar & suplicamos & \\
\hline reconhecer & resolução & semelhante & suplicante & $\mathbf{U}$ \\
\hline recorrer & resolver & senado & suplicar & unânime \\
\hline recurso & respectivo & sensível & suposto & união \\
\hline redito & respeitar & sentido & supremo & unido \\
\hline reduzido & respeitável & sentimento & suprir & uniforme \\
\hline refazer & respeito & ser & suspenção & urgência \\
\hline referir & responder & sereníssimo & suspender & utilidade \\
\hline reflexão & resurreição & série & sustar & único \\
\hline reformar & reter & sério & sustentação & usado \\
\hline refutar & retificar & serra & & ultramarino \\
\hline regente & retirar & serrano & $\mathbf{T}$ & \\
\hline reges & rever & serviço & tabelião & V \\
\hline régia & reverendo & servidor & taboado & vaca \\
\hline regimento & reverente & servir & tabularia & vacante \\
\hline régio & revestido & servo & talento & vácuo \\
\hline registar & revisto & significado & tara & valor \\
\hline registo & ribanceira & significar & taxa & vara \\
\hline rei & rio & sinal & temer & vassalo \\
\hline reino & ripa & $\sin 0$ & temos & vela \\
\hline réis & risco & sítio & tenente & venda \\
\hline relação & rócio & situação & teor & vender \\
\hline relavada & rogar & situado & ter & veneração \\
\hline religião & rua & soberano & terço & venerador \\
\hline religioso & rubricado & socorrer & termo & venerar \\
\hline rematado & ruína & socorro & terra & ventilar \\
\hline rematar & & soldado & terreno & veras \\
\hline remédio & S & soldo & terretorio & verdade \\
\hline remessa & saber & sorte & tesoureiro & verdadeira \\
\hline remeter & sábio & sossego & testamento & vereador \\
\hline render & sacerdote & subdito & testemunho & vereança \\
\hline rendimento & sacristaõ & subir & tipográfico & veredicto \\
\hline reparação & saída & subitar & tomar & veríssimo \\
\hline
\end{tabular}




\begin{tabular}{|l|l|l|l|l|}
\hline verso & vila & violência & voluntário & $\mathbf{Z}$ \\
\hline via & vinagre & virtude & vontade & zelar \\
\hline vida & vincular & visível & voto & zelo \\
\hline vigário & vinda & vista & voz & zeloso \\
\hline vigor & vindo & visto & & \\
\hline vigoroso & vinho & viver & & \\
\hline
\end{tabular}


APÊNDICE C - Questionário Semântico-Lexical

\section{VERBOS}

1. ACAUTELAR (Acepção: Prevenir, precaver)

Você conhece a palavra ACAUTELAR?

Pode dar um exemplo desta palavra dentro de uma frase?

2. ACOMPANHAR (Acepção: Seguir, observar)

Você conhece a palavra ACOMPANHAR?

Pode dar um exemplo desta palavra dentro de uma frase?

3. ACORDAR (Acepção: Decidir conjuntamente)

Você conhece a palavra ACORDAR?

Pode dar um exemplo desta palavra dentro de uma frase?

\section{ACUDIR (Acepção: Socorrer, ajudar)}

Você conhece a palavra ACUDIR?

Pode dar um exemplo desta palavra dentro de uma frase?

5. ADMOESTAR (Acepção: Avisar, Sugerir)

Você conhece a palavra ADMOESTAR?

Pode dar um exemplo desta palavra dentro de uma frase?

6. ALENTAR (Acepção: Dar ânimo, encorajar)

Você conhece a palavra ALENTAR? Dar alento.

Pode dar um exemplo desta palavra dentro de uma frase?

7. ANSIAR (Acepção: Oprimir, afligir)

Você conhece a palavra ANSIAR?

Pode dar um exemplo desta palavra dentro de uma frase? 
8. APANHAR (Acepção: Capturar, pegar)

Você conhece a palavra APANHAR?

Pode dar um exemplo desta palavra dentro de uma frase?

9. APENAR (Acepção: Obrigar, impor pena)

Você conhece a palavra APENAR?

Pode dar um exemplo desta palavra dentro de uma frase?

10. APOSSAR (Acepção: Tomar posse, apoderar)

Você conhece a palavra APOSSAR?

Pode dar um exemplo desta palavra dentro de uma frase?

11. ARRANCHAR (Acepção: Conseguir)

Você conhece a palavra ARRANCHAR?

Pode dar um exemplo desta palavra dentro de uma frase?

12. ARROMBAR (Acepção: Derrubar, romper)

Você conhece a palavra ARROMBAR?

Pode dar um exemplo desta palavra dentro de uma frase?

13. ASSENHOREAR-SE (Acepção: Apossar-se, dominar)

Você conhece a palavra ASSENHOREAR-SE?

Pode dar um exemplo desta palavra dentro de uma frase?

14. ASSISTIR (Acepção: Residir, permanecer)

Você conhece a palavra ASSISTIR?

Pode dar um exemplo desta palavra dentro de uma frase?

15. ATALHAR (Acepção: Impedir, estorvar)

Você conhece a palavra ATALHAR?

Pode dar um exemplo desta palavra dentro de uma frase? 
16. AVANÇAR A DINHEIRO (Acepção: Conceder, dispor)

Você conhece a expressão AVANÇAR A DINHEIRO?

Pode dar um exemplo desta palavra dentro de uma frase?

17. AVOCAR (Acepção: Chamar, invocar)

Você conhece a palavra AVOCAR?

Pode dar um exemplo desta palavra dentro de uma frase?

18. BOTAR (Acepção: Pôr, colocar)

Você conhece a palavra BOTAR?

Pode dar um exemplo desta palavra dentro de uma frase?

19. BOTAR PINGOS (Acepção: Impedir que receba chuva densa)

Você conhece a expressão BOTAR PINGOS?

Pode dar um exemplo desta palavra dentro de uma frase?

20. BROTAR (Acepção: Resultar, ter como consequência)

Você conhece a palavra BROTAR?

Pode dar um exemplo desta palavra dentro de uma frase?

21. CESSAR (Acepção: Acabar, parar)

Você conhece a palavra CESSAR?

Pode dar um exemplo desta palavra dentro de uma frase?

22. COIBIR (Acepção: Reprimir, impedir)

Você conhece a palavra COIBIR?

Pode dar um exemplo desta palavra dentro de uma frase?

23. COMISERAR-SE (Acepção: Ter compaixão, piedade)

Você conhece a palavra COMISERAR?

Pode dar um exemplo desta palavra dentro de uma frase? 
24. DELIBERAR (Acepção: Determinar, resolver)

Você conhece a palavra DELIBERAR?

Pode dar um exemplo desta palavra dentro de uma frase?

25. DEMITIR (Acepção: Deixar, abandonar)

Você conhece a palavra DEMITIR?

Pode dar um exemplo desta palavra dentro de uma frase?

26. DEPOR (Acepção: Destituir de função, demitir)

Você conhece a palavra DEPOR?

Pode dar um exemplo desta palavra dentro de uma frase?

27. DESPEJAR (Acepção: Desocupar, evacuar)

Você conhece a palavra DESPEJAR?

Pode dar um exemplo desta palavra dentro de uma frase?

28. EMBARAÇAR (Acepção: Atrapalhar, estorvar)

Você conhece a palavra EMBARAÇAR?

Pode dar um exemplo desta palavra dentro de uma frase?

29. EMPREGAR-SE (Acepção: Servir a alguém, dedicar-se)

Você conhece a palavra EMPREGAR-SE?

Pode dar um exemplo desta palavra dentro de uma frase?

30. ENJEITAR (Acepção: Rejeitar, recusar, não aceitar)

Você conhece a palavra ENJEITAR?

Pode dar um exemplo desta palavra dentro de uma frase?

31. ERIGIR-SE (Acepção: Fundar, elevar)

Você conhece a palavra ERIGIR?

Pode dar um exemplo desta palavra dentro de uma frase?

32. ESCUSAR (Acepção: Recusar, dispensar)

Você conhece a palavra ESCUSAR? 
Pode dar um exemplo desta palavra dentro de uma frase?

33. EXPENDER (Acepção: Ter despesas, gastar)

Você conhece a palavra EXPENDER?

Pode dar um exemplo desta palavra dentro de uma frase?

34. FACULTAR (Acepção: Permitir, conceder)

Você conhece a palavra FACULTAR?

Pode dar um exemplo desta palavra dentro de uma frase?

35. FAISCAR (Acepção: Garimpar, procurar minerais preciosos em terras anteriormente lavradas)

Você conhece a palavra FAISCAR?

Pode dar um exemplo desta palavra dentro de uma frase?

36. FELICITAR (Acepção: Desejar felicidades)

Você conhece a palavra FELICITAR?

Pode dar um exemplo desta palavra dentro de uma frase?

37. FOMENTAR (Acepção: Causar, provocar)

Você conhece a palavra FOMENTAR?

Pode dar um exemplo desta palavra dentro de uma frase?

38. INCORRER (Acepção: Causar, ter como consequência)

Você conhece a palavra INCORRER?

Pode dar um exemplo desta palavra dentro de uma frase?

39. INTEIRAR-SE (Acepção: Juntar o que falta, completar)

Você conhece a palavra INTEIRAR?

Pode dar um exemplo desta palavra dentro de uma frase? 
40. INTENTAR (Acepção: Pretender fazer algo)

Você conhece a palavra INTENTAR?

Pode dar um exemplo desta palavra dentro de uma frase?

41. LANCEAR (Acepção: Arrancar, retirar)

Você conhece a palavra LANCEAR?

Pode dar um exemplo desta palavra dentro de uma frase?

42. LAVRAR (Acepção: Explorar, trabalhar nas minas) Você conhece a palavra LAVRAR?

Pode dar um exemplo desta palavra dentro de uma frase?

43. LOGRAR (Acepção: Estar de posse, conseguir)

Você conhece a palavra LOGRAR?

Pode dar um exemplo desta palavra dentro de uma frase?

44. MEDIANDO (Acepção: Estar próximo, entre)

Você conhece a palavra MEDIANDO?

Pode dar um exemplo desta palavra dentro de uma frase?

45. OBRAR (Acepção: Executar, realizar, produzir)

Você conhece a palavra OBRAR?

Pode dar um exemplo desta palavra dentro de uma frase?

46. OBVIAR (Acepção: Opor, contrapor, obstar) Você conhece a palavra OBVIAR?

Pode dar um exemplo desta palavra dentro de uma frase?

47. PATENTEAR (Acepção: Manifestar, evidenciar)

Você conhece a palavra PATENTEAR?

Pode dar um exemplo desta palavra dentro de uma frase? 
48. PENDER (Acepção: Depender, estar sujeito)

Você conhece a palavra PENDER?

Pode dar um exemplo desta palavra dentro de uma frase?

49. PERVERTER-SE (Acepção: Efetuar alteração, mudança)

Você conhece a palavra PERVERTER?

Pode dar um exemplo desta palavra dentro de uma frase?

50. PÔR OS OLHOS (Acepção: Cuidar)

Você conhece a expressão PÔR OS OLHOS?

Pode dar um exemplo desta palavra dentro de uma frase?

51. SUBITAR (Acepção: Ir a baixo, derrubar)

Você conhece a palavra SUBITAR?

Pode dar um exemplo desta palavra dentro de uma frase?

52. SUBSCREVER (Acepção: Aprovado, aceito)

Você conhece a palavra SUBSCREVER?

Pode dar um exemplo desta palavra dentro de uma frase?

53. SUSTAR-SE (Acepção: Parar, interromper)

Você conhece a palavra SUSTAR?

Pode dar um exemplo desta palavra dentro de uma frase?

54. VENTILAR (Acepção: Discutir, debater um assunto, levantar hipóteses) Você conhece a palavra VENTILAR?

Pode dar um exemplo desta palavra dentro de uma frase? 


\section{SUBSTANTIVOS}

55. ACENO (Acepção: Sinal)

Você conhece a palavra ACENO?

Pode dar um exemplo desta palavra dentro de uma frase?

56. AGUARDENTE (Acepção: Bebida de teor alcoólico) Você conhece a palavra AGUARDENTE?

Pode dar um exemplo desta palavra dentro de uma frase?

57. ALQUEIRE (Acepção: Unidade de medida agrária) Você conhece a palavra ALQUEIRE?

Pode dar um exemplo desta palavra dentro de uma frase?

58. ALUGADOR (Acepção: Pessoa que aluga, locatário) Você conhece a palavra ALUGADOR?

Pode dar um exemplo desta palavra dentro de uma frase?

59. ARBITRAMENTO (Acepção: Decisão, julgamento) Você conhece a palavra ARBITRAMENTO?

Pode dar um exemplo desta palavra dentro de uma frase?

60. ARDIL (Acepção: Astúcia, cilada, visa iludir)

Você conhece a palavra ARDIL?

Pode dar um exemplo desta palavra dentro de uma frase?

61. ARREMATAÇÃO (Acepção: Finalização, conclusão) Você conhece a palavra ARREMATAÇÃO?

Pode dar um exemplo desta palavra dentro de uma frase? 
62. ARROBA (Acepção: Unidade de medida de peso)

Você conhece a palavra ARROBA?

Pode dar um exemplo desta palavra dentro de uma frase?

63. ASILO (Acepção: Proteção, amparo)

Você conhece a palavra ASILO?

Pode dar um exemplo desta palavra dentro de uma frase?

64. ATRAVESSADOR (Acepção: Pessoa que compra e revende com grande margem de lucro)

Você conhece a palavra ATRAVESSADOR?

Pode dar um exemplo desta palavra dentro de uma frase?

65. AULISTA (Acepção: Professor, aquele que ministra aulas)

Você conhece a palavra AULISTA?

Pode dar um exemplo desta palavra dentro de uma frase?

66. AVULSÃO/EVULSÃO (Acepção: Arrancar de forma violenta)

Você conhece as palavras AVULSÃO/EVULSÃO?

Pode dar um exemplo desta palavra dentro de uma frase?

67. BALANDRA (Acepção: Tipo de embarcação antiga)

Você conhece a palavra BALANDRA?

Pode dar um exemplo desta palavra dentro de uma frase?

68. BANDO (Acepção: Pregão, divulgação, proclamação pública)

Você conhece a palavra BANDO?

Pode dar um exemplo desta palavra dentro de uma frase?

69. BARRA (Acepção: Entrada estreita de porto)

Você conhece a palavra BARRA?

Pode dar um exemplo desta palavra dentro de uma frase? 
70. BOTICA (Acepção: Antiga loja de produtos farmacêuticos)

Você conhece a palavra BOTICA?

Pode dar um exemplo desta palavra dentro de uma frase?

71. BRAÇA (Acepção: Medida antiga de extensão)

Você conhece a palavra BRAÇA?

Pode dar um exemplo desta palavra dentro de uma frase?

72. BRAÇAME (Acepção: Tipo de madeira para construção de embarcação)

Você conhece a palavra BRAÇAME?

Pode dar um exemplo desta palavra dentro de uma frase?

73. CAMARISTA (Acepção: Membro de uma câmara legislativa municipal, função de vereador)

Você conhece a palavra CAMARISTA?

Pode dar um exemplo desta palavra dentro de uma frase?

74. CEIFA (Acepção: Ato de cortar, colher)

Você conhece a palavra CEIFA?

Pode dar um exemplo desta palavra dentro de uma frase?

75. CIRCUITO (Acepção: Ao redor, periferia)

Você conhece a palavra CIRCUITO?

Pode dar um exemplo desta palavra dentro de uma frase?

76. CIRCUNVIZINHANÇA (Acepção: Arredores de uma povoação)

Você conhece a palavra CIRCUNVIZINHANÇA?

Pode dar um exemplo desta palavra dentro de uma frase?

77. CÔMPUTO (Acepção: Soma, conta, resultado)

Você conhece a palavra CÔMPUTO?

Pode dar um exemplo desta palavra dentro de uma frase? 
78. CONJUNTURA (Acepção: Circunstância, situação)

Você conhece a palavra CONJUNTURA?

Pode dar um exemplo desta palavra dentro de uma frase?

79. CONSTERNAÇÃO (Acepção: Abatimento, desolação)

Você conhece a palavra CONSTERNAÇÃO?

Pode dar um exemplo desta palavra dentro de uma frase?

80. CULTURA (Acepção: Plantação, cultivo)

Você conhece a palavra CULTURA?

Pode dar um exemplo desta palavra dentro de uma frase?

81. DATA (Acepção: Pedaço de terra, faixa de terreno) Você conhece a palavra DATA?

Pode dar um exemplo desta palavra dentro de uma frase?

82. DEMASIA (Acepção: Falta de respeito, abuso)

Você conhece a palavra DEMASIA?

Pode dar um exemplo desta palavra dentro de uma frase?

83. DESARRANJO (Acepção: Desordem, confusão)

Você conhece a palavra DESARRANJO?

Pode dar um exemplo desta palavra dentro de uma frase?

84. DESCONSOLAÇÃO (Acepção: Tristeza, frustração) Você conhece a palavra DESCONSOLAÇÃO?

Pode dar um exemplo desta palavra dentro de uma frase?

85. DESMEMBRAÇÃO (Acepção: Separação, desagregação)

Você conhece a palavra DESMEMBRAÇÃO?

Pode dar um exemplo desta palavra dentro de uma frase? 
86. DETRIMENTO (Acepção: Prejuízo, dano)

Você conhece a palavra DETRIMENTO?

Pode dar um exemplo desta palavra dentro de uma frase?

87. DILIGÊNCIA (Acepção: Providência, zelo, presteza)

Você conhece a palavra DILIGÊNCIA?

Pode dar um exemplo desta palavra dentro de uma frase?

88. DISCÍPULO (Acepção: Aluno, aquele que aprende)

Você conhece a palavra DISCÍPULO?

Pode dar um exemplo desta palavra dentro de uma frase?

89. DITO (Acepção: Referido, mencionado)

Você conhece a palavra DITO?

Pode dar um exemplo desta palavra dentro de uma frase?

90. EMBARGO (Acepção: Impedimento, obstáculo, empecilho)

Você conhece a palavra EMBARGO?

Pode dar um exemplo desta palavra dentro de uma frase?

91. EMOLUMENTO (Acepção: Lucro, proveito, gratificação)

Você conhece a palavra EMOLUMENTO?

Pode dar um exemplo desta palavra dentro de uma frase?

92. ENFERMO (Acepção: Doente, sem saúde)

Você conhece a palavra ENFERMO?

Pode dar um exemplo desta palavra dentro de uma frase?

93. ENGENHO (Acepção: Propriedadelestabelecimento destinado a cultura da cana e a fabricação do açúcar)

Você conhece a palavra ENGENHO?

Pode dar um exemplo desta palavra dentro de uma frase? 
94. ESTERILIDADE (Acepção: Escassez, penúria)

Você conhece a palavra ESTERILIDADE?

Pode dar um exemplo desta palavra dentro de uma frase?

95. EXCRETO (Acepção: Dejeto, excremento)

Você conhece a palavra EXCRETO?

Pode dar um exemplo desta palavra dentro de uma frase?

96. EXPEDIÇÃO (Acepção: Despacho, remessa)

Você conhece a palavra EXPEDIÇÃO?

Pode dar um exemplo desta palavra dentro de uma frase?

97. FAISQUEIRA (Acepção: Lugar onde se encontrava faísca de ouro)

Você conhece a palavra FAISQUEIRA?

Pode dar um exemplo desta palavra dentro de uma frase?

98. FIEL (Acepção: Pessoa provida em cargo público responsável em cobrar, guardar e receber dinheiro)

Você conhece a palavra FIEL?

Pode dar um exemplo desta palavra dentro de uma frase?

99. FINTA (Acepção: Tributo, imposto extraordinário)

Você conhece a palavra FINTA?

Pode dar um exemplo desta palavra dentro de uma frase?

100. FOGO (Acepção: Casa, residência, família)

Você conhece a palavra FOGO?

Pode dar um exemplo desta palavra dentro de uma frase?

101. FORTUNA (Acepção: Sorte, fado)

Você conhece a palavra FORTUNA?

Pode dar um exemplo desta palavra dentro de uma frase? 
102. HABITADOR (Acepção: Habitante, morador)

Você conhece a palavra HABITADOR?

Pode dar um exemplo desta palavra dentro de uma frase?

103. IMINENTE (Acepção: Preste a acontecer)

Você conhece a palavra IMINENTE?

Pode dar um exemplo desta palavra dentro de uma frase?

104. INCONVENIENTE (Acepção: Dificuldade em executar algo)

Você conhece a palavra INCONVENIENTE?

Pode dar um exemplo desta palavra dentro de uma frase?

105. INCUMBÊNCIA (Acepção: Obrigação imposta)

Você conhece a palavra INCUMBÊNCIA?

Pode dar um exemplo desta palavra dentro de uma frase?

106. LAVRA (Acepção: Terreno de mineração)

Você conhece a palavra LAVRA?

Pode dar um exemplo desta palavra dentro de uma frase?

107. LÉGUA (Acepção: Antiga unidade brasileira de medida itinerária)

Você conhece a palavra LÉGUA?

Pode dar um exemplo desta palavra dentro de uma frase?

108. LETRA (Acepção: Documento, carta)

Você conhece a palavra LETRA?

Pode dar um exemplo desta palavra dentro de uma frase?

109. LIBRA (Acepção: Antiga medida de peso)

Você conhece a palavra LIBRA?

Pode dar um exemplo desta palavra dentro de uma frase? 
110. LONGES (Acepção: Grande distância)

Você conhece a palavra LONGES?

Pode dar um exemplo desta palavra dentro de uma frase?

111. MANTIMENTO (Acepção: Alimento para sustento próprio)

Você conhece a palavra MANTIMENTO?

Pode dar um exemplo desta palavra dentro de uma frase?

112. MEIRINHO (Acepção: Antigo funcionário judicial, o mesmo que oficial da justiça) Você conhece a palavra MEIRINHO?

Pode dar um exemplo desta palavra dentro de uma frase?

113. MERCÊ / FAZER MERCÊ (Acepção: Conceder benefício)

Você conhece a palavra MERCÊ?

Pode dar um exemplo desta palavra dentro de uma frase?

114. MESTRE (Acepção: Comandante de embarcação)

Você conhece a palavra MESTRE?

Pode dar um exemplo desta palavra dentro de uma frase?

115. MILICIANO (Acepção: $O$ mesmo que soldado militar)

Você conhece a palavra MILICIANO?

Pode dar um exemplo desta palavra dentro de uma frase?

116. MOLÉSTIA (Acepção: Doença, enfermidade)

Você conhece a palavra MOLÉSTIA?

Pode dar um exemplo desta palavra dentro de uma frase?

117. MOLHADO (Acepção: Gênero alimentício líquido)

Você conhece a palavra MOLHADO?

Pode dar um exemplo desta palavra dentro de uma frase? 
118. NAU (Acepção: Navio de porte grande)

Você conhece a palavra NAU?

Pode dar um exemplo desta palavra dentro de uma frase?

119. OBSERVÂNCIA (Acepção: Observação, execução fiel)

Você conhece a palavra OBSERVÂNCIA?

Pode dar um exemplo desta palavra dentro de uma frase?

120. OPULÊNCIA (Acepção: Abundância, acúmulo de bens)

Você conhece a palavra OPULÊNCIA?

Pode dar um exemplo desta palavra dentro de uma frase?

121. ORDENAÇÃO (Acepção: Ato ou efeito de ordenar, mandado)

Você conhece a palavra ORDENAÇÃO?

Pode dar um exemplo desta palavra dentro de uma frase?

122. ORDENADO (Acepção: Salário, remuneração)

Você conhece a palavra ORDENADO?

Pode dar um exemplo desta palavra dentro de uma frase?

123. PARAGEM (Acepção: Ponto, lugar de parada)

Você conhece a palavra PARAGEM?

Pode dar um exemplo desta palavra dentro de uma frase?

124. PARIDADE (Acepção: Igualdade, analogia, semelhança)

Você conhece a palavra PARIDADE?

Pode dar um exemplo desta palavra dentro de uma frase?

125. PENÚRIA (Acepção: Extrema pobreza, miséria)

Você conhece a palavra PENÚRIA?

Pode dar um exemplo desta palavra dentro de uma frase? 
126. PRIVANÇA (Acepção: Desfavorecimento, destituição)

Você conhece a palavra PRIVANÇA?

Pode dar um exemplo desta palavra dentro de uma frase?

127. PROPINA (Acepção: Pagamento, gratificação em dinheiro)

Você conhece a palavra PROPINA?

Pode dar um exemplo desta palavra dentro de uma frase?

128. RÁBULA (Acepção: Indivíduo trapaceiro, ardiloso)

Você conhece a palavra RÁBULA?

Pode dar um exemplo desta palavra dentro de uma frase?

129. REBATE (Acepção: Ataque repentino, sinal de alarme, aviso)

Você conhece a palavra REBATE?

Pode dar um exemplo desta palavra dentro de uma frase?

130. RÉDITO (Acepção: Rendimento, ganho)

Você conhece a palavra RÉDITO?

Pode dar um exemplo desta palavra dentro de uma frase?

131. REMÉDIO DA SUA FOME (Acepção: Plantação) Você conhece a expressão REMÉDIO DA SUA FOME?

Pode dar um exemplo desta palavra dentro de uma frase?

132. RIPA (Acepção: Pedaço de madeira estreito e comprido) Você conhece a palavra RIPA?

Pode dar um exemplo desta palavra dentro de uma frase?

133. ROSSIO (Acepção: Praça larga, espaçosa)

Você conhece a palavra ROSSIO?

Pode dar um exemplo desta palavra dentro de uma frase? 
134. SEARA (Acepção: Plantação, terra cultivada)

Você conhece a palavra SEARA?

Pode dar um exemplo desta palavra dentro de uma frase?

135. SOLDO (Acepção: Salário, remuneração de militar)

Você conhece a palavra SOLDO?

Pode dar um exemplo desta palavra dentro de uma frase?

136. SUMACA (Acepção: Antigo navio a vela, pequena embarcação)

Você conhece a palavra SUMACA?

Pode dar um exemplo desta palavra dentro de uma frase?

137. SUSTENTAÇÃO (Acepção: Abastecimento de alimento, sustento)

Você conhece a palavra SUSTENTAÇÃO?

Pode dar um exemplo desta palavra dentro de uma frase?

138. TABUADO (Acepção: Conjunto de tábua)

Você conhece a palavra TABUADO?

Pode dar um exemplo desta palavra dentro de uma frase?

139. TABULARIA (Acepção: Uma espécie de tábua)

Você conhece a palavra TABULARIA?

Pode dar um exemplo desta palavra dentro de uma frase?

140. VERAS (Acepção: Verdade)

Você conhece a palavra VERAS?

Pode dar um exemplo desta palavra dentro de uma frase?

141. VIGÁRIO (Acepção: Padre que substitui o pároco)

Você conhece a palavra VIGÁRIO?

Pode dar um exemplo desta palavra dentro de uma frase? 


\section{ADJETIVOS}

142. ABASTADO (Acepção: Rico, possuidor de bens) Você conhece a palavra ABASTADO?

Pode dar um exemplo desta palavra dentro de uma frase?

143. ACOMETIDO (Acepção: Entregue, confiado) Você conhece a palavra ACOMEDITO?

Pode dar um exemplo desta palavra dentro de uma frase?

144. ACOMODADO (Acepção: Instalado, alojado)

Você conhece a palavra ACOMODADO?

Pode dar um exemplo desta palavra dentro de uma frase?

145. AFETO (Acepção: Partidário, adepto)

Você conhece a palavra AFETO?

Pode dar um exemplo desta palavra dentro de uma frase?

146. APONTADO (Acepção: Indicados, referidos) Você conhece a palavra APONTADO?

Pode dar um exemplo desta palavra dentro de uma frase?

147. ASSENTADO (Acepção: Estabelecido, decidido) Você conhece a palavra ASSENTAR?

Pode dar um exemplo desta palavra dentro de uma frase?

148. ASSOMBRADO (Acepção: Coberto de sombras) Você conhece a expressão ASSOMBRADO?

Pode dar um exemplo desta palavra dentro de uma frase? 
149. BRIOSO (Acepção: Cheio de coragem, orgulhoso)

Você conhece a palavra BRIOSO?

Pode dar um exemplo desta palavra dentro de uma frase?

150. CABAL (Acepção: Completo, perfeito, rigoroso)

Você conhece a palavra CABAL?

Pode dar um exemplo desta palavra dentro de uma frase?

151. DE BOA NOTA (Acepção: Alguém experiente, reconhecido)

Você conhece a expressão BOA NOTA?

Pode dar um exemplo desta palavra dentro de uma frase?

152. DECOROSO (Acepção: Digno, honrado, decente)

Você conhece a palavra DECOROSO?

Pode dar um exemplo desta palavra dentro de uma frase?

153. DEPOSTO (Acepção: Destituído do cargo, demitido)

Você conhece a palavra DEPOSTO?

Pode dar um exemplo desta palavra dentro de uma frase?

154. DERROGADO (Acepção: Sem validade, anulado)

Você conhece a palavra DERROGADO?

Pode dar um exemplo desta palavra dentro de uma frase?

155. DESCONCERTADO (Acepção: Confuso, desordenado)

Você conhece a palavra DESCONCERTADO?

Pode dar um exemplo desta palavra dentro de uma frase?

156. DILATADO (Acepção: Muito, longo, vasto)

Você conhece a palavra DILATADO?

Pode dar um exemplo desta palavra dentro de uma frase? 
157. DIMINUTO (Acepção: Insuficiente, reduzido)

Você conhece a palavra DIMINUTO?

Pode dar um exemplo desta palavra dentro de uma frase?

158. EMBRENHADO (Acepção: Escondido, metido dentro de matos)

Você conhece a palavra EMBRENHADO?

Pode dar um exemplo desta palavra dentro de uma frase?

159. ENFADONHO (Acepção: Incomodado, aborrecido)

Você conhece a palavra ENFADONHO?

Pode dar um exemplo desta palavra dentro de uma frase?

160. FALTO (Acepção: Necessitado, desprovido)

Você conhece a palavra FALTO?

Pode dar um exemplo desta palavra dentro de uma frase?

161. FINDO (Acepção: Concluído, terminado)

Você conhece a palavra FINDO?

Pode dar um exemplo desta palavra dentro de uma frase?

162. FRÍVOLO (Acepção: Fútil, pouca ou nenhuma importância, em vão) Você conhece a palavra FRÍVOLO?

Pode dar um exemplo desta palavra dentro de uma frase?

163. INDECOROSO (Acepção: Vergonhoso)

Você conhece a palavra INDECOROSO?

Pode dar um exemplo desta palavra dentro de uma frase?

164. IRRESOLUTO (Acepção: Indeciso, sem resolução)

Você conhece a palavra IRRESOLUTO?

Pode dar um exemplo desta palavra dentro de uma frase? 
165. LADINO (Acepção: Indivíduo que apresentava certo grau de aculturação, intelectualmente fino)

Você conhece a palavra LADINO?

Pode dar um exemplo desta palavra dentro de uma frase?

166. LIMITADO (Acepção: De pouco valor, baixo)

Você conhece a palavra LIMITADO?

Pode dar um exemplo desta palavra dentro de uma frase?

167. LUZIDO (Acepção: Brilhante, ilustre)

Você conhece a palavra LUZIDO?

Pode dar um exemplo desta palavra dentro de uma frase?

168. MÓDICO (Acepção: Modesto, de pouco valor)

Você conhece a palavra MÓDICO?

Pode dar um exemplo desta palavra dentro de uma frase?

169. OB-REPTÍCIO (Acepção: Algo obtido por meio de dissimulação, astúcia)

Você conhece a palavra OB-REPTÍCIO?

Pode dar um exemplo desta palavra dentro de uma frase?

170. OBSEQUIOSO (Acepção: Que presta favores, obséquios, revela ter boa vontade) Você conhece a palavra OBSEQUIOSO?

Pode dar um exemplo desta palavra dentro de uma frase?

171. PERNICIOSO (Acepção: Que causa dano, nocivo)

Você conhece a palavra PERNICIOSO?

Pode dar um exemplo desta palavra dentro de uma frase?

172. PERVENCIDO (Acepção: Perder a validade, caducar)

Você conhece a palavra PERVENCIDO?

Pode dar um exemplo desta palavra dentro de uma frase? 
173. PRINCIPIADO (Acepção: Iniciado, começado)

Você conhece a palavra PRINCIPIADO?

Pode dar um exemplo desta palavra dentro de uma frase?

174. PROFITENTE (Acepção: Aquele que professsa)

Você conhece a palavra PROFITENTE?

Pode dar um exemplo desta palavra dentro de uma frase?

175. RELAVADO (Acepção: Explorado, exaurido)

Você conhece a palavra RELAVADO?

Pode dar um exemplo desta palavra dentro de uma frase?

\section{IV - ADVÉRBIO}

176. DEBALDE (Acepção: Inutilmente, em vão)

Você conhece a palavra DEBALDE?

Pode dar um exemplo desta palavra dentro de uma frase? 
Crexos 
ANEXO A - Localização de Paranaguá e ilhas no litoral paranaense

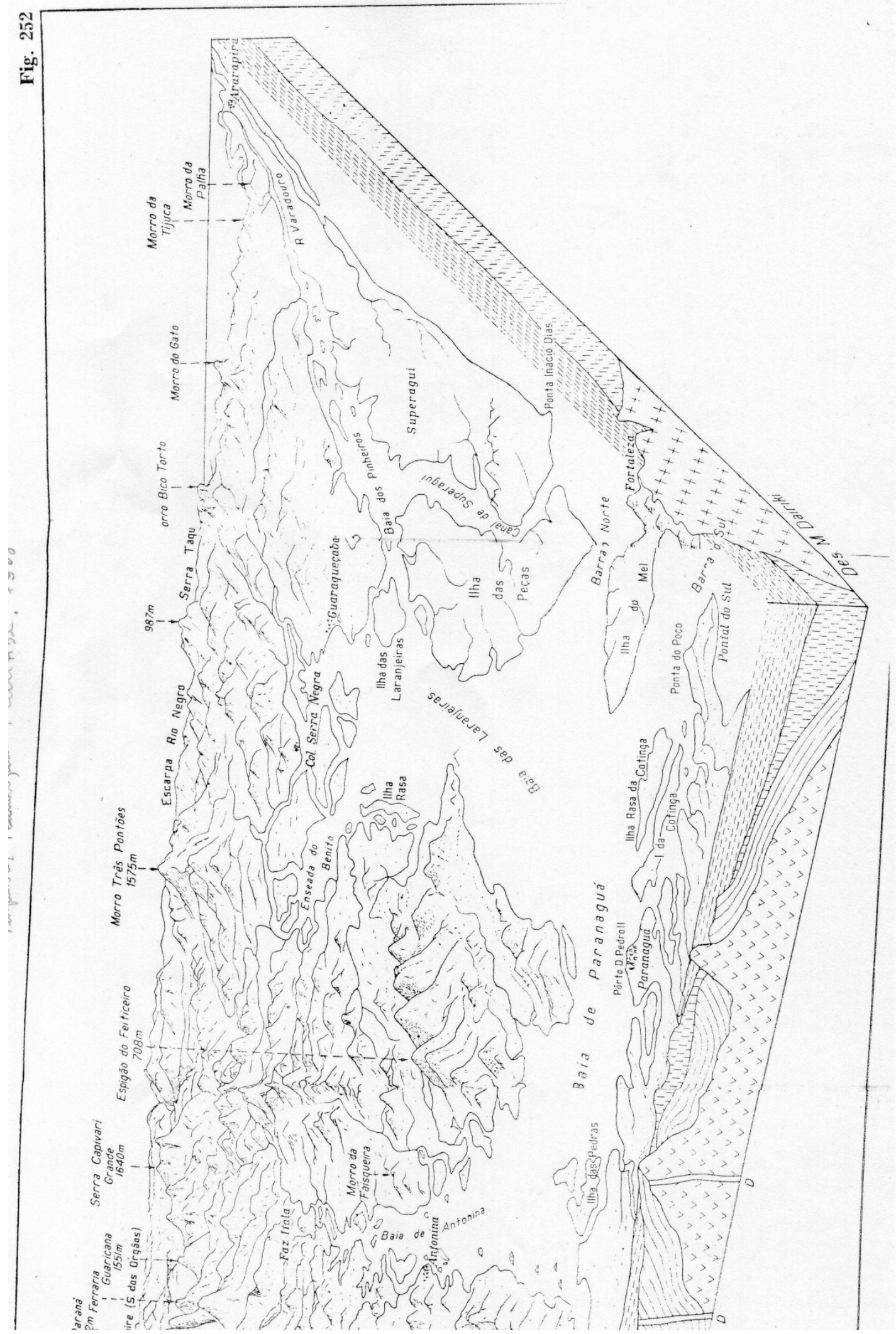

Fonte: Maack, 1968. Encarte. 
ANEXO B - Ficha do informante

\begin{tabular}{|c|c|c|c|}
\hline \multicolumn{4}{|c|}{ DADOS PESSOAIS DO INFORMANTE } \\
\hline \multicolumn{3}{|l|}{ 1. NOME: } & 2. ALCUNHA: \\
\hline \multicolumn{2}{|l|}{ 3. DATA DE NASCIMENTO: } & 4. SEXO: ( ) M ( ) F & 5. IDADE: \\
\hline \multicolumn{4}{|l|}{ 6. ENDEREÇO: } \\
\hline \multicolumn{4}{|c|}{ 7. ESTADO CIVIL: ( ) solteiro $($ ) casado $($ ) viúvo $($ ) outro } \\
\hline 8.NATURALIDADE: & \multicolumn{3}{|c|}{$\begin{array}{l}\text { 9. COM QUE IDADE CHEGOU A ESTA CIDADE? (CASO } \\
\text { NÃO SEJA NATURAL DE PARANAGUÁ): }\end{array}$} \\
\hline \multicolumn{2}{|l|}{ 10. ESCOLARIDADE: } & \multicolumn{2}{|c|}{$\begin{array}{l}\text { 11. OUTROS CURSOS: } \\
\text { ( ) especialização ( ) profissionalizante } \\
\text { ( )outros }\end{array}$} \\
\hline \multicolumn{2}{|l|}{$\begin{array}{l}\text { 12. NATURALIDADE: } \\
\text { a. da mãe: } \\
\text { b. do pai: } \\
\text { c. do cônjuge: }\end{array}$} & \multicolumn{2}{|c|}{$\begin{array}{l}\text { 13. FOI CRIADO PELOS PRÓPRIOS PAIS? } \\
(\quad) \operatorname{sim}(\quad) \text { não }\end{array}$} \\
\hline \multicolumn{4}{|c|}{ 14. ONDE EXERCE SUA PROFISSÃO : } \\
\hline \multicolumn{2}{|c|}{ 15: OUTRAS PROFISSÕES/OCUPAÇÕES: } & \multicolumn{2}{|l|}{$\begin{array}{l}\text { 16. PROFISSÃO: } \\
\text { a. do pai: } \\
\text { b. da mãe: } \\
\text { c. do cônjuge: }\end{array}$} \\
\hline
\end{tabular}


ANEXO C - Representação Esquemática do Macrozoneamento Municipal de Paranaguá 


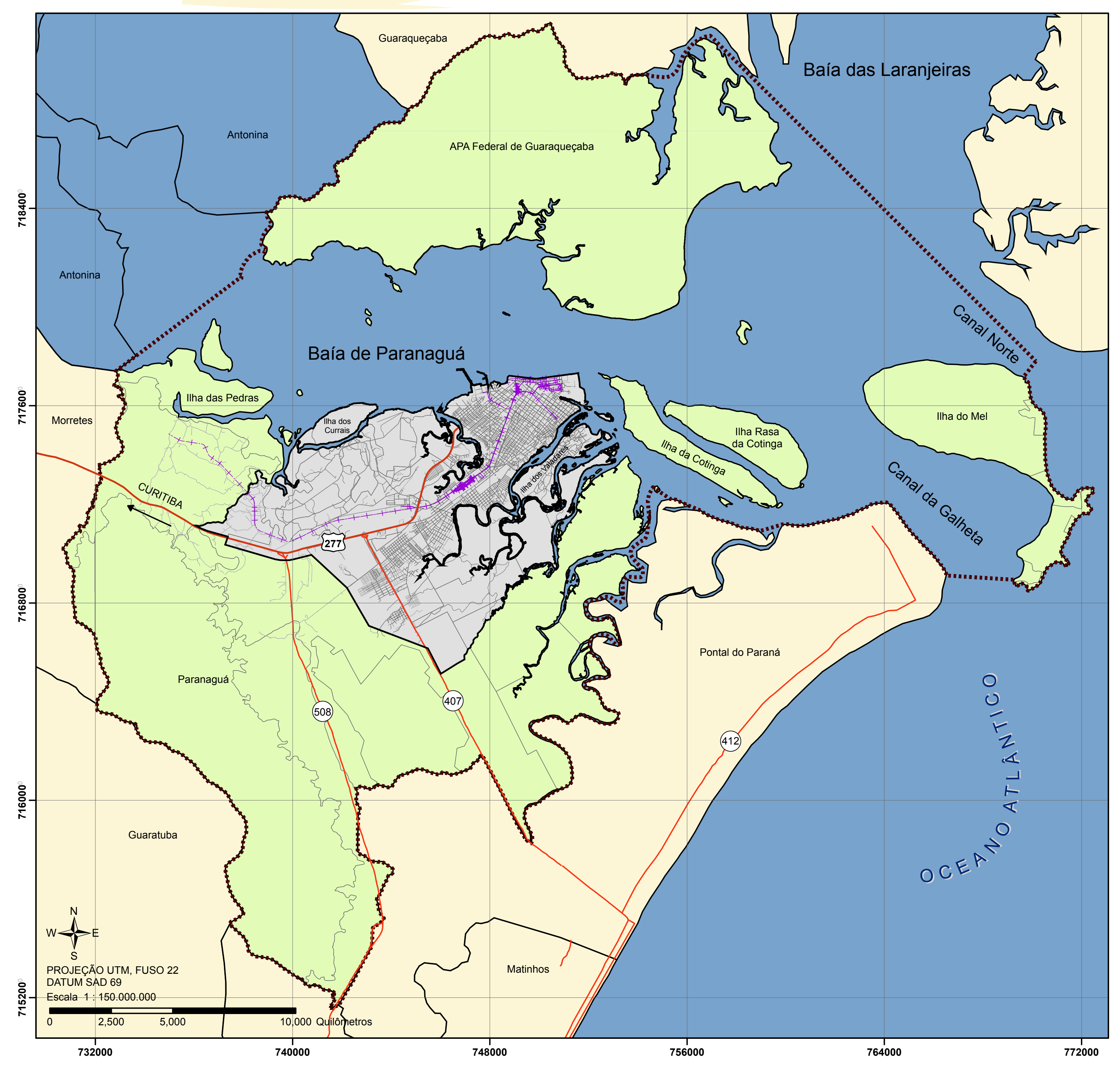

\section{ANEXO I}

MACROZONEAMENTO MUNICIPAL

Legenda

MR - MACROZONA RURAL

MU - MACROZONA URBANA

— Rodovia federal

_ Rodovias estaduais

Sistema viário urbano

++ Ferrovia

Sistema viário rural

Limite municipal

\section{PDDI PARANMEUIA

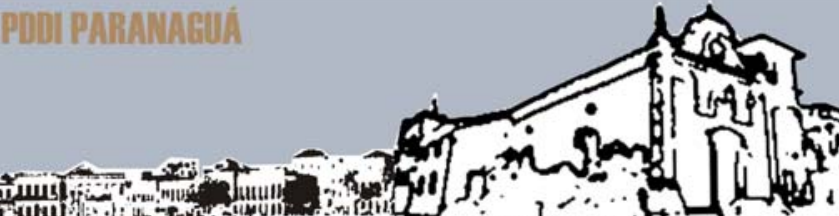 1...}

PDDI PARANAGUÁ,
FONTE DE DADOS

Imagem de satélite Spot5, 2005: Cedida por PICS

(Programme International de Coopération Scientifique) 